\title{
Arctic Ice Islands
}

\section{Final Report}

\author{
W.M. Sackinger \\ M.O. Jeffries \\ M.C. Lu \\ F.C. Li
}

1988

Work Performed Under Contract No.: DE-AC21 33MC20037

For

U.S. Department of Energy

Office of Fossil Energy

Morgantown Energy Technology Center

Morgantown, West Virginia

By

University of Alaska

Geophysical Institute

Fairbanks, Alaska 


\section{DISCLAIMER}

This report was prepared as an account of work sponsored by an agency of the United States Government. Neither the United States Government nor any agency thereof, nor any of their employees makes any warranty, express of implied, or assumes any legal liability or responsibility for the accuracy, completeness or usefulress of any information, apparatus, product, or process disclosed, or represents that its use would not infringe privately owned rights. Reference herein to any specific commercial product, process, or service by trade name, trademark, manufacturer, or otherwise, does not necessarily constitute or imply its endorsement, recommendation, or favoring by the United States Government or any agency thenef. The views and opinions of authors expressed herein do not necessarily state or reflect those of the United States Government or any agency thereof.

This report has been reproduced directly from the best available copy.

Available to DOE and DOE contractors from the Office of Scientific and Technical Information, P.O. Box 62, Oak Ridge, TN 37831; prices available from (615)576.8401, FTS 626-8401.

Available to the public from the National Technical Information Service, U.S. Department of Commerce, 5285 Pon Royal Rd., Springfield, VA 22161. 


\section{TABLE OF CONTENTS}

page

LIST OF FIGURES $\ldots \ldots \ldots \ldots \ldots \ldots \ldots \ldots \ldots \ldots \ldots \ldots \ldots \ldots \ldots \ldots \ldots \ldots \ldots$

LIST OF TABLES $\ldots \ldots \ldots \ldots \ldots \ldots \ldots \ldots \ldots \ldots \ldots \ldots \ldots \ldots \ldots \ldots \ldots \ldots \ldots \ldots \ldots$

CHAPTER I: INTRODUCTION AND EXECUTIVE

SUMMARY $(W . M$. Sackinger $) \ldots \ldots \ldots \ldots \ldots \ldots \ldots \ldots \ldots \ldots$

CHAPTER W: ICE ISLAND SOURCES (M. O. Jeffries) $\ldots \ldots \ldots \ldots \ldots \ldots \ldots \ldots$

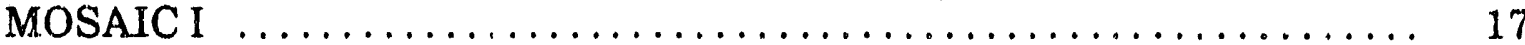

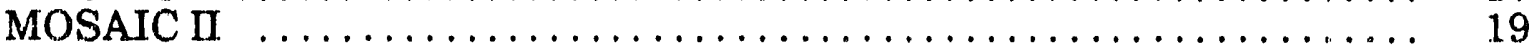

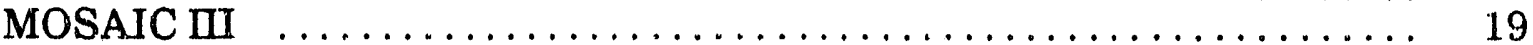

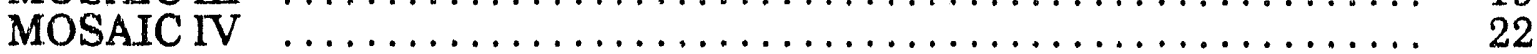

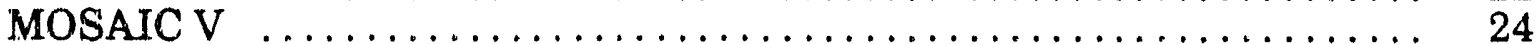

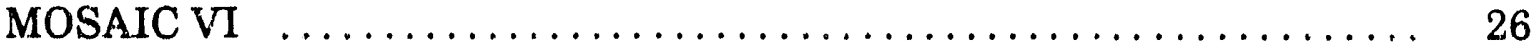

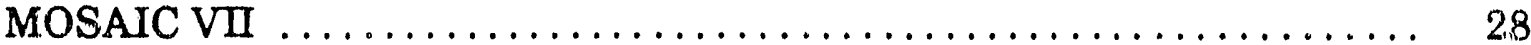

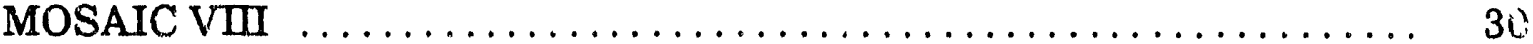

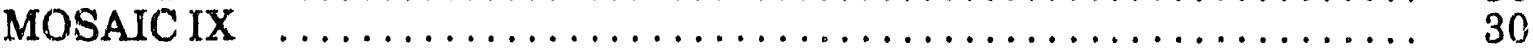

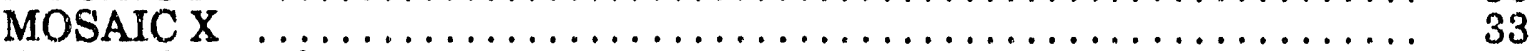

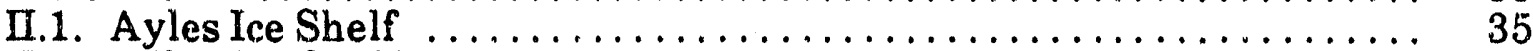

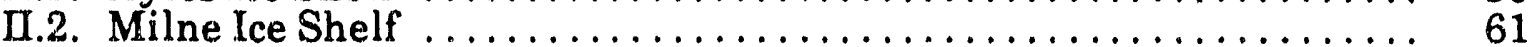

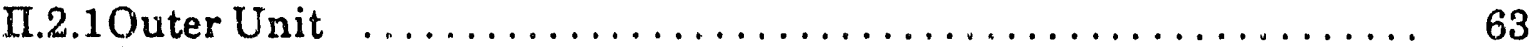

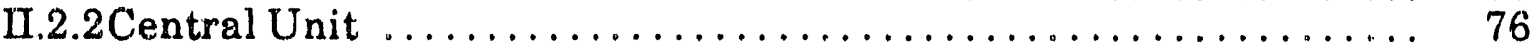

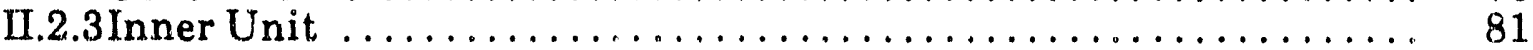

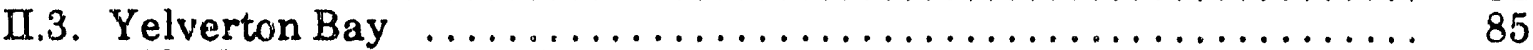

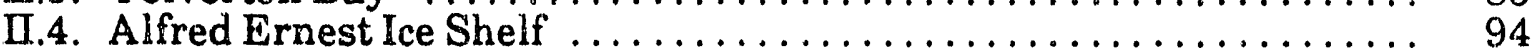

CHAPTER III: ANALYSIS OF ICE ISLAND MOVEMENT (M. C. Lu) $\ldots \ldots$. . 100

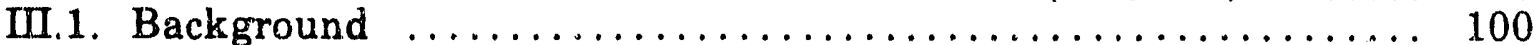

III.2. Features and Movements of Ice Islands $\ldots \ldots \ldots \ldots \ldots \ldots \ldots \ldots \ldots \ldots . \ldots \ldots$

III.3. Hobson's Choice Ice Island and Research Emphasis . . . . . . . . . . 106

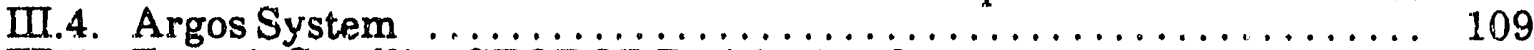

III.5. Transit Satellite GEODOP Positioning System . . . . . . . . . . 110

III.6. Basic Equations ................................ 112

III.7. Trajectory Analysis for Hobson's Choice Ice Island . . . . . . . . . . 115

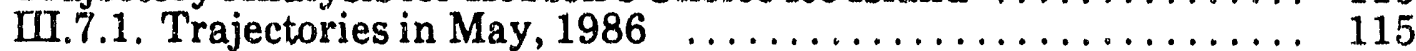

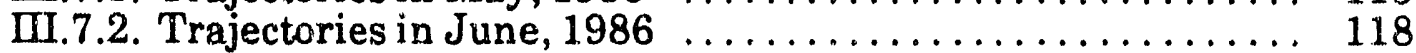

III.7.3. Large daily movements in July, August and

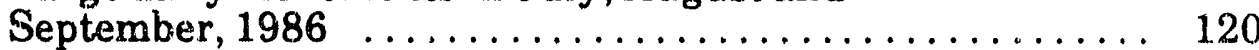

III.8. Relationship between Surface Wind, Geostrophic Wind and

Ice Island Movement $\ldots \ldots \ldots \ldots \ldots \ldots \ldots \ldots \ldots \ldots \ldots \ldots \ldots \ldots$

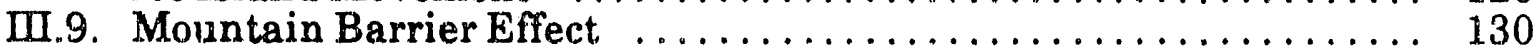

III.10. Ice Island Dynamic Analysis $\ldots \ldots \ldots \ldots \ldots \ldots \ldots \ldots \ldots \ldots \ldots$

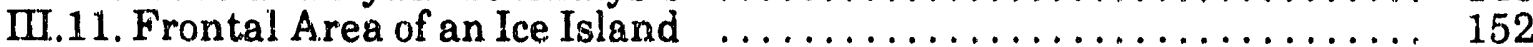

III.12. Force Balance $\ldots \ldots \ldots \ldots \ldots \ldots \ldots \ldots \ldots \ldots \ldots \ldots \ldots \ldots \ldots$

III.13. Pack Ice and Ocean Tilt Forces . . . . . . . . . . . . . . . . . 184

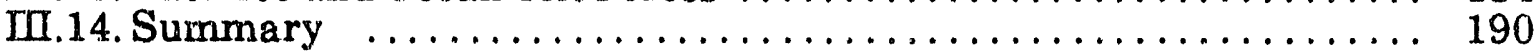

CHAPTER IV: SIMULATION OF THE RECURRENCE PROBABILITY OF ICE ISLANDS IN THE ARCTIC OCEAN (F. C. Li) . . . . . . . . . . . . . . 193 
IV.1. Introduction to the Trajectory Simulation $\ldots \ldots \ldots \ldots \ldots \ldots \ldots 193$

IV.2. Randor Ice Island Generation $\ldots \ldots \ldots \ldots \ldots \ldots \ldots \ldots \ldots \ldots, 196$

IV.3. Dynamic Model of Ice Island Movement ................. 207

IV. 4. Monte Carlo Model of Random Wind Generation ............. 215

IV.5. Simulation and Domain Mesh $\ldots \ldots \ldots \ldots \ldots \ldots \ldots \ldots \ldots \ldots, 222$

IV.6. Simulation Results and Comparisons ................... 226

IV.7. Conclusions of the Simulation $\ldots \ldots \ldots \ldots \ldots \ldots \ldots \ldots \ldots \ldots \ldots \ldots \ldots \ldots \ldots \ldots, 272$

CHAPTER V: CONCLUSIONS (W. M. Sackinger et al.) _............ 275

CHAPTER VI: REFERENCES $\ldots \ldots \ldots \ldots \ldots \ldots \ldots \ldots \ldots \ldots \ldots, 277$

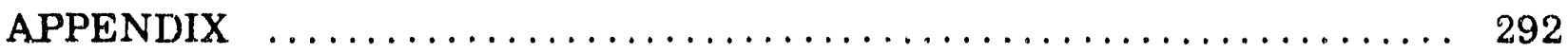




\section{LIST OF FIGURES}

Fig. 1. Map of the Arctic Ocean showing the location of Arctic Ice shelves off the north coast of Ellesmere Island (shaded), ice islands T-1 to T-5 and the Pacific (or Beaufort) Gyral and Transpolar Drift Stream (source: Jeffries, 1987).

Fig. 2. Oblique aerial photograph looking east across Ward Hunt Ice Shelf, taken by the RCAF from $9144 \mathrm{~m}(30,000 \mathrm{ft}$.) in August 1950. Note the undulating surface of the ice shelf that is revealed by meltwater in the troughs creating a dark tone between linear ridges (Air photograph T404L-4, available from the National Air Photographic Library, Ottawa, Ontario).

Fig. 3. Maps of ice shelf di:integration and changes in ice shelf extent, 1906-1985. (A): Shaded areas represent those ice shelves that remained in 1960 after ice calvings since 1906 (dashed line). Question marks denote uncertainties in ice shelf extent. (B): Ice shelf extent in 1985 (source: Jeffries, 1987).

Fig. 4. Oblique aerial view from 3048 meters looking east across Ayles Ice Shelf and multiyear landfast sea ice at the mouth of Ayles Fiord, July 23, 1984.

Fig. 5. Oblique aerial view from 3045 meters looking east across the front of Milne Ice Shelf showing the 10-meter-thick multiyear landfast sea ice of the Milne Re-entrant in the right foreground, July 23, 1984.

Fig. 6. A: Map of north coast of Ellesmere Island from Cape Discovery to Cape Egerton. B: Map of north coast of Ellesmere Island from Cape Fanshawe Martin to Cape Egerton. This map shows the location of Ayles Ice Shelf as it was in 1959.

Fig. 7. A: Oblique aerial photo yraph looking east across Ayles Ice Shelf, August 1, 1950. (Air photograph T407L-6, National Air Photograph Library, Ottawa, Ontario, Canada). B: Vertical air photo-mosaic of Ayles Ice Shelf, July 1959. (Air photographs A16706-3, A16785-75, A16785-76, National Air Photograph Library, Ottawa, Ontario, Canada).

Fig. 8. View looking west across the mouth of Ayles Fiord from Cape Fanshawe Martin.

Fig. 9. View looking east across the mouth of Ayles Fiord to Cape Fanshawe Martin.

Fig. 10. View of the northeastern area of the mouth of Ayles Fiord. This shows the location of the maximum movement of Ayles Ice Shelf away from the shore.

Fig. 11. View louking along the east shore of Ayles Fiord and the sea ice that has grown since the ice shelf moved. 
Fig. 12. Undulating sea ice near the east shore of Ayles Fiord. A crack in the ice is arrowed. Note how the crack meets the rest of the shelf ice.

Fig. 13. Undulating sea ice rear the east shore of Ayles Fiord. A crack in the ice is arrowed.

Fig. 14. Ayles Ice Shelf is in the foreground with some recent sea ice at the left side. Note the more random patterns in the ice beyond the ice shelf.

Fig. 15. View looking south across the east arm of Ayles Fiord from Cape Fanshawe Martin.

Fig. 16. Glacier at the head of the east arm of Ayles Fiord. Note the curios eastwest alignment of the melt-pools that is reminiscent of the ice shelves.

Fig. 17. View looking south across the mouth of the east arm of Ayles Fiord from Cape Fanshawe Martin.

Fig. 18. View looking east across Ayles Fiord to the east arm of the fiord. Compare this with Figure $7 \mathrm{~A}$ and note the change in ice conditions.

Fig. 19. Scattered fragments of shelf ice and glacier tongue in central Ayles Fiord.

Fig. 20. Scattered fragments of shelf ice and glacier tongue in central Ayles Fiord. Small, remaining glacier tongue is arrowed.

Fig. 21. Scattered fragments of shelf ice and glacier tongue in central Ayles Fiord. Note that the shelf ice in the foreground is grey in color.

Fig. 22. Icebergs in Ayles Fiord. This photograph looks towards the east shore of the fiord. The line across the snow is a snowmobile track.

Fig. 23. Curvi-linear debris zone at the west side of Ayles Ice Shelf (right side of photograph). In 1950-59, this debris was adjacent to the cirque glacier that is ar. ed (see also Figs. 7A and 7B).

Fig. 24. View looking east across Ayles Ice Shelf in the mouth of Ayles Fiord. The location of an ice island calving and the sea ice that has regrnwn since that event is arrowed.

Fig. 25. Looking down at the outermost part of Ayles Ice Shelf. The arrow indicates sea ice accretion since an ice island calving.

Fig. 26. The front of Ayles Ice Shelf and icefield at Cape Bicknor (right). Note the open water and leads that suggest the pack ice is in tension.

Fig. 27. Ayles Ice Shelf and sea ice belt extending from the shelf front along the shore of the ice field between Cape Bicknor and Cape Egerton.

$\mathrm{Fi}_{1}$. 28. Air-photo mosaic of Milne Ice Shelf taken from an altitude of 91.14 meters $(30,000$ feet) in July 1959. (Air photographs available from the National Air Photographic Library, Ottawa, Ontario, Canada) 
Fig. 29. View looking east over Milne Ice Shelf, Cape Egerton and Ayles Ice Shelf.

Fig. 30. View looking southwest across Cape Egerton and the outer unit of Milne Ice Shelf.

Fig. 31. The outer unit of Milne Ice Shelf with sea ice accretion along the ice front.

Fig. 32. Oblique aerial photograph looking southwest across outer Milne Ice Shelf and Cape Evans to Yelverton Bay from an altitude of 6096 meters, August 1950. Area $A$ has an area of about $35 \mathrm{~km}^{2}$ and calved during the interval 1959-74. (Air photograph T407R-8 available from National Air Photographic Library, Ottawa, Ontario, Canada.)

Fig. 33. Looking southwest across Milne Re-entrant. A water-filled crack is arrowed.

Fig. 34. Close up view of melt-pools on Milne Re-entrant. Cape Evans is arrowed.

Fig. 35. Looking northeast across Milne Re-entrant and the outer unit of Milne Ice Shelf from Cape Evans. Note the difference between the melt-pools on the Re-entrant and those on the ice shelf.

Fig. 36. West side of the outer unit of Milne Ice Shelf. A water-filled crack running across the rolls towards the re-entrant is arrowed. The dark material at lower left is moraine (see Figure 17).

Fig. 37. Looking south across Milne Ice Shelf from Cape Egerton. The second, linear line of weakness is arrowed. Cape Egerton Icefield is at the left side.

Fig. 38. The second, linear line of weakness cuts across the ire shelf from left to right in the center of the photograph.

Fig. 39. Outer unit of Milne Ice Shelf. The second line of weakness running south from the Cape Egerton Icefield shows clearly at the left side.

Fig. 40. Looking northwest across Milne Ice Shelf to Cake Evans. The linear concentrations of debris at the left side are morailes which mark the southern boundary of the outer unit.

Fig. 4i. Moraine at the surface of the central unit of Milne Ice Shelf. The moraine at the left side is associated with Glacier 3 while that at the right side is associated with Glacier 1 . Glacier 2 is in the center.

Fig. 42. Looking north out of Milne Fiord. In the foreground is the inner ice shelf unit of which the northern boundary is marked by the dark moraines. The left moraine is associated with Glacier 3 and the right moraines with Glacier 2. Moraines from Glacier 1 can be seen in the distance.

Fig. 43. View looking south into Milne Fiord. Milne Glacier (see Figure 25 also) is in the background with considerable morainal material at the surface. On the ice shelf, the moraine at the left side comes from Glacier 2 and the moraine on the right from Glacier 3. 
Fig. 44. Radial crevasses in Milne Ic Shelf near the front of Glacier 2.

Fig. 45. Ice in the northeast corner of inner Milne Ice Shelf (right side). At the left side are moraines on the central unit.

Fig. 46. Ice on the east side of inner Milne Ice Shelf. Note the gray color on the ice which becomes cleaner with much less evidence of rolls at the right side.

Fig. 47. View looking north out of Milne Fiord. Milne Ice Shelf is in the foreground and the dark bands are medial moraines.

Fig. 48. The western ice stream of Milne Clacier. Note the grayness of the ice.

Fig. 49. Map of the north coast of Ellesmere Island from Cape Fanshawe Martin to Cape Evans.

Fig. 50. Oblique aerial view looking SSE across inner Yelverton Bay and Mitchell Pt. (center). Note the glacier that flows into Yelverton Bay as a glacier tongue and creates a thick ice (shelf?) barrier across the mouth of the inlet. (Frame RR108R-113, 9 April 1951, RCAF, National Air Photograph Library, Ottawa, Ontario, Canada).

Fig. 51. Oblique aerial view looking south over Yelverton Bay across to Mitchell Pt. (left), from $3048 \mathrm{~m}$ on 23 July 1984.

Fig. 52. SLAR (side-looking airborne radar) image of the Yelverton Ice Shelf at the west side of Yelverton Bay (right), the Alert Pt. Ice-field (center) and the Alfred Ernest Ice Shelf (left), 11 May 1983. (Flight NDE-1051, Atmospheric Environment Service, Ottawa, Ontario, Canada).

Fig. 53. Oblique aerial photograph looking east across the outer section of the Alfred Ernest Ice Shelf, 15 July 1950. (RCAF photograph, frame T405R32, available from the National Air Photograph Library, Ottawa, Ontario,
Canada).

Fig. 54. Oblique aerial view from $3048 \mathrm{~m}$ of one of the glaciers and glacier-tongues of the Alfred Ernest Ice Shelf, 24 July 1984. The dark features at the right and center are moraines.

Fig. 55. Oblique aerial view from $3048 \mathrm{~m}$ looking south over the ice of the inner bay between Cape Woods and Alert Point, 24 July 1984. Cape Alfred Ernest is the hooked feature in the lower left corner. The Alfred Ernest Ice Shelf is located to the right of the picture and adjacent to the land in the background.

Fig. 56. Calving history of ice shelves of Ellesmere Island, based on historical records and traverses (H. Serson, 1984). (Gain in parenthesis). Units are $\mathrm{km}^{2}$.

Fig. 57. Oblique aerial photograph looking along the long axis of Hobson's Choice Ice Island, 11 August 1987. The main shelf ice section of the ice island in the center of the photograph is characterized by undulations about $2 \mathrm{~m}$ deep and spaced about $200 \mathrm{~m}$ apart. At the left side of the shelf ice is an area 
multiyear landfast sea ice (MLSI) that was previously attached to the front of the Ward Hunt Ice Shelf. At the right side of the shelf ice is an area of consolidated multiyear pack ice (MYPI) that has become attached to the shelf ice since the calving event of 1982-83. Photo credit: Michael Schmidt, Geological Survey of Canada).

Fig. 58. Oblique aerial photograph of two ice islands located at approximately $81.14^{\circ} \mathrm{N}, 96.7^{\circ} \mathrm{W}, 45 \mathrm{~km}$ west of Rens Fiord, northern Axel Heiberg Island, 3 May 1986. In the foreground is part of Hobson's Choice Ice Island and beyond it is the second largest ice island presently known in the Arctic Ocean (SLAR 2: Jeffries et al., 1988). The undulations on the ice islands' surface can be seen clearly despite the snow cover. The relatively smooth surfaces of the ice islands contrast with the surrounding, rough pack ice surface. (Photo credit: Martin Jeffries, Geophysical Institute, UAF).

Fig. 59. Drift tracks of ice islands T-3 and Arlis-II in the Arctic Ocean (based on Sackinger and Yan, 1986).

Fig. 60. The location of Hobson's Choice Ice Island with buoy 2996 and its vicinity. The study area and Ward Huni. Ice Shelf are shown in the small map above. Crossed area on Axel Heiberg Islarid corresponds to surface elevation above 1500 meters.

Fig. 61. Argos system data flow chart and general structure of each center.

Tig. 62. Ice island positions from May $1^{\text {st }}$ to $31^{\text {st }}, 1986$.

Fig. 63. Ice island positions in the period May $7^{\text {th }}$ to $16^{\text {th }}, 1986$.

Fig. 64. Ice island positions from June $1^{\text {st }}$ to $30^{\text {th }}, 1986$.

Fig. 65. Ice island positions in the period june $14^{\text {th }}$ to $21^{\text {st }}, 1986$.

F'ig. 66. Ice island positions in the period July $1^{\text {st }}$ to $6^{\text {th }}, 1986$.

Fig. 67. Ice island positions in the period August $22^{\text {nd }}$ to $27^{\text {th }}, 1986$.

Fig. 68. Ice island positions in the period September $10^{\text {th }}$ to $16^{\text {th }}, 1986$.

Fig. 69. Direction and speed of surface wind, geostrophic wind and ice island movement in the period May 7-16, 1986.

Fig. 70. Direction and speed of surface wind, geostrophic wind aur ice island movement in the period June 14-21, 1986.

Fig. 71. Mountain-parallel wind components $(\mathrm{m} / \mathrm{s})$ from calculations by Parish (1983) for a geostrophic wind of $10 \mathrm{~m} / \mathrm{s}$ normal to the mountain barrier.

Fig. 72. Wind components $(\mathrm{m} / \mathrm{s})$ normal to the mountain barrier for a geostrophic wind of $10 \mathrm{~m} / \mathrm{s}$ normal to the barrier, after Parish (1983).

Fig. 73. The concept that a geostrophic wind blowing from the west causes a surface wind parallel to the mountain, because of the mountain barrier 
effect (Parish, 1983). Crossed area corresponds to elevation greater than 1500 meters on Axel Heiberg Island.

Fig. 74. The specific wind data from June $17^{\text {th }}$, 1986, likely due to mountain barrier effect. Crossed area corresponds to elevation greater than 1500 meters on Axel Heiberg Island.

Fig. 75. Direction and speed of surface wind and geostrophic wind in the period July 1-9, 1986, Axel Heiberg Island.

Fig. 76. Wind speed and direction on July $5^{\text {th }}, 1986$, suggesting presence of mountain barrier effect. Crossed area corresponds to elevation greater than 1500 meters on Axel Heiberg Island.

Fig. 77. The Arctic surface weather map of $1200 \mathrm{Z}$ July $5^{\text {th }}, 1986$ (CMC).

Fig. 78. The direction and speed of surface wind and geostrophic wind in the period August 22-27.

Fig. 79. The Arctic surface weather map of $1200 \mathrm{Z}$ August $26^{\text {th }}, 1986$ (CMC).

Fig. 80. The direction and speed of surface wind and geostrophic wind in the period September 11-17.

Fig. 81. The Arctic surface weather map of $1200 \mathrm{Z}$ September $15^{\text {th }}, 1986$ (CMC).

Fig. 82. The geostrophic wind direction versus surface wind direction for time segments May 7-16, June 14-21, July 1-9, August 22-27 and September 1.1-17, 1986. Box area shows evidence of mountain barrier effect for North/South mountain chain on Axel Heiberg Island.

Fig. 83. The relationship between frontal width, rotation and movement direction of Hobson's Choice ice island.

Fig. 84. The rotation of the ice island itself is plotted as a function of time, (a) for May 7-16; (b) for June 14-21, 1986.

Fig. 85. The frontal area $A_{f}$ is plotted as a function of time, (a) for May 7-16; (b) for June 14-21, 1986.

Fig. 86. The ratio of frontal water drag force to total water drag force versus time, (a) for May 7-16; (b) for June 14-21, 1986.

Fig. 87. Force balance on May 7 for wind shear force $\left(F_{a}\right)$, total drag force $\left(F_{w}\right)$, Coriolis force $\left(F_{\mathrm{c}}\right)$ and the force due to accelerating or decelerating $\left(F_{t}\right)$

(a) at $0300 \mathrm{Z},\left(\mathrm{F}_{\mathrm{r}}=0.5\left(236^{\circ}\right)\right)$,

(b) at $1200 \mathrm{Z},\left(\mathrm{F}_{\mathrm{r}}^{\mathrm{r}}=0.6\left(193^{\circ}\right)\right)$,

(c) at $1500 \mathrm{Z},\left(\mathrm{F}_{r}^{\mathrm{r}}=1.2\left(186^{\circ}\right)\right)$,

(d) at $1800 \mathrm{Z},\left(\mathrm{F}_{\mathrm{r}}=0.7\left(119^{\circ}\right)\right)$.

$\mathrm{F}_{r}$ : residual force, $\mathrm{V}_{\mathrm{i}}$ : ice island velocity $(\mathrm{cm} / \mathrm{s})$, dashed line means that $V_{i}$ is too small and just indicates the direction of the ice island movement. 
Fig. 88. Force balance on May 8
(a) at $0000 \mathrm{Z},\left(\mathrm{F}=6.6\left(94^{\circ}\right)\right)$,
(b) at $0300 \mathrm{Z},\left(\mathrm{F}_{\mathrm{r}}=6.4\left(127^{\circ}\right)\right)$,
(c) at $1200 \mathrm{Z},\left(\mathrm{F}_{\mathrm{r}}^{\mathrm{r}}=5.4\left(122^{\circ}\right)\right)$,
(d) at $1500 \mathrm{Z},\left(\mathrm{F}_{\mathrm{r}}=3.9\left(155^{\circ}\right)\right)$,
(e) at $1800 \mathrm{Z},\left(\mathrm{F}_{\mathrm{r}}^{\mathrm{r}}=0.7\left(143^{\circ}\right)\right)$.

Fig. 89. Same as Figure 87 except
(a) $\left(F_{r}=1.3\left(123^{\circ}\right)\right)$,
(b) $\left(\mathrm{F}_{\mathrm{r}}^{\mathrm{r}}=1.3\left(76^{\circ}\right)\right)$,
(c) $\left(F_{r}=1.5\left(95^{\circ}\right)\right)$,
(d) $\left(F_{r}=1.2\left(123^{\circ}\right)\right)$,
(e) $\left(F_{r}^{r}=1.0\left(112^{\circ}\right)\right)$, May 9 .

Fig. 90. Force balance on May 10 for
(a) $\left(F_{r}=1.6\left(62^{\circ}\right)\right)$, (b) $\left(F_{r}=3.8\left(63^{\circ}\right)\right)$,
(c) $\left(\mathrm{F}_{\mathrm{r}}=3.0\left(78^{\circ}\right)\right)$, (d) $\left(\mathrm{F}_{\mathrm{r}}^{\mathrm{r}}=3.5\left(83^{\circ}\right)\right)$,
(e) $\left(F_{r}^{r}=4.0\left(92^{\circ}\right)\right)$.

Fig. 91. Forice balance on May 11 for
(a) $\left(F_{r}=4.4\left(90^{\circ}\right)\right)$, (b) $\left(F_{r}=7.8\left(92^{\circ}\right)\right)$,
(c) $\left(F_{r}=7.0\left(94^{\circ}\right)\right)$, (d) $\left(F_{r}^{r}=7.2\left(90^{\circ}\right)\right)$,
(e) $\left(F_{r}:=9.0\left(82^{\circ}\right)\right)$.

Fig. 92. Force balance on May 12 for

(a) $\left(\mathrm{F}_{\mathrm{r}}=10.8\left(90^{\circ}\right)\right),(\mathrm{b})\left(\mathrm{F}_{\mathrm{r}}=12.6\left(94^{\circ}\right)\right)$,

(c) $\left(\mathrm{F}_{\mathrm{r}}=7.9\left(108^{\circ}\right)\right),(\mathrm{d})\left(\mathrm{F}_{\mathrm{r}}^{\mathrm{r}}=8.7\left(96^{\circ}\right)\right)$,

(e) $\left(F_{r}=9.4\left(93^{\circ}\right)\right)$.

Fig. 93. Force balance on May 13 for

(a) $\left(F_{r}=10.9\left(91^{\circ}\right)\right),\left(\right.$ b) $\left(F_{r}=10.8\left(96^{\circ}\right)\right)$,

(c) $\left(\mathrm{F}_{\mathrm{r}}^{\mathrm{r}}=6.0\left(113^{\circ}\right)\right)$, (d) $\left(\mathrm{F}_{\mathrm{r}}^{\mathrm{r}}=6.0\left(107^{\circ}\right)\right)$,

(e) $\left(F_{r}^{r}=6.4\left(129^{\circ}\right)\right)$.

Fig. 94. Force balance on May 14 for
(a) $\left(F_{r}=8.1\left(90^{\circ}\right)\right),(b)\left(F_{r}=9.2\left(93^{\circ}\right)\right)$,
(c) $\left(\mathrm{F}_{\mathrm{r}}{ }^{2}=5.2\left(124^{\circ}\right)\right),(\mathrm{d})\left(\mathrm{F}_{\mathrm{r}}=3.7\left(14 \mathrm{1}^{\circ}\right)\right)$,
(e) $\left(F_{r}=2.0\left(119^{\circ}\right)\right)$.

Fig. 95. Force balance on May 15 for
(a) $\left(F_{r}=4.5\left(119^{\circ}\right)\right),(b)\left(F_{r}=3.1\left(161^{\circ}\right)\right)$,
(c) $\left(F_{r}=0.7\left(280^{\circ}\right)\right),(d)\left(F_{r}^{r}=1.4\left(131^{\circ}\right)\right)$,
(e) $\left(F_{r}=2.9\left(103^{\circ}\right)\right)$.

Fig. 96. Force balance on May 16 for

(a) at $0000 \mathrm{Z},\left(\mathrm{F}_{\mathrm{r}}=3.0\left(140^{\circ}\right)\right)$,

(b) at $0300 \mathrm{Z},\left(\mathrm{F}_{\mathrm{r}}^{\mathrm{r}}=2.6\left(168^{\circ}\right)\right)$,

(c) at $1200 \mathrm{Z},\left(\mathrm{F}_{\mathrm{r}}^{\mathrm{r}}=1.1\left(194^{\circ}\right)\right)$,

(d) at $1800 \mathrm{Z},\left(\mathrm{F}_{\mathrm{s}}=2.5\left(181^{\circ}\right)\right)$.

Fig. 97. Force balance on June 15 for

(a) at $0000 Z,\left(F_{r}=0.2\left(186^{\circ}\right)\right)$,

(b) a.t $1200 Z,\left(F_{r}{ }^{r}=1.7\left(137^{\circ}\right)\right)$, 
(c) at $1500 \mathrm{Z},\left(\mathrm{F}=2.5\left(159^{\circ}\right)\right)$,

(d) at $1800 \mathrm{Z},\left(\mathrm{F}_{\mathrm{r}}=1.6\left(131^{\circ}\right)\right)$.

Fig. 98. Force balance on June 16 for

(a) $\left(F_{r}=4.4\left(91^{\circ}\right)\right)$, (b) $\left(F_{r}=6.8\left(89^{\circ}\right)\right)$,

(c) $\left(\mathrm{F}_{\mathrm{r}}^{\mathrm{r}}=12.3\left(123^{\circ}\right)\right)$, (d) $\left(\mathrm{F}_{\mathrm{r}}=9.2\left(154^{\circ}\right)\right)$,

(e) $\left(F_{r}=3.0\left(184^{\circ}\right)\right)$.

Fig. 99. Force balance on June 17 for

(a) $\left(\mathrm{F}_{\mathrm{r}}=0.5\left(136^{\circ}\right)\right)$,

(b) $\left(\mathrm{F}_{\mathrm{r}}^{\mathrm{r}}=0.3\left(181^{\circ}\right)\right)$,

(c) $\left(\mathrm{F}^{\mathrm{r}}=0.4\left(160^{\circ}\right)\right)$,

(d) $\left(\mathrm{F}_{\mathrm{r}}=0.7\left(187^{\circ}\right)\right)$.

Fig. 100. Force balance on June 18 for

(a) at $0300 \mathrm{Z},\left(\mathrm{F}_{\mathrm{r}}=3.2\left(83^{\circ}\right)\right)$,

(b) at $1500 \mathrm{Z},\left(\mathrm{F}_{\mathrm{r}}^{\mathrm{r}}=5.5\left(78^{\circ}\right)\right)$,

(c) at 1800Z, $\left(\mathrm{F}_{\mathrm{r}}^{\mathrm{r}}=7.8\left(86^{\circ}\right)\right)$.

Fig. 101. Force balance on June 19 for

(a) at $0300 \mathrm{Z},\left(\mathrm{F}_{\mathrm{r}}=0.8\left(109^{\circ}\right)\right)$,

(b) at $1500 \mathrm{Z},\left(\mathrm{F}_{\mathrm{r}}^{\mathrm{r}}=3.2\left(89^{\circ}\right)\right)$,

(c) at 1800Z, $\left(\mathrm{F}_{\mathrm{r}}{ }^{\mathrm{r}}=1.2\left(132^{\circ}\right)\right)$.

Fig. 102. Force balance on June 20 for
(a) $\left(F_{r}=7.4\left(78^{\circ}\right)\right),(b)\left(F_{1}=8.6\left(94^{\circ}\right)\right)$,
(c) $\left(\mathrm{F}_{\mathrm{r}}=2.1\left(137^{\circ}\right)\right)$, (d) $\left(\mathrm{F}_{\mathrm{r}}=2.3\left(85^{\circ}\right)\right)$,
(e) $\left(F_{r}=1.5\left(134^{\circ}\right)\right)$.

Fig. 103. Force balance on June 21 for

(a) $\left(F_{r}=3.7\left(182^{\circ}\right)\right),(b)\left(F_{r}=3.3\left(207^{\circ}\right)\right)$,

(c) $\left(\mathrm{F}_{\mathrm{r}}^{\mathrm{r}}=4.7\left(174^{\circ}\right)\right),(\mathrm{d})\left(\mathrm{F}_{\mathrm{r}}^{\mathrm{r}}=3.6\left(186^{\circ}\right)\right)$,

(e) $\left(F_{r}=4.5\left(202^{\circ}\right)\right)$.

Fig. 104. Ocean tilt forces, (a) at $0300 \mathrm{Z}$ May 12; (b) at $1200 \mathrm{Z}$ June 16, 1986, when the two largest residual forces were occurred. Dash line indicates only the direction of ocean tilt force.

Fig. 105. Relationship between residual force and ice island movement.

Fig. 106. Relationship between the directions of residual force, ice island movement and wind speed.

Fig. 107. Map of ice shelf area.

Fig. 108. Spatial Distribution of probability of ice shelf calving event. M.S.C. mouth of Sverdrup channel. C.M.I. - Clements Markham Inlet.

Fig. 109. Scatter diagram of the length and width of ice islands. The parallel diagonal lines are for length-width ratios of 1 to 6 . Note that a lagarithmic scale is used for the axes (source: Jeffries et. al. 1988). 
Fig. 110. Assumed length distribution of ice islands newly calved from ice shelves (based on anaiysis of Jeffries et al., 1988).

Fig. 111. Frequency distribution of ice isiand Length-Width (L-W) ratios. The distribution is very similar to that observed for Antarctic tabular icebergs, most of which have L-W ratios between 1 and 2 (Nazarov, 1962 [see Weeks and Mellor, 1978], (source: Jeffries et al. 1988).

Fig 112. Distribution of calved area of ice shelves.

Fig. 113. Sketch of forces acting on an idealized ice island.

Fig. 114. Ratio of form and surface water drag for an ice island in the simulation model.

Fig.11t. Observed time correlation function for geostrophic wind at zero lag. The variances are $\operatorname{var}(\mathrm{u})=\operatorname{var}(\mathrm{v})=4.4 \mathrm{~m}^{2} \mathrm{~s}^{2}$ (from Thorndike, 1982).

Fig. 116. Observed autocovariance function for pressure at space lag $r(\mathrm{~km})$ and tin:e lag $\tau$ (days) (from Thorndike, 1982).

Fig. 117. Simulation mesh for trajectory calculation, $56 \times 51$ elements with 50 $\mathrm{km}$ spacing.

Fig. 118. Simulation mesh for wind calculation, $10 \times 9$ elements with $300 \mathrm{~km}$ spacing.

Fig. 119. Computer program flow chart.

Fig. 120. Random ice island trajectory 1.

Fig. 121. Random ice island trajectory 2.

Fig. 122. Random ice island trajectory 3.

Fig. 123. Random ice island trajectory 4.

Fig. 124. Random :ce island trajectory 5.

Fig. 125. Random ice island trajectory 6.

Fig. 126. Random ice island trajectory 7.

Fig. 127. Random ice island trajectory 8.

Fig. 128. Random ice island trajectory 9.

Fig. 129. Random ice island trajectory 10.

Fig. 130. Random ice island trajectory 11.

Fig. 131. Random ice island trajectory 12. 
Fig. 132. Random ice island trajectory 13.

Fig. 133. Random ice island trajectory 14.

Fig. 134. Random ice island trajectory 15.

Fig. 135. Random ice island trajectory 16.

Fig. 136. Random ice island trajectory 17.

Fig. 137. Random ice island trajectory 18.

Fig. 138. Randorn ice island trajectory 19.

Fig. 13j. Random ice island trajectory 20.

Fig. 140. Random ice island trajectory 21.

Fig. 141. Drift tracks of ice islands T. 3 and Arlis- $I$ in the Arctic Ocean (based on Sackinger and Yan, 1986).

Fig. 142. Random ice island trajectory in fine detailed scale.

Fig. 143. Hobson's Choice Ice Island track showing many small loops (source: Yan, 1.986).

Fig. 144. Frequency of ice island lifetime in the Arctic Ocean (4=year interval of generation).

Fig. 145. Frequency of ice island number in the Arctic Ocean (4-year interval of generation).

Fig. 146. Return period contours (years) of simulated ice islands in the Arctic Ocean.

Fig. 147. Monthly averaged pressure map over the Arctic Ocean for January (source: Colony, 1987).

Fig. 148. Monthly averaged pressure map over the Arctic Ocean for February (source: Colony, 1987).

Fig. 149. Monthly averaged pressure map over the Arctic Ocean for March (source: Colony, 1987).

Fig. 150. Monthly averaged pressure map over the Arctic Ocean for April (source: Cclony, 1987).

Fig. 151. Monthly averaged pressure map over the Arctic Ocean for May (source: Colony, 1987).

Fig. 152, Monthly averaged pressure map over the Arctic Ocean for June (source: Colony, 1987). 
Fig. 153. Nonthly averaged pressure map over the Arctic Ocean for July (source: Colony, 1987).

Fig. 154. Monthly averaged pressure map over the Arctic Ocean for August (source' Colony, 1987).

Fig. 155. Monthly averaged pre sure map over th: Arctic Ocean for September (source: Colony, 1987).

Fig. 156. Monthly averaged pressure map over the Arctic Ocean for October (source: Colony, 1987).

Fig. 157. Monthly averaged pressure map over the Arctic Ocean for November (source: Colony, 1987).

Fig. 158. Monthly averaged pressure map over the Arctic Ocean for December (source: Colony, 1987).

Fig. 159. Annually averaged pressure map over the Arctic Ocean (source: Coiony, 1987).

Fig. 160. Return period contours (years) of simulated ice isiands in the Arctic Ocean ior the case where the annually-averaged pressure field was used throughout the year for wind generation. This is less exact than Fig. 146.

Fig. 161. Return period contours (years) of simulated ice islands in the Arctic Ocean for the case where the Chukchi and Beaufort Sea water currents were set to zero. This is less exact than Fig. 146. 


\section{LIST OF TABLES}

Table 1. Dimensions of old ice islands photographed in July 1984

Table 2. Aerial photographic missions that include ice shelves and landfast sea ice off the north coast of Ellesmere Island

Table 3. Summary data concerning the track of Hobson's Choice ice island in May 1986

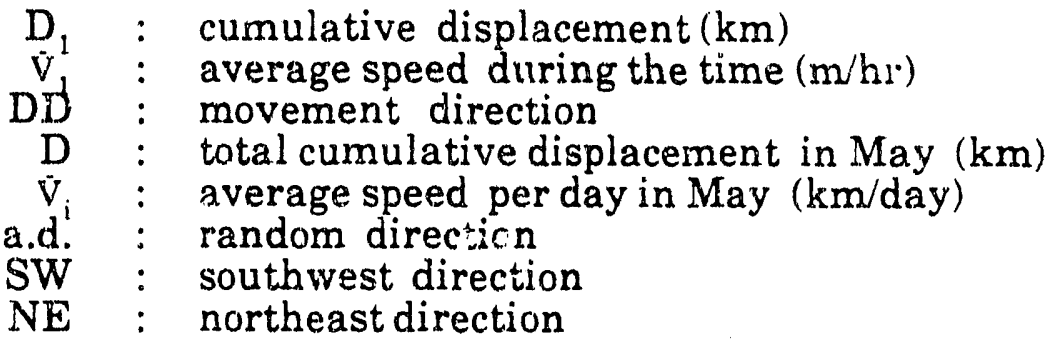

Table 4. Large daily displacements in the period of May 7-16

Table 5. Summary data concerning the track of Hobson's Choice ice island in June 1986

$\begin{aligned} \tilde{V}_{j} & \text { average speed during the time }(\mathrm{m} / \mathrm{hr}) \\ \mathrm{D} & \vdots \text { movement direction } \\ \mathrm{D} & \vdots \text { total cumulative displace nent in May }(\mathrm{km}) \\ \hat{\mathrm{V}}_{\mathrm{i}} & \vdots \text { average speed per day in May }(\mathrm{km} / \mathrm{day}) \\ \text { a.d. } & \vdots \text { random direction } \\ \mathrm{SW} & \vdots \text { southwest direction } \\ \mathrm{NE} & : \text { northeast direction }\end{aligned}$

Table 6. The average daily ice island velocities and average daily surface wind velocities for large movement episodes

$\mathrm{V}_{i}, \theta \quad: \quad$ ice island speed and movement direction

$\mathrm{V}_{\mathrm{s}}, \theta_{\mathrm{s}}:$ surface wind speed and direction

Table 7. The average daily ice island velocities and geostrophic wind velocities for large movement episodes

$V_{i}, \theta:$ ice island speed and movement direction

$\mathrm{V}_{\mathrm{g}}, \theta_{\mathrm{g}} \quad:$ surface wind speed and direction

Table 8 . The average daily surface wind velocities and geostrophic wind velocities for large movement episodes

Table 9. Velocities of surface wind and ice isiand movement in the period May 7-16, 1986

$\begin{array}{ll}\mathrm{V}_{\mathrm{a}} & : \text { surface wind speed } \\ \theta^{\mathrm{a}} & \vdots \text { surface wind direction } \\ \mathrm{V}_{\mathrm{i}} & \vdots \text { ice island movernent speed } \\ \theta_{\mathrm{i}} & : \text { ice island movement direction }\end{array}$

Table 10. Velocities of surface wind and ice island movement in the period June 1421,1986 
Table 11. Frontal area change as a result of change in the direction of ice island movement, for the period May 7-16, 1986

$\mathrm{D}_{\mathrm{i}} \quad$ : ice island movement direction

$A_{f}$ : frontal area of ice island

azi : azimuth of ice island rotation

Table 12. Frontal area change as a result of change in the direction of ice island movement, for the period June 14-21, 1986

$\mathrm{D}_{i} \quad$ : ice island movement direction

Af : frontal area of ice island

azi : azimuth of ice island rotation

Table 13. The force balance for wind shear force $\left(F_{a}\right)$; water shear force $\left(F_{w s}\right)$; drag force due to the frontal area of ice island ( $\left.F_{w p}\right)$; the force due to the acceleration or decceleration $\left(F_{t}\right)$ and the Coriolis force $\left(F_{c}\right)\left(F_{w}=F_{w s}+\right.$ $\mathrm{F}_{\mathrm{wp}}$; force unit: $\mathrm{MN}$ ), in the period of May 7-16, 1986.

Table 14. The force balance for wind shear force $\left(F_{a}\right)$; water shear force $\left(F_{w s}\right)$; drag force due to the frontal area of ict island $\left(F_{w p}\right)$; the force due to the acceleration or decceleration $\left(F_{l}\right)$ and the Coriolis force $\left(F_{c}\right)\left(F_{w}=F_{w s}+\right.$ $F_{\text {wp }}$; force unit: $M N$ ), in the period of June 14-21, 1986.

Table 15. Residual force coefficients for ice island movement

Table 16. $\mathrm{Km}^{2}$ Ice Lost (Gained) Since Previous Observation

Table 17. Frequencies of ejection of ice islands. 


\section{CHAPTER I}

\section{INTRODUCTION AND EXECUTIVE SUMMARY}

(W. M. Sackinger)

The development of offshore oil and gas resources in the Arctic waters of Alaska requires offshore structures which successfully resist the lateral forces due to moving, drifting ice. The annual sea ice, which grows to a thickness of as much as 2 meters each winter, and which melts during the brief summer, usually fragments at the boundary of an offshore structure affixed to the seafloor, or may form ice rubble adjacent to the structure. Multiyear sea ice, formed from the ice rubble and riaging action of earlier years, is a complex blend of thick ridges (up to 52 meters) with partially-consolidated cores (up to about 12 meters), and thinner areas ( 0 to 3 meters,) with surficial melt ponds. Ice islands are floating, tabular icebergs, up to 60 meters thick, of solid ice throughout their thickness. The ice islands are thus regarded as the strongest ice features in the Arctic; fixed offshore structures which can directly withstand the impact of ice islands are possible but in some locations may be so expensive as to make oilfield development uneconomic.

The resolution of the ice island problem requires two research steps: (1) calculation of the probability of interaction between an ice island and an offshore structure in a given region; and (2) if the probability is sufficiently large, then the study of possible interactions between ice island and structure, to discuver mitigative measures to deal with the moving ice island. The ice island researci. conducted during the 1983-1988 interval, which is summarized in this report, was concerned with the first step.

Ice islands originate by calving from floating, partially-grounded ice shelves located along the northern coast of Ellesmere Island, Canada. Analysis of calving records shows random 3 to 5 -year intervals, and thickness categories of 42 meters and 
10 meters to be most common. Movernent along the coast toward the southwest is most likely. Analysis of wind-driven movement episodes shows that short-term ice island trajectories are different from sea ice, due to the larger values of water drag and Coriolis effect for ice islands. Open water on one side and sea ice ridgebuilding on the opposite side are the results. A threshold windspeed of 5 meters/second is needed to initiate a major ice island movement episode. Monte Carlo simulations of ice island generation and movement suggest that ice island lifetimes range from 0 to 70 years, and that $85 \%$ of the lifatimes are less then 35 years. The simulation shows a mean value of 18 ice islands present at any time in the Arctic Ocean, with a $90 \%$ probability of less than 30 ice islands. At this time, approximately 34 ice islands are knowa, from observations, to exist in the Arctic Ocean, not including the 10-meter thick class of ice islands. Return interval plots from the simulation show that coastal zones of the Beaufort and Chukchi Seas, already leased for oil development, have ice island recurrences of 10 to 100 years. This implies that the ice island hazard must be considered thoroughly, and appropriate safety measures adopted, when offshore oil production plans are formulated for the Alaskan Arctic offshore. 


\section{CHAPTER II}

\section{ICE ISLAND SOURCES}

(M. O. Jeffries)

Ice islands are large, tabular icebergs which have broken away from floating ice shelves. In the northern hemisphere, the major source region is the northern ccast of Ellesmere Island, but other possible sources include the fjords of northern Greenland, and the coasts of Svalbard, Zemlya Frantsa Josifa, and Svernaya Zemlya. The timeaveraged drift direction of ice in the Arctic Ocean, shown in Figure 1, moves ice from the latter locations into the Barents and Greenland Seas, whereas ice islands from northern Canada are carried to Alaskan coastal regions. Therefore, the Ellesmere Island source region is believed to be the dominant source of ice islands which appear in Alaskan waters, and was the focus of the research program.

The literature of polar exploration in the northern hemisphere contains many references to exceptionally large ice floes that, in the light of present knowledge, might be considered to have been ice islands (cf. Dunbar, in Koenig et al., 1952). Descriptions by explorers such as Peary and Storkerson, Cook and Greely can be interpreted as ice islands, but of course there is no way to check these ground-level observations. It was not until the advent of aerial reconnaissance that the existence of these unique drifting ice features was recognized.

On 14 August 1946, the crew of a USAF Arctic Ocean reconnaissance flight found a large heart-shaped ice mass floating amongst the pack ice at $76^{\circ} 15^{\prime} \mathrm{N}$, $160^{\circ} 15^{\prime} \mathrm{W}$ (Figure 1). This piece of ice became known as T-1 and was about $29 \times 24 \mathrm{~km}$ with an area of about $500 \mathrm{~km}^{2}$ (Koenig, in Koenig et al., 1952). This was the first ice island seen in modern times, and was observed for three years, during which it moved a distance of over $2240 \mathrm{~km}$ at an average rate of $1.92 \mathrm{~km} /$ day.

On 21 July 1950 , a second, $700 \mathrm{~km}^{2}$ ice island (T-2) was found at $86^{\circ} 40^{\prime} \mathrm{N}$, $167^{\circ} 00^{\prime} \mathrm{W}$ (Figure 1). Eight days later, ice island T-3 was discovered at $75^{\circ} 24^{\prime} \mathrm{N}$, 


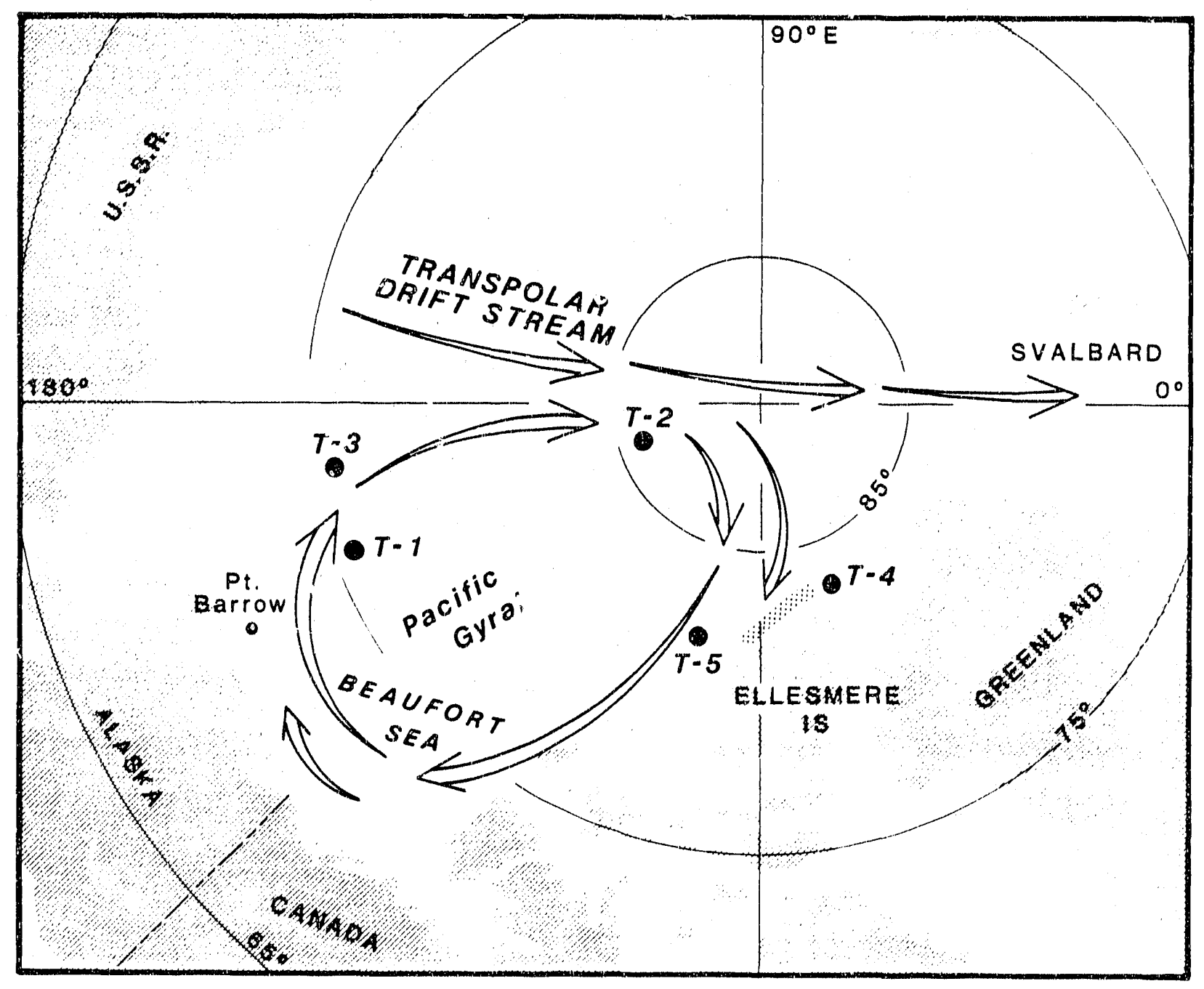

Figure 1. Map of the Arctic Ocean showing the location of Arctic Ice shelves off the north coast of Ellesmere Is!and (shaded), ice islands T.1 to T.5 and the Pacific (or Beaufort) Gyral and Transpolar Drift Stream (after Jeffries 1987). 
$173^{\circ} 00^{\prime} \mathrm{W}$ (Figure 1). The ice island $\mathrm{T}-3$ was kidney-shape and much smaller than $\mathrm{T}$ 1 and T-2, with dimensions of about $8 \times 16 \mathrm{~km}$. In 1947 and 1948 , unsuspecting observers photographed ice island T-4 and T-5 respectively, but they were not recognized until later. T-4 was "discovered" $8-16 \mathrm{~km}$ off Cape Columbia, northern Ellesmere Island, while T-5 was about $160 \mathrm{~km}$ northwest of Cape Stallworthy, Axel Heiberg Island (Figure 1). Soon after the sighting of T-2 and T-3, twenty-eight ice islands were recognized on RCAF air photographs of the Canadian Arctic Archipeiago. The ice islands, scattered throughout the inter-island channels, varied in size from 0.4 to $14 \mathrm{~km}$ across (Koenig et al., 1952).

From the air, the ice islands were readily distinguished from the pack ice by their size and a strikingly-regular surfane pattern (Koenig et al., 1952). The surface of each ice island had an undulating topography of ridges and troughs. The ridges (or rolls) were thought to be as much as $800 \mathrm{~m}$ from crest to crest and were roughly parallel, running from one end of the island to the other.

By spring 1951, photographs and reports from Canadian observers suggested that the ice islands might have originated from the north coast of Ellesmere Island. In March 1951, a USAF reconnaissance flight observed that much of the coastline of northern Ellesmere Island, from Nansen Sound to Ward Hunt Island (Figure 2), was covered with undulating ice similar to that of T-3 (Koenig, in Koenig et al., 1952). After a similar flight in August 1951 it was concluded that the ice islands could have originated from the ice shelves off the northern shore of Ellesmere Island.

The ice islands described above were the first of many to be sighted in the Arctic Ocean. Since 1946 there have been an estimated 465 (maximum) ice island sightings (Jeffries, 1985a). It is probable that most of the ice islands, large or small, originated from the ice shelves of northern Ellesmere Island and thus it is logical to assume that the ice shelves were once more extensive than they are today. It is worthwhile, therefore, to consider evidence of the former extent and subsequent disintegration of 


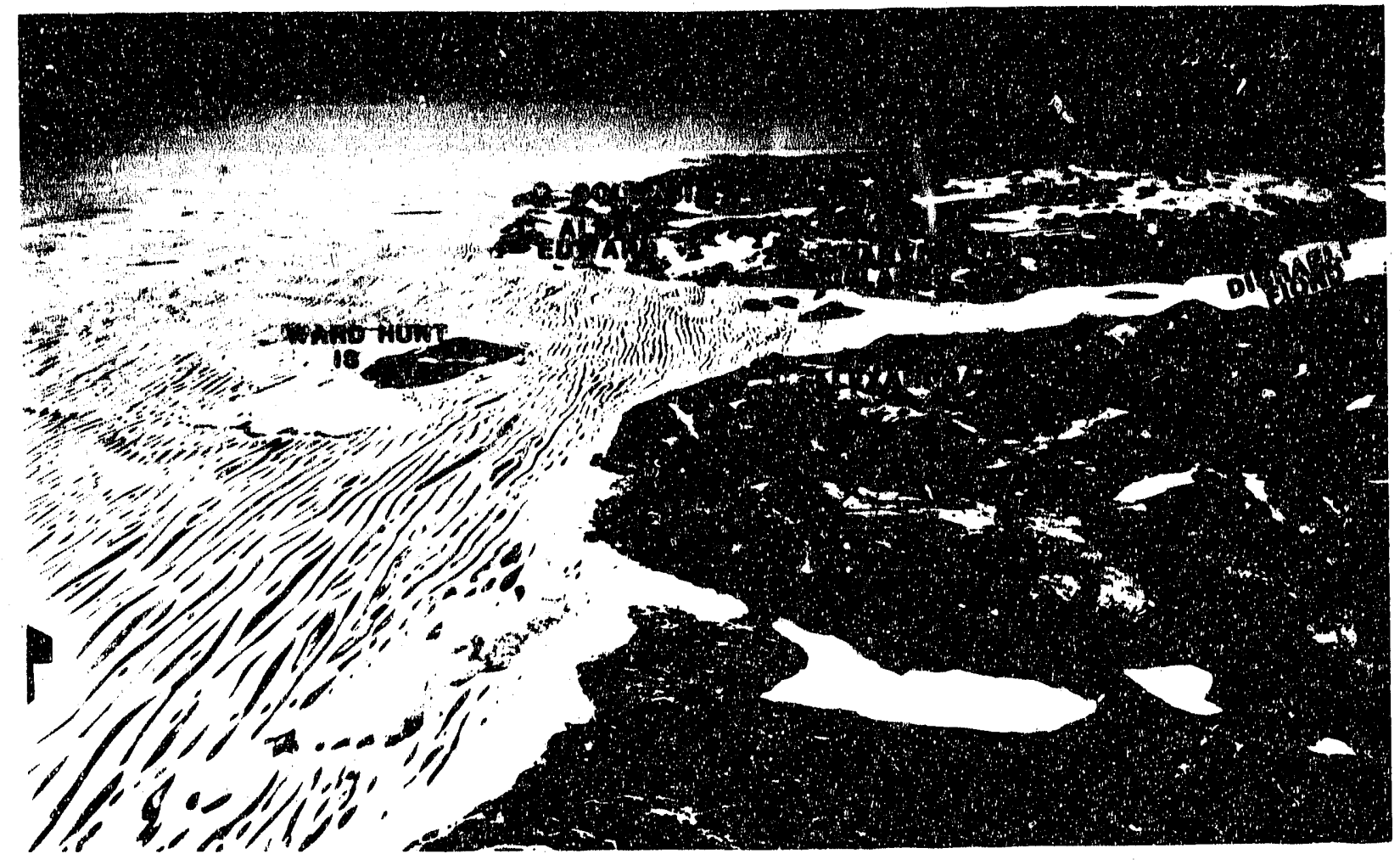

FIGURE 2. Oblique aerial photograph looking east across Ward Hunt lce Shelf, taken by the RCAF from $9144 \mathrm{~m}(30,000 \mathrm{ft}$.) in August 1950. Note the undulating surface of the ice shelf that is revealed by meltwater in the troughs creating a dark tone between linear ridges (Air photograph T404L-4, available from the National Air Photographic Library, Ottawa, Ontario). 
Arctic ice shelves. In the interval 1876-1906, there was exploration of the north coast of Ellesmere Island, beginning in spring 1876 when Lieutenant Pelham Aldrich, R.N., led a man-hauled sled expedition along the coast from Cape Sheridan $(110 \mathrm{~km}$ east of Point Moss, Figure 3) to Alert Point. In his report of the journey over the ice he often described the travel over humrocks and heavy floes. From a camp at Cape Albert Edward, Aldrich described the scene over the "ice rollers and ridges" across to Cape Alexandra (Figure 2) as follows;

"Several low ridges from 30 to 40 feet high, and varying from a few hundred yards to about a mile in length, show up in front of the cliffs. Their general direction being SE to NW, hence on the east coast of the bay (Dissaeli Fiord) to the southwestward they are nearly parallel with it. I imagine these ridges are composed of hard ice under the snow... (Parliamentary Paper, 1877, p.201-202). As the party passed between Ward Hunt Island (Figure 2) and the mainland, Aldrich notes, "...we crossed a ridge about 30 feet high, and a half mile in width, which runs quite a mile from about the middle of the south shore (of the island)... Similar looking ridges extended to the eastward and westward of the island." (Parliamentary Paper, 1877, p.201-202). What Aldrich describes are the ridges and troughs on Ward Hunt Ice Shelf that show very clearly in Figure 2.

Not until the spring and summer of 1906 was there further exploration of the north coast of Ellesmere Island. At this time, Commander Robert Peary, U.S.N., led a dogsled expedition westward from Cape Sheridan to Axel Heiberg Island (Figure 3), Peary described features that are now known to be ridges and troughs. From a camp west of Point Moss (Figure 3), Peary described the first encounter with, "What later became a constant and striking feature of the glacial fringe, the long, prairie-like swells of its surface.... The swells which were traversed coming from Point Moss, showed up beautifully...... as parallel swells following the main contour of the shore" (Peary, 1907, p.181). A little to the west of Cape Alexandra (Figure 2), Peary notes 


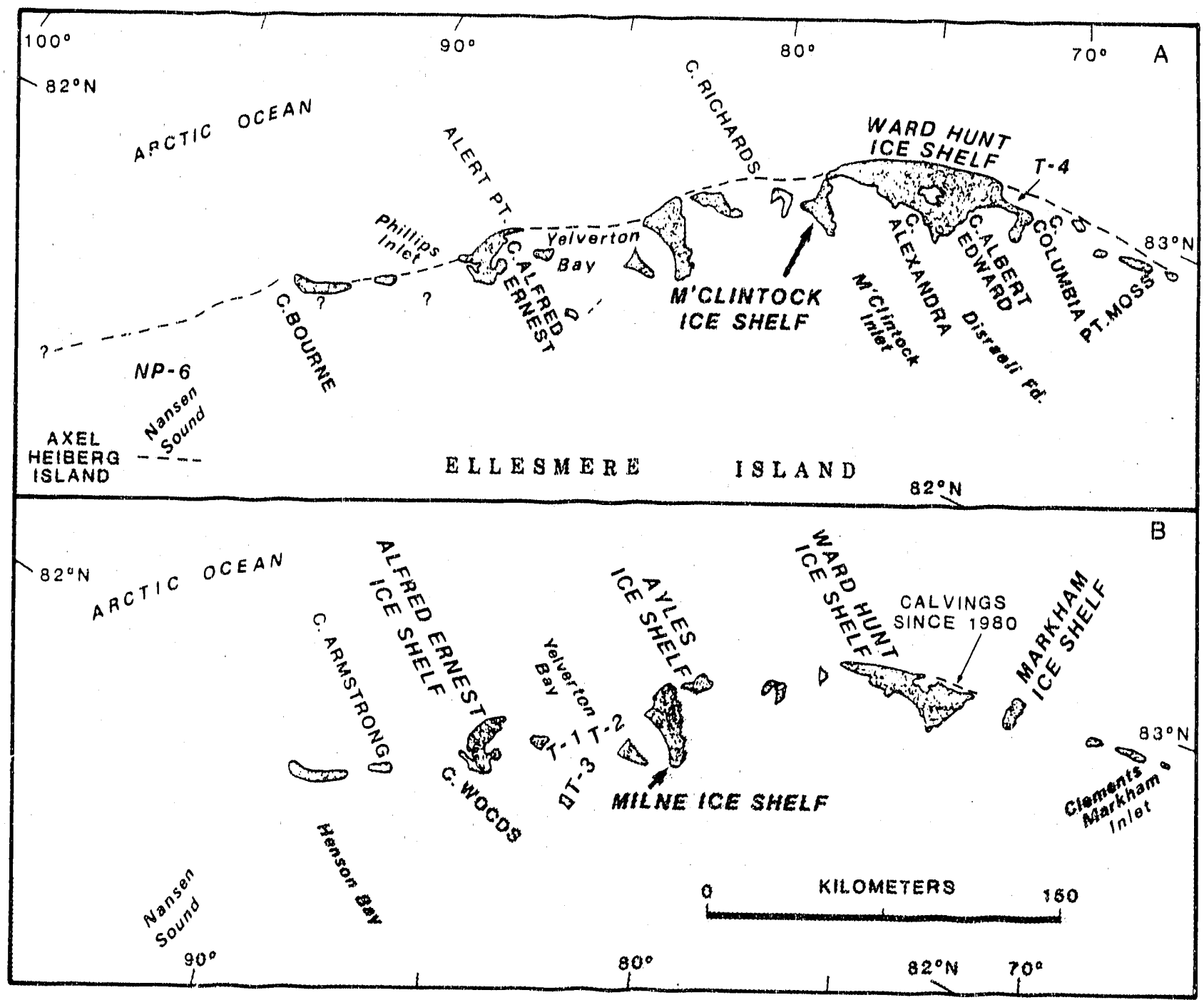

Figure 3. Maps of ice shelf disintegration and changes in ice shelf extent, 1906-1985. (A): Shaded areas represent those ice shelves that remained in 1960 after ice calvings since 1906 (dashed line). Question marks denote uncertainties in ice shelf extent. (B): Ice shelf extent in 1985 (after Jeffries 1987). 
the difficulty of the travel which, ".... Nas accentuated in the series of rolling swells which are a feature of this peculiar ice-foot (?) along here. These swells are on a large scale..... If they are not huge drifts I did not know how to account fo." them. Off Ward Hunt Island and especially the western end, they are particularly marked, and here they blend into drifts formed in the lee of the island." (Peary, 1907, p.185). On the return journey from Axel Heiberg Island in late July, Peary writes of the ice near Cape Columbia (Figure 2), "Coming back over the bluffs, to our camp the orography of the glacial fringe both east and west was very strongly brought out by the streams and blue lakes which filled every depression and furrow" (Peary, 1907, p.231).

Aldrich and Peary did not know it at the time, but they were traveling over what later became known as the Ellesmere Ice Shelf. Although not very detailed, the accounts of both Aldrich and Peary provide enough evidence on which to base a reconstruction of former ice shelf extent (Figure 3A). Furthermore, the extent of the ice shelf between Point Moss and Cape Richards has been quite accurately mapped according to the location of ocean depth soundings taken in the summer of 1906 by Ross Marvin, a member of Peary's expedition (Bushnell, 1956).

Aldrich mentions "rollers" particularly at Disraeli Bay, M'Clintock Bay (Inlet), Yelvertun Bay and near Cape Alexandra (Figure 3). The descriptions by both Aldrich and Peary of the ice (Ward Hunt Ice Shelf) in Disraeli Bay (Fiord) suggest that the ice shelf was in the same position in 1906 as it was in 1876. In Yelverton Bay, both explorers give the impression that it too was full of "rollers" (Dunbar, in Koenig et al., 1952). Aldrich (Parliamentary Paper, 1877, p.213) writes "Looking back on the bay (Yelverton), I observed a series of ice rollers, two of which we crossed yesterday." As will be shown in the next section, the ice shelf in Yelverton Bay no longer exists.

In 1906, Peary traveled beyond Yelverton Bay as far west as Axel Heiberg Island and described undulating ice surfaces all the way around the coast (Dunbar, in Koenig et al., 1952). Beyond Cape Alfred Ernest (Figure 3A), "we were up above sea 
level on the undulating surface of the glacial fringe" (Peary, 1907, p.190). "The surface of the glacial fringe..... was intersected with narrow wate: cracks which seemed to delineate the larger swells...." (p.191). "The ice traversed... was a succession of swells of moderate height. The light and shade after the sun came out, allowed the undulations of this remarkable ice-foot to be very clearly seen" (p.201). "I then headed across the strait (Nansen Sound) to the northern extremity of the western land (Axel Heiberg Island). The ice in the strait; was to all appearance a continuation of that forming the glacial fringe of the Grant Land coast" (p.203).

It is quite clear that the "glacial fringe" or Ellesmere Ice Shelf extended all the way along the north coast of Ellesmere Island from Point Moss to Nansen Sound (Figure 3A). Furthermore, it extended a considerable distance offshore in some places. Spedding (1977) estimates that the Ellesmere Ice Shelf had a maximum area of about $7500 \mathrm{~km}^{2}$.

From 1906 to 1953 , reports from the region are few. In 1959 and 1960 an aerial photographic survey of the north coast of Ellesmere Island was completed by the RCAF。Canadian National Topographic Survey maps were subsequently produced from the photographs and ground survey. The maps showed little ice shelf change between 1960 and 1953/54 when G. Hattersley-Smith of the Defence Research Board of Canada had led two expeditions that explored the coast between Cape Sheridan and Nansen Sound (Hattersley-Smith, 1955). These expeditions found the Ellesmere Ice Shelf to be much less extensive than it was in 1906 ancl it was clear that there had been a considerable loss of ice. The extent of the ice shelves is shown in Figure 3A.

Ice islands T-1 to T-5 undoubtedly owed their existence to the disintegration of part of the Ellesmere Ice Shelf, but the time and location of calving is subject to speculation. Of these five ice islands, the origins of T-3 and T-4 are defined with most confidence. Ice island T-3 not only had undulating topography, but there was also misch rock material on the ice surface that might have originated from the shores of 
Yelverton Bay (Hattersley-Smith, 1957). Crary and Cotell (1952) identified ice in T-3 that might have come from one of the glaciers that reach tide-water in Yelverton Bay. Analysis of T-3 rocks indicated Cape Bourre or Yelverton Bay to be the most likely sources (Stoiber et al., 1960; Muguruma and Higuchi, 1963). Polunin (1955) suggested that T-3 calved after the summer of 1935 and Crary (1960) mapped a likely location in Yelverton Bay (Figure 3B). Ice island T-4 almost certainly calved from the east end of Ward Hunt Ice Shelf, near Cape Columbia (Figure 3A) in 1947 (Greenaway, in Koenig et al., 1952).

With the exception of T-4, ice islands T-1 to T-5 were all located in the Beaufort Gyre (Figure 1). Ice island drift patterns will be discussed in greater detail in a later section, but one may note that it takes about ten years for a piece of ice to complete a full, outer circuit of the Gyre (Dunbar and Wittman, 1963). Furthermore, it has been estimated (without substantial evidence) that there is a $50 \%$ probability (Crary, 1958), even a 70\% probability (de Paoli et al., 1952), of an ice island escaping the gyre during those ten years. This kind of assumption will be discussed in connection with trajectory simulations in a later section. This information can be used to estimate the time of calving. Each of the ice islands was large in area, not only because they had calved from a once-extensive ice shelf, but also, it is suggested, because they had calved only a few years (perhaps weeks in the case of T-4) prior to their discovery. Larger ice islands disintegrate for two reasons; 1 ) they melt and become thinner as they circulate, and 2) they ground and break up in shallow water (Jeffries, 1985a). This had not happened to T-1. to T-5, possibly because they were still in their first or second circuit of the gyre. The position at which T-3 was located in 1950 is about halfway round the gyre, i.e., about 5 years from source. Therefore, perhaps T-3 calved about 1935 or 1945 . The position at which T-1 was discovered in 1946 (Figure 1) is about 4 to 5 years from source, i.e., it may have calved in 1941 or 1942 , or a decade earlier. The position of T-2 in 1950 is about 8 or 9 years from source and it 
also, therefore, calved in 1941 or 1942 or a decade earlier. If they did calve simultaneously, it is quite possible that they broke out of Yelverton Bay since this area is large enough to contain such a large ice mass (Figure 3). The only other likely location for a large calving is from the mouth of Nansen Sound (Figure 3). However, it has been suggested that the ice plug in the mouth of Nansen Sound dates from 1932, when it replaced the ice shelf that calved and created ice island NP-6 (Serson, 1972). Ice island T-5 was located one to two years away from source and thus probably calved in 1946 or 1947.

If one makes the assumption that T-1 to T-5 had not completed full circuits of the gyre when they were discovered, then a considerable ice shelf disintegration occurred during the relatively brief period 1941-46. There is additional evidence to support this possibility.

It has been shown that since 1906 Ward Hunt Ice Shelf suffered a period of net surface melting that probably caused ice shelf thinning (Hattersley-Smith, 1955; Hattersley-Smith and Serson, 1970). The climatic warming that brought about the large surface ice losses began in about 1925 and continued to a maximum in 1940 (Hattersley-Smith, 1963a). This has since been confirmed by ice core studies on Devon Island ice cap which is representative of other High Arctic ice caps, $90 \%$ of the time (Koerner, 1977). The Little Climatic Optimum between 1925 and 1940 could have led to a considerable thinning of the Ellesmere Ice Shelf. Exceptional meteorological and oceanographic factors could then combine with these conditions to cause an almost catastrophic disintegration of a large part of the ice shelf, so that it contracted to the extent shown in Figure 3a.

Although the greatest ice island calving activity in the past century occurred prior to 1950 , there have been numerous, occasionally large, breakaways during the past 25 years. The last, very large disintegration occurred some time between August 1961 and April 1962 at Ward Hunt Ice Shelf (Hattersiey-Smith, 1963b). An 
estimated $596 \mathrm{~km}^{2}$ of ice shelf, with a volume of 18 to $24 \mathrm{~km}^{3}$, became detached and formed 19 ice islands. Five of these (WH-1 to WH-5) were very large, with areas ranging from $70 \mathrm{~km}^{2}$ to $140 \mathrm{~km}^{2}$.

In April 1966, during a flight along the north coast of Ellesmere Island, Hattersley-Smith (1967) observed that both M'Clintock Ice Shelf (Figure 3A) and Ayles Ice Shelf (Figure 3B) were virtually non-existent. There is no doubt about the break-up of M'Clintock Ice Shelf which occurred during the interval April 1962 and April 1966 (Hattersley-Smith, 1.963b; 1967). However, it has since been shown that although an ice island $(10 \times 1.5 \mathrm{~km})$ calved from the front of Ayles Ice Shelf at some time between 1959 and 1974, Ayles Ice Sheif remains in the mouth of Ayles Fiord (Figure 3B and Figure 4) (Jeffries, 1986).

In May 1982, the presence of apparently "flat ice" was noted at the northwest edge of Milne Ice Shelf (Jeffries, 1982). This area of ice (Figure 5) has subsequently been shown to be $\leqq 10 \mathrm{~m}$ thick, which is much thinner than the adjacent Milne Ice Shelf (Prager, 1983). Comparison of zir photographs taken in 1959 and 1974 has shown that a $35 \mathrm{~km}^{2}$ ice island calved from NW Milne Ice Shelf at some time between July 1959 and July 1974 (Figure 3) (Jeffries, 1986). The calving event has since been dated at 1965, at the latest (Jeffries and Krouse, 1988). It has also been suggested that the disintegration of M'Clintock Ice Shelf and the movement of Ayles Ice Shelf occurred at much the same time (Jeffries, 1985b).

In April 1967, two ice islands, later named WH-6 and WH-7 (Lindsay et al., 1968), were sighted and reported as being only $10-30 \mathrm{~m}$ off the extreme western end of Ward Hunt Ice Shelf (U.S. Navy, 1968). It seems likely that at the time of sighting the ice islands were still located close to their point of origin, i.e., Ward Hunt Ice Shelf or perhaps M'Clintock Inlet. Further, small ice losses occurred in 1973-1974 at Ward Hunt Ice Shelf (Serson, 1984). 


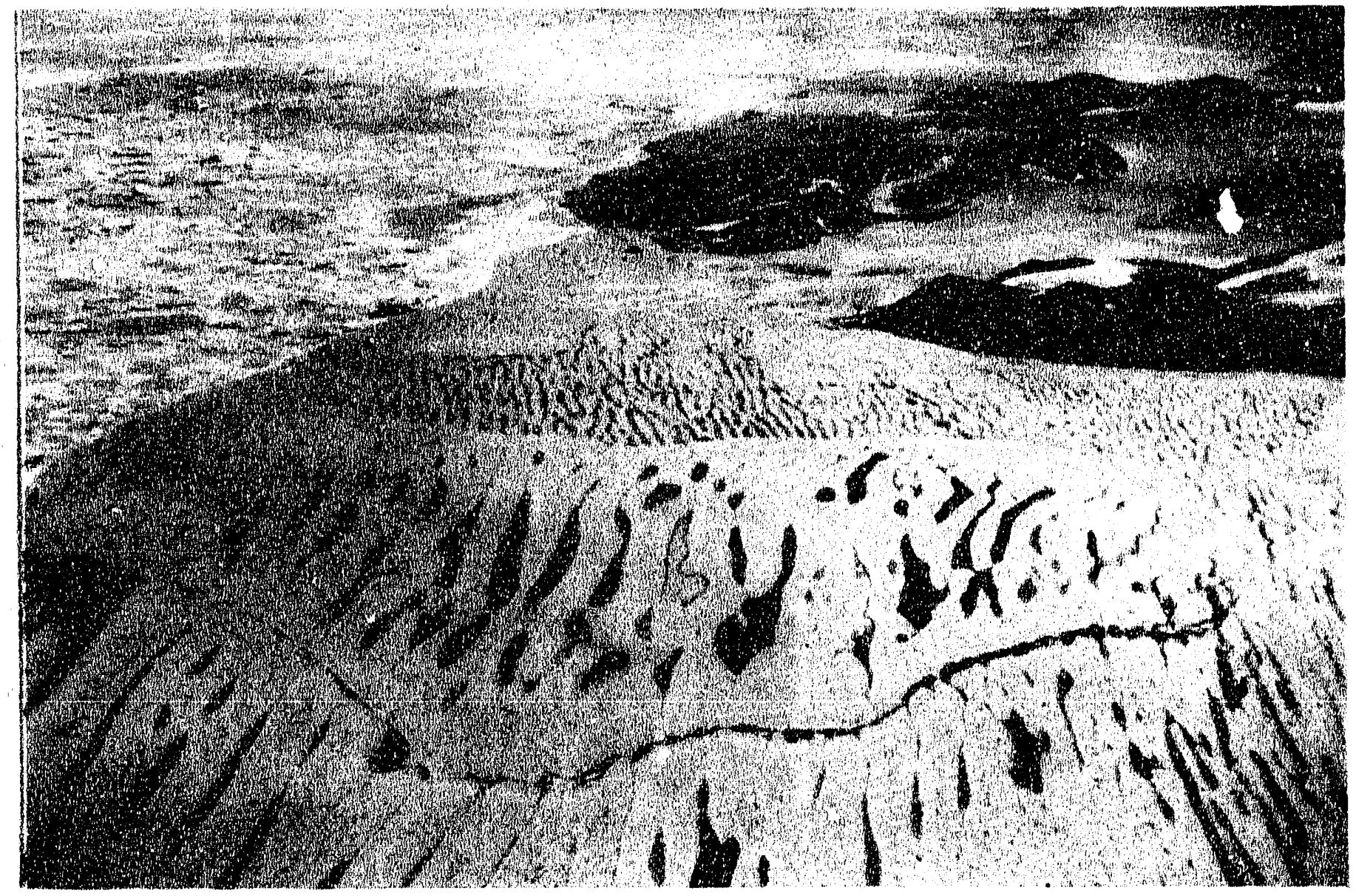

FIGURE 4. Oblique aerial view from 3048 meters looking east across Ayles Ice Shelf and multiyear landfast sea ice at the mouth of Ayles Fjord, July 23, 1984. 


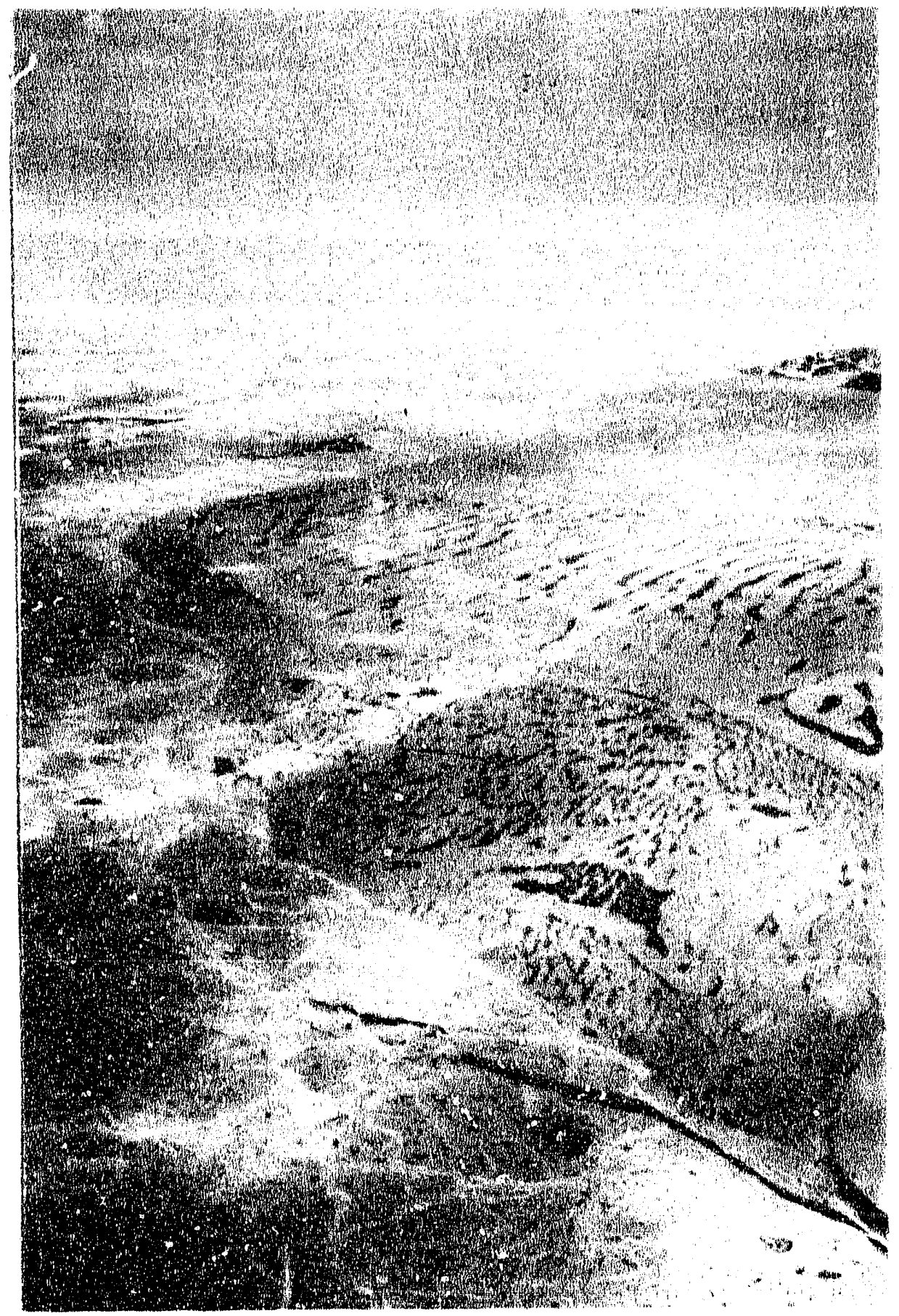

FIGURE 5. Oblique aerlal view from 3045 meters looking east across the front of Milne Ice Shelf showing the 10-meter-thick multiyear landfast sea ice of the Milne re-entrant in the right foreground, July $23,1984$. 
Table 1. Dimensions of old ice islands photographed in July 1984.

\begin{tabular}{|c|c|c|c|}
\hline Ice Island I.D. & Length(km) & Width $(\mathrm{km})$ & Area $\left(\mathrm{km}^{2}\right)$ \\
\hline $84-1$ & 0.07 & 0.06 & 0.005 \\
\hline $84-2$ & 0.07 & 0.06 & 0.003 \\
\hline $84-3$ & 0.23 & 0.06 & 0.02 \\
\hline $84-4$ & 0.59 & 0.17 & 0.075 \\
\hline $84-5$ & 0.34 & 0.12 & 0.03 \\
\hline $84-6$ & 0.79 & 0.39 & 0.25 \\
\hline $84-7$ & $*$ & $*$ & $*$ \\
\hline $84-8$ & 0.16 & 0.12 & 0.02 \\
\hline $84-9$ & 0.28 & 0.12 & 0.03 \\
\hline
\end{tabular}

*No data avanlable.

The most recent and known ice island calvings have occurred since 1980, all from Ward Hunt Ice Shelf. Between spring 1980 and April 1982. 35-40km² of shelf ice calved and/or grounded at the extreme western end of the ice shelf (Jeffries, 1982). Since 1982, eight islands, with a total area of abut $40 \mathrm{~km}^{2}$, have calved from the east end of the ice shelf between Ward Hunt Island and Cape Albert Edward (Figure 3B) Jeffries and Serson, 1983). The largest of those ice islands (Hobson's Choice) was about $10 \times 4 \mathrm{~km}$ in size at the time of discovery. It is now the site of a research station operated by the Canadian Polar Continental Shelf Project.

Arctic ice shelf extent in spring 1985 is shown in Figure 3B. The major ice shelves that remain are Ward Hunt Ice Shelf, Ayles Ice Shelf, Milne Ice Shelf, Alfred Ernest Ice Shelf and Markham Ice Shelf (the latier two are unofficial names). Little is known about Alfred Ernest Ice Shelf except that a $2.5 \times 5 \mathrm{~km}$ ice island brolse away from the southwest edge near Cape Woods (Figure 3). This was first noted by M.O. Jeffries and H. Serson during a ground survey in spring 1984, and subsequent analysis indicates that the calving probably occurred during the interval 1950-59. 
Also included in Figure 3 are ice shelves at Cape Armstrong and Henson Bay. During the 1984 ground survey it was belitved that these ice shelves remained in place. In order to carefully determine the ice shelf extent on major ice shelves, an aerial photography mission was undertaken on 22nd and 23rd July, 1984, to obtain oblique and vertical air photographs of the ice along the north coast of Ellesmere Island. The work was undertaken with the support of the Polar Continental Shelf Project (Canada); Mr. David Terroux (Surveys and Mapping; Energy, Mines and Resources, Canada) operated the aerial camera and the Twin Otter aircraft was piloted by Mr. Ken Lee and Mr. Richard Duncan of Bradley Air Services. Oblique photography was by M.O. Jeffries and W.M. Sackinger. Vertical air photographs were obtained from an altitude of $3048 \mathrm{~m}(10,000 \mathrm{feet})$. Ten photo-mosaics have been assembled which cover the coastal margin, from Stuckberry Point/Point Moss to the Alert Point Ice Field (Figure 1).

\section{MOSAIC I}

Mosaic I has a scale of $1: 94,530$ and covers $22.5 \mathrm{~km}$ of coast west of Stuckberry Point. There are many large multiyear ice floes and there is a considerable amount of open water, which suggests a wind from the land with ice motion away from shore. The movement of the pack ice away from the shore makes it easier to distinguish the landfast ice. Most of the ice in this mosaic is multiyear landfast sea ice (MLSI), but there are some small pieces of shelf ice. A small area of shelf ice is visible in the bay between Point Moss and Stuckberry Point. There are more numerous pieces of shelf ice, with a dark gray or apparently dirty surface, in Moss Bay, immediately west of Point Moss. The pieces of shelf ice show some evidence of the undulating topography that characterizes Arctic ice shelves in general and which is more apparent in later mosaics. Also in this mosaic there are linear melt-pools apparent on the surface of the MLSI, particularly in western Moss Bay, at the left of the mosaic. As with the ice 





shelf undulations, which are most obvious in the summer due to the pooling of meltwater in linear lakes, the linear melt-pools on MLSI are more apparent in later mosaics.

\section{MOSAIC II}

Mosaic II has a scale of $1: 94,740$ and covers $22 \mathrm{~km}$ of coast between Good Point and Cape Aldrich. This mosaic shows only the outer part of Doidge Bay which is occupied by MLSI, on which there is some development of linear melt-pools. The inner part of Doidge Bay (just off the lower edge of the mosaic) contains a piece of shelf ice (see Figure 1.15, 4 th Quarterly Report, Sackinger and Stringer, 1984).

A large part of Parr Bay, particularly in the western part towards Cape Aldrich, is occupied by shelf ice. The ice has a dark gray or dirty surface, similar to that of the shelf ice in Moss Bay (Mosaic I) and a small area of eastern Ward Hunt Ice Shelf, adjacent to Ward Hunt Island (see Figures 22, 23, 5th Quarterly Report, Sackinger and Jeffries, 1985). Sackinger and Jeffries (1985) listed three possible ways in which the ice can become so dirty. Of these three, it is now thought that the most likely reason for the dirty ice is the adfree ing of frazil or anchor ice at the bottom of the ice. If the ice accreting at the bottom of the ice shelf contains significant quantities of dirt and debris then, given sufficient time when bottom accretion is balanced or exceeded by surface ablation, the dirt and debris will appear at the ice surface.

As in Mosaic I, numerous large multiyear ice floes and open leads are evident offshore.

\section{MOSAIC III}

Mosaic III has a scale of $1: 76,730$ and covers $17.5 \mathrm{~km}$ of coast between Cape Columbia and Cape Nares. The major ice feature in this area is the Markham Ice Shelf which occupies Markham Fiord. A very small ice shelf also occupies the bay immediately east (right) of Markham Ice Shelf. 


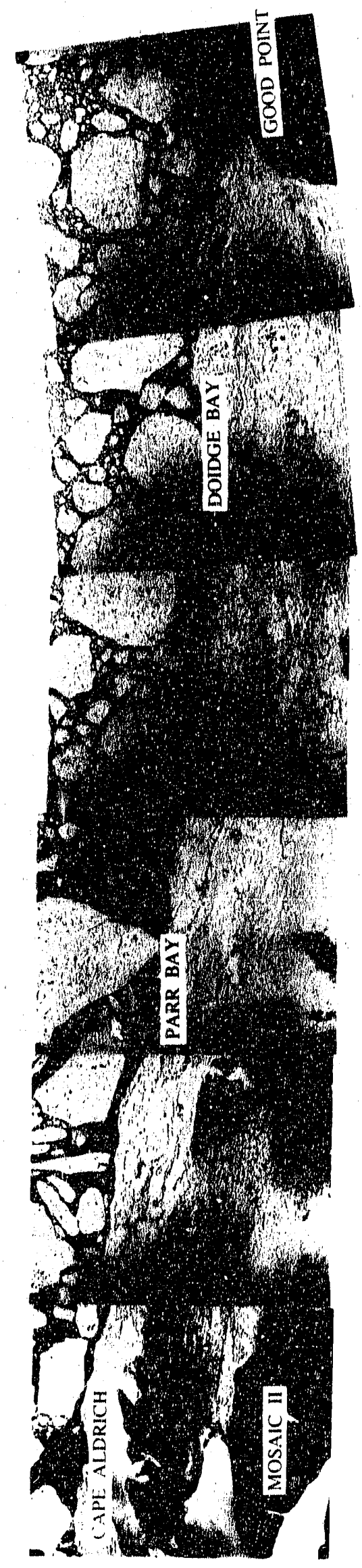




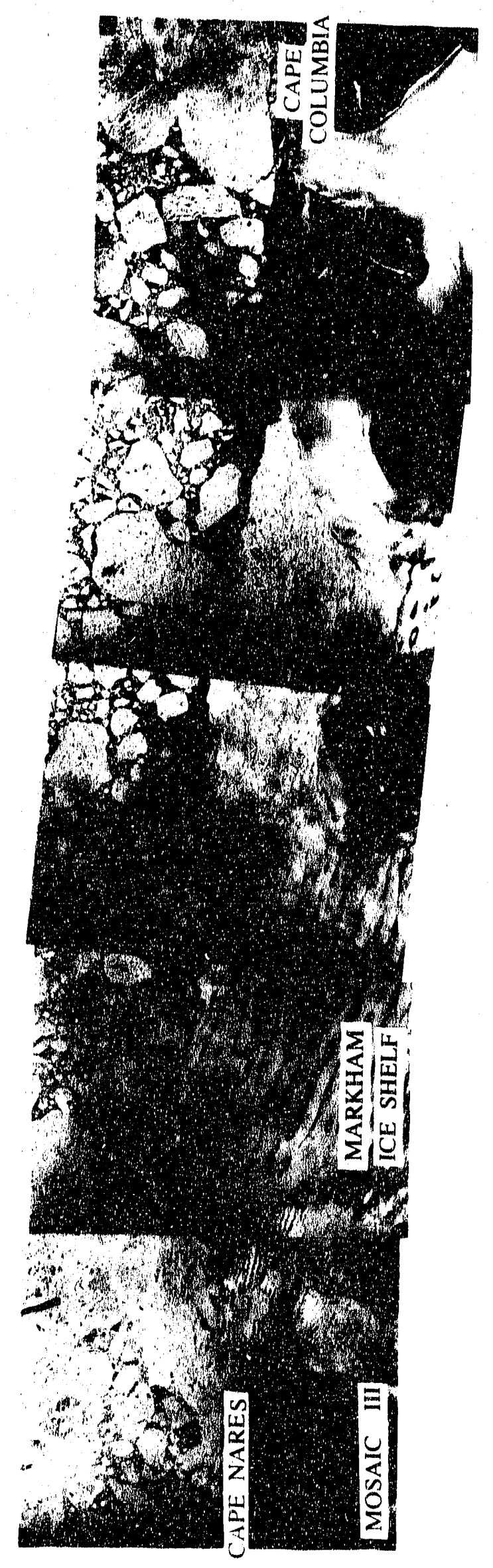


Unlike the shelf ice described in the previous mosaics (I and II), the surface of Markham Ice Shelf is relatively clean. Also, the linear development of the meltwater lakes on the undulating ice shelf surface is clearly visible. Linear melt-pools have also developed on the MLSI adjacent to Cape Nares; this is in contrast to the meltpools on the multiyear ice floes in the offshore pack ice. It is also noted that the orientation of the MLSI melt-pools at Cape Nares is not constant; some of the meltpools clcse to the shore apparently curve around Cape Nares. A similar melt-pool phenomenon occurred on the former M'Clintock Ice Shelf at Borup Point (see Figure 3, 6th Quarterly Report, Sackinger and Jeffries, 1985a). The exact cause of this changing melt-pool orientation is not known, but it is possibly related to local wind direction changes associated with the steep headlands or capes.

Apart from the MLSI at Cape Nares, there is little other MLSI development evident. A narrow fringe of MLSI exists along the front of eastern Markham Ice Shelf and also at the front of the other small ice shelf. There is no MLSI fringe along the Cape Columbia foreshore, where only a narrow ice-foot exists. In the centre of the mosaic there is a broad, triangular accumulation of pack ice off the small headland. If this were to remain fast for a number of years, it would be considered to be MLSI. At the time this mosaic was taken (July 1984), this area of ice was probably relict only to the previous winter, at most.

\section{MOSAIC IV}

Mosaic IV has a scale of $1: 84,100$ and covers $20.5 \mathrm{~km}$ of coast between Cape Albert Edward and the Ward Hunt Ice Rise. The Ward Hunt Ice Rise is located at the northern side of Ward Hunt Island. They both occur at about the centre of Ward Hunt Ice Shelf and thereby divide the ice shelf into an eastern part and a western part. This mosaic shows the outer part of eastern Ward Hunt Ice Shelf. 


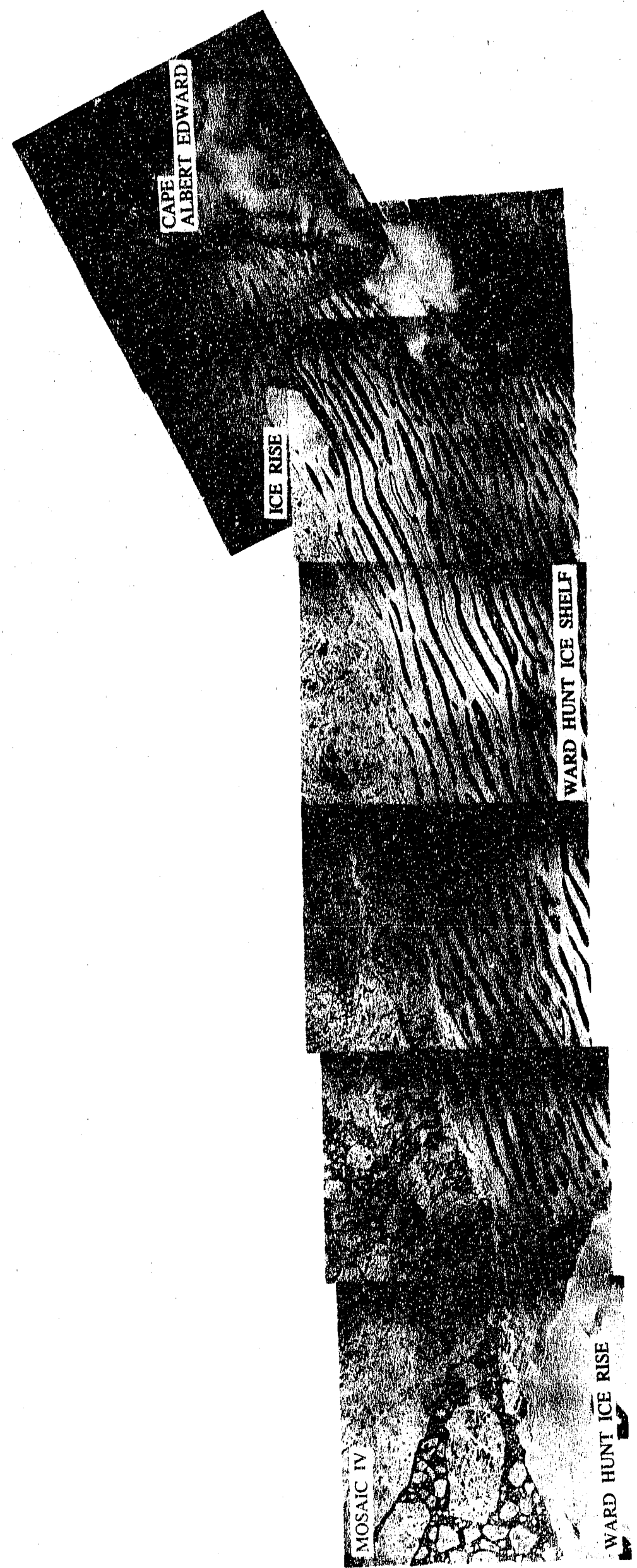


Like the Markham Ice Shelf, the relatively clean ice surface with an undulating topography of elongate meltwater lakes and intervening ridges or hummocks is clearly visible. The eastern part of Ward Hunt Ice Shelf is significant because it was from here that a number of ice islands calved in 1982-83. At that time, ice calved from the entire ice front between Cape Albert Edward and the Ward Hunt Ice Rise. A further, smaller calving occurred in $1983-84$ along $2.5 \mathrm{~km}$ front between Cape Albert Edward and the small ice rise to the west (see Figures $6 \& 27,5$ th Quarterly Report, Sackinger and Jeffries, 1985).

During over-ice traverses of this region in spring 1984, 1985 and 1986, M.O. Jeffries and H.V. Serson observed very little post-calving fast ice development since May 1983 at the front of the eastern ice shelf. The previous MLSI fringe was carried away with the ice islands and was probably similar to that visible in Mosaic V of western Ward Hunt Ice Shelf.

\section{MOSAIC V}

Mosaic V (A, B and C) have a scale of $1: 94,000$ and cover approximately $40 \mathrm{~km}$ along the front of western Ward Hunt Ice Shelf from Ward Hunt Ice Rise to Cape Discovery Ice Rise. Each mosaic has two common features: 1) the characteristic undulating topography of elongated meltwater lakes separated by ice hummocks and; 2) a fringe of MLSI along the ice shelf front. The MLSI itself is most extensive towards the Ward Hunt Ice Ilise (Mosaic V) where the melt-pools are also developing an elongate topography. Probably the best MLSI melt-pool development is visible at the centre of Mosaic VA (see also Figure 27, 5th Quarterly Report, Sackinger and Jeffries, 1985).

Mosaic VB is significant because of the presence of a number of small old ice islands embedded in the pack ice off the front of the ice shelf. Six ice islands are outlined on Mosaic VB. A seventh ice island (84-7) was observed a little further 

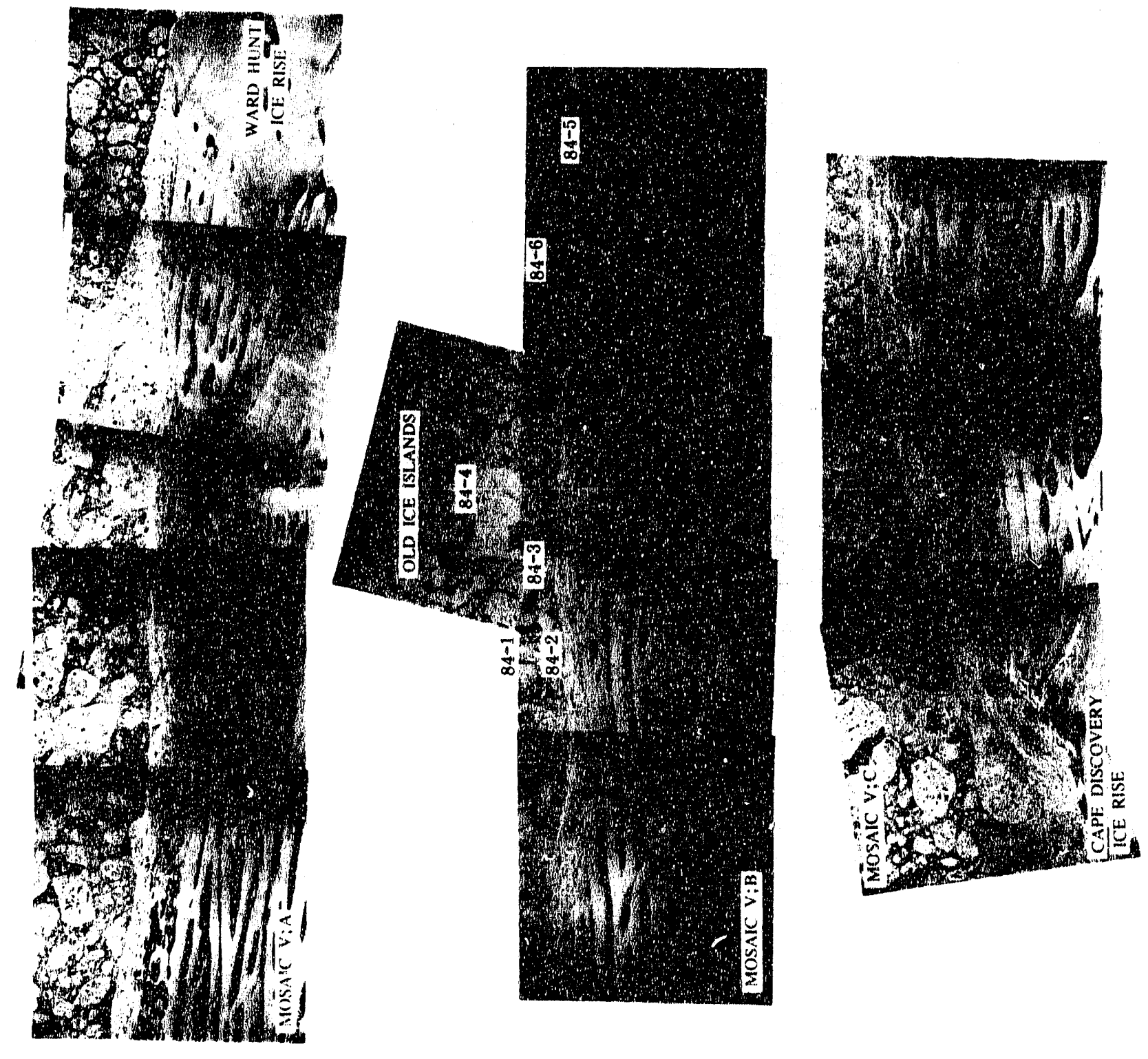
offshore from ice island 84-6 (see Figure 9, 5th Quarterly Report, Sackinger and Jeffries, 1985). The dimensions of the ice islands have been given in Table 1, p. 16. Ice island 84-8 is not shown, but was located a little further west, off the Cape Discovery Ice Rise. Ice Island 84-9 was located off the mouth of Ayles Fiord.

\section{MOSAIC VI}

Mosaics VIA \& VIB have a scale of $1: 82,140$ and show the mouth of M'Clintock Inlet, a distance of $35 \mathrm{~km}$ from the Cape Discovery Ice Rise to Cape Richards. A shorelead is evident in each mosaic and is probably due to an offshore wind directed seaward, separating the pack ice from the fast ice-edge and the edge of the Cape Discovery Ice Rise.

M'Clintock Inlet was once occupied by the M'Clintock Ice Shelf. The ice shelf disintegrated in the mid-1960s and a few pieces of shelf ice remain embedded in MLSI that now occupies most of the mouth of $\mathrm{M}^{\prime}$ Clintock Inlet. The shelf ice fragments lie further south than the line of Mosaic VI, but some the MLSI is clearly visible. The only piece of in situ ice shelf is to be found in the extreme left frame of Mosaic VIB. Elongate lakes and hummocks are evident despite the dirty ice surface which characterizes all of the small ice shelves in this bay (see Figures 15 and 16, 6th Quarterly Report, Sackinger and Jeffries, 1985a).

The surface topography of the MLSI in Mosaic VI, as delineated by the development of melt-pools, is quite variable and is probably related to how long the ice has remained fast in one place. The greatest linear development of melt-pools and, therefore, probably the oldest ice, occurs off the west end of Cape Discovery Ice Rise (Mosaic VIA) and at the west side of M'Clintock Inlet near Cape Richards (Mosaic VIB). The youngest MLSI, with the least linear melt-pool development is located in the centre of Mosaic VIB. Observations made during over-ice traverses in 

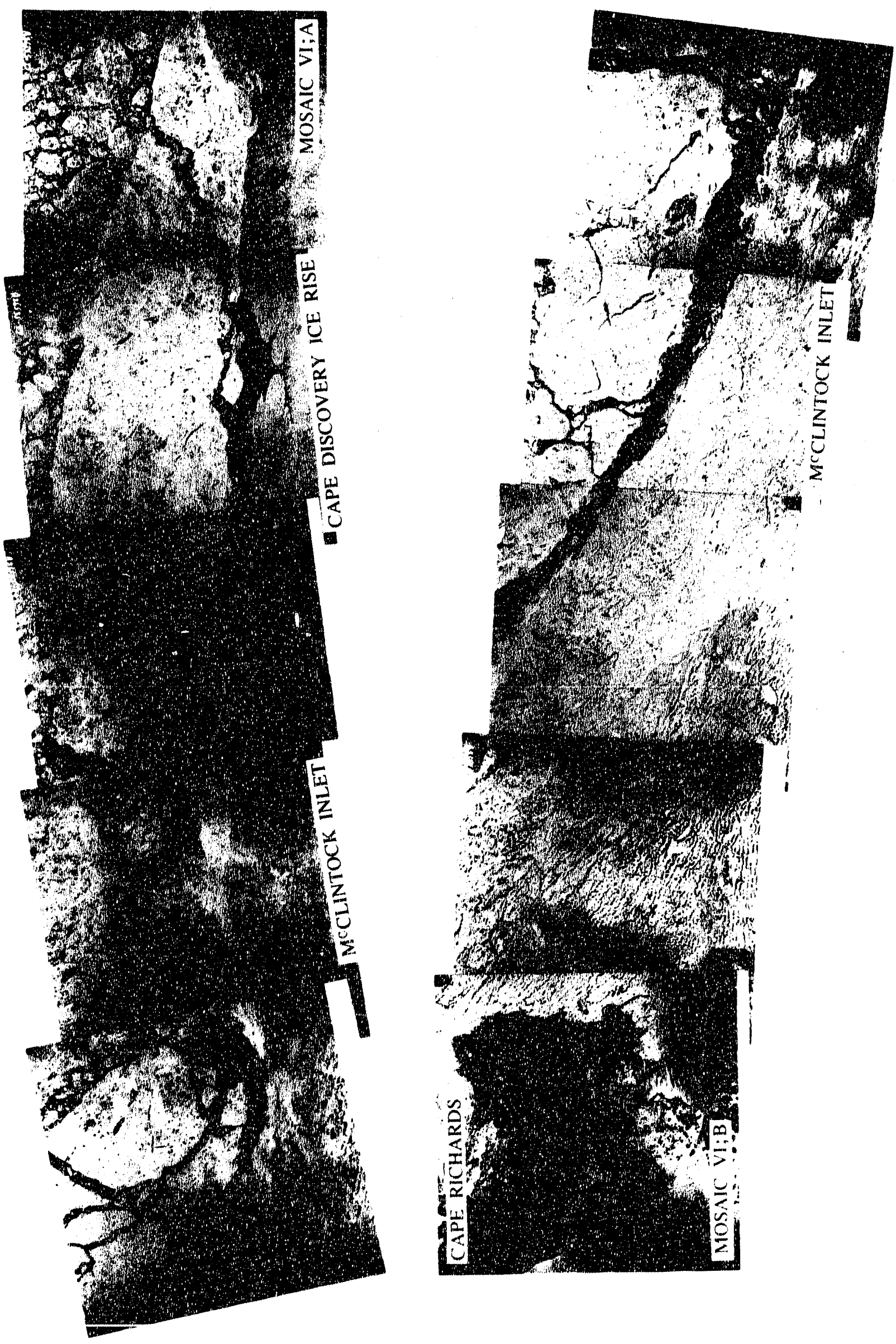
1982, 1983 and 1984, by M.O. Jeffries and H.V. Serson, indicate that this particular area of ice had only been there for 2-3 years.

\section{MOSAIC VII}

Mosaic VII has a scale of $1: 80,300$ and covers a distance of $20 \mathrm{~km}$ between Cape Fanshawe Martin and Cape Bicknor. The main ice feature of interest here is the Ayles Ice Shelf that occupies most of the mouth of Ayles Fiord. The ice shelf does not occupy the entire mouth of the fiord because at some time between 1959 and 1974 the ice shelf moved up to $5 \mathrm{~km}$ out of the fiord and away from the east shore (Jeffries, 1986). The area that was once occupied by the ice shelf along the east shore of the fiord is now the site of MLSI that has a very well-developed undulating topography of elongate pools and hummocks. This area of MLSI is clearly seen on the second frame from the right; the MLSI also contains an old fragment of shelf or glacier ice and, in addition, there is a diagonal crack near the seaward edge of the MLSI. A second zone of MLSI, with less well developed melt-pools/undulations is evident along the western front of the ice shelf, from the centre of the mosaic to Cape Bicknor.

As might be expected, the surface of the ice shelf displays characteristically well-developed elongate undulations. A particularly interesting feature to note is the narrow melt-pool at the centre of the mosaic that cuts diagonally across the parallel pools. It is likely that this is the surface expression of an old fracture in the ice shelf and a potential line of weakness. This feature is at least 35 years old as it can be seen on aerial photographs of the ice shelf taken in summer 1950 (see Figure 2A, 7th Quarterly Report, Sackinger and Jeffries, 1985b). 


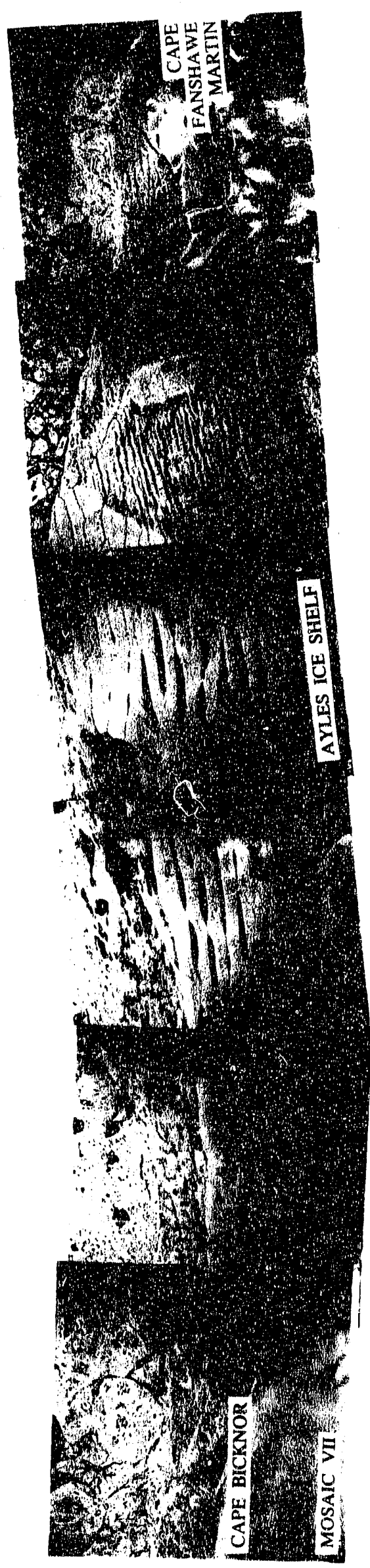




\section{MOSAIC VIII}

Mosaic VIII has a scale of $1: 92,860$ and covers a distance of $19 \mathrm{~km}$ between Cape Egerton and Cape Evans, which define the mouth of Milne Fiord. The fiord is occupied by the Milne Ice Shelf which is visible at the right side of the mosaic. The majority of the ice shelf undulations lie parallel to each other. However, there are two melt-pools at the outer edge of the ice shelf that are oriented at a quite different angle, similar to that of adjacent MLSI. We have no explanation for this, other than to suggest that it is related to changing summer average wind directions combined with local wind effects.

All along the front of the ice shelf there is a fringe of MLSI, particularly at the Cape Evans side, i.e. the Milne Re-entrant. The MLSI is distinguished from the ice shelf by its smaller scale undulations. The Milne Re-entrant is a fairly recent addition at the front of the ice shelf, having replaced a $35 \mathrm{~km}^{2}$ piece of shelf ice that calved in 1973 at the latest and probably as early as 1965 (Jeffries, 1986; Jeffries and Krouse, 1988). Over a minimum 10 year period, elongation and coalescence of the melt-pools has occurred and given the ice a recognizable topography characteristic of the fast ice in this region. The best-developed undulating topography on MLSI occurs on a narrow strip along the north-eastern margin of the ice shelf near Cape Egerton. The advanced elongate development of the melt-pools suggests that the MLSI has remained in place for some considerable time at this location. We have analyzed air photographs of this area taken in 1950, 1959 and 1974 and the MLSI has indeed been there since 1950, at least (Jeffries et al., 1987).

\section{MOSAIC IX}

This T-shaped mosaic has a scale of $1: 86,000$ and covers an area at the eastern shore of Yelverton Bay. Hanson Ice Shelf (unofficial name) occupies a small bay and though it has an undulating topography, the melt-pools and hummocks are not 


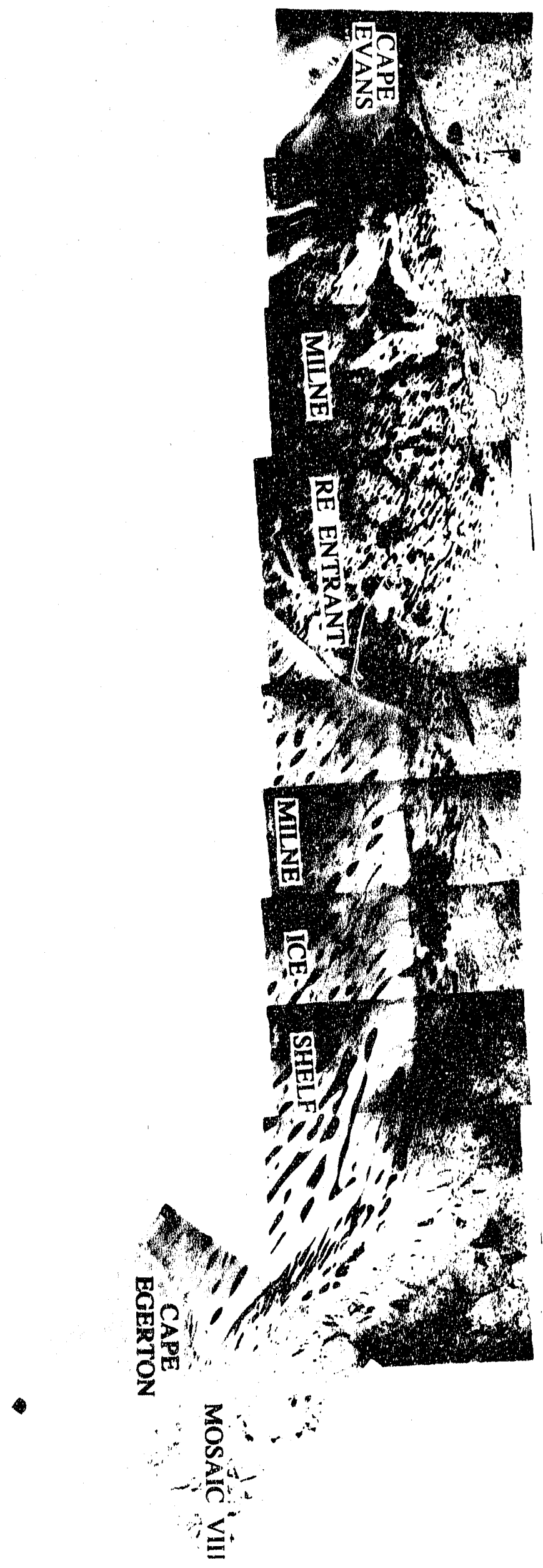




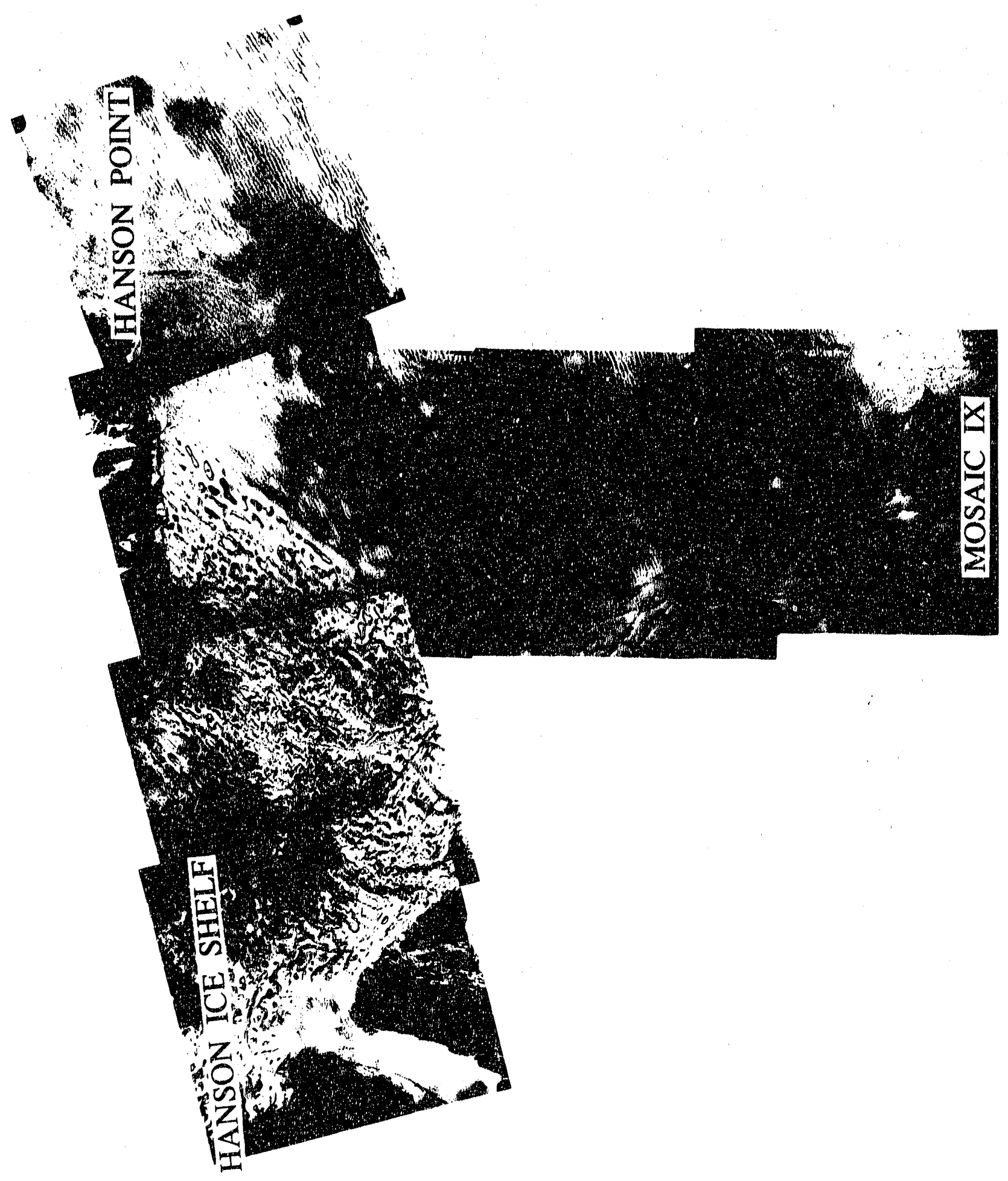


nearly as well developed linearly as on the other ice shelves. This suggests that there is no dominant wind direction in this small bay, perhaps due to local topographic variations. However, unlike the shelf ice, the MLSI outside the bay has a very well developed elongated topography. Since the MLSI is at the east side of the bay we assume that the topography has developed under the influence of westerly winds that blow in summer across the long fetch of Yelverton Bay. It will become apparent from consideration of the next mosaic (X) and the MLSI in this region that Hanson Ice Shelf has probably the best-developed topography in the entire Yelverton Bay.

A short, thin arm of shelf ice extends away from Hanson Ice Shelf towards the bottom of the mosaic. There is some evidence to suggest that this piece of ice shelf is in the process of disintegration, albeit slowly. Not only are there some large fissures in the ice, but there are fragments of shelf ice locked in the MLSI. A crack-like feature is also evident in the MLSI, running generally diagonal to the undulations.

\section{MOSAIC X}

Mosaic X has a scale of $1: 125,000$ and covers a distance of about $38 \mathrm{~km}$ across Yelverton Bay from Hanson Point (see Mosaic IX) at the right side to the Alert Point Ice Field. As noted for Mosaic IX, the MLSI near Hanson Point, or on the east side of Yelverton Bay in general, has a particularly well-developed elongated topography. This is evident in the first frame on the right. Elsewhere in the mosaic, though there are clear indications of the coalescence and elongation of the melt-pools, this has not developed to the same degree as it has in the eastern bay. At the left side of the mosaic there are two crack-like features in the ice, running almost parallel to each other and about $2.5 \mathrm{~km}$ apart.

The successful completion of the 1984 air photography and the subsequent documentation adds substantially to the aerial photographic record of the coastal ice in this region. In view of the remoteness of the area and the probable limited and 


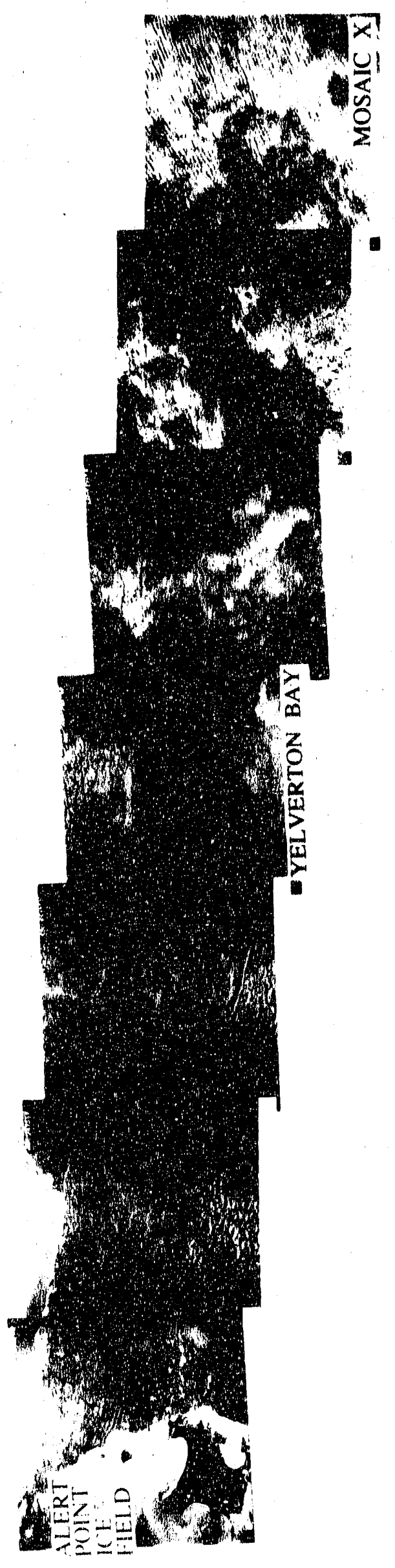


occasional use of air photographs, the aerial photographic record is quite good and represents a valuable time of changing ice conditions. Past aerial photographic missions of this region are summarized in Table 2 below.

Table 2. Aerial photographic missions that include ice shelves and landfast sea ice off the north coast of Ellesmere Island

\begin{tabular}{|l|c|c|c|}
\hline \multicolumn{1}{|c|}{ Year } & Aititude $(\mathrm{m})$ & Vertical & Oblique \\
\hline 1) August 1950 & 6096 & yes & yes \\
\hline 2) July 1959 & 9144 & yes & no \\
\hline 3) June 1962 & 2255 & yes & yes \\
\hline 4) July 1974 & 3048 & yes & no \\
\hline 5) July 1984 & 3048 & yes & yes* \\
\hline
\end{tabular}

Oblique aerial photographs obtained in July 1984 are part of a private collection. All other photographs are available from the National Air Photography Library, Department of Energy, Mines and Resources, Ottawa, Ontario, Canada.

In this particular report we have presented 10 mosaics of the fast ice edge in 1984. Aerial photographs were also obtained of ice in the bays and fiords and more extensive aerial photographic coverage is available, particularly for Ward Hunt Ice Shelf, Milne Ice Shelf, Ayles Ice Shelf, Yelverton Bay and Alfred Ernest Ice Shelf. The oblique photographs obtained in July 1984 for the region from Alert to Cape Discovery have been presented in the 5th and 6th Quarterly Reports (Sackinger and Jeffries, 1985). The Ayles Ice Shelf, Yelverton Bay and Alfred Ernest Ice Shelf regions, however, have not been discussed previously. Since they may produce ice islands in the future, the aerial photographs are presented and discussed below.

\section{II.1. AYLES ICE SHELF}

The ice conditions in Ayles Fiord between Cape Fanshawe Martin and Cape Egerton (Figures 6A and 6B) will be considered. Ayles Fiord is an interesting location because until recently it was believed that Ayles Ice Shelf had completely 


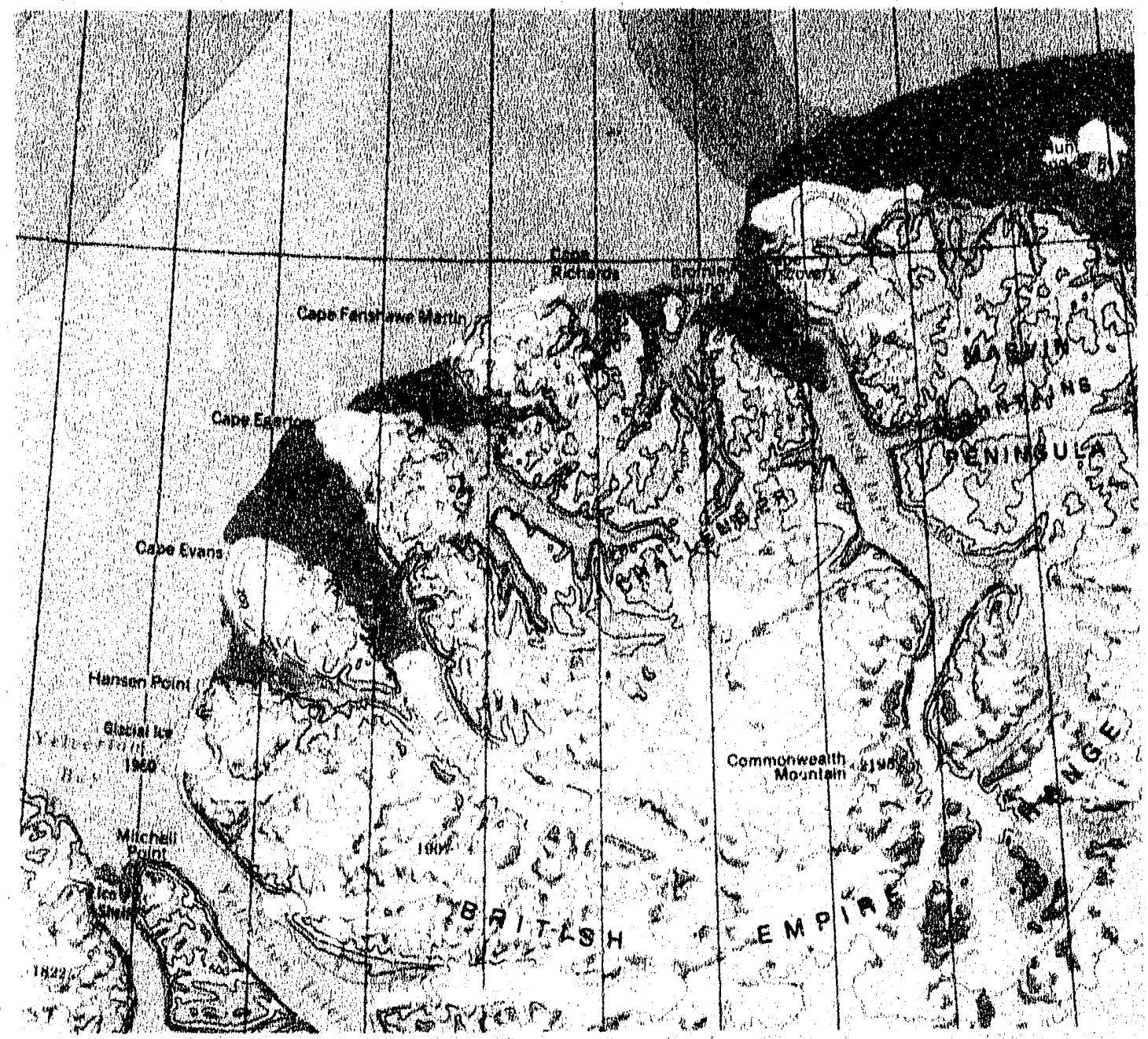

FIGURE 6A. Map of north coast of Ellesmere Island from Cape Discovery to Cape Egerton. 


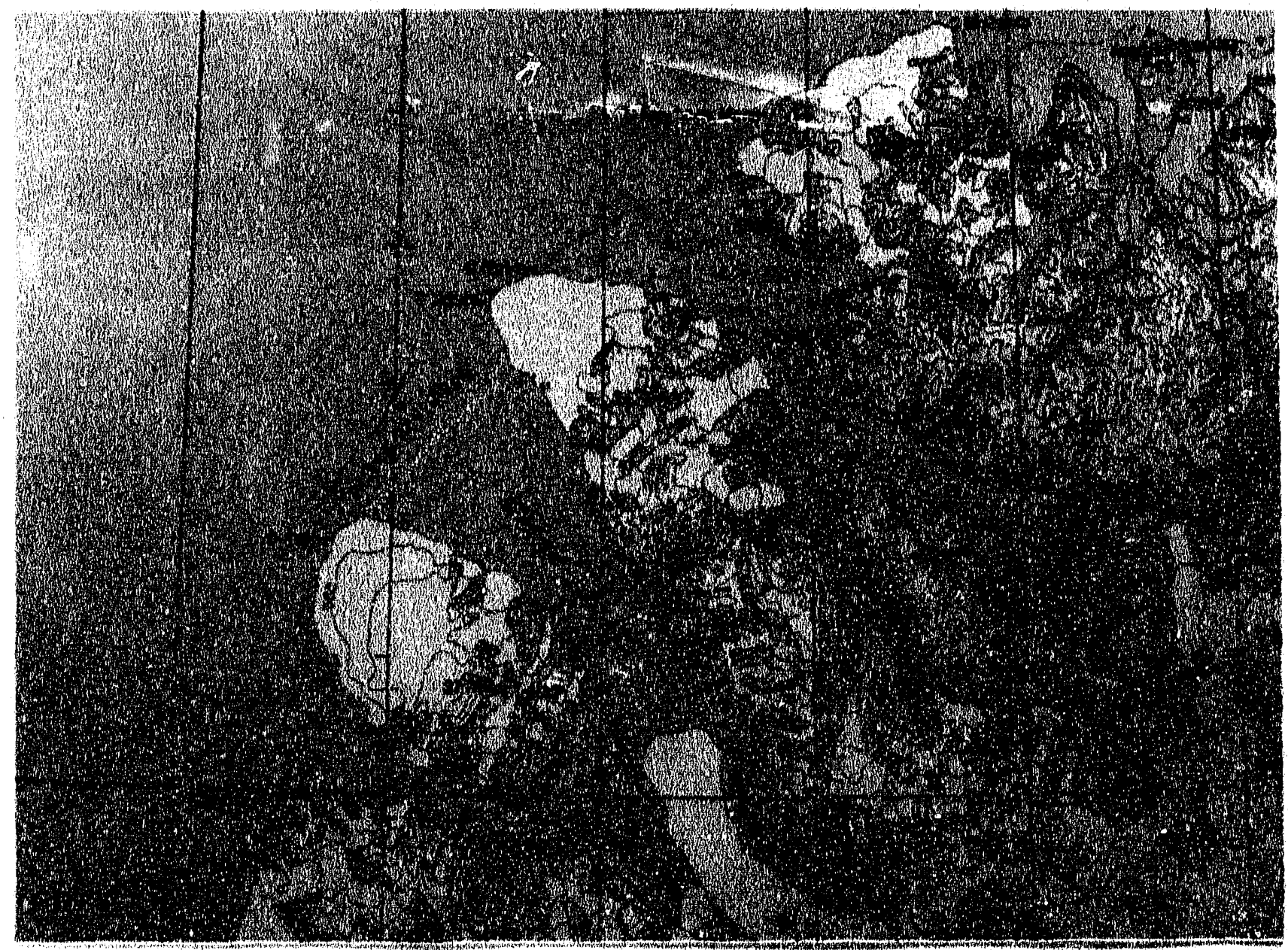

FIGURE 6B. Map of north coast of Ellesmere Island from Cape Fanshawe Martin to Cape Egarton. This map shows the location of Ayles ice Shelf as it was in 1959. 
broken out of the fiord during the interval 1962-66 (Hattersley-Smith, 1967). It has since been shown that this was not the case (Jeffries, 1986), and in this report the "new" ice regime of Ayles Fiord will be describecl.

In 1950 (Figure 7A) and 1959 (Figure 7B) the outer 12.5km of Ayles Fiord was occupied by Ayles Ice Shelf. Immediately south of the ice shelf the fiord is largely occupied by a disintegrating glacier tongue. The inner fiord is covered with fiord ice. Ayles Ice Shelf, like the seaward portions of other arctic ice shelves, is characterized by an undulating topography of parallel ridges and troughs. In summer meltwater accumulates in the troughs and forms long, linear lakes which appear as a darker tone than adjacent ridges on air photographs (Figures 7A and 7B), Also at the ice surface there are crack-like features and debris zones. The most obvious crack is $\mathrm{S}$ shaped and curves across the ice shelf from the north edge to the south edge. A second crack is located parallel to the undulations and close to the front of the ice shelf (Figure 7B). Adjacent to the west shore of the fiord is a curvilinear debris zone that might be a moraine derived from the adjacent cirque glacier (Figures $7 \mathrm{~A}$ and $7 \mathrm{~B}$ ). Glaciers flowing off the land into fiords and inlets do contribute in some cases to the growth of parts of certain arctic ice shelves. Thus, it is likely that that part of the ice shelf, however, appeared to have begun disintegrating by 1950-59. The fiord ice contrasts sharply with shelf ice, as fiord ice appears to be essentially smooth and flat.

In April 1966, Hattersley-Smith (1967) observed that only scattered ice islands and slivers of ice shelf remained in Ayles Fiord. Figures 8 and 9, however, indicate that a large piece of ice shelf remains in the mouth of the fiord. Comparison of Figures 7A and 9 shows how the position of that ice shelf has changed. Although Ayles Ice Shelf remains largely intact, it has moved some distance out of the fiord, with the greatest movement having occurred away from the eastern shore. Figure 10 shows the area of maximum movement where the gap between shelf and shore is now occupied by old sea ice. The sea ice contains iwo fragments of shelf ice that would 


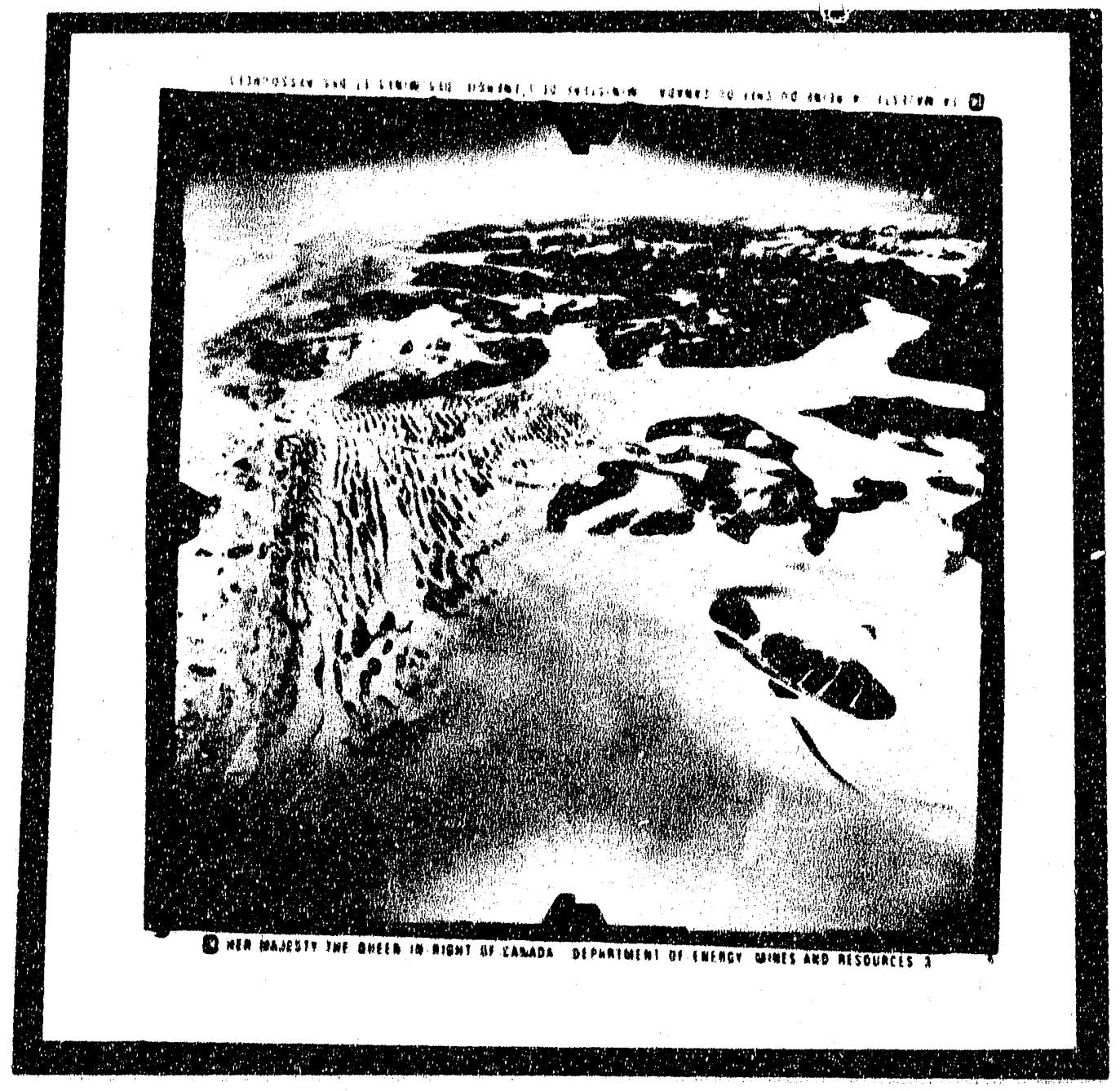

FIGURE 7A. Oblique aerial photograph looking east across Ayles lee Shelf, August 1, 1850. (Air photograph T407L-6, National Air Photograph Library, Ottawa, Ontario, Canada). 


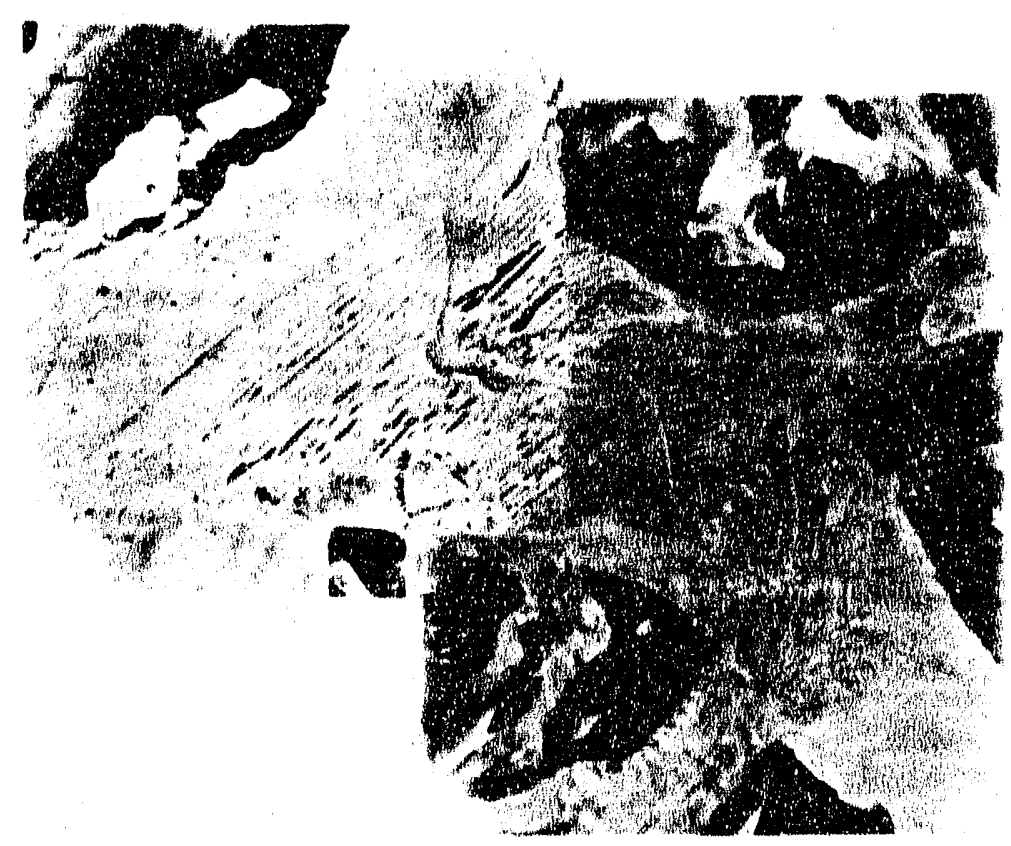

FIGURE 7B. Vertical air photo-mosaic of Ayles Ice Shelf, July 1959. (Air photographs A16706-3, A16785.75, A16785-76, National Air Photograph Library, Ottawa, Ontario, Canada). 


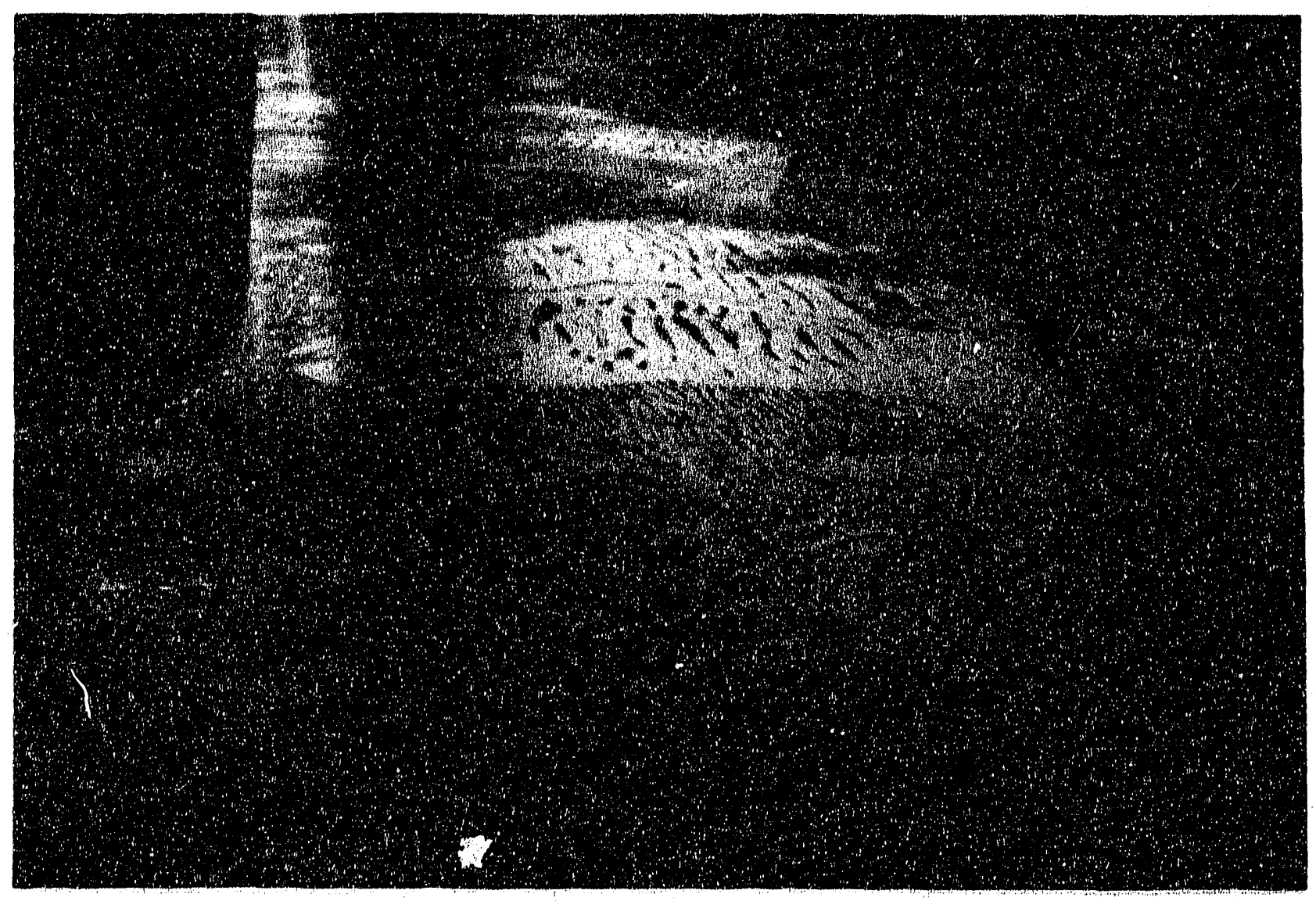

FIGURE 8. View looking west across the mouth of Ayles Fiord from Cape Fanshawe Martin. 


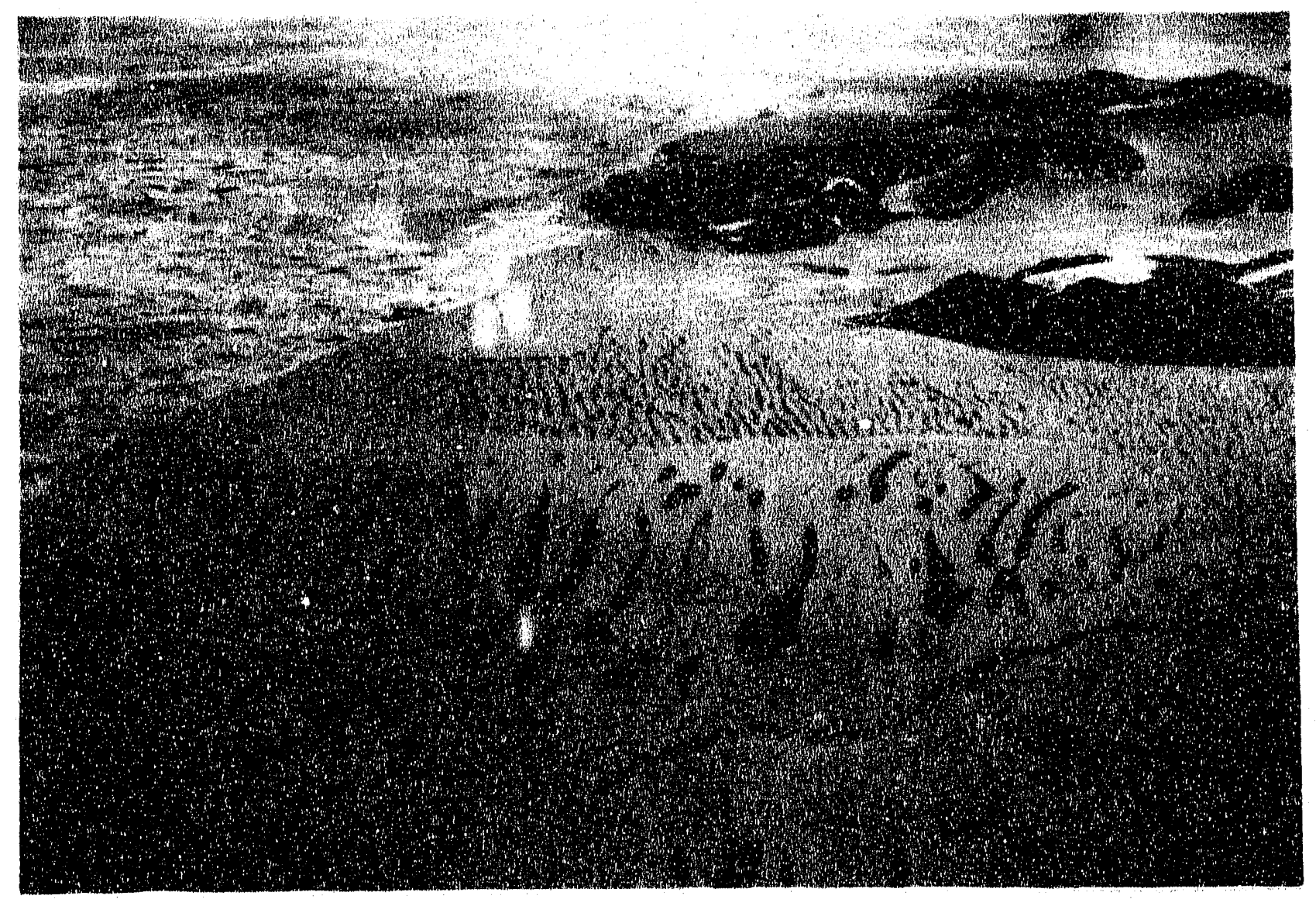

FIGURE 9. View looking east across the mouth of Ayles Fiord to Cape Fanshawe Martin. 


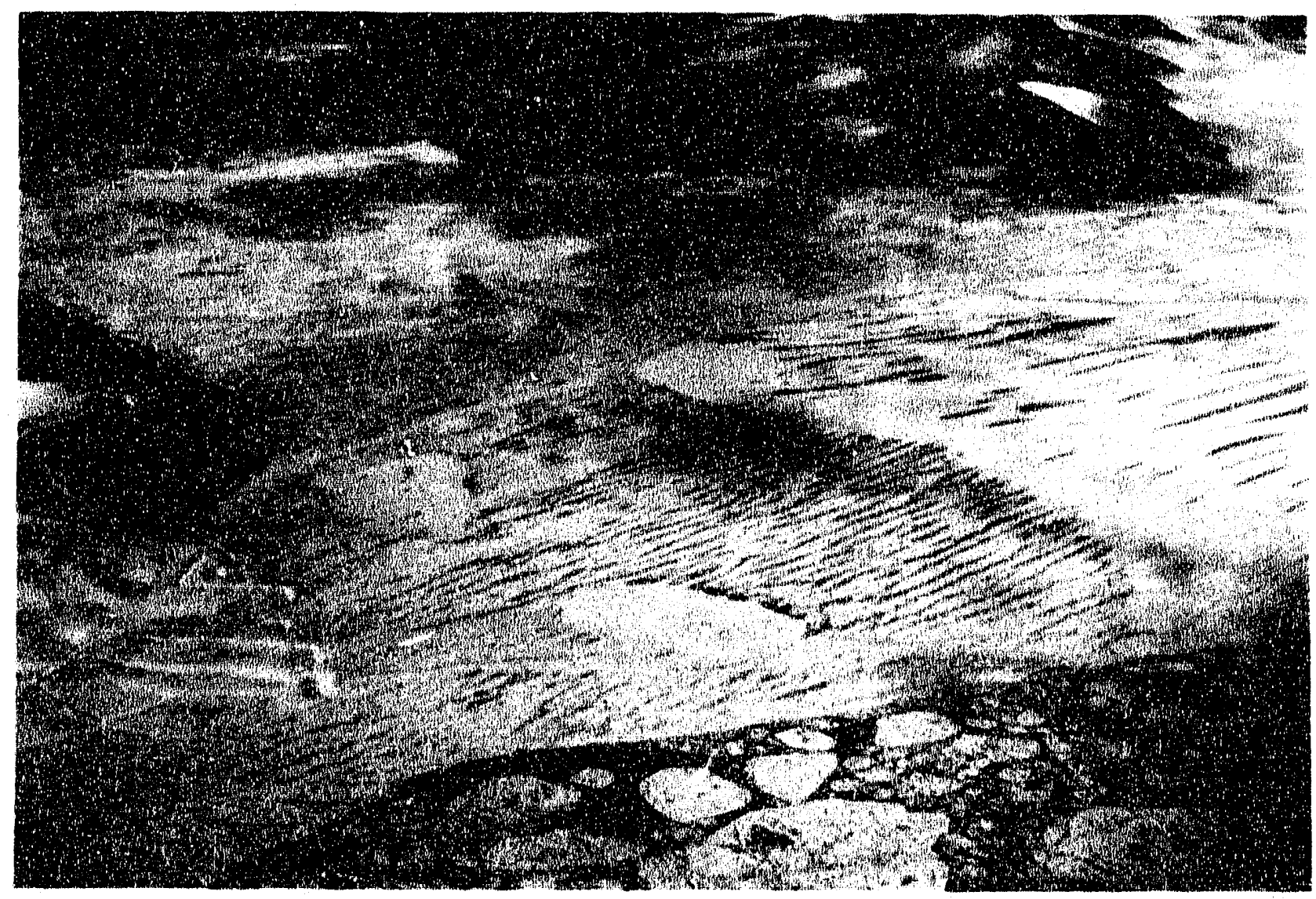

FIGURE 10. View of the northeastern area of the mouth of Ayles Fiord. This shows the location of the maximum movement of Ayles Ice Shelf away trom the shore. 
become part of the freely-circulating ice island population if the ice were to break out of Ayles Fiord completely. It is interesting to note that the sea ice that has grown since the ice shelf movement has developed an undulating topography of parallel ridges and troughs (Figures 8, 9, 10,11, 12 and 13). The wavelength of the rolls, as they are known, is shorter than those on the ice shelf. Furthermore, ground observations made by M.O. Jeffries and H. Serson in May 1985 indicate that the troughs are less deep than on the ice shelf. In May 1983, before the ice shelf movement was confirmed, M.O. Jeffries and H. Serson traversed the sea ice and crossed a wide crack that ran perpendicular to the east shore. There was refrozen water in the crack that had a freeboard of about $50 \mathrm{~cm}$. This suggested an ice thickness of $5 \mathrm{~m}$. The crack is shown in Figures 12 and 13. In spring 1985 it was noted that the crack runs right across Ayles Fiord and effectively marks the transition from shelf ice to sea/fiord ice.

Figure 13 shows that the nature of the surface of the ice along the the east shore changes, with the features becoming more random. The contrast between the regular oriented topography of the shelf ice, the old sea ice in the mouth of the fiord, and the ice further south in the fiord is shown in Figure 14. For the moment we will turn our attention to this ice before returning to the shelf ice.

The east arm of Ayles fiord is shown in Figure 15. A large glacier remains at the head of this arm (Figures 7A, 7B and 16), but there is no longer an intact shelf ice cover (Figures 17 and 18). Figures 7A and 18 each look in the same direction in to the east arm. In 1950 (Figure 7A) and 1959 (Figure 7B) the ice had an undulating topography characterized by elongate meltwater lakes, but in 1984, (Figure 18) the ice was no longer there. The mouth of the east arm is largely filled with many small fragments of shelf ice or ice from the disintegrating glacier tongue (Figure 19). Figures 20 and 21 clearly show how extensive is this disintegration. In 1950 and 1959 (Figures 7A and 7B), the appearance of the glacier tongue suggested some 


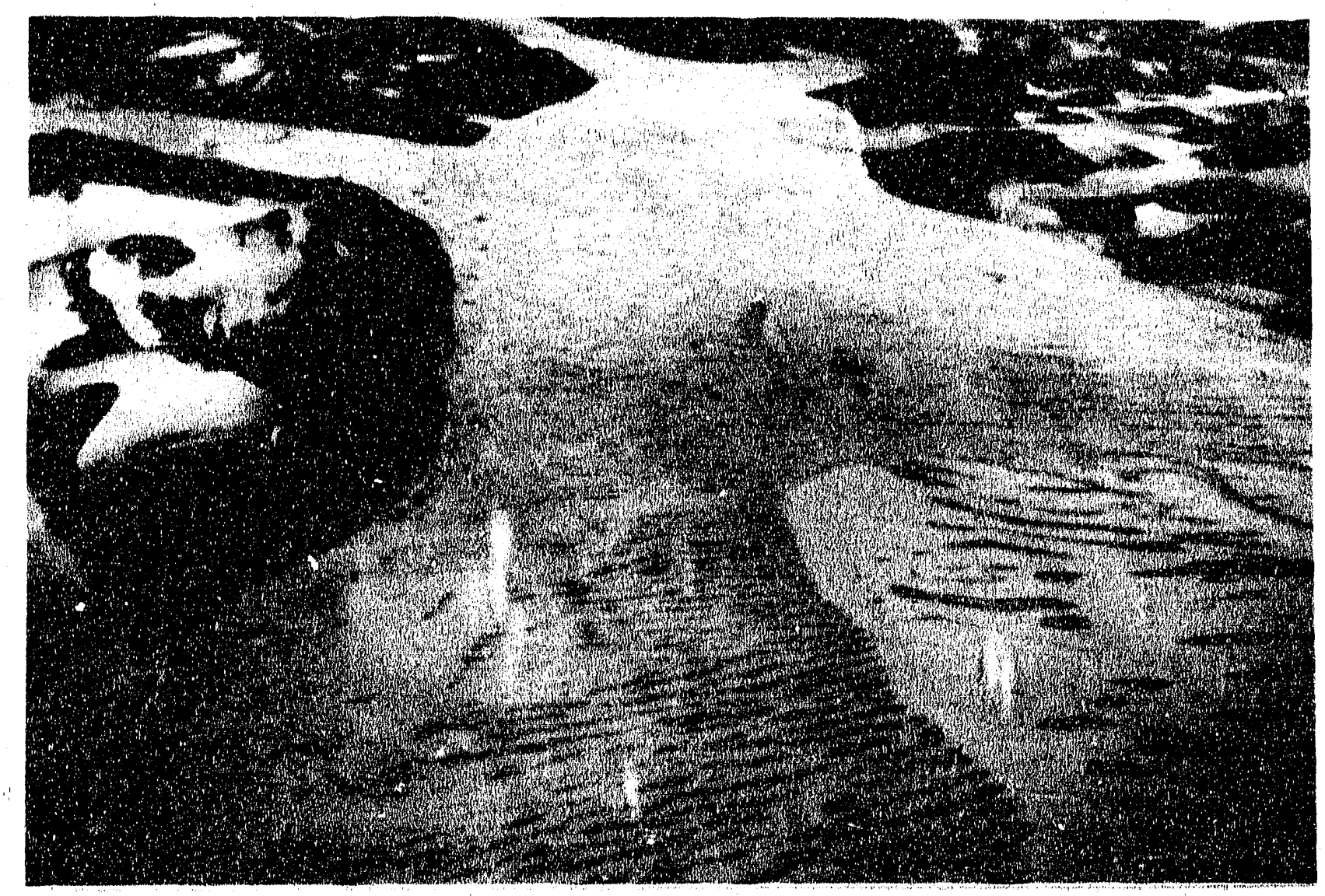

FIGURE 11. View looking along the east shore of Ayles Fiord and the sea ice that has grown since the ice sheir moved. 


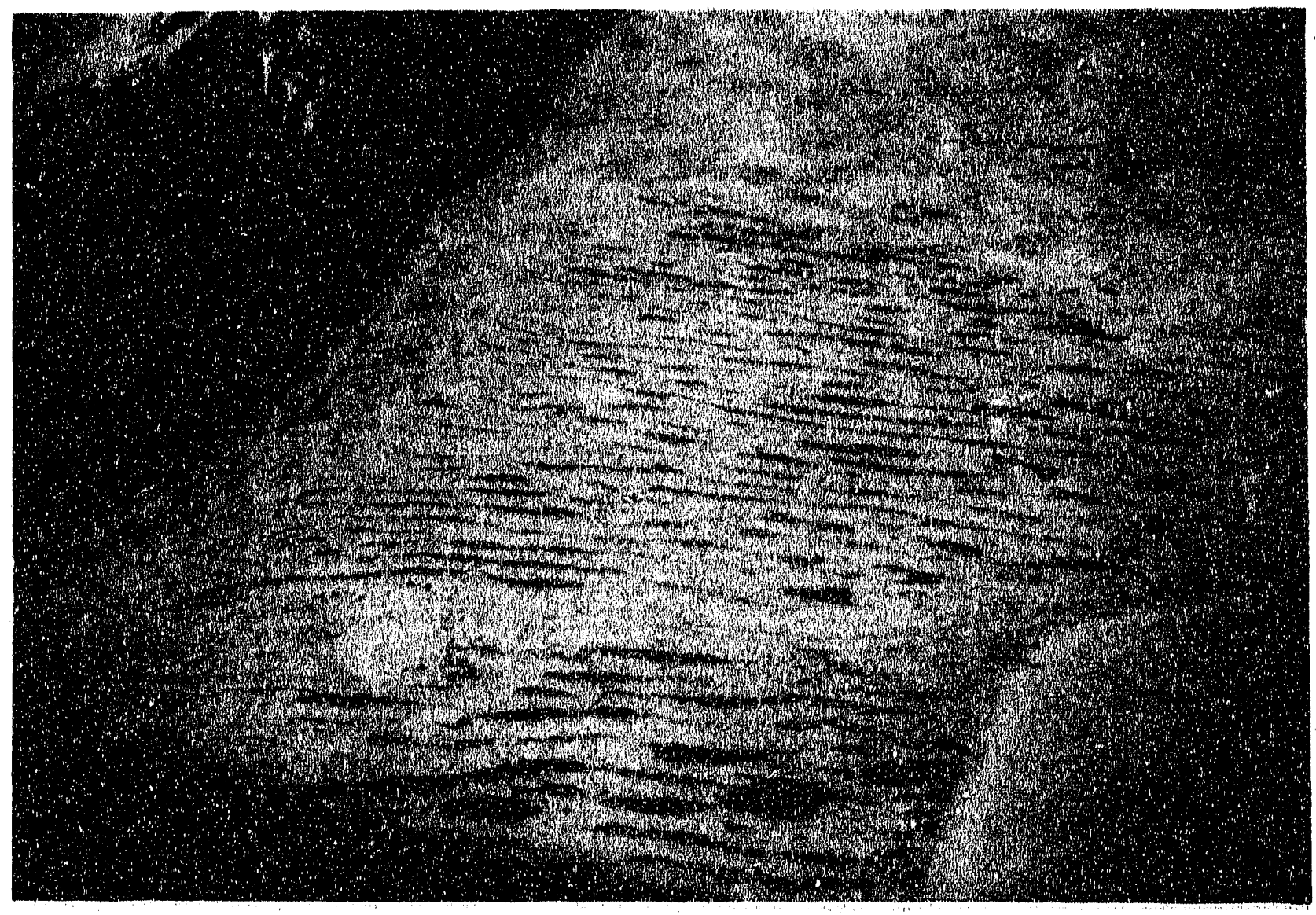

FIGURE 12. Undulating sea ice near the east shore of Ayles Fiord. A crack in the ice is arrowed. Note how the crack meets the rear of the shelf ice.

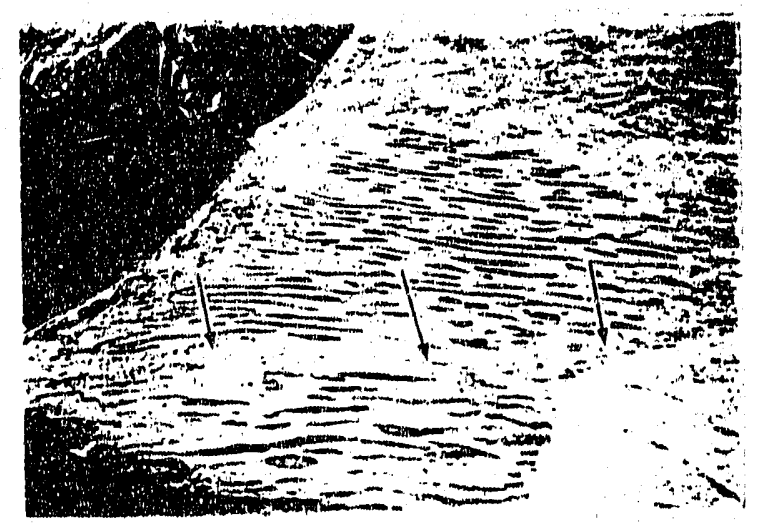




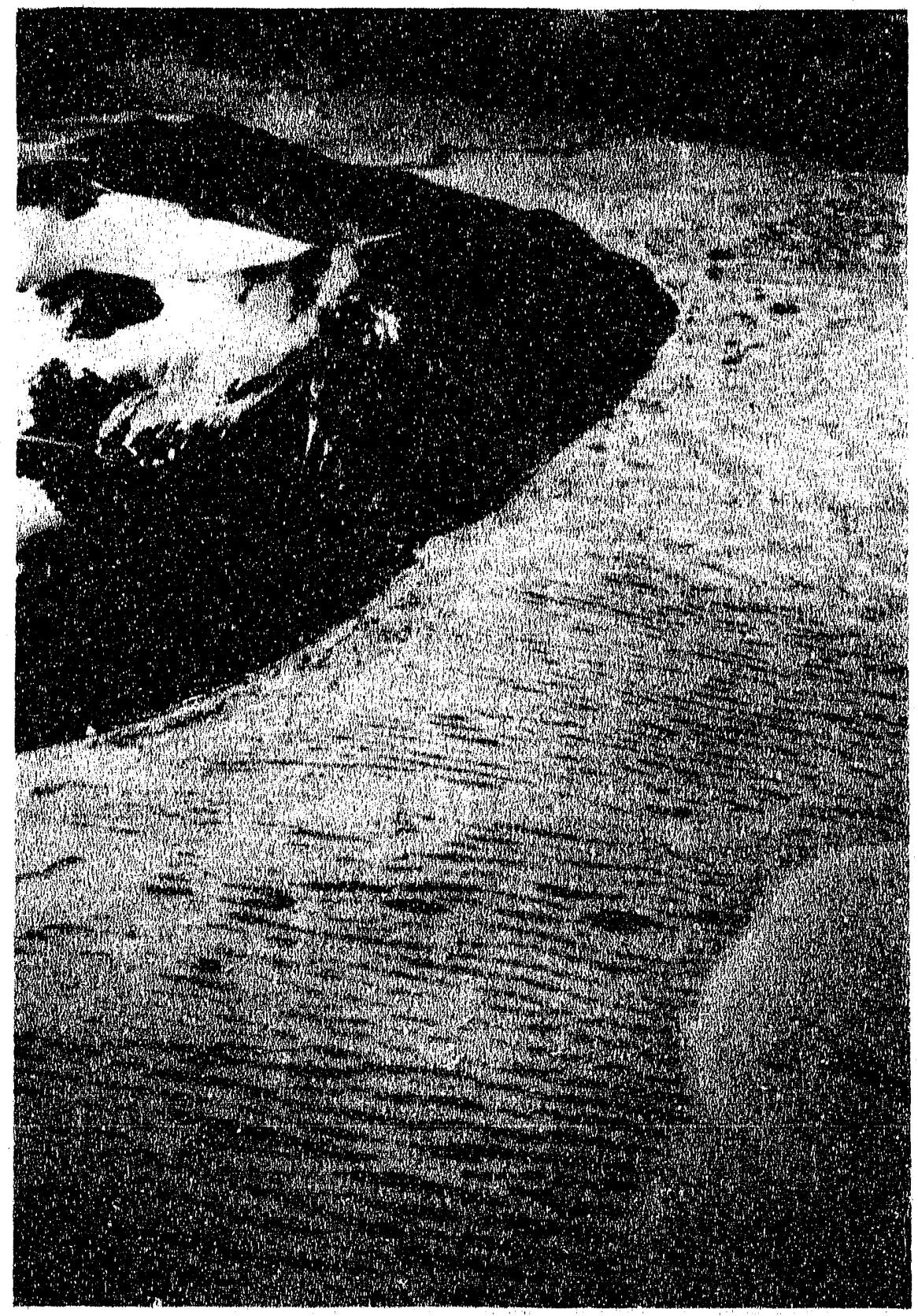

FIGURE 13. Undulating sea ice near the east shore of Ayles Fiord. A crack in the ice is arrowed.

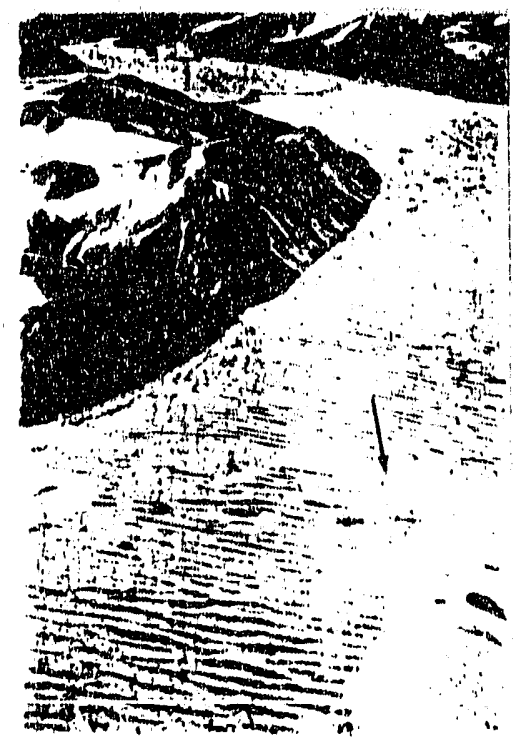




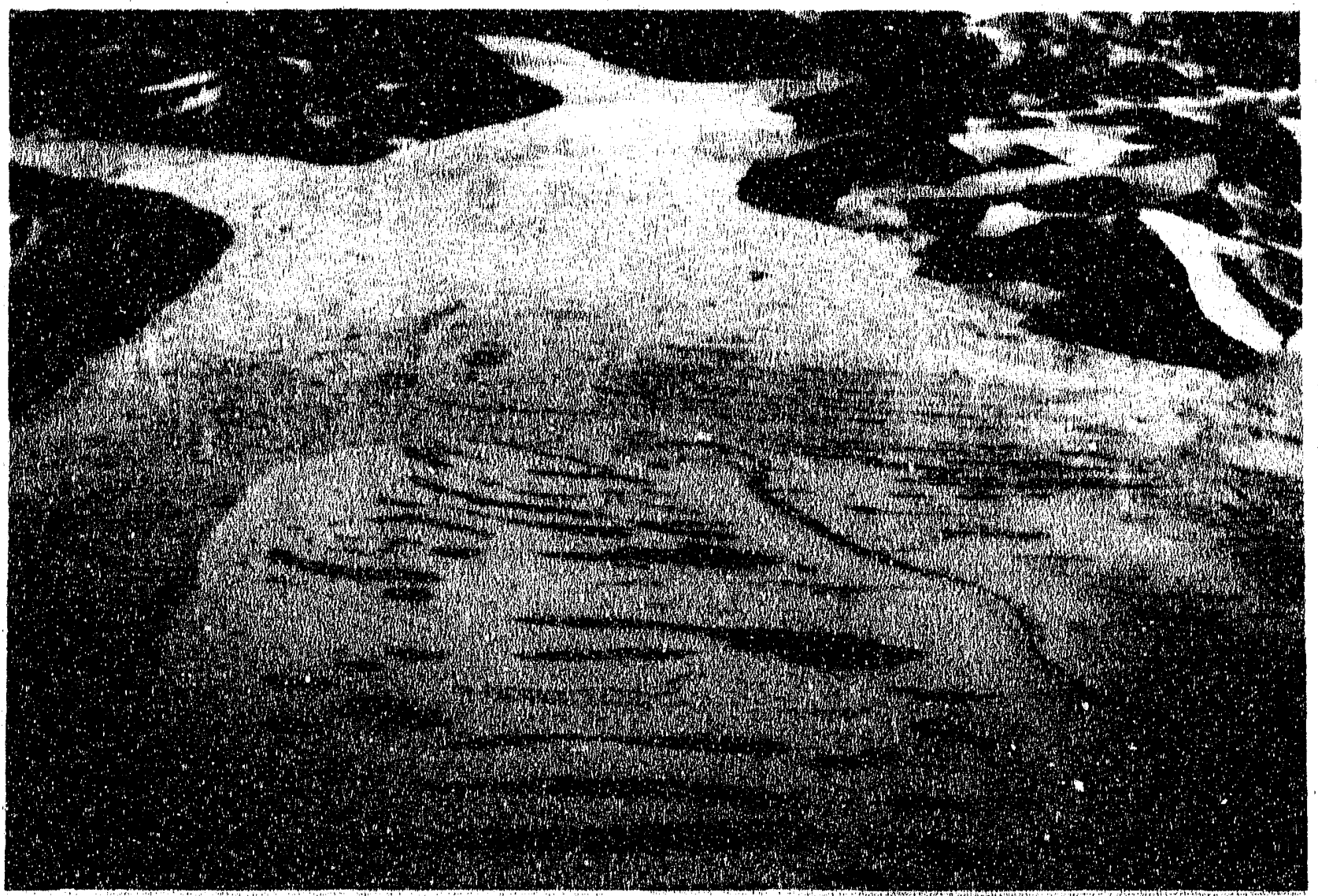

FIGURE 14. Ayles lce Shelf is in the foreground with some recent sea ice at the left side. Note the more random patterns in the ice beyond the ice shelf. 


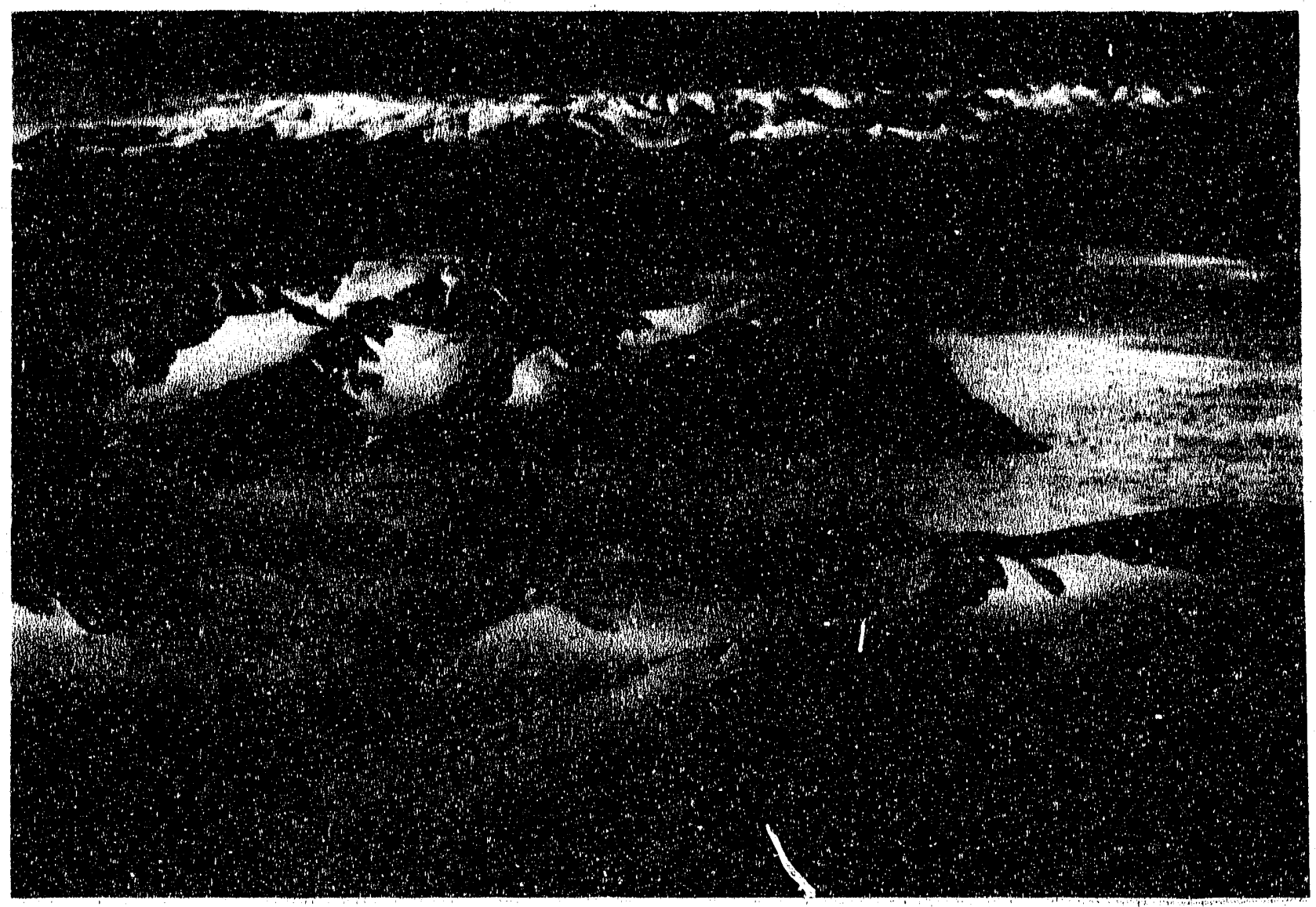

FIGURE 15. View looking south across the east arm of Ayles Fiord from Cape Fanshawe Martin. 


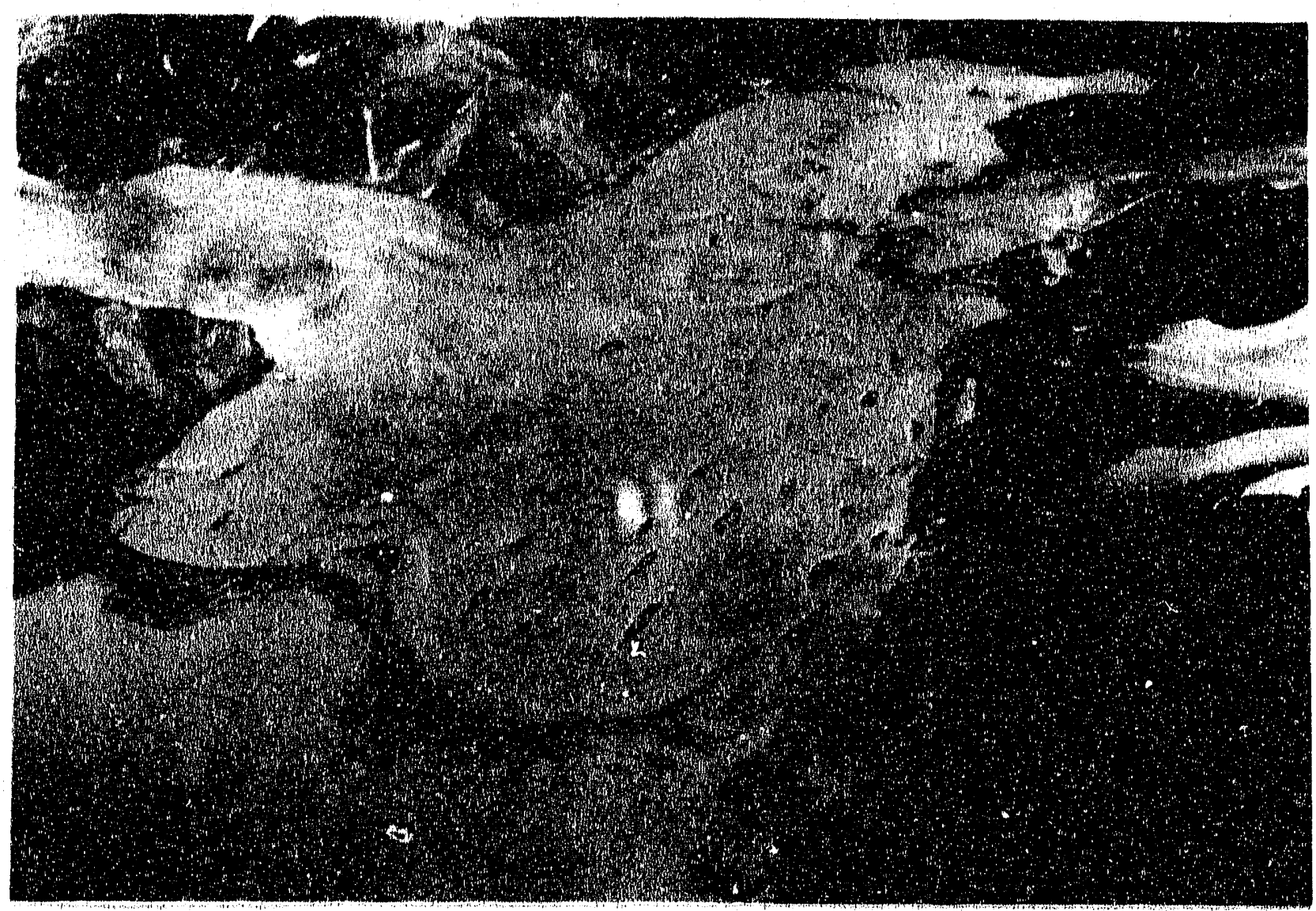

FIGURE 16. Glacier at the head of the east arm of Ayles Fiord. Note the curious east-west alignment of the melt-pools that is reminiscent of the ice sholves. 


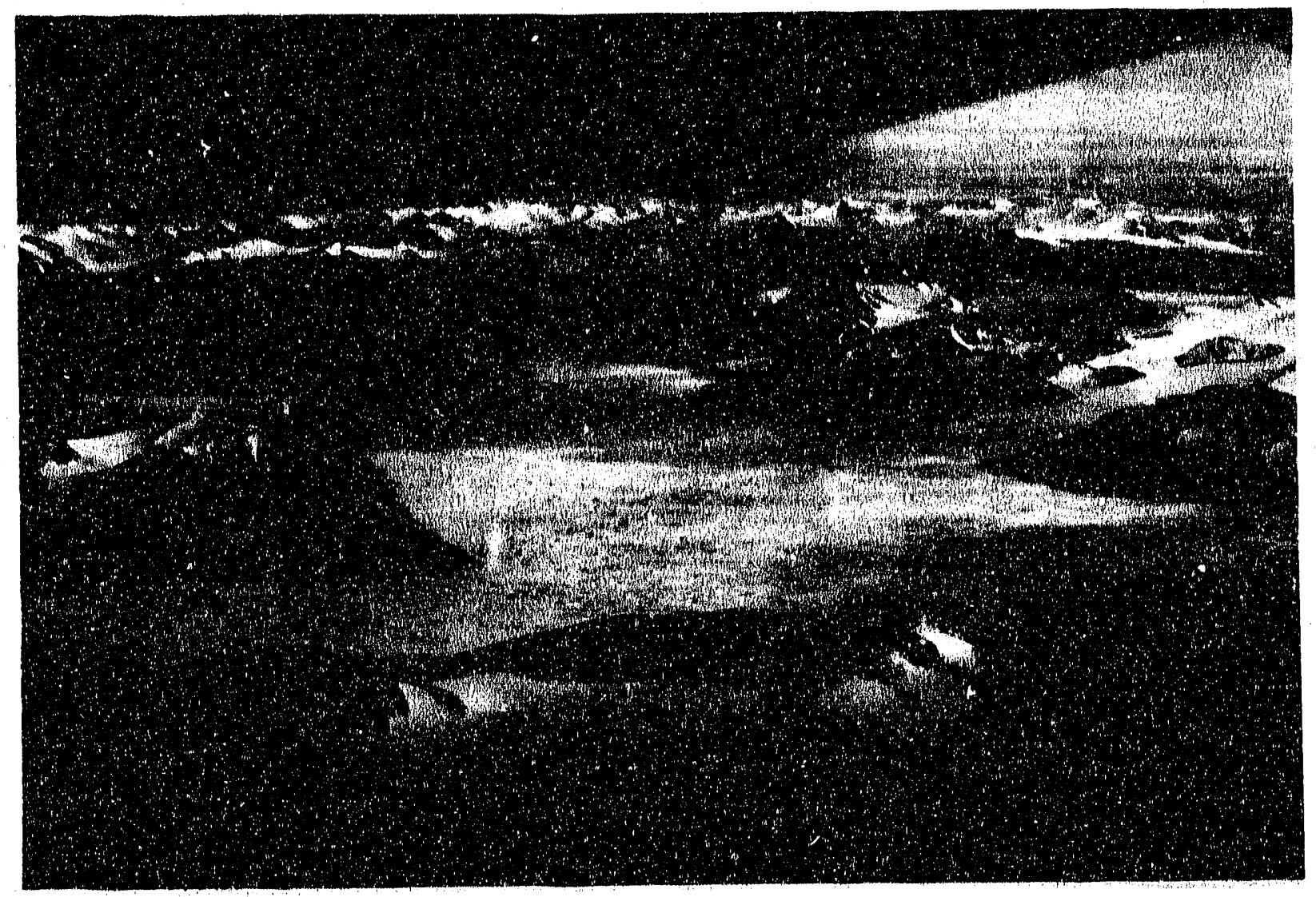

FIGURE 17. View looking south across the mouth of the east arm of Ayles Fiord from Cape Fanshawe Martin. 


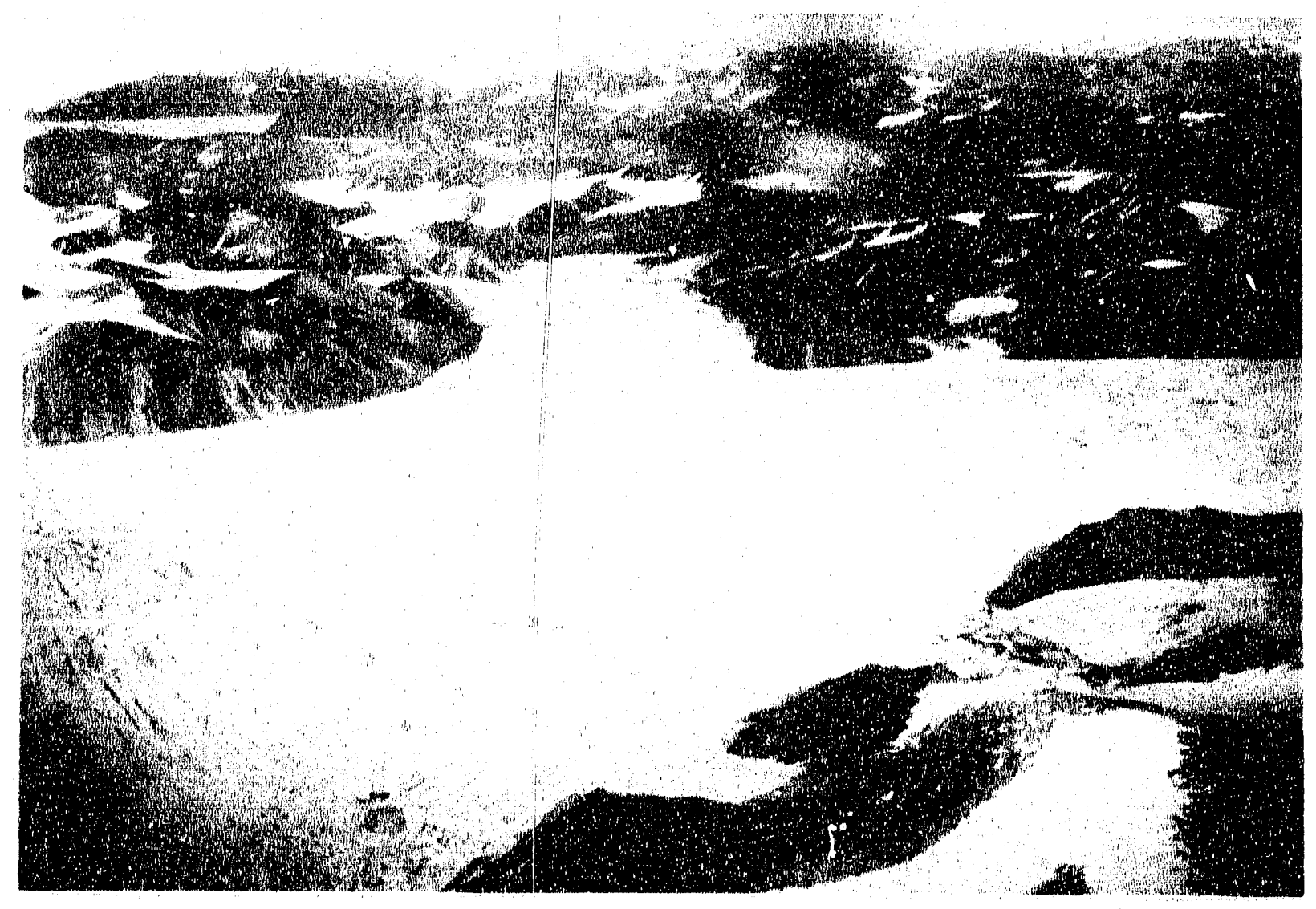

FIGURE 18. View looking east across Ayles Fiord to the east arm of the fiord Compare this with Figure $\mathrm{TA}$ and note the change in ice conditions. 


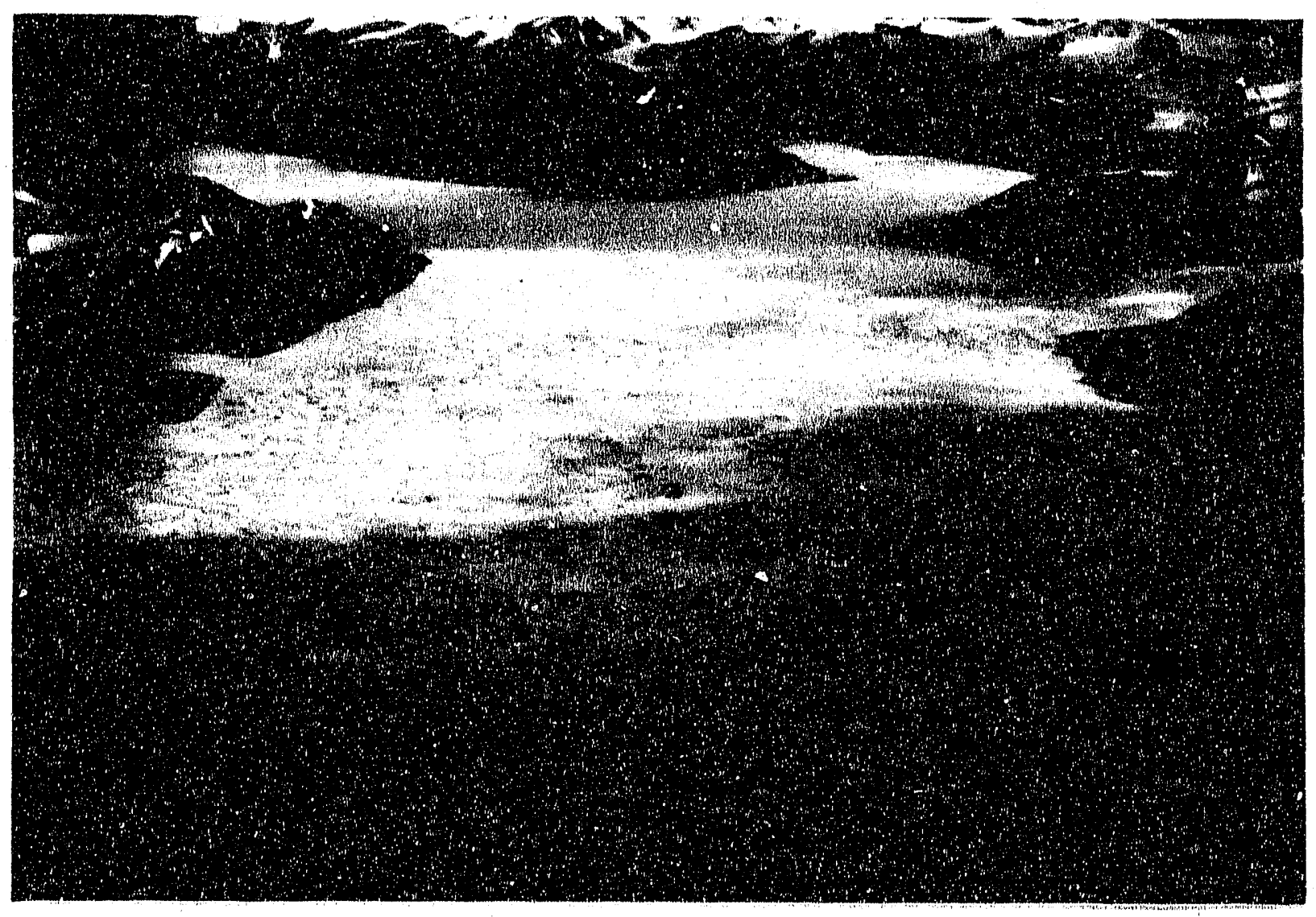

FIGURE 19. Scattered fragments of shelf ice and glacier tongue in central Ayles Fiord. 


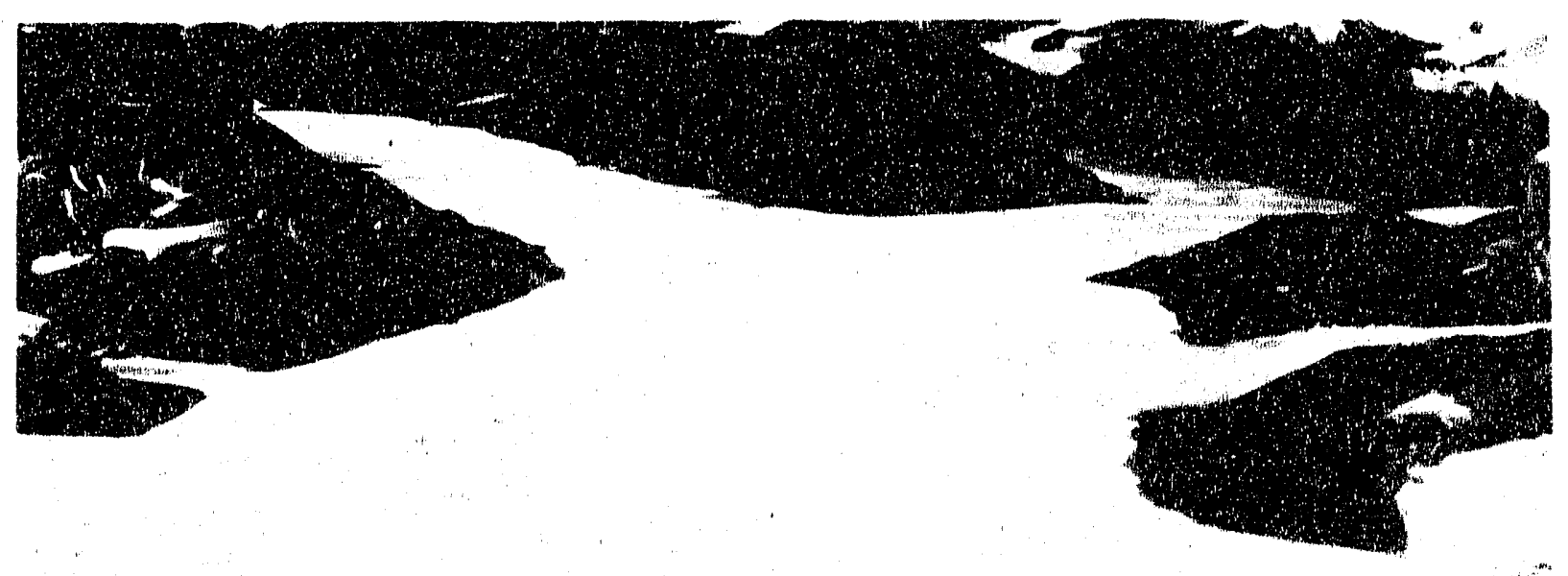

4

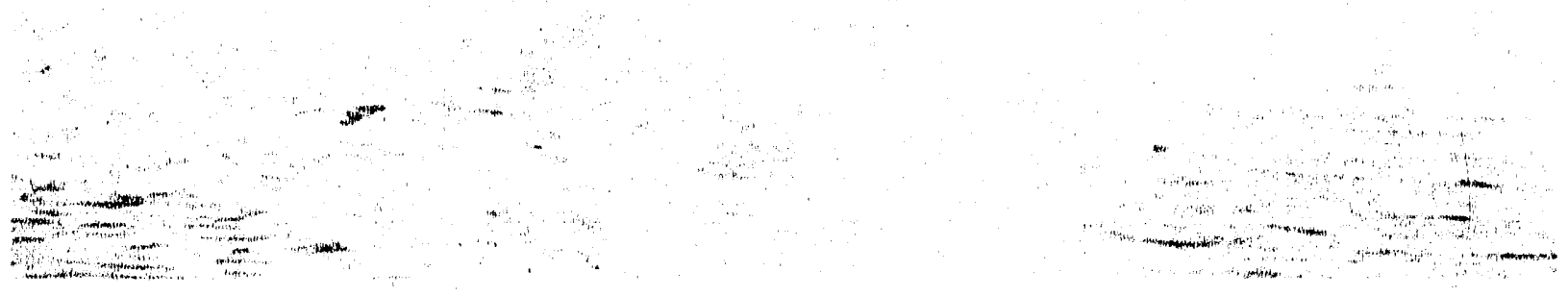

FIGURE 20. Scattered fragments of shelf ice and glacier tongue in central Ayles Fiord. Small, remaining glacier tongue is arrowed.

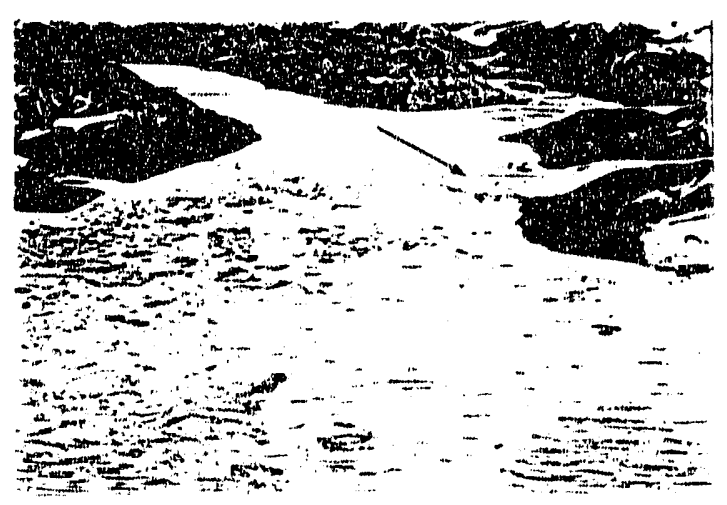




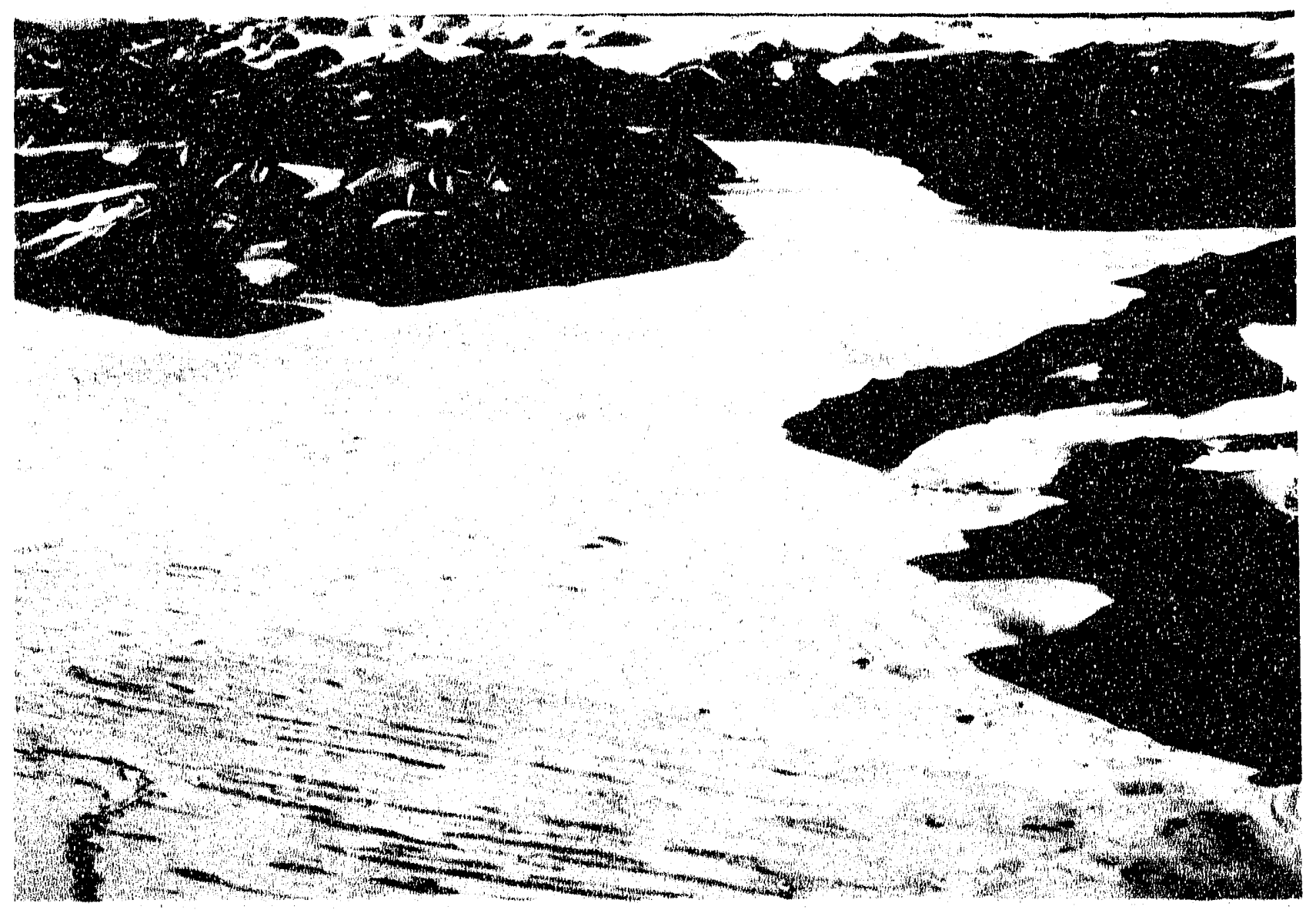

FIGURE 21. Scattered fragments of shelf ice and glacier tongue in central Ayles Fiord. Note that the shelf ice in the foreground is grey in color. 
disintegration, but the ice retained some recognizable form and was indicative of glacier flow into the fiord. In 1984, some glacier ice remained afloat as a small glacier tongue but fragments of the old glacier tongue were scattered more widely across central Ayles Fiord (Figures 20 and 21). These glacier tongue fragments are, to all intents and purposes, icebergs, and were briefly investigated by M.O. Jeffries and H. Serson in field trips on the ice in spring 1982 and 1983. Some of the icebergs are shown in Figure 22 and they are $2-3 \mathrm{~m}$ high. Thus, they might be $20-30 \mathrm{~m}$ thick.

Earlier it was noted that in 1950 and 1959 there was a curvilinear debris zone on the surface of the western ice shelf. At that time the debris was adjacent to a cirque glacier that probably once flowed out into the fiord. The debris remains in a curvilinear configuration, but it is no longer adjacent to the glacier (Figure 23). This is further evidence of the recent movement of Ayles Ice Shelf.

In Figure 24 one can see, once again, how far Ayles Ice Shelf moved out of Ayles Fiord. Although the ice shelf did not completely break out of the fiord and create a large ice island, there is evidence that an ice island calved from the front of the shelf. A crack located parallel to the shelf front has already been described (Figure 7B). Shelf ice no longer exists to the north of where the crack was once located. Instead, there is a long, narrow belt of sea ice that has accreted since an ice island calving (Figures 24, 25 and 26). This zone of sea ice continues along the shore of the icefield at Cape Bicknor as far as Cape Egerton (Figure 27). The sea ice in tension (Figure 26) which has developed a crack, must be quite weak as only the wind and water current shear force on the seaward part of that floe is available to cause the cracking seen in that floe.

In summary, it is noted that though there has been a considerable change in the ice conditions in Ayles Fiord, this is not as serious as was once imagined. Ayles Ice Shelf has moved a short distance out of the fiord, but it remains there. Probably associated with this movement was the disintegration of shelf ice in and near the east 


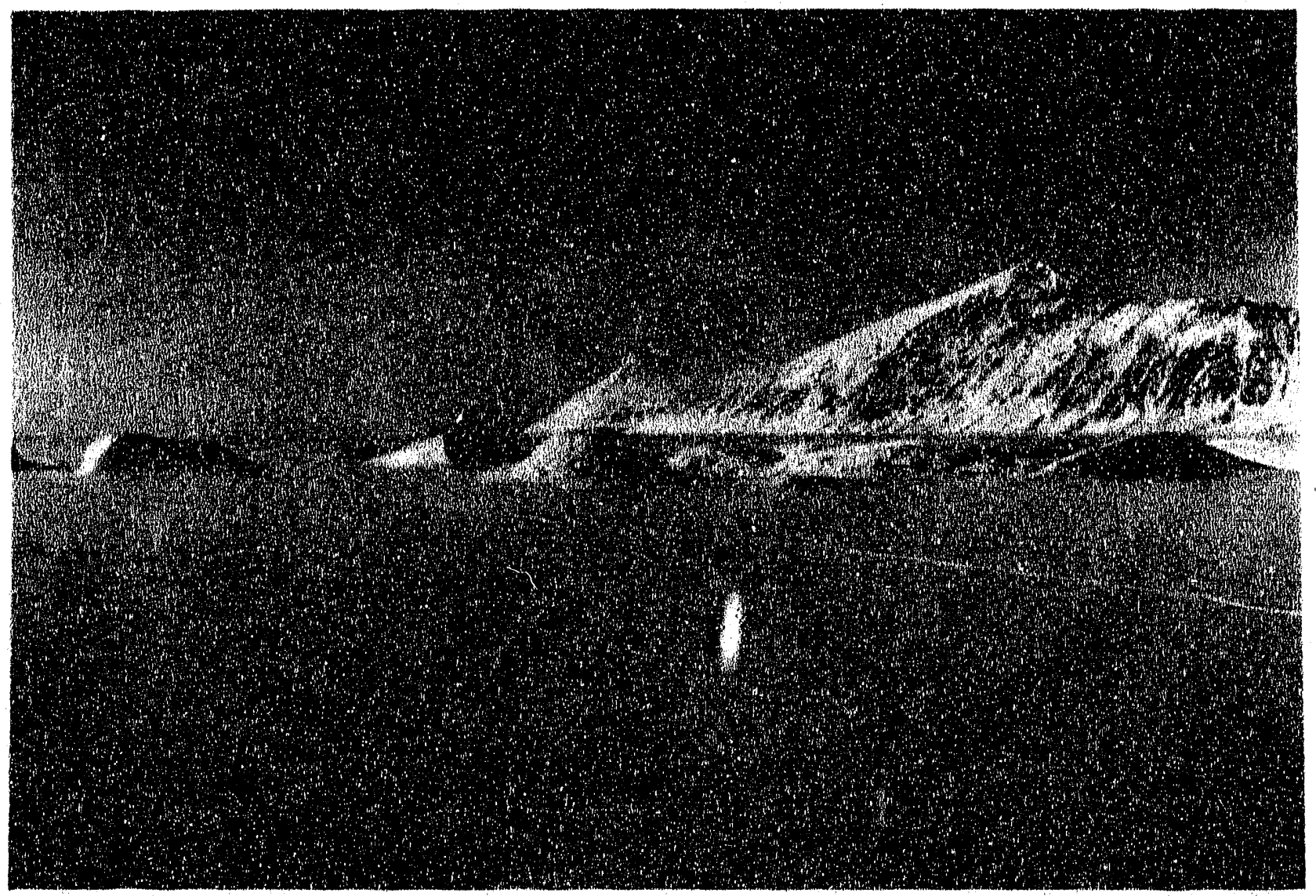

FIGURE 22. lcebergs in Ayles Fiord. This photograph looks towards the east shore of the fiord. The line across the snow is a snowmobile track. 


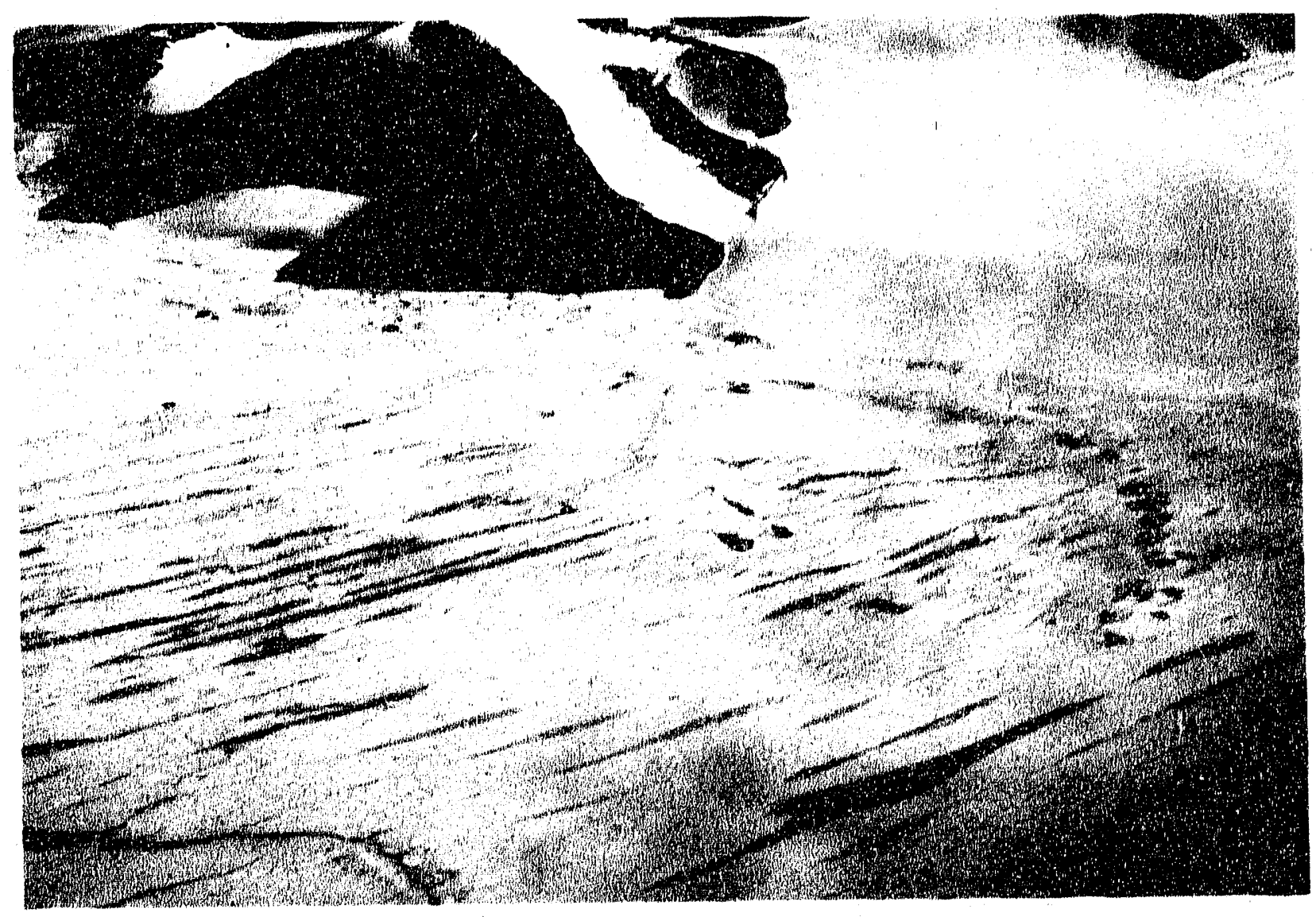

FIGURE 23. Curvi-linear debris zone at the west side of Ayles Ice Shelf (right side of photograph). In 1950.59, this debris was adjacent to the cirque glacier that is arrowed (see also Figs. 7A and 7B).

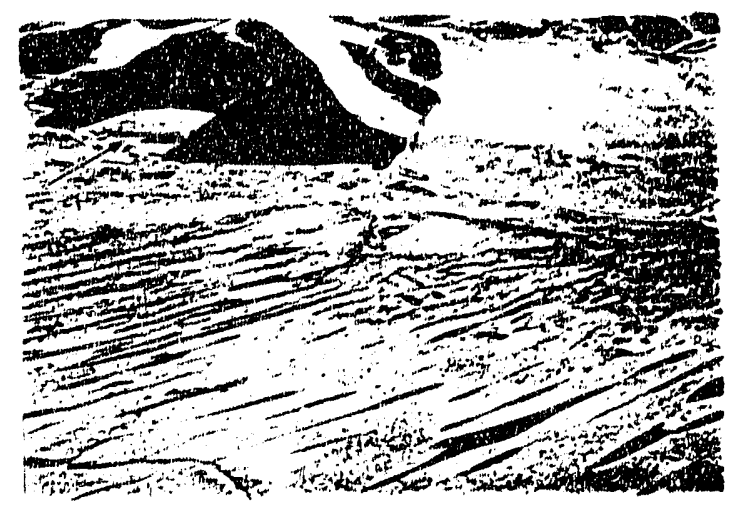




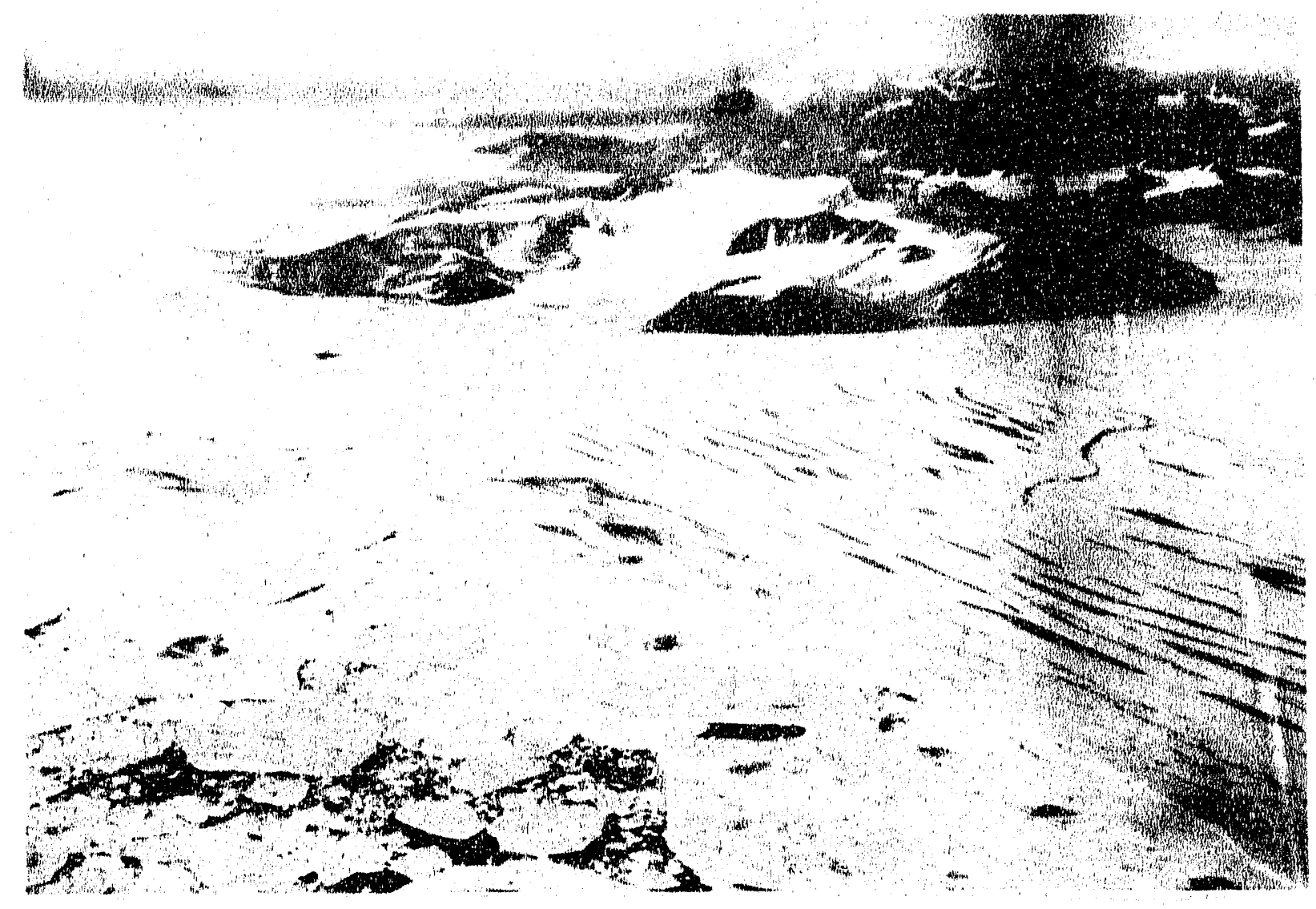

FIGURE 24. View looking east across Ayles Ice Shelf in the mouth of Ayles Fiord. The location of an ice island calving and the sea ice that has regrown since that event is arrowed.

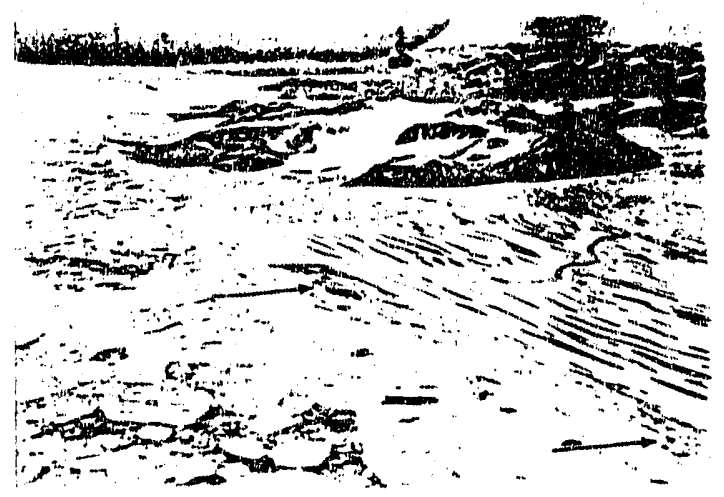




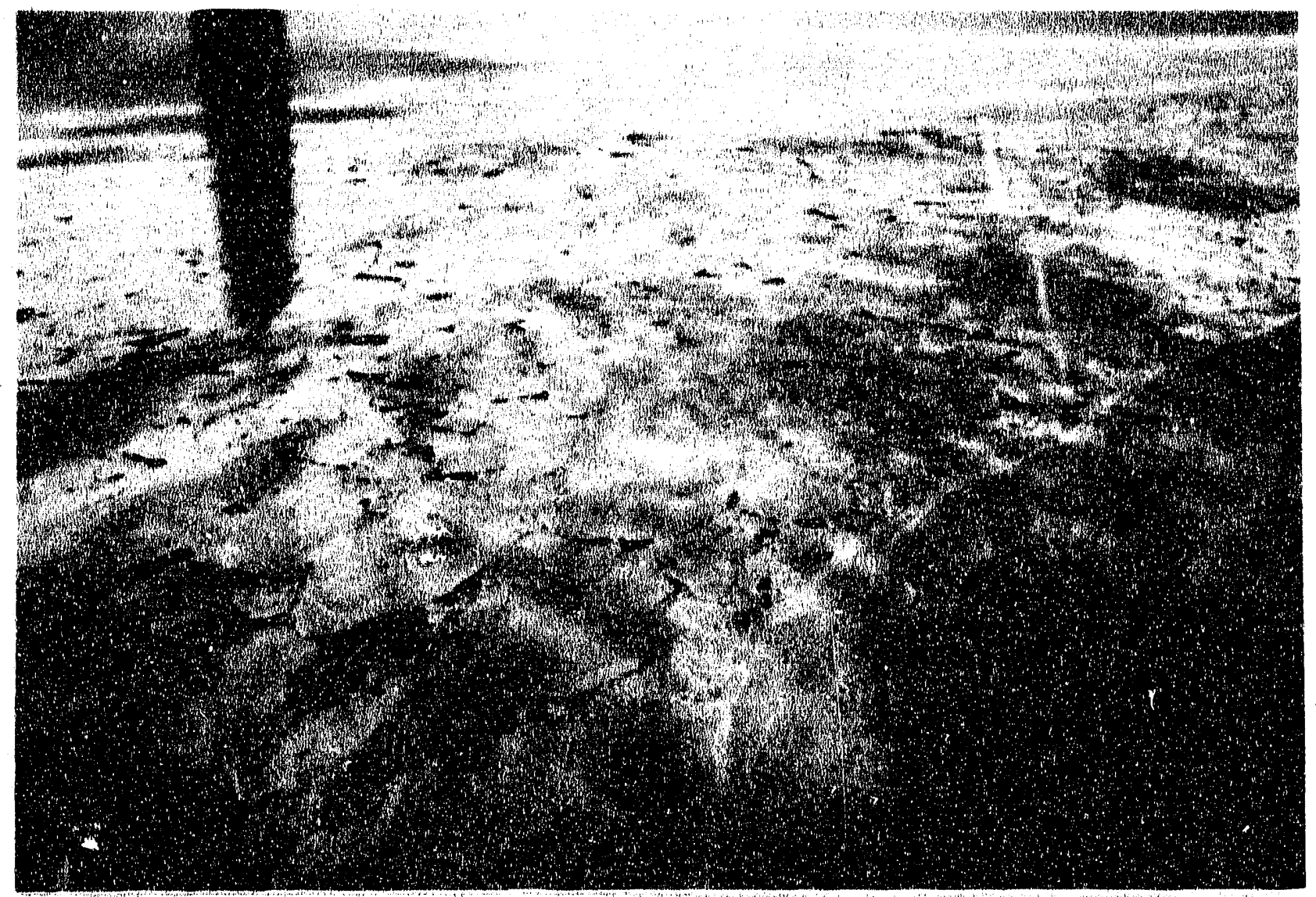

FIGURE 25. Looking down at the outermost part of Ayles Ice Shelf. The arrow indicates sea ice accretion since an ice island calving.

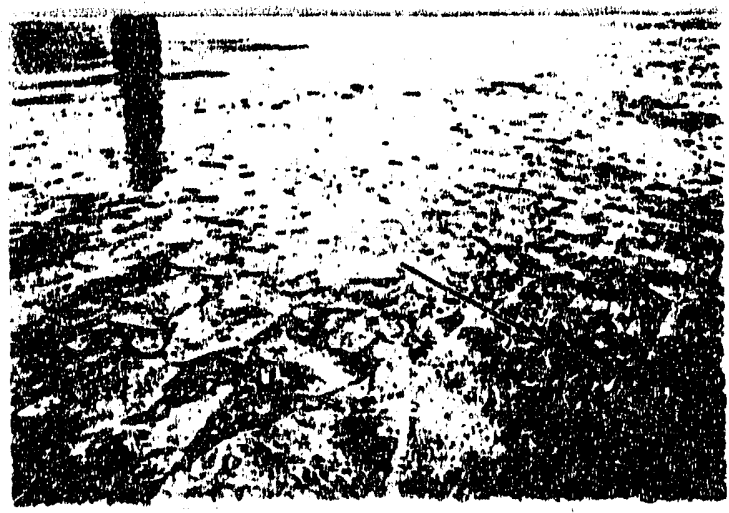




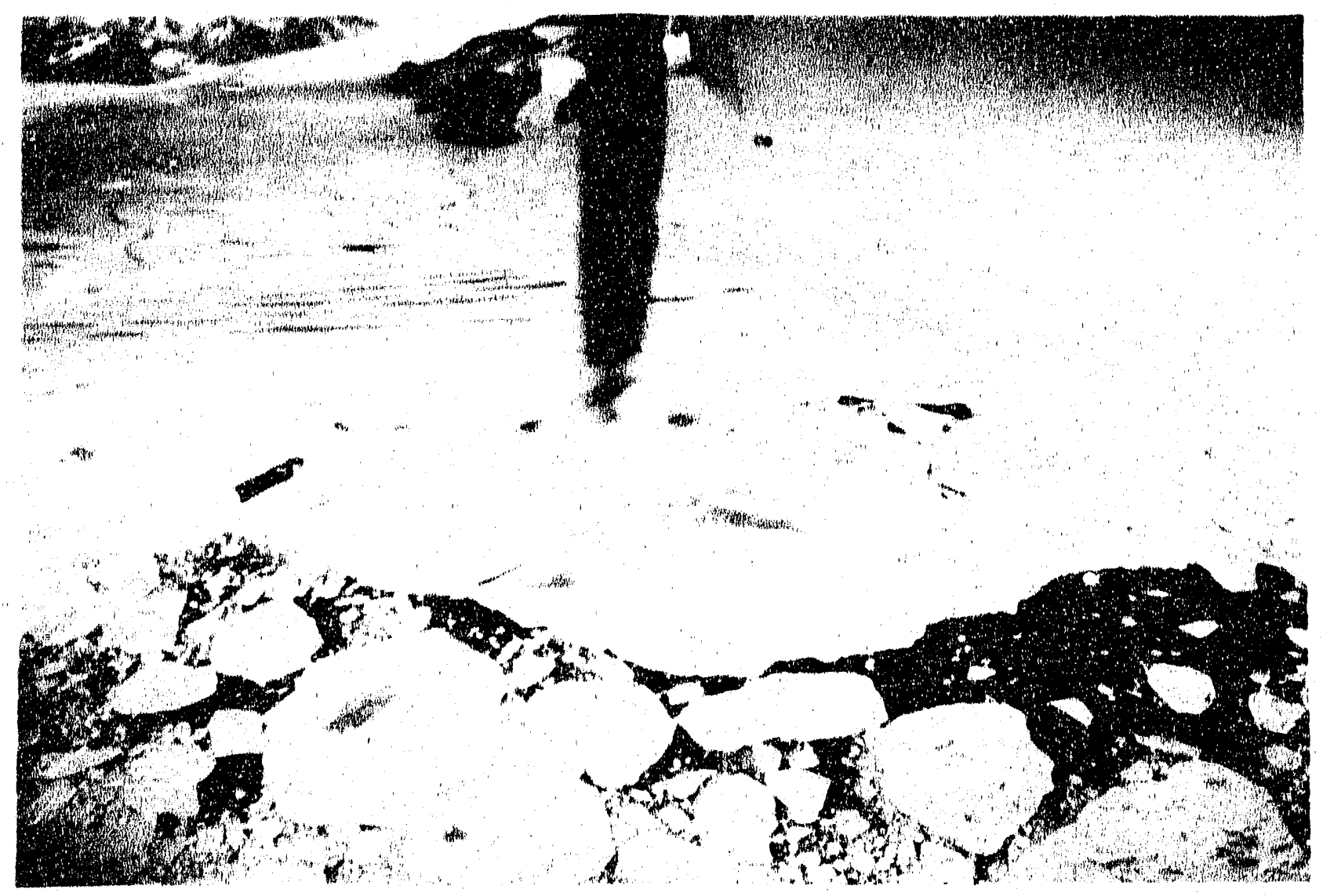

FIGURE 26. The front of Ayles Ice Shelf and icefield at Cape Bicknor (right). Note the open water and leads that suggest the pack ice is in tension. 


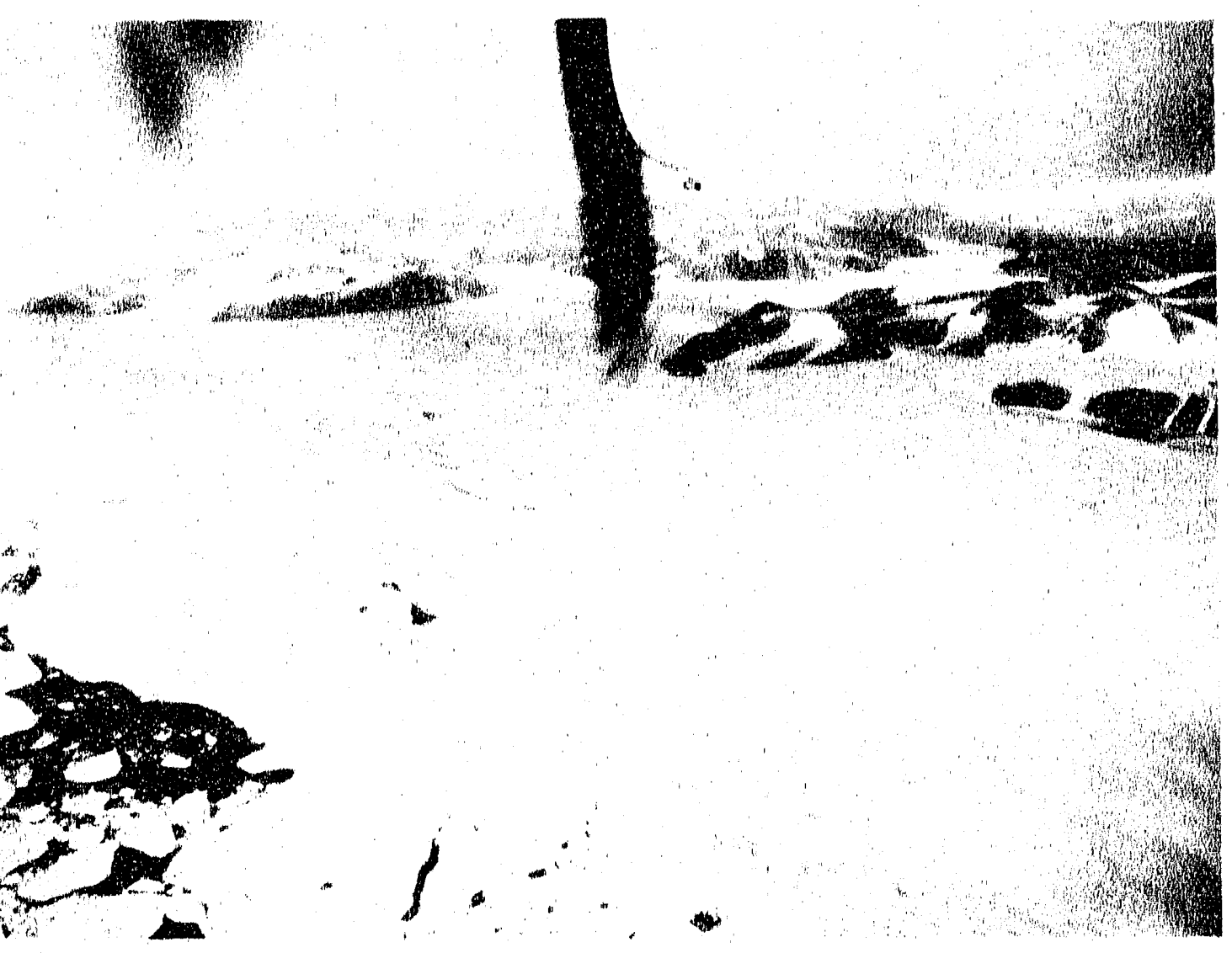

FIGURE 27. Ayles lce Shelf and sea ice belt exiending from the shelf front along the shore of the ice field between Cape Bicknor and Cape Egerton. 
arm of the fiord, and the final breakup of a glacier tongue that once contributed to the growth of Ayles Ice Shelf. Observations indicate that all of the ice movement has been toward the mouth of the fiord, since there are no thick ice fragments found in southern Ayles Fiord. While this might be a function of the fiord ice remaining intact, it is more likely an indication that, at the time of disintegration and movement, winds were blowing out of the fiord. Presumably it would only require winds blowing out of the fiord, perhaps in combination with other oceanographic and meteorologic factors (e.g., storm surges), to complete the removal of Ayles Ice Shelf from Ayles Fiord. If this were to happen there would be considerable addition to the ice island population of the Arctic Ocean. Ayles Ice Shelf is now floating in a precarious position, with release quite possible in the next few years, and should be monitored regularly in view of the possible threat posed by ice islands to offshore development in the Beaufort Sea.

\section{II.2. MILNE ICE SHELF}

Oblique photographs were also obtained in July 1984 of Milne Ice Shelf which is afloat in Milne Fiord (Figures 6A and 6B). Milne Ice Shelf has an area of about $290 \mathrm{~km}^{2}$ and is the second largest of the remaining arctic ice shelves. As with the other ice shelves, Milne Ice Shelf has an undulating topography of ridges and troughs (Figure 28). In summer, water accumulates in the troughs forming elongate lakes which create a darker tone than the adjacent ridges of ice (Figure 28). Unlike the other ice shelves, where the undulations (rolls) are almost linear and parallel, with a fairly constant wavelength, those on Milne Ice Shelf show considerable variation (Jeffries, 1985). At the mouth of Milne Fiord the rolls are essentially linear and parallel, but the degree of disorientation and curvature increases towards the end of the fiord (Figure 28). In addition, the wavelength of the rolls decreases in this direction (Figure 28). On the basis of the surface features, the ice shelf can be divided 


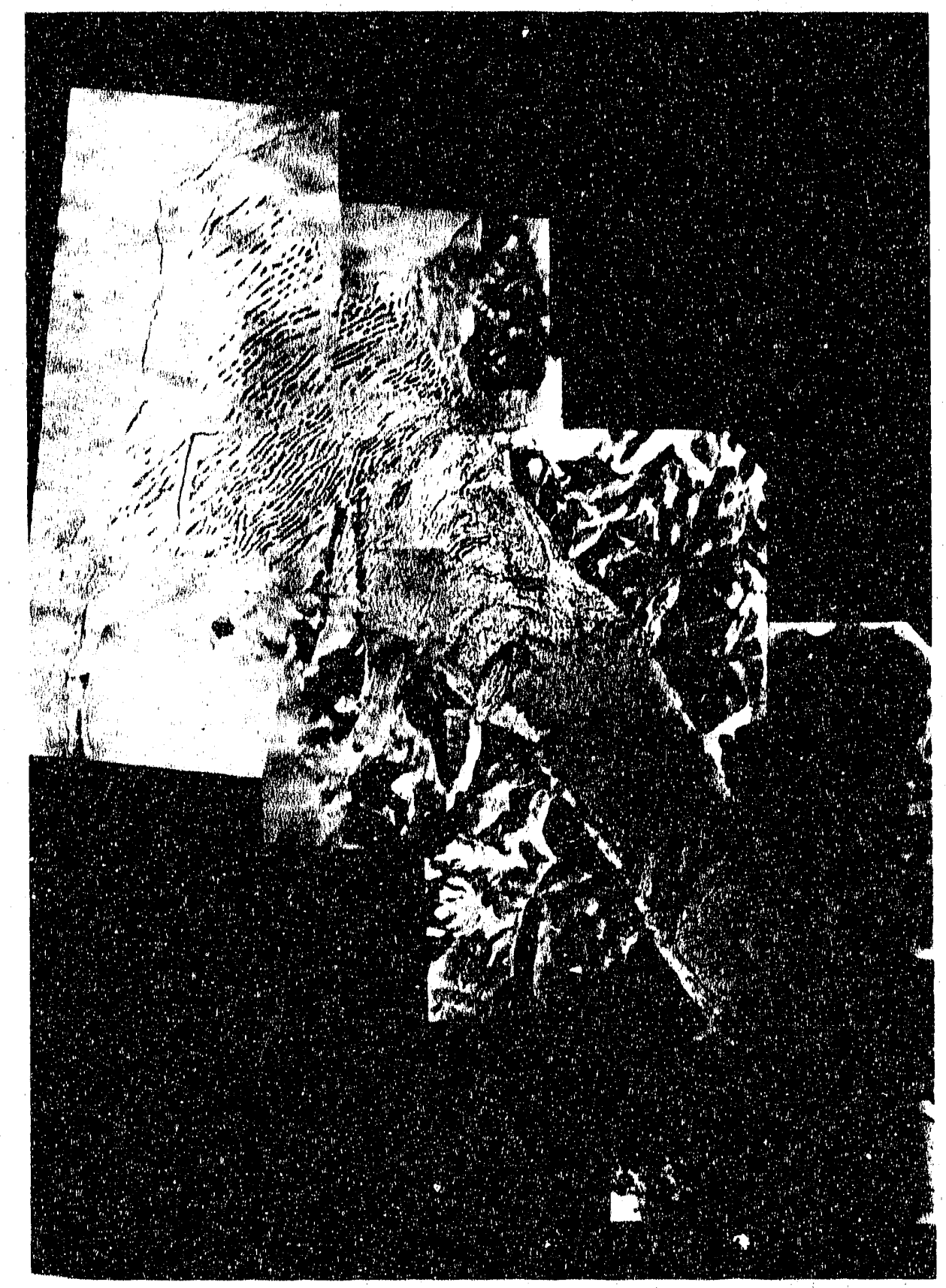

FIGURE 28 Air-photo mosaic of Milne Ice Shelf taken from an altitude of 9114 meters $(30,000$ feet) in July 1959. (Air photographs available from the National Air Photographic Library, Ottawa, Ontario, Canada). 
into three main units: outer unit, central unit and inner unit (Jeffries, 1985). These units are also characterized by ice thickness variations (Prager 1983).

\section{II.2.1. Outer Unit}

The fringe of sea ice continues from Ayles Fiord, as is seen in Figure 29, along the front of Milne Ice Shelf to Cape Evans (Figures 29, 30, 31, 32, and 33). There are two particularly interesting zones in this sea ice that becomes attached to the front of the ice shelf and remains fast for some considerable time. The first zone is a long, narrow piece of ice near Cape Egerton; the second zone is a broader, larger area of ice near Cape Evans.

Meltwater also accumulates in pools on the sea ice (Figures 29, 30, 31, 33, 34, and 35 ), but the pools are neither so deep nor as elongated as those on the ice shelf. However, the areal development of the pools varies across the sea ice with the most advanced melt-pool coalescence and elongation occurring near Cape Egerton. In Figures 29 and 30 , the relatively mature development of the melt-pool pattern on a long, narrow piece of ice near Cape Egerton is shown. The appearance of the ice suggests that it has been there for quite some time ( $>25$ years) in order for "rolls" to develop. It is difficult to put a precise date on the age of any of the ice, with the exception of the sea ice that is now attached to Milne Ice Shelf near Cape Evans. This second zone of ice is 11-19 years old, based on aerial photographic evidence (Jeffries, 1986). In Figures 28 and 32, it is shown that between 1950 and 1959 a piece of Milne Ice Shelf near Cape Evans was surrounded on two, if not three, sides by water-filled cracks that cut across the rolls. On the basis of a comparison of 1959 and 1974 aerial photographs it has been shown that Area A (Figure 32) calved between 1959-74 and was replaced completely by sea ice (Jeffries, 1986). Figures 32 and 33 show this area of Milne Ice Shelf in 1950 and in 1984 respectively. The area of sea ice that replaced Area A is known as Milne Re-entrant (Jeffries, 1985). In 1981, a radio-echo sounding 




FIGURE 29 View looking east over Milne Ice Shelf, Cape Egerton and Ayles Ice Shelf. 


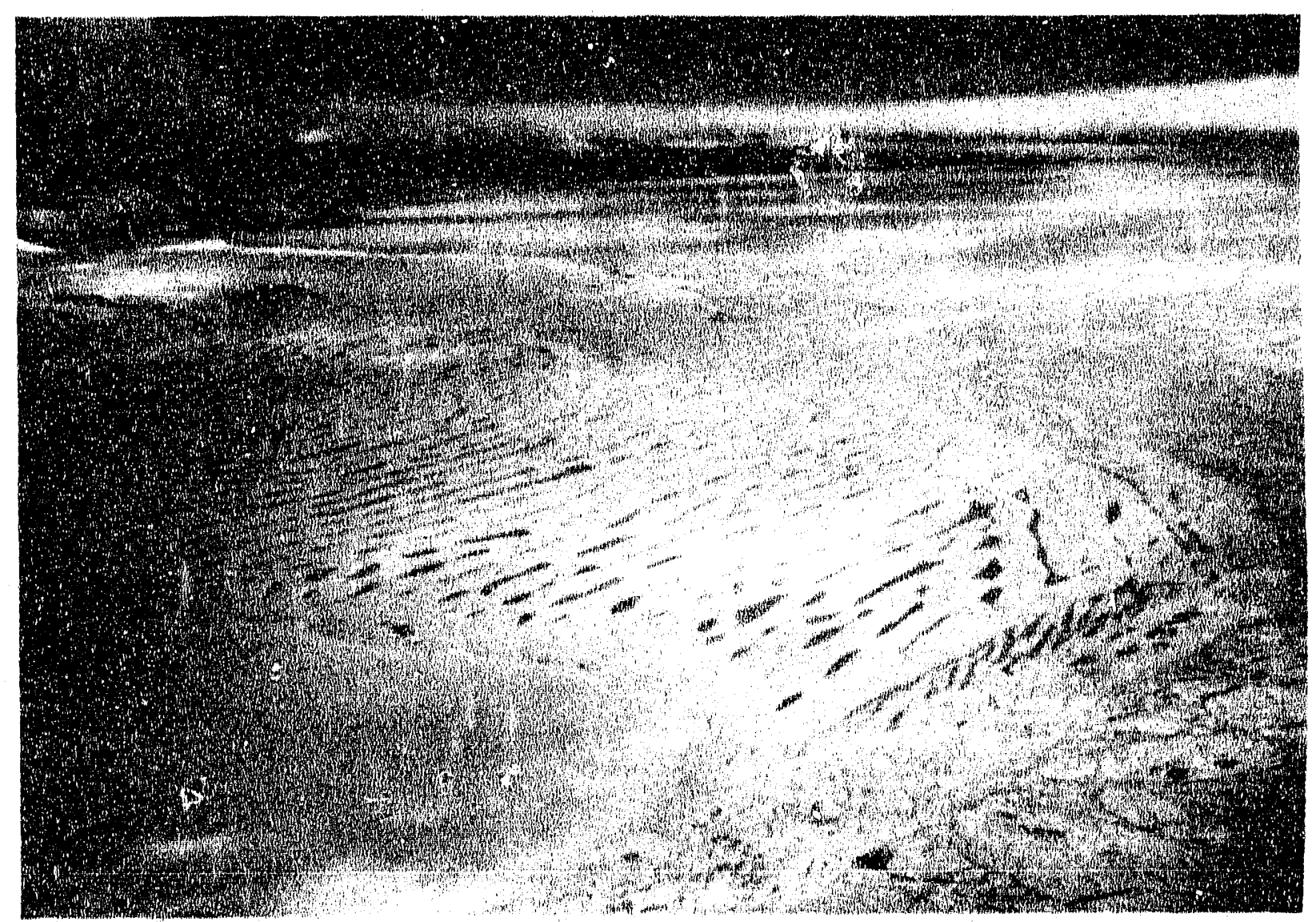

FIGURE 30 View looking southwest across Cape Egerton and the outer unit of Milne Ice Shelf. 


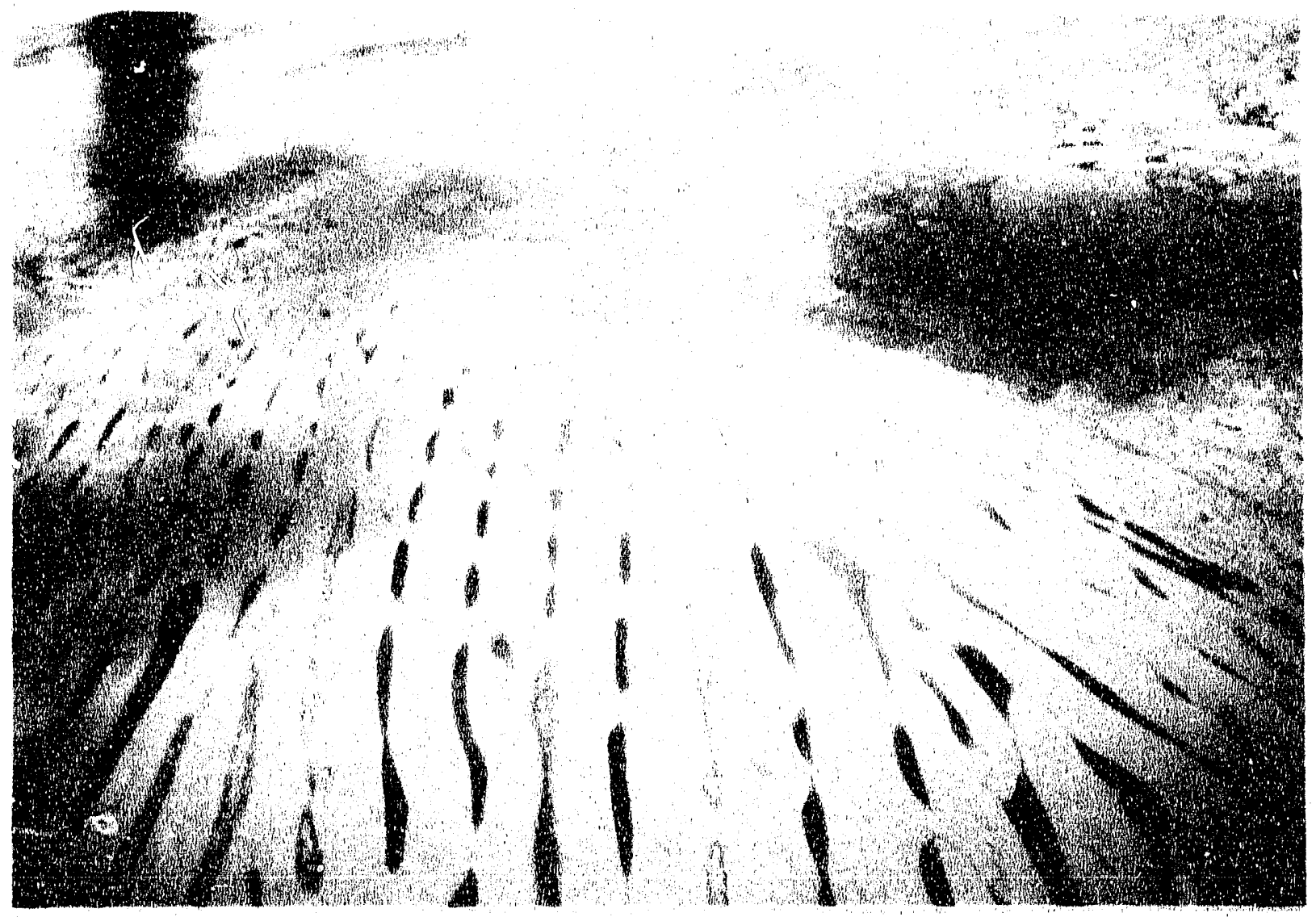

FIGURE 31 The outer unit of Milne Ice Shelf with sea ice accretion along the ice front. 


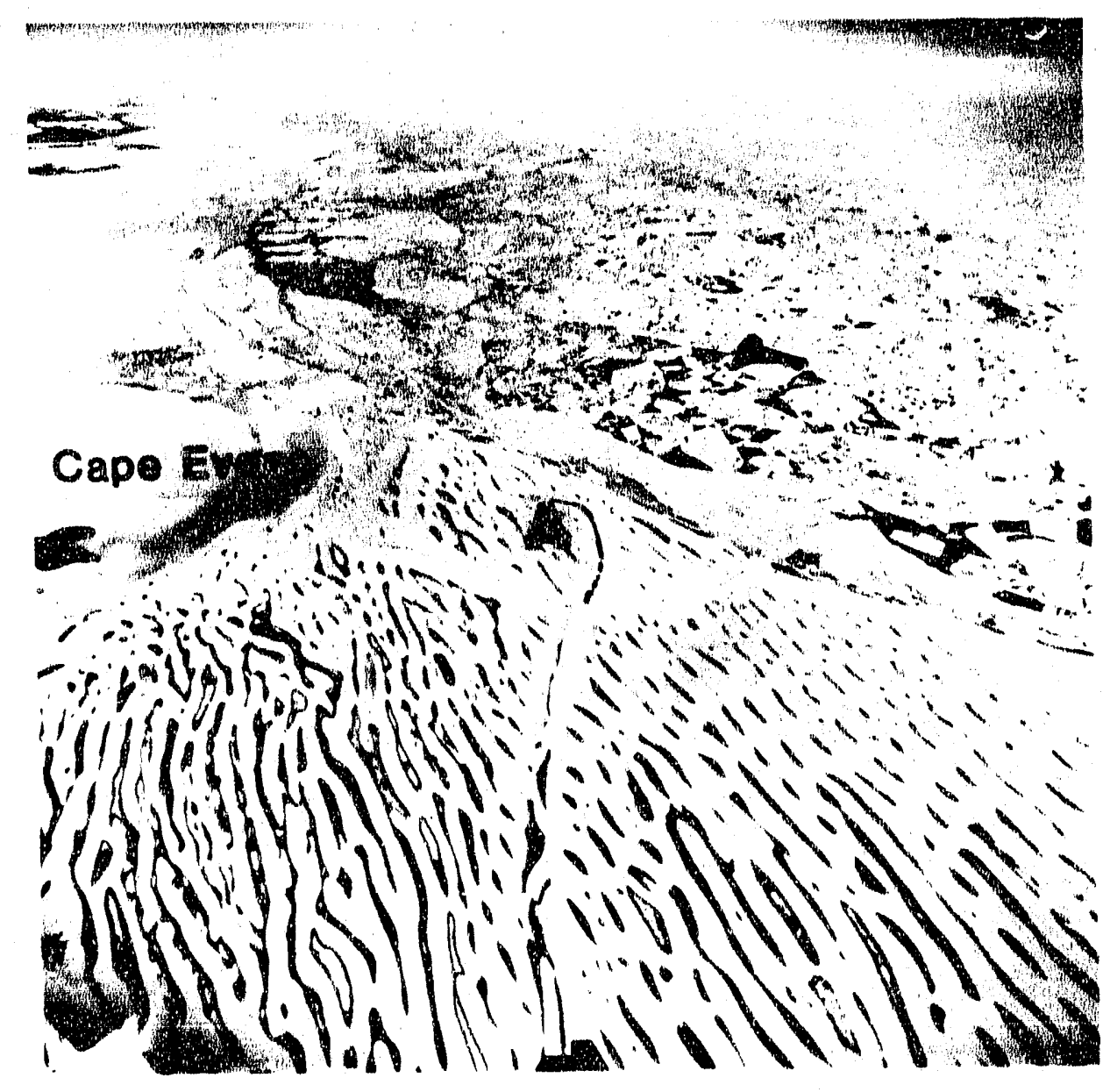

FIGURE 32 Oblique aerial photograph looking southwest across outer Milne lce Shelf and Cape Evans to Yelverton Bay from an altitude of 6096 meters, August 1950 . Area A las an area of about $35 \mathrm{~km}^{2}$ and calved during the interval 1959-74. (Air photograph T407R-8 available from National Air Photographic Library, Ottawa, Ontario, Canada.) 


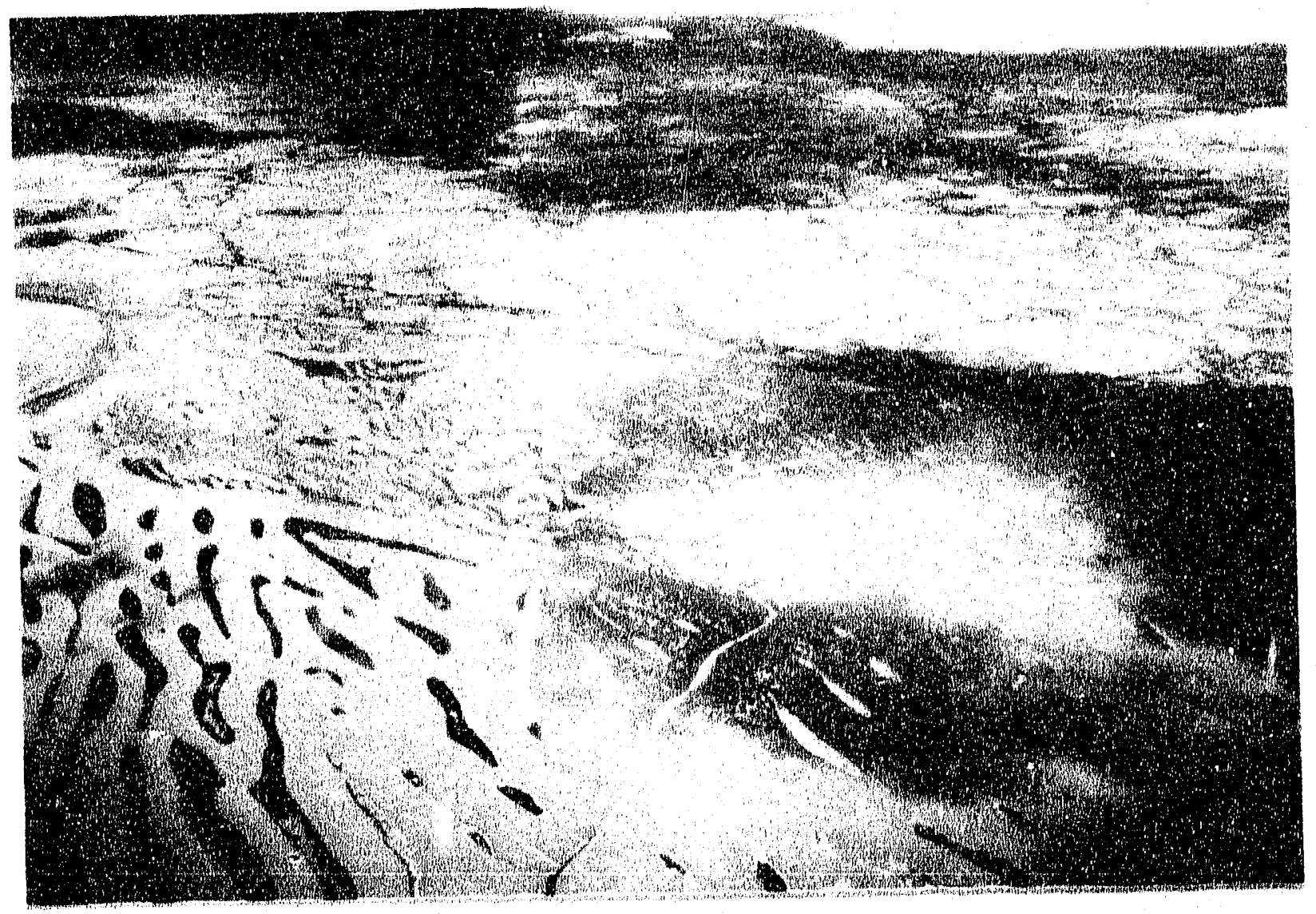

FIGURE 33 Looking southwest across Milne Re-entrant. A water-filled crack is arrowed.

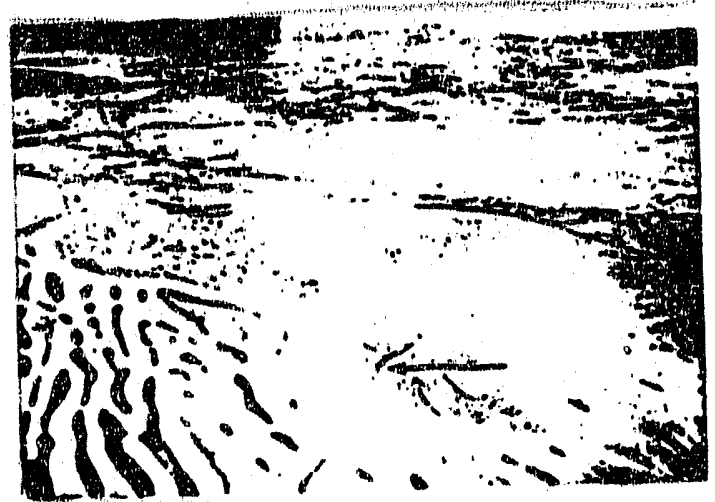




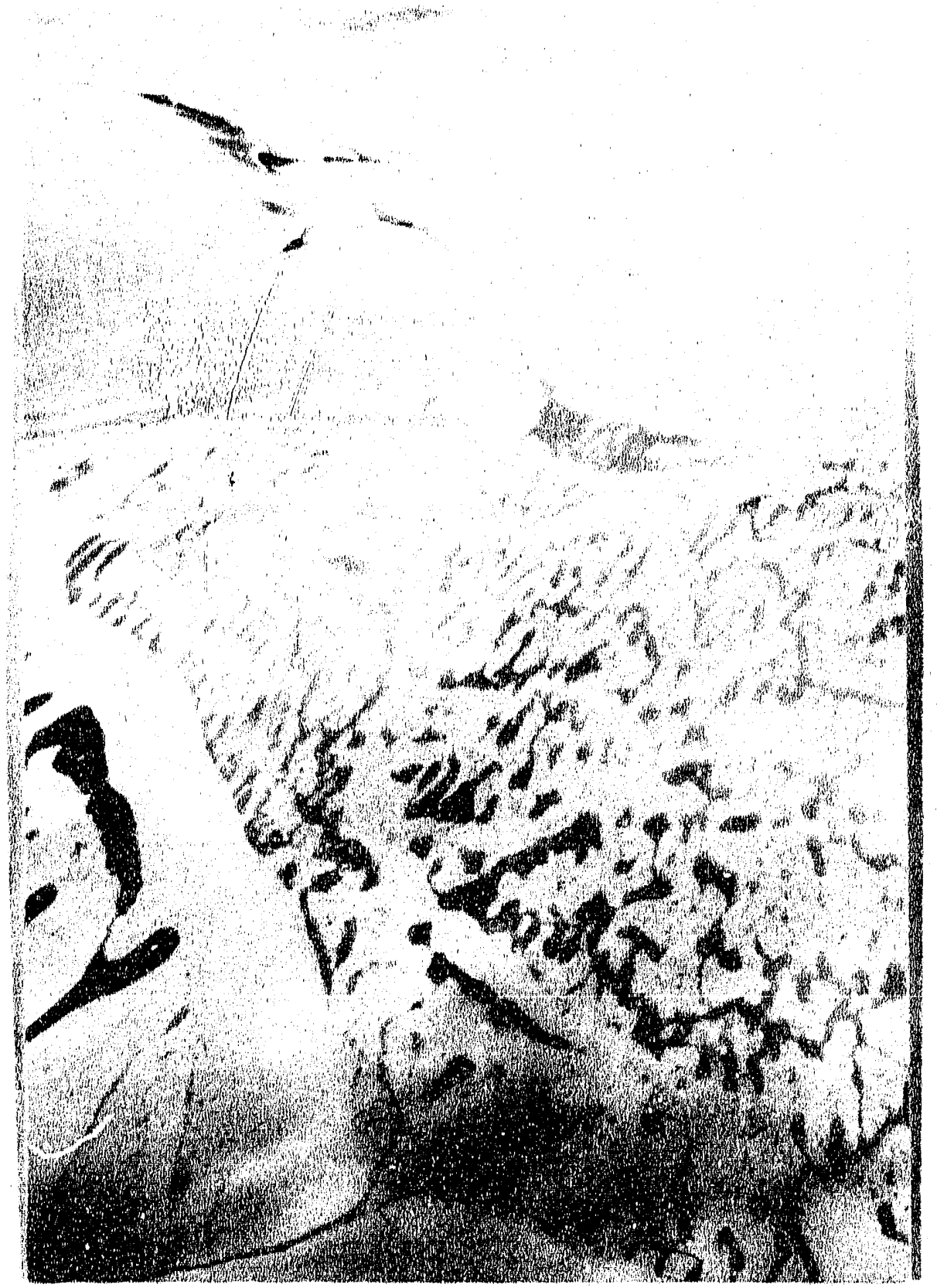

FIGURE 34. Close up view of melt-pools on Milne Re-entrant. Cape Evans is arrowed.

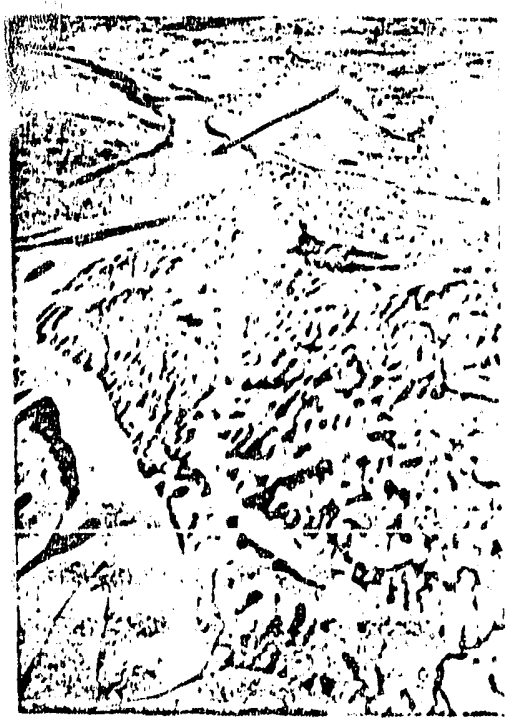






FIGURE 35. Looking northases acros Miln fla-entrant and the outer unit of Milne lce Shulf from Cape Evens. Note the diffarwes between tha meltpools on the Po-entrent and those on the ise shelf. 
survey found the ice to be $\leqq 10 \mathrm{~m}$ thick (Prager, 1983). In spring 1985, adjacent ridge and trough ice thicknesses of $9.8 \mathrm{~m}$ and $7.24 \mathrm{~m}$ respectively were found at one location (Jeffries, et al., 1989, 1990). The melt-pools on the re-entrant are shown clearly in Figures 34 and 35 and although they show evidence of coalescence and elongation, they are not as well developed as the older sea ice near Cape Egerton (Figures 29 and $30)$.

Sea ice accretion at the front of the Milne Ice Shelf has a total area of about $40 \mathrm{~km}^{2}$. The remainder of the outer unit has an area of about $140 \mathrm{~km}^{2}$ with mature roll development and ice thicknesses of up to $90 \mathrm{~m}$ (Prager 1983). The wavelength of the rolls averages about $300 \mathrm{~m}$ and they reach depths of up to $7.5 \mathrm{~m}$. It has already been noted that in 1959 there were two water-filled cracks on the west side of the outer unit (Figures 28 and 32). These cracks created weaknesses in the ice that were subsequently exploited by unknown processes that caused an ice island calving. Two possible lines of weakness remain in the outer unit. The first is a water-filled cracklike feature that runs approximately due east across the outer unit from the reentrant (Figures 28, 32, 33, 34 and 36). While the first line of weakness is a curvilinear feature that cuts across the rolls, the second feature is almost linear in appearance as it cuts across the rolls in a southerly direction from the Cape Egerton icefield (Figures 37, 38 and 39). The feature contains almost no water; its appearance suggests that it is an older crack than the other, and that it has refrozen and rehealed. The origin of the cracks is unknown, but they might be related to some bottom crevasses detected by radio-echo sounding (Prager, 1983). Presumably it required some considerable external force to create these lines of weakness. A repetition of this force, of sufficient magnitude, might conceivably cause further weakening of the outer unit and possible further calving.

The first line of weakness noted above appears to divide the outer unit into two areas which have slightly different roll patterns (Figure 28). To the north of the line 


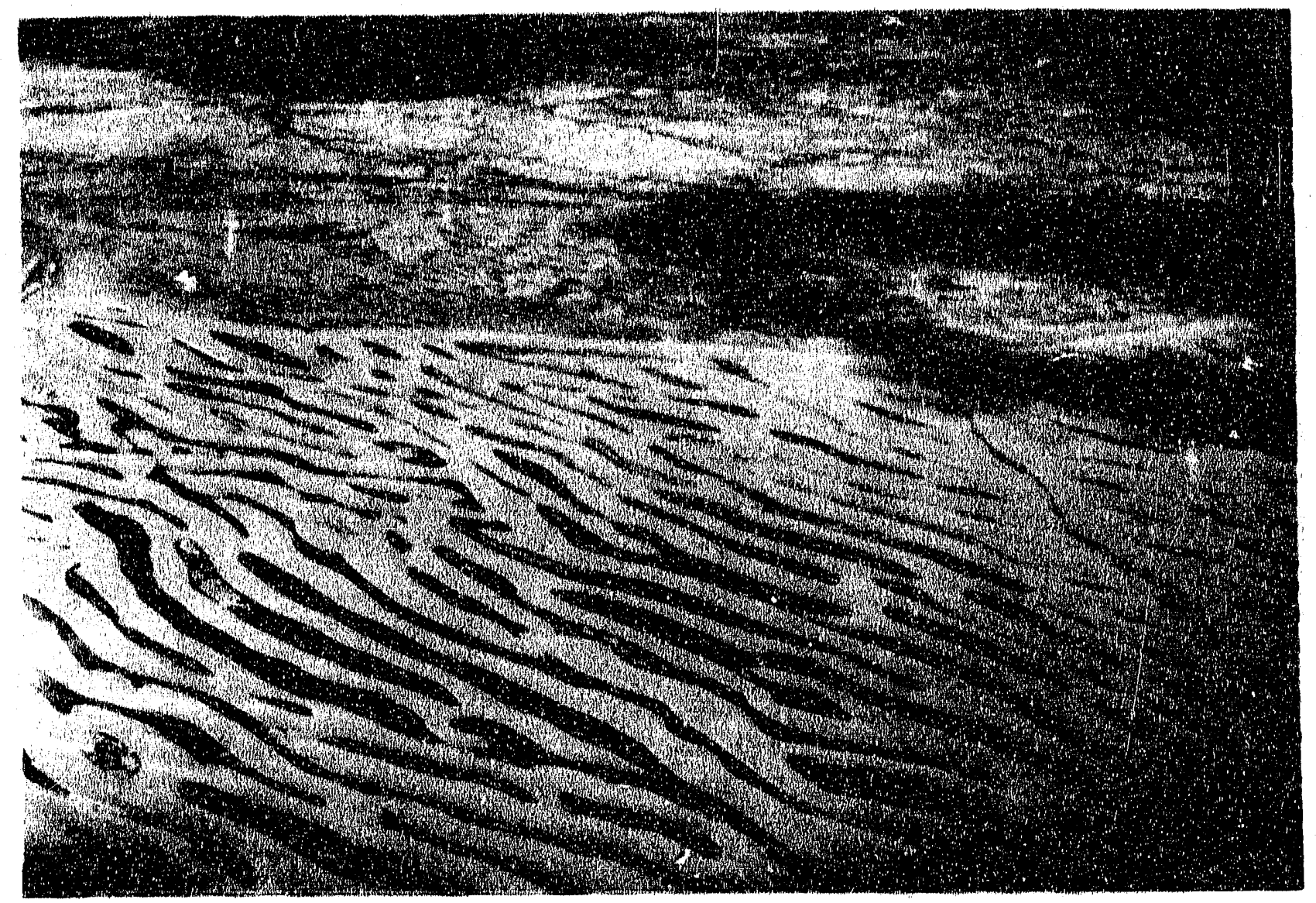

FIGURE 36. West side of the outer unit of Milne Ice Shelf. A water-filled crack running across the rolls towards the re-entrant is arrowed. The dark material at lower left is moraine (see Figure 17).

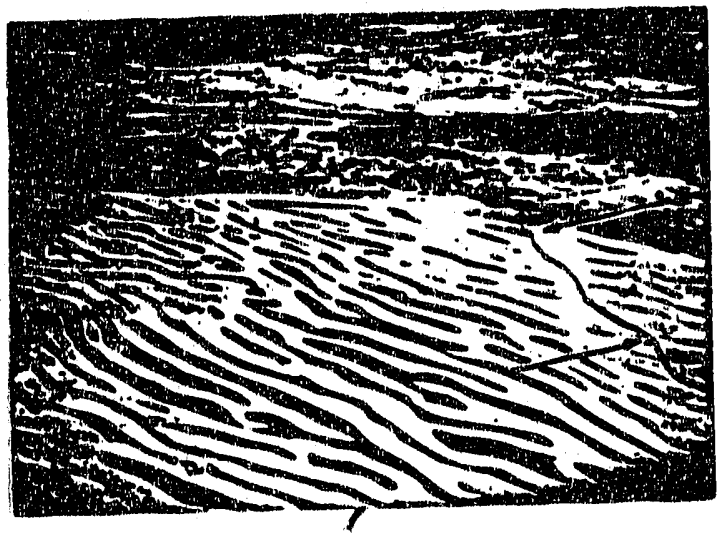




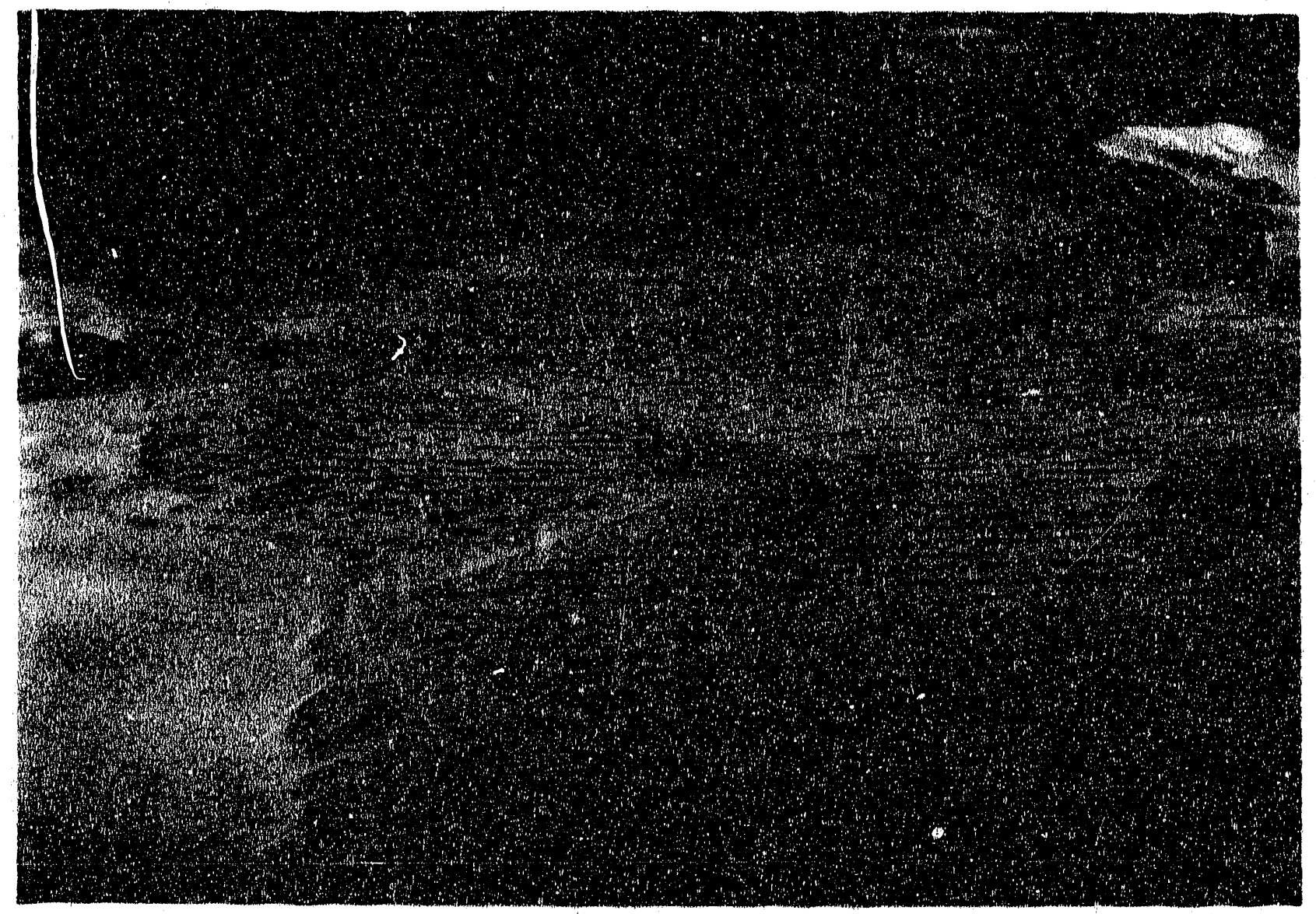

FIGURE 37. Looking south across Milne Ice Shelf from Cape Egerton. The second, linear line of weakness is arrowed. Cape Egerton lcefield is at the left side.

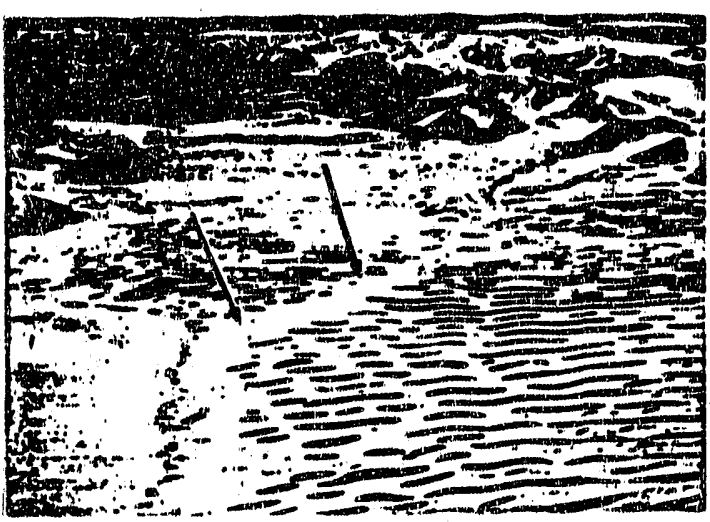




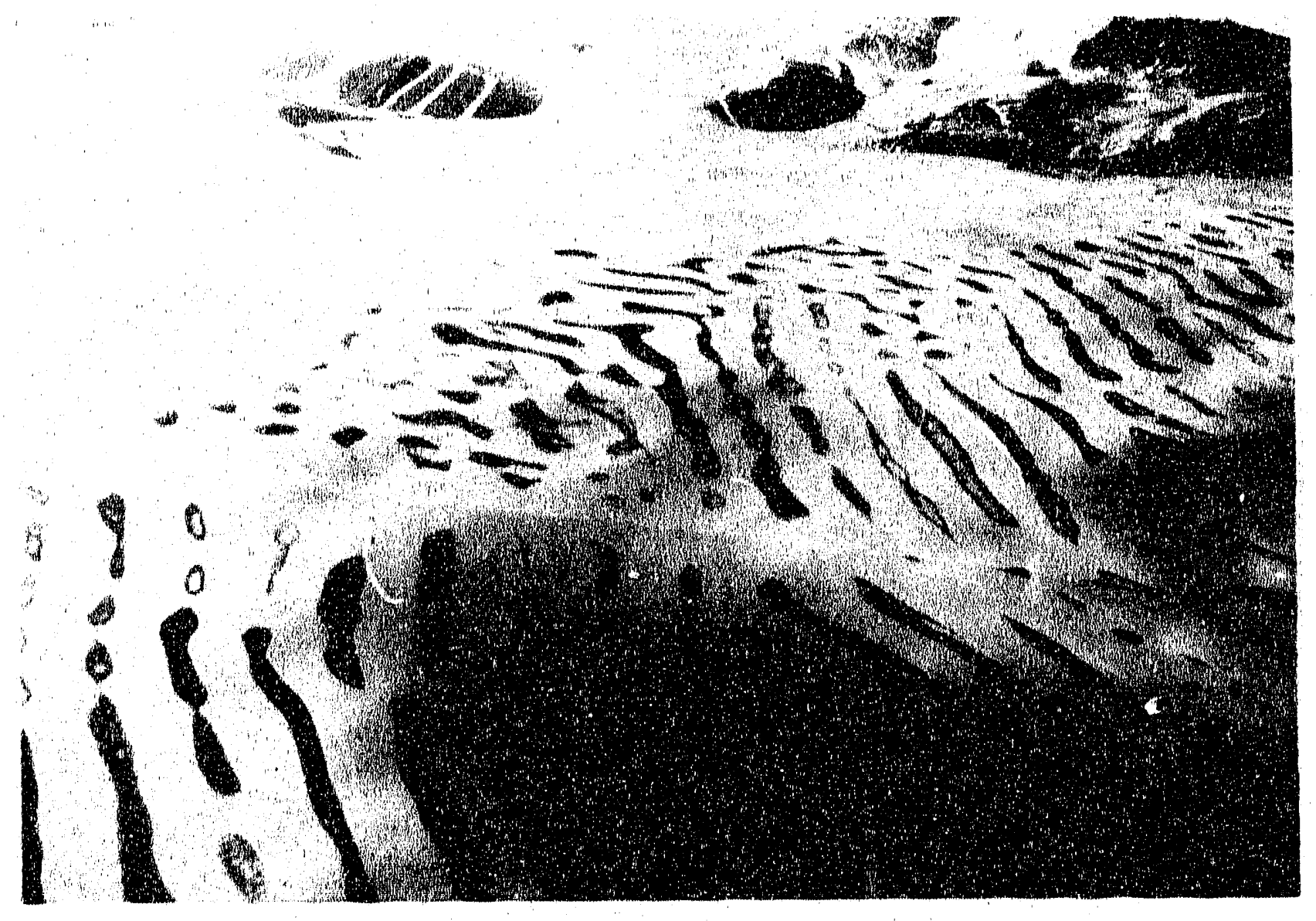

FIGURE 38. The second, linear line of weakness cuts across the ice shelf from left to right in the center of the photograph. 


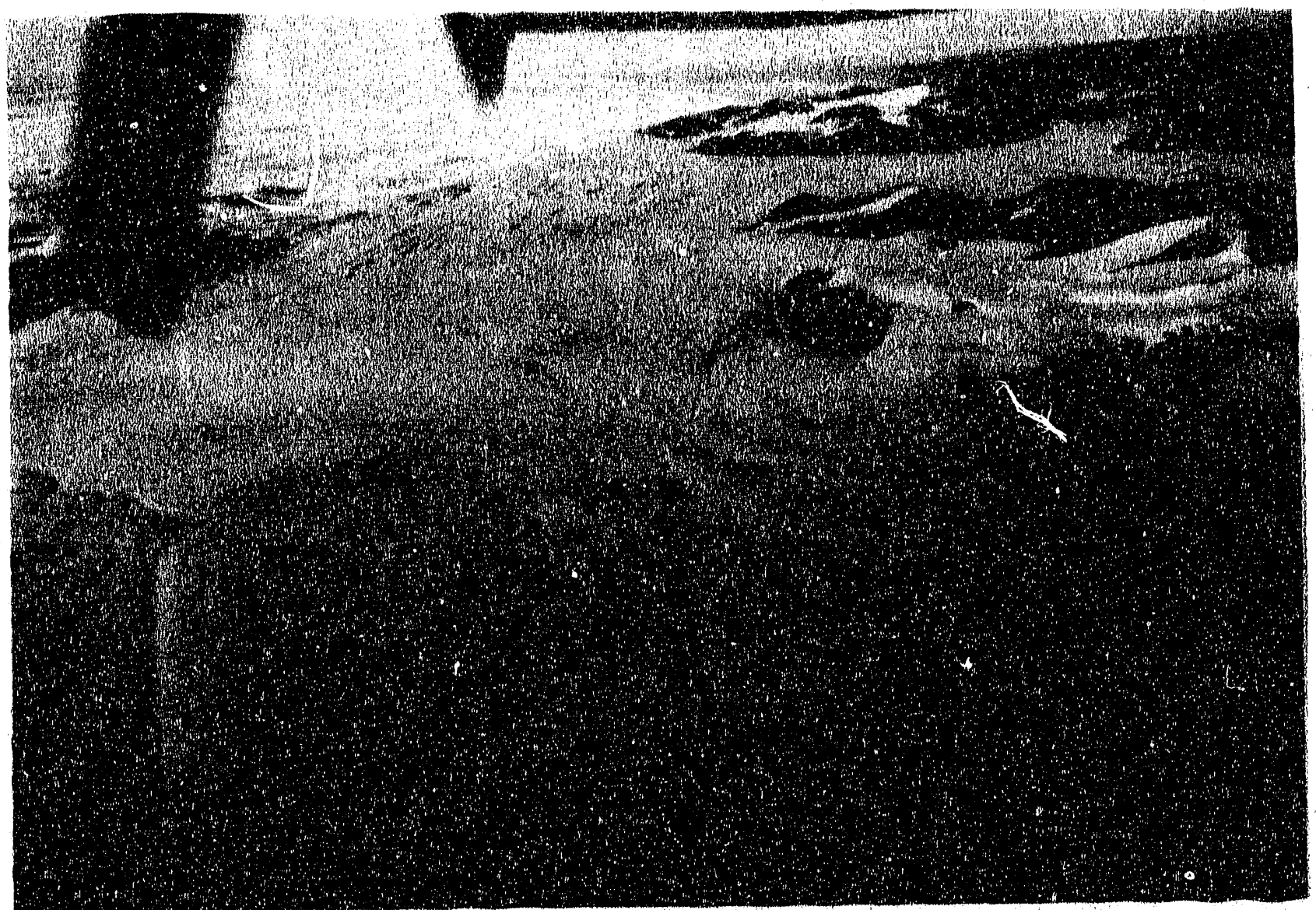

FIGURE 39. Outer unit of Milne Ice Shelf. The econd line of weakness running south from the Cape Egerton Icefield shows clearly at the left side. 
the rolls are mostly long and straight and the meltwater lakes rarely connect with adjacent lakes (Figures $31,32,37$ and 38 ). To the south of the line the rolls display a little more curvature and the slight irregularity is emphasized by interconnecting lakes (Figures 32, 33, 36 and 40). The origin of the rolls on arctic ice shelves is not proven, but they are almost certainly elongated by summer winds and directional convective heat transfer in the melt pools. It is noted that the greatest ice thicknesses in the outer unit occur adjacent to the Cape Egerton icefield (Prager 1983). Furthermore, the ice thicknesses suggest a flow of ice off the icefield into Milne Fiord in the past. Thus, while part of the outer unit might owe its origin to a glacier tongue floating at the mouth of Milne Fiord, the other part might owe its origin to a completely different kind of ice, e.g. sea ice.

\section{II.2.2. Central Unit}

While the origin of the ice of the outer unit is unclear, it is almost certain that the central unit is of glacier origin (Jeffries, 1986). The main evidence for this is the many moraines that are scattered across the surface of the ice (Figure 28). In addition, the curvi-linear appearance of the rolls suggest that they largely follow lines in the ice that was once composed of glacier tongues that flowed into and coalesced in central Milne Fiord.

The first set of moraines is associated with Glacier 1 at the northern margin of the central unit (Figures 36 and 40). These two moraines are quite linear and about $3 \mathrm{~km}$ in length. A second set of moraines is associated with Glacier 3 at the southern margin of the central unit (Figures 28,41 and 42 ). This moraine is composed of a complete ribbon of material that extends about $3 \mathrm{~km}$ into Milne Fiord. The rest of the moraines are associated with the flow of Glacier 2 into Milne Fiord. These are found right across the central unit with a major concentration on the east side up to $7 \mathrm{~km}$ distant from the glacier (Figures 42 and 43 ). This suggests that Glacier 2 was the 


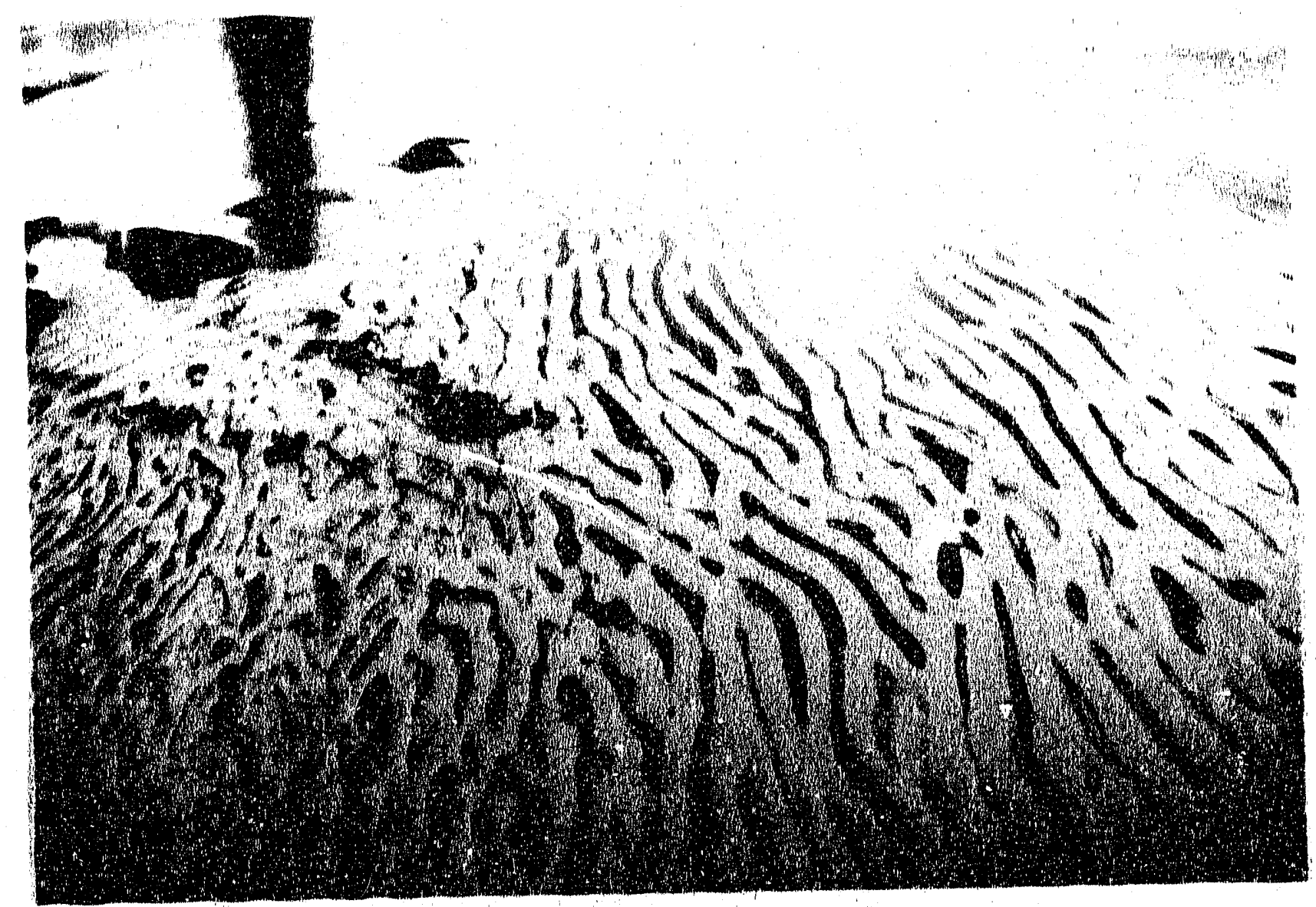

FIGURE 40. Looking northwest Mcross Milne lce Shelf to Cape Evans. The linear concentrations of debris at the loft side are moraines which mark the eouthern boundary of the wuter unit. 


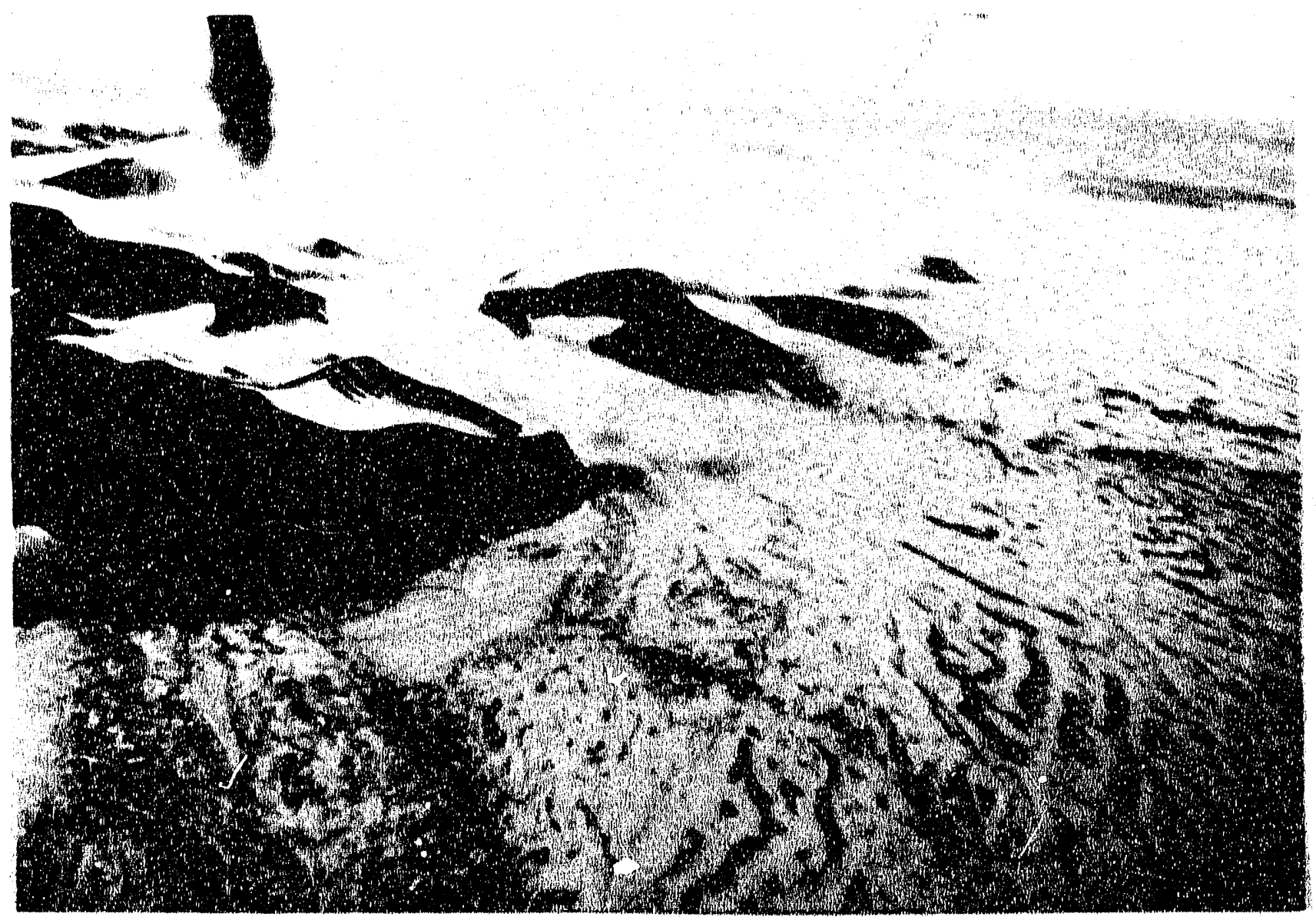

FIGURE 41. Moraine at the surface of the central unit of Milne lce Shelf. The moraine the left side is axsociated with Glacier 3 while that at the right side is associated with Glacier 1. Glacier 2 is in the center. 


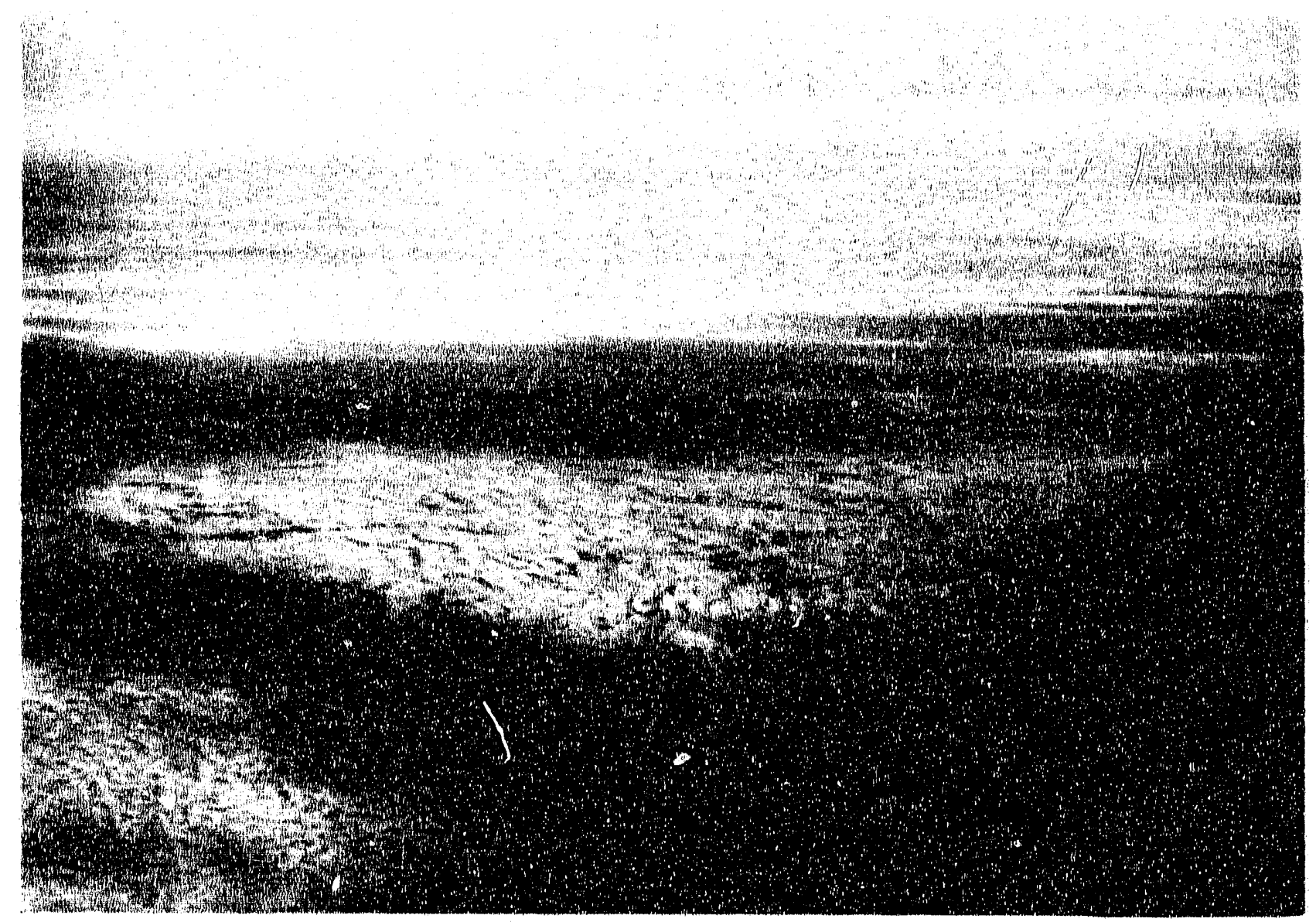

FIGUAE 42. Looking north oust of Milne Fiord. In the foreground is the inner ice shelf unit of which the northern boundary is marked by the dark moraines. The left moraine is anvociated with Glacier 3 and the right moraines with Glacier 2. Moraines from Glacier 1 can be in the distence. 


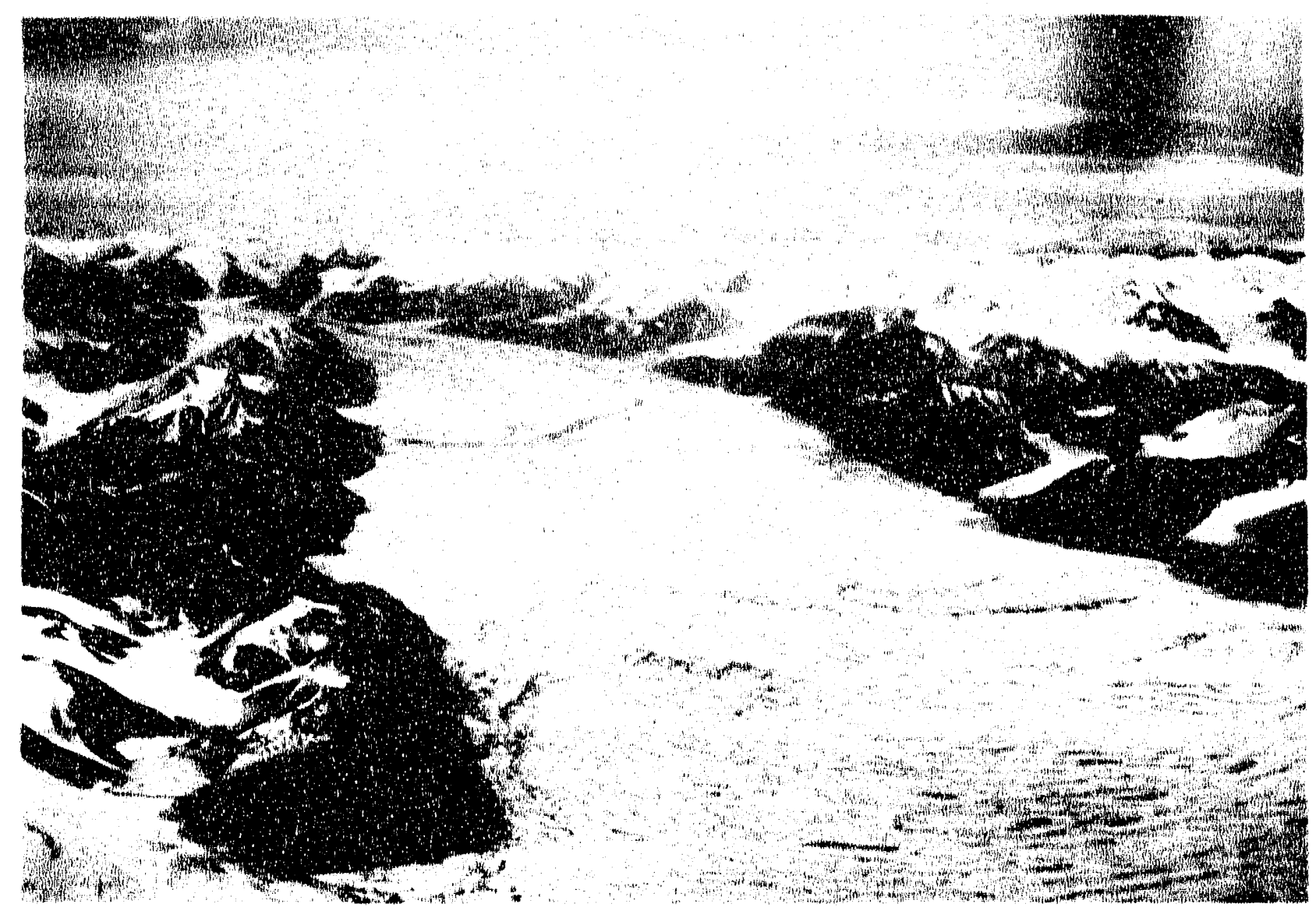

FIGURE 43. View looking south into Milne Fiord. Milne Glacier (see Figure 25 also) is in the back. ground with considerable morainal material at the surface. On the ice shelf, the moraine at the left side comes from Glacier 2 and the moraine on the right from Glacier 3. 
main contributor to the growth of the central unit. In Figure 44, Glacier 2 is shown with the region where it flows into Milne Fiord, becoming part of Milne Ice Shelf. Here there are numerous deep trenches that resemble radial crevasses. The latter form as a result of tensional stresses due to the spreading of the ice that is no longer constrained by the valley walls. Ice from Glacier 2 has spread over a large part of central Milne Fiord, but the ice has thinned as distance increased across the fiord (Prager, 1985).

In addition to a general curvi-linear form that resembles flow lines of the parent glacier, the rolls of the central unit meander and interconnect much more than on the outer unit (Figures 40 and 41). In spring 1983, M.O. Jeffries and H. Serson observed that the rolls are asymmetric in form, with the outside bends of troughs often being vertical and even overhanging. This is consistent with lateral convective transport of warm surface water in the melt-pools, due to winds and to meltwater "erosion" in summer, and suggests a considerable flow of water along the troughs, as well as an explanation of transverse migration of the position of the elongated melt-pools over decades, and their coalescence.

\subsection{Inner Unit}

Prior to a recent advance of Milne Glacier (Jeffries, 1984), the inner unit of Milne Ice Shelf had an area of about $60 \mathrm{~km}^{2}$. It presently has an area of abut $40 \mathrm{~km}^{2}$. Unlike the outer and central units, this unit has relatively thin ice and the short wavelength, shallow rolls show considerable curvature and disorientation (Figure 28). In 1981 , the ice was found to be $\leqq 10 \mathrm{~m}$ thick by radio-echo sounding (Prager, 1983 ) and at one location the ice was as little as $3.19 \mathrm{~m}$ thick (Jeffries, 1985b). Along the northern edge of the inner unit (Figures 42,45 and 46$)$ ), rolis are quite evident and ground observations by M.O. Jeffries and H. Serson in recent years show them to be about $1 \mathrm{~m}$ deep. However, as one proceeds further south on the ice the rolls become 


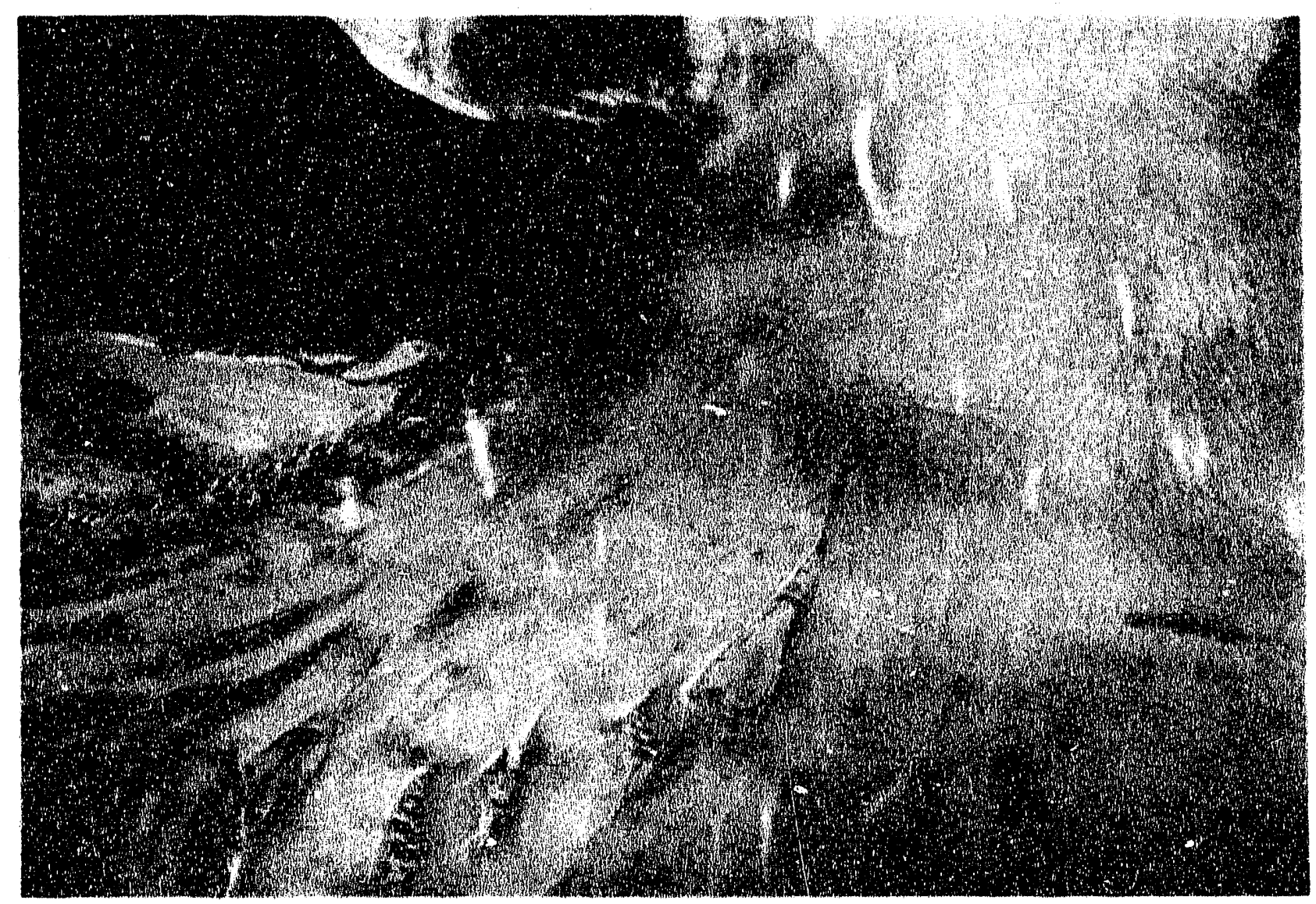

FIGURE 44. Radial crevasses in Milne Ice Shelf near the front of Glacier 2. 


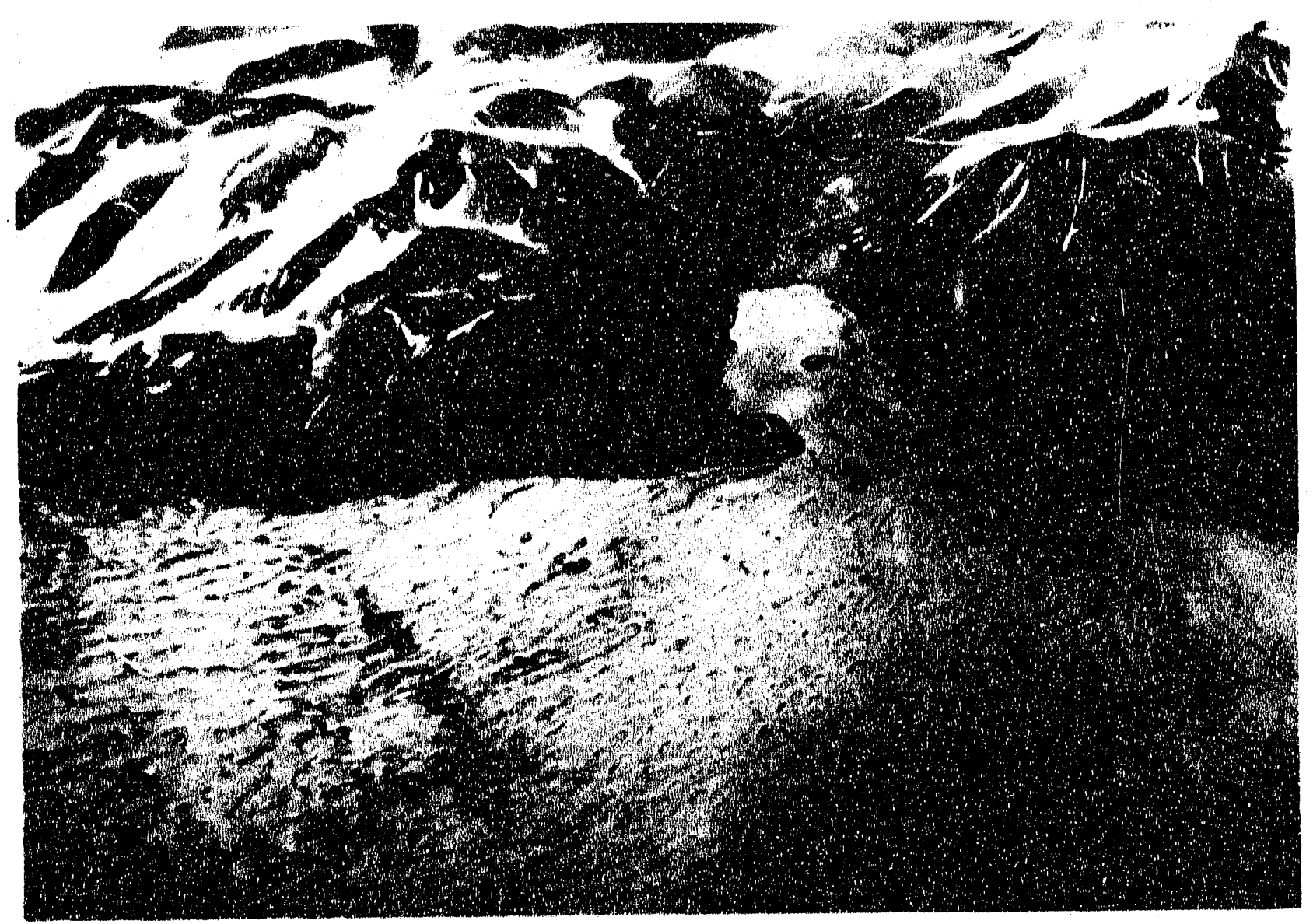

FIGURE 45. Ice in the northeast corner of inner Milne Ice Shelf (right side). At the left side are moraines on the central unit. 


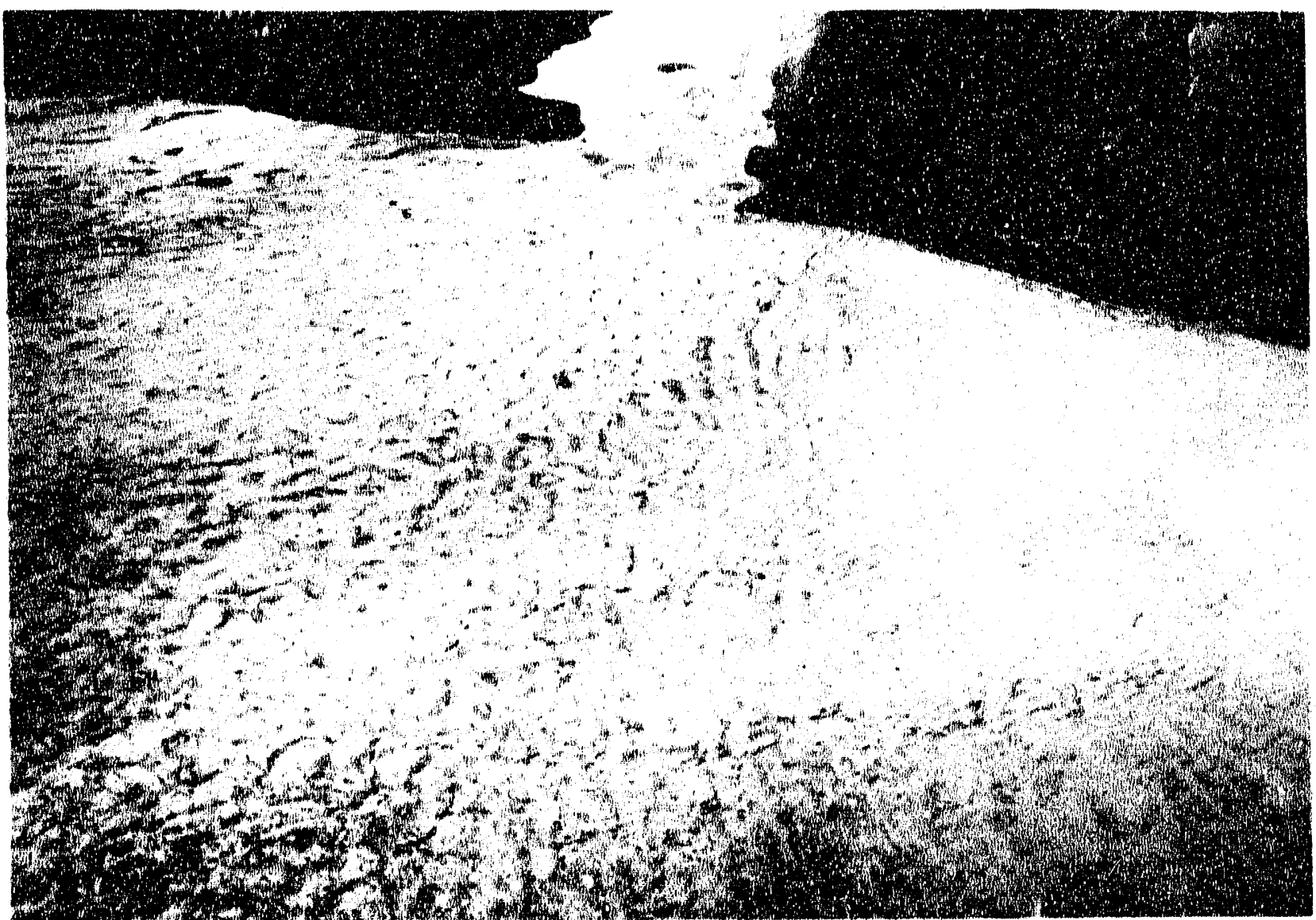

FIGURE 46. Ice on the east side of inner Milne Ice Shelf. Note the gray color of the ice which bf comes cleaner with much less evidence of rolls at the right side. 
much less obvious and perhaps almost non-existent (Figure 46). Much of the ice is quite grey in colour, perhaps as a result of the accumulation of wind-blown dust. The absence of rolls seems to be manifested by a distinct lack of meltwater accumulation on the ice surface. Although it is possible to delineate former traces of rolls, there appears to be insufficient surface relief for ponding of water.

Milne Glacier is contiguous with the inner unit and since the glacier is afloat for a few kilometers it might be considered to be a part of the ice shelf. In Figures 28,43 and 47 Milne Glacier is shown with numerous moraines on its surface. The glacier can be divided into an eastern and western ice stream. The eastern ice stream has a quite irregular and undulating topography with numerous meandering supra-glacial meltwater streams. On the other hand, the western ice stream has a fairly regular undulating topography of almost linear ridges and troughs (Figure 48).

\section{II.3. YELVERTON BAY}

A consistent and unifying feature of arctic ice shelves and ice islands is their undulating topography of parallel ridges and troughs. Ice island T-3 not only had an undulating topography, but there was also much rock debris on the ice surface. Crary and Cotell (1952) identified ice in T-3 that might have come from one of the glaciers that reach tide-water in Yelverton Bay. On the basis of radiocarbon dated material it was suggested that 'T-3 calved after the summer of 1935 (Polunin, 1955) and a likely location in inner Yelverton Bay was mapped (Crary, 1960). In Figure 50, a large area of inner Xelveiton Bay is shown in 1951, one to two decades after the calving event. The possible source region of T. 3 has been covered by a large expanse of sea ice, but there are many small, scattered fragments of shelf ice remaining frozen into that sea ice. The sarne area of Yelverton Bay in 1984 is shown in Figure 51, and it is clear that many shelf ice fragments still remain embedded in the sea ice. This suggests 

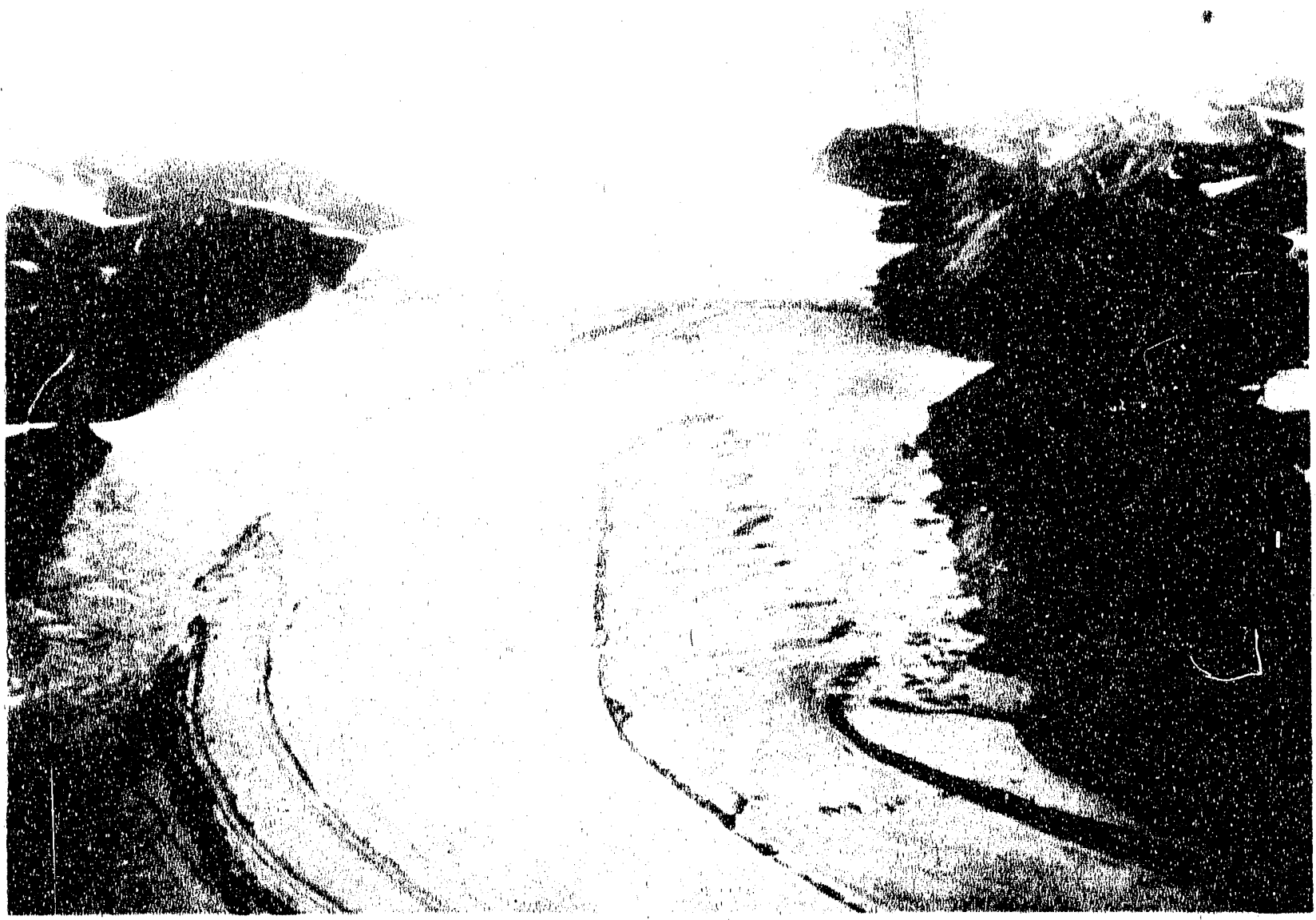

FIGURE 47. View looking north out of Milne Fiord. Milne Ice Shelf is in the foreground and the dark bands are medial moraines. 




FIGURE 48. The western ice stream of Milne Glacier. Note the grayness of the ice. 


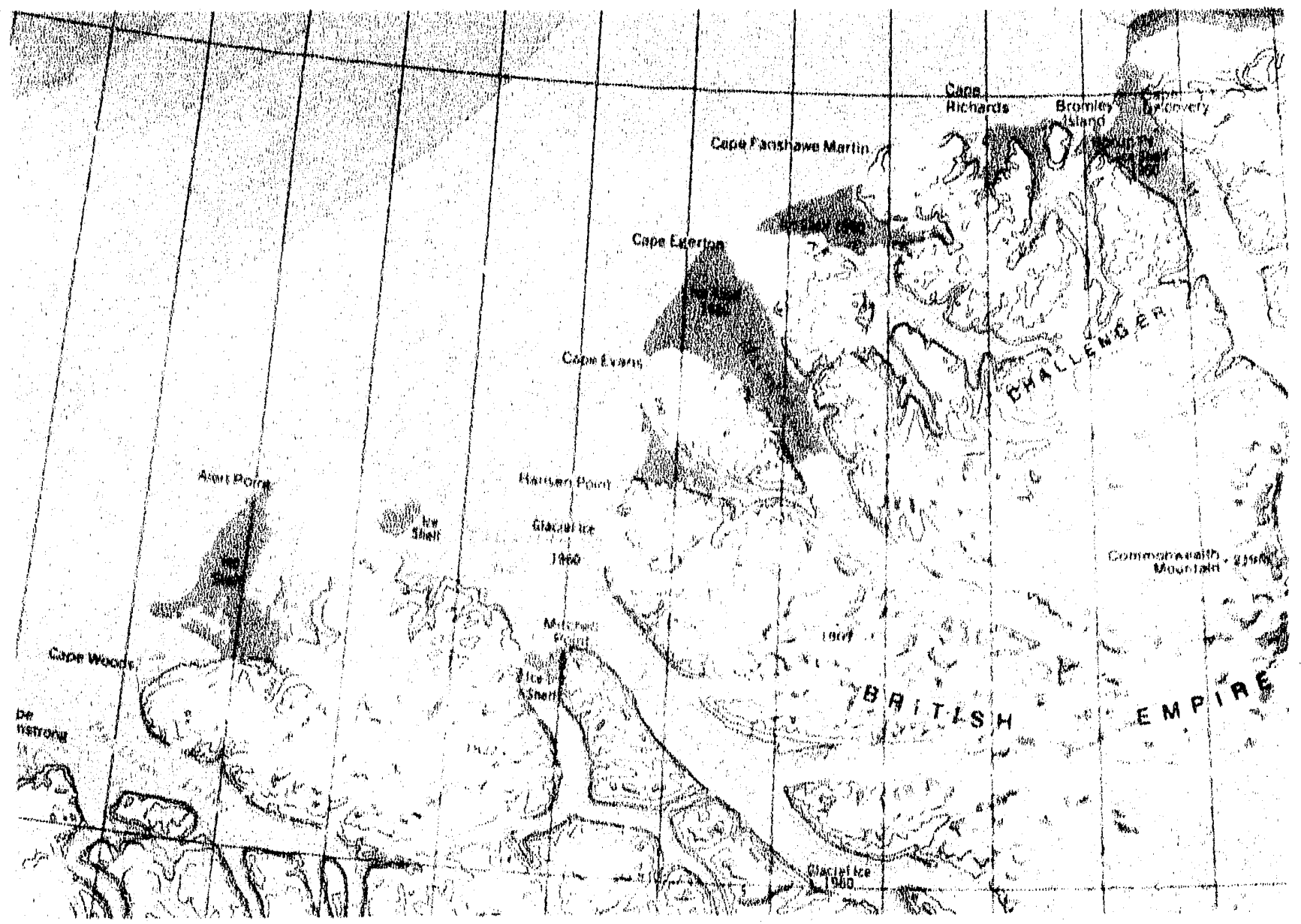

FIGURE 49 Map of north coast of Ellesmere Island from Cape Fanshawe Martin to Cape Evans. 


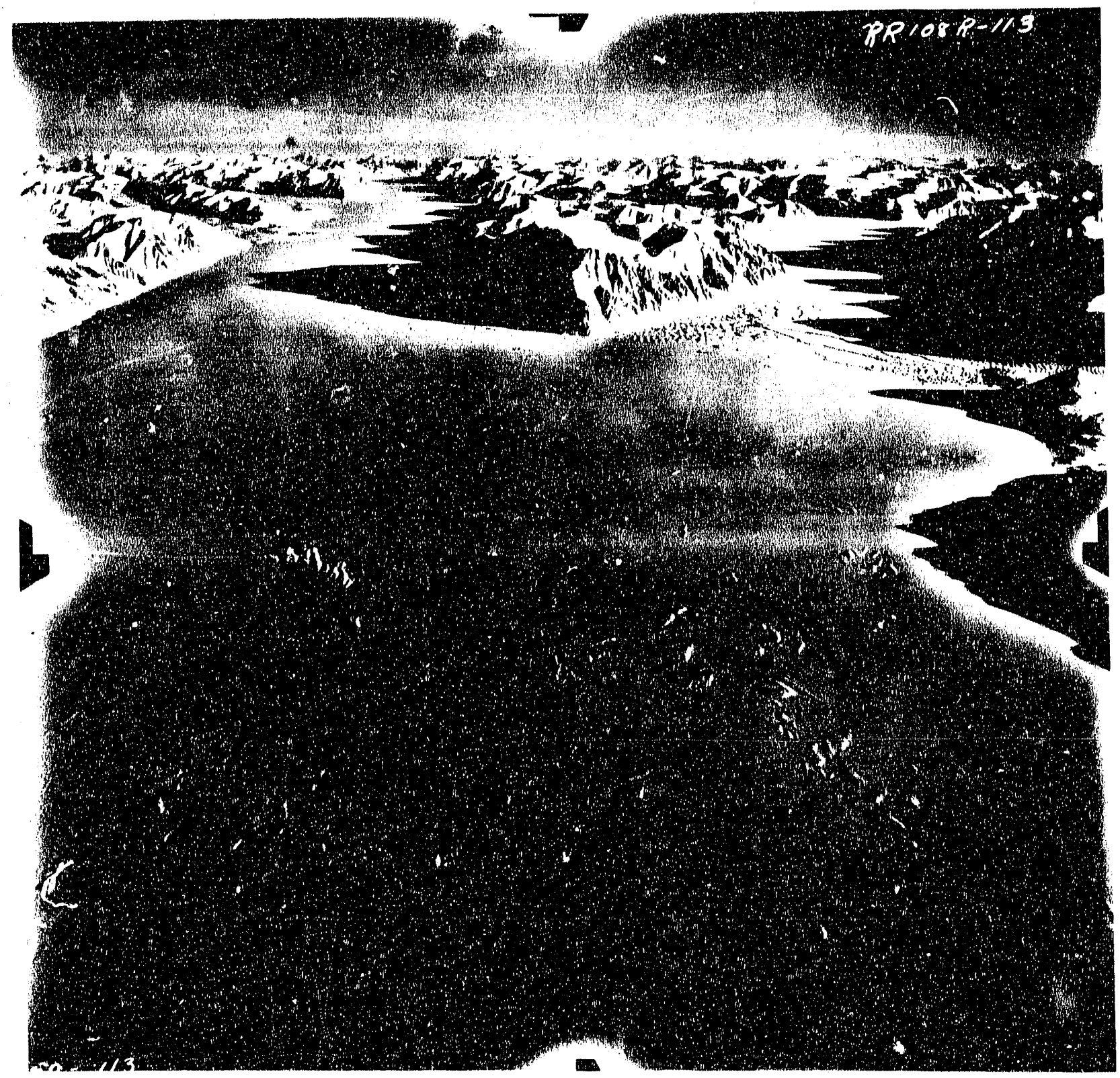

FIGURE 50. Oblique aerial view looking SSE across inner Yelverton Bay and Mitchell Pt. (center). Note the glacier that flows into Yelverton Bay as a glacier tongue and creates a thick ice (shelf?) barrier across the mouth of the inlet. (Frame RR 108R-113, April 1951, National Air Photographic Library Ottawa, Ontario, Canada). 


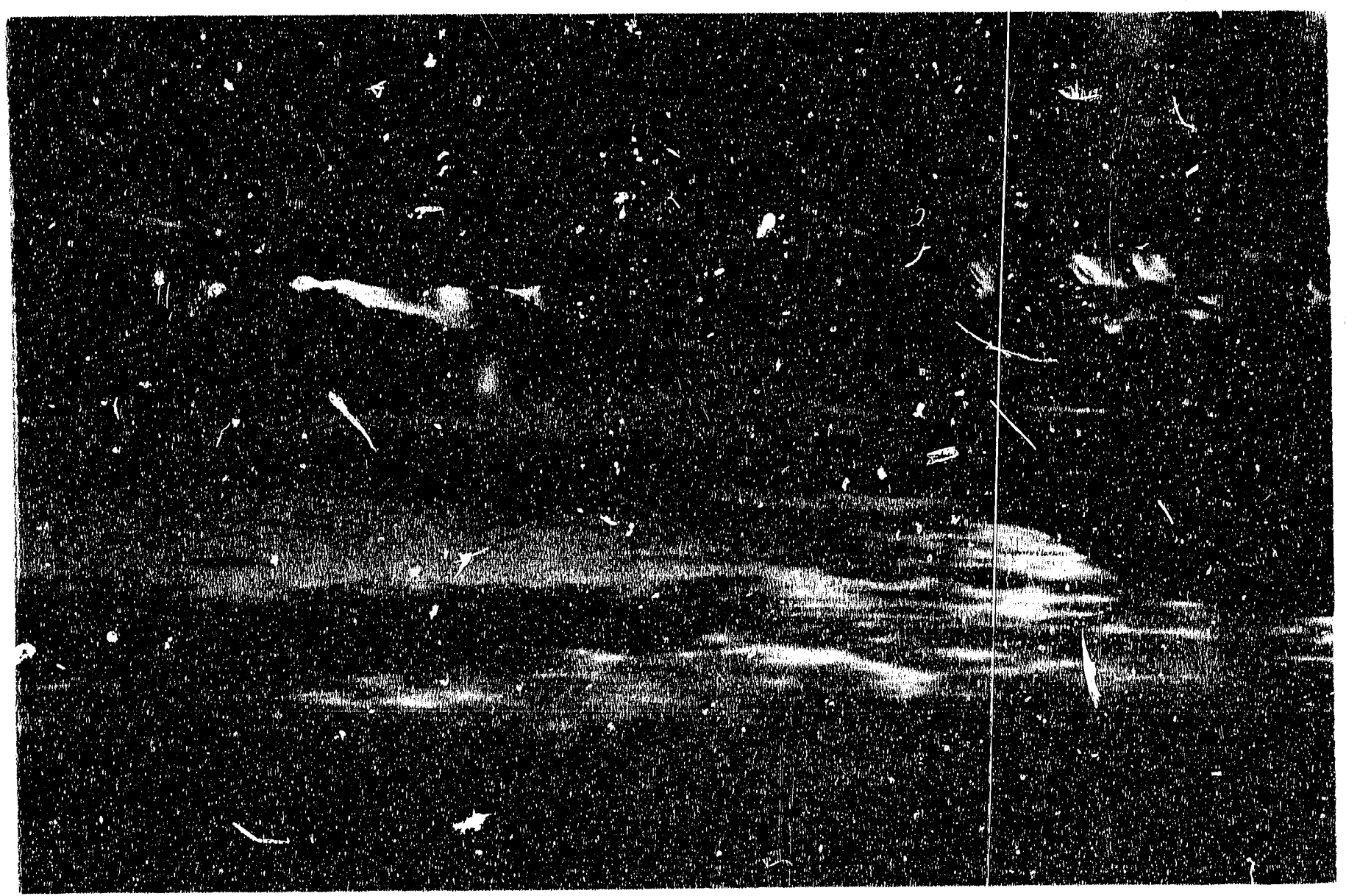

FIGURE 51. Oblique aerial view looking south over Yelverton Bay across to Mitchell Point (left), from $3048 \mathrm{~m}$ on 23 July 1984. 
that the multiyear landfast sea ice in Yelverton Bay has not been greatly disturbed over a period of three to four decades.

Although most of the former shelf ice present a century ago has disintegrated and broken out of Yelverton Bay, there remain small, isolated intact ice shelves at three locations: east of Hansen Point, west of Mitchell Point, and adjacent to ine icefield at the west side of Yelverton Bay (Figures 36 and 49). For the purposes of this report we will vefer to these as Hansen Ice Shelf, Mitchell Ice Shelf and Yelverton Ice Shelf respectively, but is is noted that these are are not official names.

Hansen Ice Shelf has an area of about $50 \mathrm{~km}^{2}$ and has been shown in Mosaic IX. Unlike the majority of arctic ice shelves, especially those on the peripheral parts of the coast where the undulations or "rolls" show linear development parallel to the shore, Hansen Ice Shelf has a very irregular surface topography. Certainly the surface undulates, but there is no regularity or preferred orientation, especially on the outer ice shelf (Mosaic IX). At the present time there are three glaciers contiguous with the ice shel: (one can be seen at the left side of Mosaic IX) that might have contributed to early ice shelf growth, and the irregularity of the patterns might be related, in part, to glacier flow. The large-scale and predominantly irregular topography of Hansen Ice Shelf contrasts with the more regular, but smaller-scale landfast sea ice topography adjacent to the ice shelf front. Across most of Yelverton Bay, the multiyear landfast sea ice has developed a ridge and trough system with a regular spacing of the order $60-100 \mathrm{~m}$ (Mosaics IX and X, Figure 51). At the west side of Yelverton Bay, off the front of Hansen Ice Shelf, the undulations are oriented approximately E-W (Mosaic IX). On the other hand, in central Yelverton Bay the undulations are oriented approximately ESE-WNW (Mosaic X). In Yelverton Inlet the orientation is SSE-NNW and parallel to the shores of the inlet. These varying roll directions follow the orographic variation of prevailing summer winds expected in the Yelverton Bay area. Old shelf ice fragments have already been noted in inner 
and west Yelverton Bay (Figures 50 and 51). There are also numerous shelf ice fragments on the east side of the bay (Mosaic IX), some of which most likely calved from the front of Hansen Ice Shelf. In spr .g 1983, while traveling by snowmobile across the ice in this area, M.O. 'effries and H.V. Serson came across many large rocks or the surface. It is ssumed that the rocks were located on old shelf ice fragments.

Eariier it was noted that the multiyear landfast sea ice in Yelverton Bay appeared to have remained largely undisturbed for many years. The linear development of the undulations on the sea ice attests to its age and stationary nature. However, there is one recent documented break of sea ice from the scaward edge of Yelverton Bay. In August 1984, a $30 \mathrm{~km}^{2}$ piece of ice with a thickness of $7 \mathrm{~m}$ broke away from the northeast edge of Yelverton Bay (R. Verrall, personal communication). It is possible that the calving occurred a few weeks prior to August 1984, but we observed no significant change in late July 1984.

Mitchell Ice Shelf (Figure 50) owes its existence to the flow of a glacier across the mouth of an inlet. The extent of the ise appears to have remained largely unchanged since 1950 and the area is approximately $10 \mathrm{~km}^{2}$.

Yelverton Ice Shelf has an area of approximately $20 \mathrm{~km}^{2}$. The ice shelf was not photographed in July 1984, but M.O. Jeffries and H.V. Serson crossed the ice in May 1984 and May 1986. The ice shelf can be seen in Figure 50 and was also detectable by side-looking airborne radar (SLAR, Figure 52). From Yelverton Ice Shelf to Alert Point an icefield forms the shore, with the pack ice building pressure ridges against the glacier ice. 


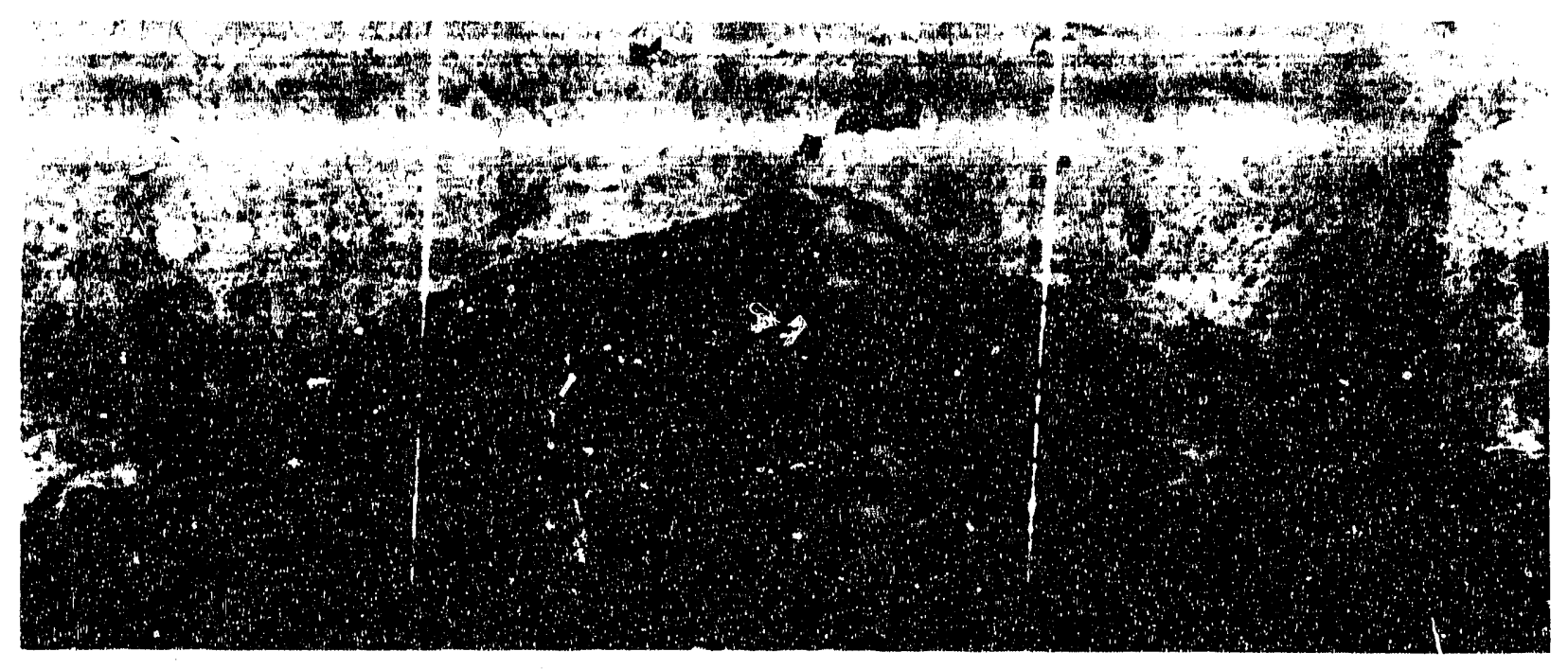

FIGURE 52. SLAR (Side-looking airborne radar) image of the Yelverton lce Shelf at the west side of Yelverton Bay (right), the Alert Point Icefield (center) and the Alfred Ernest lce Shelf (left), i1 May 1983. (Flight NDZ-1051, Atmospheric Environment Service, Ottawa, Canada). 


\section{II.4. ALFRED ERNEST ICE SHELF}

The large embayment between Alert Point and Cape Woods is largely occupied by the Alfred Ernest Ice Shelf, which has an area of about $150 \mathrm{~km}^{2}$ and is shown in Figures 52 and 53.

The southern part of the Alfred Ernest ice shelf, approximately $40 \%$ of the total shelf area, is derived from glacier ice. The glaciers flow off the land in to the embayment and remain afloat in situ to form glacier tongues and thus part of the ice shelf. One of the glaciers and its glacier tongue with moraines carried out into the bay is shown in Figure 54. M.O. Jeffries and H.V. Serson came across these extensive deposits in May 1984 and May 1986; the moraines consist of individual boulders and conical mounds of rock debris as much as $5-10 \mathrm{~m}$ high. It is likely that the ice shelf in this area of the embayment is quite thick but no ice thickness data are available; glacier ice in Milne Ice Shelf is up to 100m thick (Prager, 1983).

Most of the ice shelf has the typical ribbed appearance of alternating melt-pools and ridges, which in this case are oriented approximately E-W (Figures 52 and 53). In Figure 52, the main body of the ice shelf occupies the outer part of the embayment. Some ice of the inner bay has a lighter grey tone than the ribbed shelf ice texture, and it also appears not to have an undulating topography. In SLAR imagery, the ice shelf topography shows to best advantage when the "look direction" is as nearly as possible perpendicular to the rolls. When the "look direction" is nearly parallel to the rolls, or the ridges are lower than a certain threshold height, the ice appears to be featureless. In the case of the inner bay ice the rolls are neither so well developed, nor oriented $\mathrm{E}$ $W$ like those on the main shelf (Figure 55). Because the rolls have a very low relative relief and are oriented approximately N-S they do not show very well on the available SLAR imagery.

It is likely that the inner bay ice is younger than the main ice shelf, having grown after the outer ice shelf was detached from the shore and moved 


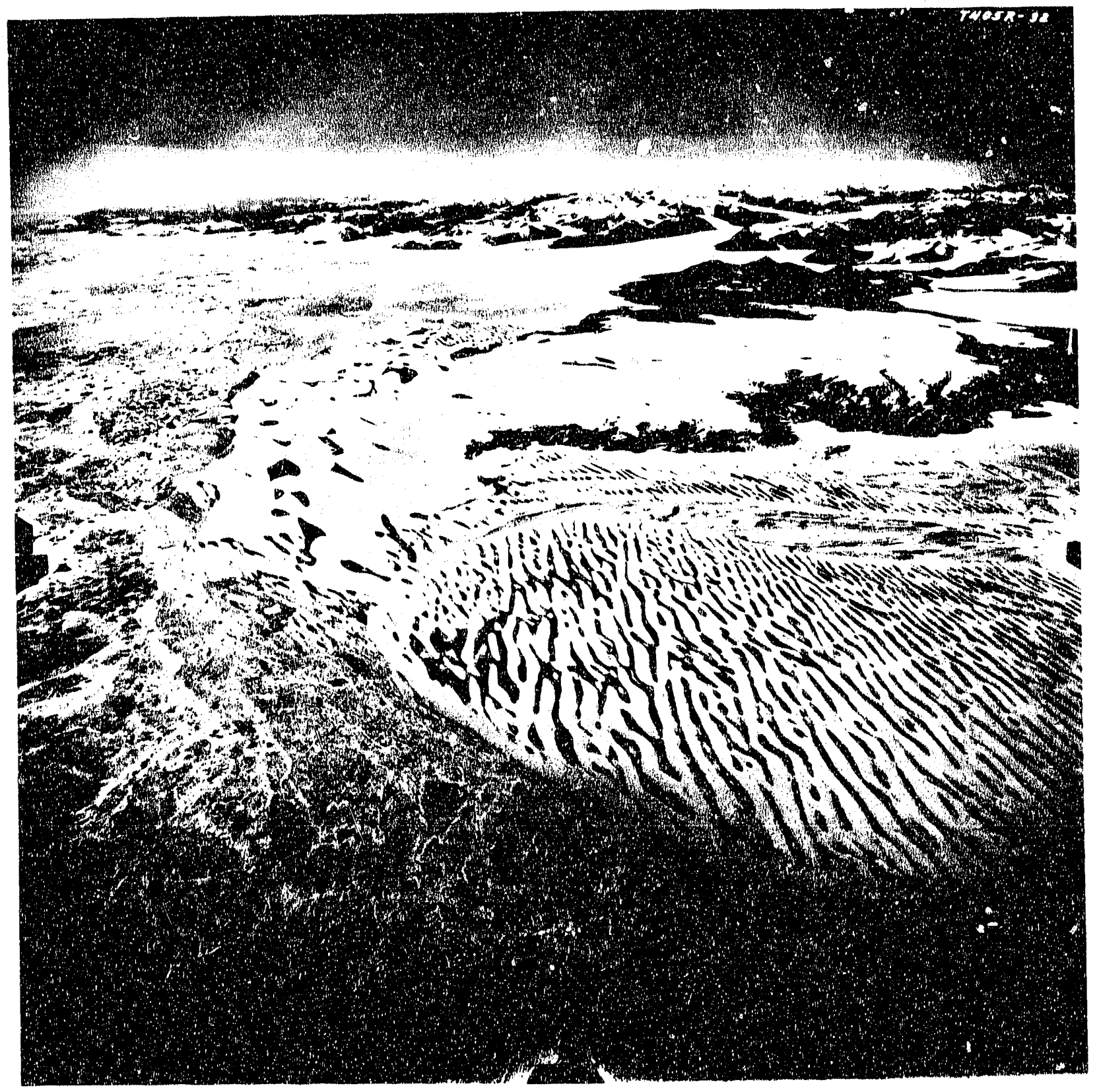

FIGURE 53. Oblique aerial photograph looking east across the outer section of the Alfred Ernest lce Shelf, 15 July 1950 (RCAF photograph, frame T405R-32, available from the National Air Photograph Library, Ottawa, Ontario, Canada). 


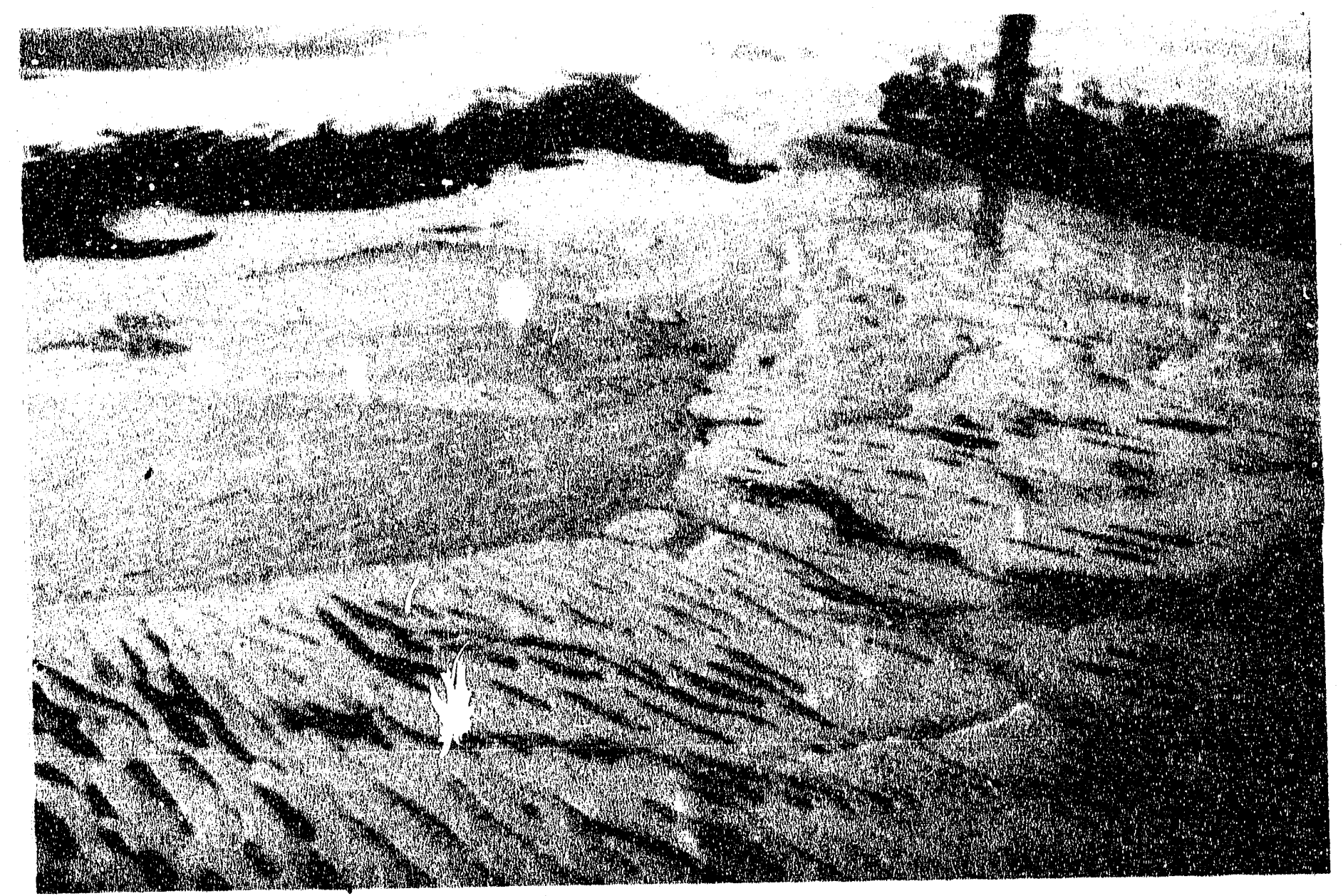

FIGURE 54. Oblique aerial view of one of the glaciers and glacier tongues of the Alfred Ernest lce Shelf, from $3048 \mathrm{~m}$ on 24 July 1984 . The dark features at the right and center are moraines. 
northwestward. It is probable also that the inner bay ice is not as thick as the shelf ice, since longer wavelength rolls are usually associated with thicker, older ice (Jeffries et al., 1990a). The ice thickness differences give rise to buoyancy variations that are manifested as cracks in the ice caused by differential response to water movement below the partially-grounded ice (Figure 55).

The timing of the outer ice shelf movement is unknown and it is possible only to speculate on the causes. The first possibility is related to the glacier tongues which could have pushed the main ice shelf mass away from shore. The second possibility is a combination of extreme oceanographic and meteorologic conditions; a storm surge may have detached the ice which was subsequently blown a short distance from shore by an offshore wind. This raises the question of why the ice did not calve completely and create a large ice island. This is probabiy related to the general pattern of pack ice movement in this area. The pack ice drifts parallel to the general trend of the coast towards the southwest. The icefield at Alert Point presents an obstacle to the pack and probably ofien protects ice in its lee; hence, Alfred Ernest Ice Shelf occupies a sheltered bay. Although the main shelf moved a short distance seaward, it was not pushed sufficiently far for it to become embedded in the pack ice. The subsequent growth of the inner ice shelf may help anchor the main shelf in place.

The calving history of ice from the Ellesmere ice shelves is summarized in the second Quarterly Report, based on the field observations of Serson (1984). A summary table of his observations is shown in Figure 56; it has been modified slightly to take into account the fact that the Ayles Ice Shelf break-up did not result in the release of all of the produced ice into the Arctic Ocean, but rather, some of the ice islands thus produced remained in the mouth of Ayles Fiord. 


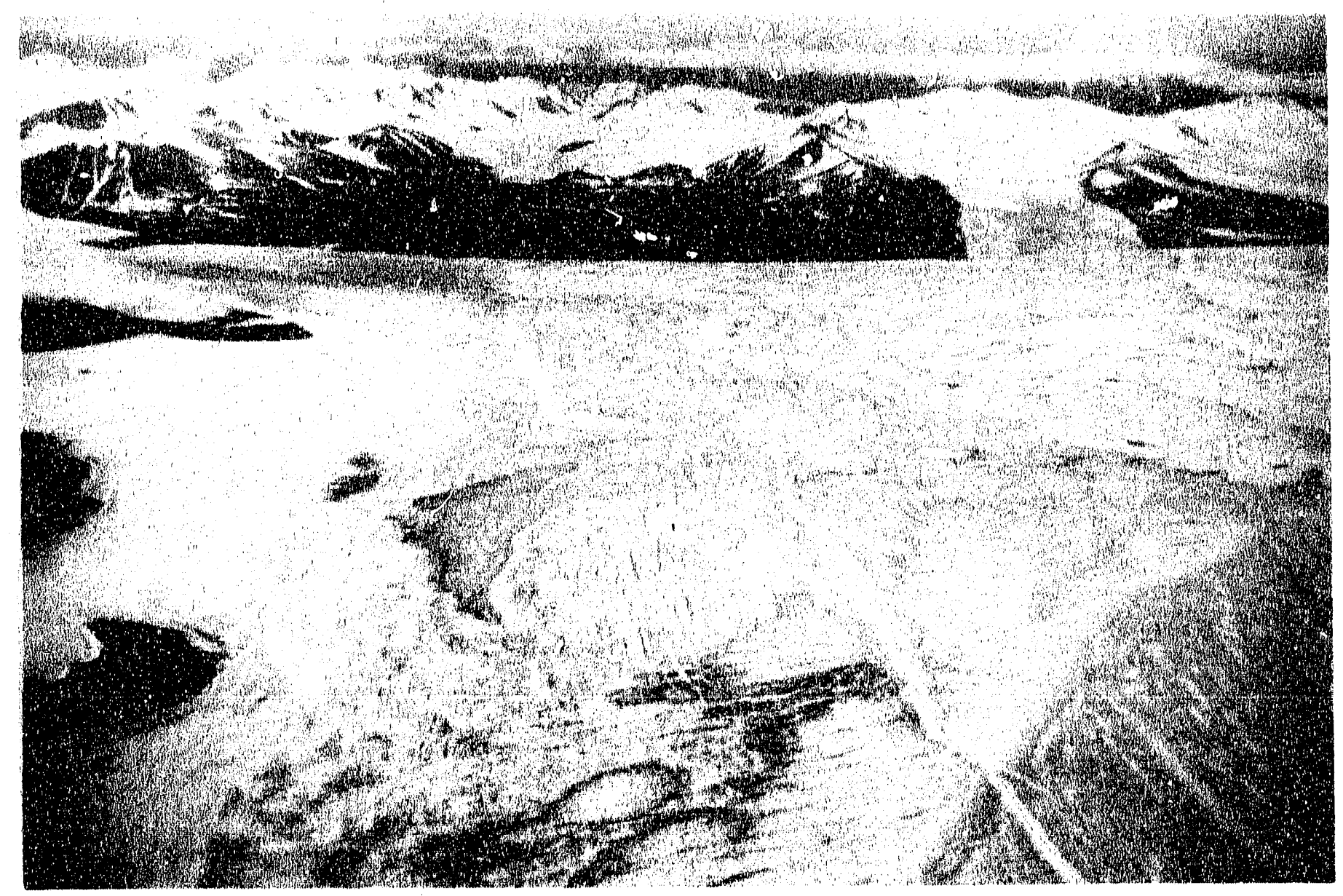

FIGURE 55. Orlique aerial view from $3048 \mathrm{~m}$ looking south over the ice of the inner bay be veen Cape Woods and Alert Point, 23 July 1984. Cape Alfred Ernest is the looked feature in the lower left corner, and the Alfred Ernest ice Shelf is in the background adjacent to the land and to the right. 


\begin{tabular}{|c|c|c|c|c|c|c|c|}
\hline Year & W. Hunt & McClintock & Nansen & Milne & Ayles & Other & Total \\
\hline 1963 & 569 & & & & & & 569 \\
\hline \multicolumn{8}{|l|}{1964} \\
\hline \multicolumn{8}{|l|}{1965} \\
\hline 1966 & & 95 & & & & & 110 \\
\hline 1967 & & & & 35 & 15 & $10_{a}\left(15_{c}\right)$ & $45(40)$ \\
\hline \multicolumn{8}{|l|}{1968} \\
\hline \multicolumn{8}{|l|}{1969} \\
\hline \multicolumn{8}{|l|}{1970} \\
\hline 1971 & 4.5 & & 240 & & & & 244.5 \\
\hline 1972 & & & & & & & 1.5 \\
\hline \multicolumn{8}{|l|}{1973} \\
\hline 1974 & 10 & & & & & & 10 \\
\hline 1975 & $\cdots$ & & & & & & \\
\hline \multicolumn{8}{|l|}{1976} \\
\hline $\begin{array}{l}1977- \\
1979\end{array}$ & $\cdots$ & & & & & & \\
\hline 1980 & (1) & & & & & $3 \mathrm{~b}$ & $3(1)$ \\
\hline TOTALS & $585(1)$ & 95 & 240 & 35 & $85(2)$ & $13(15)$ & $1053(41)$ \\
\hline
\end{tabular}

a) West of Bromley Island

b) Cape Fanshawe Martin

c) East of Hansen Point

Figure 56. Calving history of ice shelves of Ellesmere Island, based on historical records and traverses (H. Serson, 1984). (Gain in parenthesis). Units are $\mathrm{km}^{2}$. 


\section{CHA PTER III}

\section{ANALYSIS OF ICE ISLAND MOVEMENT}

(M. C. Lu)

A detailed study of ice island movements was presented by Lu Mingchi in his M.S. thesis (Lu, 1988), and the discussions in this chapter are based upon that work.

\section{III.1. Background}

Ice islands (tabular icebergs) are generated by calving from the ice shelves along the northern coast of Ellesmere Island. The first ice island discovered in recent times was designated T.1 (Koenig et al., 1952). In fact, there have been ice islands discovered north of Alaska before 1952 (Zubov, 1945). Early explorers noticed the ice shelves on the coust of Ellesmere Island as having an upper surface topography which looked like hills and dales, with long linear lakes and watercourses. These features were noted also on drifting islands of ice in 1886 by Greeley, in 1918 by Storkerson, and by other early explorers as well (Peary, 1907; Stefansson, 1922; Zubov, 1945). A thorough search of aerial photos by Greenaway in 1952 yielded 59 possible ice islands at that time, as well as many more small fragments (Greenaway, 1952).

Ice island T-1 was discovered less than $500 \mathrm{~km}$ north of Point Barrow in 1946, and measured approximately $28 \times 33 \mathrm{~km}$. In 1950, ice island T-2 was discovered at $86^{\circ} 40^{\prime} \mathrm{N}, 167^{\circ} 00^{\circ} \mathrm{W}$, and measured about $31 \times 33 \mathrm{~km}$. In the same year, the most famous ice island, T-3, was discovered, at $75^{\circ} 24^{\prime} \mathrm{N}, 173^{\circ} 0 \mathrm{n}^{\prime} \mathrm{W}$, and measured about $8 \mathrm{x}$ $16 \mathrm{~km}$ (Koenig et al., 1952). A research camp was established on T-3 for scientific studies of the ice island itself and of the Arctic Ocean generally. In May 1961, ice island, Arlis II, was sighted at $73^{\circ} \mathrm{N}, 156^{\circ} \mathrm{W}$; it was approximately $3 \times 6 \mathrm{~km}$ in size with a thickness of 12-25m (LeSchack, 1961; Smith, 1964). 
In early 1962 there was a massive calving event from the Ward Hunt Ice Shelf on the north coast of Ellesmere Island during which five large ice islands(WH-1, WH2, WH-3, WH-4, WH-5) and 14 smaller fragments were created (Hattersley-Smith, 1963). This particular calving event has been correlated with abnormal tidal excursions and a small seismic event (Holdsworth, 1971) but detailed mechanisms of calving remain unclear. Another smaller calving event occurred in the same area in early 1967, in which two ice islands, WH-6 and WH-7, were created (Spedding, 1977). In an aerial reconnaissance of the coastal waters of the Canadian and Alaska Beaufort Sea, 433 ice islands or ice island fragments were observed in 1972, and 299 were observed in 1973. From 1974 to 1976 , the total number of ice islands counted decreased to 27 (Spedding, 1977).

In April 1974, scientists involved in the Arctic Ice Dynamics Joint Experiment (AVDJEX) reported an ice island located about $160 \mathrm{~km}$ north of the Mackenzie River delta in the southern Beaufort Sea. This ice island was measured to be about $7 \mathrm{~km}$ long and $3 \mathrm{~km}$ wide with a thickness of about $9 \mathrm{~m}$. Later on, this ice island was manned by Soviet scientists as a drifting station and designated NP-23 (Martin and Thorndike, 1974).

A recent, substantial calving of ice islands occurred in 1982-83, when at least eight ice islands were produced from the Ward Hunt Ice Shelf (Jeffries and Serson, 1983). Since then, an additional 26 ice islands have been observed in the pack ice near the northern coasts of Ellesmere and Axel Heiberg Islands (Jeffries et al., 1988). Some of those produced at the Ward Hunt Ice Shelf in 1982-83 were named, and have been instrumented and tracked on a daily basis using both the system Argos stations and satellite navigation systems.

Station 2992 was deployed on a small ice island off the mouth of Yelverton Bay, and has been delivering atmospheric pressure and temperature regularly since April 1985 with a 4-hour-on, 8-hour-off cycle to conserve batteries for 6 years. Stations 
2993, 2995, 2996, and 2998 were, at overlapping times, located on Hobson's Choice Ice Island, which is the largest piece of ice, ani which has been the major object of our research (Figure 57). In May 1986 stations 2990, 2991, 2994, 2996 and 2997 were deployed on a number of different ice islands (Sackinger and Jeffries, 1987). A substantial amount of data has been obtained from these stations, including ice island drift, surface pressure variations, and surface temperatures, which will be useful in future studies.

\section{III.2. Features and Movements of Ice Islands}

Ice islands surrounded by pack ice are the largest ice features in the Arctic Ocean, and have been observed with thicknesses of up to $60 \mathrm{~m}$ and lateral dimensions of up to approximately $40 \times 4 \mathrm{v} \mathrm{km}$. From aloft, ice islands appear different from the surrounding pack ice in that they have a homogeneous appearance and regular surface patterns. The surface of pack ice looks rougher because of the breaking and reforming of the pack ice as shown in Figure 58.

The general trajectories of ice islands have been observed to move towards the southwest after their creation by salving from the ice shelves of Ellesmere Island. One exception is the easterly movement of WH.5, shortly after its creation in 1962 from the Ward Hunt ice shelf (Hattersley-Smith, 1963; Nutt, 1966). Many ice islands have been carried around the Beaufort Gyre (Figure 59), finally being ejected in to the Greenland Sea. They then move around the southern tip of Greenland and disappear in the warmer waters of the Labrador Sea. Often, early in their path, these massive ice features drift along the edge of the Canadian Arctic islands, and have been observed along the coast of the Beaufort Sea (Spedding, 1977).

A comprehensive work by Yan (1986) gave details of ice island movements in 1983-85. Three types of movement were described: large movements $(10 \mathrm{~km} /$ day typically) in the southwest direction along the coastline, medium movements (1-10 


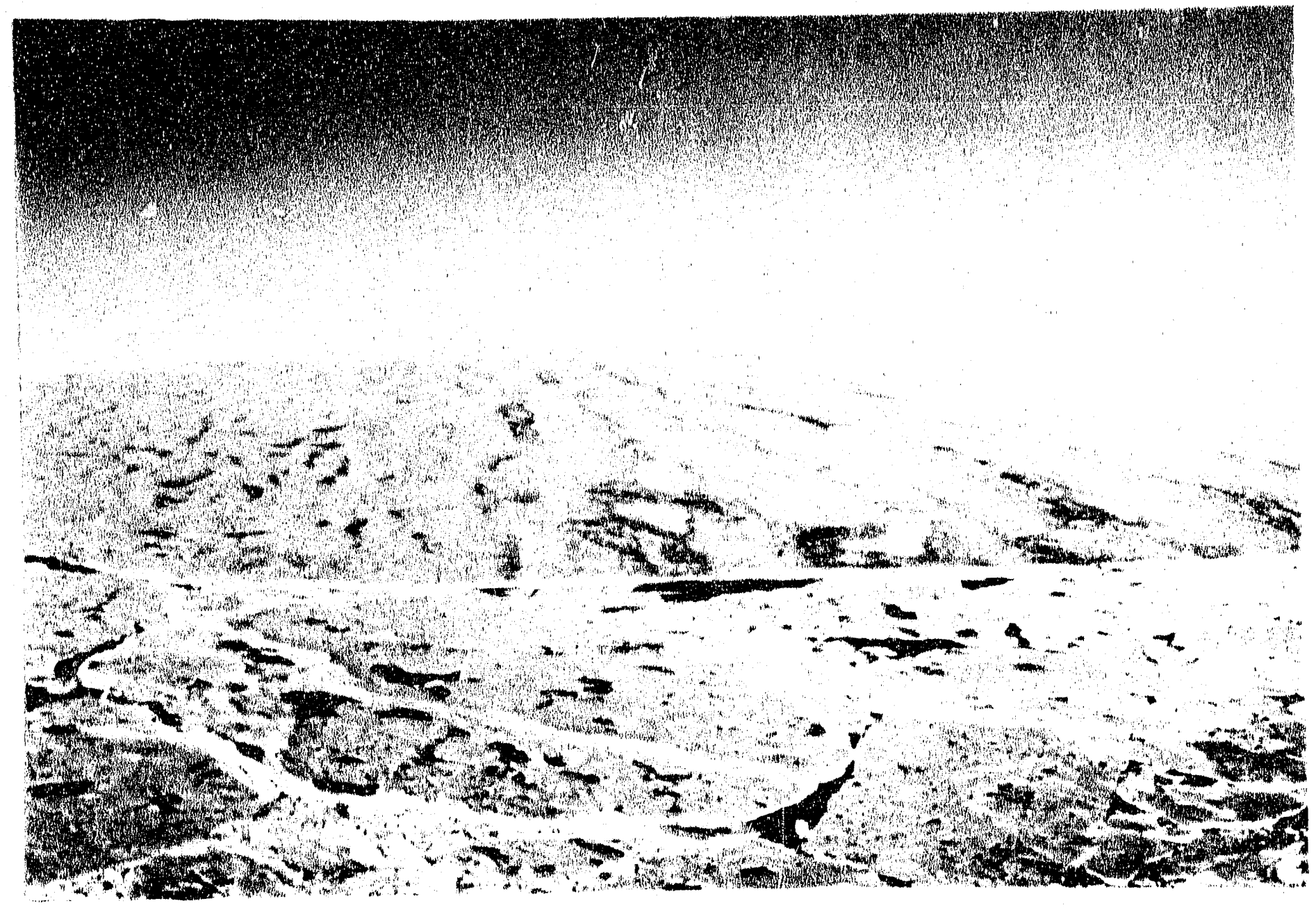

Fig. 57. Oblique aerial photograph looking along the long axis of Hobson's lce Island, 11 August 1987. The main shelf ice sertion of the ice island in the center of the photograph is characterized by undulations about $2 \mathrm{~m}$ deep and spaced about $200 \mathrm{~m}$ apart. At the left side of the shelf ice is an area of multiyear landfast sea ice (MLSI) that was previously attached to the front of the Ward Hunt lce Shelf. At the right side of the shelf ice is an area of consolidated multiyear pack ice (MYl') that has become attached to the shelf ice since the calving event of 1982-83. Photo credit: Michael Schmidt, Geological Survey of Canada. 
Fig. 58. Oblique aerial photograph of two ice islands located at approximate'y $81.14^{\circ} \mathrm{N}, 96.7^{\circ} \mathrm{W}, 45 \mathrm{~km}$ west of Rens fiord, northern Axel Heiberg Island, 3 May 1986. In the foreground is part of Hobson's Ice Island and beyond it is the second largest ice island presently known in the Arctic Ocean (SLAR 2: Jefiries et al., 1988). The undulations on the ice islands' surface can be seen clearly despite the snow cover. The relatively smooth surfaces of the ice islands contrast with the surrounding, rough pack ice surface. Photo credit: Martin deffries, Geophysical Institute, UAF. 


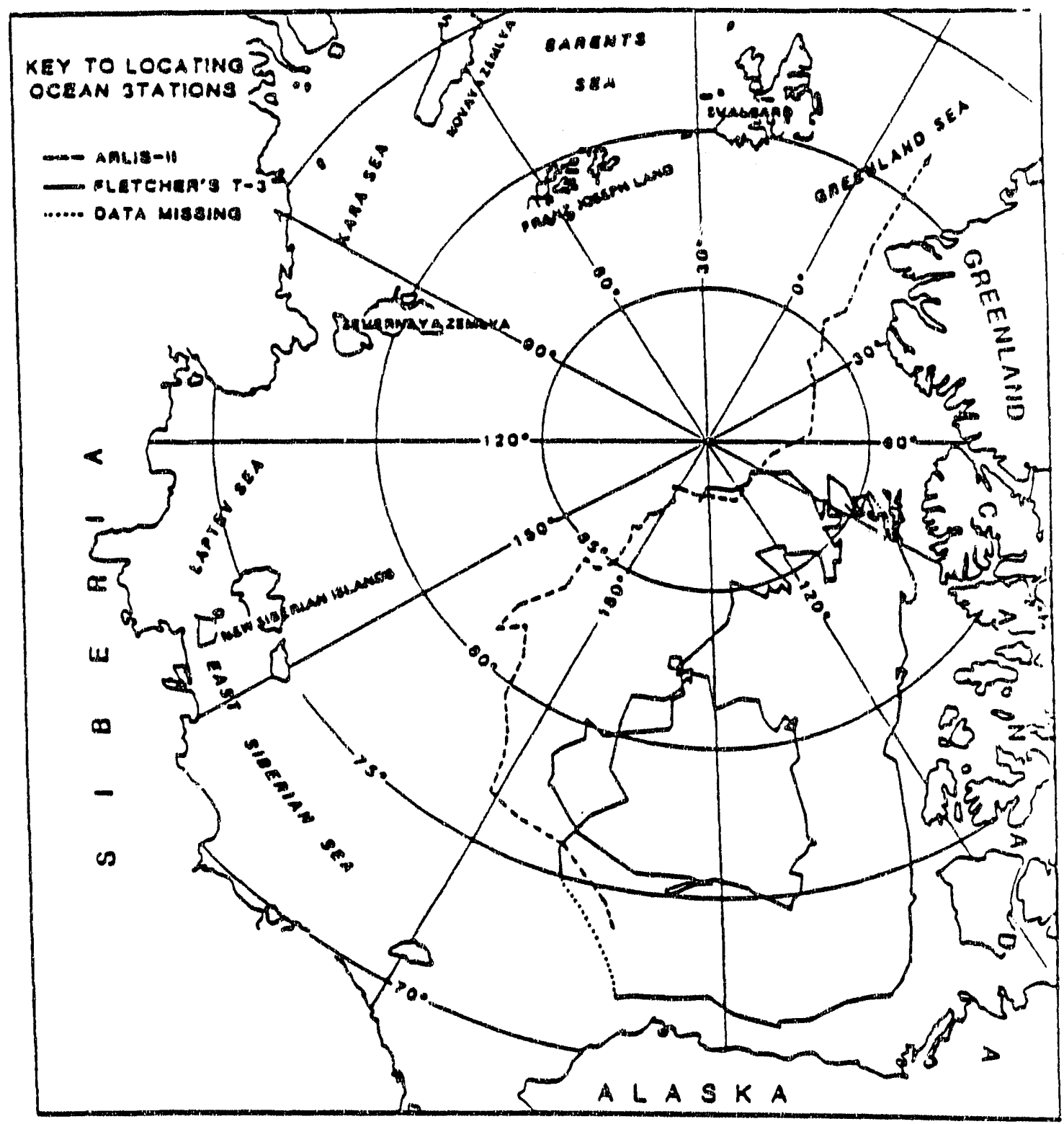

Fig. 59. Drift tracks of ice islands T-3 and Arlis.II in the Arctic Ocean (source: Sackinger and Yan, 1986). 
$\mathrm{km} /$ day) in two sequentially opposite directions along the coastline; and small $(<1$ $\mathrm{km} /$ day) random movements in any direction which may have been random fluctuations in the Argos positioning system as well as possible small tidally-driven movements. It was indicated that the trajectories of the ice island are generally along the coastline. The speed ratios between the ice island and the geostrophic wind ranged from $1.0 \%$ to $1.5 \%$ for the large movements, and the average angle of the geostrophic wind ranged from 20 to 26 degrees counterclockwise from the ice island movement direction (Yan, 1986).

\section{III.3. Hobson's Choice Ice Island and Research Emphasis}

Hobson's Choice Ice Island was produced from the east side of the Ward Hunt Ice Shelf some time between May 1982 and April 1983 (Jeffries and Serson, 1983). It was first instrumented by G. D. Hobson, Director of the Canadian Polar Continental Shelf Project (PCSP), who deployed buoy 3831 on the subject ice island in 1983. For some unknown reason, buoy 3831 stopped transmitting in August 1984. In April 1985 and in April 1986, stations 2993 and 2996 respectively were deployed on the

same ice island by W. M. Sackinger, M. O. Jeffries and H. V. Serson of the Geophysical Institute, University of Alaska Fairbanks.

This particular ice island is roughly rectangular in shape, and has been measured to be approximately $9.0 \mathrm{~km}$ long, $5.5 \mathrm{~km}$ wide, with a mean thickness of $42.5 \mathrm{~m}$ on the shelf ice portion (Jeffries et al., 1988). A roughly rectangular attachment of multiyear landfast sea ice (MLSI) is attached to one side of the shelf ice (Figure 57). The average shelf ice density is $870 \mathrm{~kg} / \mathrm{m}^{3}$ and the surface area is $1.65 \mathrm{x}$ $10^{7} \mathrm{~m}^{2}$; the average old sea ice density is $910 \mathrm{~kg} / \mathrm{m}^{3}$ and the surface area is $0.95 \times 10^{7}$ $\mathrm{m}^{2}$ (Jeffries et al., 1988). Thus, the total surface area is $2.6 \times 10^{7} \mathrm{~m}^{2}$ and the total mass of this ice island is approximately $7.0185 \times 10^{11} \mathrm{~kg}$. 
The location of Hobson's Choice with station 2996, and the positions of the study area and Ward Hunt Ice Shelf, are shown in Figure 60. The ice island is generally surrounded by pack ice. During the period of this study the ice island was located near Axel Heiberg Island; here, there is a mountain barrier which has an average width of $30 \mathrm{~km}$, with the heights of the ridge crests at $900 \mathrm{~m}, 1200 \mathrm{~m}, 1500 \mathrm{~m}$ and $1800 \mathrm{~m}$, respectively, along a $110 \mathrm{~km}$ length. Both stations 2996 and 2993 were located at approximately the centre and one end respectively of Hobson's Choice and reported position. In addition, station 2996 reported wind speed and direction, wind gusts, barometric pressure and air temperature. These data have been used to calculate and analyze movement, together with other data from satellite navigation systems.

Studies of ice islands have been related mainly to ice islasd generation, drifting patterns, surface relief and thicknesses, relationship beiween synoptic weather conditions and ice island movement, and movement analysis of an ice island ( $\mathrm{De}$ Paoli et al., 1982; Sackinger, 1986; Sackinger and Jeffries, 1986; Yan, 1986). It was initially assumed that the water drag coefficient of an ice island was that of a sphere when the movement of the ice island was considered (Yan, 1986; Sackinger et al., 1988). Recent studies have suggested that a rectangular cross-section with a vertical side is more typical. Neither was the mountain barrier effect taken into consideration when the ice island movement close to the coastline was considered. Also, the study of the forces on an ice island was only in the preliminary stages (Yan, 1986).

In this report, we use the more exact size of Hobson's Choice, new and more precise information from the daily ice island positions, surface wind velocities from station 2996, and surface weather maps, data on the rotation of the ice island itself and the ice island shape effect for the water drag force. More accurate relationships between ice island movement, surface wind velocities and geostrophic wind velocities 


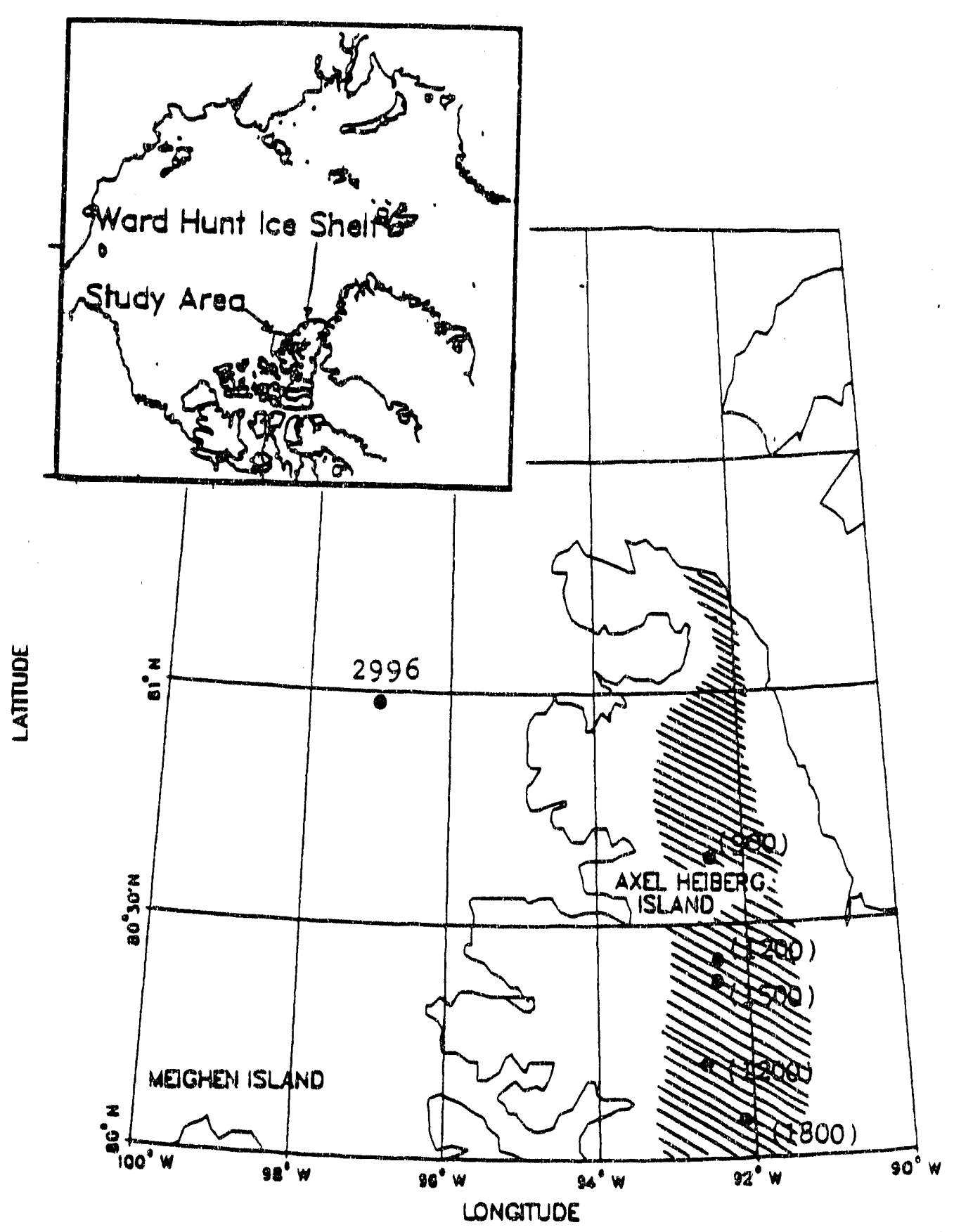

Fig. 60. The location of Hobson's Choice with buoy 2996 and its vicinity. The study area and Ward Hunt Ice Shelf a:e shown in the small map above. Crossed area on Axel Heiberg Island corresponds to surface elevation above 1500 meters. 
are thus obtained, and the mountain barrier effect especially, is shown. A study of the forces on Hobsor's Choice, which is suitable for the ice island movement near coastline or mountains is also developed. It has provided more practical results useful in future prediction of ice island movement.

\section{III.4. Argos System}

The Argos system is intended for applications cuncerned with environmental data collection, such as meteorology, oceanography and remote sensing of earth resources, through a cooperative project between Centre National d'Études Spatiales (CNES, France), the National Aeronautics and Space Administration (NASA, USA) and the National Oceanic and Atmospheric Administration (NOAA, USA). The Argos data collection and platfora location system offers capabilities for the location of fixed and moving platforms and for the collection of sensor data transmitted by platforms located anywhere on the Earth's surface. There are three main components in the Argos system (Service Argos, 1984):

(1) a set of user platforms, such as drifting buoys, each equipped with sensors and a platform transmitter terminal, which transmit their message to the satellite.

(2) a space segment consisting of two satellites, each equipped with an onboard data collection system ensuring user's platform message reception, processing and retransmission.

(3) the ground data processing center. Data concerning the Argos system are transmitted by NESS (National Environmental Satellite Service) to CNES, Toulouse, France, where the Argos data processing center is located. The processing performed by Service Argos at the center permits the determination of platform positions and the extraction of sensor data. 
Beginning in 1879, the Argos system services have been accessible to researchers. Since 1985, there have been many enhancements in system operation, in particular the real-time access to data. In early 1987, the new United States Argos Prncessing Center (USAPC) and Toulouse Argos Processing Center (French APC or FRAPC) were established, each independent and offering internal redundancy. The Argos system data flow chart and general structure of the centers is shown in Figure 61.

The data collection time is twice daily, at 1:00-5:00 in the morning and 13:0017:00 in the afternoon. The accuracy of location for moving buovs is about $1 \mathrm{~km}$. The wind speed measured on the drifting buoys is accurate to within $0.3 \mathrm{~m} / \mathrm{s}$ for $99 \%$ of the cases (Service Argos, 1984).

\section{III.5. Transit Satellite GEODOP Positioning System}

The Transit Satellite Geodetic Doppler (GEODOP) Positioning System is used by the Geodynamics Section, Geophysical Surveys, Hazards and Terrain Sciences Branch, Geological Survey of Canada, to determine the ice island's posiiion when the PCSP research station is operating (generally March to September).

The reference posi ion for Hobson's Choice refers to the electrical center of the Transit Satellite receiver antenna, which was mounted on a tower at the navigation hut on the ice island. Data has been collected on a continuous basis, 24 hours a day, seven days a week during periods of carsp occupancy, April 5 to October 2, 1986, and recorded on magnetic tape for further processing and analysis. The data available dealing with the ice island movement, such as tirne (U.T., Hr., Min.), positions of the ice island (Reference Latitude and Longitude, Degree, Min., Sec.,), ice island movement velocity (meter per hour) and direction of ice island drift on the Universal Polar Stereographic (U.P.S) plane (degrees), are published at three hour intervals based on the post-processed values (Schmidt et al., 1987). The azimuth of rotation of 


\section{GENERAL DLFGRAM}

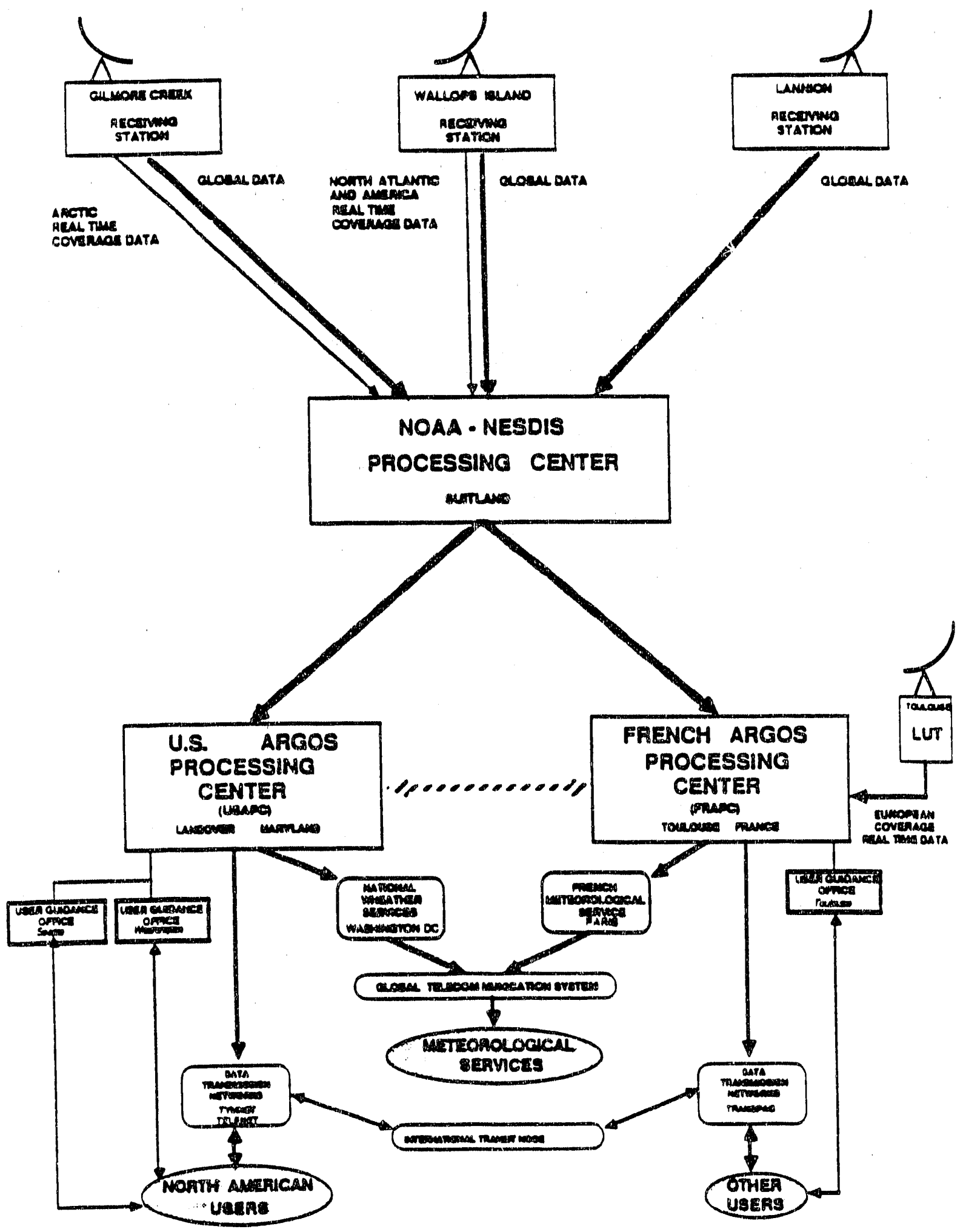

Fig. 61. Argos system data flow chart and general structure of each center. 
the ice island itself is also provided by the system, from which we can determine the frontal area of the ice island. The Transit Satellite GEODOP Positioning System offers more accurate locations, which are within about 30 meters.

The local data, such as air temperature, barometric pressure, surface wind speed and direction, the location of ice island and other data, are from both the Argos stations deployed on Hobson's ice island and the Transit Satellite GEODOP Positioning System.

\section{III.6. Basic Equations}

The movement of sea ice, pack ice or ice islands in the Arctic Ocean has been investigated since the early 1900 's. It has been shown that the equation governing the sea ice, pack ice or ice island movement is the momentum equation which includes several forces: wind shear, water drag, Coriolis force, sea surface tilt, and pack ice force (Nansen, 1902; Sverdrup, 1928; Campbell, 1965; Skiles, 1968; McPhee, 1980; Thorndike and Colony, 1982; Hibler, 1984; Yan, 1986; Sackinger et al., 1988).

The force equation for the sequence of transient movements of the ice island in the presence of nearly total ice cover can be written as

$$
M \frac{d V_{i}}{d t}=F_{a}+F_{w}+F_{c}+F_{r}
$$

where $\quad M:$ total mass of the ice island

$\mathbf{V}_{\mathrm{i}}$ : ice island velocity

$F_{a}$ : wind shear force acting on the upper surface of the ice island

$F_{\mathrm{w}}=\mathbf{F}_{\mathrm{ws}}+\mathbf{F}_{\mathrm{wp}}:$ total drag force

$F_{\text {ws }}$ : water shear force acting on the lower surface of the ice island 


$$
\begin{aligned}
& F_{w p}: \text { water drag force due to the frontal area of the submerged } \\
& \text { portion of the ice island } \\
& F_{c}: \text { Coriolis force } \\
& F_{r}=F_{s t}+F_{p i}: \text { a residual force } \\
& F_{s t}: \text { the force due to sea surface tilt } \\
& F_{p i}: \text { pack ice force acting on the boundary of the ice island. }
\end{aligned}
$$

In calculations of forces acting on the ice island, the wind shear force is given by (McPhee, 1980; Sackinger et al., 1988)

$$
\mathbf{F}_{\mathrm{a}}=\rho_{a} \mathrm{C}_{\mathrm{a}} \mathrm{A}_{\mathrm{s}}\left|\mathrm{V}_{\mathrm{a}}-\mathrm{V}_{\mathrm{i}}\right|\left(\mathrm{V}_{\mathrm{a}}-\mathrm{V}_{\mathrm{i}}\right)
$$

where

$$
\rho_{\mathrm{a}}: \text { density of air }
$$

$\mathrm{C}_{\mathrm{a}}$ : air drag coefficient

$A_{s}$ : surface area of ice island

$V_{\mathrm{a}}:$ velocity of the air.

The water shear force on the lower surface of the ice island is written as (McPhee, 1980; Sackinger et al., 1988)

$$
\mathrm{F}_{\omega \mathrm{s}}=\rho_{\omega} C_{w} A_{s}\left|\mathbf{V}_{\omega}-\mathrm{V}_{\mathrm{i}}\right|\left(\mathrm{V}_{\omega}-\mathrm{V}_{i}\right)
$$

where

$\rho_{w}$ : density of sea water

$C_{w}$ : the drag coefficient of water on the flat bottom surface of the ice island

$\mathbf{V}_{\mathbf{w}}$ : the velocity of the water beneath the ice island.

The geostrophic flow $V_{w}$ is due to sea surface tilt, as discussed by McPhee (1982).

An additional component of water drag is due to the frontal area and the trailing area of the ice island. Adapting the results of Shirasawa et al. (1984) for the form drag of a cube, one may write 


$$
\mathbf{F}_{w p}=p_{w} h A_{f}\left|\mathbf{v}_{w}-\mathbf{v}_{1}\right|\left(\mathbf{V}_{w}-\mathbf{V}_{i}\right)
$$

where $\mathrm{b}=0.45$ is the pressure drag coefficient, and $\mathrm{A}_{\mathrm{f}}$ is the frontal area of the wetted portion of the ice island (Shirasawa et al., 1984).

The direction and magnitude of the water drag force varies with time as the transient ice movements affect a changing volume of water, which then is subject to Coriolis effect, as discussed in detail by $\mathrm{McPhee}$ (1982). For a constant ice velocity, and rough sea ice, with $F_{w p}=0, M c P h e e(1982)$ has found that an average angle of $24^{\circ}$ between the water drag vector and the negative of the ice velocity vector fits experimental data for sea ice, but notes that there is a large scatter in the data.

The Coriolis iorce $F_{c}$ acts orthogonal to the ice island velocity $V_{i}$ and with magnitude

$$
\left|\mathbf{F}_{\mathrm{c}}\right|=M(2 \Omega \sin \phi)\left|\mathbf{V}_{\mathrm{i}}\right|
$$

where $\Omega$ is the angular velocity of the earth, and $\phi$ is the latitude.

The area in which ice island motion was studied was west of Axel Heiberg Island in the Arctic Ocean. Weather conditions and geostrophic wind calculations used were mainly based upon Canadian weather maps produced by the Canadian Meteorological Center, Edmonton, Alberta (CMC). The geostrophic wind velocity, $\mathbf{V}_{\mathbf{g}}$, is calculated by setting the surface air pressure gradient $\Delta \mathbf{P}$ in to balance against. the Coriolis force

$$
\mathrm{V}_{\mathrm{g}}=\frac{1}{\rho_{\mathrm{a}} 2 \Omega \sin \phi}(\mathbf{k} \times \nabla \mathrm{P})
$$

In scalar form, the geostrophic wind speed can be written as

$$
\left|V_{g}\right|=\frac{1}{p_{B} 2 \Omega \sin \phi}\left(\frac{\partial p}{\partial n}\right)
$$


where $\mathrm{k} \mathrm{x}$ is the operator, which presents a $90^{\circ}$ angle to the isobars, and $\mathrm{n}$ is the direction normal to the isobars, pointing toward higher values.

In the northern hemisphere, the geostrophic wind direction is parallel to the isobars with low pressure or the left side and high pressure on the right side. The closer the spacing of the isobars, the sironger the geostrophic wind becomes. Due to the effect of surface friction, the suraace wind will blow to the left of the geostrophic wind direction, with a lower wind speed.

From the analysis of observed data, the additional effect of the mountain barrier will be shown.

\section{III.7. Trajectory Analysis for Hobson's Choice Ice Island}

\section{III.7.1 Trajectories in May, 1986}

The trajectory of Hobson's Choice from May $1^{\text {st }}$ to $31^{\text {st }}, 1986$ (Figure 62), may be compared with the trajectory during the period from May $7^{\text {th }}$ to $16^{\text {th }}$ (Figure 63 ), for which a large daily motion took place parallel to the coastline. From May $1^{\text {st }}$ to $9^{\text {th }}$, the ice island moved towards the northeast; from May $1^{\text {st }}$ to $6^{\text {th }}$ the movement was very small, but two larger movement events occurred on $7^{\text {th }}-8^{\text {th }}$ and $8^{\text {th }}-9^{\text {th }}$. From May $9^{\text {th }}$ to $10^{\text {th }}$ the movement of the ice island turned from northeast to southwest. The largest daily movement took place on May $12^{\text {th }}$. On May $11^{\text {th }}$ and $13^{\text {th }}$ two significant movement events also occurred. From May $14^{\text {th }}$ to $16^{\text {th }}$ the ice island drifted towards the southeast. From May $16^{\text {th }}$ to $31^{\text {st }}$ motion was minor.

The detailed data describing the track of the ice island, with its velocity and direction, are summarized in Table 3 . The total cumulative displacement for the whole month of May 1986 was about $41.2 \mathrm{~km}$ and, therefore, the average speed can be calculated as approximately $1.33 \mathrm{~km}$ per day. However, the ice island moved along the coastline much more rapidly from May $7^{\text {th }}$ to $16^{\text {th }}$; an interval in which the ice 


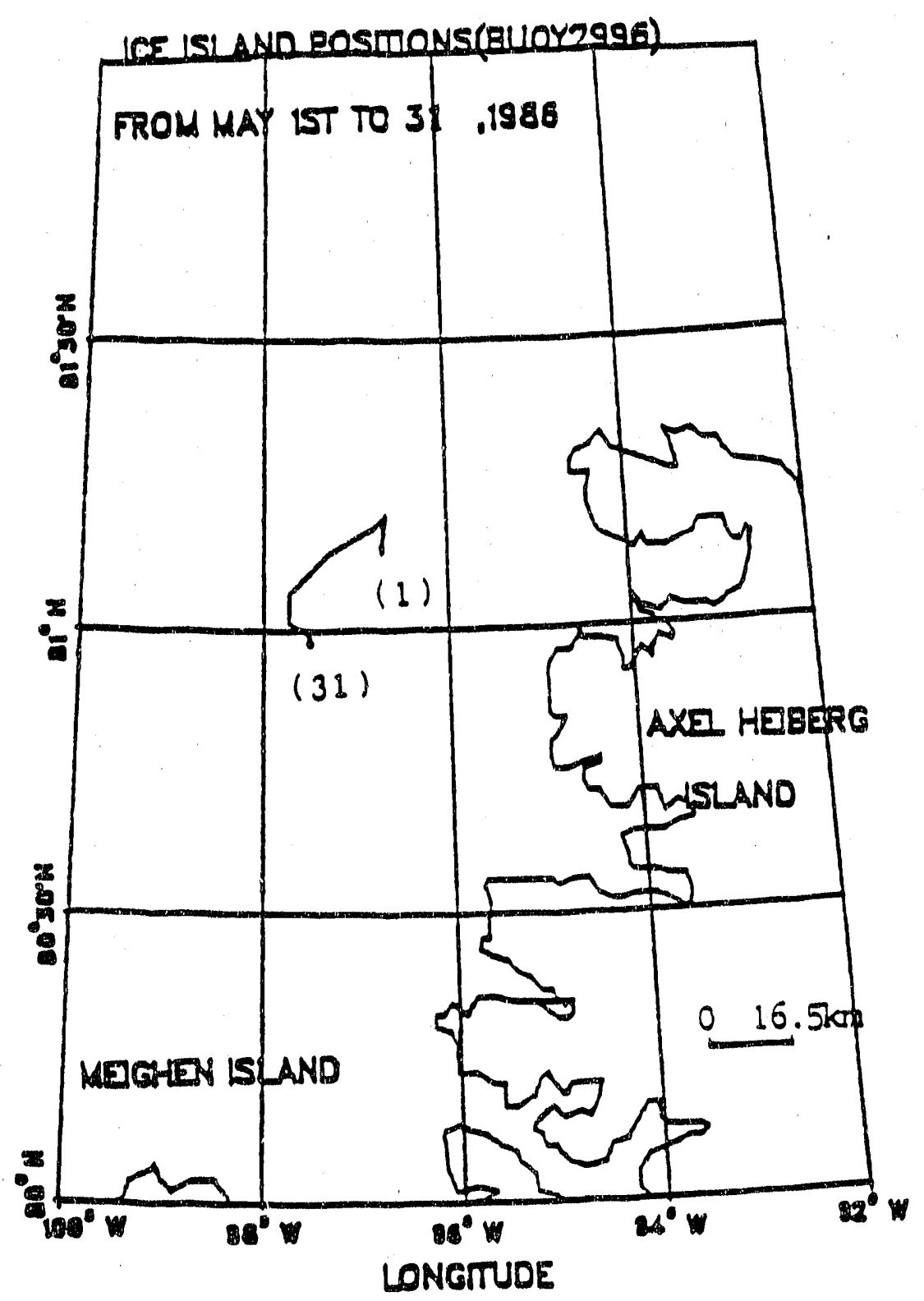

Fig. 62. Ice island positions from May $1^{\text {st }}$ to $31^{\text {st }}, 1986$. 
lce Island positions(May 7-16, 1986)

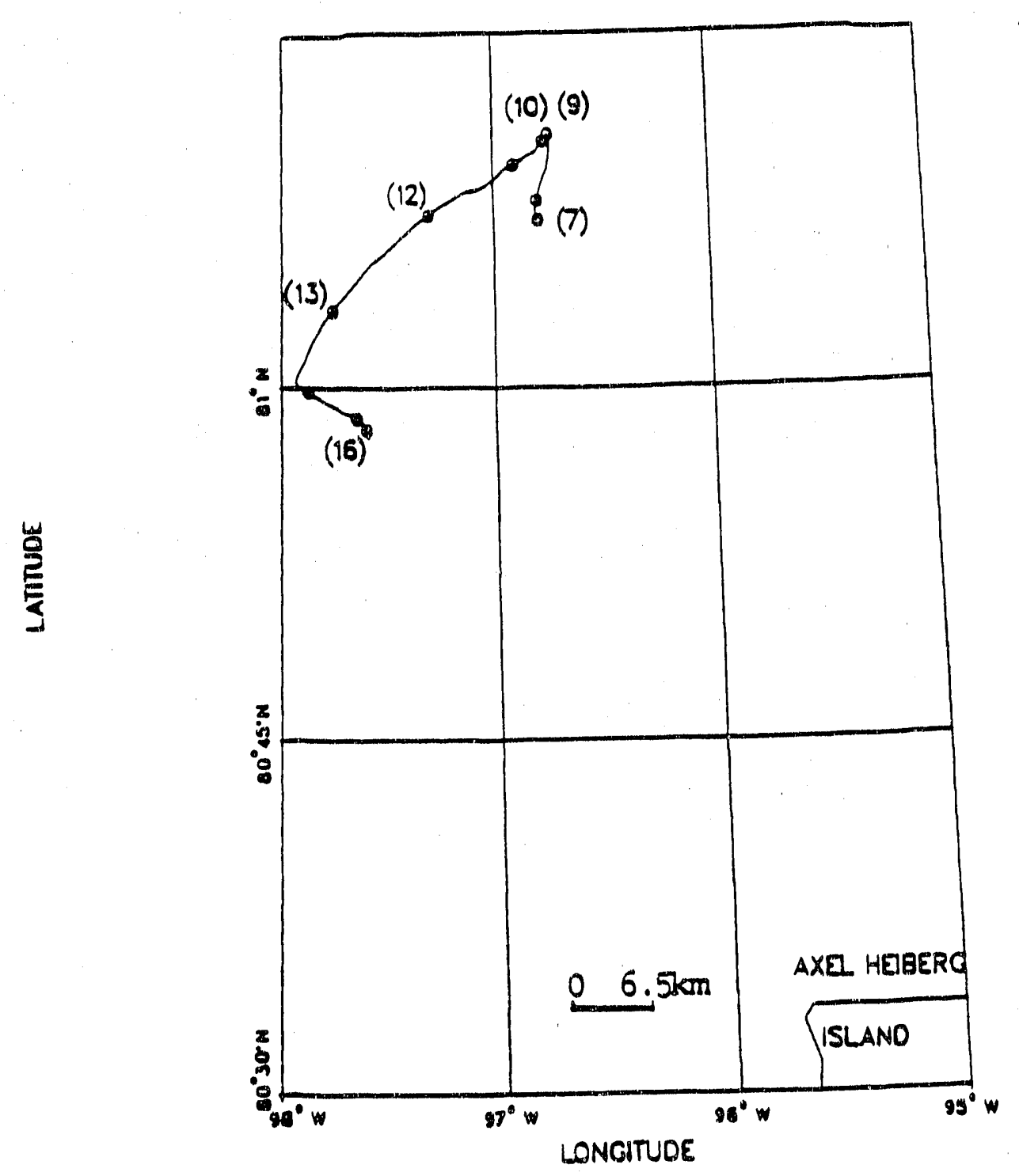

Fig. 63. Ice island positions in the period May $7^{\text {th }}$ to $16^{\text {th }}, 1986$. 
Table 3. Summary data concerning the track of Hobson's Choice in May 1986

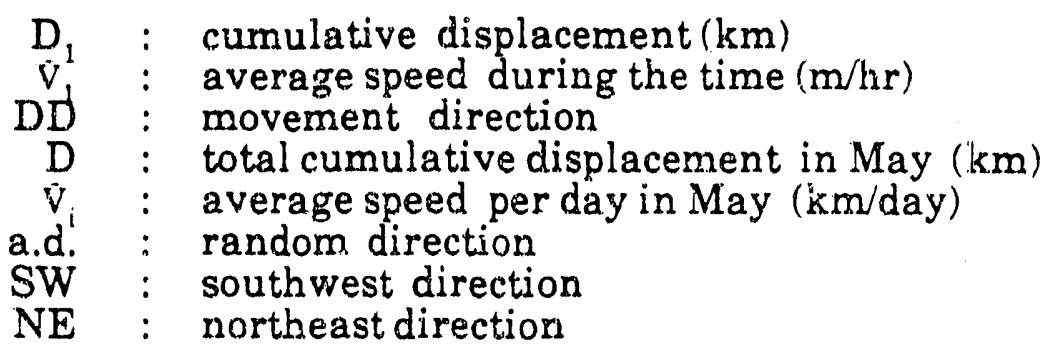

\begin{tabular}{cccc}
\hline Time (day) & $1-6$ & $7-16$ & $17-31$ \\
\hline $\mathrm{L}_{1}$ & $0.10 \mathrm{~km}$ & $40 \mathrm{~km}$ & $1.10 \mathrm{~km}$ \\
$\dot{\mathrm{V}}_{1}$ & $0.7 \mathrm{~m} / \mathrm{hr}$ & $167 \mathrm{~m} / \mathrm{hr}$ & $3.0 \mathrm{~m} / \mathrm{hr}$ \\
$\mathrm{DD}$ & a.d. & $S W$ or NE & a.d. \\
\hline & $\mathrm{D}$ & $41.20 \mathrm{~km}$ & \\
& $\dot{\mathrm{V}}_{1}$ & $1.33 \mathrm{~km} /$ day & \\
\hline
\end{tabular}

island moved $40 \mathrm{~km}$. Detailed large daily distances for this period are shown in Table 4 , and the maximum displacement was $10.8 \mathrm{~km}$ on May $12^{\text {th }}$.

Table 4. Large daily displacements in the period of May 7-16 $\mathrm{d}$ : daily cumulative displacement $(\mathrm{km})$

\begin{tabular}{ccccccc}
\hline Date & $8-9$ & $10-11$ & $11-12$ & $12-13$ & $13-14$ & $14-15$ \\
$\mathrm{~d}$ & 5.4 & 3.0 & 8.0 & 10.8 & 6.6 & 4.4 \\
\hline
\end{tabular}

\section{III.7.2. Trajectories in June, 1986}

In Figure 64, the trajectory of Hobson's Choice in June 1986 is presented. Two movement events occurred in June, from June $1^{\text {st }}$ to $4^{\text {th }}$ and from June $14^{\text {th }}$ to $21^{\text {st }}$. From June $1^{\text {st }}$ to $4^{\text {th }}$ the ice island drifted southwest along the coastline, whereas on June 14 and 15, the ice island turned and started moving from southwest to northeast. 


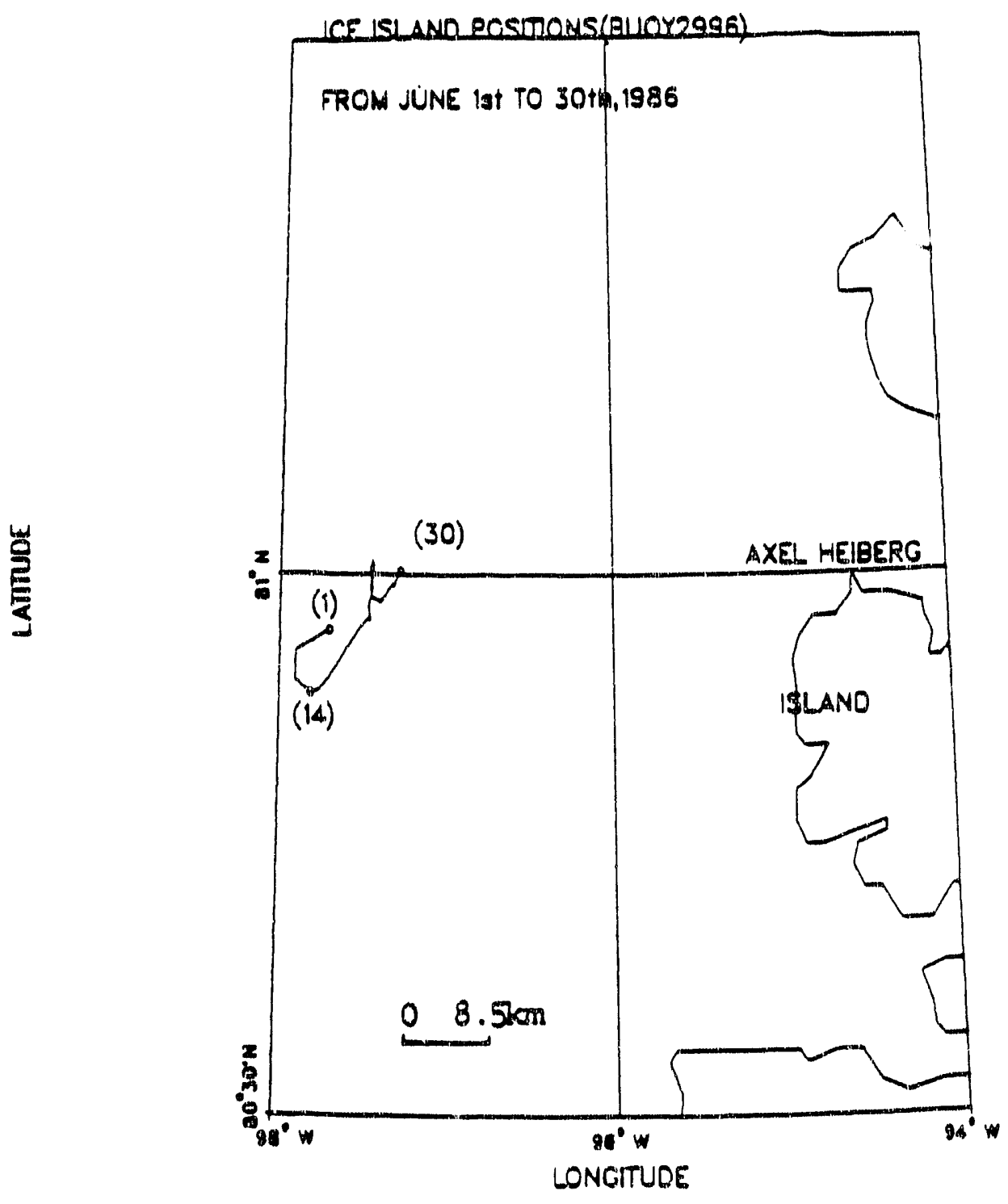

Fig. 64. Ice island positions from June $1^{\text {st }}$ to $30^{\text {th }}, 1986$. 
The detailed positions of the ice island from June $14^{\text {th }}$ to $21^{\text {st }}$ are given in Figure 65. The maximum movement of the ice island occurred on June $16^{\text {th }}$, a distance of about $8.3 \mathrm{~km}$. On June 19 , the ice island made a transition from northward motion at $00 Z, 03 Z, 06 Z$ and $09 Z$ to southward motion at $12 Z$. From June 20 to 22 the movement of the ice island was toward the south, and finally to the northeast. It is interesting to note that large daily motion was usually parallel to the coastline in the direction of the southwest or the northeast.

The total cumulative displacement in June was about $34.6 \mathrm{~km}$, giving an average speed of approximately $1.15 \mathrm{~km} /$ day. Summary data concerning the track of Hobson's ice island in June are shown in Table 5. From $15^{\text {th }}$ to $16^{\text {th }}, 18^{\text {th }}$ to $19^{\text {th }}, 20^{\text {th }}$ to $21^{\text {st }}$ and $21^{\text {st }}$ to $22^{\text {nd }}$, the daily distances were $1.6,5.6,3.5$ and $2.0 \mathrm{~km}$, respectively.

The dynamic analysis of major ice island motions for May and June, 1986, were of main concern in our study.

\section{III.7.3. Large daily movements in July, August and September, 1986}

Large daily movements also occurred in July, August and September, 1986. Specifically, the trajectories in the period of July 1-6, August 22-27 and September 10-16, 1986, are shown in Figure 66, Figure 67 and Figure 68 respectively. For most of these three large motion episodes, the ice island moved in the direction of the northeast along the coastline, except for August $22^{\text {nd }}$ when it moved briefly towards the southwest.

\section{III.8. Relationship between Surface Wind, Geostrophic Wind and Ice Island Movement}

Surface winds were measured at a height of 2 meters with Argos buoy 2996. These data are shown in Figure 69 from May $7^{\text {th }}$ to $16^{\text {th }}, 1986$, and in Figure 70 from June $14^{\text {th }}$ to $21^{\text {th }}, 1986$. In the same figures, a comparison is made with the velocity of 
Ice Island Positions(June 14-21, 1986)

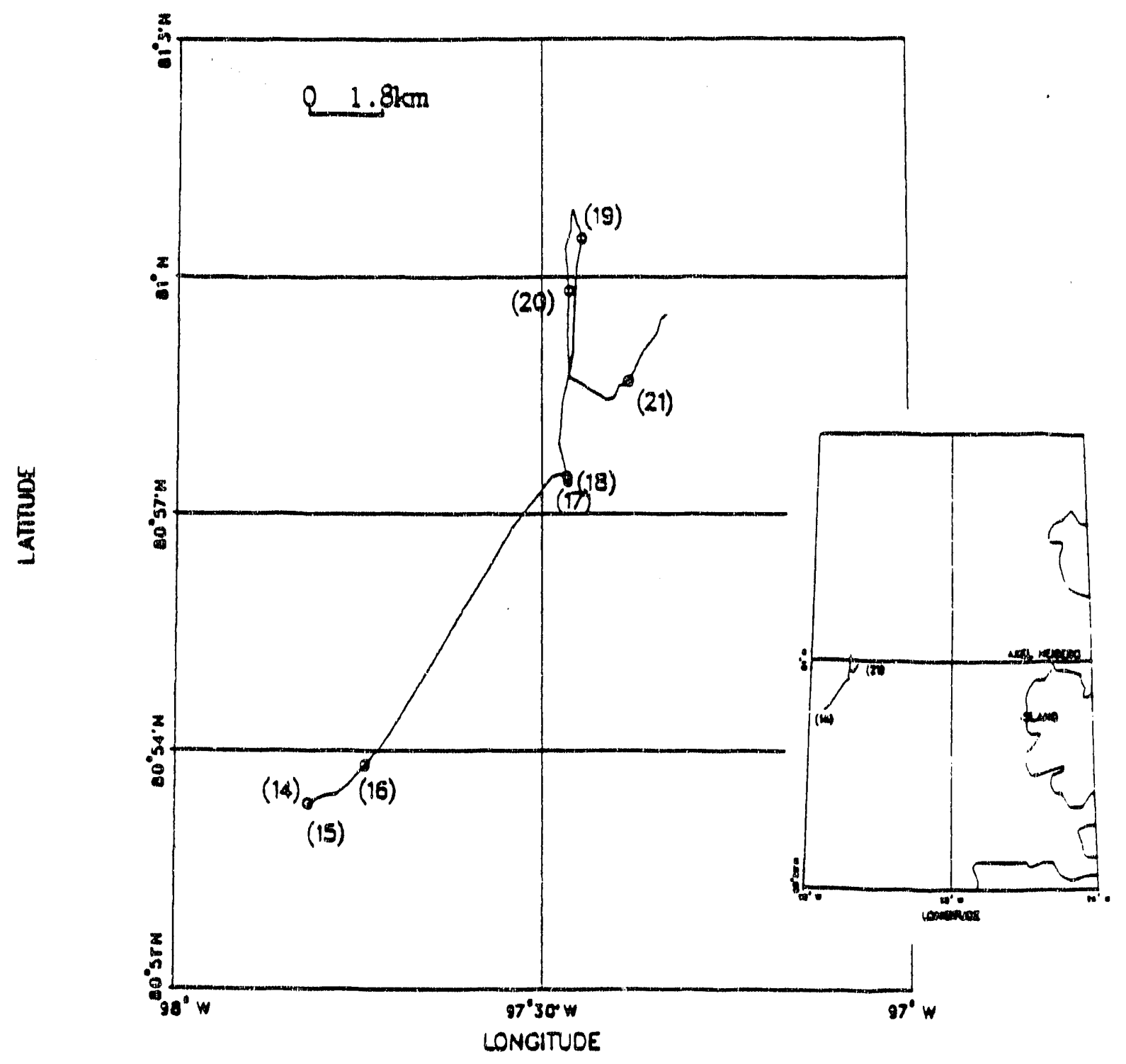

Fig. 65. Ice islands positions in the period June $14^{\text {th }}$ to $21^{\text {st }}, 1986$. 
Table 5. Summary data concerning the track of Hobson's Choice in June 1986

$\mathrm{D}_{1} \quad$ : cumulative displacement $(\mathrm{km})$

$\dot{V}_{j}:$ average speed during the time $(\mathrm{m} / \mathrm{hr})$

DD : movement direction

D : total cumulative displacement in May $(\mathrm{km})$

$\dot{v}_{\mathrm{i}}$ : average speed per day in May ( $\mathrm{km} /$ day)

a.d. : random direction

SW : southwest direction

$\mathrm{NE}:$ northeast direction

\begin{tabular}{ccccc}
\hline Time (day) & $1-4$ & $5-13$ & $14-21$ & $22-30$ \\
\hline $\mathrm{D}_{1}$ & $10.5 \mathrm{~km}$ & $0.5 \mathrm{~km}$ & $23.0 \mathrm{~km}$ & $0.6 \mathrm{~km}$ \\
$\dot{\mathrm{V}}_{1}$ & $109.0 \mathrm{~m} / \mathrm{hr}$ & $2.5 \mathrm{~m} / \mathrm{hr}$ & $120 \mathrm{~m} / \mathrm{hr}$ & $2.8 \mathrm{~m} / \mathrm{hr}$ \\
$\mathrm{DD}$ & $\mathrm{SW}$ & 2.d. & $\mathrm{NE}$ & a.d. \\
\hline \multicolumn{5}{c}{} \\
& $\mathrm{D}$ & $3.46 \mathrm{~km}$ & \\
& $\dot{\mathrm{V}}_{\perp}$ & \multicolumn{1}{c}{$1.15 \mathrm{~km} /$ day } \\
\hline
\end{tabular}

the ice island and the geostrophic wind velocity, which were calculated from the surface pressure maps, making use of equations (6) and (7).

From Figure 69(b), the angle of the surface wind direction is smaller than the angle of the geostrophic wind direction from May $7^{\text {th }}$ to $8^{\text {th }}$, and from May $10^{\text {th }}$ to $16^{\text {th }}$, which indicates that the surface wind turns to the left of the geostrophic wind due to the effect of surface friction. However, on May $9^{\text {th }}$ the turning angle was $90^{\circ}$. This was probably due to the mountain barrier effect, since the geostrophic wind blows towards the mountain barrier; the same phenomenon occurred also on June $17^{\text {th }}$ (Figure 70(b)). Details will be discussed in the next section.

It is still noticed from Figure 70(b) that the surface wind turns to the left of the geostrophic wind. The ice island motion direction was to the left of the geostrophic wind, and to the right of the surface wind, as seen in both Figures 69 and 70.

Albright (1980) and Thorndike and Colony (1982) stated that the geostrophic winds are related to the observed surface winds and pack ice motion in the central 
Ice Island Positions(July 1-6, 1986)

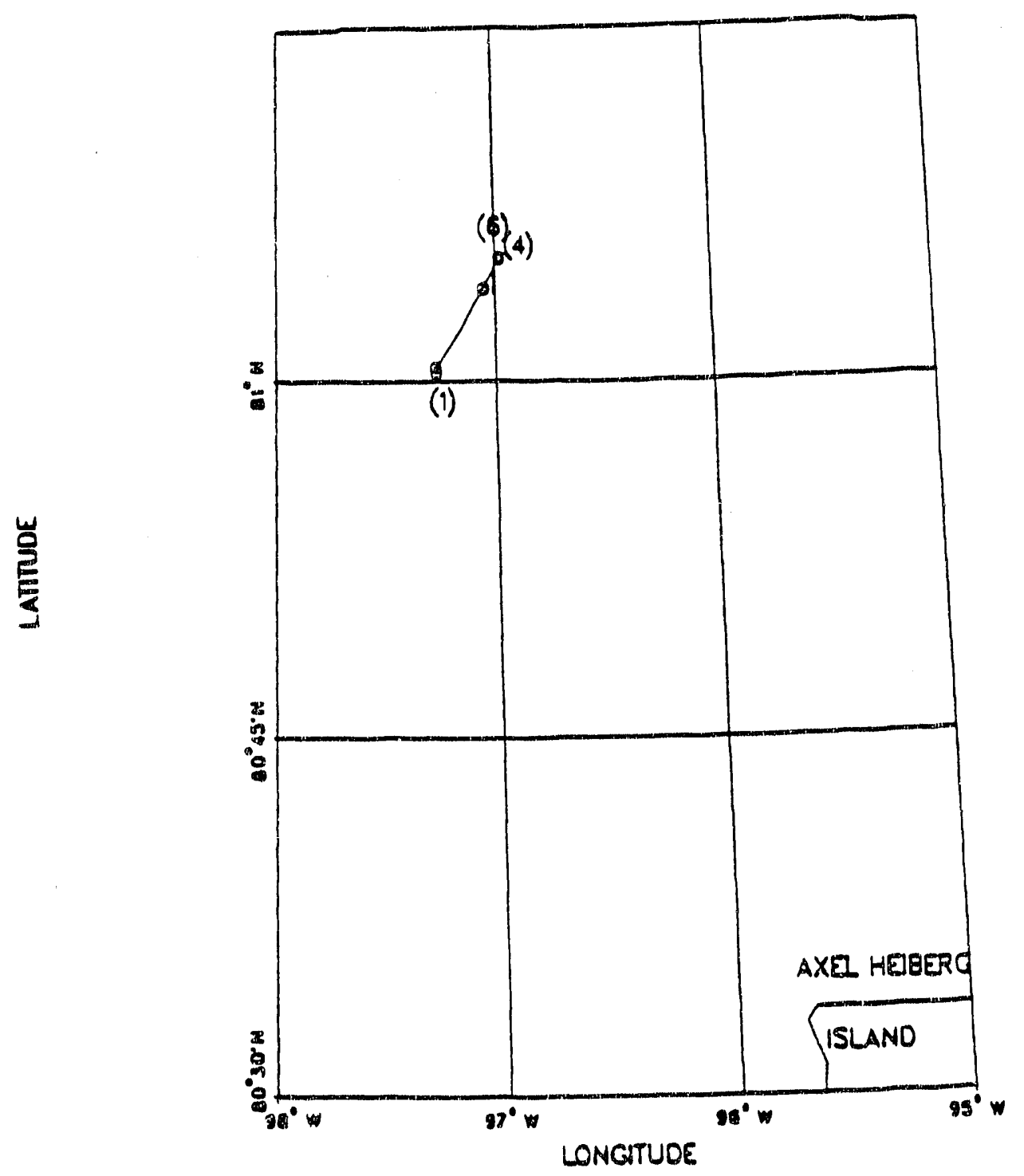

Fig. 66. Ice island positions in the period July $1^{\text {st }}$ to $6^{\text {th }}, 1986$. 


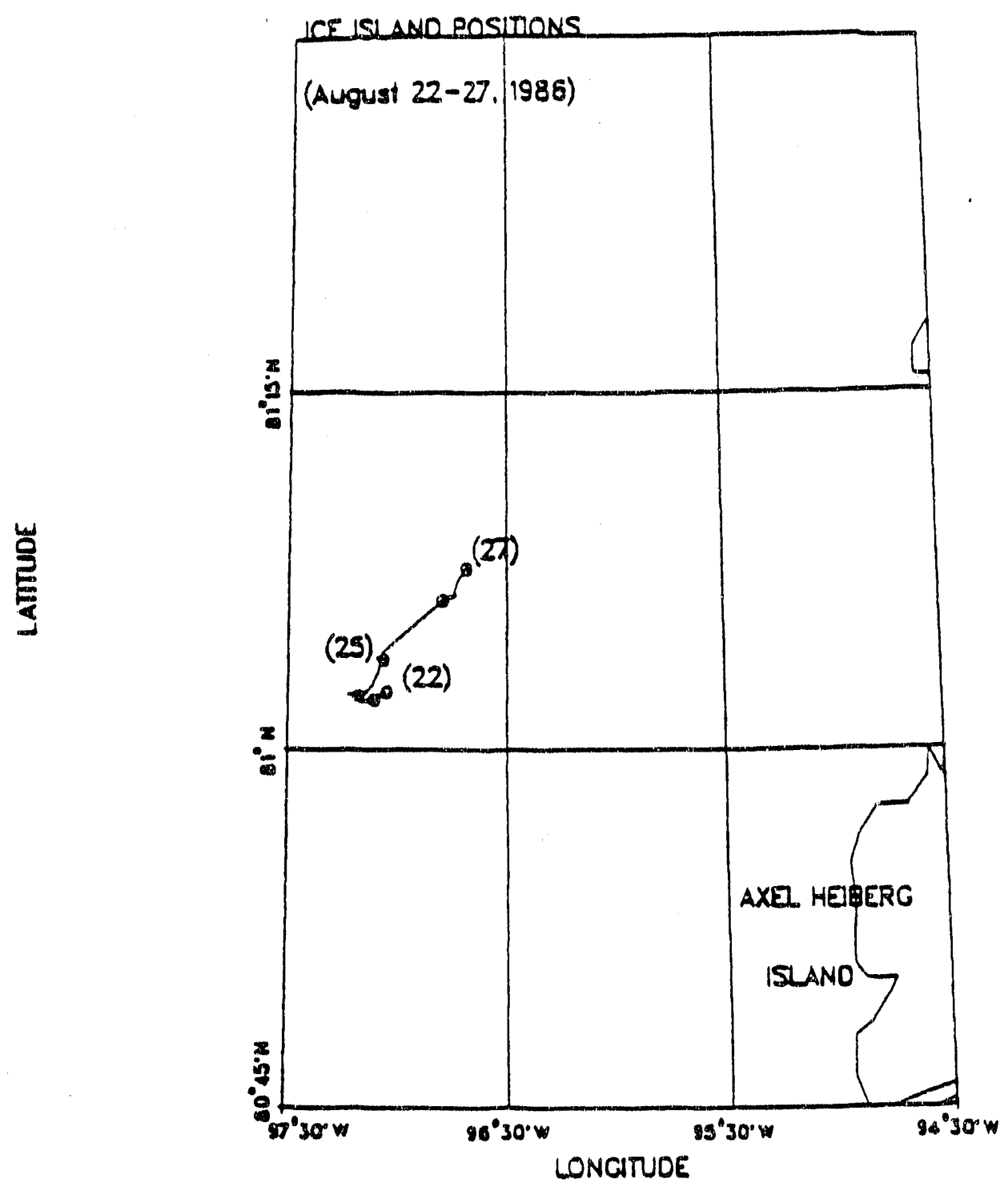

Fig. 67. Ice island positions in the period August $22^{\text {nd }}$ to $27^{\text {th }}, 1986$. 


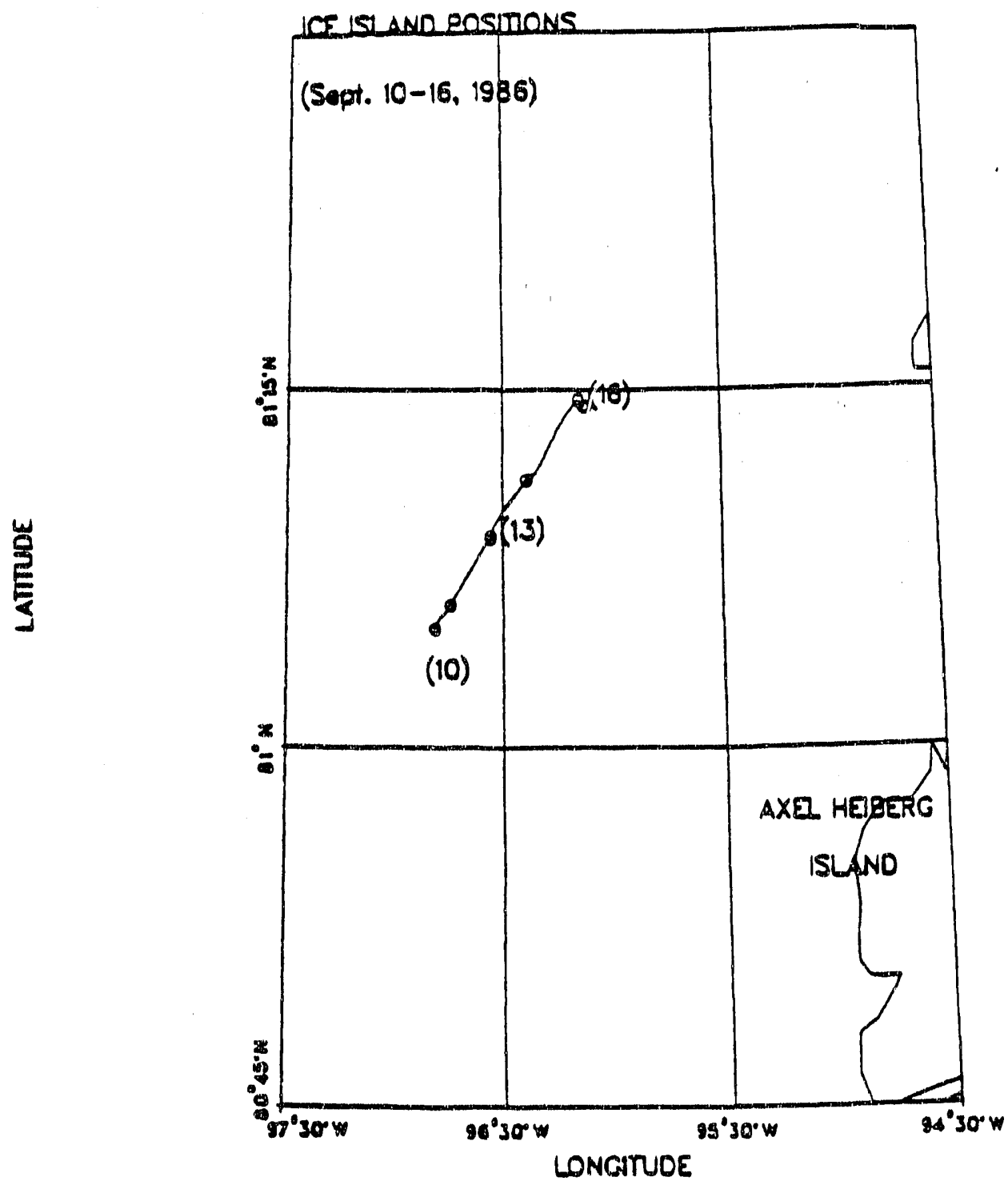

Fig. 68. Ice island positions in the period September $10^{\text {th }}$ to $16^{\text {th }}, 1986$. 

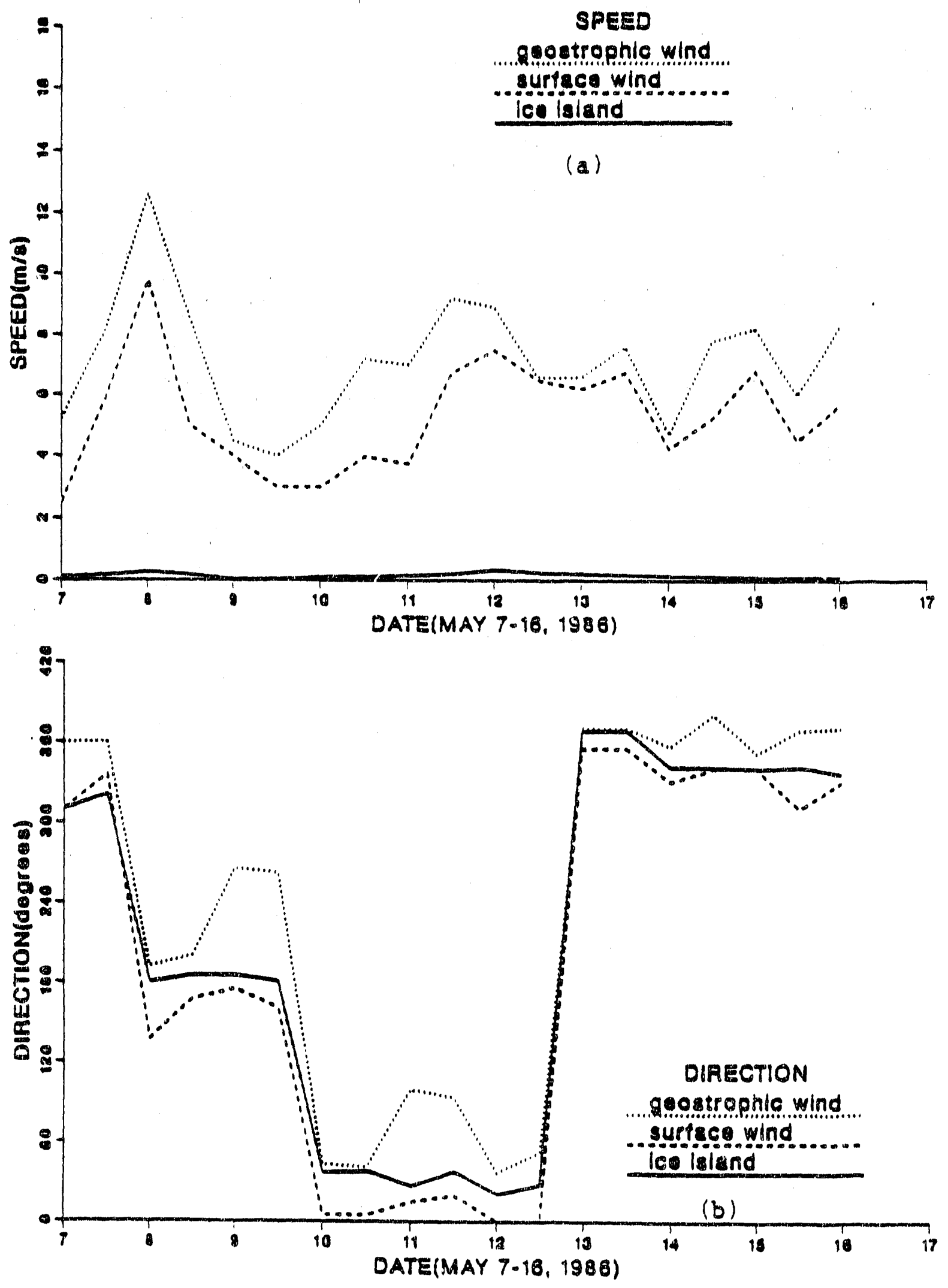

Fig. 69. Direction and speed of surface wind, geostrophic wind and ice island
movement in the period May $7-16,1986$. 

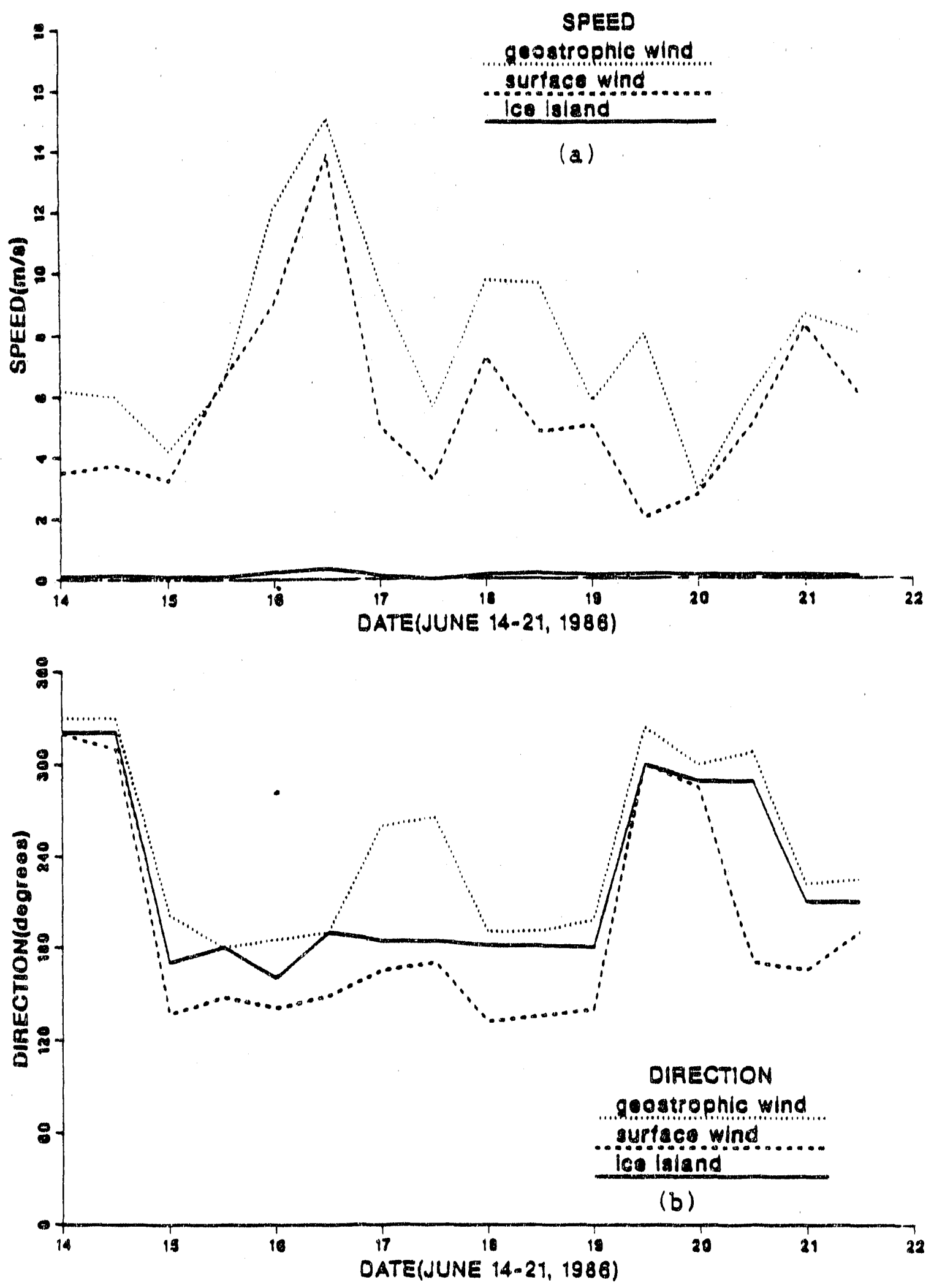

Fig. 70. Direction and speed of surface wind, geostrophic wind and ice island movement in the period June 14-21, 1986 . 
Arctic. Their observations showed large deviations in the directional relationships, indicating that wind shear in the central Arctic is a time-variable condition, as yet not thoroughly understood.

For large movement episodes the average daily velocities of ice island movement $\left(\mathrm{V}_{\mathrm{i}}\right)$ and the daily average surface wind velocities $\left(\mathrm{V}_{\mathrm{s}}\right)$ are shown in Table 6 . The relationships between the velocity of ice island movement and the geostrophic wind velocity, as well as the daily average surface wind velocity and geostrophic wind velocity for times of large movement episodes are shown in Table 7 anc Table 8.

The classic approximate ratio of sea ice speed to surface wind speed $\left(V_{s}\right)$ is about 2\% (Thorndike and Colony, 1982). The ratio of sea ice speed to geostrophic wind speed $\left(\mathrm{V}_{\mathrm{g}}\right)$ is about $1 \%$ (Zubov, 1945). These were based upon annual ice floes free to move without restraint from adjacent land masses. For the ice island the ratios $\left(\mathrm{V}_{\mathrm{i}} / \mathrm{V}_{\mathrm{s}}\right)$ are distributed from $1.0 \%$ to $1.8 \%$ with an average value of $1.4 \%$ (Table 6). The ratios $\left(\mathrm{V}_{\mathrm{i}} \mathrm{V}_{\mathrm{g}}\right)$ range from $0.5 \%$ to $1.4 \%$, with average value of $0.86 \%$. These smaller values could be caused by the transient response due to the huge mass of the ice island, and by the large form drag due to the great ice island thickness. The angles between the ice island velocity vector, surface wind vector and geostrophic wind vector are shown in Table 6 and Table 7. The ice island in steady motion usually moves to the left of the geostrophic wind direction with an average angle of $25 \pm 10$ degrees, and to the right of the surface wind direction with an average angle of $20 \pm 10$ degrees.

Albright (1980) examined the relationship between the geostrophic wind and the surface wind, using the Arctic Ice Dynamics Joint Experiment (AIDJEX) data from 1975 and 1976 in the Beaufort Sea it was, shown that the average ratios of surface wind speed to geostrophic wind speed are 0.55 in winter and 0.60 in summer and there was an average clockwise angle from surface wind to geostrophic wind of $30^{\circ}$ in winter and $24^{\circ}$ in surnmer. From our results for the ice island shown in Table 
Table 6. The average daily ice island velocities and average daily surface wind velocities for large movement episodes

$\mathrm{V}_{1}, \theta \quad: \quad$ ice island speed and movement direction $\mathrm{V}_{\mathrm{s}}, \theta_{\mathrm{s}} \quad:$ surface wind speed and direction

\begin{tabular}{cccc}
\hline Time interval & $\mathrm{V}_{\mathrm{i}}(\mathrm{m} / \mathrm{s})$ & $\mathrm{V}_{\mathrm{s}}(\mathrm{m} / \mathrm{s})$ & $\mathrm{V}_{\mathrm{i}} \mathrm{V}_{\mathrm{s}}(\%)$ \\
\hline May 8-9 & 0.06 & 5.7 & 1.1 \\
May 11-12 & 0.10 & 6.4 & 1.6 \\
May 12-13 & 0.13 & 7.5 & 1.8 \\
May 13-14 & 0.08 & 6.2 & 1.3 \\
June 1-2 & 0.05 & 4.0 & 1.3 \\
June 2-3 & 0.06 & 5.6 & 1.1 \\
June 16-17 & 0.10 & 10.5 & 1.0 \\
June 18-19 & 0.07 & 4.8 & 1.5 \\
June 20-21 & 0.04 & 2.4 & 1.7 \\
\hline Time interval & $\theta$ & $\theta_{\mathrm{s}}$ & $\theta-\theta_{\mathrm{s}}$ \\
\hline May 8-9 & $183^{\circ}$ & $165^{\circ}$ & $18^{\circ}$ \\
May 11-12 & $27^{\circ}$ & $15^{\circ}$ & $12^{\circ}$ \\
May 12-13 & $21^{\circ}$ & $356^{\circ}$ & $25^{\circ}$ \\
May 13-14 & $8^{\circ}$ & $355^{\circ}$ & $13^{\circ}$ \\
June 1-2 & $17^{\circ}$ & $343^{\circ} 1$ & $34^{\circ}$ \\
June 2-3 & $336^{\circ}$ & $333^{\circ}$ & $3^{\circ}$ \\
June 17-17 & $166^{\circ}$ & $147^{\circ}$ & $19^{\circ}$ \\
June 18-19 & $181^{\circ}$ & $136^{\circ}$ & $45^{\circ}$ \\
June 20-21 & $245^{\circ}$ & $237^{\circ}$ & $8^{\circ}$ \\
\hline
\end{tabular}

8 , the averaged magnitude ratio $\left(\mathrm{V}_{\mathrm{s}} / \mathrm{V}_{\mathrm{g}}\right)$ is $0.62 \pm 0.10$ and the turning angle is about $36^{\circ} \pm 10^{\circ}$. 
Table 7. The average daily ice island velocities and geostrophic wind velocities for large movement episodes

$\mathrm{V}_{\mathrm{i}}, \theta \quad$ : ice island speed and movement direction $\mathrm{V}_{\mathrm{g}}, \theta_{\mathrm{g}}:$ geostrophic wind speed and direction

\begin{tabular}{|c|c|c|c|}
\hline Time interval & $\mathrm{V}_{\mathrm{i}}(\mathrm{m} / \mathrm{s})$ & $\mathrm{V}_{\mathrm{g}}(\mathrm{m} / \mathrm{s})$ & $\mathrm{V}_{i} / \mathrm{V}_{\mathrm{g}}(\%)$ \\
\hline May 8-9 & 0.06 & 12.61 & 0.5 \\
\hline May $11-12$ & 0.10 & 9.2 & 1.4 \\
\hline May $12-13$ & 0.13 & 8.9 & 1.4 \\
\hline May $13-14$ & 0.08 & 7.6 & 1.0 \\
\hline June 1-2 & 0.05 & 6.15 & 0.81 \\
\hline June 2-3 & 0.06 & 8.39 & 0.72 \\
\hline June 16-17 & 0.10 & 15.1 & 0.71 \\
\hline June 18-19 & 0,07 & 9.62 & 0.73 \\
\hline June 20-21 & 0.04 & 5.74 & 0.70 \\
\hline Time interval & $\theta$ & $\theta_{\mathrm{g}}$ & $\theta-\theta_{\mathrm{g}}$ \\
\hline May 8-9 & $183^{\circ}$ & $192^{\circ}$ & $9^{\circ}$ \\
\hline May 11-12 & $27^{\circ}$ & $93^{\circ}$ & $66^{\circ}$ \\
\hline May $12-13$ & $21^{\circ}$ & $37^{\circ}$ & $16^{\circ}$ \\
\hline May 13-14 & $8^{\circ}$ & $11^{\circ}$ & $3^{\circ}$ \\
\hline June $1-2$ & $17^{\circ}$ & $41^{\circ}$ & $24^{\circ}$ \\
\hline June 2-3 & $336^{\circ}$ & $349^{\circ}$ & $13^{\circ}$ \\
\hline June 16-17 & $166^{\circ}$ & $185^{\circ}$ & $19^{\circ}$ \\
\hline June 18-19 & $181^{\circ}$ & $190^{\circ}$ & $9^{\circ}$ \\
\hline June 20-21 & $245^{\circ}$ & $260^{\circ}$ & $15^{\circ}$ \\
\hline
\end{tabular}

\section{III.9. Mountain Barrier Effect}

As mentioned, the location of Hobson's Choice was near Axel Heiberg Island. The surface elevation of Axel Heiberg Island rises very abruptly from sea level to over 1,500 meters (Figure 60). This could cause a mountain barrier effect (Parish, 1983). The effect of the mountains is to modify the direction and speed of the surface winds as compared with the geostrophic winds (Schwerdtfeger, 1974; Parish, 1983; 
Table 8. The average daily surface wind velocities and geostrophic wind velocities for large movement episodes

\begin{tabular}{cccc}
\hline Time interval & $\mathrm{V}_{\mathrm{s}}(\mathrm{m} / \mathrm{s})$ & $\mathrm{V}_{\mathrm{g}}(\mathrm{m} / \mathrm{s})$ & $\mathrm{V}_{\mathrm{s}} / \mathrm{V}_{\mathrm{g}}(\%)$ \\
\hline May 8-9 & 5.7 & 12.61 & 0.45 \\
May 11-12 & 6.4 & 9.2 & 0.70 \\
May 12-13 & 7.5 & 8.9 & 0.84 \\
May 13-14 & 6.2 & 7.6 & 0.81 \\
May 14-15 & 4.7 & 7.8 & 0.6 \\
June 1-2 & 4.0 & 6.15 & 0.65 \\
June 2-3 & 5.6 & 8.39 & 0.67 \\
June 16-17 & 10.5 & 15.1 & 0.69 \\
June 18-19 & 4.8 & 9.62 & 0.49 \\
June 20-21 & 2.4 & 5.74 & 0.41 \\
\hline Time interval & $\theta_{\mathrm{s}}$ & $\theta_{\mathrm{g}}$ & $\theta_{\mathrm{g}}-\theta_{\mathrm{s}}$ \\
\hline May 8-9 & $165^{\circ}$ & $192^{\circ}$ & $9^{\circ}$ \\
May 11-12 & $15^{\circ}$ & $93^{\circ}$ & $66^{\circ}$ \\
May 12-13 & $356^{\circ}$ & $37^{\circ}$ & $16^{\circ}$ \\
May 13-14 & $355^{\circ}$ & $11^{\circ}$ & $3^{\circ}$ \\
June 1-2 & $343^{\circ} 1$ & $41^{\circ}$ & $24^{\circ}$ \\
June 2-3 & $333^{\circ}$ & $349^{\circ}$ & $13^{\circ}$ \\
June 16-17 & $147^{\circ}$ & $185^{\circ}$ & $19^{\circ}$ \\
June 18-19 & $136^{\circ}$ & $190^{\circ}$ & $9^{\circ}$ \\
June 20-21 & $237^{\circ}$ & $260^{\circ}$ & $15^{\circ}$ \\
\hline
\end{tabular}

Kozo, 1988); the values obtained by Albright (1980) for the central Arctic should not be applied within $150 \mathrm{~km}$ of a mountain barrier if the geostrophic winds are directed either towards or away from the barrier. The effect of a mountain barrier perpendicular to the geostrophic wind is to create a surface wind component on the incoming side, which is to the left (in the northern hemisphere) blowing parallel to the mountain chain, and extending up to $150 \mathrm{~km}$ away from it, as shown in Figure 71 


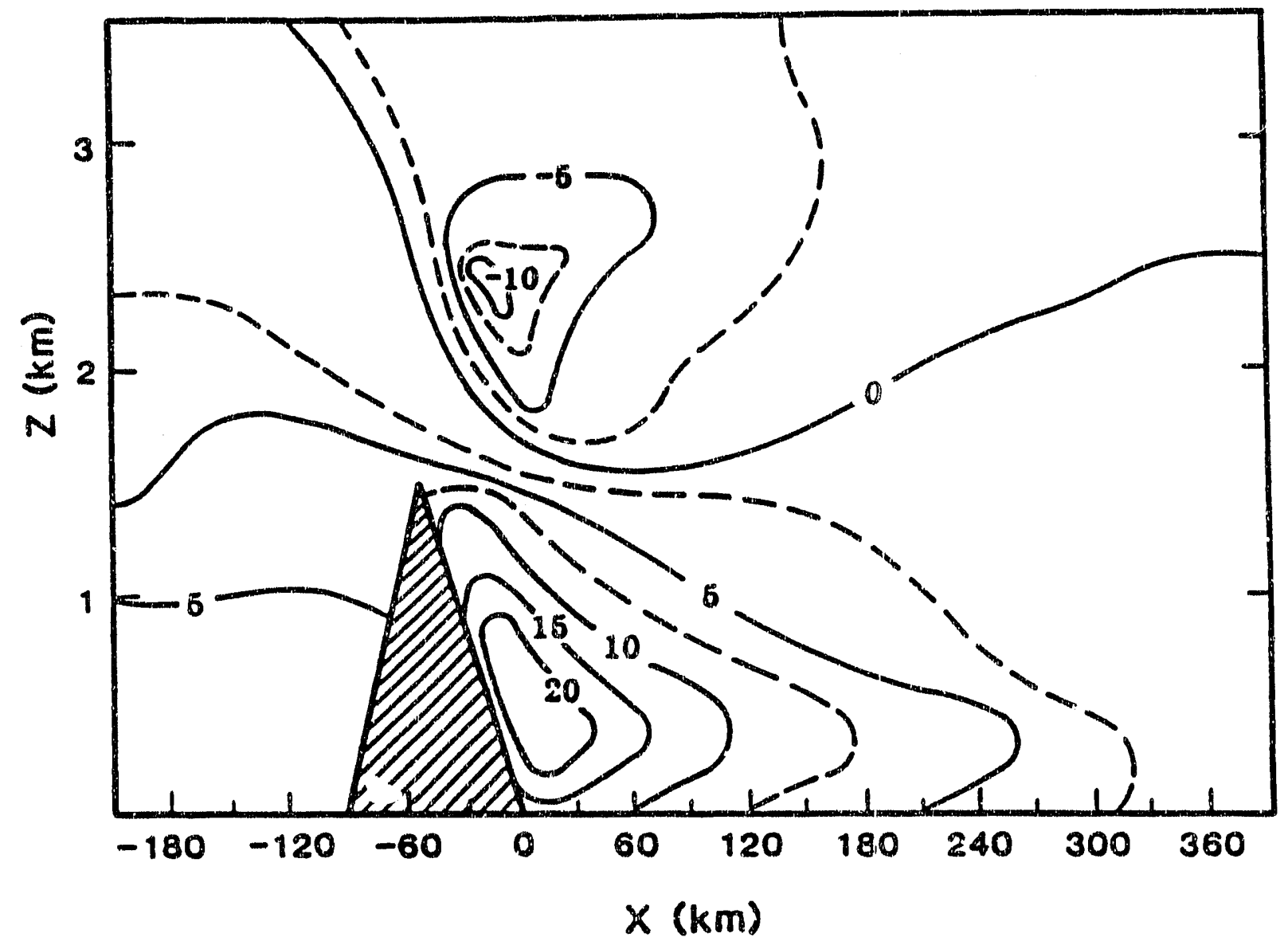

Fig. 71. Mountain-parallel wind components $(\mathrm{m} / \mathrm{s})$ from calculations by Parish (1983) for a geostrophic wind of $10 \mathrm{~m} / \mathrm{s}$ normal to the mountain barrier. 
(Parish, 1983). In Figure 71, computed by Parish for a $10 \mathrm{~m} / \mathrm{sec}$ geostrophic wind, the mountain-parallel wind at the surface is $5 \mathrm{~m} / \mathrm{sec}$ at a distance of $210 \mathrm{~km}$ from the base of the mountain. On the downwind side of the mountain for the same $10 \mathrm{~m} / \mathrm{sec}$ geostrophic wind, a surface wind of $10-12 \mathrm{~m} / \mathrm{sec}$ exists directed perpendicular to the mountain chain, for a region within $60 \mathrm{~km}$ of the mountain edge, illustrated in Figure 72 (Parish, 1983.)

One data set for surface wind at 2 meter elevation is from the Argos buoy 2996 , which was located on Hobson's Choice at $81^{\circ}$ latitude, $97^{\circ}$ longitude, for the period of May 6-16, 1986. In Figure 69, this data is presented and compared with the geostrophic wind as calculated from the synoptic chart (CMC). The significant data on May 9 shows a turning angle from the surface wind to the geostrophic wind of greater than 90 degrees. This could be due to the mountain barrier effect, because the geostrophic wind was blowing towards the mountain barrier from the west. Using the results of the model by Parish, it is reasonable to attribute the relationship between surface wind and geostrophic wind to the mountain barrier effect, as shown in Figure 73.

In Figure 74, the specific case occurred when the geostrophic wind blew from the west on June $17^{\text {th }}$. Another significant example occurred during the interval July 1-9 as shown in Figure 75, which was the first day in the total data set for which the geostrophic wind blew from the south parallel to the mountain barrier. The surface wind was also from the south on July 1 with a turning angle of about 30 degrees. The magnitude of the geostrophic wind was about $11.2 \mathrm{~m} / \mathrm{s}$, much larger than the surface wind, which was about $6 \mathrm{~m} / \mathrm{s}$. After the second day, on July 3-7, the geostrophic wind changed direction to southwest, blowing towards the mountain barrier, but the surface wind maintained its direction still parallel to the mountain barrier, from the south. The magnitude of the geostrophic wind approached that of the surface wind, especially on the day of July $5^{\text {th }}$, when the surface wind was slightly larger than the 


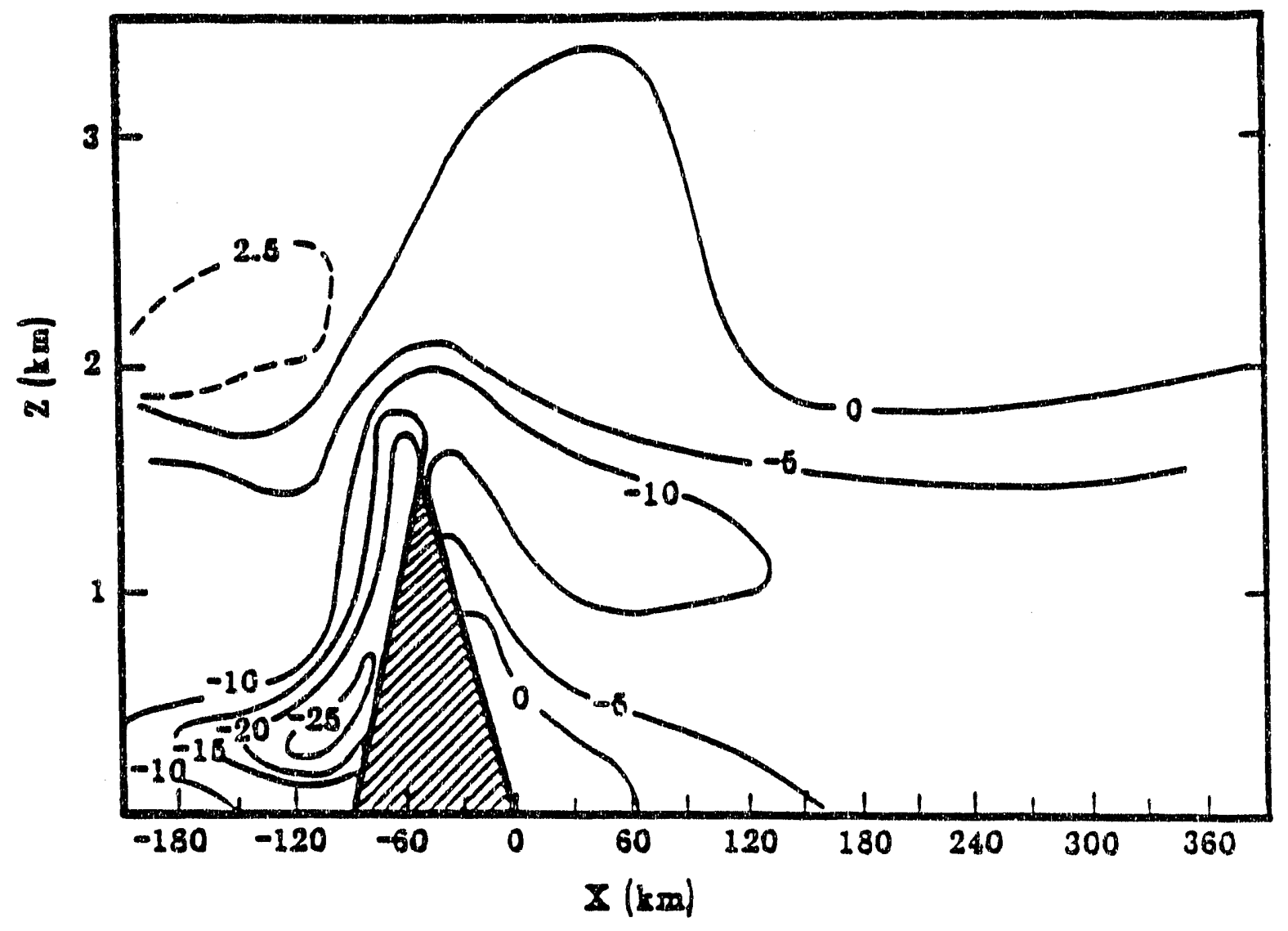

Fig. 72. Wind components $(\mathrm{m} / \mathrm{s})$ normal to the mountain barrier for a geostrophic wind of $10 \mathrm{~m} / \mathrm{s}$ normal to the barrier, after Parish (1983). 


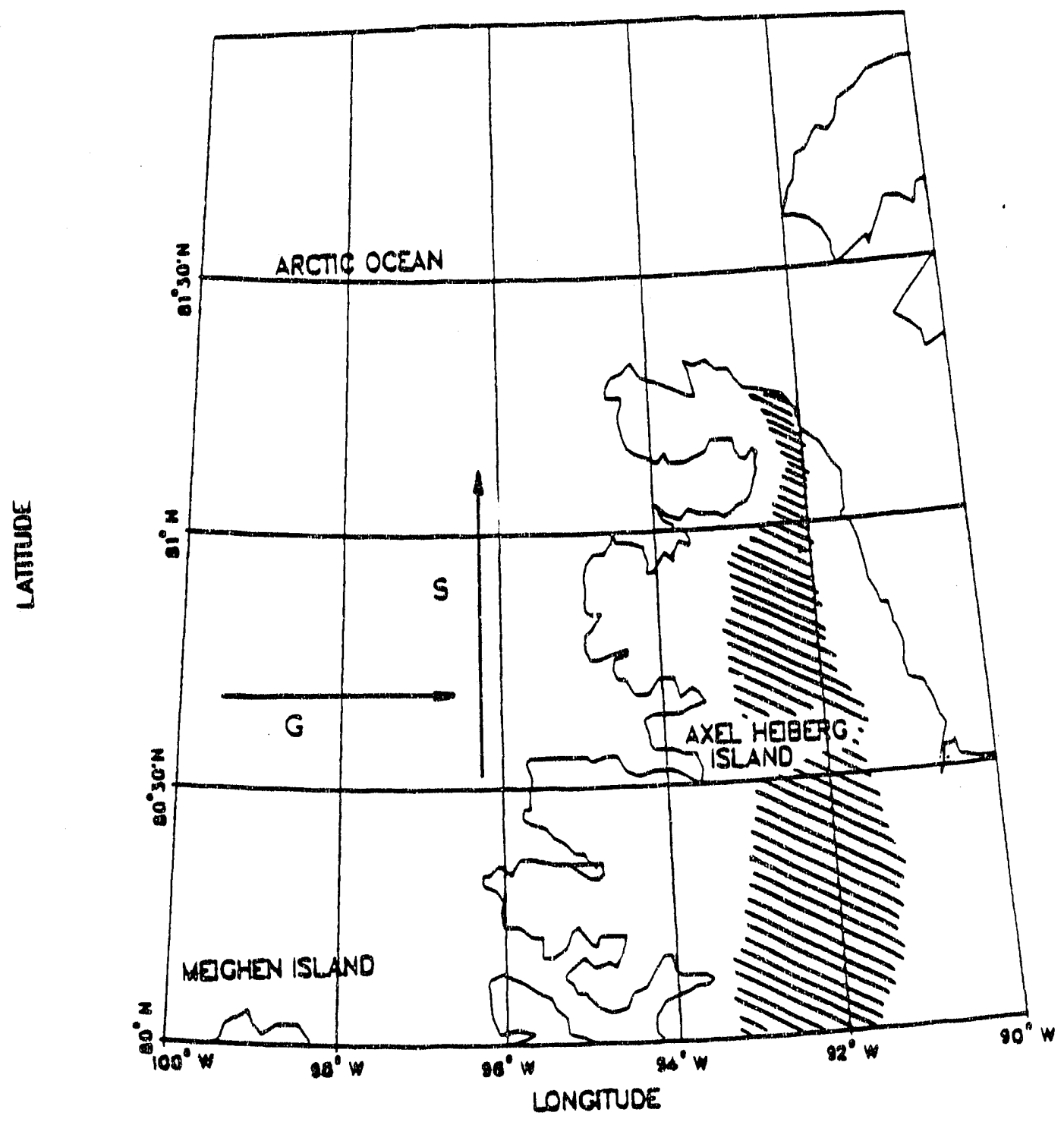

Fig. 73. The concept that a geostrophic wind blowing from the west causes a surface wind parallel to the mountain, because of the mountain barrier effect (Parish, 1983). Crossed area corresponds to elevation greater than 1.500 meters on Axel Heiberg Island. 


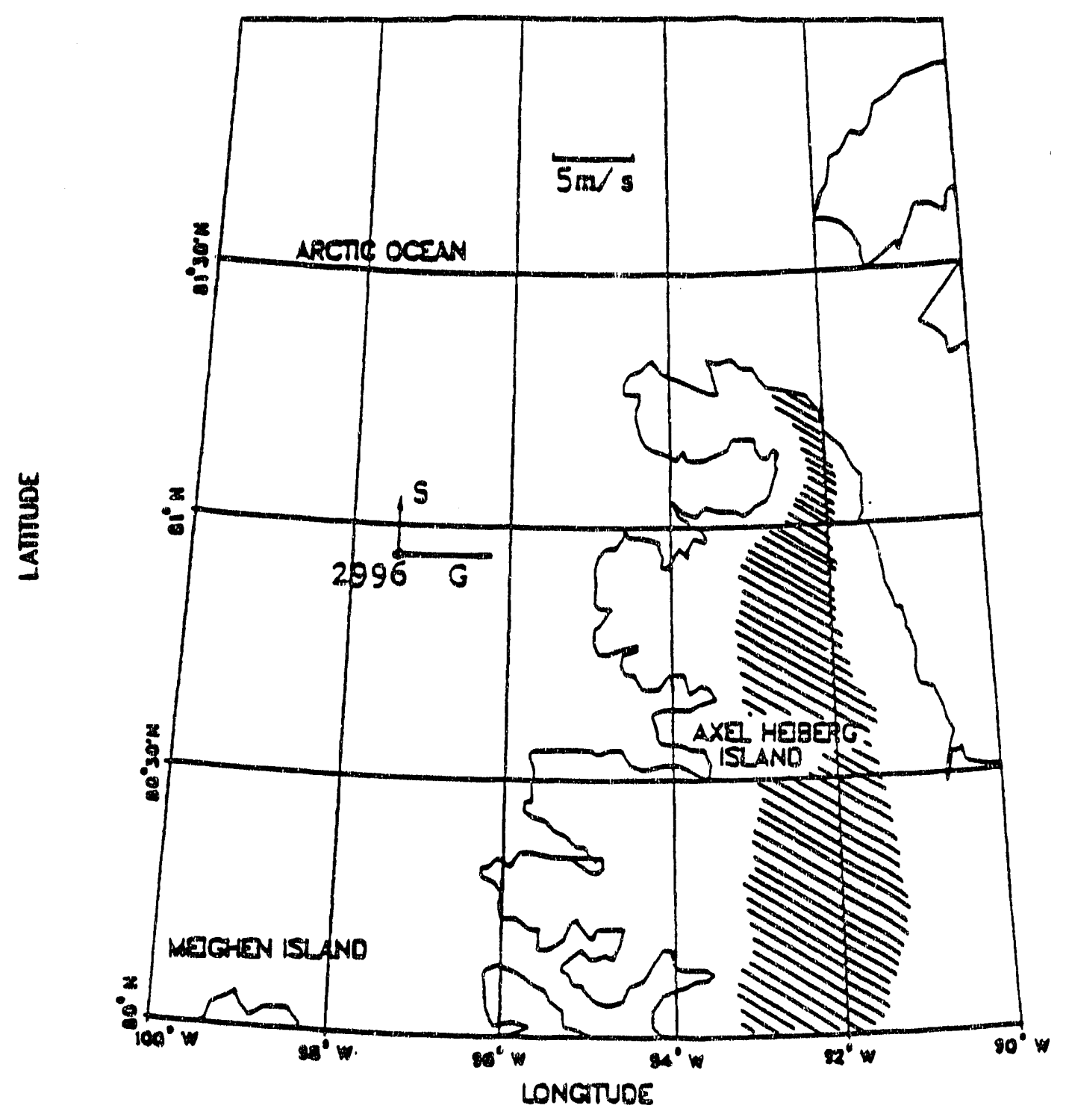

Fig. 74. The specific wind data from June $17^{\text {th }}, 1986$, likely due to mountain barrier effect. Crossed area corresponds to elevation greater than 1500 meters on Axel Heiberg Island. 

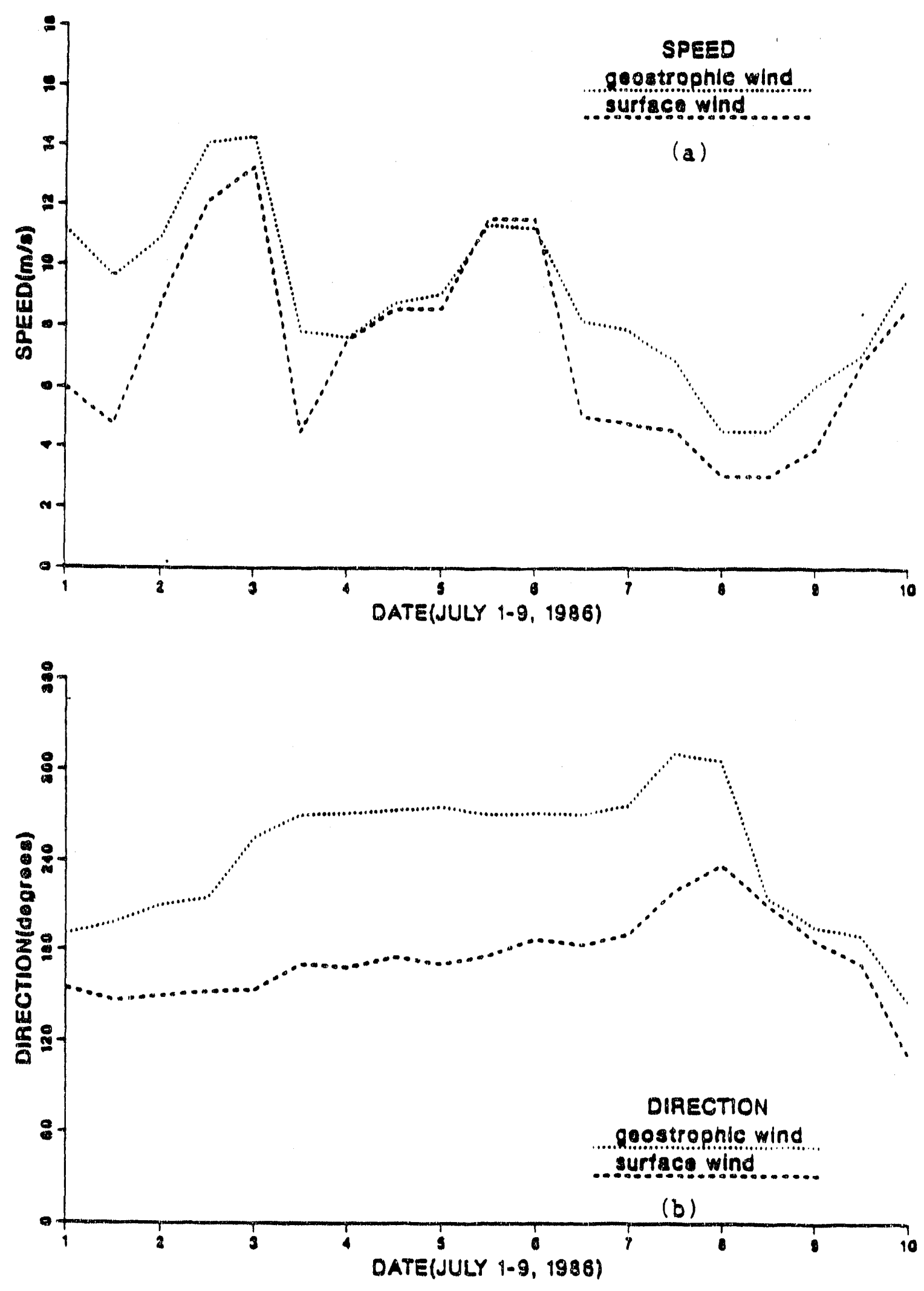
Fig. 75. Direction and speed of surface wind and geostrophic wind in the period
July $1-9,1986$. 
geostrophic wind. This is likely evidence of the mountain barrier effect (Figure 76). In Figure 77 , the corresponding surface weather map of $1200 \mathrm{Z} \mathrm{July} 5^{\text {th }}$ is presented.

Evidence of mountain barrier effects were also observed for August and Sept., 1986. In Figure 78, the direction and magnitude of the geostrophic wind and surface wind is given for the period August 22-27, 1986. The mountain barrier effect occurred on August 26, which is a case similar to that mentioned before, when the geostrophic wind blew from the west towards the mountain barrier, and the surface wind was from the south, parallel to the mountain barrier. It is interesting to note that the speed of the geostrophic wind was slightly smaller than that of the surface wind during the onset of the mountain barrier effect. This is consistent with the results of Parish (1983). The corresponding Arctic surface weather map of $1200 \mathrm{Z}$ August 26 ch, 1986, is presented in Figure 79.

An additional episode of this type took place in the September 11-17, 1986 interval as shown in Figure 80. For the entire time, a geostrophic wind from the west produced a surface wind parallel to the mountain barrier. The corresponding Arctic surface weather map for the day of September 15th, 1986, is given in Figure 81.

The relationships between surface wind direction and geostrophic wind direction for time segments 7-16 May, 14-21 June, 1-9 July, 22-27 August and 11-17 September, 1986, are plotted in Figure 82. Data points within the small square show the influence of mountain barrier effect, for which the geostrophic wind is in the 270 degree direction (from the west towards the mountains) and the surface wind direction is about 180 degrees (parallel to the mountains). The turning angle between them is about 90 degrees in this case.

A noteworthy feature in Figure 80 is that small changes in geostrophic wind direction did not affect surface wind direction, but they did affect the ratio of surface wind intensity to geostrophic wind intensity, as predicted by Parish (1983). From the evidence discussed above, when considering the relationship between ice island 


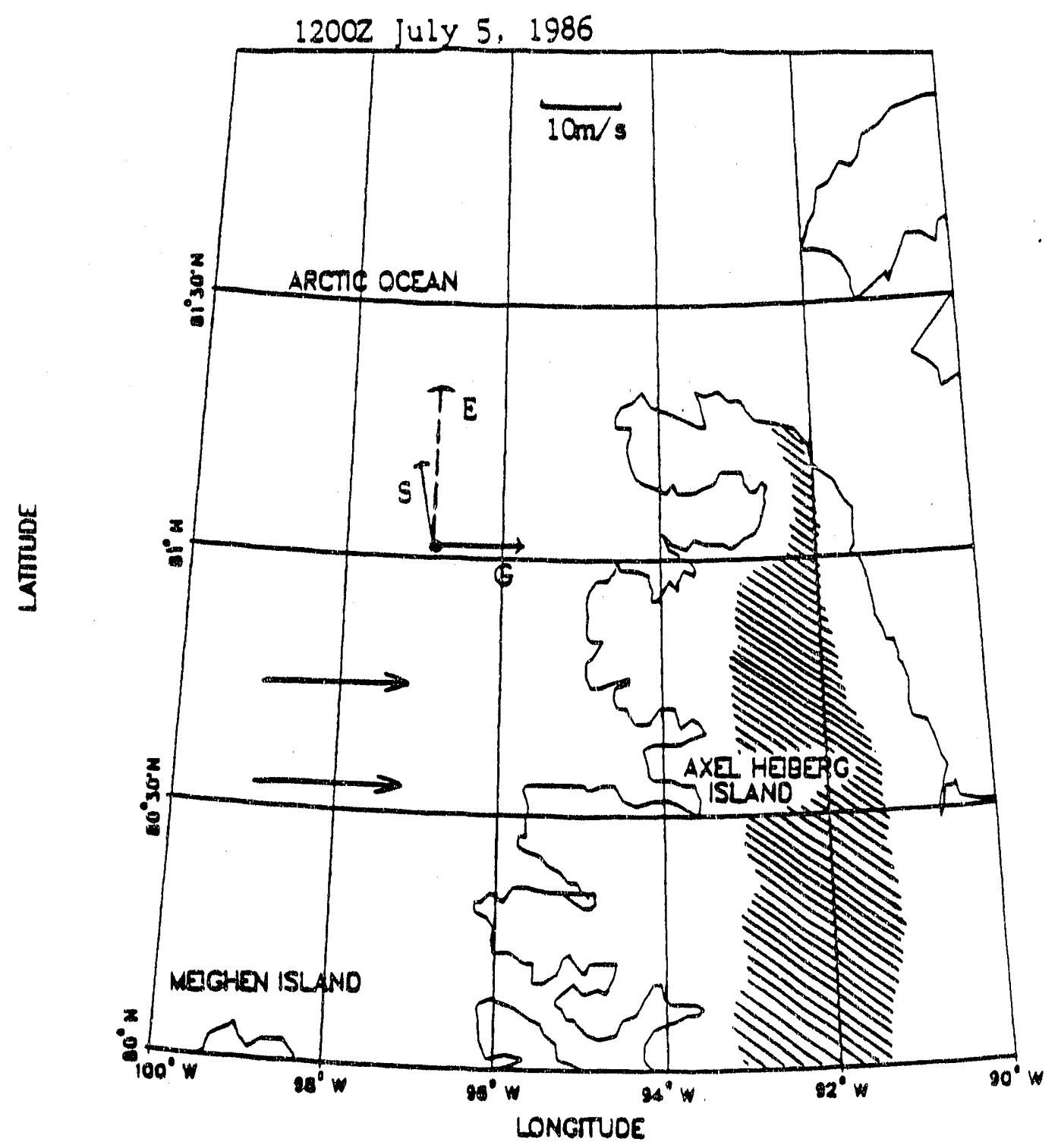

Fig. 76. Wind speed and direction on July $5^{\text {th }}, 1986$, suggesting presence of mountain barrier effect. Crossed area corresponds to elevation greater than 1500 meters on Axel Heiberg Island. 


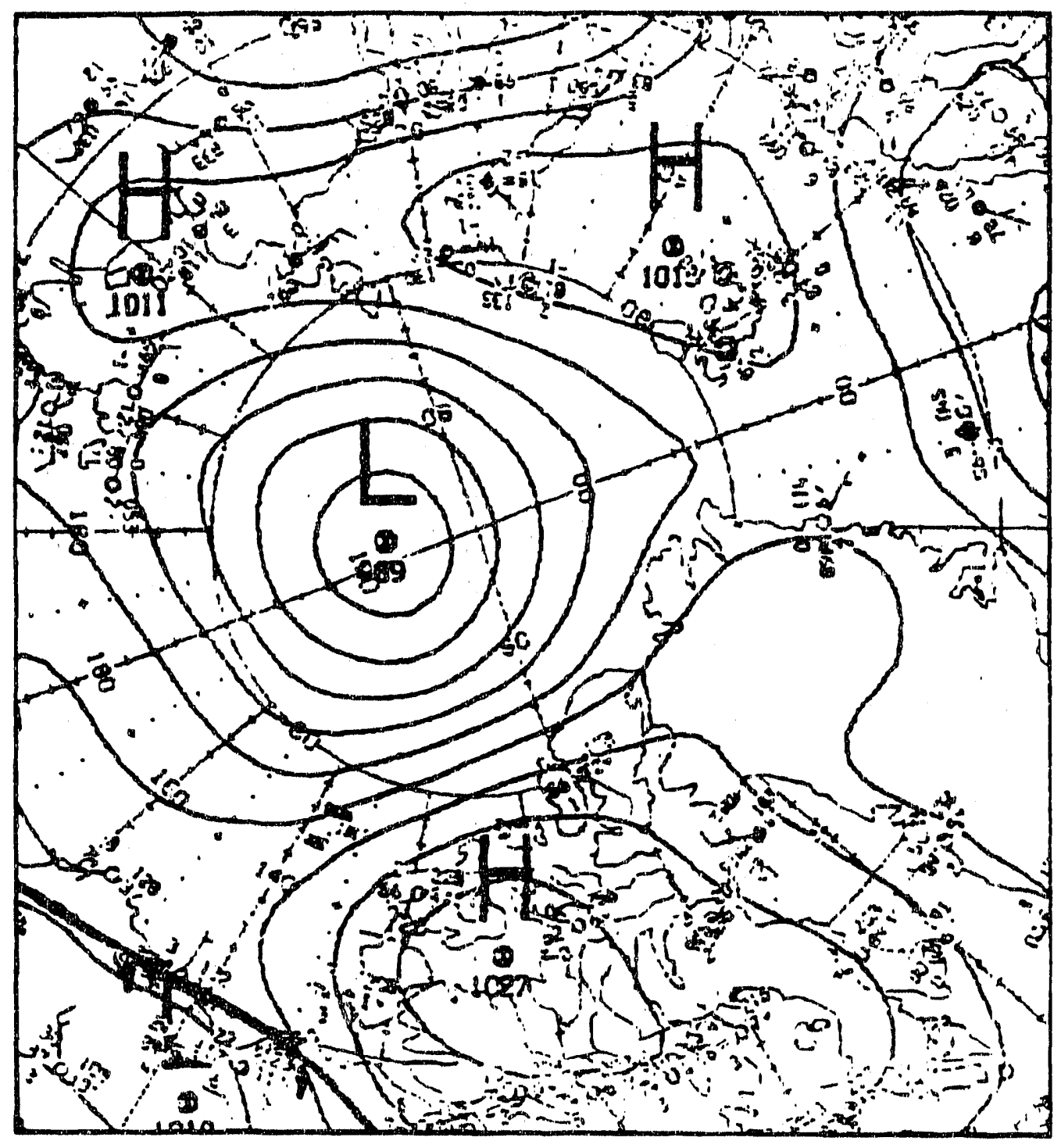

Fig. 77. The Arctic surface weather map of $1200 \mathrm{Z}$ July $5^{\text {th }}, 1986$ (CMC). 

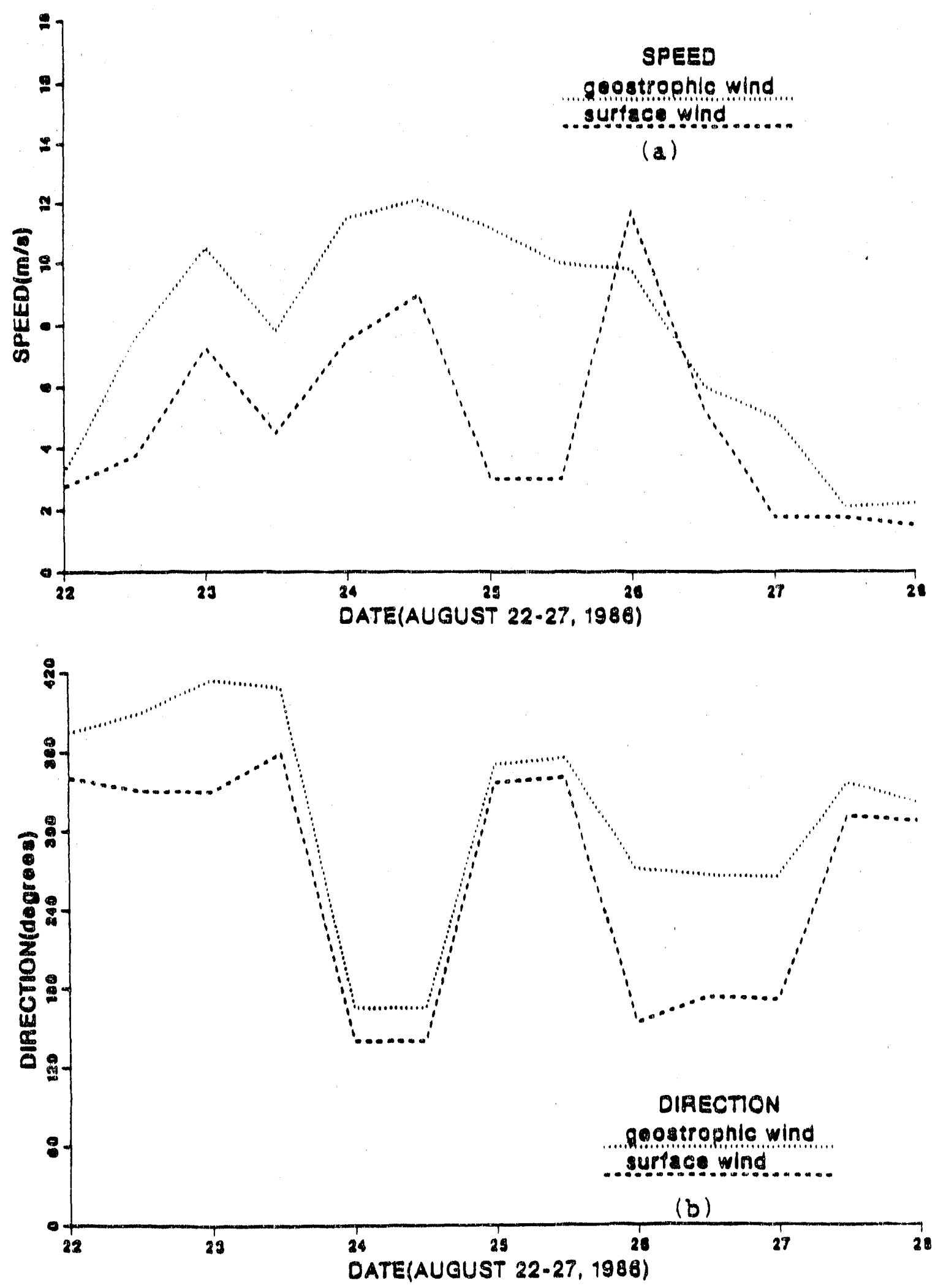

Fig. 78. The direction and speed of surface wind and geostrophic wind in the period August 22-27. 


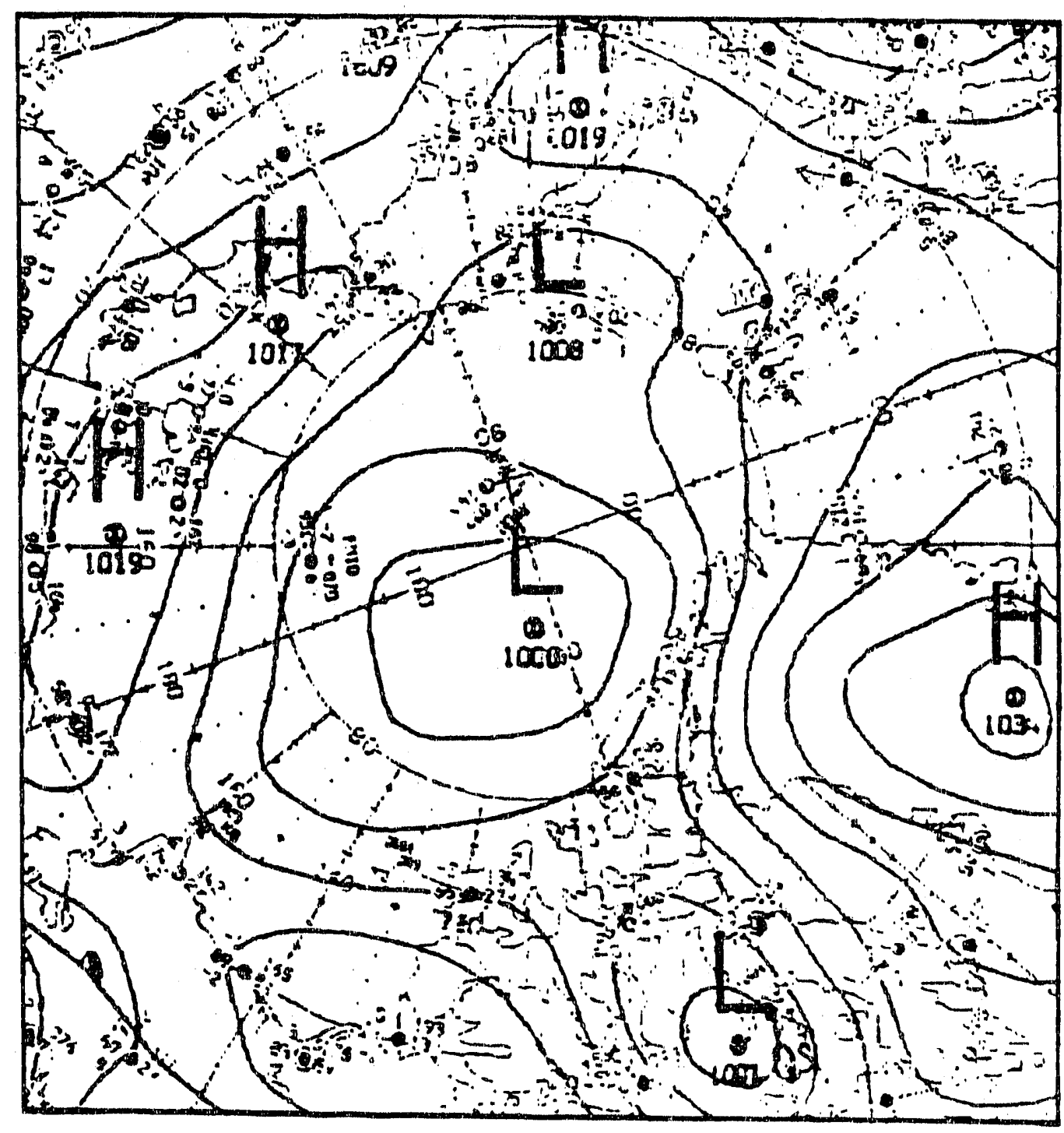

Fig. 79. The Arctic surface weather map of $1200 \mathrm{Z}$ August $26^{\text {th }}, 1986$ (CMC). 

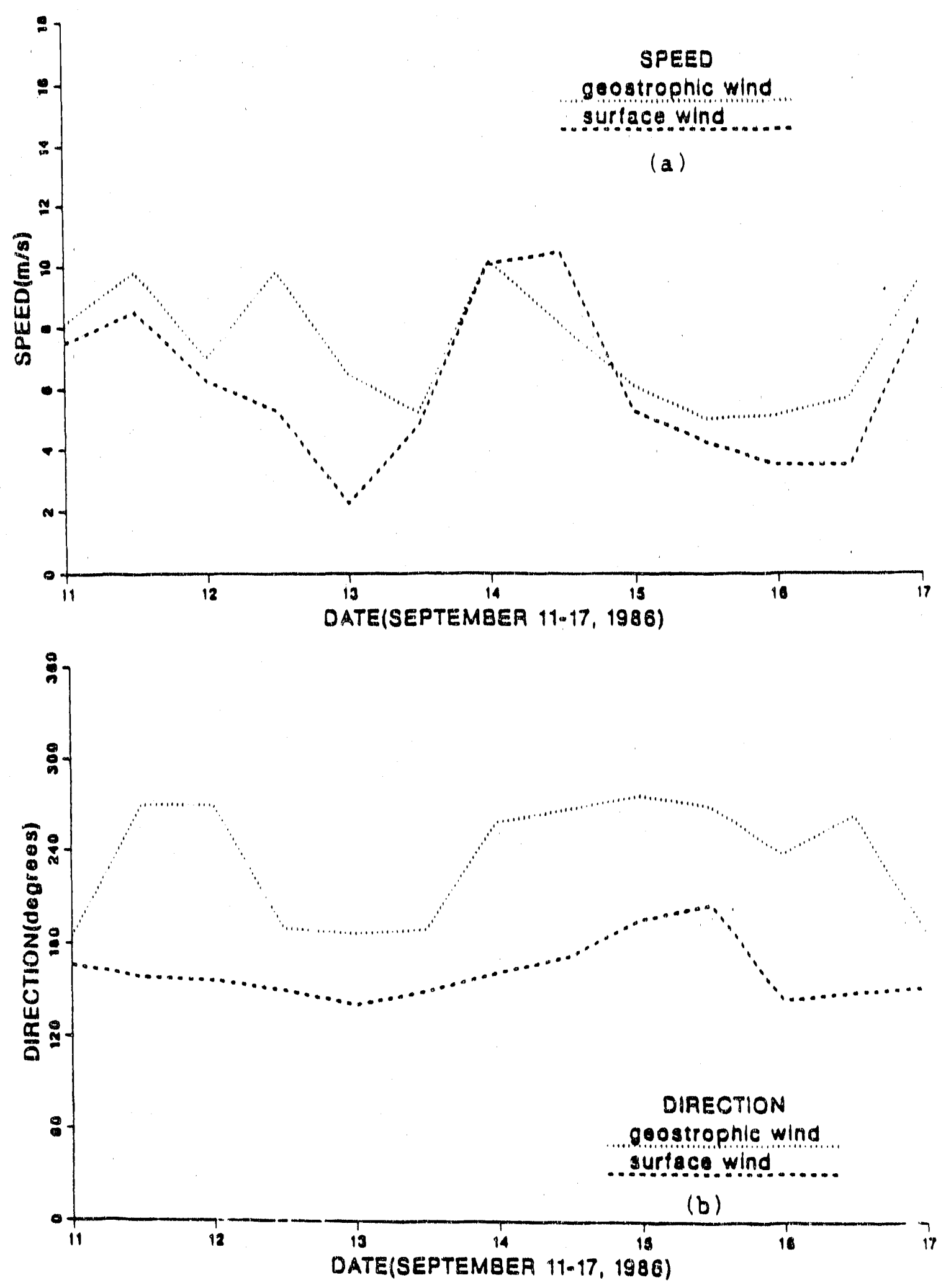

Fig. 80. The direction and speed of surface wind and geostrophic wind in the period September 11-17. 


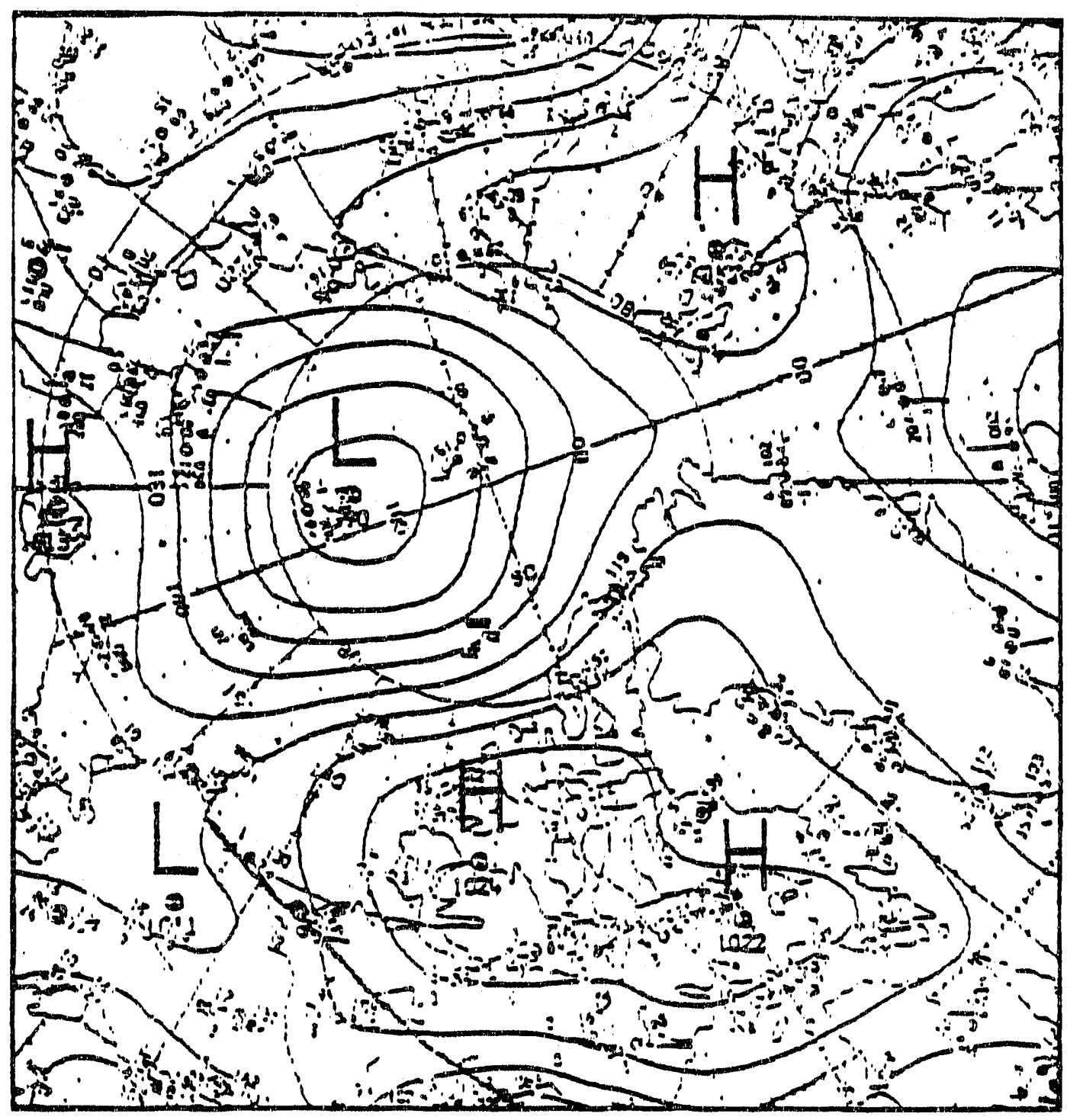

Fig. 81. The Arctic surface weather map of $1200 \mathrm{Z}$ September $15^{\text {th }}, 1986$ (CMC). 


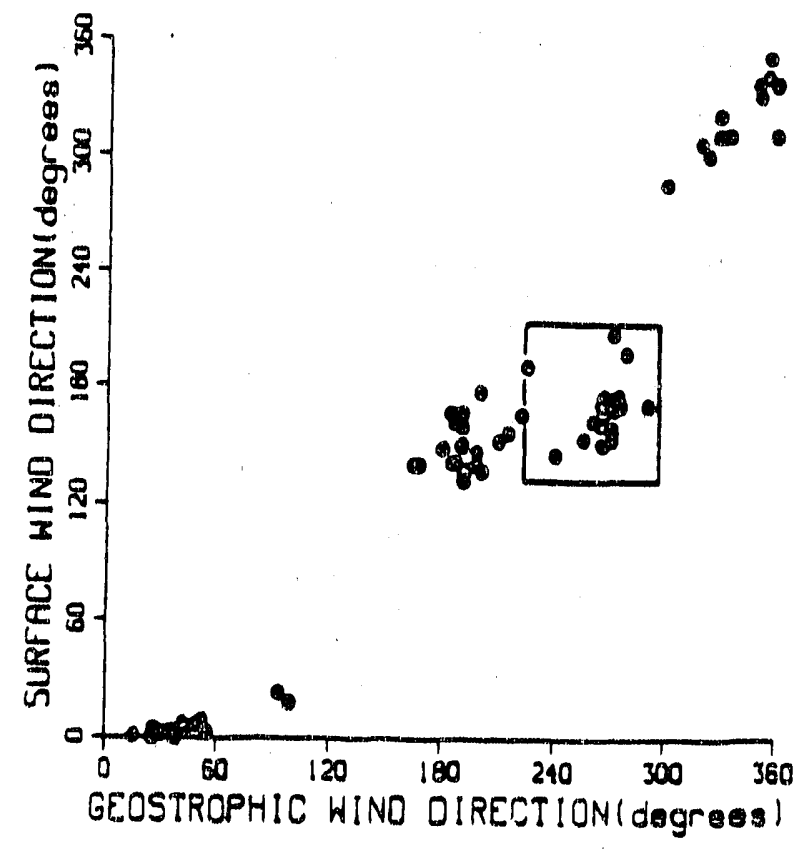

Fig. 82. The geostrophic wind direction versus surface wind direction for time segments May 7-16, June 14-21, July 1-9, August 22-27 and September 11-17, 1986. Box area shows evidence of mountain barrier effect for North/South mountain chain on Axel Heiberg Island. 
movements and the wind velocity, the mountain barrier effect should be taken into account if ice islands move near a mountain coastline.

\section{III.10. Ice Island Dynamic Analysis}

Many researchers have considered the movement of sea ice. The wind provides a shear stress on the upper surface of the ice, as well as upon the surface of any adjacent open water areas, which acts as a driving force, and water currents or geostrophic flow due to sea surface tilt as discussed by McPhee (1982) provides a shear stress on the submerged portion of the ice, which acts either as a retarding force, or, for strong currents, as an accelerating force. With no externally-driven ocean current, the water drag force will oppose the velocity, but with an angle difference due to the Ekman spiral. The Coriolis effect acting upon the ice changes the direction of motion of the ice. Locally-variable pack ice strength allows ice fracture. For an ice island with a huge mass per unit area, the Coriolis force per unit area is nituch larger than in a unit area of sea ice. Water stress acting on an ice island may be divided in to two parts: (i) the water shear force on the lower surface of the ice island, and (ii) the additional form drag due to the frontal area and the trailing area of the ice island. Wind provides a shear stress on the surface of an ice island, however, which is not dramatically different from that for smooth sea ice. Because of the smooth upper surface of an ice island, wind stress may be less than that on the surrounding rough pack ice.

The momentum balance of an ice island is expressed by

$$
M \frac{d V_{i}}{d t}=F_{a}+F_{w}+F_{c}+F_{r}
$$

The wind shear force, water shear force, form drag force and Coriolis forces can be expressed as follows

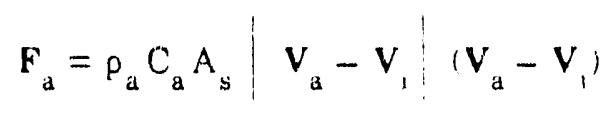




$$
\begin{gathered}
F_{w s}=\rho_{w} C_{w} A_{s}\left|V_{w}-V_{i}\right|\left(V_{w}-V_{i}\right) \\
F_{w p}=\rho_{w} h A_{f}\left|V_{w}-V_{i}\right|\left(V_{w}-V_{i}\right) \\
\left|F_{c}\right|=M(2 \Omega \sin \phi)\left|V_{i}\right|
\end{gathered}
$$

where the symbols were defined earlier in this chapter.

In order to calculate the force balance, the following data have been used: $p_{a}=$ $1.3 \mathrm{~kg} / \mathrm{m}^{3}$ is taken as the density of air corresponding to the temperature of $5^{\circ} \mathrm{C}$ (Weast et al., 1985); $\mathrm{C}_{\mathrm{a}}=0.0014$ is the skin drag coefficient by using the equation of Macklin (1983) for a smooth ice condition with the roughness length $z_{0}=0.0002 \mathrm{~m}$ (Banke et al., 1980), and the reference height $z=2 \mathrm{~m} ; \rho_{w}=1032 \mathrm{~kg} / \mathrm{m}^{3}$ is taken as the density of sea water corresponding to the temperature of $-1.7^{\circ} \mathrm{C}$ and salinity of 32 $\times 10^{-3}$ (Bialek, 1966); $\mathrm{C}_{\mathrm{w}}=0.00132$ is the skin drag coefficient for water under smooth, flat ice (Langleben, 1982), as is believed to be typical of the underwater surface of the ice island; $\mathbf{V}_{\mathrm{a}}$ and $\mathrm{V}_{\mathrm{i}}$ are the velocities of the air and the ice island movement listed in Table 9 for the period of May 7-16, 1986, and in Table 10 for the period of June 14-21, 1986; $\mathbf{V}_{w}$ is the velocity of the water beneath the ice island. The geostrophic flow $\mathbf{V}_{w}$ is due to sea surface tilt (McPhee, 1982). Since the ice island movements generally involve a sequence of transient events, as weather systems move through the region, the calculation of the local water velocity can be quite involved (Kowalik and Untersteiner, 1978). The transient movements of the ice island include instances of a low-velocity disturbed water layer which prevails initially, gradually increasing in thickness as a function of both time and ice island velocity. Applying the equation of $\mathrm{McPhee}$ (1986), the largest geostrophic water flow 
Table 9. Velocities of surface wind and ice island movement in the period May $7-16,1986$

$\begin{array}{lll}\mathrm{V}_{a} & : \text { surface wind speed } \\ \theta^{a} & : \text { surface wind direction } \\ \mathrm{V}_{i} & : \text { ice island movement speed } \\ \theta_{i} & : \text { ice island movement direction }\end{array}$

\begin{tabular}{cccccc}
\hline Date & Hours & $\mathrm{V}_{\mathrm{a}}(\mathrm{m} / \mathrm{s})$ & $\theta_{\mathrm{a}}$ (degrees) & $\mathrm{V}_{\mathrm{i}}(\mathrm{cm} / \mathrm{s})$ & $\theta_{\mathrm{i}}($ degrees $)$ \\
\hline May 7 & 00 & 1.5 & 228 & 0.17 & 115 \\
& 03 & 4.5 & 10 & 0.04 & 97 \\
& 12 & 4.25 & 157 & 0.13 & 201 \\
& 15 & 6.25 & 165 & 0.35 & 192 \\
& 18 & 6.25 & 158 & 3.49 & 177 \\
\hline May 8 & 00 & 9.5 & 140 & 9.84 & 191 \\
& 03 & 8.5 & 141 & 7.1 & 1.95 \\
& 12 & 5.75 & 165 & 5.2 & 186 \\
& 15 & 6.25 & 151 & 1.22 & 201 \\
& 18 & 4.25 & 176 & $\mathrm{u} .97$ & 189 \\
\hline May 9 & 00 & 3.75 & 174 & 0.73 & 99 \\
& 03 & 2.5 & 171 & 1.21 & 22 \\
& 12 & 2.0 & 66 & 1.73 & 1143 \\
& 15 & 2.75 & 56 & 1.3 & 90 \\
& 18 & 2.25 & 77 & 1.1 & 343 \\
\hline May 10 & 00 & 1.5 & 82 & 2.14 & 46 \\
& 03 & 1.0 & 280 & 4.5 & 36 \\
& 12 & 0.25 & 4 & 3.28 & 70 \\
& 15 & 1.25 & 0 & 4.0 & 49 \\
& 18 & 3.5 & 10 & 4.5 & 60 \\
\hline May 11 & 00 & 4.25 & 10 & 6.0 & 58 \\
& 03 & 5.0 & 350 & 8.5 & 51 \\
& 12 & 5.0 & 352 & 8.36 & 57 \\
& 15 & 6.0 & 4 & 9.47 & 63 \\
& 18 & 6.25 & 348 & 12.57 & 51 \\
& & & & &
\end{tabular}




\begin{tabular}{|c|c|c|c|c|c|}
\hline Date & Hours & $\mathrm{V}_{\mathrm{a}}(\mathrm{m} / \mathrm{s})$ & $\theta_{\mathrm{a}}($ degrees $)$ & $\mathrm{V}_{\mathrm{i}}(\mathrm{cm} / \mathrm{s})$ & $\theta_{i}($ degrees $)$ \\
\hline \multirow[t]{5}{*}{ May 12} & 00 & 6.75 & 347 & 14.0 & 41 \\
\hline & 03 & 6.75 & 350 & 16.0 & 31 \\
\hline & 12 & 7.0 & 350 & 9.1 & 45 \\
\hline & 15 & 7.25 & 351 & 11.0 & 33 \\
\hline & 18 & 7.25 & 354 & 12.4 & 42 \\
\hline \multirow[t]{5}{*}{ May 13} & 00 & 6.0 & 0 & 12.0 & 43 \\
\hline & 03 & 6.25 & 340 & 13.0 & 29 \\
\hline & 12 & 7.75 & 352 & 7.8 & 24 \\
\hline & 15 & 7.25 & 0 & 7.78 & 27 \\
\hline & 18 & 7.05 & 0 & 4.9 & 11 \\
\hline \multirow[t]{5}{*}{ May 14} & 00 & 4.25 & 343 & 8.0 & 307 \\
\hline & 03 & 5.5 & 340 & 8.2 & 307 \\
\hline & 12 & 5.5 & 340 & 3.97 & 307 \\
\hline & 15 & 5.5 & 336 & 1.0 & 295 \\
\hline & 18 & 6.0 & 326 & 1.46 & 302 \\
\hline \multirow[t]{5}{*}{ May 15} & 00 & 6.5 & $\overline{334}$ & 3.3 & 309 \\
\hline & 03 & 5.5 & 330 & 0.9 & 316 \\
\hline & 12 & 5.5 & 35 & 0.13 & 98 \\
\hline & 15 & 5.75 & 320 & 0.16 & 278 \\
\hline & 18 & 5.25 & 328 & 2.2 & 351 \\
\hline \multirow[t]{5}{*}{ May 16} & 00 & 5.75 & 322 & 2.6 & 345 \\
\hline & 03 & 5.75 & 324 & 1.0 & 335 \\
\hline & 12 & 5.25 & 324 & 0.2 & 355 \\
\hline & 15 & $-\cdot$ & -- & 2.3 & 359 \\
\hline & 18 & 5.75 & 330 & 0.6 & 2 \\
\hline
\end{tabular}


Table 10. Velocities of surface wind and ice island movement in the period June 14-21, 1986

\begin{tabular}{|c|c|c|c|c|c|}
\hline Date & Hours & $V_{a}(m / s)$ & $\theta_{a}$ (degrees) & $\mathrm{V}_{\mathrm{i}}(\mathrm{cm} / \mathrm{s})$ & $\theta_{i}$ (degrees) \\
\hline \multirow{5}{*}{ June 14} & 00 & $\cdots$ & -- & 0.03 & 277 \\
\hline & 03 & 1.5 & 247 & 0.15 & 97 \\
\hline & 12 & 3.5 & 141 & 0.1 & 97 \\
\hline & 15 & 3.75 & 140 & 0.05 & 97 \\
\hline & 18 & 3.75 & 150 & 0.08 & 277 \\
\hline \multirow[t]{5}{*}{ June 15} & 00 & 3.25 & 150 & 0.15 & 197 \\
\hline & 03 & 1.75 & 210 & 0.2 & 294 \\
\hline & 12 & 7.0 & 140 & 2.8 & 165 \\
\hline & 15 & 6.5 & 132 & 1.46 & 171 \\
\hline & 18 & 7.25 & 150 & 3.3 & 177 \\
\hline \multirow[t]{5}{*}{ June 16} & 00 & $\overline{7.5}$ & 147 & $\overline{7.27}$ & 201 \\
\hline & 03 & 10.25 & 145 & 14.0 & 203 \\
\hline & 12 & 13.5 & 145 & 14.7 & 210 \\
\hline & 15 & 8.75 & 148 & 3.3 & 211 \\
\hline & 18 & 8.75 & 152 & 1.4 & 209 \\
\hline \multirow[t]{5}{*}{ June 17} & 00 & 3.25 & 145 & 0.17 & 97 \\
\hline & 03 & 3.25 & 141 & 0.05 & 277 \\
\hline & 12 & 3.5 & 140 & 0.03 & 213 \\
\hline & 15 & 3.5 & 107 & 0.13 & 74 \\
\hline & 18 & 5.0 & 130 & 0.1 & 187 \\
\hline \multirow[t]{5}{*}{ June 18} & 00 & -- & $\overline{--}$ & 1.8 & 172 \\
\hline & 03 & 5.5 & 140 & 5.68 & 175 \\
\hline & 12 & -. & -- & 4.3 & 199 \\
\hline & 15 & 5.75 & 109 & 7.97 & 177 \\
\hline & 18 & 7.25 & 96 & 10.8 & 162 \\
\hline
\end{tabular}




\begin{tabular}{cccccc}
\hline Date & Hours & $\mathrm{V}_{\mathrm{a}}(\mathrm{m} / \mathrm{s})$ & $\theta_{\mathrm{a}}$ (degrees) & $\mathrm{V}_{\mathrm{i}}(\mathrm{cm} / \mathrm{s})$ & $\theta_{\mathrm{i}}$ (degrees) \\
\hline June 19 & 00 & -- & - & 1.5 & 175 \\
& 03 & 4.25 & 83 & 1.5 & 159 \\
& 12 & -- & -- & 3.8 & 11 \\
& 15 & 1.75 & 320 & 4.1 & 14 \\
& 18 & 2.25 & 310 & 3.1 & 356 \\
\hline June 20 & 00 & 2.75 & 286 & 10.2 & 350 \\
& 03 & 2.0 & 292 & 8.5 & 355 \\
& 12 & 0.75 & 232 & 1.9 & 317 \\
& 15 & 1.25 & 146 & 1.5 & 242 \\
& 18 & 2.75 & 172 & 1.6 & 222 \\
\hline June 21 & 00 & 8.25 & 151 & 0.7 & 193 \\
& 03 & 9.25 & 151 & 0.6 & 201 \\
& 12 & 10.0 & 152 & 3.25 & 206 \\
& 15 & 9.25 & 154 & 1.2 & 217 \\
& 18 & 10.5 & 157 & 0.4 & 202 \\
\hline
\end{tabular}


velocity beneath Hobson's ice island during the interval of data analysis has been calculated to be $0.7 \mathrm{~cm} / \mathrm{s}$, which is small compared with the largest (non-concurrent) movement velocity of the ice island $(16 \mathrm{~cm} / \mathrm{s})$. During the movement episodes the geostrophic water current velocity was much smaller $(<0.01 \mathrm{~cm} / \mathrm{s})$, due to the small sea surface tilt ( $<1.0 \times 10^{-7}$ degrees). It therefore appears justified to assume that $\left|\mathbf{V}_{\mathrm{w}}-\mathbf{V}_{\mathrm{i}}\right| \equiv\left|\mathbf{V}_{\mathrm{i}}\right|$.

\section{III.11. Frontal Area of an Ice Island}

As mentioned previously, the frontal area of a rectangular ice island is changed with the direction of ice island movement. For example, the shelf ice portion of Hobson's Choice has a length of $9.25 \mathrm{~km}$ and a width of $2.0 \mathrm{~km}$ (M. O. Jeffries, personal communication). Associated with the rotation of an ice island, the frontal area $A_{f}$ is given by:

$$
A_{f}=2(L|\sin \theta|+B|\cos \theta|) H
$$

For Hobson's Choice, $L=4.625 \mathrm{~km}$ is the half length, $B=1 \mathrm{~km}$ is the half width, $\mathrm{H}=38 \mathrm{~m}$ is the depth of the wetted portion of the ice island, $\theta=\theta_{i}-A_{z i}$ as shown in

Figure $83, \theta_{i}$ is the direction of ice island movement and $A_{2 i}$ is the rotation azimuth of the ice island.

Examination of values in Tables 11 and 12, and Figure 84, show that the rotation of the ice island itself changed very little; in particular, the total azimuth difference of the ice island rotation was $7.9^{\circ}$ and the average rotation angle was $0.79^{\circ}$ per day in the period May 7-16, 1986; the total azimuth difference of the ice island rotation was just $1.9^{\circ}$ in the period June $14-21,1986$, and the average rotation angle was only $0.24^{\circ}$ per day. The frontal area changed considerably (Figure 85) as the direction of ice island movement changed during these movement episodes. For instance, from $0300 \mathrm{Z}$ to $1200 \mathrm{Z}$ on May 9 the frontal area was changed from $1.52 \times 10^{5}$ 


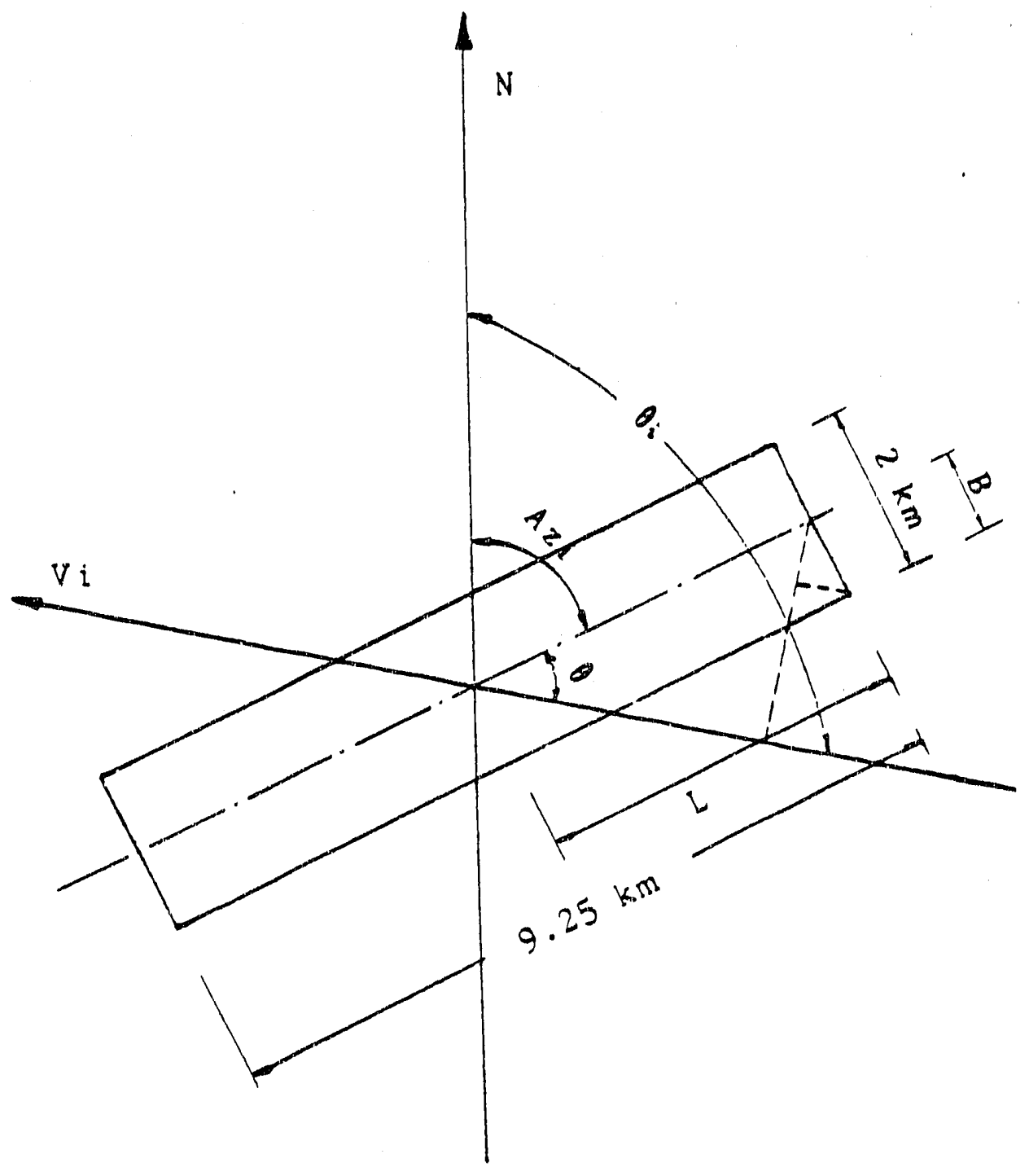

Fig. 83. The relationship between frontal width, rotation and movement direction of Hobson's Choice. 
Table 11. Frontal area change as a result of change in the direction of ice island movement, for the period May 7-16, 1986

$\mathrm{D}_{\mathrm{i}} \quad$ : ice island movement direction

$A^{\prime}$ : frontal area of ice island

azi : azimuth of ice island rotation

\begin{tabular}{|c|c|c|c|c|}
\hline Date & Hours & azi(degrees) & $\mathrm{D}_{\mathrm{i}}$ (degrees) & $A_{p}(m \times k m)$ \\
\hline \multirow[t]{5}{*}{ May 7} & 00 & 31.5 & 115 & 349 \\
\hline & 03 & 31.5 & 97 & 349 \\
\hline & 12 & 31.5 & 201 & 121 \\
\hline & 15 & 31.5 & 192 & 189 \\
\hline & 18 & 31.5 & 177 & 262 \\
\hline \multirow[t]{5}{*}{ May 8} & 00 & 34.4 & 191 & 182 \\
\hline & 03 & 34.4 & 195 & 178 \\
\hline & 12 & 34.4 & 186 & 234 \\
\hline & 15 & 34.4 & 201 & 110 \\
\hline & 18 & 34.4 & 189 & 190 \\
\hline \multirow[t]{5}{*}{ May 9} & 00 & 34.8 & 99 & 347 \\
\hline & 03 & 34.8 & 22 & 152 \\
\hline & 12 & 34.8 & 143 & 354 \\
\hline & 15 & 34.8 & 90 & 319 \\
\hline & 18 & 34.8 & 343 & 319 \\
\hline \multirow[t]{5}{*}{ May 10} & 00 & 34.8 & 46 & 136 \\
\hline & 03 & 34.8 & 36 & 83 \\
\hline & 12 & 34.8 & 70 & 264 \\
\hline & 15 & 34.8 & 49 & 160 \\
\hline & 18 & 34.8 & 60 & 218 \\
\hline \multirow[t]{5}{*}{ May 11} & 00 & 35.9 & 58 & 251 \\
\hline & 03 & 35.9 & 51 & 190 \\
\hline & 12 & 35.2 & 57 & 249 \\
\hline & 15 & 35.2 & 63 & 247 \\
\hline & 18 & 35.2 & 51 & 191 \\
\hline
\end{tabular}




\begin{tabular}{|c|c|c|c|c|}
\hline Date & Hours & azi(degrees) & $\mathrm{D}_{\mathrm{i}}$ (degrees) & $A_{f}(\mathrm{~m} \times \mathrm{km})$ \\
\hline \multirow[t]{5}{*}{ May 12} & 00 & 35.2 & 41 & 146 \\
\hline & 03 & 35.2 & 31 & 76 \\
\hline & 12 & 35.2 & 45 & 182 \\
\hline & 15 & 35.2 & 33 & 99 \\
\hline & 18 & 35.2 & 42 & 98 \\
\hline \multirow[t]{5}{*}{ May 13} & 00 & 34.5 & 43 & 150 \\
\hline & 03 & 34.5 & 29 & 91 \\
\hline & 12 & 34.5 & 24 & 121 \\
\hline & 15 & 34.5 & 27 & 106 \\
\hline & 18 & 34.5 & 11 & 129 \\
\hline \multirow[t]{5}{*}{ May 14} & 00 & 34.5 & 307 & 349 \\
\hline & 03 & 34.5 & 307 & 349 \\
\hline & 12 & 34.5 & 307 & 349 \\
\hline & 15 & 34.5 & 295 & 349 \\
\hline & 18 & 34.5 & 302 & 343 \\
\hline \multirow[t]{5}{*}{ May 15} & 00 & 39.0 & 309 & 349 \\
\hline & 03 & 39.0 & 316 & 348 \\
\hline & 12 & 39.0 & 98 & 334 \\
\hline & 15 & 39.0 & 278 & 342 \\
\hline & 18 & 39.0 & 351 & 304 \\
\hline \multirow[t]{5}{*}{ May 16} & 00 & 39.4 & 345 & 327 \\
\hline & 03 & 39.4 & 335 & 310 \\
\hline & 12 & 39.4 & 355 & 256 \\
\hline & 15 & 39.4 & 359 & \\
\hline & 18 & 39.4 & 2 & 266 \\
\hline
\end{tabular}


Table 12. Frontal area change as a result of change in the direction of ice island movement, for the period June 14-21, 1986

$\mathrm{D}_{\mathrm{i}} \quad$ : ice island movement direction

A : frontal area of ice island

azi : azimuth of ice island rotation

\begin{tabular}{|c|c|c|c|c|}
\hline Date & Hours & azi(degrees) & $D_{i}($ degrees $)$ & $A_{f}(m \times k m)$ \\
\hline \multirow{5}{*}{ June 14} & 00 & 41.8 & 277 & 326 \\
\hline & 03 & 41.8 & 97 & 326 \\
\hline & 12 & 41.8 & 97 & 326 \\
\hline & 15 & 41.8 & 97 & 326 \\
\hline & 18 & 41.8 & 277 & 326 \\
\hline \multirow[t]{5}{*}{ June 15} & 00 & 41.8 & 197 & 212 \\
\hline & 03 & 41.8 & 294 & 342 \\
\hline & 12 & 41.8 & 165 & 326 \\
\hline & 15 & 41.8 & 171 & 334 \\
\hline & 18 & 41.8 & 178 & 76 \\
\hline \multirow[t]{5}{*}{ June 16} & 00 & 40.9 & 201 & 144 \\
\hline & 03 & 40.9 & 203 & 159 \\
\hline & 12 & 40.9 & 210 & 114 \\
\hline & 15 & 40.9 & 211 & 84 \\
\hline & 18 & 40.9 & 209 & 84 \\
\hline \multirow[t]{5}{*}{ June 17} & 00 & 40.9 & 97 & 84 \\
\hline & 03 & 40.9 & 277 & 319 \\
\hline & 12 & 40.9 & 213 & 326 \\
\hline & 15 & 40.9 & 74 & 121 \\
\hline & 18 & 40.9 & 187 & 250 \\
\hline \multirow[t]{5}{*}{ June 18} & $\overline{00}$ & 40.9 & & \\
\hline & 03 & 40.9 & 175 & 304 \\
\hline & 12 & 40.9 & 199 & \\
\hline & 15 & 40.9 & 177 & 250 \\
\hline & 1.8 & 40.9 & 162 & 311 \\
\hline
\end{tabular}




\begin{tabular}{ccccc}
\hline Date & Hours & azi(degrees) & $D_{i}$ (degrees) & $A_{f}(\mathrm{mxkm})$ \\
\hline June 19 & 00 & 43.7 & 175 & \\
& 03 & 43.7 & 159 & 334 \\
& 12 & 43.7 & 11 & \\
& 15 & 43.7 & 14 & 228 \\
& 18 & 43.7 & 356 & 281 \\
\hline June 20 & 00 & 43.7 & 350 & 326 \\
& 03 & 43.7 & 355 & 301 \\
& 12 & 43.7 & 317 & 349 \\
& 15 & 43.7 & 242 & 182 \\
& 18 & 43.7 & 222 & 83 \\
\hline June 21 & 00 & 43.7 & 193 & 205 \\
& 03 & 43.7 & 201 & 137 \\
& 12 & 43.7 & 206 & 159 \\
& 15 & 43.7 & 217 & 84 \\
& 18 & 43.7 & 202 & 137 \\
\hline
\end{tabular}




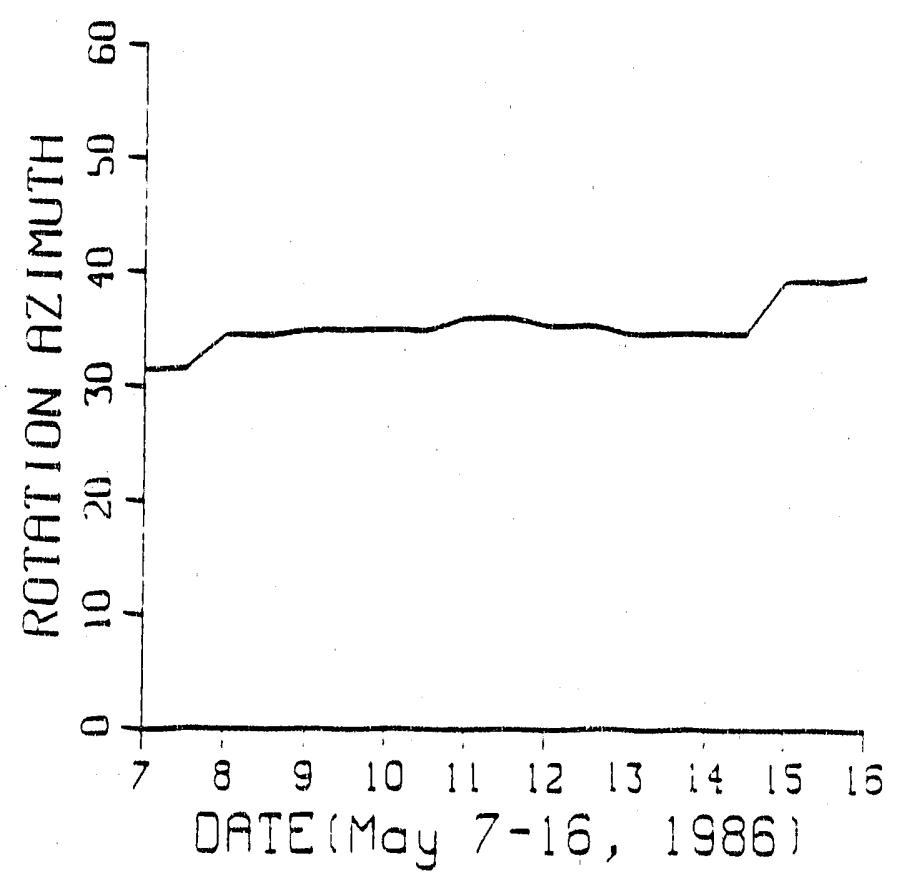

(a)

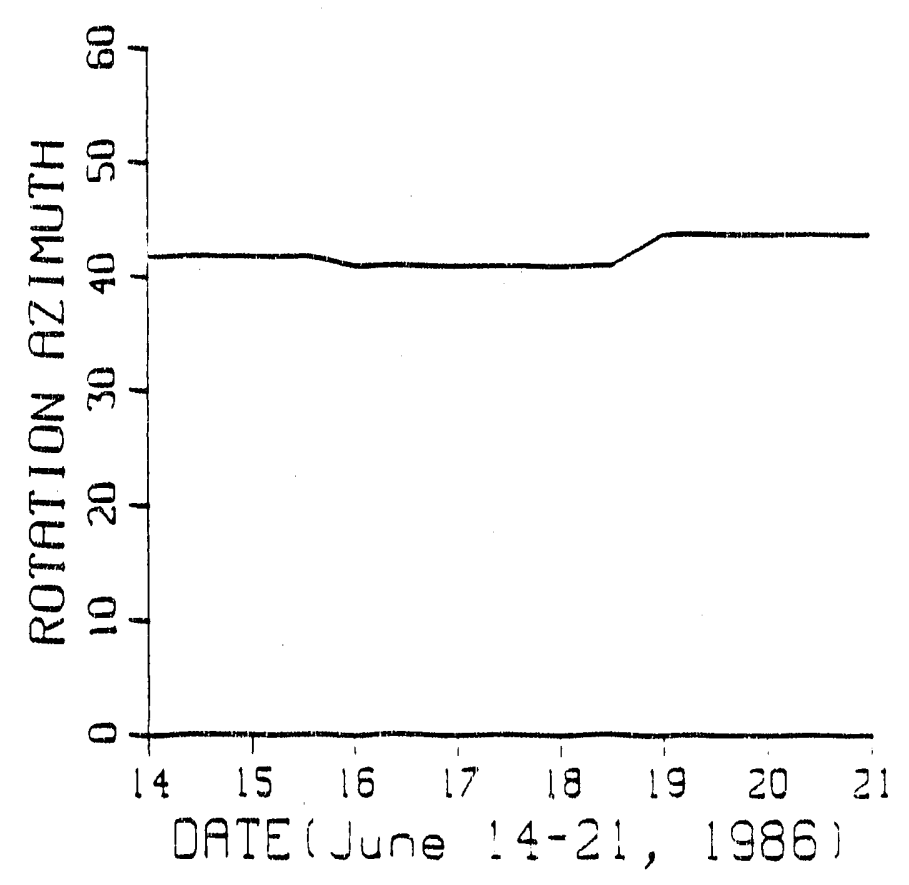

(b)

Fig. 84. The rotation of the ice island itself is plotted as a function of time, (a) for May 7-16; (b) for June 14-21, 1986. 


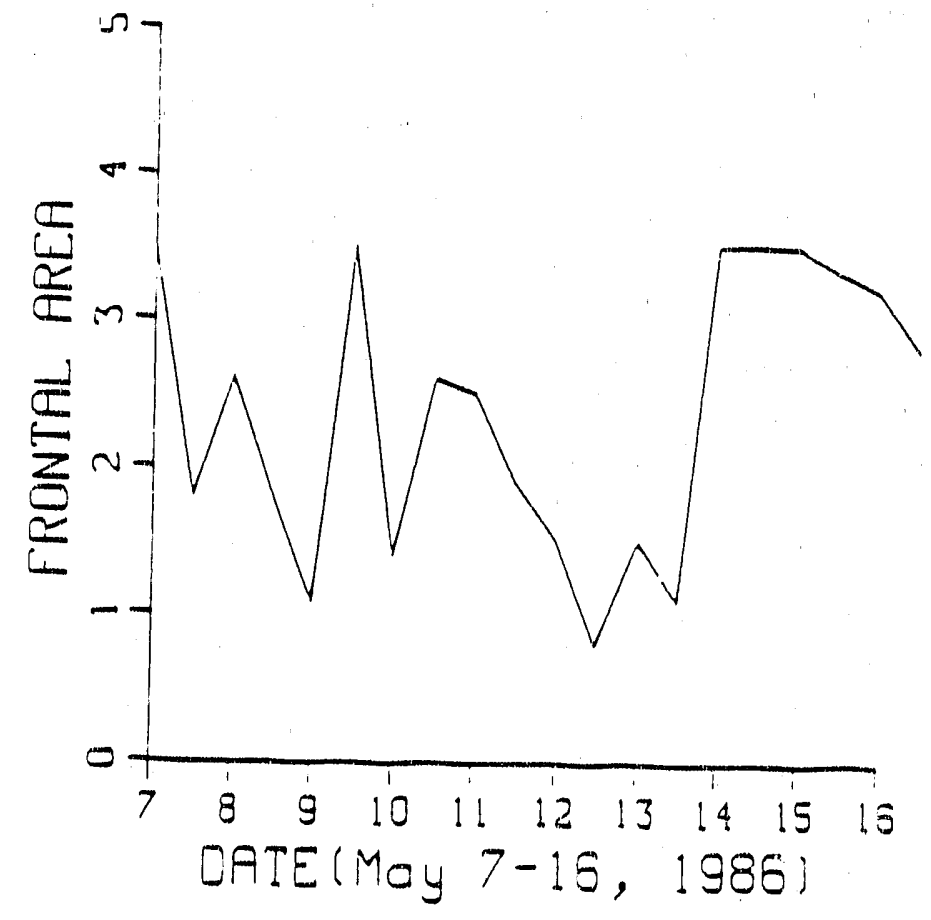

(a)

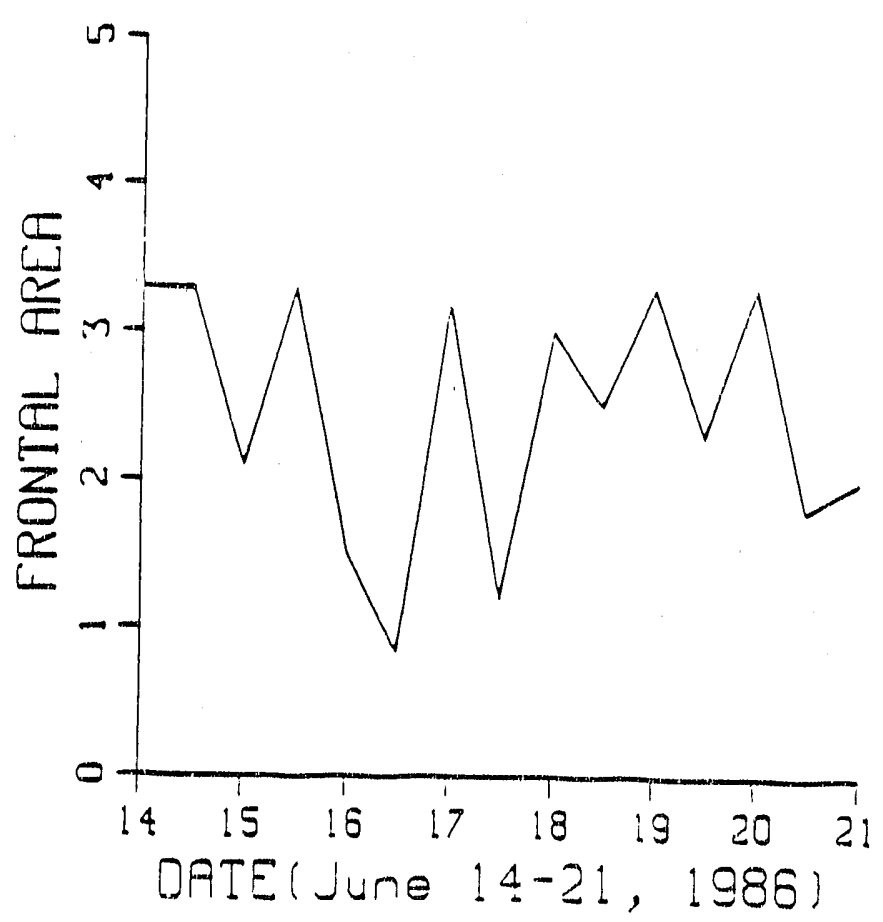

(b)

Fig. 85. The frontal area $A_{f}$ is plotted as a function of time, (a) for May 7-16; (b) for June 14-21, 1986. 
$\mathrm{m}^{2}$ to $3.54 \times 10^{5} \mathrm{~m}^{2}$, a change of $2.02 \times 10^{5} \mathrm{~m}^{2}$ or $57 \%$ within 9 hours. Thus the total drag force is notably affected. In Figure 86, the additional form drag force due to the frontal area, divided by the total drag force, is shown. The ratio between them was transformed from 0.615 at $0300 \mathrm{Z}$ to 0.775 at $1200 \mathrm{Z}$ on May 9 (Table 11), for example, which indicated that the additional form drag increased and the proportion of the additional irm drag in the total drag increased as weil. The averaged ratio was 0.66 \pm 0.12 , which shows that the water form drag was the dominant contributor to the total water drag.

\section{III.12. Force Balance}

In Table 13 and 14, and in Figures 87-103 are shown the force balance for 5 times each day at $00,03,12,15$ and 18 hours Universal Time for the periods May 7 . 16 , and June 14-21, 1986. Included are the wind shear force $\left(F_{a}\right)$, total water drag force $\left(F_{w}=F_{w s}+F_{w p}\right)$, Coriolis force $\left(F_{c}\right)$ and the change in momenturn due to the acceleration or deceleration of the ice island (denoted by $F_{t}$ ), as calculated from the tables and the data shown above.

On May 7 (Figure 87) at $0300 \mathrm{Z}$ and 1200Z, because the movements of Hobson's Choice had just started due to wind shear, which was larger than the Coriolis force, the force balance shows that the residual calculated forces due to pack ice and sea surface tilt were 0.5 and $0.6 \mathrm{MN}$, directed $236^{\circ}$ and $193^{\circ}$ to the left of the direction of movement; it is clear tha ${ }^{+}$pack ice opposed ice island movement. From $1500 \mathrm{Z}$ to $1800 \mathrm{Z}$, when the wind speed was $6.25 \mathrm{~m} / \mathrm{s}$ (Table 9) as a threshold for initiation of ice island movement, ice island velocity increased, so that the Coriolis t. ice and the acceleration terms were increased. The residual forces were redirected from $186^{\circ}$ in $119^{\circ}$, and become increasingly large, with the ice island movement increasing. A much larger movement occur ed on the day of May 8 (Figure 88); the force balances were almost the same except at $1800 Z$, when the movernent decreased. The force 


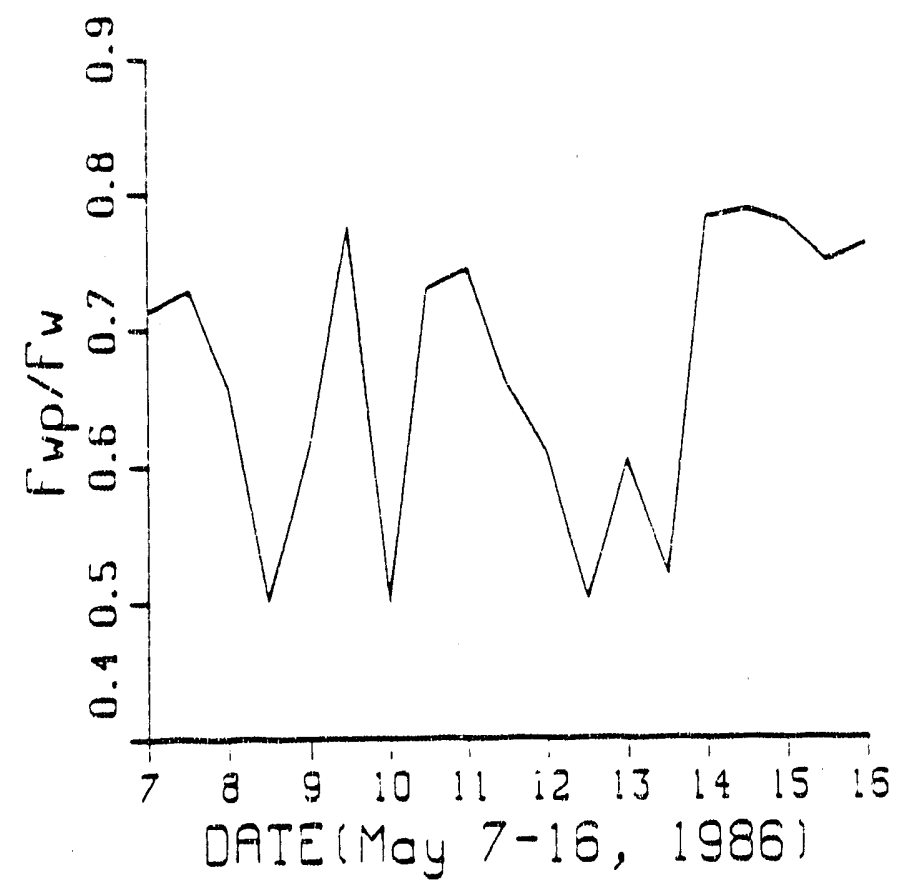

(a)

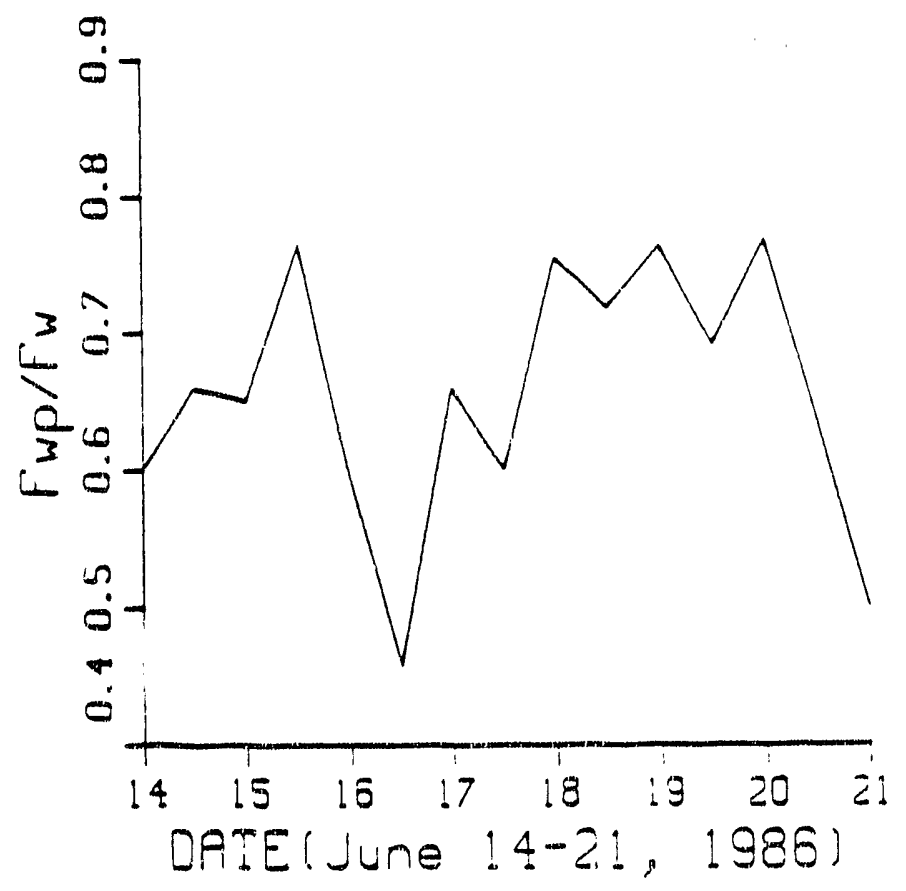

(a)

Fig. 86. The ratio of frontal water drag force to total water drag force versus timie, (a) for lifay $7-16$; (́) for June $14-21$, 1986 . 
Tabia 13. The force balance for wind shear force $\left(F_{a}\right)$; water shear force $\left(F_{w s}\right)$; drag force due to the frontal area of ice island $\left(F_{w p}^{a}\right)$; the force due to the acceleration or decceleration $\left(F_{f}\right)$ and the Coriolis force $\left(F_{c}\right)\left(F_{w}=F_{w g}+F_{w p}\right.$; force unit: MN), in the period of May 7-16.

\begin{tabular}{|c|c|c|c|c|c|c|c|c|}
\hline Date & Hours & $\mathrm{F}_{\mathrm{a}}$ & $F_{t}$ & $F_{\text {ws }}$ & $F_{w p}$ & $F_{w}$ & $\mathrm{~F}_{\mathrm{c}}$ & $F_{w p} / F_{w}$ \\
\hline \multirow[t]{5}{*}{ May 7} & 00 & 0.106 &.- & 0.000 & 0.000 & 0.000 & 0.168 & 0.000 \\
\hline & 03 & 0.957 & -0.082 & -. & -- & -- & 0.160 & -- \\
\hline & 12 & 0.857 & 0.037 & -- & -- & -. & 0.128 & -- \\
\hline & 15 & 1.847 & 0.1 .47 & 0.001 & 0.001 & 0.002 & 0.200 & 0.713 \\
\hline & 18 & 1.847 & 1.443 & 0.060 & 0.161 & 0.221 & 1.100 & 0.728 \\
\hline \multirow[t]{5}{*}{ May 8} & 00 & 4.499 & 1.100 & 0.570 & 1.090 & 1.660 & 9.000 & 0.657 \\
\hline & 03 & 3.199 & -2.001 & 0.350 & 0.610 & 0.959 & 7.001 & 0.636 \\
\hline & 12 & 1.564 & -1.719 & 0.096 & 0.227 & 0.323 & 5.010 & 0.703 \\
\hline & 15 & 1.847 & -2.586 & 0.005 & 0.005 & 0.010 & 3.001 & 0.500 \\
\hline & 18 & 0.855 & -0.162 & 0.003 & 0.006 & 0.009 & 0.975 & 0.667 \\
\hline \multirow[t]{5}{*}{ May 9} & 00 & 0.664 & -0.809 & 0.002 & 0.006 & 0.008 & 0.735 & 0.750 \\
\hline & 03 & 0.295 & 0.311 & 0.005 & 0.008 & 0.013 & 1.01 .5 & 0.615 \\
\hline & 12 & 0.188 & 0.025 & 0.011 & 0.038 & 0.049 & 1.739 & 0.775 \\
\hline & 15 & 0.358 & -0.258 & 0.006 & 0.020 & 0.026 & 1.340 & 0.769 \\
\hline & 18 & 0.239 & -0.146 & 0.004 & 0.014 & 0.018 & 1.114 & 0.778 \\
\hline \multirow[t]{5}{*}{ May 10} & 00 & 0.106 & 1.211 & 0.016 & 0.022 & 0.038 & 1.200 & 0.579 \\
\hline & 03 & 0.047 & 1.547 & 0.072 & 0.061 & 0.133 & 3.300 & 0.459 \\
\hline & 12 & 0.003 & 0.510 & 0.038 & 0.102 & 0.140 & 2.899 & 0.729 \\
\hline & 15 & 0.073 & 0.470 & 0.057 & 0.092 & 0.149 & 1.500 & 0.617 \\
\hline & 18 & 0.579 & 0.320 & 0.072 & 0.159 & 0.231 & 4.521 & 0.688 \\
\hline \multirow[t]{5}{*}{ May 11} & 00 & 0.816 & 0.900 & 0.130 & 0.350 & 0.480 & 5.399 & 0.729 \\
\hline & 03 & 1.166 & 1.000 & 0.190 & 0.550 & 0.740 & 6.899 & 0.743 \\
\hline & 12 & 1.182 & 0.041 & 0.248 & 0.626 & 0.874 & 8.100 & 0.716 \\
\hline & 15 & 1.703 & 0.721 & 0.318 & 0.798 & 1.116 & 8.090 & 0.715 \\
\hline & 18 & 1.847 & 2.011 & 0.560 & 1.086 & 1.646 & 9.980 & 0.659 \\
\hline
\end{tabular}




\begin{tabular}{|c|c|c|c|c|c|c|c|c|}
\hline Date & Hours & $F_{a}$ & $F_{t}$ & $\mathrm{~F}_{\mathrm{ws}}$ & $F_{w p}$ & $\mathbf{F}_{w}$ & $\mathrm{~F}_{\mathrm{c}}$ & $\mathrm{F}_{\mathrm{wp}} / \mathrm{F}_{\mathrm{w}}$ \\
\hline \multirow[t]{5}{*}{ May 12} & 00 & 2.155 & 1.700 & 0.650 & 1.010 & 1.660 & 11.000 & 0.608 \\
\hline & 03 & 1.999 & 0.929 & 0.700 & 0.601 & 1.301 & 13.498 & 0.462 \\
\hline & 12 & 2,318 & -1.063 & 0.294 & 0.544 & 0.838 & 9.150 & 0.649 \\
\hline & 15 & 2.487 & 1.227 & 0.429 & 0.431 & 0.860 & 9.980 & 0.501 \\
\hline & 18 & 2.487 & 0.700 & 0.548 & 0.545 & 1.093 & 11.299 & 0.500 \\
\hline \multirow[t]{5}{*}{ May 13} & 00 & 1.703 & 0.060 & 0.529 & 0.806 & 1.355 & 11.000 & 0.604 \\
\hline & 03 & 1.847 & 0.060 & 0.669 & 0.619 & 1.288 & 11.800 & 0.481 \\
\hline & 12 & 2.801 & 0.200 & 0.217 & 0.266 & 0.483 & 6.800 & 0.551 \\
\hline & 15 & 2.487 & -0.023 & 0.215 & 0.231 & 0.446 & 6.780 & 0.518 \\
\hline & 18 & 2.351 & -1.855 & 0.086 & 0.112 & 0.198 & 4.949 & 0.566 \\
\hline \multirow[t]{5}{*}{ May 14} & 00 & 0.584 & 0.170 & 0.227 & 0.804 & 1.031 & 7.300 & 0.780 \\
\hline & 03 & 1.399 & 0.143 & 0.240 & 0.849 & 1.089 & 7.400 & 0.780 \\
\hline & 12 & 1.431 & -2.231 & 0.056 & 0.198 & 0.254 & 3.992 & 0.779 \\
\hline & 15 & 1.431 & -1.955 & 0.003 & 0.011 & 0.014 & 0.971 & 0.785 \\
\hline & 18 & 1.703 & 0.325 & 0.008 & 0.026 & 0.034 & 1.199 & 0.765 \\
\hline \multirow[t]{5}{*}{ May 15} & 00 & 1.999 & -0.178 & 0.039 & 0.135 & 0.174 & 3.317 & 0.776 \\
\hline & 03 & 1.431 & -1.564 & 0.003 & 0.010 & 0.013 & 0.900 & 0.769 \\
\hline & 12 & 1.431 & -0.203 & -- & -- & -- & 0.139 & -- \\
\hline & 15 & 1.564 & 0.018 & -. & -- & -- & 0.167 & -- \\
\hline & 18 & 1.304 & 1.340 & 0.018 & 0.053 & 0.071 & 2.239 & 0.747 \\
\hline \multirow[t]{5}{*}{ May 16} & 00 & 1.564 & -0.945 & 0.025 & 0.083 & 0.108 & 2.673 & 0.769 \\
\hline & 03 & 1.564 & -1.099 & 0.003 & 0.010 & 0.013 & 0.976 & 0.769 \\
\hline & 12 & 1.304 & 0.095 & -- & -- & -- & 0.100 & -- \\
\hline & 15 & -- & -- & -- & -- & -- & -. & - \\
\hline & 18 & 1.564 & -1.164 & 0.003 & 0.003 & 0.004 & 0.586 & 0.750 \\
\hline
\end{tabular}


Table 14. The force balance for wind shear force $\left(F_{F}\right)$; water shear force $\left(F_{w s}\right)$; drag force due to the frontal area of ice island $\left(\mathrm{F}^{\mathrm{a}}{ }_{\mathrm{wp}}\right)$; the force due to the acceleration or decceleration $\left(F_{t}\right)$ and the Coriolis force $(F)\left(F_{w}=F_{w s}+F_{w p}\right.$; force unit: $M N$ ), in the period of June 14-21.

\begin{tabular}{|c|c|c|c|c|c|c|c|c|}
\hline Date & Hours & $F_{a}$ & $F_{t}$ & $F_{w s}$ & $F_{w p}$ & $F_{w}$ & $F_{c}$ & $F_{w p} / F_{w}$ \\
\hline \multirow[t]{5}{*}{ June 14} & 00 & -- & -0.651 & - & - & $\cdots$ & 0.036 & $\overline{-\cdots}$ \\
\hline & 03 & 0.106 & 0.075 & 0.000 & 0.000 & 0.000 & 0.152 & -- \\
\hline & 12 & 0.579 & 0.038 & 0.000 & 0.000 & 0.000 & 0.098 & -- \\
\hline & 15 & 0.665 & -0.031 & 0.000 & 0.000 & 0.000 & 0.502 & -- \\
\hline & 18 & 0.665 & 0.024 & 0.000 & 0.000 & 0.000 & 0.089 & \\
\hline \multirow[t]{5}{*}{ June 15} & 00 & $\overline{0.499}$ & -0.009 & 0.000 & 0.000 & 0.000 & 0.151 & -- \\
\hline & 03 & 0.144 & 0.037 & 0.000 & 0.000 & 0.000 & 0.208 & -- \\
\hline & 12 & 2.318 & 0.823 & 0.028 & 0.091 & 0.119 & 2.100 & 0.765 \\
\hline & 15 & 1.999 & -0.893 & 0.008 & 0.025 & 0.033 & 1.990 & 0.758 \\
\hline & 18 & 2.487 & 1.200 & 0.039 & 0.029 & 0.068 & 2.399 & 0.427 \\
\hline \multirow[t]{5}{*}{ June 16} & 00 & 2.661 & 1.100 & 0.187 & 0.274 & 0.461 . & 5.998 & 0.594 \\
\hline & 03 & 4.971 & $2.0 \mathrm{G} 0$ & 0.727 & 1.174 & 1.901 & 9.900 & 0.618 \\
\hline & 12 & 8.623 & -3.953 & 0.767 & 0.886 & 1.653 & 16.000 & 0.536 \\
\hline & 15 & 3.622 & -7.201 & 0.039 & 0.033 & 0.072 & 6.500 & 0.458 \\
\hline & 18 & 3.622 & -1.230 & 0.007 & 0.005 & 0.01 .2 & 2.200 & 0.417 \\
\hline \multirow[t]{5}{*}{ June 17} & 00 & 0.499 & -0.032 & 0.001 & 0.000 & 0.000 & 0.178 & -- \\
\hline & 03 & 0.499 & -0.084 & 0.000 & 0.000 & 0.000 & 0.049 & -. \\
\hline & 12 & 0.579 & -0.041 & 0.000 & 0.000 & 0.000 & 0.031 & -- \\
\hline & 15 & 0.579 & 0.065 & 0.000 & 0.000 & 0.000 & 0.132 & -- \\
\hline & 18 & 1.182 & -0.020 & r.000 & 0.000 & 0.000 & 0.101 & -- \\
\hline \multirow[t]{5}{*}{ June 18} & 00 & - & 1.038 & -- & -- & - & 1.833 & $-n$ \\
\hline & 03 & 1.431 & 2.000 & 0.114 & 0.351 & 0.465 & 3.680 & 0.755 \\
\hline & 12 & - & -1.502 & -- & -- & -- & 4.329 & -- \\
\hline & 15 & 1.564 & 1.900 & 0.225 & 0.572 & 0.797 & 6.000 & 0.718 \\
\hline & 18 & 2.487 & 1.844 & 0.414 & 1.301 & 1.715 & 8.990 & 0.759 \\
\hline
\end{tabular}




\begin{tabular}{lllllllll}
\hline Date & Hours & \multicolumn{1}{c}{$\mathrm{F}_{\mathrm{a}}$} & \multicolumn{1}{c}{$\mathrm{F}_{\mathrm{t}}$} & \multicolumn{1}{c}{$\mathrm{F}_{\mathrm{ws}}$} & \multicolumn{1}{c}{$\mathrm{F}_{\mathrm{wp}}$} & \multicolumn{1}{c}{$\mathrm{F}_{\mathrm{w}}$} & \multicolumn{1}{c}{$\mathrm{F}_{\mathrm{c}}$} & $\mathrm{F}_{\mathrm{wp}} / \mathrm{F}_{\mathrm{w}}$ \\
\hline June 19 & 00 & -- & -3.352 & -- & -- & - & 1.584 & -- \\
& 03 & 0.854 & -0.002 & 0.009 & 0.029 & 0.038 & 1.580 & 0.763 \\
& 12 & & - & - & -- & - & -- & -- \\
& 15 & 0.144 & 0.192 & 0.059 & 0.132 & 0.191 & 4.098 & 0.691 \\
& 18 & 0.239 & -0.590 & 0.036 & 0.101 & 0.137 & 3.187 & 0.737 \\
\hline June 20 & 00 & 0.357 & 2.000 & 0.368 & 1.220 & 1.588 & 7.000 & 0.768 \\
& 03 & 0.189 & -1.097 & 0.256 & 0.791 & 1.047 & 8.542 & 0.756 \\
& 12 & 0.026 & -1.316 & 0.013 & 0.040 & 0.053 & 1.899 & 0.755 \\
& 15 & 0.074 & 0.376 & 0.022 & 0.039 & 0.061 & 2.481 & 0.639 \\
& 18 & 0.357 & -0.581 & 0.009 & 0.007 & 0.016 & 1.584 & 0.437 \\
\hline June 21 & 00 & 3.220 & -1.265 & 0.002 & 0.003 & 0.005 & 1.500 & 0.600 \\
& 03 & 4.048 & -0.065 & 0.001 & 0.001 & 0.002 & 0.614 & 0.500 \\
& 12 & 4.731 & -1.627 & 0.038 & 0.060 & 0.098 & 4.000 & 0.612 \\
& 15 & 4.048 & -1.330 & 0.005 & 0.004 & 0.009 & 1.213 & 0.444 \\
& 18 & 5.216 & -0.517 & 0.001 & 0.001 & 0.002 & 0.900 & 0.500 \\
\hline
\end{tabular}




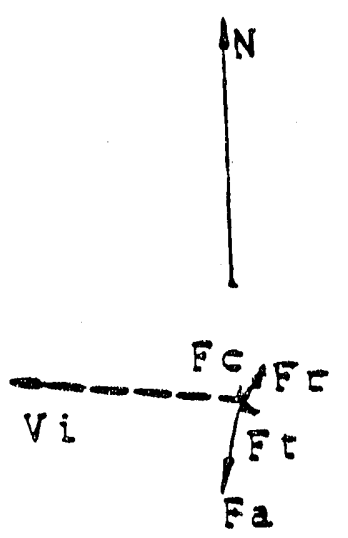

(a)

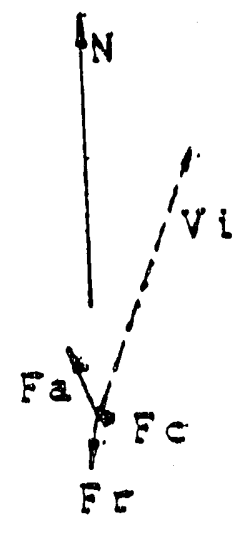

(b)

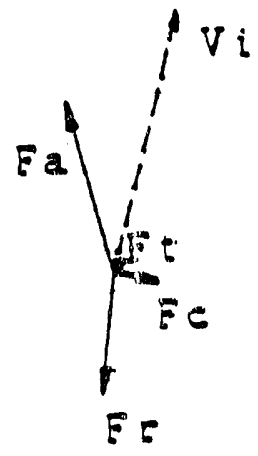

(c)

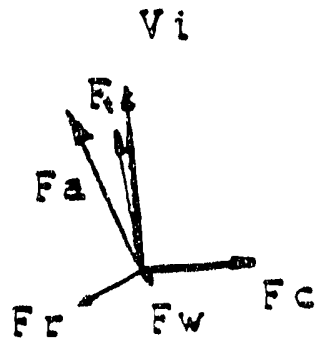

(d)

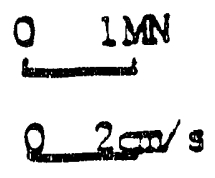

Fig. 87. Force balance on May 7 for wind shear force $\left(F_{\mathrm{a}}\right)$, total drag force $\left(F_{w}\right)$, Coriolis force $\left(F_{c}\right)$ and the force due to accelerating or decelerating $\left(F_{\mathrm{t}}\right)$

(a) at $0300 Z,\left(\mathrm{~F}_{\mathrm{r}}=0.5\left(236^{\circ}\right)\right)$,

(b) at $1200 \mathrm{Z},\left(\mathrm{F}_{\mathrm{r}}^{\mathrm{r}}=0.6\left(193^{\circ}\right)\right)$,

(c) at $1500 \mathrm{Z},\left(\mathrm{F}^{\mathrm{r}}=1.2\left(186^{\circ}\right)\right)$,

(d) at $1800 \mathrm{Z},\left(F_{\mathrm{r}}=0.7\left(119^{\circ}\right)\right)$.

$\mathrm{F}_{\mathrm{r}}$ : residual force, $\mathrm{V}_{\mathrm{i}}$ : ice island velocity $(\mathrm{cm} / \mathrm{s})$, dashed line means that $V_{i}$ is too small and just indicates the direction of the ice island movement. 


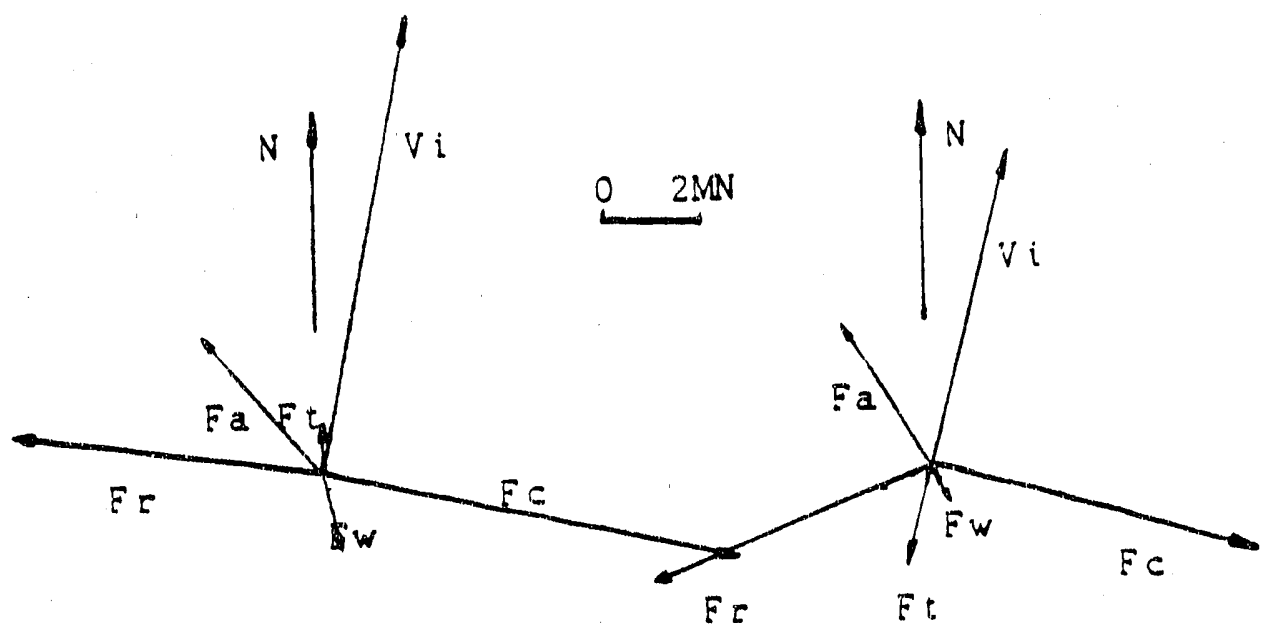

(a)

(b)
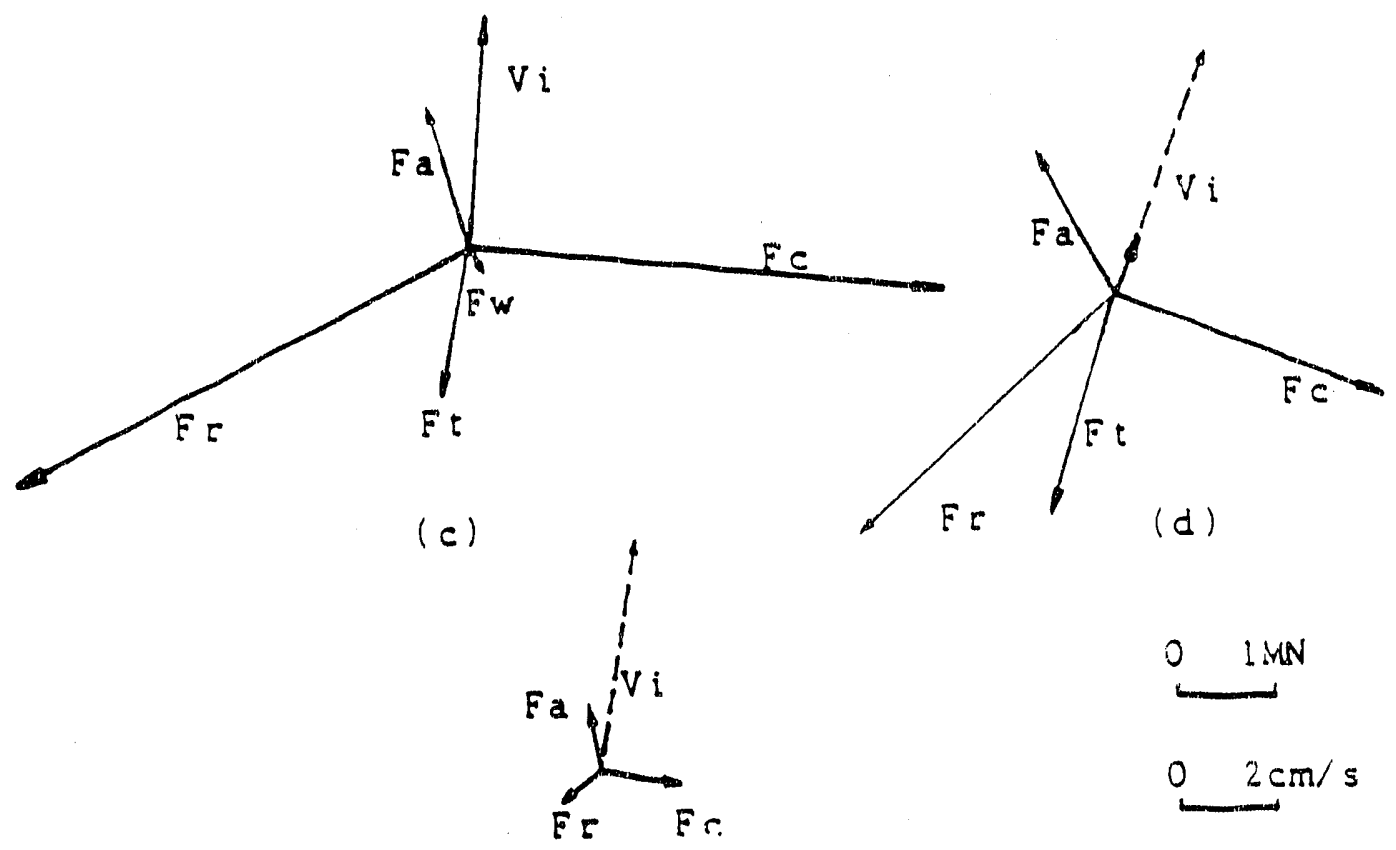

(e)

Fig. 88. Force balance on May 8
(a) at $0000 \mathrm{Z},\left(F_{r}=6.6\left(94^{\circ}\right)\right)$
(b) at $0300 \mathrm{Z},\left(\mathrm{F}^{\mathrm{r}}=6.4\left(127^{\circ}\right)\right)$,
(c) at $1200 \mathrm{Z},\left(\mathrm{F}^{\mathrm{r}}=5.4\left(122^{\circ}\right)\right)$,
(d) at $1500 \mathrm{Z},\left(\mathrm{F}_{\mathrm{r}}=3.9\left(155^{\circ}\right)\right)$,
(e) at 1800Z, $\left(F_{r}^{r}=0.7\left(143^{\circ}\right)\right)$. 


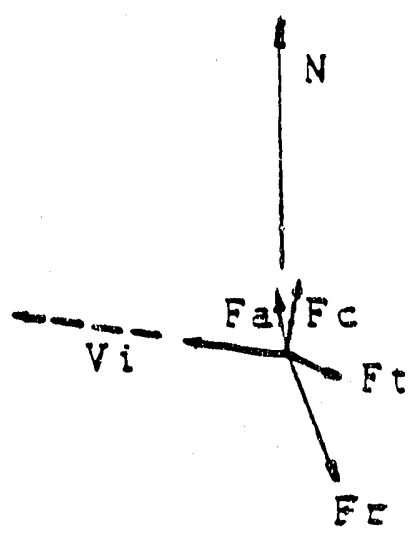

(a)

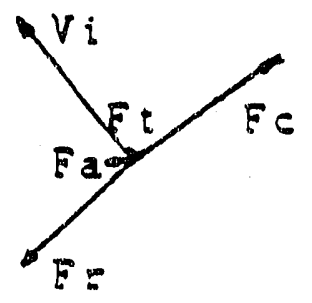

(e)

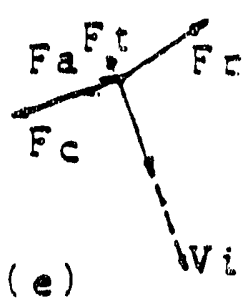

Fig. 89. Same as Figure 87 except
(a) $\left(F_{r}=1.3\left(123^{\circ}\right)\right)$,
(b) $\left(F_{r}=1.3\left(76^{\circ}\right)\right)$,
(c) $\left(F_{r}=1.5\left(95^{\circ}\right)\right.$ ),
(d) $\left(F_{r}=1.2\left(123^{\circ}\right)\right)$,
(e) $\left(\mathrm{F}_{\mathrm{r}}^{\mathrm{r}}=1.0\left(112^{\circ}\right)\right)$, May 9 .
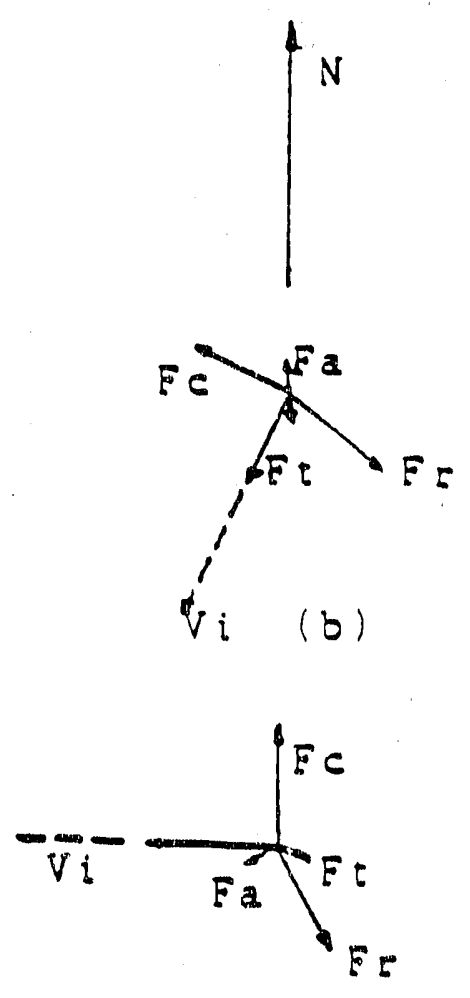

(d)

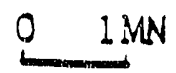

$0 \quad 1 \mathrm{~cm} / \mathrm{s}$ 


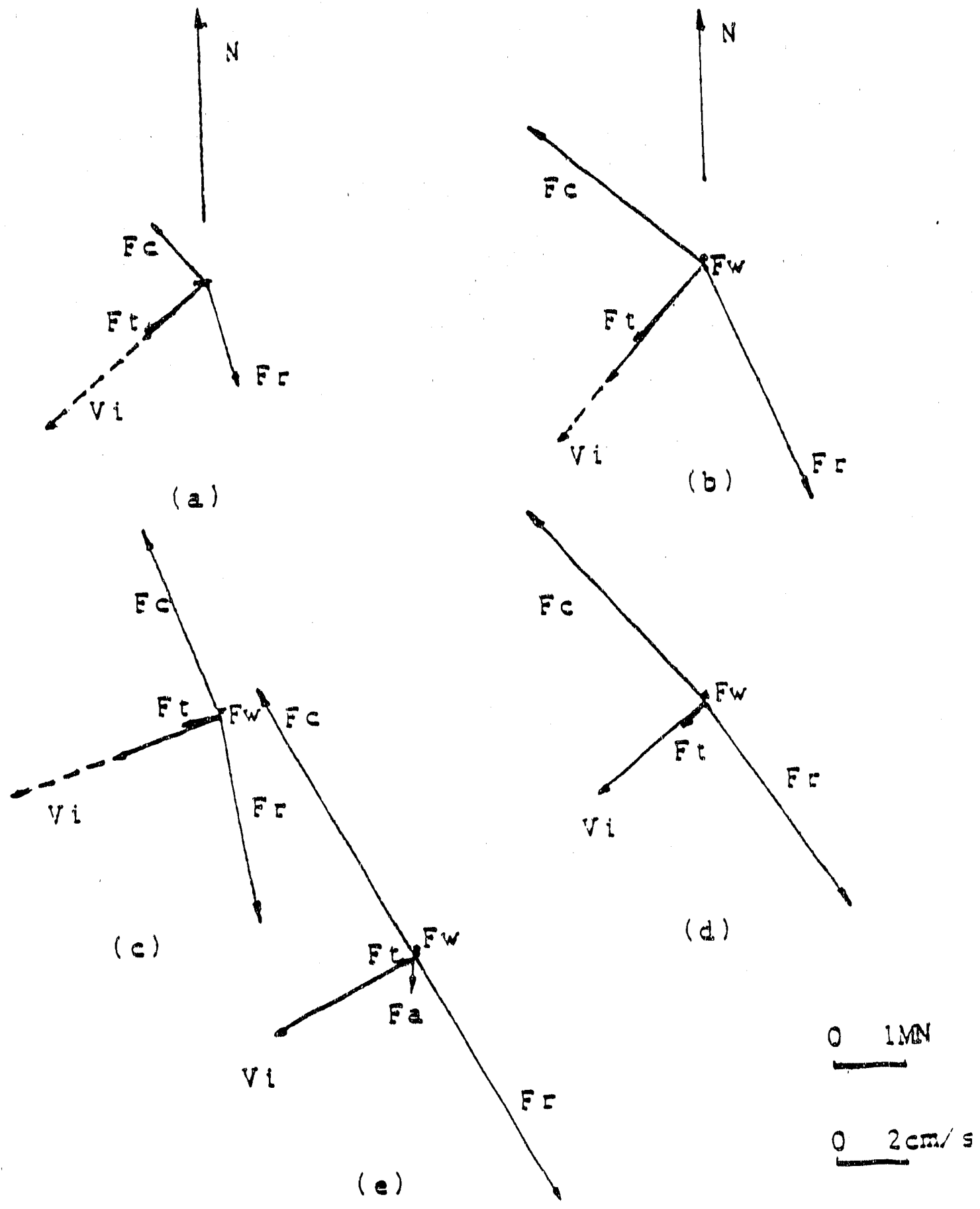

Fig. 90. Force balance on May 10 for
(a) $\left(F_{r}=1.6\left(62^{\circ}\right)\right)$, (b) $\left(F_{r}=3.8\left(63^{\circ}\right)\right)$,
(c) $\left(F_{r}{ }^{r}=3.0\left(78^{\circ}\right)\right),(d)\left(F_{r}{ }_{r}=3.5\left(83^{\circ}\right)\right)$,
(e) $\left(F_{r}=4.0\left(92^{\circ}\right)\right)$. 


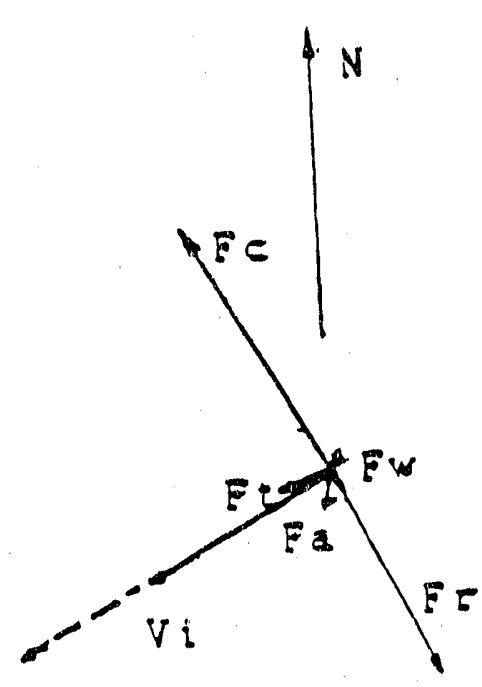

(a)
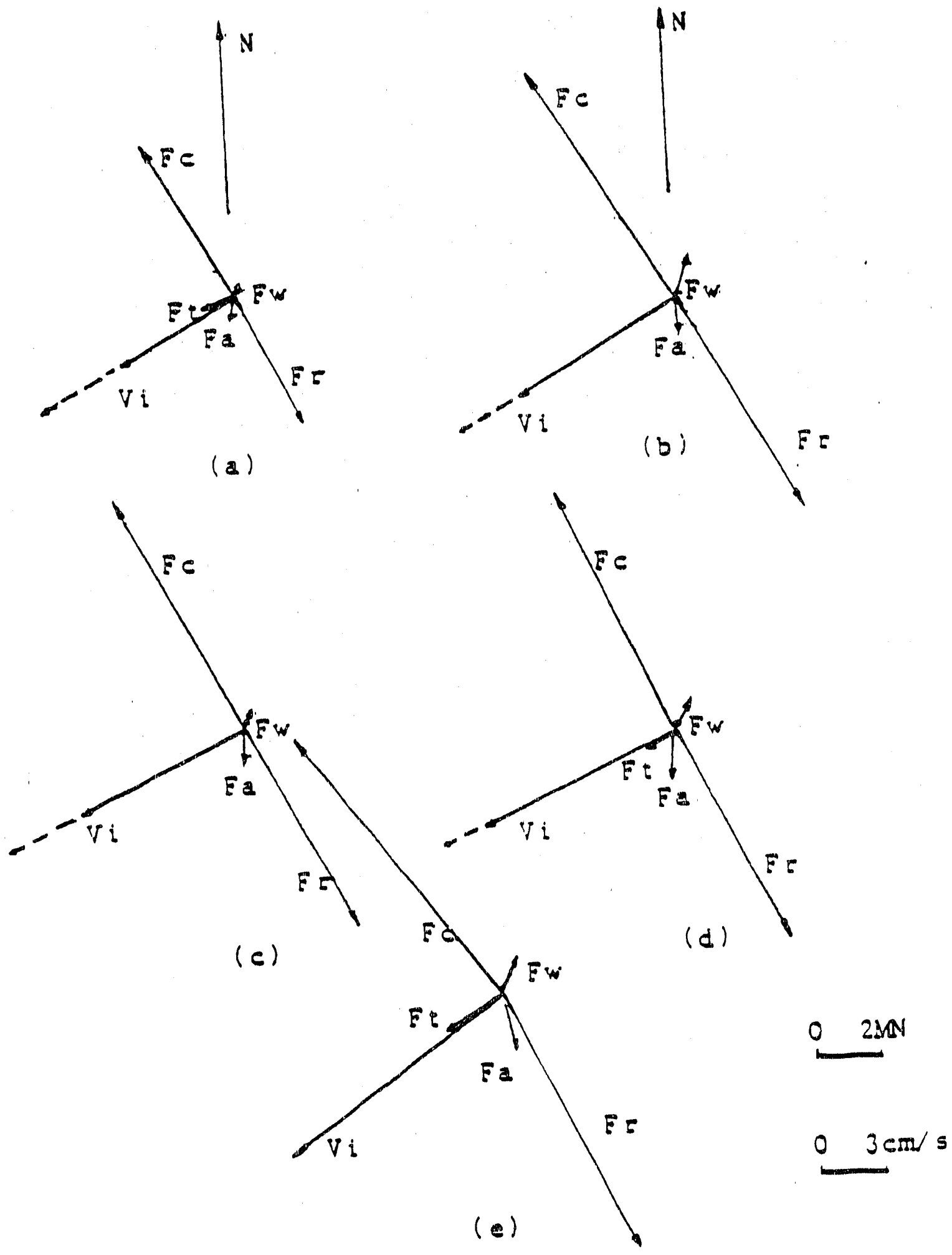

Fig. 91. Force balance on May 11 for
(a) $\left(F_{r}=4.4\left(90^{\circ}\right)\right)$, (b) $\left(F_{r}=7.8\left(92^{\circ}\right)\right)$,
(c) $\left(\mathrm{F}_{\mathrm{r}}^{\mathrm{r}}=7.0\left(94^{\circ}\right)\right)$, (d) $\left(\mathrm{F}_{\mathrm{r}}^{\mathrm{r}}=7.2\left(90^{\circ}\right)\right)$,
(e) $\left(F_{r}^{r}=9.0\left(82^{\circ}\right)\right)$. 


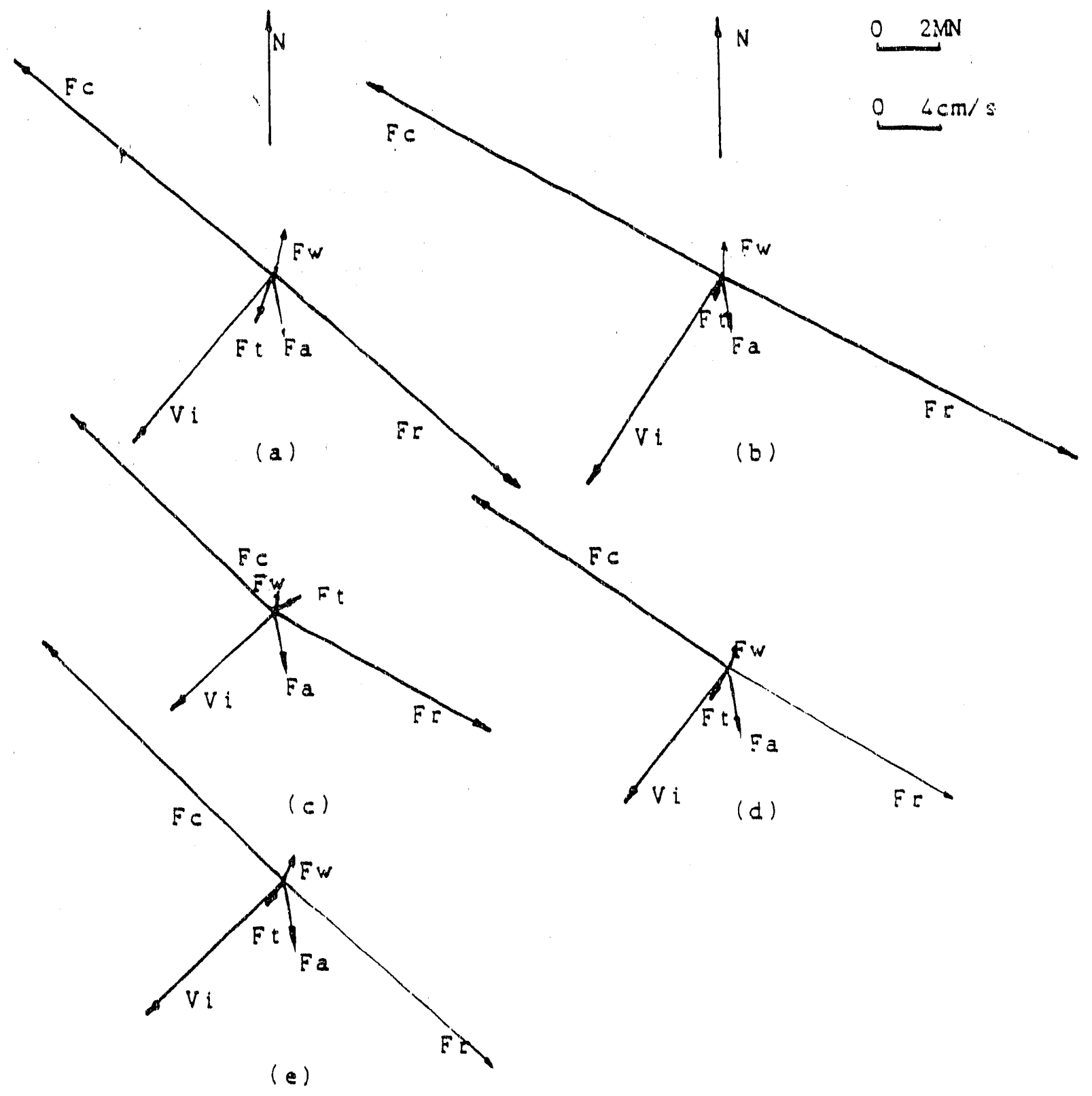

Fig. 92. Force balance on May 12 for

(a) $\left(F_{r}=10.8\left(90^{\circ}\right)\right),(b)\left(F_{r}=12.6\left(94^{\circ}\right)\right)$,

(c) $\left(F_{r}^{r}=7.9\left(108^{\circ}\right)\right)$, (d) $\left(F_{r}^{r}=8.7\left(96^{\circ}\right)\right)$,

(e) $\left(F_{r}=9.4\left(93^{\circ}\right)\right)$. 


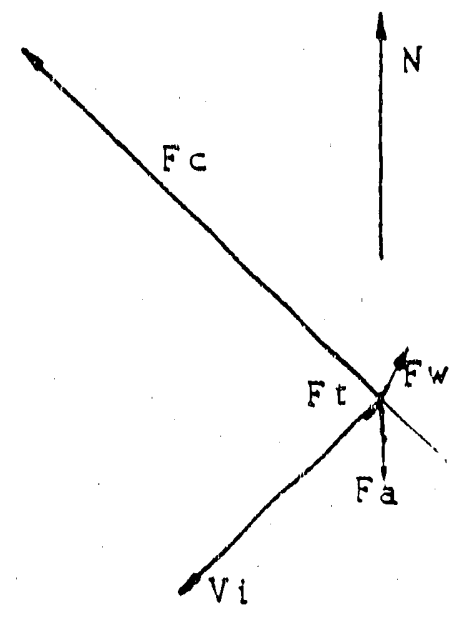

(a)

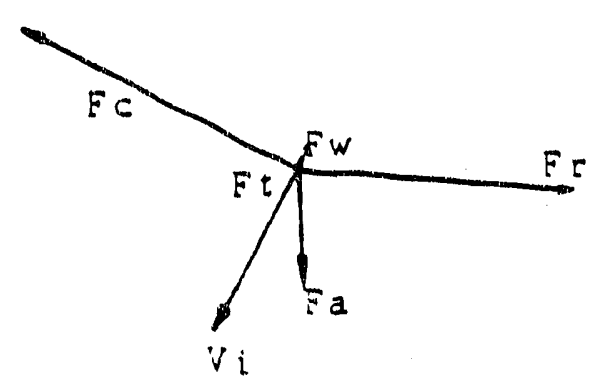

(c)
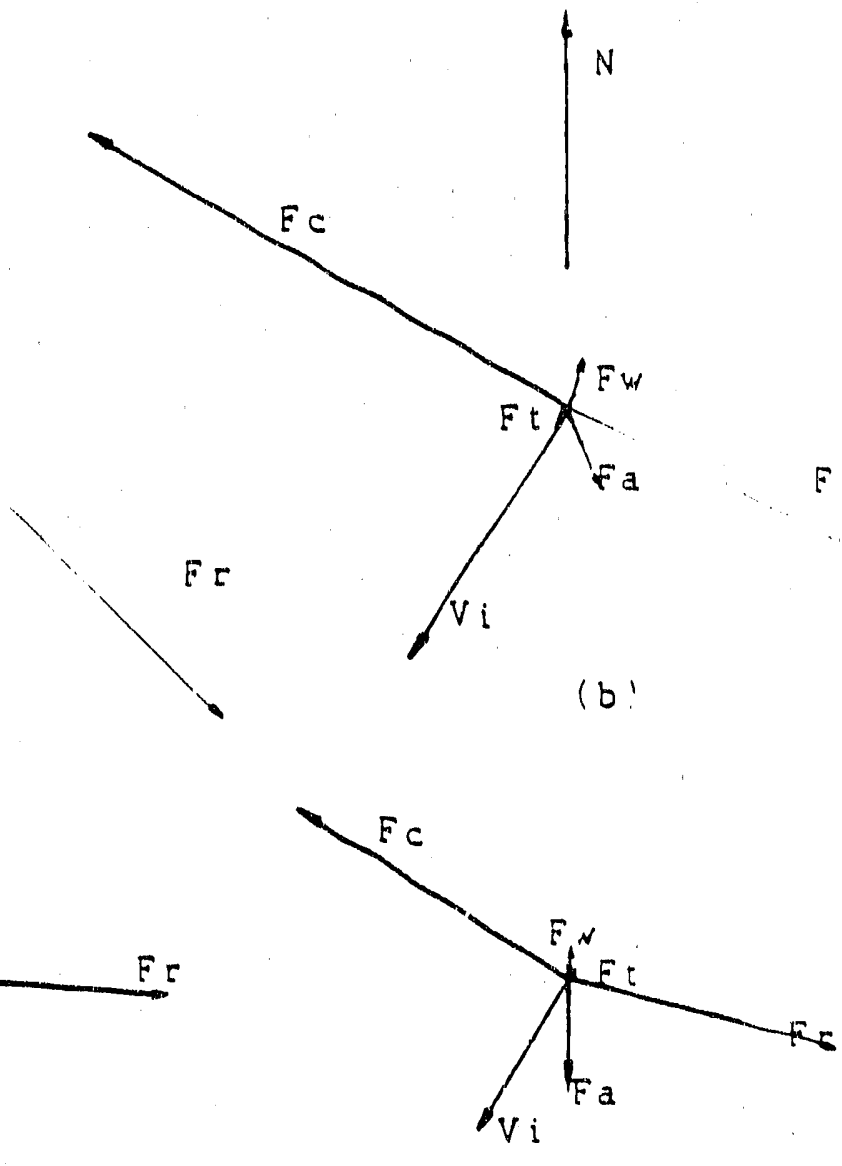

(d)
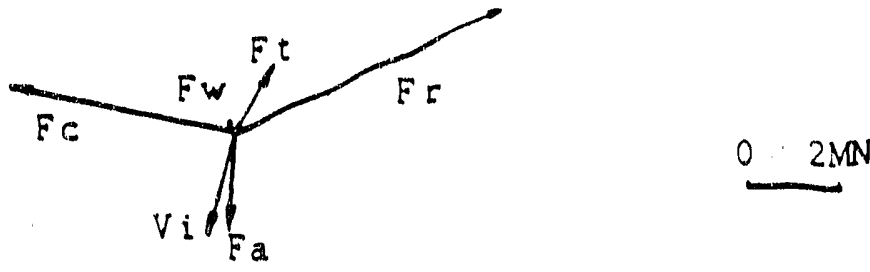

$$
\text { (e) }
$$

Fig. 93. Force balance on May 13 for

(a) $\left(F_{\mathrm{r}}=10.9\left(91^{\circ}\right)\right),(\mathrm{b})\left(\mathrm{F}_{\mathrm{r}}=10.8\left(96^{\circ}\right)\right)$,

(c) $\left(\mathrm{F}_{\mathrm{r}}^{\mathrm{r}}=6.0\left(113^{\circ}\right)\right)$, (d) $\left(\mathrm{F}_{\mathrm{r}}^{\mathrm{r}}=6.0\left(107^{\circ}\right)\right)$,

(e) $\left(F_{r}=6.4\left(129^{\circ}\right)\right)$. 

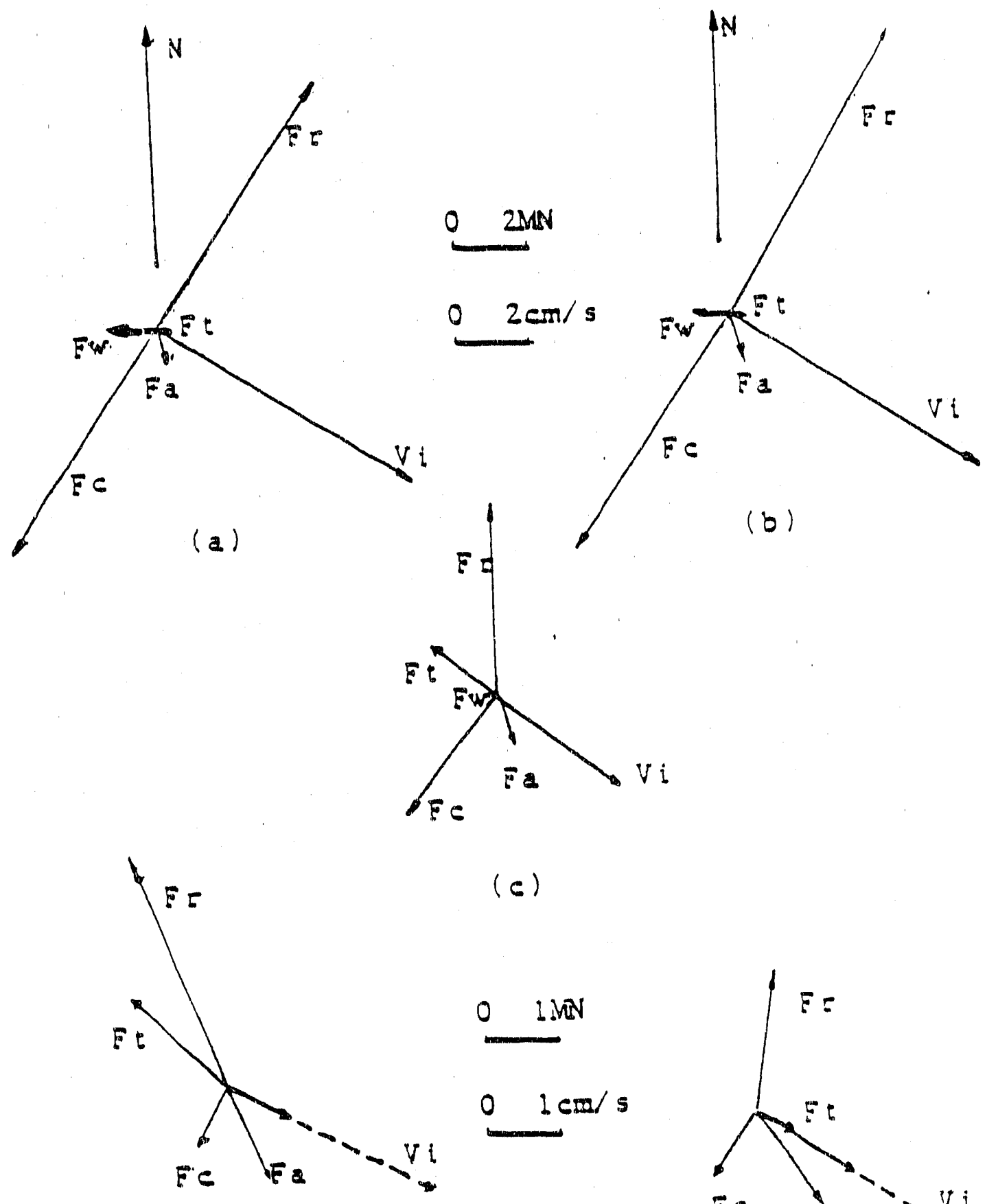

(d)

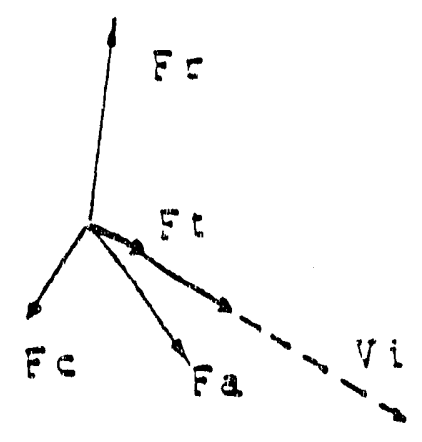

(e)

Fig. 94. Force balance on May 14 for
(a) $\left(F_{r}=8.1\left(90^{\circ}\right)\right)$, (b) $\left(F=9.2\left(93^{\circ}\right)\right)$,
(c) $\left(\mathrm{F}^{\mathrm{r}}=5.2\left(124^{\circ}\right)\right),(\mathrm{d})\left(\mathrm{F}_{\mathrm{r}}=3.7\left(141^{\circ}\right)\right)$,
(e) $\left(F_{r}^{r}=2.0\left(119^{\circ}\right)\right)$. 


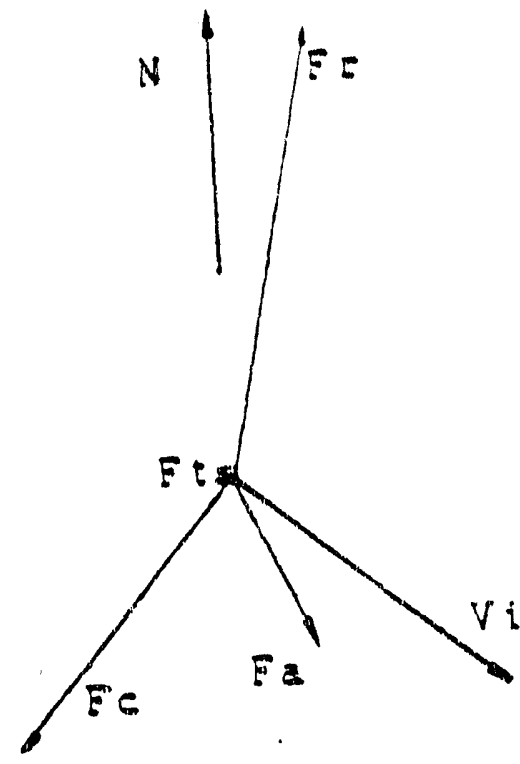

(a)

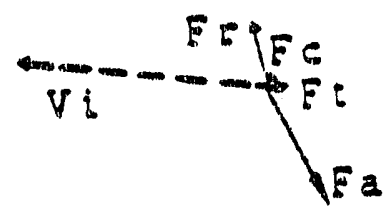

(e)

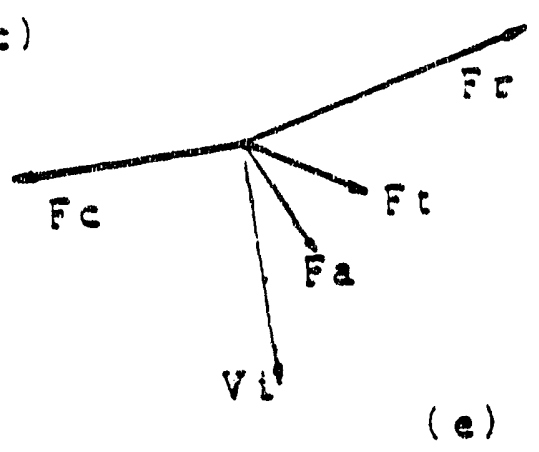

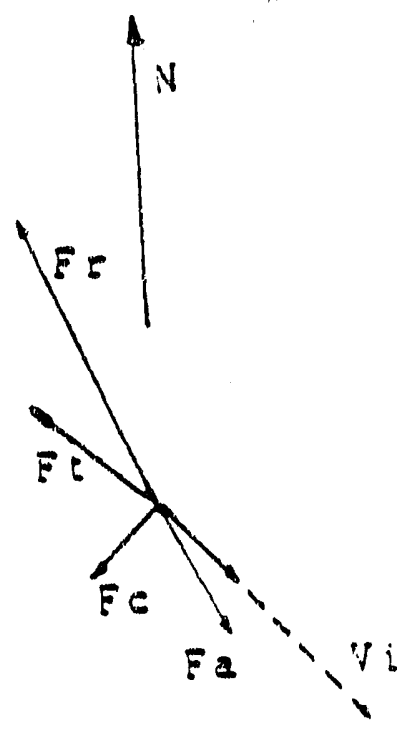

(b)

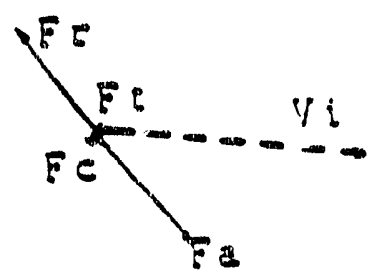

(d)

Fig. 95. Force balance on May 15 for

(a) $\left(F_{\mathrm{r}}=4.5\left(119^{\circ}\right)\right)$, (b) $\left(\mathrm{F}_{\mathrm{r}}=3.1\left(161^{\circ}\right)\right)$,

(c) $\left(F_{r}{ }^{r}=0.7\left(280^{\circ}\right)\right),(d)\left(F_{r}{ }^{r}=1.4\left(131^{\circ}\right)\right)$,

(e) $\left(F_{r}=2.9\left(103^{\circ}\right)\right)$. 


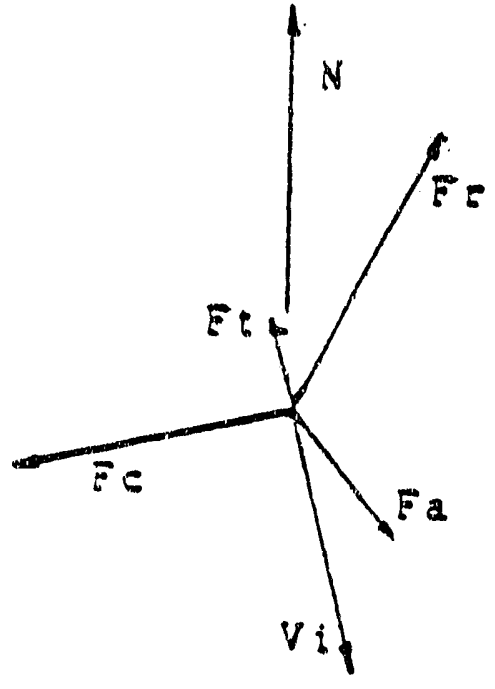

(a)

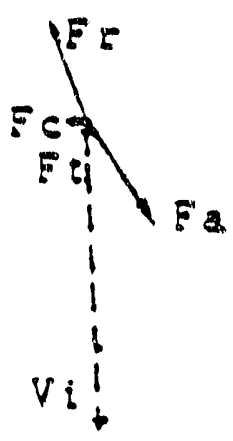

(e)
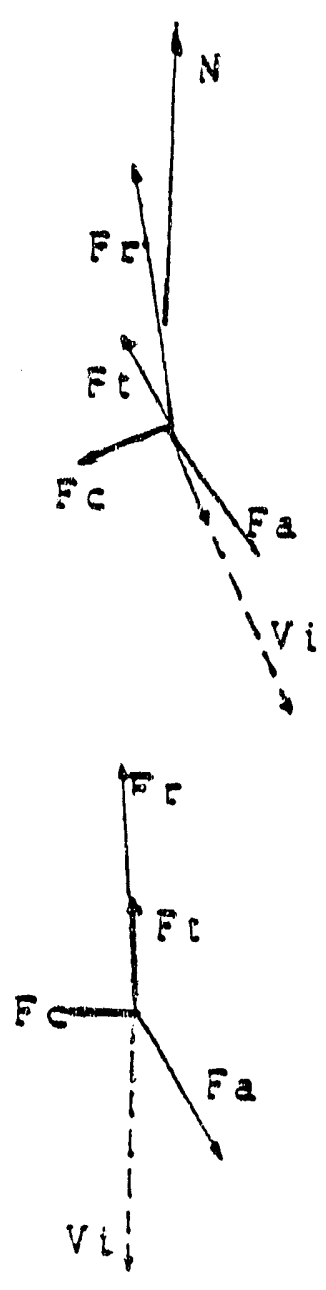

(b)
$0 \quad$ 2.RN

(d)

$0 \quad 1 \mathrm{cra} / \mathrm{s}$

Fig. 96. Force balance on May 16 for (a) at $0000 \mathrm{Z},\left(F_{r}=3.0\left(140^{\circ}\right)\right)$,

(b) at $0300 \mathrm{Z},\left(\mathrm{F}_{\mathrm{r}}=2.6\left(168^{\circ}\right)\right)$,

(c) at $1200 \mathrm{Z},\left(\mathrm{F}^{\mathrm{r}}=1.1\left(194^{\circ}\right)\right)$,

(d) at $1800 \mathrm{Z},\left(\mathrm{F}_{\mathrm{r}}=2.5\left(181^{\circ}\right)\right)$. 


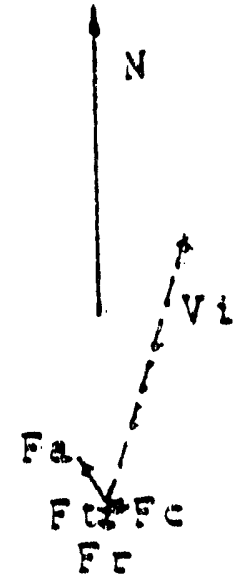

(a)

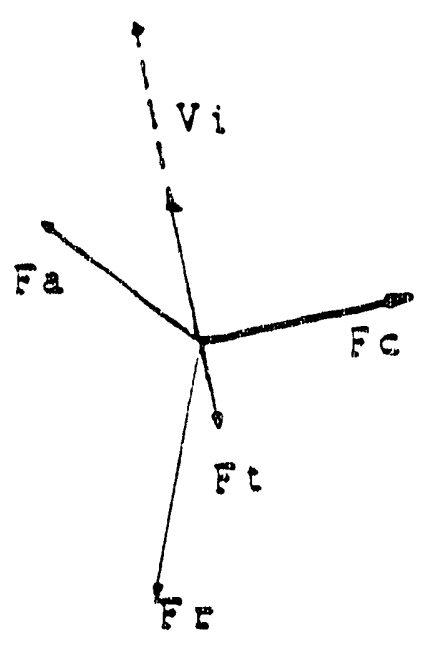

(e)
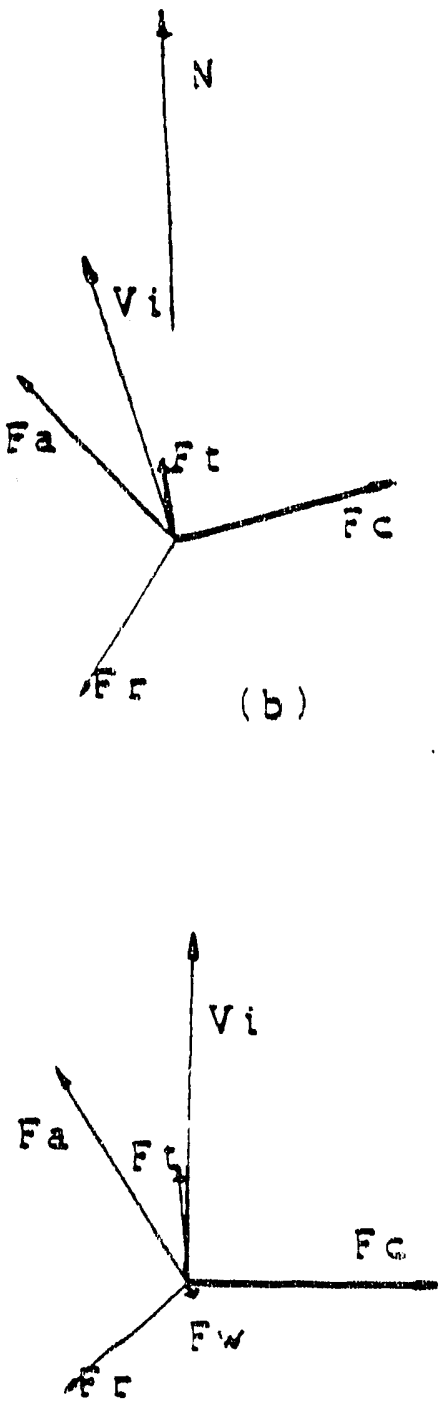

O $\quad I: N$

(d)

0 ! cos $s$

Fig. 97. Force balance on June 15 for (a) at $0000 \mathrm{Z},\left(\mathrm{F}_{\mathrm{r}}=0.2\left(186^{\circ}\right)\right.$ ),

(b) at $1200 \mathrm{Z},\left(\mathrm{F}_{\mathrm{r}}^{\mathrm{r}}=1.7\left(137^{\circ}\right)\right)$,

(c) at $1500 Z,\left(F^{r}=2.5\left(159^{\circ}\right)\right)$,

(d) at $1800 \mathrm{Z},\left(\vec{F}_{\mathrm{r}}^{f}=1.6\left(131^{\circ}\right)\right)$. 


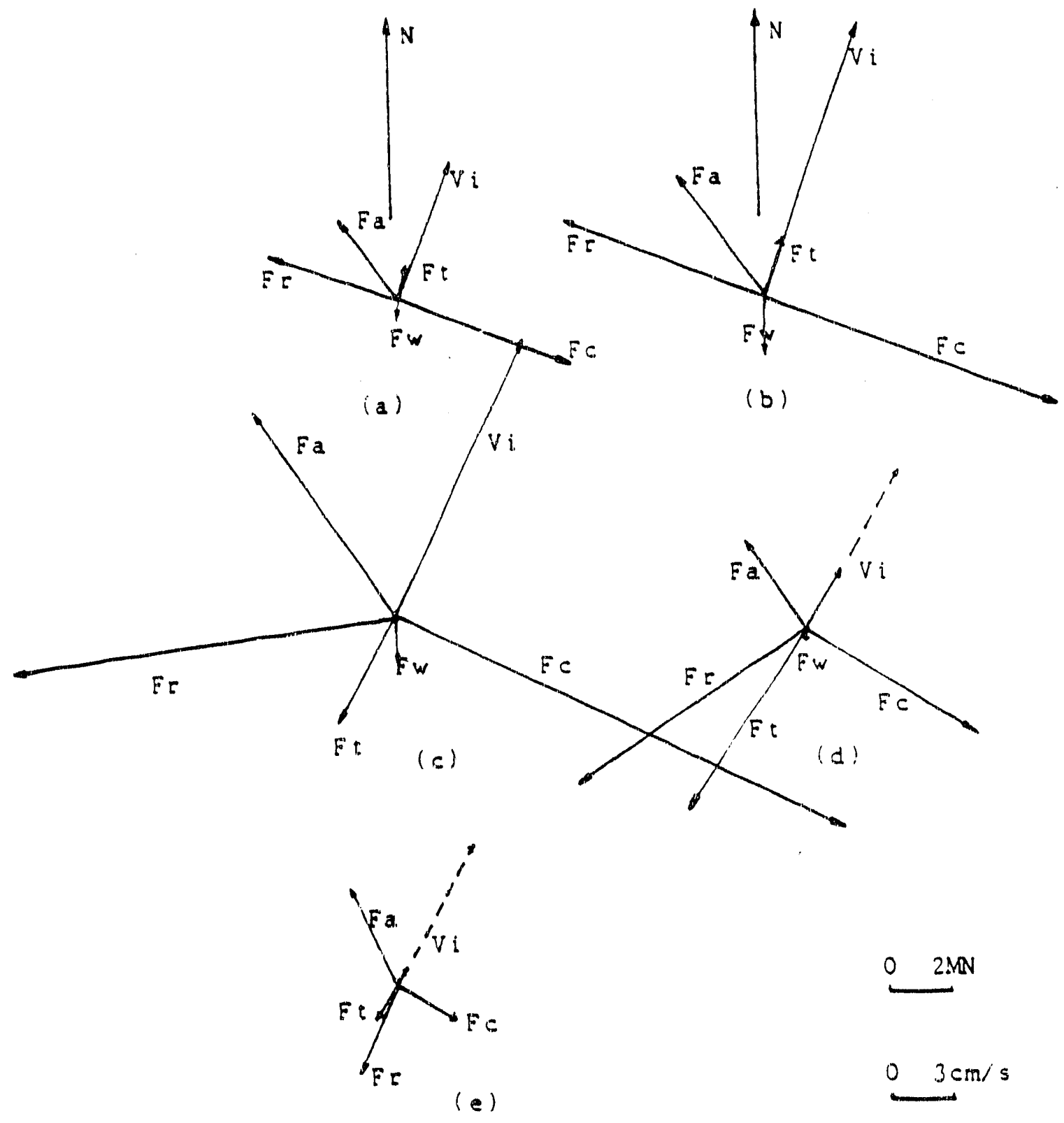

Fig. 98. Force balance on June 16 for
(a) $\left(F_{r}=4.4\left(91^{\circ}\right)\right)$, (b) $\left(F_{r}=6.8\left(89^{\circ}\right)\right)$,
(c) $\left(\mathrm{F}_{\mathrm{r}}=12.3\left(123^{\circ}\right)\right)$, (d) $\left(\mathrm{F}_{\mathrm{r}}=9.2\left(154^{\circ}\right)\right)$,
(e) $\left(F_{r}=3.0\left(184^{\circ}\right)\right)$. 


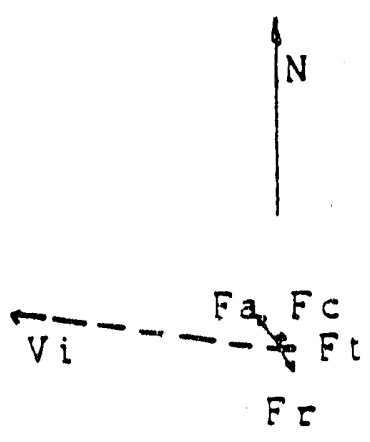

(a.)

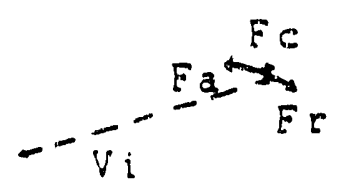

(c)

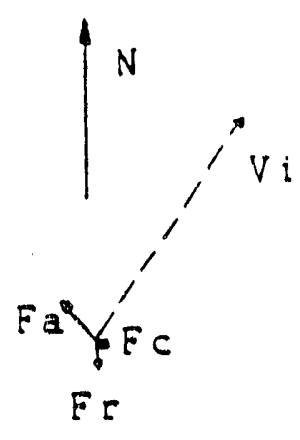

(b)

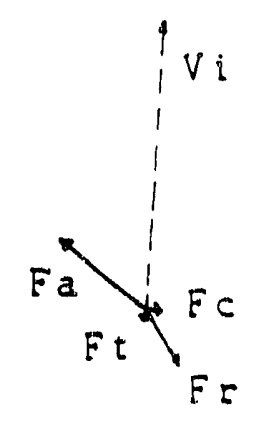

(d)

$0 \quad \therefore M N$

Fig. 99. Force balance on June 17 for
(a) $\left(F_{r}=0.5\left(136^{\circ}\right)\right)$,
(b) $\left(F^{r}=0.3\left(181^{\circ}\right)\right)$,
(c) $\left(\mathrm{F}^{\mathrm{r}}=0.4\left(160^{\circ}\right)\right)$,
(d) $\left(F_{\mathrm{r}}=0.7\left(187^{\circ}\right)\right)$. 

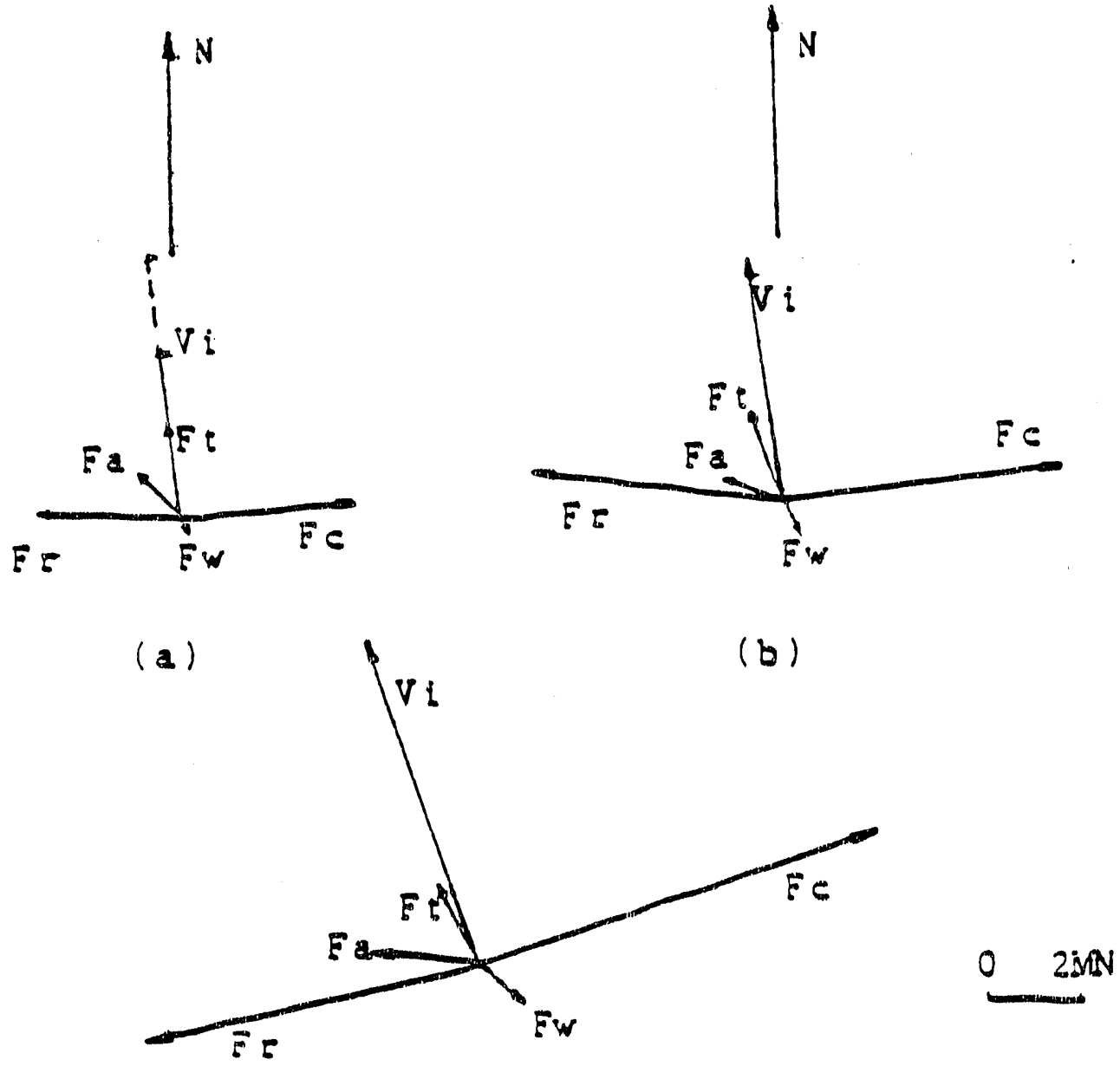

(c)

$03 \mathrm{~cm} / \mathrm{s}$

Fig. 100. Force balance on June 18 for

(a) at $0300 \mathrm{Z},\left(\mathrm{F}_{\mathrm{r}}=3.2\left(83^{\circ}\right)\right)$,

(b) at $1500 \mathrm{Z},\left(\mathrm{F}_{\mathrm{r}}^{\mathrm{r}}=5.5\left(78^{\circ}\right)\right)$,

(c) at $1800 \mathrm{Z},\left(\mathrm{F}_{\mathrm{r}}^{\mathrm{r}}=7.8\left(86^{\circ}\right)\right)$. 


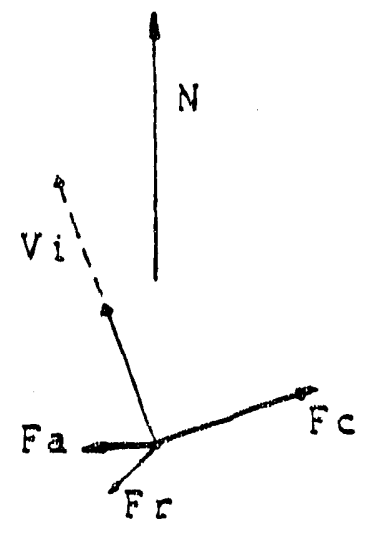

(a)

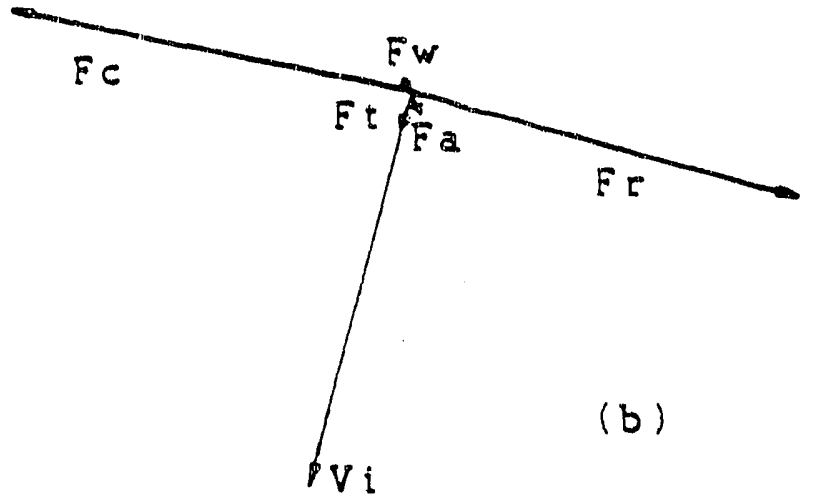

Fig. 101. Force balance on June 19 for
(a) at $0300 \mathrm{Z},\left(\mathrm{F}=0.8\left(109^{\circ}\right)\right)$,
(b) at $1500 \mathrm{Z},\left(\mathrm{F}_{\mathrm{r}}^{\mathrm{r}}=3.2\left(89^{\circ}\right)\right)$,
(c) at 1800Z, $\left(F_{\mathrm{r}}^{\mathrm{r}}=1.2\left(132^{\circ}\right)\right)$.

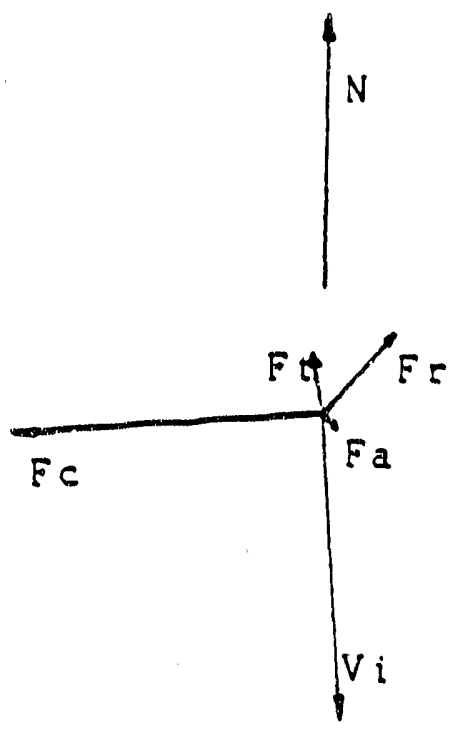

(c) 

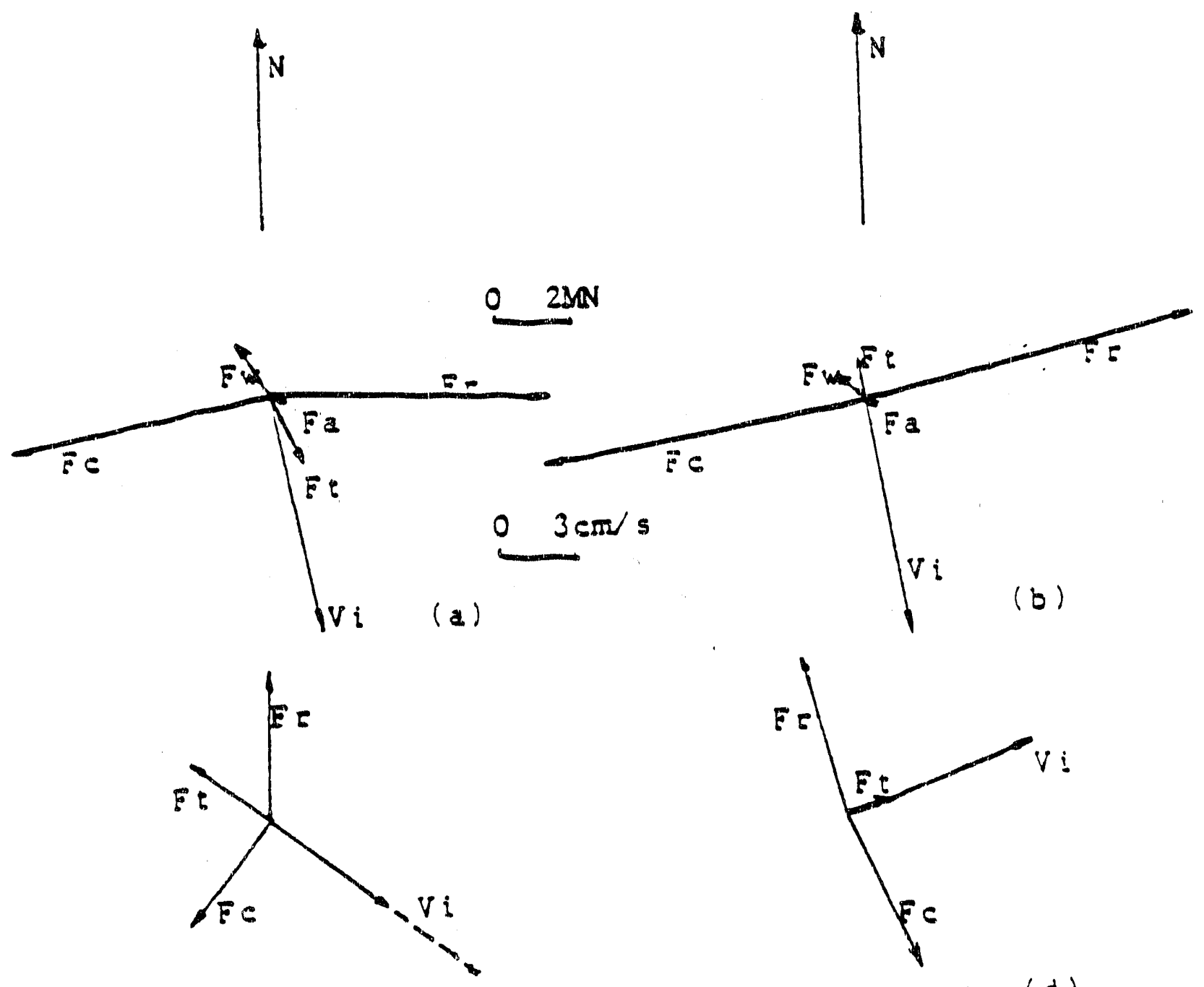

(e)

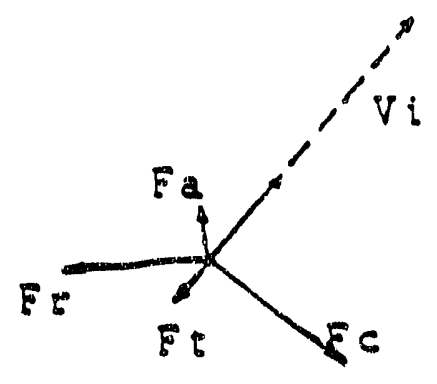

(e)

Fig. 102. Force balance on June 20 for

(a) $\left(\mathrm{F}_{\mathrm{r}}=7.4\left(78^{\circ}\right)\right)$, (b) $\left(\mathrm{F}_{\mathrm{f}}=8.6\left(94^{\circ}\right)\right)$,

(c) $\left(\mathrm{F}_{\mathrm{r}}^{\mathrm{r}}=2.1\left(137^{\circ}\right)\right)$, (d) $\left(\mathrm{F}_{\mathrm{r}}=2.3\left(85^{\circ}\right)\right)$,

(e) $\left(F_{r}=1.5\left(134^{\circ}\right)\right)$. 

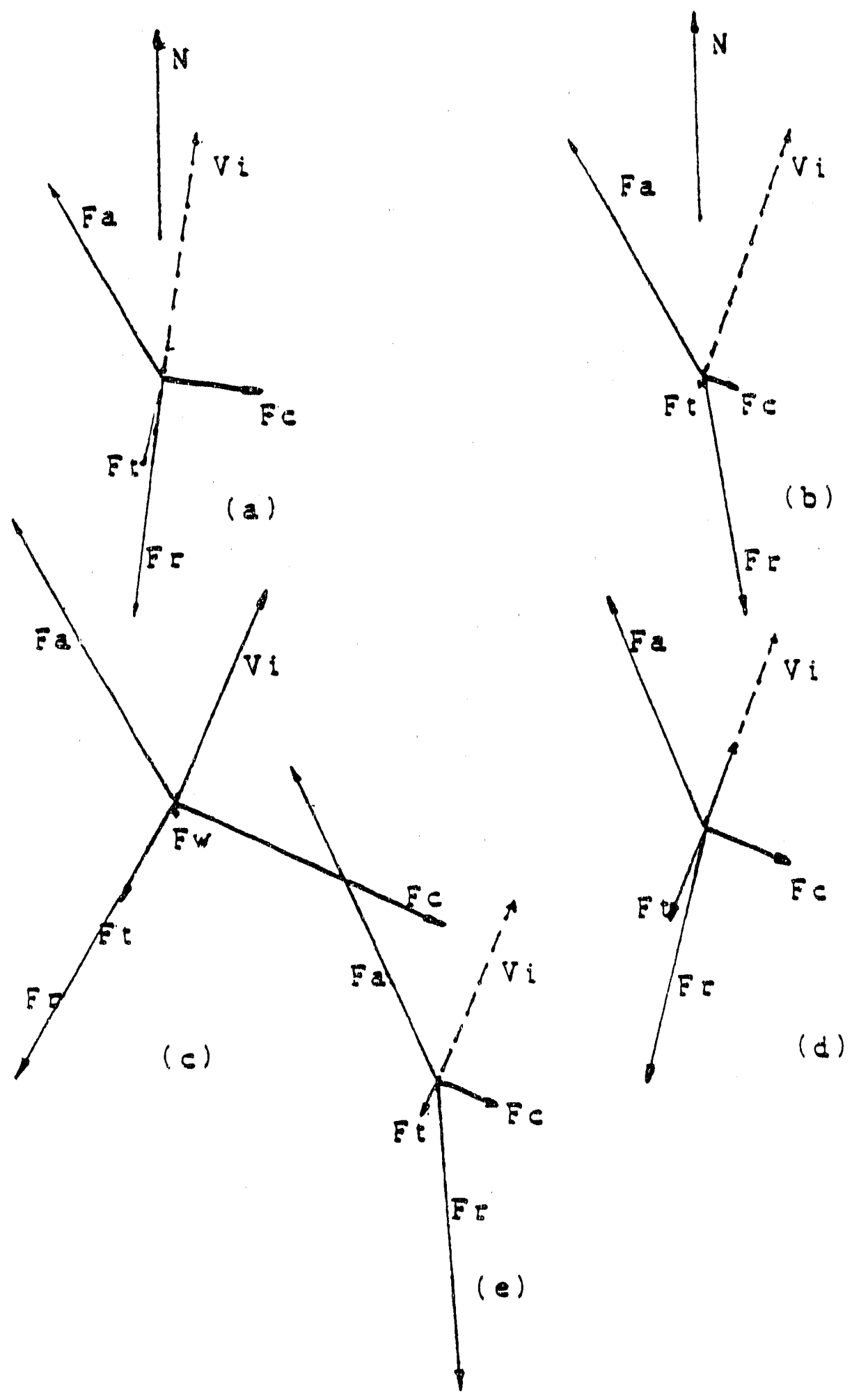

Fig. 103. Force balance on June 21 for
(a) $\left(F_{r}=3.7\left(182^{\circ}\right)\right)$, (b) $\left(F_{r}=3.3\left(207^{\circ}\right)\right)$,
(c) $\left(F_{r}=4.7\left(174^{\circ}\right)\right),(d)\left(F_{r}=3.6\left(186^{\circ}\right)\right)$,
(e) $\left(F_{r}=4.5\left(202^{\circ}\right)\right)$. 
balance shows that the largest residual force was $6.6 \mathrm{MN}$ and directed $94^{c}$ to the left of the movement direction at $0000 \mathrm{Z}$; the speed of the ice island movement was 10 $\mathrm{cm} / \mathrm{s}$, which was also the largest speed on that day.

The movement continued, but more slowly, on the day of May 9 (Figure 89) due to smaller wind shear. The direction of movement was changed, and the force balance shows that residual forces were directed from $95^{\circ}$ to $123^{\circ}$ except at $0300 Z$. This special circumstance may have been due to pack ice or geostrophic currents transferring some energy to the ice island, which was already slowed dowr. Unfortunately, there is no data available at $0600 \mathrm{Z}$ and $0900 \mathrm{Z}$ to show further details. However, on the day of May 10 (Figure 90) the same case occurred again (The movement direction of the ice island was averaged over the time interval from May 8 to May 10 in preparing Figure 70, thus removing the tidally-driven component of motion). In that case, the wind shear was very small but the movement of the ice island was not small, as the residual forces were directed from $62^{\circ}$ to $92^{\circ}$. It is likely that the pack ice or the geostrophic currents were transferring energy to the ice island and maintaining its movement.

From May 10 at $1800 \mathrm{Z}$ to May 13 at $1800 \mathrm{Z}$ the wind shear forces were nearly in the same direction, and before the resulting large movement started, the pack ice or the geostrophic currents transferred a small momentum to the ice island at $0000 \mathrm{Z}$ and $1800 \mathrm{Z}$ un May 11 (Figure 91). The threshold for initiation of the ice island movement was a wind speed ranging from $4.25 \mathrm{~m} / \mathrm{s}$ to $6.25 \mathrm{~m} / \mathrm{s}$ (Table 4.1 ). The movement was increasing until May 12 (Figure 92) at 0300Z, with the largest movement velocity (about $16 \mathrm{~cm} / \mathrm{s}$ ), and the same direction, until May 13 at $1800 \mathrm{Z}$ (Figure 93). In these three days a large movement event took place and the force balance shows that the greatest residual force was $12.6 \mathrm{MN}$, directed $94^{\circ}$ to the left of the ice island movement at the same time as the largest ice island movement 
occurred. During the episode, the residual force was directed from $82^{\circ}$ to $129^{\circ}$, usually in fact directed from $91^{\circ}$ to $113^{\circ}$.

From May 14 at $0000 \mathrm{Z}$ to May 16 at $1800 \mathrm{Z}$ the movements gradually slowed. On the day of May 14 (Figure 94) the residual force was from the direction $90^{\circ}$ to $141^{\circ}$, and also during the day of May 15 (Figure 95) the residual forces were directed from $103^{\circ}$ to $161^{\circ}$ except at $1200 Z$, a transient event for which forces were very small with residual force shifted to $280^{\circ}$. This case and a few others, may be due to the wind shear being larger than the Coriolis force, or it may be due to tidal effects, in which case it is the same as for May 16 at $1200 \mathrm{Z}$ and $1800 \mathrm{Z}$ (Figure 96).

From Figure 97 to Figure 103, the force balance is shown for the period of June 15-21. Because during the day of June 14, forces are too small to calculate, that day was not included. These results present the same behavior as in May; for large movement the force balance shows that the residual forces were directed from $90^{\circ}$ to about $150^{\circ}$. The greatest ice island movement speed occurred at $1200 \mathrm{Z}$, June 16 , and it was $14.7 \mathrm{~cm} / \mathrm{s}$; the residual force was $12.3 \mathrm{MN}$, directed $123^{\circ}$ to the left of the ice island movemerit direction.

\section{III.13. Pack Ice and Ocean Tilt Forces}

As mentioned above, the residual calculated force, including the pack ice force combined with the ocean tilt force, was the main object of study. Unfortunately no field measurement data are available for the ocean tilt which occurred near the ice island. From air pressure charts, it can be seen that the air pressure gradient is only $4 \mathrm{mb}$ over a $400 \mathrm{~km}$ distance on May 12, and also on June 16, 1986. The two largest residual forces and ice island movemento occurred with values $12.6 \mathrm{MN}$ and $12.3 \mathrm{MN}$, and $16 \mathrm{~cm} / \mathrm{s}$ and $14.7 \mathrm{~cm} / \mathrm{s}$, respectively, on these dates. For Hobson's Choice (length, $9.25 \mathrm{~km}$ ), the pressure gradient across its length is about $0.1 \mathrm{mb}$, corresponding to an ice island tilt angle of $6.2 \times 10^{-6}$ degrees. The ocean surface tilt force is equal to 0.7 
MN. It is very small compared with $12.6 \mathrm{MN}$ and $12.4 \mathrm{MN}$, the total residual forces. During the other movement episodes the ocean surface tilt force was much smaller $(<0.01 \mathrm{MN})$, due to the small sea surface tilt $\left(<1.0 \times 10^{-7}\right.$ degrees $)$, so it may be ignored. In Figure 104, the directions of ocean tilt force at $0300 \mathrm{Z}$ May 12 and at $1200 \mathrm{Z}$ June 16, 1986, when the two largest residual forces occurred, are shown. The dashed line indicates the direction of the ocean tilt force, but the magnitude was very small compared with other forces. Therefore, the residual force mainly includes the pack ice force and the tidal forces.

Using the numerical method as described in the Appendix of the thesis (Lu, 1988) applied to the force balance results, the magnitude of the residual force $\left(F_{r}\right)$ can be written as

$$
\mathrm{F}_{\mathrm{r}}=0.36+2.57 \mathrm{~V}_{\mathrm{i}}-1.28 \mathrm{~V}_{\mathrm{i}}^{2}, \quad 0 \leq \mathrm{V}_{\mathrm{i}}<1.5 \mathrm{~cm} / \mathrm{s}
$$

or

$$
F_{r}=0.02+0.89 V_{i}-0.009 V_{i}^{2}, V_{i} \geq 1.5 \mathrm{~cm} / \mathrm{s}
$$

where $V_{i}$ is the speed of the ice island movement in $\mathrm{cm} / \mathrm{s}$, equation (14) is for $V_{i}$ less than $1.5 \mathrm{~cm} / \mathrm{s}$, and equation (15) is for $V_{i}$ equal or greater than $1.5 \mathrm{~cm} / \mathrm{s}$ and is the more important part.

The parts above the cubic polynomial for equation (15) were deleted hecause the coefficients were so small $(<0.0004)$.

In Figure 105, the results of numerical methods applied to analyze the relationship between residual force and ice island movement are shown. From both Figure 105 and equation (15) the relationship between them is almost linear. 


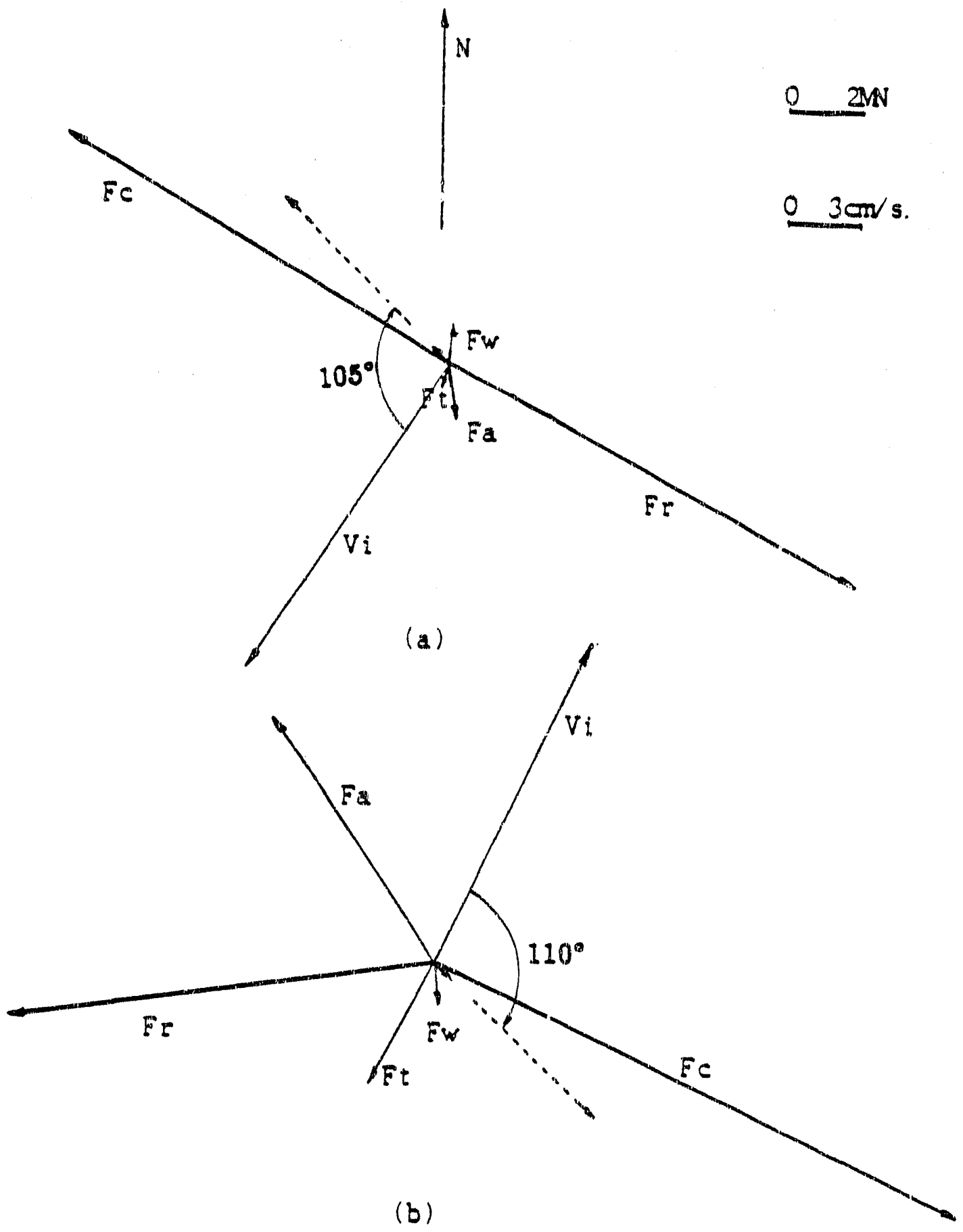

Fig. 104. Ocean tilt forces, (a) at $0300 \mathrm{Z}$ May 12; (b) at $1200 \mathrm{Z}$ June 16, 1.986, when the two largest residual forces were occurred. Dash line indicates only the direction of ocean tilt force. 

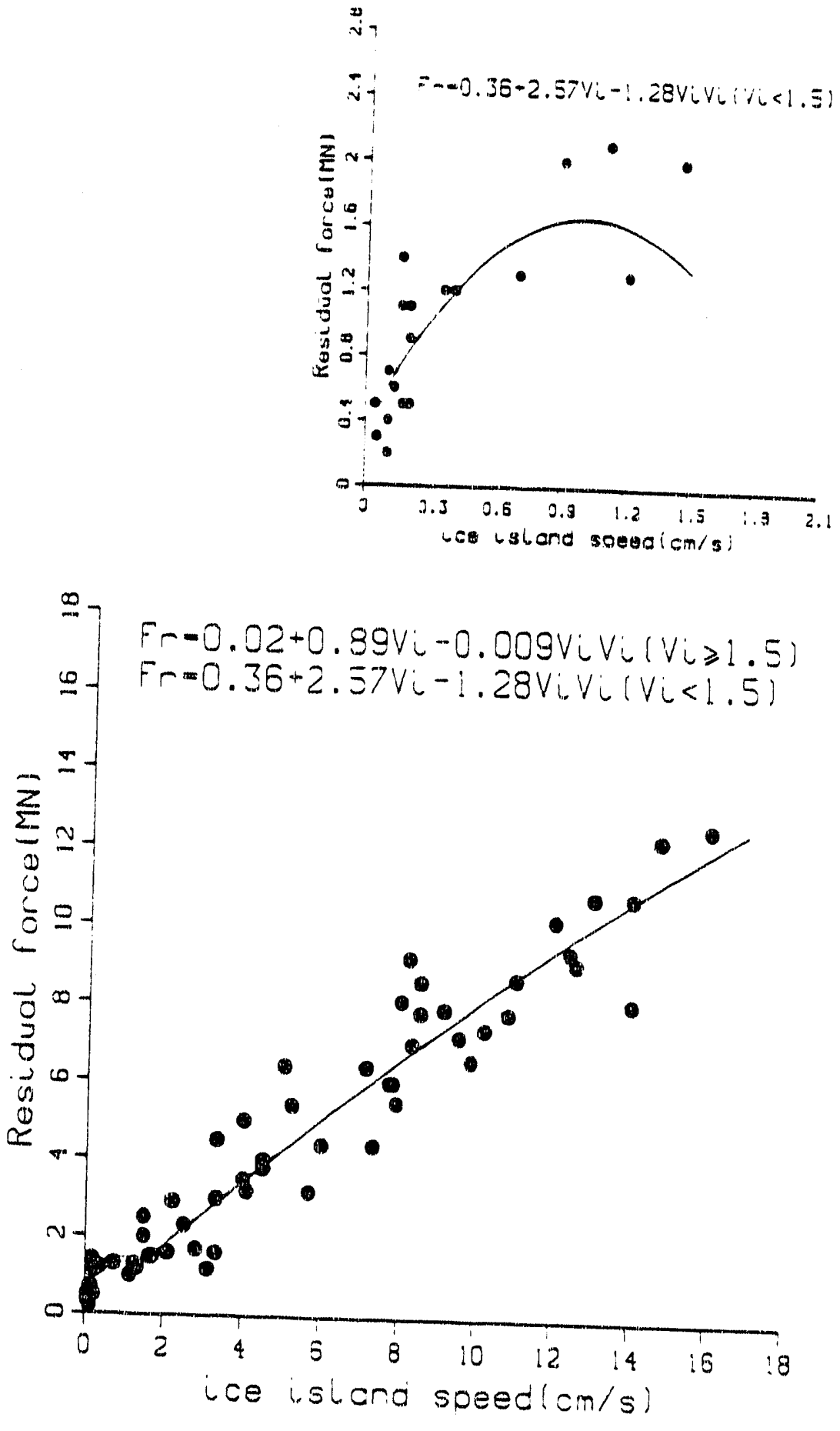

Fig. 105. Relationship between residual force and ice island movement. 
The direction of the residual rorce, associated with both wind and ice island movement, can be written as (Figure 106)

$$
\theta=108^{\circ}+26.0 \times \ln \left(\frac{0.01 \mathrm{~V}_{\mathrm{a}}}{\mathrm{V}_{\mathrm{i}}}\right)
$$

where $V_{a}$ is surface wind in $\mathrm{cm} / \mathrm{s}, V_{i}$ is the speed of the ice island movement in $\mathrm{cm} / \mathrm{s}$, and $\emptyset$ is the angle of the residual force in degrees measured to the left of the direction of ice island movement. It is our subjective opinion after considering all of the graphs Figures 87-103 that the accuracy of the angle of the residual force is estimated as approximately \pm 15 degrees.

From this result, if $0.01 \mathrm{~V}_{\mathrm{a}} / \mathrm{V}_{\mathrm{i}}$ is less than 0.5 the residual force is directed less than $90^{\circ}$. This shows that the park ice or geostrophic currents may transfer some momentum to the ice island; if $0.01 \mathrm{~V}_{\mathrm{a}} / \mathrm{V}_{\mathrm{i}}$ is greater than 10.0 the residual force is directed greater than $180^{\circ}$; this shows that the threshold for initiation of movement of the ice island is a wind speed of $5.25 \pm 1 \mathrm{~m} / \mathrm{s}$. In the initial stages of ice island movernent, the residual force is directed at $190^{\circ} \pm 15^{\circ}$ to the left of the movement direction. When ice island velocity exceeds $4.0 \mathrm{~cm} / \mathrm{s}$ and ranges up to $16.0 \mathrm{~cm} / \mathrm{s}$, during the most active stages of movement, the residual force on the ice island is directed from $90^{\circ}$ to $170^{\circ}$ to the left of the movement direction. Extremely high velocity episodes $(10.0 \mathrm{~cm} / \mathrm{s}$ to $16.0 \mathrm{~cm} / \mathrm{s})$ produce a residual force direction of $92^{\circ}$ to $120^{\circ}$. During the final stages of a movement episode, when deceleration is obvious, and has values of $0.0004 \mathrm{~cm} / \mathrm{s}^{2}$, the residual force is directed at an angle of $80^{\circ} \pm 10^{\circ}$. The magnitudes of resirual force are usually much larger during the most active stages of movement than during both the initiation stage and the final stage of movement. Deceleration intervals are typically associated with low wind speeds and low residual force, implying that water drag forces cause the final deceleration. 

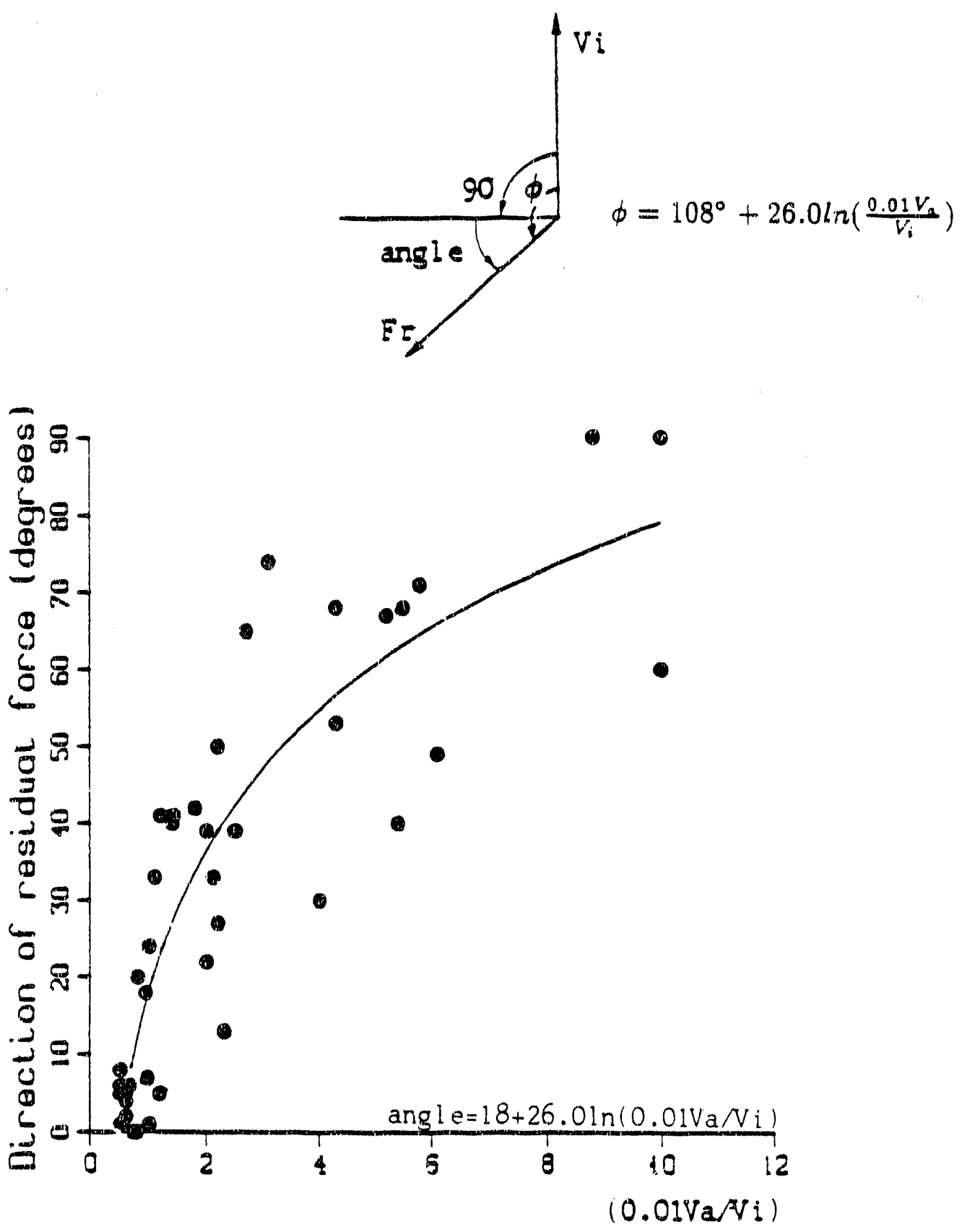

Fig. 106. Relationship between the directions of residual force, ice island movement and wind speed. 


\section{III.14. Summary}

Trajectory analysis of Hobson's Choice showed five large movement episodes in the intervals of May 7-14, June 14-21, July 1-4, August 22-27 and September 11-17, 1986, respectively, which were in the southwest or northeast direction along the coastline of Axel Heiberg Island. The May and June movements were analyzed in detail. The averaged speed ratio between the ice island and the surface wind was $1.4 \%$, the ratio of ice island speed to geostrophic wind speed was $0.86 \%$, and the average ratio of surface wind speed to geostrophic wind speed was 0.62 . The angle of the ice island velocity vector in relation to the surface wind vector ranged from $15^{\circ}$ to $25^{\circ}$ clockwise from the surface wind direction, and the angle of the ice island velocity vector in relation to the geostrophic wind direction ranged from $25^{\circ}$ to $35^{\circ}$, counterclockwise from the geostrophic wind direction.

Evidence was found for the mountain barrier effect. The surface wind produced by a geostrophic wind blowing towards a mountain barrier is directed to the left (in the Northern Hemisphere). Episodes of coastward air flow from the west induced a component of the surface wind from the south. This movement implies that the mountain barrier effect should be taken into account when predicting ice island movement near a coastline with mountains.

Force balance on the ice island shows that the residual force $\left(F_{r}\right)$ increased with ice island velocity. From analysis of many transient events, the relationship for the residual force can be expressed by

$$
\begin{gathered}
\mathrm{F}_{\mathrm{r}}=0.36+2.57 \mathrm{~V}_{\mathrm{i}}-1.28 \mathrm{~V}_{\mathrm{i}}^{2}, 0 \leq \mathrm{V}_{i} \leq 1.5 \mathrm{~cm} / \mathrm{s} \\
\mathrm{F}_{\mathrm{r}}=0.02+0.89 \mathrm{~V}_{\mathrm{i}}-0.009 \mathrm{~V}_{\mathrm{i}}^{2}, \mathrm{~V}_{\mathrm{i}} \geq 1.5 \mathrm{~cm} / \mathrm{s}
\end{gathered}
$$


where $V_{i}$ is the speed of ice island movement in $\mathrm{cm} / \mathrm{s}, F_{r}$ is the residual force in $M N$, and the equation for $\mathrm{V}_{\mathrm{i}} \geq 1.5 \mathrm{~cm} / \mathrm{s}$ is the more important part. The residual force coefficients for ice island movement are shown from the statistical analysis in Table 15.

Table 15. Residual force coefficients for ice island movemen

\begin{tabular}{cccc}
\hline & Power of $\mathrm{V}_{\mathrm{i}}$ & Median & Variation \\
\hline \multirow{3}{*}{$\mathrm{V}_{\mathrm{i}}<1.5 \mathrm{~cm} / \mathrm{s}$} & 0 & 0.36 & \pm 0.08 \\
& 1 & 2.57 & \pm 0.25 \\
& 2 & -1.28 & \pm 0.15 \\
\hline \multirow{2}{*}{$\mathrm{V}_{\mathrm{i}} \geq 1.5 \mathrm{~cm} / \mathrm{s}$} & 0 & 0.02 & \pm 0.01 \\
& 1 & 0.89 & \pm 0.10 \\
& 2 & -0.009 & \pm 0.001 \\
\hline
\end{tabular}

The direction of residual force is a function of both wind speed and ice island movement speed, and can be written as

$$
\emptyset=108^{\circ}+\ln \left(\frac{0.01 \mathrm{~V}_{\mathrm{a}}}{\mathrm{V}_{\mathrm{i}}}\right)
$$

where $V_{a}$ and $V_{i}$ are in $\mathrm{cm} / \mathrm{s}$, and $\emptyset$ is the angle of the residual force in degrees, measured to the left of the direction of ice island movement. From analysis of many transient events the variation of coefficients are $108^{\circ} \pm 10^{\circ}$ for the constant part in the equation, and $27^{\circ} \pm 5^{\circ}$ for the part of $\ln \left(0.01 \mathrm{~V}_{\mathrm{a}} / \mathrm{V}_{\mathrm{i}}\right)$.

From this result, if $0.01 \mathrm{~V}_{\mathrm{a}} / \mathrm{V}_{\mathrm{i}}$ is less than 0.5 the residual force is directed less than $90^{\circ}$; this shows that the pack ice or geostrophic currents transfer some momentum to the ice island. If $0.01 \mathrm{~V}_{\mathrm{a}} / \mathrm{V}_{\mathrm{i}}$ is greater than 10.0 , the residual force is directed greater than $180^{\circ}$. This also shows that the threshold for initiation of movement of the ice island is a wind speed of about $5.25 \pm 1 \mathrm{~m} / \mathrm{s}$. In the initial stages of ice island movement, the residual force is directed at $190^{\circ} \pm 15^{\circ}$ to the left of the movement direction. When ice island velocity exceeds $4.0 \mathrm{~cm} / \mathrm{s}$ and ranges up to 16.0 
$\mathrm{cm} / \mathrm{s}$, during the most active stages of movement, the residual force on the ice island is directed from $90^{\circ}$ to $170^{\circ}$ to the left of the movement direction. Extremely high velocity episodes $(10.0 \mathrm{~cm} / \mathrm{s}$ to $16.0 \mathrm{~cm} / \mathrm{s})$ produce a residual force direction of $92^{\circ}$ to $120^{\circ}$. During the final stages of a movement episode, when deceleration is obvious, and has values $0.0004 \mathrm{~cm} / \mathrm{s}^{2}$, the residual force is directed at an angle of $80^{\circ} \pm 10^{\circ}$. The magnitudes of residual force are usually much larger during the most active stages of movement than during both the initiation stage and the final stage of movement. Deceleration intervals are typically associated with low wind speeds and low residual force, implying that water drag forces cause the final deceleration.

Orientation of the ice island changed very little during movement episodes, regardless of direction of movement. Because of the rectangular submerged shape of the ice island, the water form drag thus varied during movement episodes, ranging from a calculated value of 0.417 to a maximum of 0.785 of the total water drag. This is thought to contribute to an ice island trajectory different than that of the adjacent pack ice.

The force balance examination of ice island movement is only applicable to Hobson's Choice. To further examine ice island movement near other coastlines or mountains, detailed data and more weather stations in the local area are necessary. Ice island trajectories far away from coastline or mountains should be analyzed in the future. 


\section{CHAPTER IV}

SIMULATION OF THE RECURRENCE PROBABILITY OF ICE ISLANDS

IN THE ARCTIC OCEAN

(F. C. Li)

\section{IV.1. Introduction to the Trajectory Simulation}

A detailed Monte Carlo simulation of the probability of ice island presence in the various regions of the Arctic Ocean was made by Li Fucheng $(1988 ; 1989)$. The discussions in this chapter are based upon that work and current $\mathrm{Ph}$.D. research.

The tabular icebergs of the Arctic Ocean are termed "ice islands", and they are the most massive ice features that have been discovered in the Arctic Ocean. These ice features are normally characterized by a large surface area and often by a deep keel depth. The largest ice island presently known to exist in the Arctic Ocean has a mass of approximately $700 \times 10^{6}$ tonnes, an area of about $26 \mathrm{~km}^{2}$ and a mean thickness of 42.5 meters over $64 \%$ of its area (Jeffries et al., 1988). These massive ice features, drifting in open water or within the pack ice zones, may approach the sites where offshore oil platforms or vessels are in operation. To design such installations, it is important to estimate the risk of ice island interaction with offshore structures or stationary vessels.

One important objective in quantitative estimates of the risk to offshore structures is to determine the recurrence interval for ice islands in a given area in the Arctic Ocean. The recurrence intervals are dependent upon the probability of ice island trajectories, as well as upon the rate of ice island generation, the probability of natural fragmenting of ice islands, and the ice island dimensions. One may directly observe the statistics of ice island trajectories, but this approach is constrained because of the very limited data at the present time. Many years are needed to gather such data. DePaoli (1982) presented an analysis of interaction probabilities between large ice features and offshore structures in the Canadian Beaufort Sea. The 
basic assumption was made that the Beaufort Gyre (the clock-wise circulation syster. of the pack ice) is that mechanism whereby large ice features (ice islands and multiyear hummock fields) drift into the Southern Beaufort Sea, i. e., the lorge ice features are transported by multi-year ice into the Southern Beaufort Sea. Further, he considered that the probability of large ice features entering an area of concern is the same as the probability of multi-year intrusion. He then calculated the probability of multi-year ice (for an averaged conceniration of 5\%) ente:ing the area of concern based on the statistical data of multi-year ice. De Paoli et al. (1982) also calculated the probabilities of pack ice edge intrusion and the intrusion of the edge of $1 / 10$ concentration of multi-year ice in summer, and took these as the probabilities of intrusion of large ice features, to compare with the probabilities of the averaged concentration of $5 \%$ multi-year ice. In fact, as shown by Lu (1988), the ice islands move in a different trajectory pattern from that for pack ice or multi-year ice. An alternative approach to analyse the probability of ice island trajectories is a computer simulation by the Monte Carlo method. This approach needs to make use of a dynamic model of ice island movement, and the statistical distributions of related driving forecs, ice island generation and the natural fragmenting of ice islands.

As for the dynamics of ice island movement, the most detailed study has taken place only since 1983. Worthy of mention, bowever, is the analysis of some aspects of the drift of ice island T-3 for example (Brown and Crary, 1958; Hunkins, 1967).from 1952 to 1983. Since April 1985 several satellite positioning buoys have been deployed on a number of different ice islands, which have delivered data by both the Argos system and satellite navigation systems as discussed in Chapter III. A substantial amount of data has been obtained from these stations, including ice island drift, surface pressure variations, and surface temperatures. These data has provided a good basis for dynamic analysis of ice island movement. A comprehensive work by Yan (1986) gave details of three types of ice island movement in 1983-85. It 
was indicated that the speed ratios between the ice island and the eostrophic wind ranged from $1.0 \%$ to $1.5 \%$ for large movements, and the average angle of the geostrophic wind ranged from 20 to 26 degrees ccunterclockwise from the ice island motion direction. More detailed analysis of ice island movement (Lu, 1988) has resulted in more accurate relationships between ice island movement, surface wind veluzities and geostrophic wind velocities, and evidence of a mountain barrier effect, presented in Chapter III. A relationship between residual force and the speed of Hobson's Choice Ice Island was also obtained.

Regarding the generation of ice islands, several ice shelf calving events have occurred at the Ward Hunt Ice Shelf on the north coast of Ellesmere Island (Hattersley-Smith, 1963; Jeffries and Serson, 1983). A report (Sackinger et al., 1985) of ice island generation rate gave a statistical review of calving area of the ice shelves and the calving event time intervals. A statistical analysis 0 ice island dimensions was presented by Jeffries et al. (1988). All of this provides a good base for understanding the statistical distributions of ice island generation.

Because many meteorological studies have investigated arctic sea ice, the many sources of information available enable one to make reasonable assumptions on the statistical characteristics of the wind field in the Arctic Ocean. Because wind force is commonly considered as the dominant driving force on ice islands, accurate wind data should be used. Moreover, it has not been observed that ice islands frag nent as they circulate in the Arctic Ocean. The observed ice island fragmenting events have occurred only in shallow water areas after the ice islands have become grounded. Ice islands T-3 and WH-4, for example, grounded a short distance nerth of Pt. Barrow, Alaska and disintegrated into many smaller pieces. The sizes of these pieces were less than $1 \mathrm{~km}$. Considering many uncertainties on ice island fragmentation and particularly the small sizes of ice island fragments, relative to ice island sizes, the decision was made to neglect the fragmenting of drifting ice islands. 
The basic dependencies of the probability of an ice island occurrence in an area of interest, considered in this study, are the ice island generation and ice island movement. The spatial and temporal distributions of ice shelf calving events are to be explained. Thereafter, the methods for generating random ice island dimensions and the numbers of random ice islands existing in the Arctic Ocean are illustrated. An explanation will be given of the governing equation of ice island movement, involving wind driving force, comparison of water form drag and ice island bottom friction, and extension of an empirical formula for pack ice force calculation. The development of a Monte Carlo model for generating random geostrophic wind will be explained, as will the domain and mesh of the computer simulation. Simulation results and comparisons are then illustrated, and conclusions and recommendations given.

\section{IV.2. Random Ice Island Generation}

Ore important factor affecting the probability of ice island occurrences is the population statistics of ice islands in the Arctic Ocean. This population is directly related to ice island calvings or generation. The generation in this study includes the spatial and temporal distribution of ice island generation, the ice island dimensions, and appropriately generated numbers of ine islands.

Because ice islands are generated by calving from the ice shelves, the spatial and temporal distributions of probability for such ice island generation is equivalent to that for the calving event of ice shelves, which can be quantified by historical statistics, assuming a time-invariant statistical process. Thus, long term global change and depletions of ice shelf ice are neglected. Many observations on ice shelf calving have been done, and ice islands related to ice shelf calving have been observedand recorded since the early 1880 's (Sackinger et al., 1985). A thorough review of this, especially on the systematic traverses of the ice shelves for the past 
two decades, (Sackinger et al., 1985) has revealed that calving events occur at ice shelves along the northern coast of Ellesmere and Axel Heiberg Islands, from Clements Markham Inlet west to the mouth of Sverdrup Channel (Figure 107). The statistics of calving events should not be considered as an annual stochastic process, but, rather, calving takes place every third or fnurth year, at seemingly pseudorandom intervals, as shown in the review summary for the period 1963 to 1983 (Table 16).

On the other hand, ice shelves can grow by seaward growth of glaciers, by sea ice accumulation, and ridge-building, and pressure ridge ablation along the seaward edges of ice shelves. Due to such growth, the ice shelves do not tend to vanish by calving. In the period 1963 to 1980 , a total of $41 \mathrm{~km}^{2}$ of ice was gained by ice shelves, mainly in Ayles Fiord and other areas. The ice shelf regeneration process and calving process is a virtually continual one when considered over time intervals of centuries (Sackinger et al., 1985).

In the computer simulation, a uniform spatial distribution of probability of an ice shelf calving event was assumed along the northern coast of Ellesmere and Axel Heiberg Islands, from Clements Markham Inlet west to the mouth of Sverdrup Channel, as shown in Figure 108. This uniform assumption in this small distance scale should not have an obvious influence on the simulation results of the probability of ice island trajectories in relative large spatial scale over the entire Arctic Ocean. For the temporal distribution, one calving event occurring every fourth year was assumed in the simulation. This is an approximation at the present time, based on limited data. As more data on ice shelf calving become available, this assumption can be easily adjusted in the simulation, and several simulation runs with 3-year and 5-year intervals have been run to test the sensitivity of the results to this assumption. 


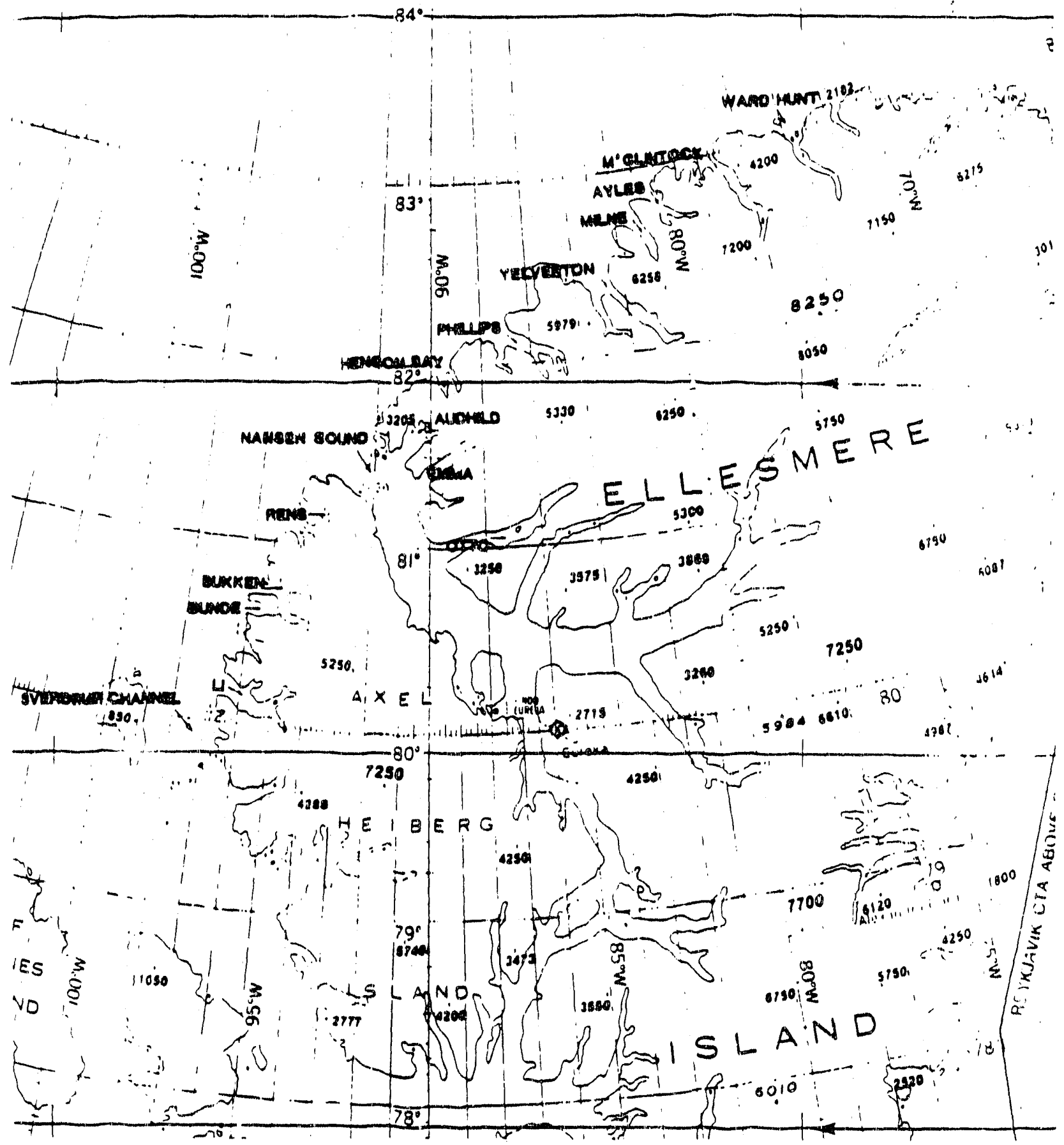

Fig. 107. Map of ice shelf area. 
Table 16. $\mathrm{Km}^{2}$ Ice Lost (Gained) Since Previous Observation)

\begin{tabular}{|c|c|c|c|c|c|c|c|}
\hline Year & W. Hunt & McClintock & Nansen & Milne & Ayles & Other & Total \\
\hline 1963 & 569 & & & & & & 569 \\
\hline \multicolumn{8}{|l|}{1964} \\
\hline \multicolumn{8}{|l|}{1965} \\
\hline 1966 & & 95 & & & & & 110 \\
\hline 1967 & & & & 35 & $15(25)$ & $10_{\mathrm{a}}\left(15_{\mathrm{c}}\right)$ & $45(40)$ \\
\hline \multicolumn{8}{|l|}{1968} \\
\hline \multicolumn{8}{|l|}{1969} \\
\hline \multicolumn{8}{|l|}{1970} \\
\hline 1971 & 4.5 & & 240 & & & & 244.5 \\
\hline 1972 & 1.5 & & & & & & 1.5 \\
\hline \multicolumn{8}{|l|}{1973} \\
\hline 1974 & 10 & & & & & & 10 \\
\hline 1975 & ---.-. & & & & & & \\
\hline \multicolumn{8}{|l|}{1976} \\
\hline $\begin{array}{l}1977- \\
1979 \\
\end{array}$ & $\cdots$ & & & & & & \\
\hline 1980 & (1) & & & & & $3 b$ & $3(1)$ \\
\hline TOTALS & $585(1)$ & 95 & 240 & 35 & $15(25)$ & $13(15)$ & $983(41)$ \\
\hline
\end{tabular}

a) West of Bromley Island

b) Cape Fanshawe Martin

c) East of Hansen Point

Ice island dimensions affect movement, and therefore affect the trajectories; they are important random variables. The statistical characteristics of these variables used in this study are based on observational data analyzed mainly by Jeffries et al. (1988), which is believed to be the most complete summary at the present time. During the past 40 years, a total of 52 ice islands have been recorded with dimension estimations, including new ice islands which are completing their first full Beaufort Gyre drift circuit, and old ice islands completing a second or greater drift circuit. The length and width of each of the ice islands are plotted in 


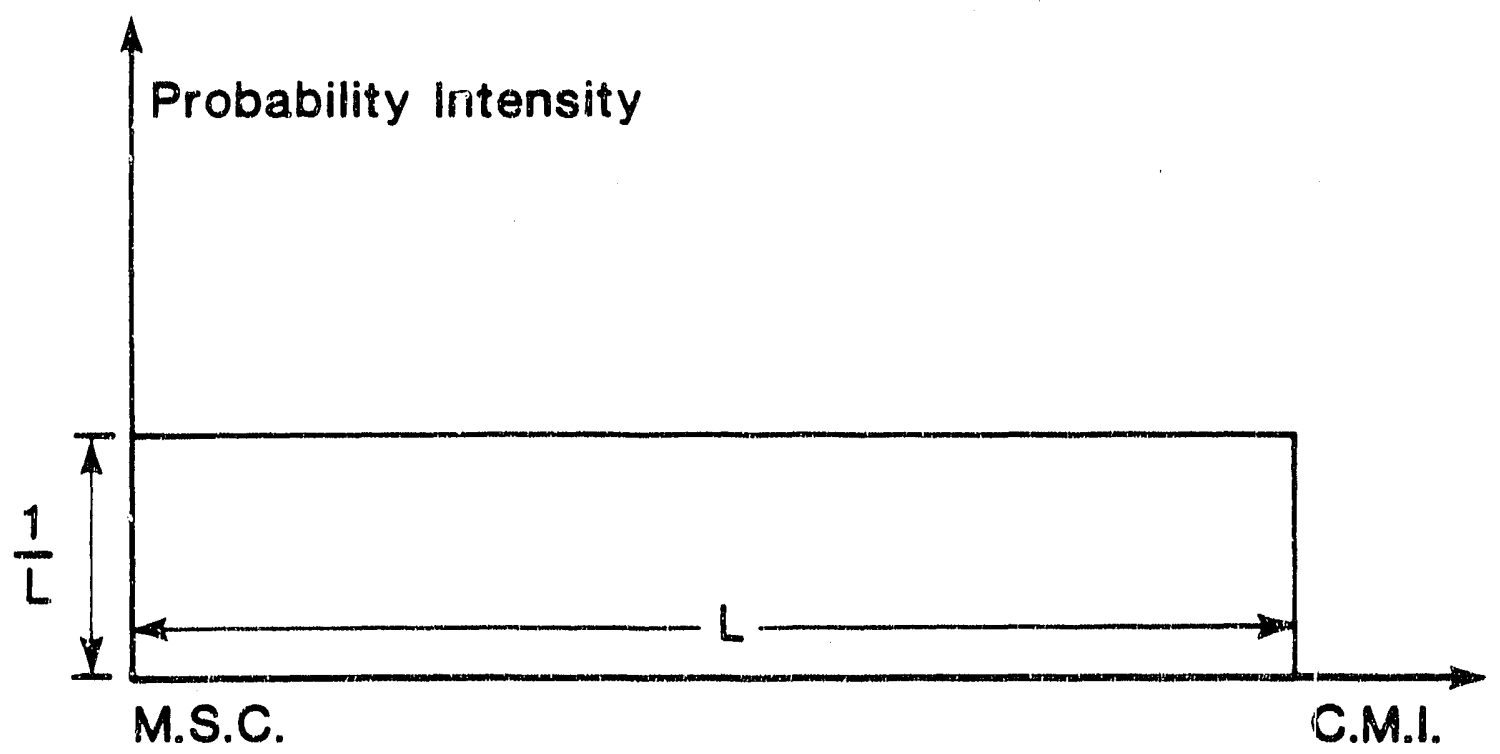

Fig. 108. Spatial Distribution of probability of ice shelf calving evert. M.S.C. mouth of Sverdrup channel. C.M.I. - Clements Markham Inlet. 
Figure 109. The dimensions of concern in this study are for newly calved ice islands, so only the dimensions for categories of "new" and "other" ice islands in Figure 109 are considered for distribution calculations. The reason for including "others" is that those which were found freely-floating in the Arctic Ocean in the 1960s and 1970s were all large, which suggests that they were relatively young when first sighted (Jeffries et al., 1988). The range of dimensions for these ice islands was from a minimum of $0.5 \times 1.48 \mathrm{~km}$ to a maximum of $27.0 \times 29.0 \mathrm{~km}$. For the random dimension generation of the ice islands the length distribution is of interest, and according to these data, the length distribution to be used in the simulation was as shown in Figure 110. The length range is quite wide, but the distribution is positively skewed; $60 \%$ of the data occurs in the class length $1-10 \mathrm{~km}$ alone and almost $92 \%$ of the data is in class $1.10 \mathrm{~km}$ and $10.1-20.0 \mathrm{~km}$ combined. Only $7.2 \%$ of ice islands have a length greater than $20 \mathrm{~km}$ when calved, according to the data.

Observations have shown that ice islands are sometimes irregular in shape, but are frequently almost rectangular with quite straight edges. Thus, they can be assumed to be rectangles and may be expressed in terms of standardized lengthwidth ratios (Jeffries, et al., 1988). These ratios of ice islands sighted in the past 40 years have a frequency distribution as shown in Figure 111. The highest frequency, almost $50 \%$, is for the ratio 1.0 to 1.99 and $80 \%$ are in the ratio classes from 1.00 to 2.99. This distribution was used in the simulation to generate a random lengthwidth ratio which was used in combination with random length, for calculation of the random area of ice islands generated.

For the new ice island thickness, the only data from observation on Hobson's Choice Ice Island shows $42.5 \mathrm{~m}$ (Jeffries et al., 1988), and this was assumed to be the mean thickness for all new ice islands. The ice island thickness may decrease at a variable rate in different latitudes, due to ablation during its drift in the Arctic Ocean. The only data to quantify this thinning rate is 


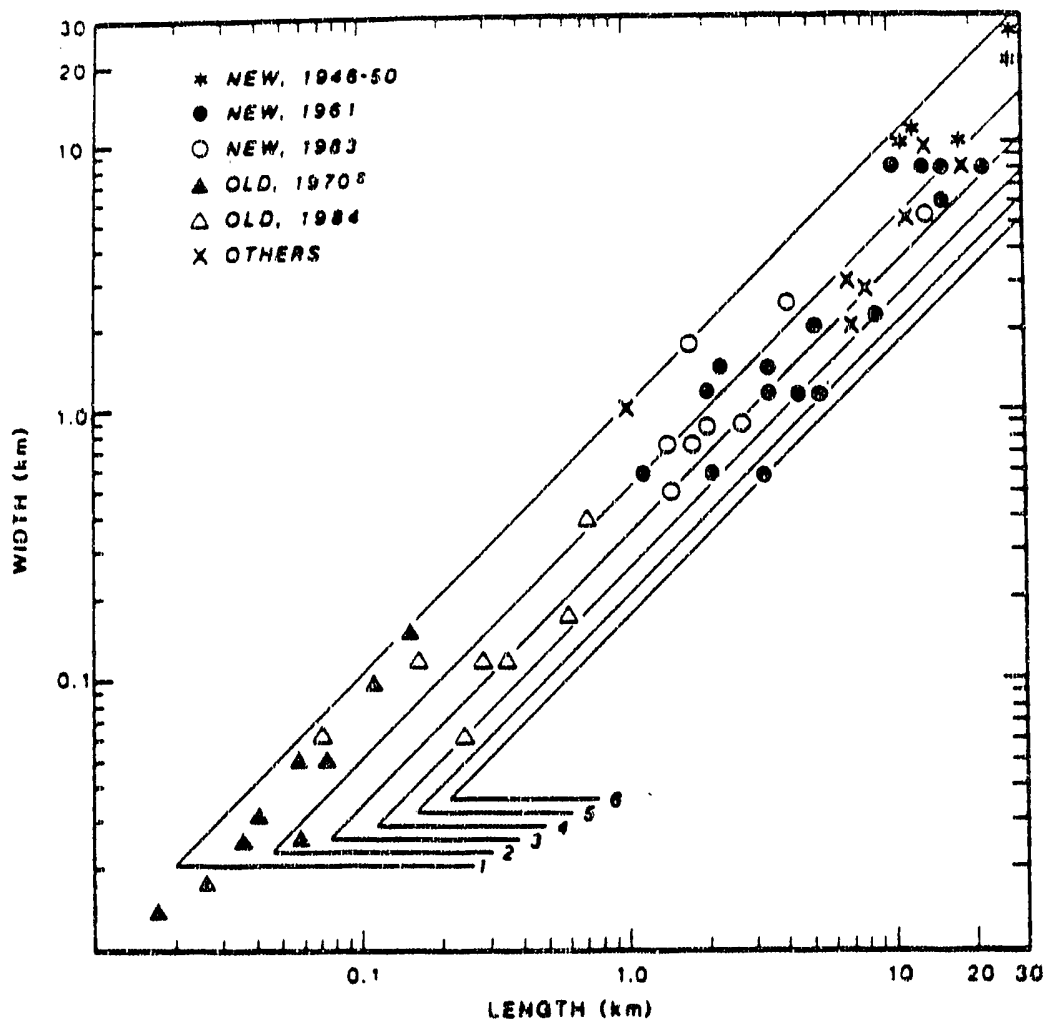

Fig. 109. Scatter diagram of the length and width of ice islands. The parallel diagonal lines are for length-width ratios of 1 to 6 . Note that a logarithmic scale is used for the axes (source: Jeffries et. al. 1988). 


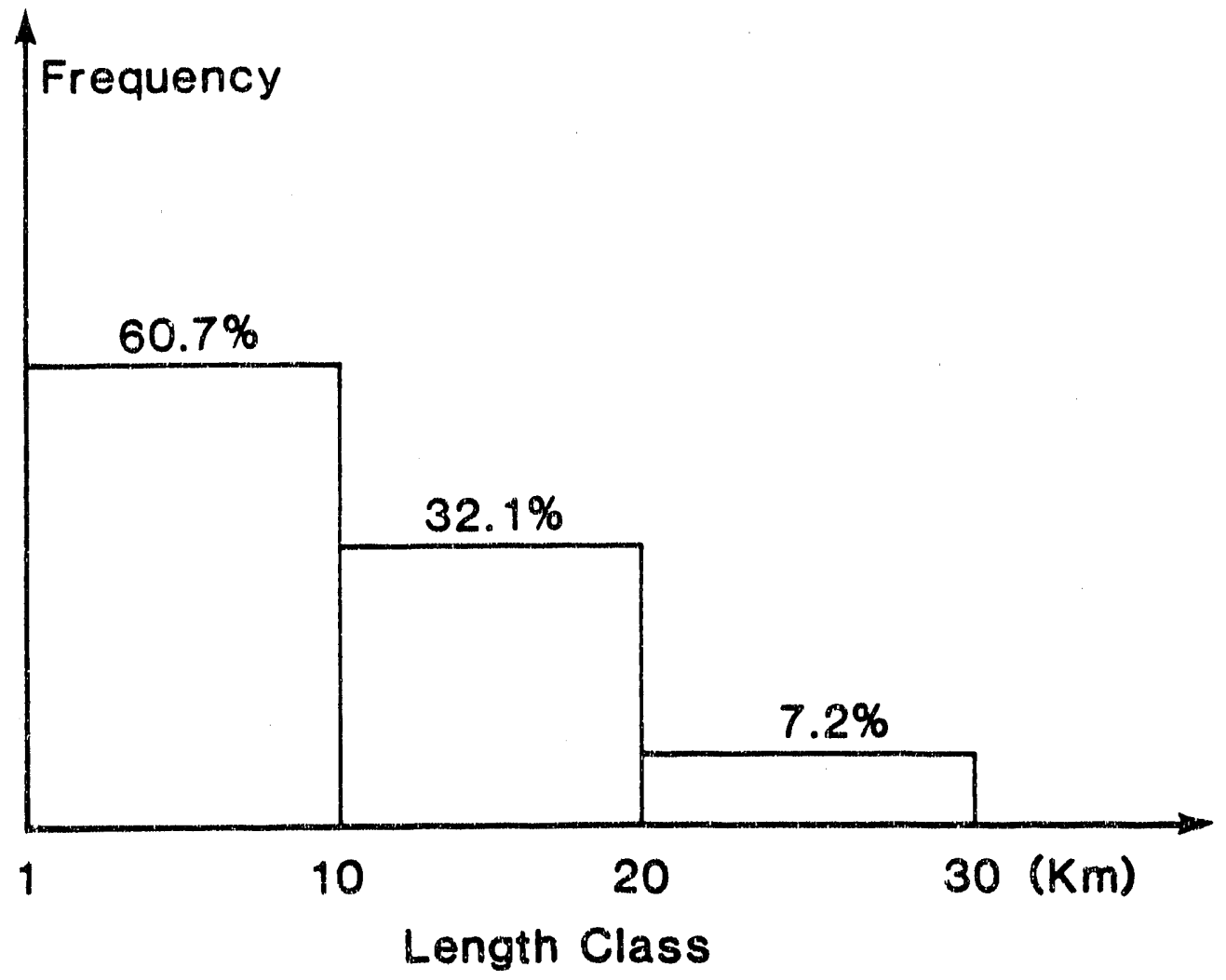

Fig. 110. Assumed length distribution of ice islands newly calved from ice shelves (based on analysis of Jeffries et al., 1988). 


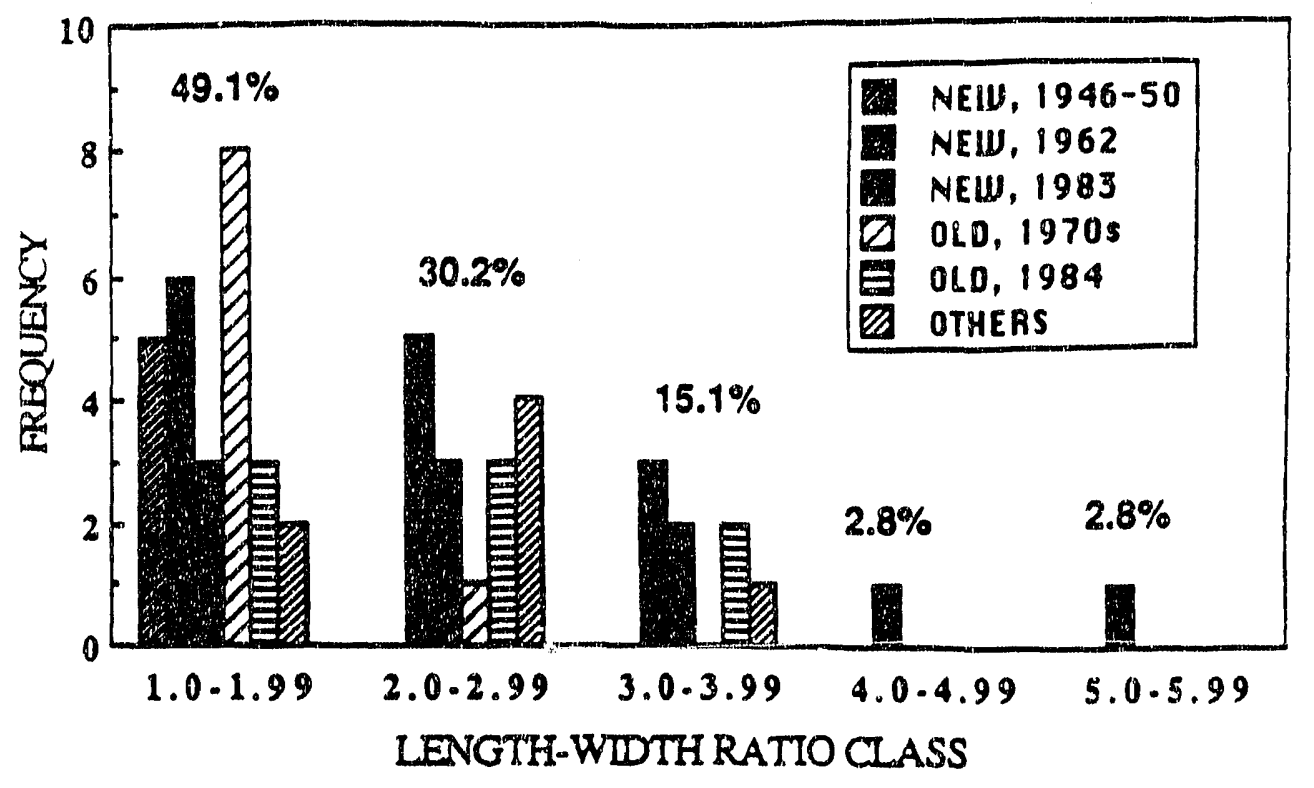

Fig. 111. Frequency distribution of ice island Length-Width (L-W) ratios. The distribution is very similar to that observed for Antarctic tabular icebergs, most of which have L-W ratios between 1 and 2 (Nazarov, 1962 [see Weeks and Mellor, 1978], (source: Jeffries et al. 1988). 
from ice island T-3. T-3 had a mean thickness of about $48 \mathrm{~m}$ in 1952, as measured by a seismic method (Crary, 1958), and a thickness of about $30 \mathrm{~m}$ in 1973 (Holcisworth and Traetteberg, 1974). This means that it might have thinned by as much as $18 \mathrm{~m}$ in 21 years, and the average thinning rate was about $0.82 \mathrm{~m}$ per year. According to such a rate, a newly-calved ice island with thickness of $42.5 \mathrm{~m}$ could only drift for at most about 50 years before it melted completely. The drift time in the Arctic Ocean may be less than this, due to grounding, fragmenting, or to ejection out of the ocean boundaries. Since no other data was available at this point in time, it was decided that the average thinning rate from $\mathrm{T}-3$ should be used in this simulation.

Few observations are avaiiable on the numbers of new ice islands calved from ice shelves in one calving event. Therefore, it was decided to use an indirect method to obtain the numbers of ice islands ranciomly generated in one calving event. One statistical data source available is the areas of calved ice shelves along the northern coasts of Eilesmere and Axel Heiberg Islands, as shown in Table 16. The data listed in Table 16 covers a period of 20 years, from 1963 to 1983 . Observing this data, a distribution of calved area of ice shelves was then assumed for the simulation, as shown in Figure 112. The random area of calved ice shelf in cne calving event can then be generated in the computer simulations according to this distribution. By deducting each random ice island area from this random calved ice shelf area, until the remaining ice shelf area is less than the last ice island are $a$, the number of randomly-generated ice islands in one calving event was an automatic result.

One may consider a possible decreasing trend in ice shelf area calved over time, as seen in Table 16. This decreasing trend may be related to the decreasing trend of ice island sizes observed from 1946 to 1983 (Jeffries et al., 1988). The reason for this decrease may be that as the total area of ice shelf decreases over time, the smaller individual ice shelves occupy only fiords and bays and do not extend far offshore (Jeffries, et al., 1988). However, entire fiords may lose their 


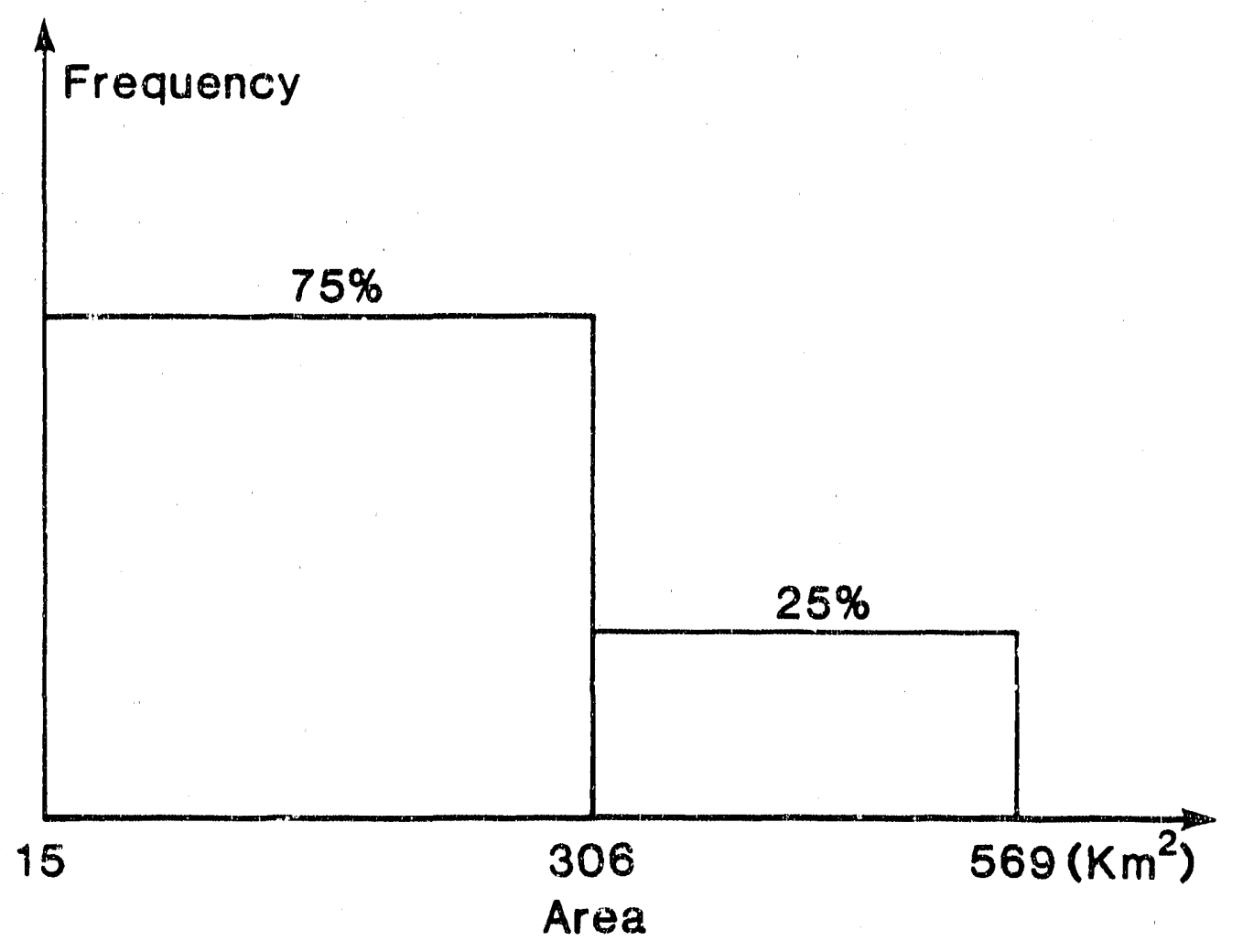

Fig. 112. Distrib ation of calved area of ice shelves. 
ice shelves in single large calving events (e.g., Yelverton Bay) and their ice shelves may rebuild in the bay or fiord. Moreover, ice shelves will not vanish in the near future, due to regeneration by multi-year ice attaching to the seaward edge of existing shelves, followed by accumulation of iced firn from above and also accretion from below. In fact, the ice shelves of Ellesmere Island have been producing ice islands sporadically for many decades, and calving processes are siill taking place (Sackinger et al., 1985). Since there is not enough data sources to quantify these longer-term statistics, this decreasing trend of ice shelf area was neglected in this simulation.

\section{IV.3 Dynamic Model of Ice Island Movement}

Observations of ice island movement show a strong correlation between ice island motion and wind velocity, even in pack ice zones (Sackinger et al.,1988). Ice island movement was therefore considered as wind-driven motion, as is commonly assumed for sea ice movement models. Geostrophic scale winds over the whole Arctic Ocean were used in this study. Therefore, wind drag force acting on an ice island was considered as the unique primary driving force. The secondary forces, which are caused by ice island motion, may include water skin friction, Coriolis force, and sea surface tilt pressure, as commonly considered in sea ice dynamic models. The sea surface tilt pressure is very small compared to other forces (Lu, 1988) and is therefore neglected in this ice island dynamic model. As shown in Chapter III, a lateral pack ice force acting on the ice island edges is significant and was considered in this ice island dynamic model. Another force acting on an ice island, which differs from that for sea ice models, is water form drag resulting from great keel depth. This force is usually larger than water skin friction, as will be shown. These two forces acting on an ice island make an ice island motion pattern different from that of the same area of sea ice. For example, trajectory data show that the ratio of ice island speed to wind 
speed is from $0.86 \%$ to $1.40 \%$ ( $\mathrm{Lu}, 1988$ ), while a ratio of $3.0 \%$ to $5.0 \%$ for wind and sea ice is generally found.

The dynamic equation which controls the movement of ice islands in the presence of pack ice can be written as

$$
M \frac{d V_{i}}{d t}=F_{a}+\left(F_{w s}+F_{w f}\right)+F_{c}+F_{p}
$$

where $M$ is ice island mass, $\vec{V}_{i}$ is ice island velocity, $\tilde{F}_{a}$ is surface wind shear force, $\tilde{F}_{w s}$ is water skin friction acting on the lower surface of the ice island, $\dot{\mathrm{F}}_{w f}$ is water form drag due to the frontal area of the submerged portion of the ice island, $\bar{F}_{\mathrm{c}}$ is Coriolis force, and $F_{p}$ is the pack ice force acting on the boundary of the ice island. There is a high incidence of transient processes in observed experimental data and in the simulations of ice island motion sequences, so the acceleration term should not be neglected. In Figure 113 a schematic illustration of the various forces acting on an ice island is depicted.

The air drag force, $F_{a}$, is expressed with a quadratic dependence upon the wind velocity rulative to the ice velocity. This formulation, verified in numerous field observations (e.g., Brown, 1980; Banke et al., 1976), may be written:

$$
F_{a}=\rho_{a} C_{a} A\left|V_{a}-V_{i}\right|\left(V_{a}-V_{i}\right)
$$

where $\rho_{a}=1.3 \mathrm{~kg} / \mathrm{m}^{3}$ is taken as the air density, $C_{a}=0.0012$ is a skin drag coefficient for wind over smooth ice at 10 meter height (Pease et al., 1983), $\mathrm{A}$ is ice island area, and $V_{a}$ and $V_{i}$ are the speeds of surface wind and ice island, respectively. The form drag term due to air flow over the ice island edge is neglected because observations have shown that pack ice rubble and snowdrifis make this a relatively smooth, gradual transition. A relation of $\mathrm{V}_{\mathrm{a}}=0.6 \overline{\mathrm{V}}_{\mathrm{g}} \mathrm{e}^{\mathrm{i} 26^{\circ}}$ (Albright, 1980) was used to transform geostrophic wind to surface wind. From the analysis of observerl data, as 


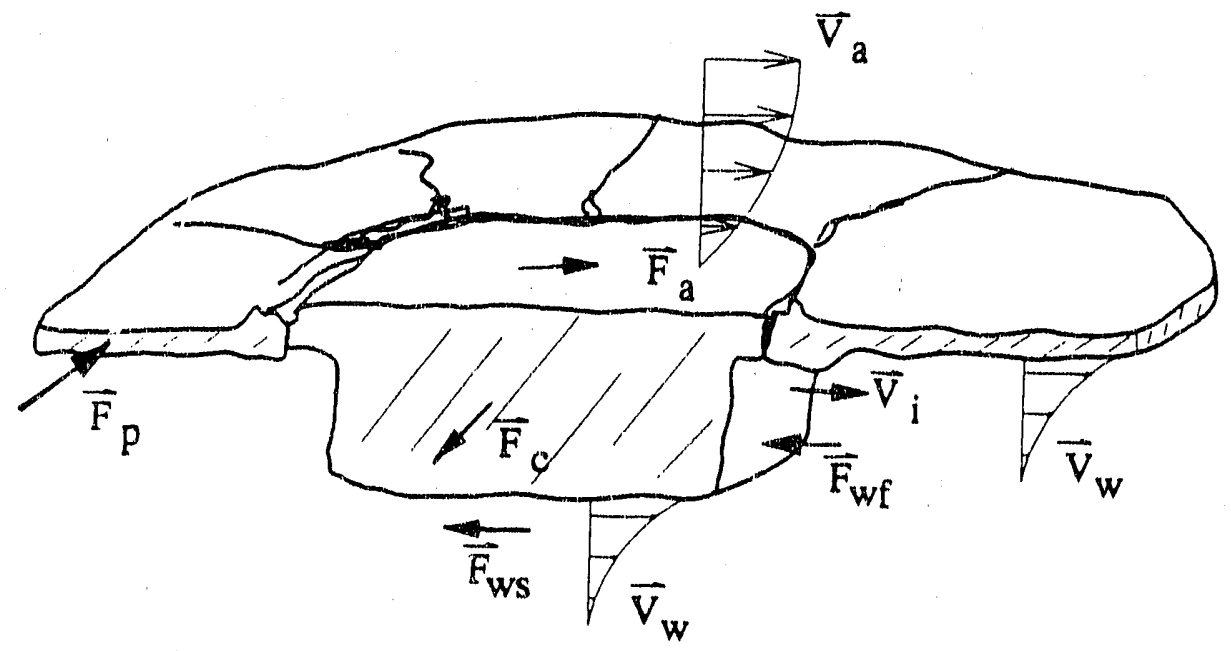

Fig. 113. Sketch of forces acting on an idealized ice island. 
reported in Chapter III, a threshold wind speed of about $5 \mathrm{~m} / \mathrm{s}$ appears to be necessary to initiate ice island motion.

Water skin friction, $F_{w s}$, is represented as a drag law with a quadratic dependence on the ice velocity relative to the water velocity. The quadratic dependence has been widely used in sea ice dynamic models and other hydraulic problems over the past several decades and has been verified by sea ice field observations by McPhee (1979). We therefore may write

$$
F_{w s}=\rho_{w} C_{w} A\left|V_{w}-V_{i}\right|\left(V_{w}-V_{i}\right)
$$

where $\rho_{w}=1032 \mathrm{~kg} / \mathrm{m}^{3}$ is a representative sea water density. A flat bottom is assumed for the ice islands; therefore a surface drag coefficient $C_{w}=0.00132$ for water and smooth ice (Langleben, 1982) was chosen. The quantity $V_{w}$ is the geostrophic water flow in the ocean. The direction of $F_{w s}$ is assumed to be turned $24^{\circ}$ to the left of the negative relative velocity $\left(\overline{\mathrm{V}}_{\mathrm{w}}-\overline{\mathrm{V}}_{\mathrm{i}}\right)$, to account for the Ekman spiral (McPhee, 1982), as an initial approximation.

The pattern of surface water movement in the Arctic Ocean is generally a slow westerly drift, driven by average wind and ice motion, forming a large clockwise gyre over the major part of the Arctic Basin. The greatest volume of water leaves the Arctic Ocean through the western part of the passage between Greenland and Svalbard. The annually-averaged current speed into the Arctic Ocean through the Bering Strait is $25 \mathrm{~cm} / \mathrm{sec}$. (Coachman and Aagaard, 1988), a not insignificant quantity, and the influence of the water currents on ice island motion in the Chukchi Sea is considered in the simulation. Time invariant surface water current data for the Chukchi Sea (Johnson, 1987) were used to compute the water force. The data of Johnson (1987) shows a velocity range from $0-30 \mathrm{~cm} / \mathrm{s}$. The current is generally north ward from the Bering Strait, and then is divided into two currents, one directed northwest toward Wrangel Island, and another toward the northeast along the 
Alaskan coastline from Point Hope to Point Barrow. Surface current data (Brower et al., 1977) near the Alaskan Beaufort Sea area were also used in some simulation runs to compute water stress. The currents given by the Climatic Atlas (Brower et al., 1977) are generally westward with a wide velocity range of $2 \mathrm{~cm} / \mathrm{s}$ to $30 \mathrm{~cm} / \mathrm{s}$. Considering the fact of ice cover during all seasons, and the limits of published data, the water current influence on ice island motion in the other areas of the Arctic Ocean was considered to be zero in this study. The general form of water form drag is (e.g., Hoerner, 1965)

$$
F_{w f}=\frac{1}{2} \rho_{w} C_{f} A_{f}\left|<\bar{V}_{w}>_{D}-\bar{V}_{i}\right|\left(\bar{v}_{w}>_{D}-\bar{V}_{i}\right)
$$

where the $\mathrm{C}_{f}$ is a form drag coefficient, taken for this simulation to be 0.71 , from the results of Shirasawa et al. (1984) for the form drag of a cube. The quantity $A_{f}$ is the average frontal area of the wetted portion of the ice island. For calculating the water form drag, the submerged portion is set to be

$$
A_{f}=\left(\frac{\rho_{i}}{\rho_{w}} H_{i}\right) \vee \bar{A}
$$

where $\mathrm{H}_{\mathrm{i}}$ is ice island thickness, and $\left\langle\tilde{\mathrm{V}}_{\mathrm{w}}>_{D}\right.$ is the vertically-averaged water velocity over the frontal area $A_{f}$ of an ice island. As an initial approximation, $<\bar{V}_{\mathrm{w}}>_{\mathrm{D}}$ was treated in the same manner as for surface water current in the above section.

For a comparison of the magnitude of water skin friction and water form drag, one may calculate the ratio of these two forces, which yields

$$
\frac{F_{w f}}{F_{w s}}=\frac{1}{2}\left(\frac{C_{f}}{C_{w}}\right)\left(\frac{\rho_{i}}{\rho_{w}}\right)\left(\frac{H_{i}}{\sqrt{A}}\right)=284\left(\frac{H_{i}}{\sqrt{\bar{A}}}\right)
$$

with numerical values of densities and drag coefficients as mentioned above. According to this result the form drag force will be greater than the water skin 
friction drag force on the bottom of the ice island when $\mathrm{H}_{\mathrm{i}}>\sqrt{\mathrm{A}} / 284$; most known ice islands fall in this range. The ratio of water form drag force and water skin friction drag force as a function of thickness and horizontal dimension of an ice island is shown in Figure 114.

Force balance analysis for Hcbson's Choice Ice Island, based on observed data, shows that the pack ice force may be significant and comparable to the Coriolis force. The pack ice force may be a function of the relative velocity between the ice island and the pack ice, of the pack ice concentration, and of the time within a movement sequence of the ice island, as shown in Chapter III. In some nearshore areas, pack ice conditions will change seasonally, and it is expected that a relatively small pack ice force may be exerted on the ice island in summer. On the other hand, in the case in which the pack ice cover is compressed between the ice island and the shore, the pack ice force exerted on the ice island prevents the movement of the ice island toward the shore. For Hobson's Choice Ice Island, an empirical relation between pack ice force and ice island velocity has been obtained ( $\mathrm{Lu}, 1988$ ), as developed in Chapter III;

$$
\mathrm{F}_{\mathrm{p}}=0.36+2.57 \mathrm{~V}_{\mathrm{i}}-1.28 \mathrm{~V}_{\mathrm{i}}^{2} \quad 0 \leq \mathrm{V}_{\mathrm{i}}<1.5 \mathrm{~cm} / \mathrm{s}
$$

and

$$
\mathrm{F}_{\mathrm{p}}=0.02+0.89 \mathrm{~V}_{\mathrm{i}}-0.0009 \mathrm{~V}_{\mathrm{i}}^{2} \quad 1.5 \mathrm{~cm} / \mathrm{s} \leq \mathrm{V}_{\mathrm{i}}
$$

with a direction angle $\varnothing$ measured counterclock wise from the ice island velocity, of

$$
\emptyset=108^{\circ}+26 \times \ln \left(\frac{0.01 \mathrm{~V}_{\mathrm{a}}}{\mathrm{V}_{\mathrm{i}}}\right) ;
$$

here $F_{p}$ is the pack ice force in $M N, V_{a}$ and $V_{i}$ are in $\mathrm{cm} / \mathrm{s}$.

Because the pack ice force is a lateral force acting on the ice islands' sides, its magnitude must be influenced by the ice island size. In the general case for various sizes of ice islands, there must be a dimensional dependence on the pack ice force. This effect can also be shown by the fact that it is comparable to Coriolis force, i.e. 


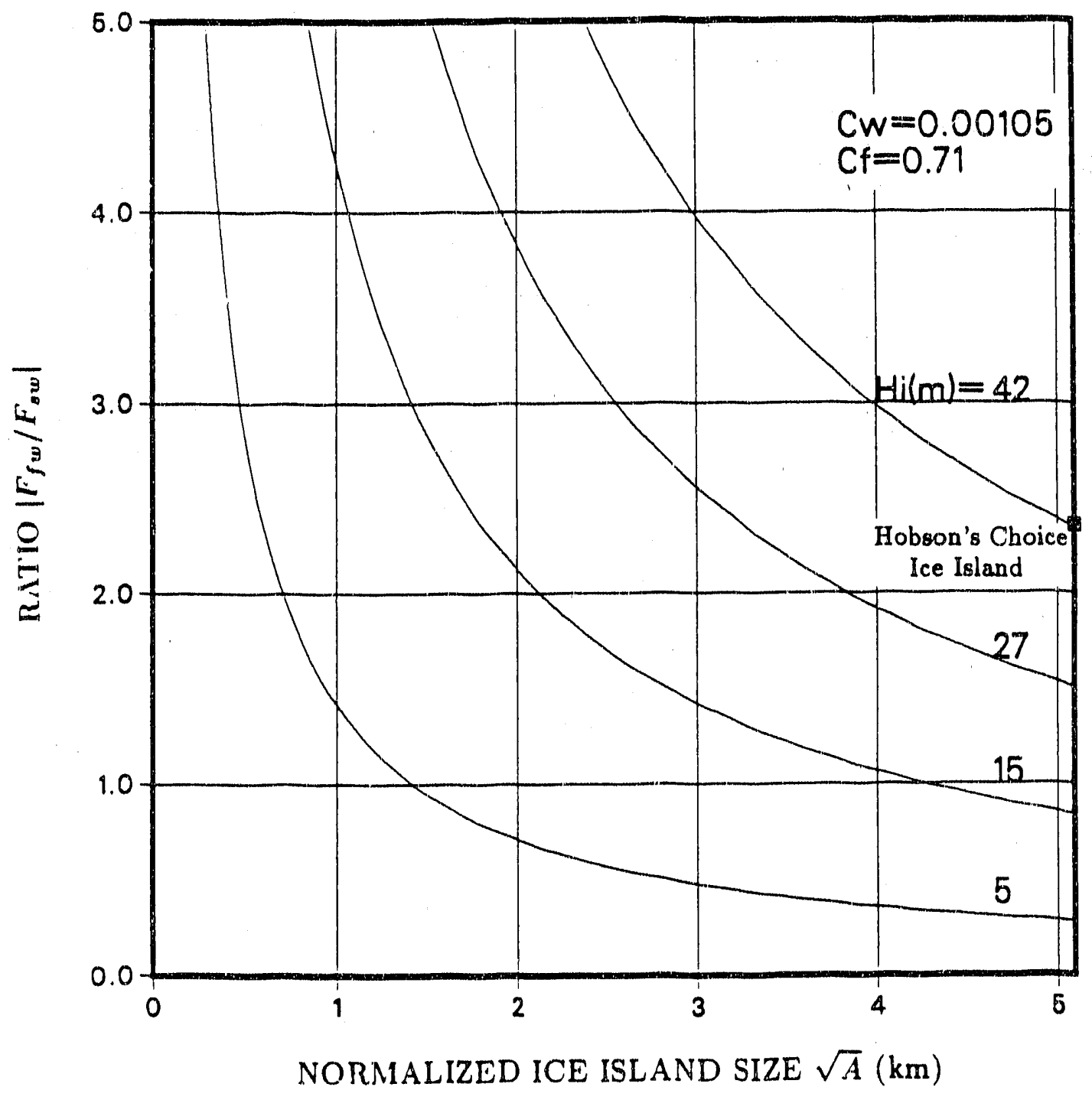

Fig. 114. Ratio of ice island form drag to surface water drag, as a function of ice island normalized dimension $\sqrt{\mathrm{A}}$. 


$$
\mathrm{F}_{\mathrm{p}} \doteq \mathrm{F}_{\mathrm{c}}=\mathrm{MrV}_{\mathrm{i}}=\rho_{\mathrm{i}} \mathrm{H}_{\mathrm{i}} \mathrm{ArV} \mathrm{V}_{\mathrm{i}}=\beta \mathrm{A} \cdot \mathrm{V}_{\mathrm{i}}
$$

with

$$
\beta=p_{i} H_{i} \text {, }
$$

where $f$ is the Coriolis parameter. Because $F_{p}$ is an integrated value of pack ice pressure over the whole lateral contact area of an ice island, it can be written as

$$
F_{p, V_{i}}=V_{0, t}=\int_{0}^{L} \int_{0}^{H(l)} \sigma d l d h=A_{p} \sigma_{p} \doteq V \bar{A} H_{p} \sigma_{p}
$$

where $\mathrm{L}$ is the contact length along the ice island edge; $H_{p}(1)$ is the contact thickness at length l; $\sigma$ is the pack ice pressure distribution on the ice island, which varies with location $(l, h)$ on the contact area, $A_{p}$ is total contact area, $\sigma_{p}$ is average pack ice pressure, $\sqrt{ } A$ is the normalized size of the $i c e$ island, and $K_{p}$ is the average thickness of the pack ice in contact with the ice island. The quantity $\sigma_{p}$ is a function of the relative velocity of the pack ice and the ice island, and of the sea ice constitutive law. A maximum value is the sea ice strength $\sigma_{u}$, i.e.

$$
o_{p}=\text { Function }\left(V_{p}-V_{i}, \sigma-\varepsilon\right) \leq o_{u}
$$

The strength of sea ice, $o_{u}$, is a function of strain rate and the temperature profile of the sea ice. For the general case in the simulation calculation, it was assumed that a constant pack ice thickness prevailed in the pack ice zones, and an invariant $\sigma-\varepsilon$ relation held. Further approximations of $\sigma_{p}$ as a function of the velocity of the ice island were wade. The above formula was related to the empirical formula for Hobson's Choice Ice Island as listed above with its area $26 \times 106_{\mathrm{m}} 2$, in the following way:

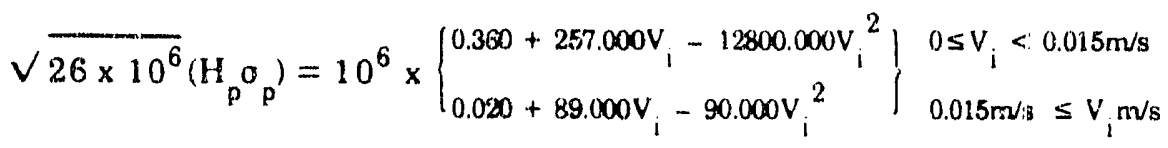

or 


$$
\left(H_{p} \sigma_{p}\right)=200 \times\left\{\begin{array}{l}
0.360+257.000 V_{i}-12800.000 V_{i}^{2} \\
0.020+89.000 v_{i}-90.000 v_{i}^{2}
\end{array} \mid \begin{array}{l}
0 \leq V_{i}<0.015 \mathrm{rr} / \mathrm{s} \\
0.015 \mathrm{~m} / \mathrm{s} \leq V_{i} \mathrm{~m} / \mathrm{s}
\end{array}\right.
$$

For the general case, therefore, the pack ice force was calculated by the formula

$$
\mathrm{F}_{p}=200 \vee \overline{\mathrm{A}} \times\left\{\begin{array} { l } 
{ 0 . 3 6 0 + 2 5 7 . 0 0 0 \mathrm { V } _ { \mathrm { i } } - 1 2 8 0 0 . 0 0 0 \mathrm { V } _ { i } ^ { 2 } } \\
{ 0 . 0 2 0 + 8 9 . 0 0 0 \mathrm { V } _ { \mathrm { i } } - 9 0 . 0 0 0 \mathrm { v } _ { \mathrm { i } } ^ { 2 } }
\end{array} \left\{\begin{array}{c}
0 \leq \mathrm{V}_{i}<0.015 \mathrm{~m} / \mathrm{s} \\
0.015 \mathrm{~m} / \mathrm{s} \leq \mathrm{V}_{i} \mathrm{~m} / \mathrm{s}
\end{array}\right.\right.
$$

with pack ice force $F_{p}$ in $\mathrm{N}$ and ice island area $A$ in $\mathrm{m}^{2}, \mathrm{~V}_{i}$ is in $\mathrm{m} / \mathrm{s}$. It was beyond the scope of this study to parameterize the pack ice pressure, and to consider the variation of pack ice thickness in space and time near the ice island.

Coriolis force $\mathrm{F}_{\mathrm{c}}$ can be written as

$$
\overline{\mathrm{F}}_{\mathrm{c}}=\mathrm{Mf} \overline{\mathrm{k}}_{\mathrm{N}} \overline{\mathrm{V}}_{\mathrm{i}}
$$

where the Coriolis parameter $f=2 \Omega \sin \phi, \Omega$ is the angular speed of rotation of the earth, and $\Phi$ is the latitude of the ice island position. The vector $\mathrm{k}$ is the vertical unit vector, positive upwards. The Coriolis force is larger than the same area of sea ice, due to the huge mass per unit area of an ice island, but the magnitude of the Coriolis acceleration

$$
{ }_{c}=\frac{F_{c}}{M}=-F_{i}
$$

may be small for low values of ice island speed.

\section{IV, 4. Monte Carlo Model of Random Wind Generation}

Since wind-driven motion was considered in this study as the primary cause of ice island movement, only the wind was considered as a random driving force in the simulations of the dynamic equation. In the Monte Carlo simulation of such ice island movement, one must generate the random wind according to its statistical distribution. For convenience, the Cartesian coordinate system was defined with the 
North Pole as the origin, the $\mathrm{X}$ axis along the Greenwich meridian, and the $\mathrm{Y}$ axis along $90^{\circ} \mathrm{E}$. The geostrophic wind vector was considered in the form of two components $\mathrm{u}$ and $\mathrm{v}$, along the $\mathrm{X}, \mathrm{Y}$ axes respectively.

For the correlation of the two components of wind, $u$ and v, Thorndike (1982) obtained a zero covariance of $u$ and $v$ at two points. This implies zero correlation and therefore one can consider the wind random process as two independent random processes $u(t)$ and $v(t)$. From the time correlation function (Thorndike, 1982) for geostrophic wind components ( $u$ and $v$ ) at zero space lag, the correlation coefficient is less than 0.2 when the time lag is greater than 4 days (Figure 115). The correlation coefficient is even smaller for non-zero space lag and greater than 4 days time lag. As an approximation, the time dependency of wind components were considered within 4 days and a time-step of 2 days. Both of the distribution functions of the random processes $u(t)$ and $v(t)$ can be written as $F_{3}\left(x_{1}, x_{2}, x_{3} ; t_{1}, t_{2}, t_{3}\right)$ where $t_{2}=t_{1}+2$ days and $t_{3}=t_{1}+4$ days. We assume an approximately Gaussian random process with a density function

$$
f_{3}\left(x_{1}, x_{2}, x_{3}, t_{1}, t_{2}, t_{3}\right)=\frac{1}{\sqrt{(2 n)^{3}|C|}} \exp \left|-\frac{1}{2}(\bar{X}-\bar{\mu})^{n} C^{-1}(\bar{X}-\bar{\mu})\right|
$$

where the variable vector is

$$
\dot{x}=\left(\begin{array}{l}
\mathbf{x}_{1} \\
\mathbf{x}_{2} \\
\mathbf{x}_{3}
\end{array}\right)
$$

the mean vector is

$$
\tilde{\mu}=\left(\begin{array}{l}
\mu_{x}\left(t_{1}\right) \\
\mu_{x}\left(t_{2}\right) \\
\mu_{x}\left(t_{3}\right)
\end{array}\right)
$$

and the autocovariance matrix 


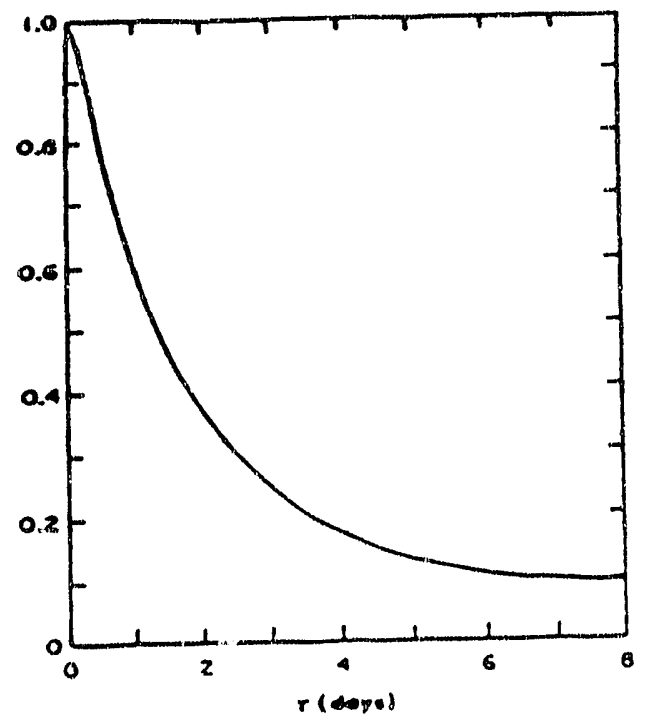

Fig. 115. Observed time correlation function for geostrophic wind at zero lag. The variances are $\operatorname{var}(\mathrm{u})=\operatorname{var}(\mathrm{v})=44 \mathrm{~m}^{2} \mathrm{~s}^{-2}$ (source: Thorndike, 1982). 


$$
C=\left(c_{x}\left(t_{i}, t_{j}\right)\right) \quad i, j=1,2,3
$$

is symmetric. $|\mathrm{C}|=$ det.C. This Gaussian process is complately determined by $\bar{\mu}$ and C.

The determination of the mean vector $\mu$ and the autocovariance matrix $C$ may be obtained as follows. The mean vector of the geostrophic wind was obtained for each month from mean pressure field charts by

$$
\mathrm{V}_{\mathrm{g}}=\mathrm{c} \overline{\mathrm{k}} \times \bar{\nabla} \mathrm{P}
$$

where $\bar{V}_{g}$ is geostrophic speed, $c=\left(\rho_{a} f\right)^{-1}$, and $P$ is sea level pressure. The monthlyaveraged pressure maps of the Arctic Ocean (Colony, 1987) represented a refinement as compared to the previous use of quarterly maps (Li et al., 1988).

In general, the annually-averaged surface geostrophic wind field over the Arctic Ocean is an anticyclonic system. When considered over short periods of time (months), however, it is more variable (Figures 147-159). The maps from October to May show that the average sea level air circulation is basically dominated by a large high pressure center over the west portion of the Arctic Ocean, i.e., anticyclones are common over the winter frozen ocean (Colony, 1987). The highest mean pressure gradient period, on the average, appears in December. After May, the mean pressure field undergoes rapid change, high pressure gradients are weaker and the prevailing air streams are directed from the Chukchi Sea to the Greenland-Spitzbergen area. In summer (August), there is a relatively weak low mean pressure centered near the North Pole, and the prevailing circulation is cyclonic. In September, there is an average prevailing weak air stream from the Siberian continent over the polar region to the Canada-Greenland area (Colony, 1987). 


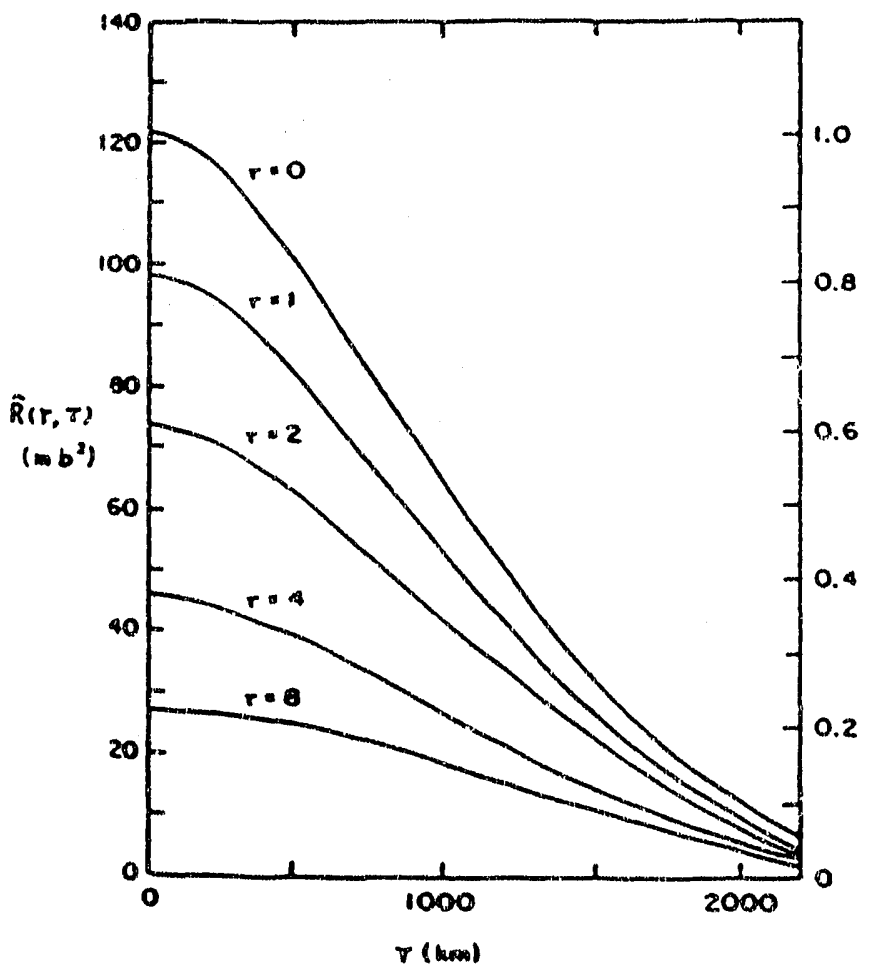

Fig. 116. Observed autocovariance function for pressure at space lag $\mathrm{r}(\mathrm{km})$ and time lag $\tau$ (days) (from Thorndike, 1982). 
From an analysis of observed data, a threshold wind speed of $5.25 \mathrm{~m} / \mathrm{s}$ appears to be necessary to initiate ice island motion ( $\mathrm{Lu}, 1988$ ). A $5.00 \mathrm{~m} / \mathrm{s}$ threshold wind speed was used in the simulation.

Thorndike (1982) presented a variance of $44 \mathrm{~m}^{2} \mathrm{~s}^{2}$ for $\mathrm{u}$ and $\mathrm{v}$, and a formula for calculating the autocovariances of wind components, which can be written as

$$
C_{i}(t, t+c)=c^{2}\left|\left(\frac{\Delta x_{i}^{2}}{r^{3}}-\frac{1}{r}\right) \frac{\partial R(r, t)}{\partial r}-\frac{\Delta x_{i}^{2}}{r^{2}} \frac{\partial^{2} R(r, t)}{\partial r^{2}}\right| i=1,2 .
$$

where $C_{i}=C_{u}$ and $\Delta x_{i}=\Delta x$ for $i=1, C_{i}=C_{v}$ and $\Delta x_{i}=\Delta y$ for $i=2$. The term $r$ is space lag in kilometers, the quantity $\tau$ is time lag in days, and $R(r, \tau)$ is the autocovariance function of pressure shown in Figure 116 (Thorndike,1982). For a time lag of zero, two and four days, $R(r, \tau)$ can be approximately expressed as

$$
R(r, \imath)=o(\tau)^{2} \exp \left[-r^{2} / 1300^{2}\right]
$$

where

$$
\sigma(\tau)^{2}=\left\{\begin{array}{r}
122 \text { if } \tau=0 \text { days } \\
74 \text { if } \tau=2 \text { days } \\
46 \text { if } \iota=4 \text { days }
\end{array}\right.
$$

Then from $R(r, r)$, one may obtain

$$
C_{i}(t, t+\tau)=0.36\left(1-2\left(\frac{\Delta x_{i}}{1300}\right)^{2} l \exp \left[-(r / 1300)^{2} J o(\tau)^{2} \quad i=1,2 .\right.\right.
$$

Thus the elements of the autocovariance matrix of the geostrophic wind are:

$$
\begin{array}{ll}
C_{\mathbf{x}}\left(t_{j}, t_{j}\right)=44 & j=1,2,3 . \\
C_{\mathbf{x}}\left(t_{1}, t_{2}\right)=C_{x}\left(t_{2}, t_{3}\right)=C_{i}(t, t+2) & i=1,2 . \\
C_{x}\left(t_{1}, t_{3}\right)=C_{i}(t, t+4) & i=1,2 .
\end{array}
$$

The transformation from uniform random numbers to a Gaussian random vector may be accomplished as follows. To produce a Gaussian random vector of geostrophic wind $\tilde{x}=\left[x\left(t_{1}\right), x\left(t_{2}\right), x\left(t_{3}\right)\right]$, which has a mean vector $\bar{\mu}$ and 
autocovariance matrix $\mathrm{C}$, from uniform random numbers generated directly by the computer, procedures described by Shreider (1962) were used. For independent random numbers $\lambda_{i}(i=1,2, \ldots, n)$ uniformly distributed over the interval $(0,1)$, the mean is $1 / 2$ and the standard deviation is $1 / 2 \sqrt{ } 3$. From the Central Limit Theorem, one can obtain a Gaussian random number

$$
\xi=\lambda_{1}+\lambda_{2}+\ldots+\lambda_{12}-6
$$

which has zero mean and variance of 1 .

To produce a Gaussian random vector $\bar{\eta}=\left(\eta_{1}, \eta_{2}, \eta_{3}\right)$ whose mean vector $\bar{\mu}=0$ with three independent Gaussian random numbers $\xi_{\mathrm{i}}(\mathrm{i}=1,2,3)$ whose mean $\mathrm{E}\left(\xi_{\mathrm{i}}\right)=0$ and variance $\mathrm{D}\left(\xi_{\mathrm{i}}\right)=1$, we choose a linear transformation

$$
\begin{aligned}
& \eta_{1}=a_{11} \xi_{1} \\
& \eta_{2}=a_{21} \xi_{1}+a_{22} \xi_{2} \\
& \eta_{3}=a_{31} \xi_{1}+a_{32} \xi_{2}+a_{33} \xi_{3}
\end{aligned}
$$

where $a_{i j}(i, j=1,2,3)$ are to be found from the conditions

$$
\mathrm{E}\left(\eta_{\mathrm{k}}-0\right)\left(\eta_{1}-0\right)=\mathrm{E}\left(\eta_{\mathrm{k}} \eta_{1}\right)=\mathrm{C}_{\mathrm{kl}} \quad \mathrm{k}=1,2,3
$$

and

$$
\mathrm{E}\left[\left(\xi_{k}-0\right)(\xi-0)=\mathrm{E}\left(\xi_{k} \xi_{1}\right)=\delta_{\mathrm{k} 1} \quad 1=1,2,3\right.
$$

where $C_{k l}$ are elements of the autocovariance matrix of vector $\bar{\eta}$. Therefore we have

$$
\begin{gathered}
E\left(\eta_{1}^{2}\right)=a_{11} E=a_{11}^{2}=c_{11}, \\
a_{11}=\sqrt{c_{11}}
\end{gathered}
$$

Similarly, we have

$$
\mathrm{a}_{21}=\frac{\mathrm{c}_{21}}{\mathrm{a}_{11}}
$$




$$
\begin{gathered}
a_{22}=\sqrt{c_{22}-a_{21}^{2}} \\
a_{31}=\frac{c_{31}}{a_{11}} \\
a_{32}=\frac{c_{32}-a_{21} a_{31}}{a_{22}} \\
a_{33}=\sqrt{c_{33}-a_{31}^{2}-a_{32}^{2}}
\end{gathered}
$$

Then one obtains a Gaussian random vector with mean vector $\bar{\mu}$ by

$$
\bar{x}=\bar{\eta}+\bar{\mu}
$$

\section{IV.5. Simulation and Domain Mesh}

The domain used in the simulation includes most of the Arctic Ocean and some marginal seas, except the shallow water areas, and is surrounded by simulated land boundaries and four open water boundaries (Figure 117). Ice islands will ground on the sea floor when they move towards the shore in shallow water coastal zones, and the water depth at which they will ground depends on the ice island thickness. On the basis of recent ice island thickness observations (Jeffries et al., 1988), a 36-meter water depth contour was considered to be appropriate as the land boundary, with some simplification on the broad continental shelf off Siberia. In the simulation, once the ice island reaches the boundary it stops moving towards the coast and can only move in a direction along or away from the coast depending on the wind direction. The open water boundaries are considered to be the main connections of the Arctic Ocean with other oceans, allowing ice islands to move out of the Arctic Ocean. The 


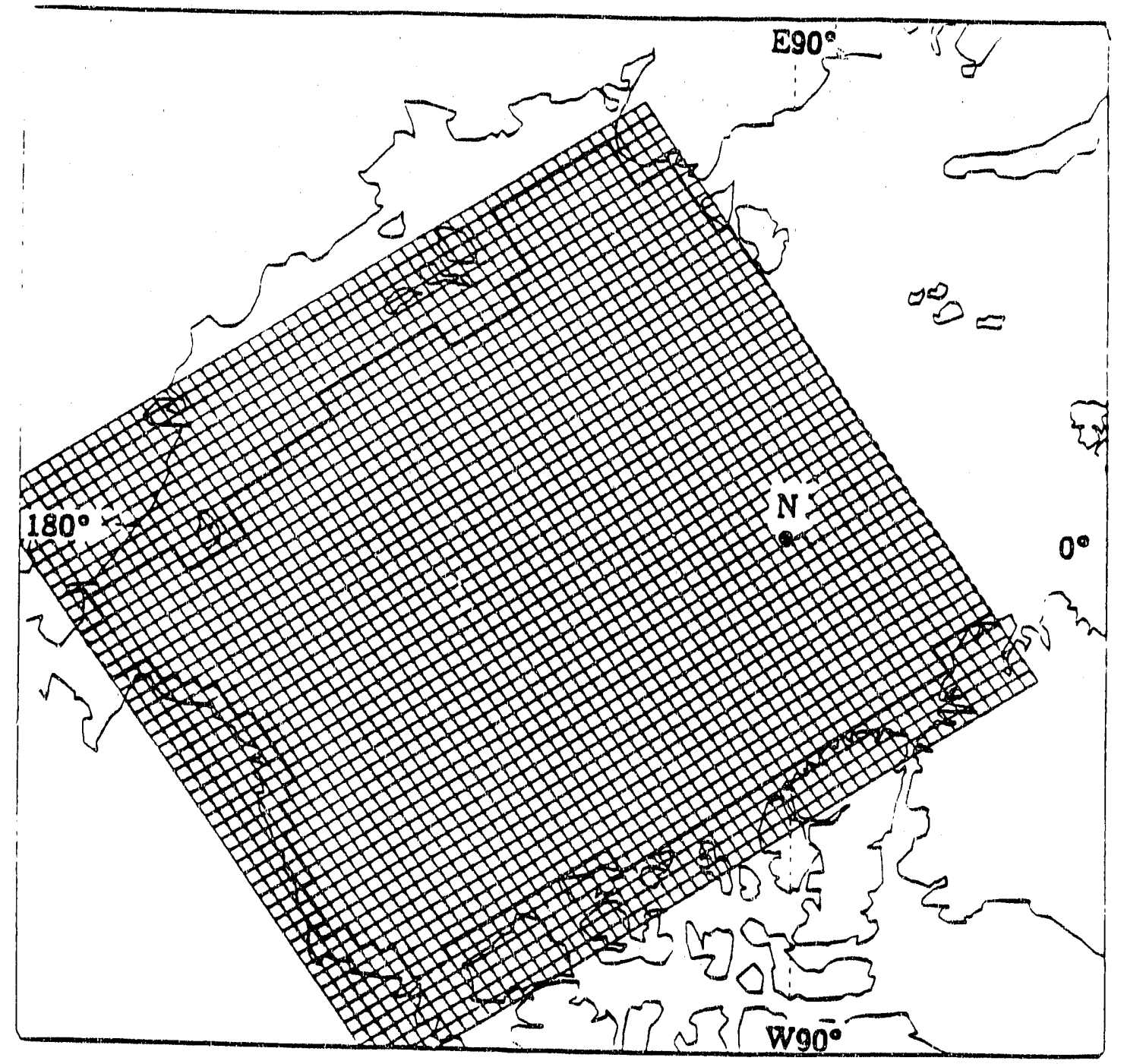

Fig. 117. Simulation mesh for trajectory calculation, $56 \times 51$ elements with 50 km spacing. 
first one is simply represented as a straight line from the northeast end of Greenland to Severnaya Zemlya. The second one is at the shallow and narrow Bering Strait. The third one is at the mouth of Nares Strait. The final open water boundary is at the Amundsen Gulf, between Banks Island and the North American mainland. Once an ice island moves beyond one of the open water boundaries, it is considered to have escaped permanently from the Arctic Ocean. There are also other connections from the Arctic Ocean through the Canadian Arctic Archipelago channels. However, these passages are usually covered by fast ice, and ice islands penetrate ti:em only infrequently; thus, these connections are considered as land boundaries in the simulation.

The simulation is performed on a $56 \times 51$ element grid with a resolution of 50 $\mathrm{km}$ for recording movement events of ice islands (Figure 117), and with a $10 \times 9$ element grid with a resolution of $300 \mathrm{~km}$ for the monthly-averaged wind field, and for the water current field (Figure 118).

The simulation area is divided into grid blocks, each with a dimension of $50 \times 50$ $\mathrm{km}$ for recording the passage of an ice island. The event of one ice island passing through an individual block ( $\mathrm{i}, \mathrm{j})$ during every 2 days is recorded as 1 and added to the accumulated sum $S_{i, j}$ for this block. After a long running time, normalized in $\mathrm{n}$ years, one obtains an approximation of the probability of ice islands passing through a block during $n$ years as

$$
P_{i, j}=\frac{S_{i, j}}{\sum_{i, j=1}^{n} S_{i, j}}
$$

The return period (years) for block $(i, j)$ is

$$
R_{i, j}=\frac{n}{S_{i, j}}
$$




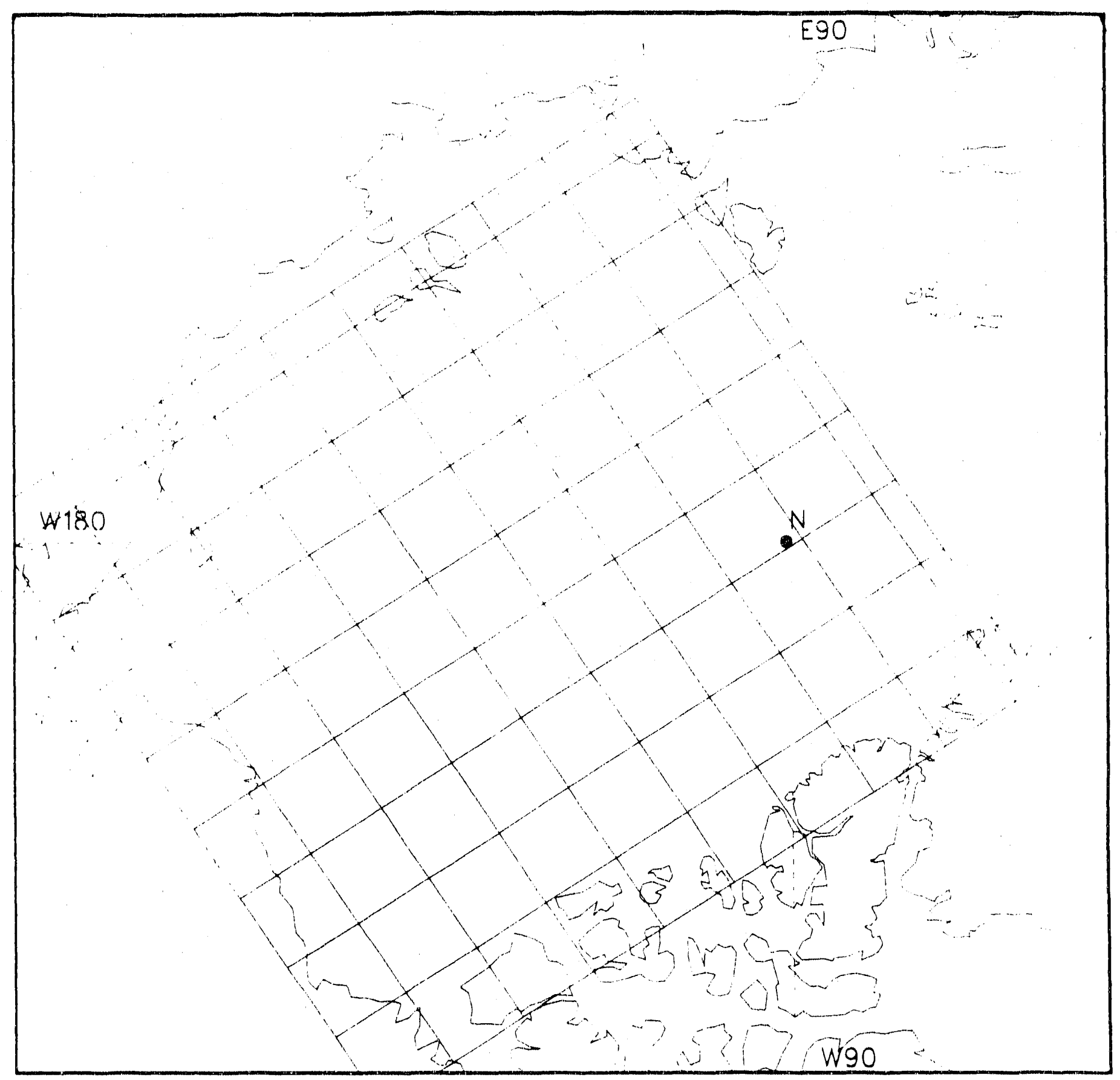

Fig. 118. Simulation mesh for wind calculation, $10 \times 9$ elements with $300 \mathrm{~km}$ spacing. 
The computer program flow chart is shown in Figure 119 and the actual program is reproduced in the Appendix.

\section{IV.6. Simulation Results and Comparisons}

Severai results were recorded in the simulation, including random trajectories, lifetimes of ice islands, total numbers of live ice islands in the Arctic Ocean, frequencies of ice island ejection through each open water boundary, and probability recurrences (in years) of ice island trajectories. All of these results are explained and compared with observed data, to the extent that the data is available. Certain sensitivity tests are also described.

In the simulation, each random ice island trajectory can be tracked, and the first 21 trajectories were recorded in this simulation and plotted as shown in Figures 120 to 140. In order to be more explicit, these figu res were plotted in different data point intervals. From these random trajectories, two basic patterns of ice island trajectories can be seen. The first pattern, is a short trajectory near the northern side of Axel Heiberg and Ellesmere Islands, directed to an ejecting route at north Greenland and Nares Strait, as shown in Figures 125, 139 and 140. Few ice island trajectories are in this pattern with only about $10 \%$ frequency, calculated from these results. The island WH-6, which is known to have entered Robeson Channel shortly after generation, is the closest known example of this brief lifetime (Nutt, 1986). The second pattern is the clockwise circulation or gyre pattern, in a large scale, covering the Beaufort Sea, as shown in Figure 120 to 140 (except for Figures 125, 139 and 140). Most ice island trajectories are in this pattern, with a frequency of $90 \%$ according to these simulated results. After generation, ice islands move down towards the southwest, along Ellesmere and Axel Heiberg Islands, with more intensive loops in the area near the Canadian Beaufort Sea coast. Then they turn right and move northwest to the Chukchi Sea, and often move into another intensive loop area nearby. Further, in 


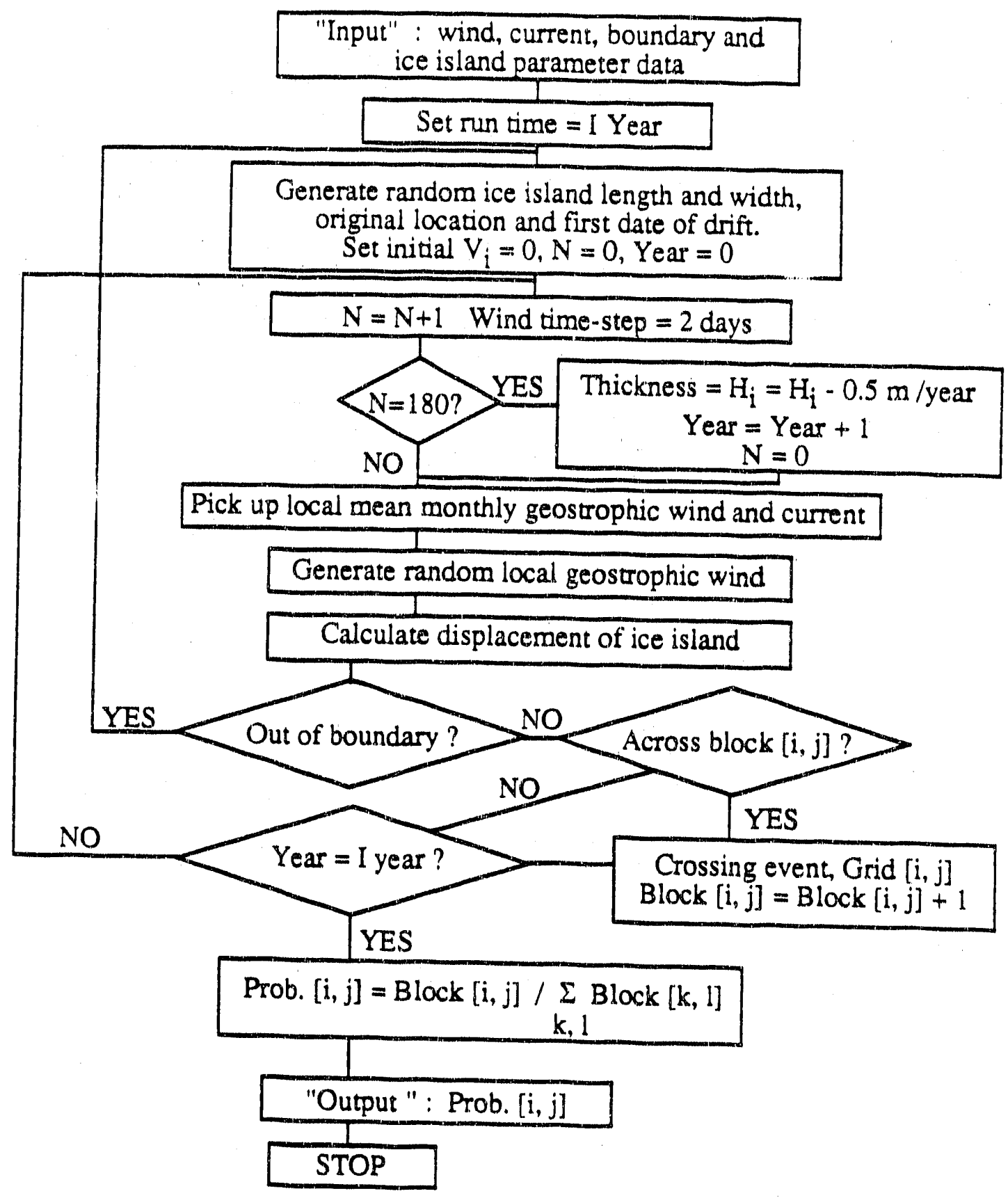

Fig. 119. Computer program flow chart. 
RANDOM ICE ISLAND TRAJECTORY 1

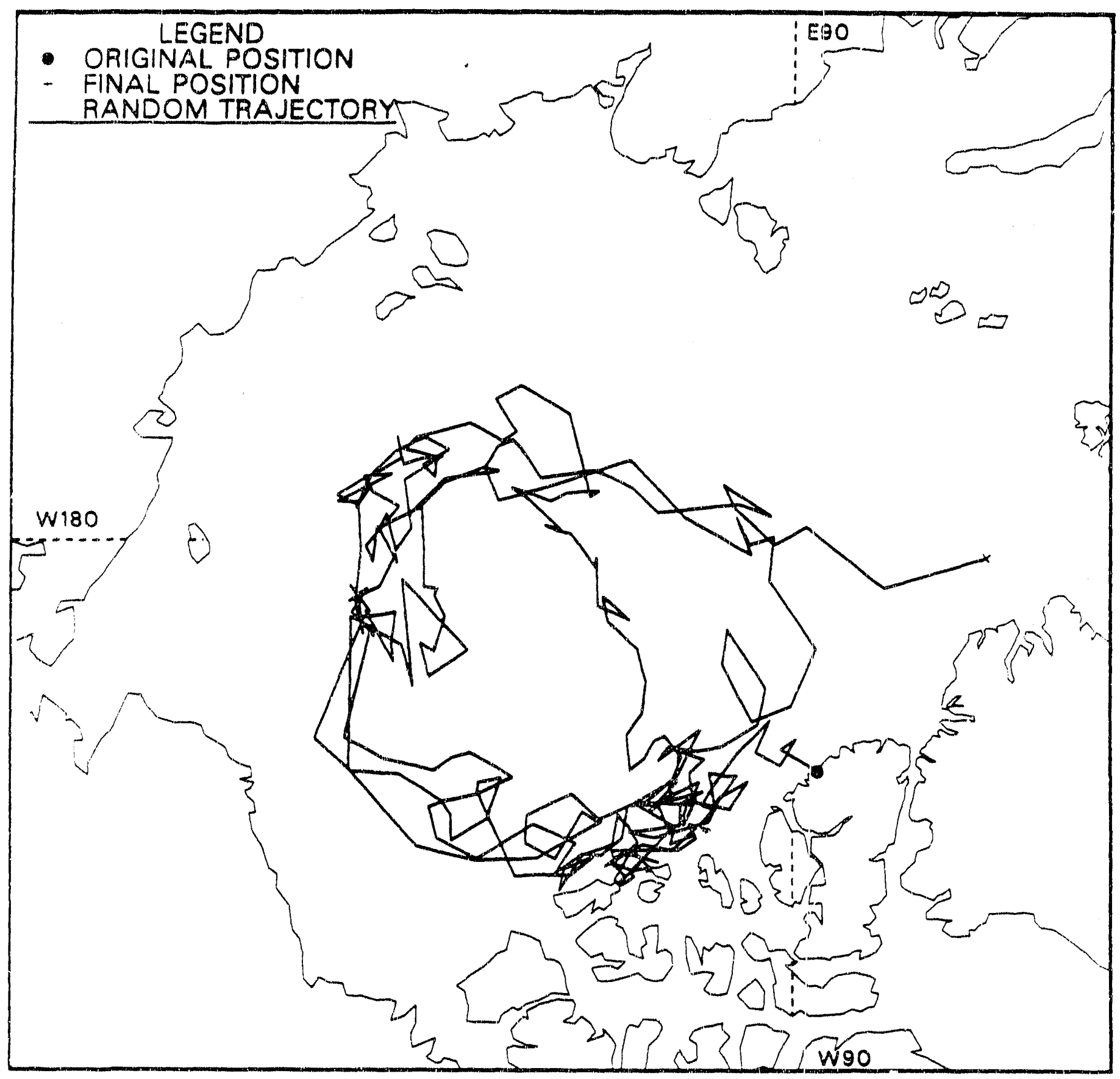

Fig. 120. Random ice island trajectory 1. 
RANDOM ICE ISLAND TRAJECTORY 2

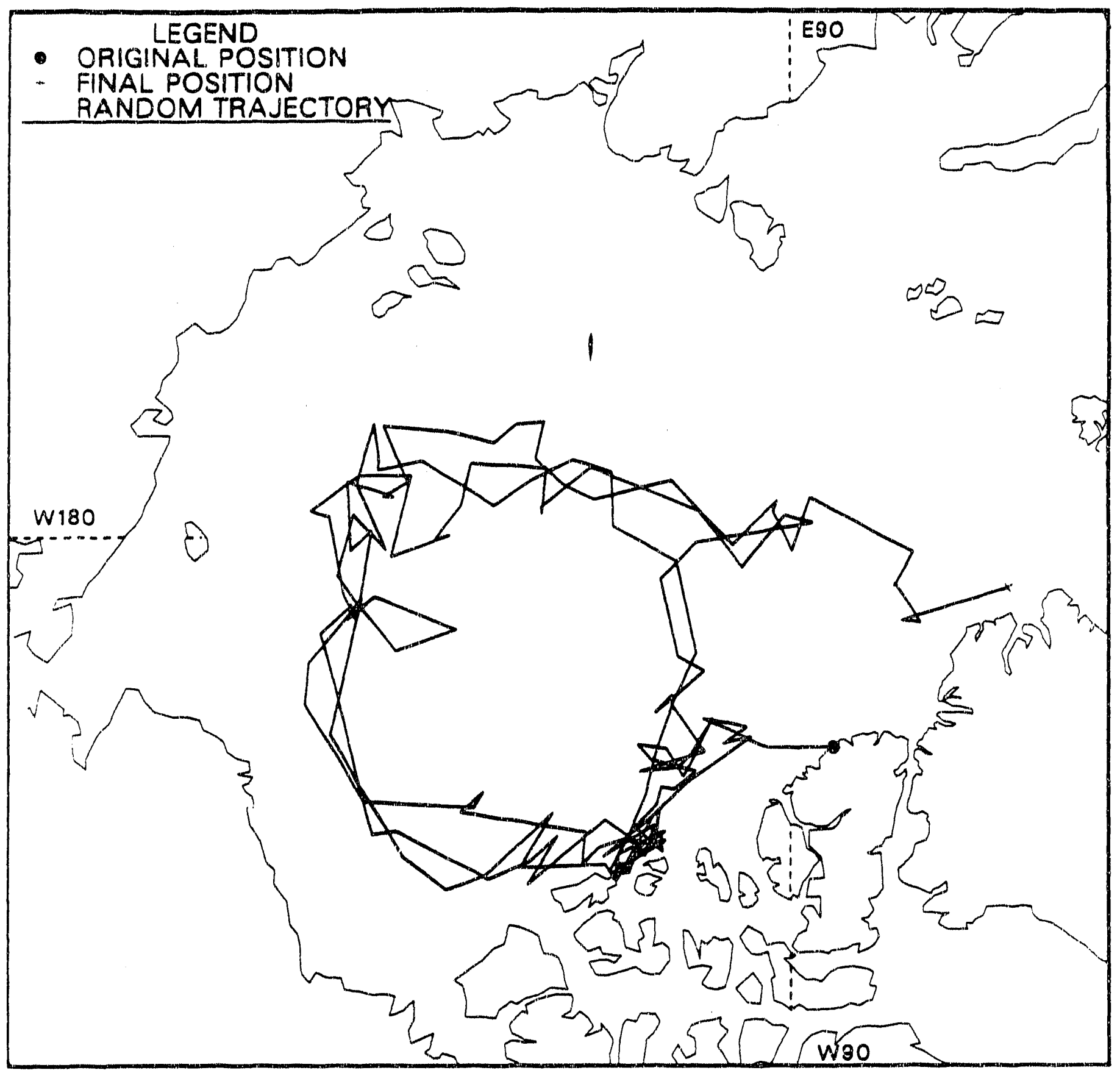

Fig. 121. Random ice island trajectory 2. 


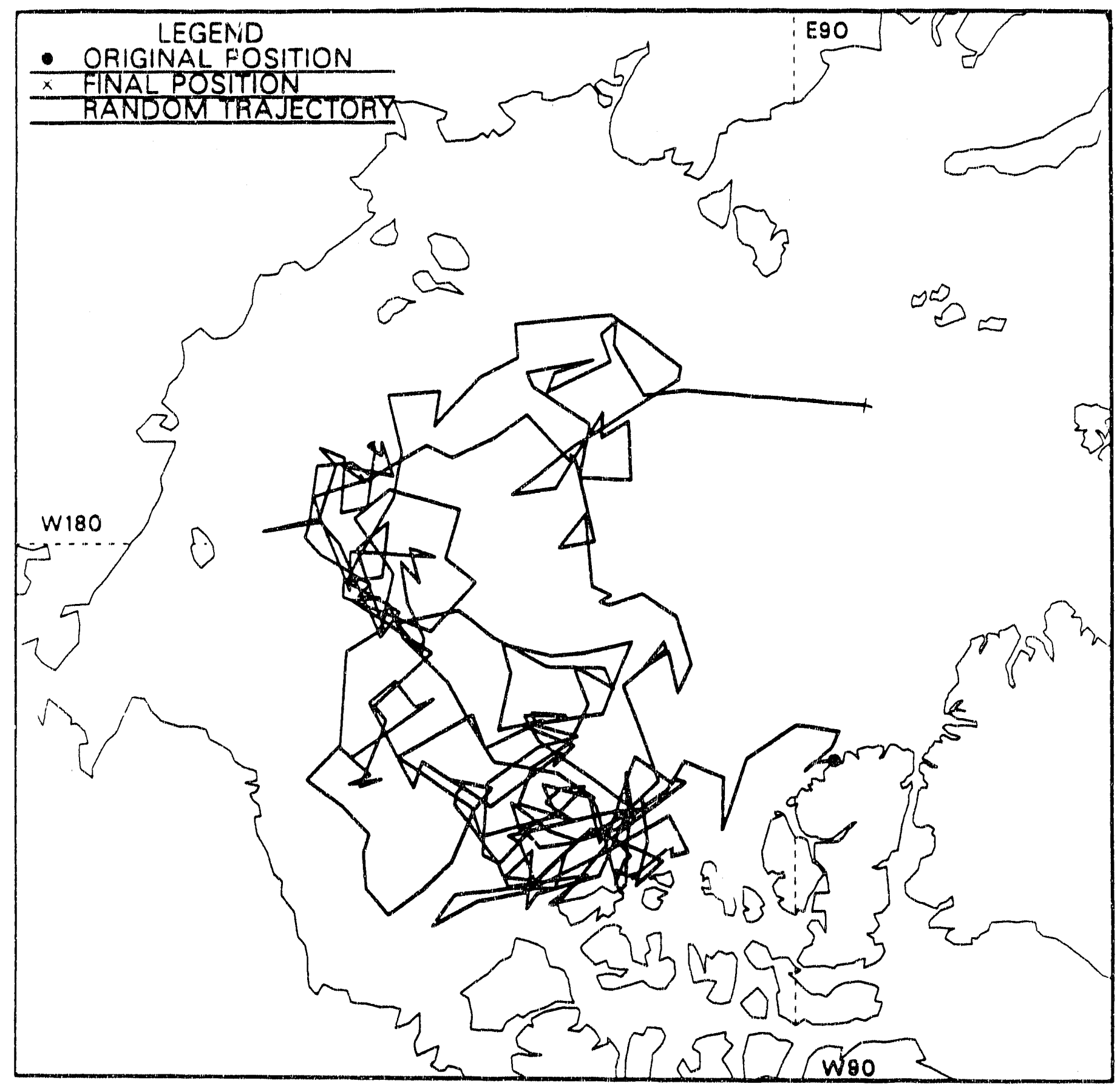

Fig. 122. Random ice island trajectory 3. 
RANDOM ICE ISLAND TRAJECTORY 4

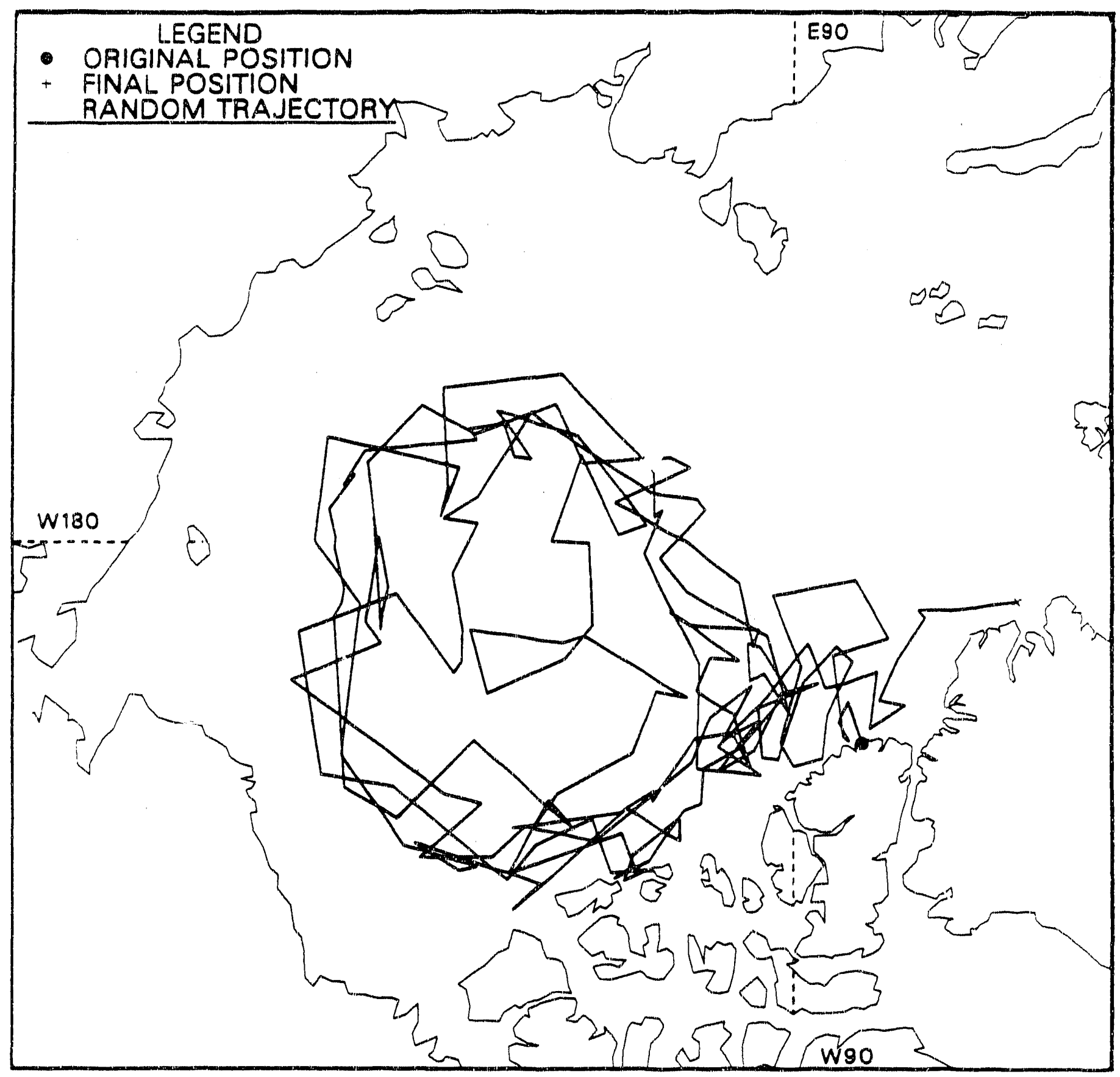

Fig. 123. Random ice island trajectory 4. 


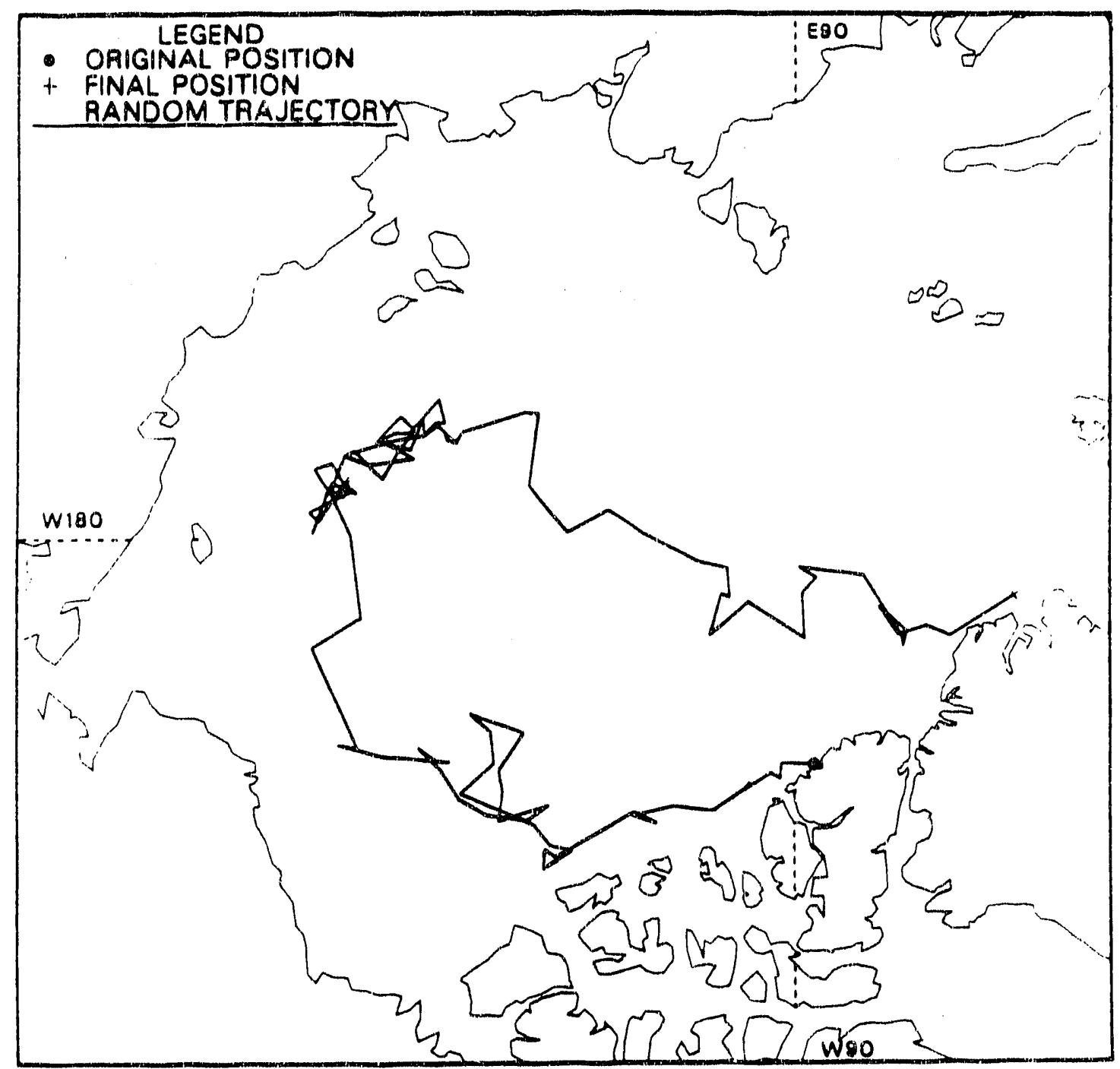

Fig. 124. Random ice island trajectory 5. 


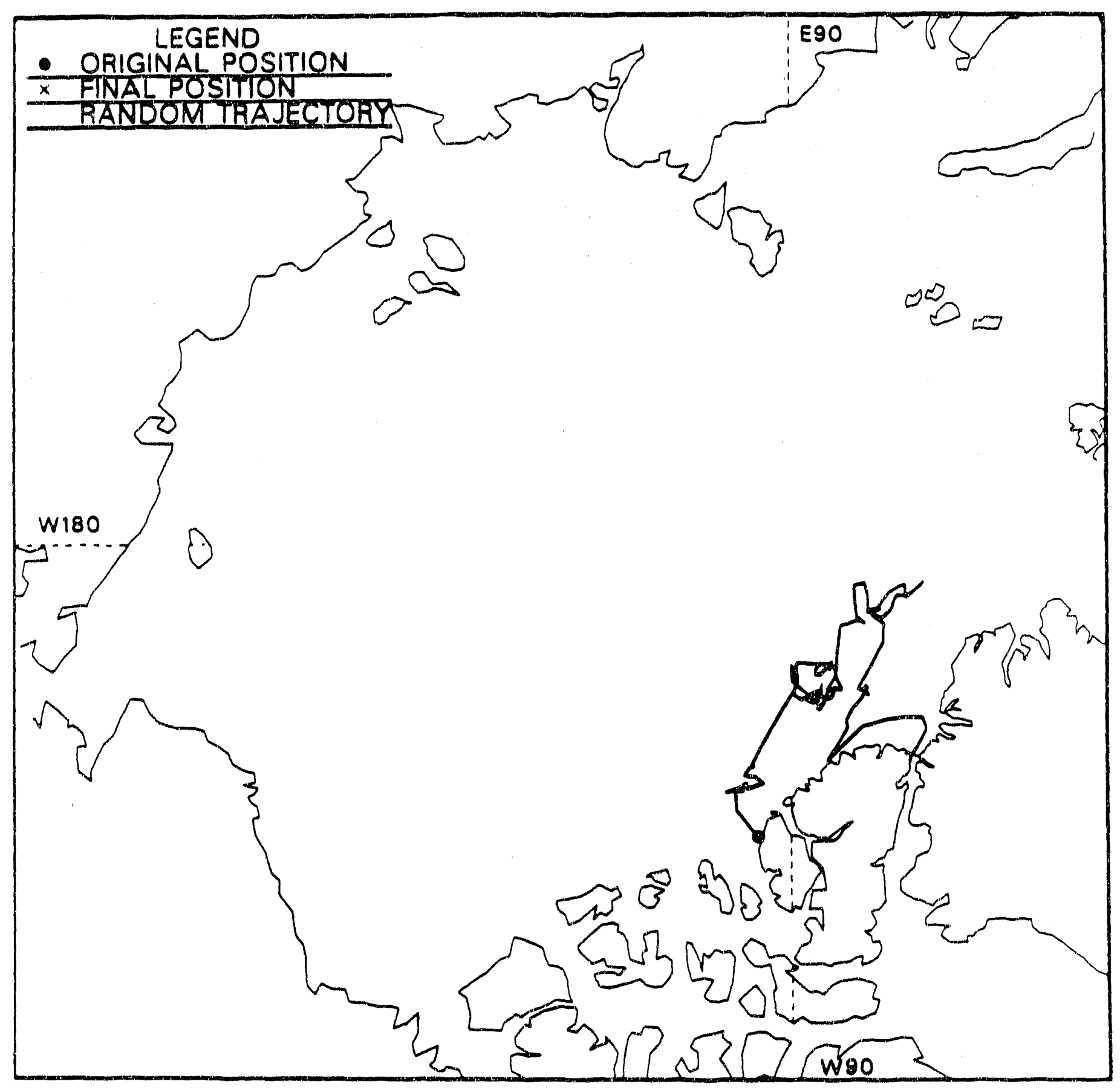

Fig. 125. Random ice island trajectory 6. 
RANDOM ICE ISLAND TRAJECTORY 7

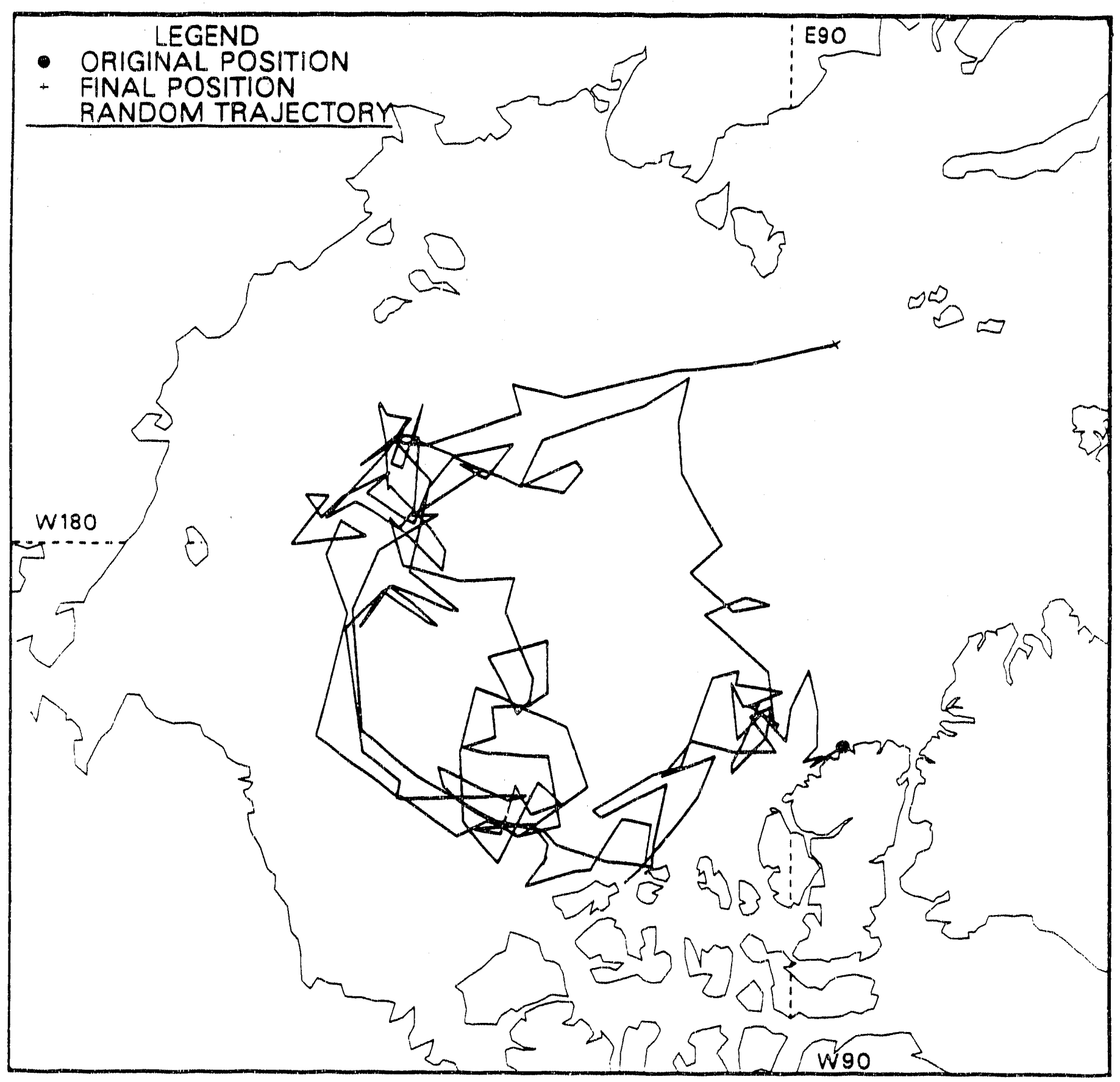

Fig. 126. Random ice island trajectory 7. 
RANDOM ICE ISLAND TRAJECTORY 8

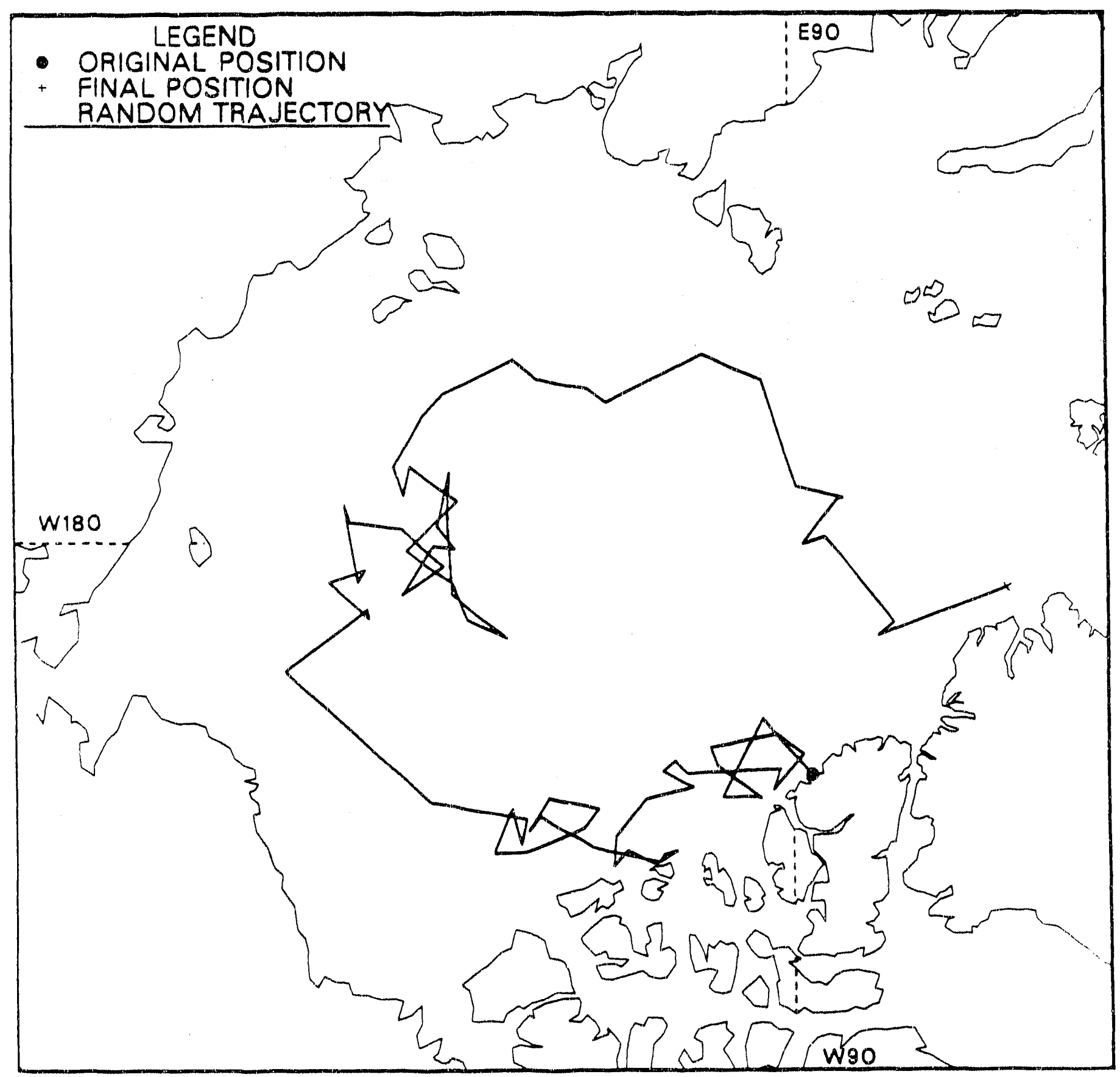

Fig. 127. Random ice island trajectory 8. 
RANDOM ICE ISLAND TRAJECTORY 9

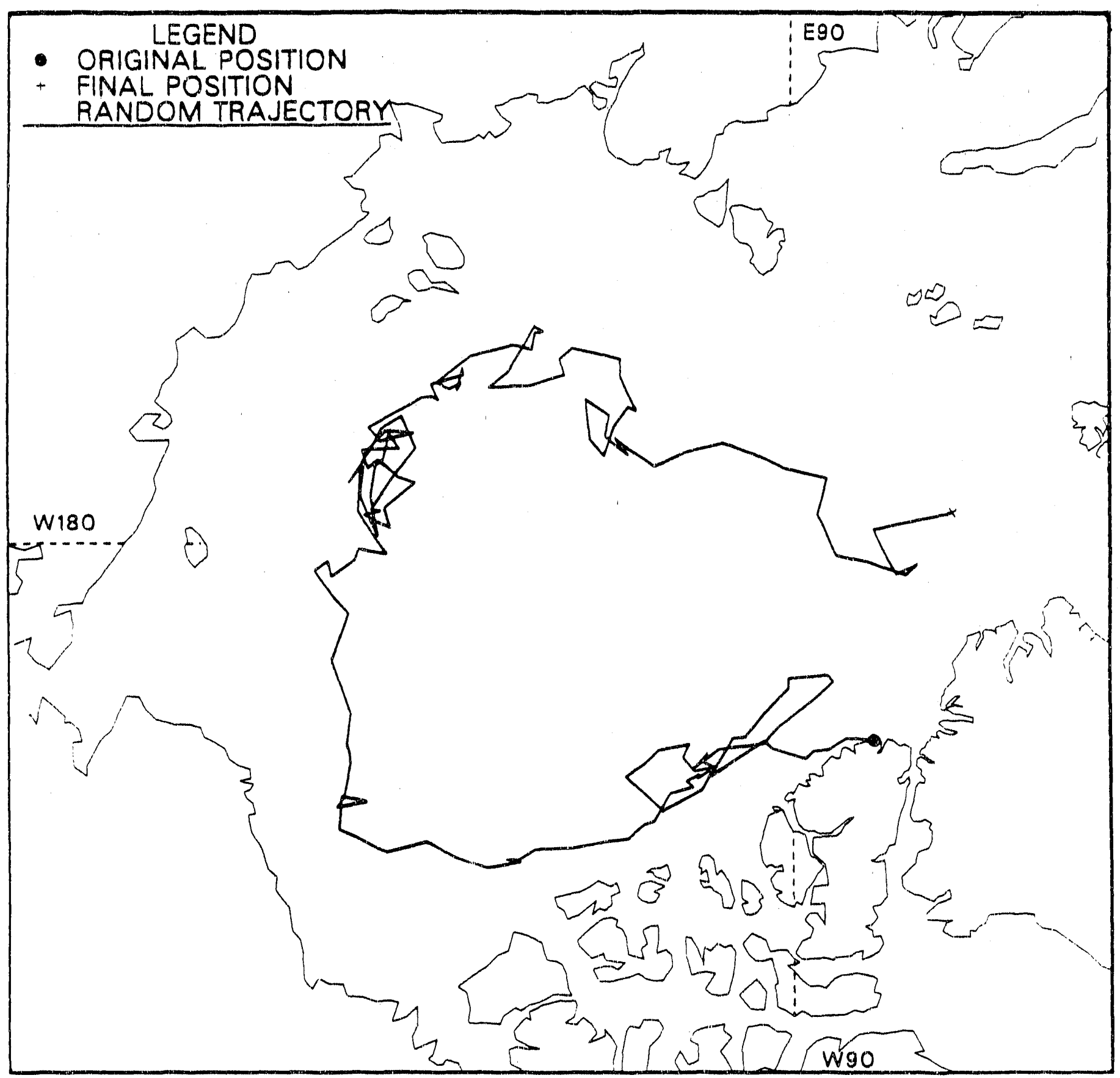

Fig. 128. Random ice island trajectory 9. 
RANDOM ICE ISLAND TRAJECTORY 10

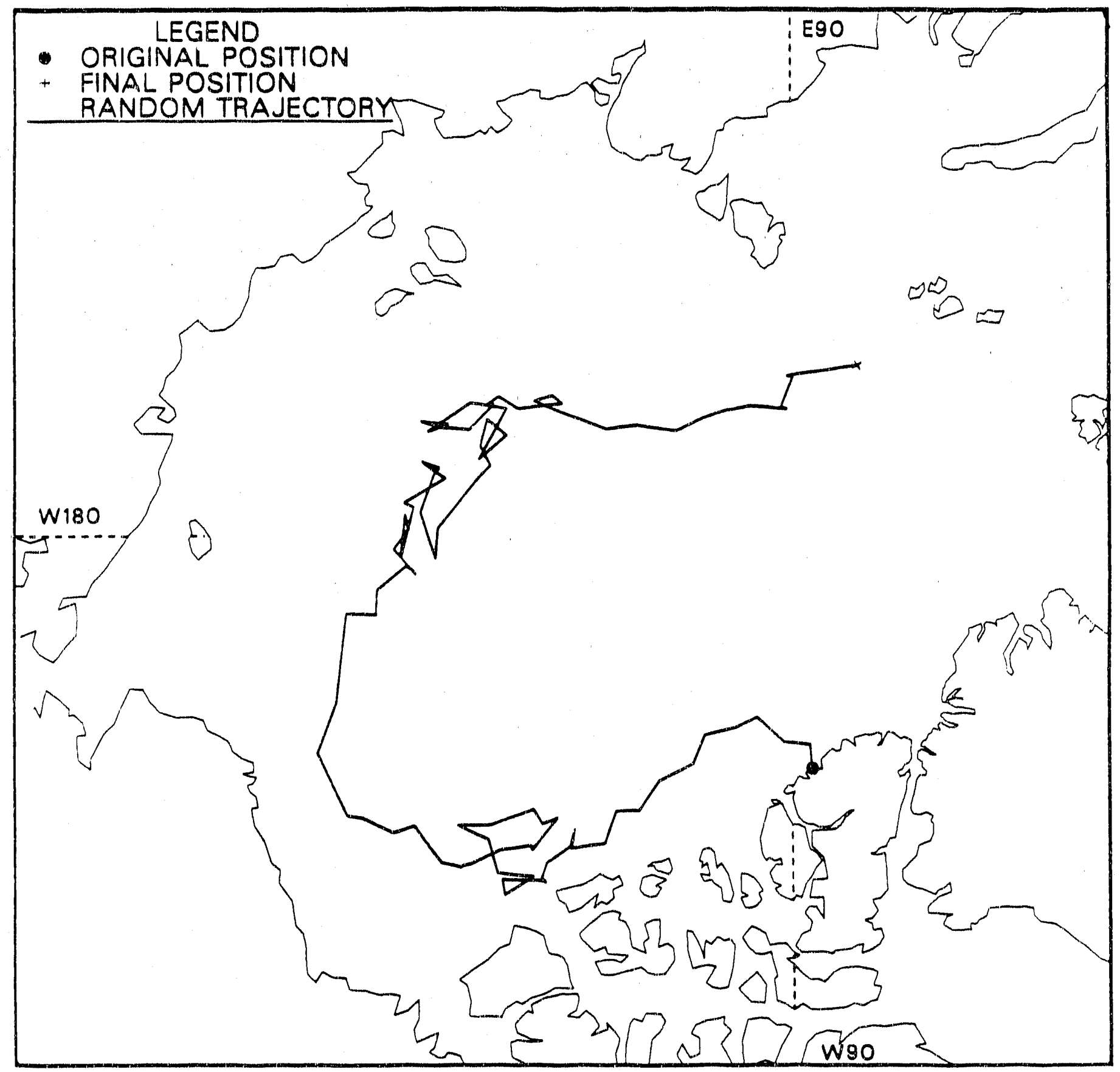

Fig. 129. Random ice island trajectory 10. 
RANDOM ICE ISLAND TRAJECTORY 11

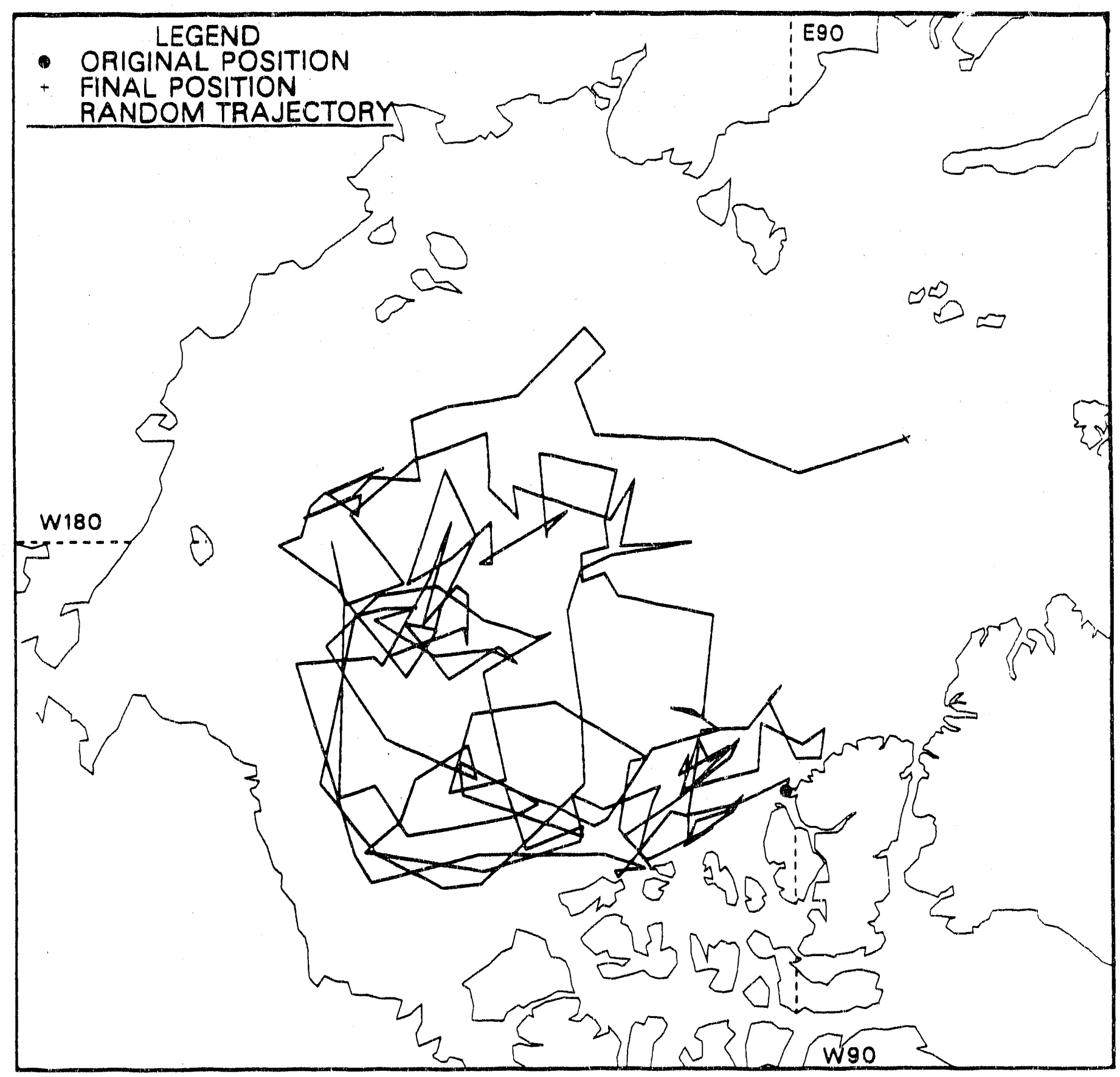

Fig. 130. Random ice island trajectory 11. 
RANDOM ICE ISLAND TRAJECTORY 12

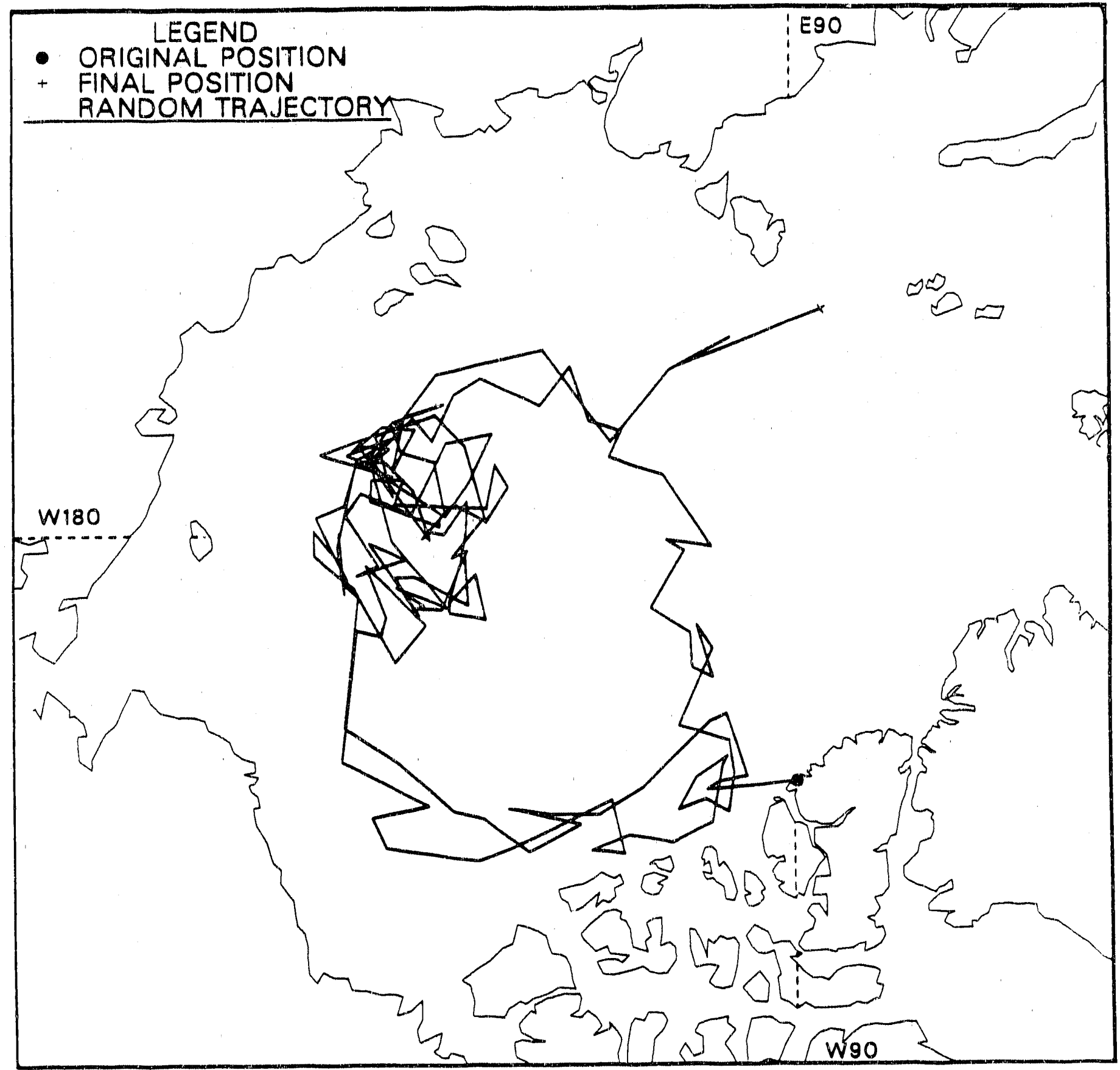

Fig. 131. Random ice island trajectory 12. 


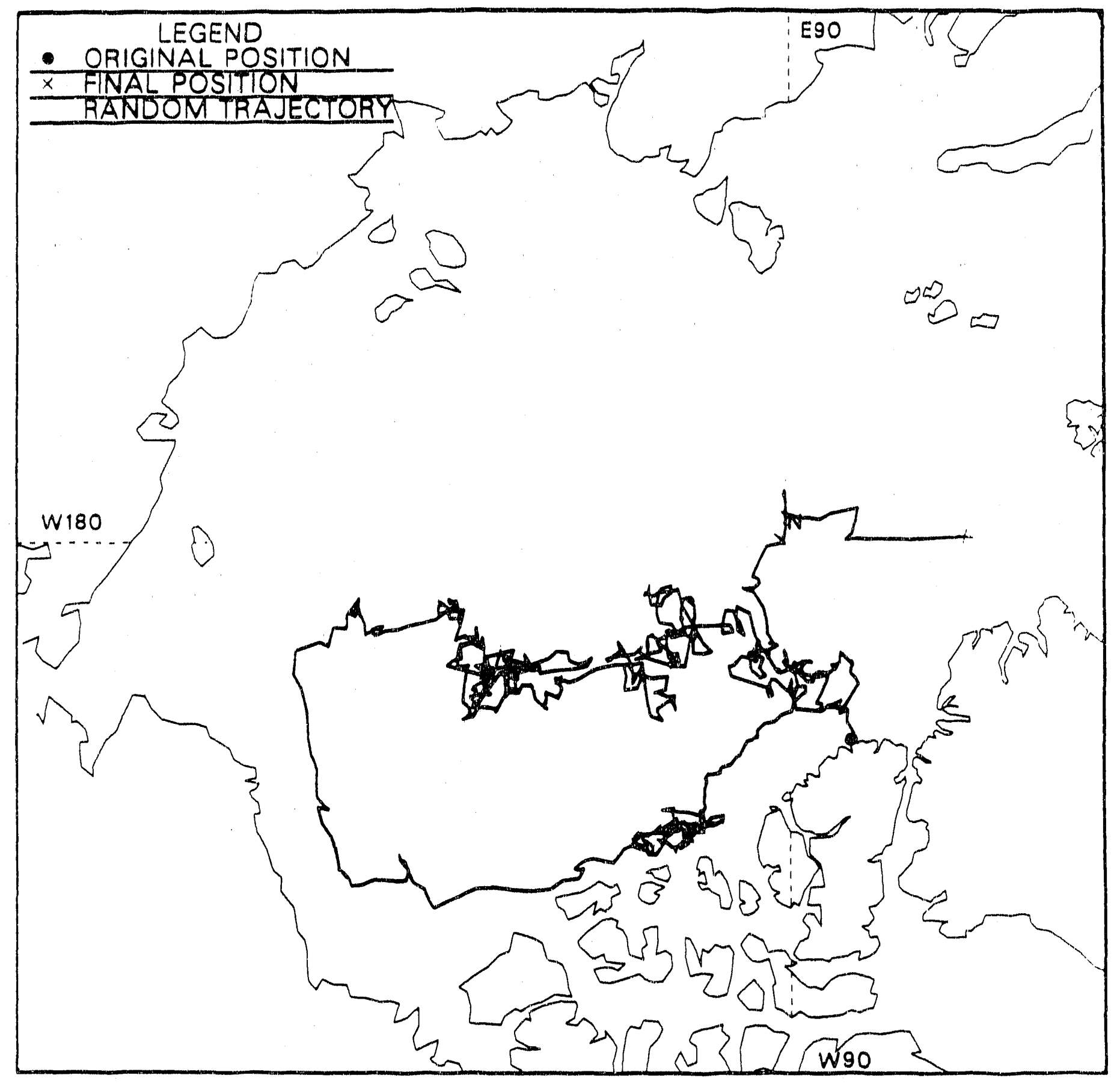

Fig. 132. Random ice island trajectory 13. 
RANDOM ICE ISLAND TRAJECTORY 14

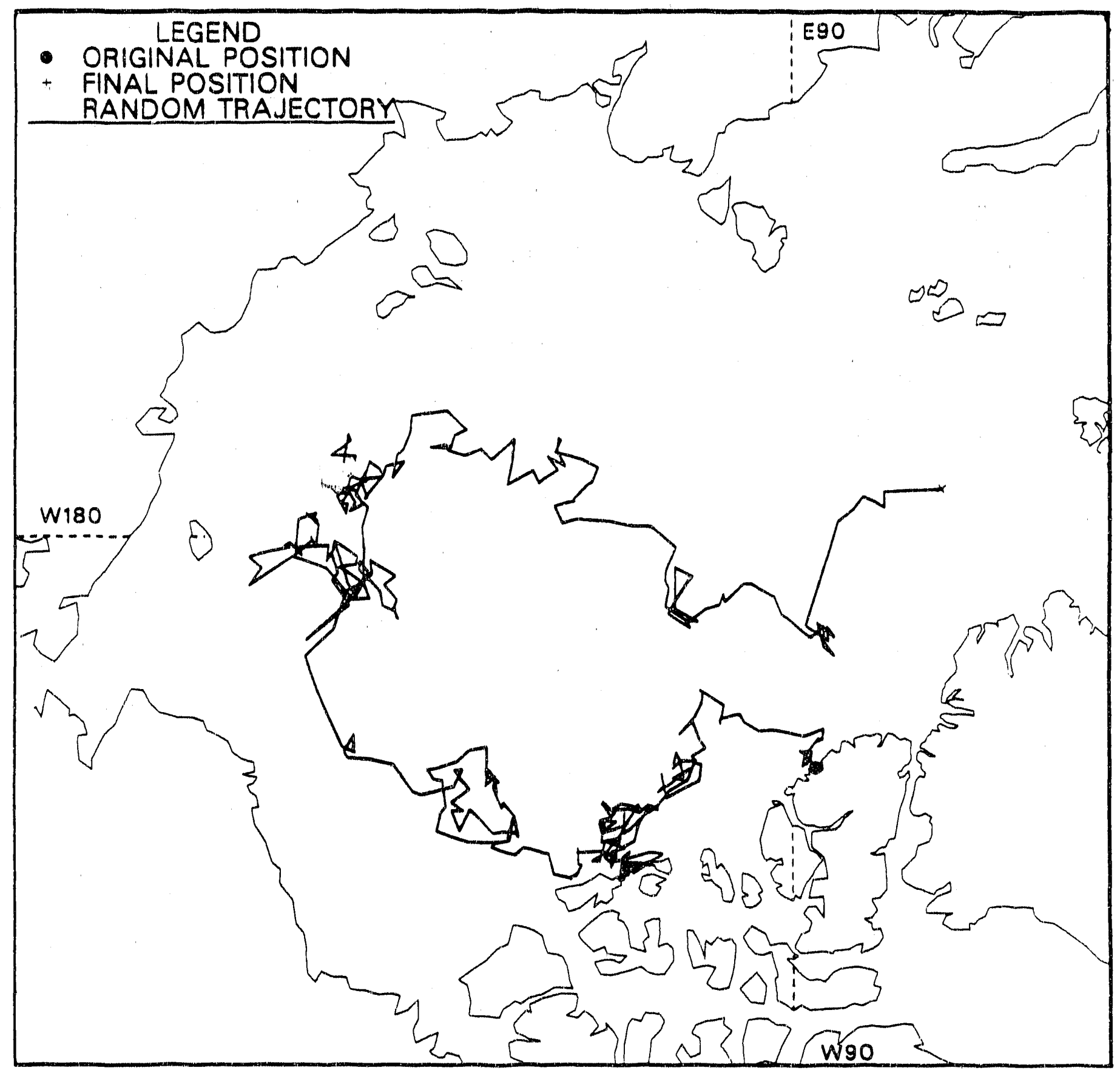

Fig. 133. Random ice island trajectory 14. 
RANDOM ICE ISLAND TRAJECTORY 15

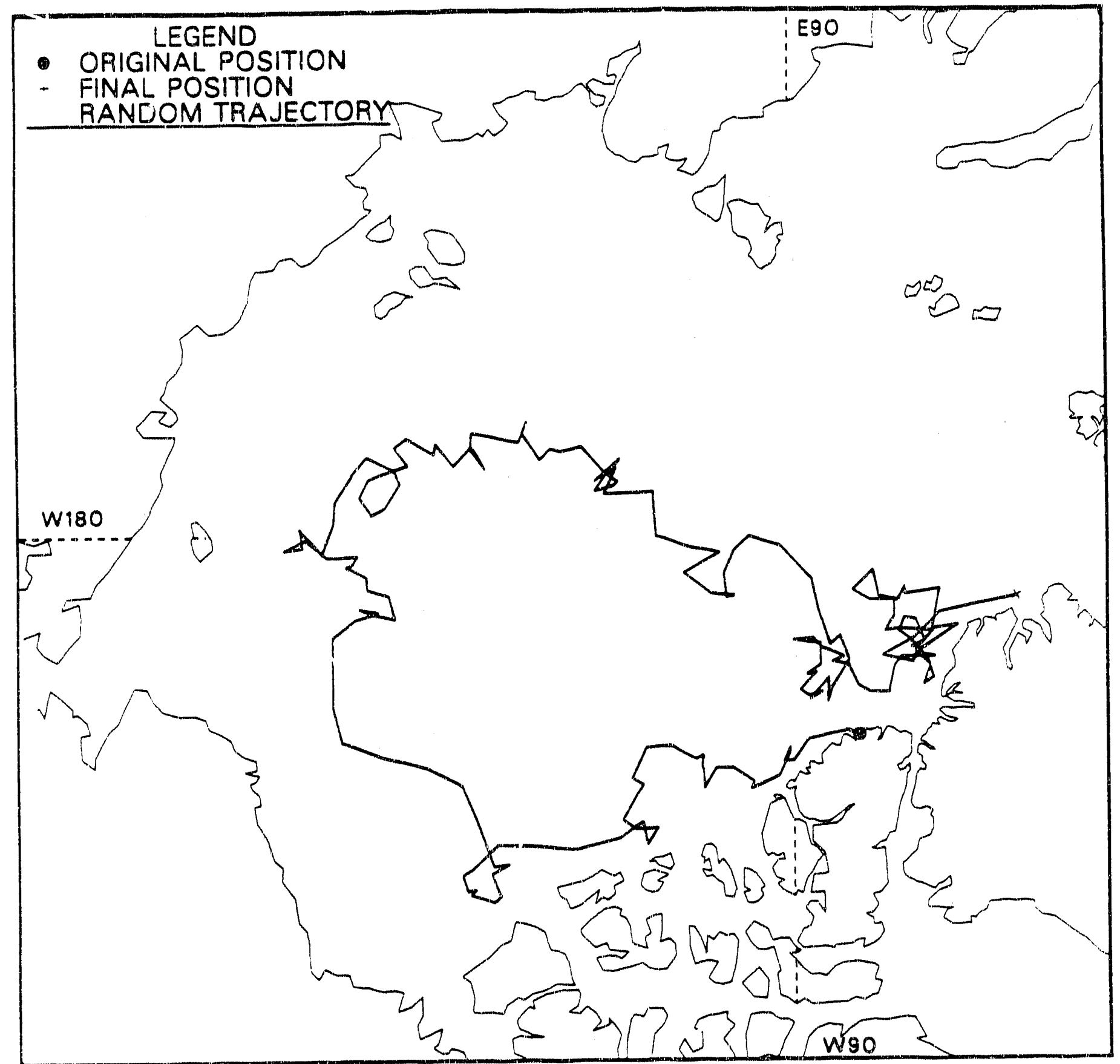

Fig. 134. Random ice island trajectory 15. 


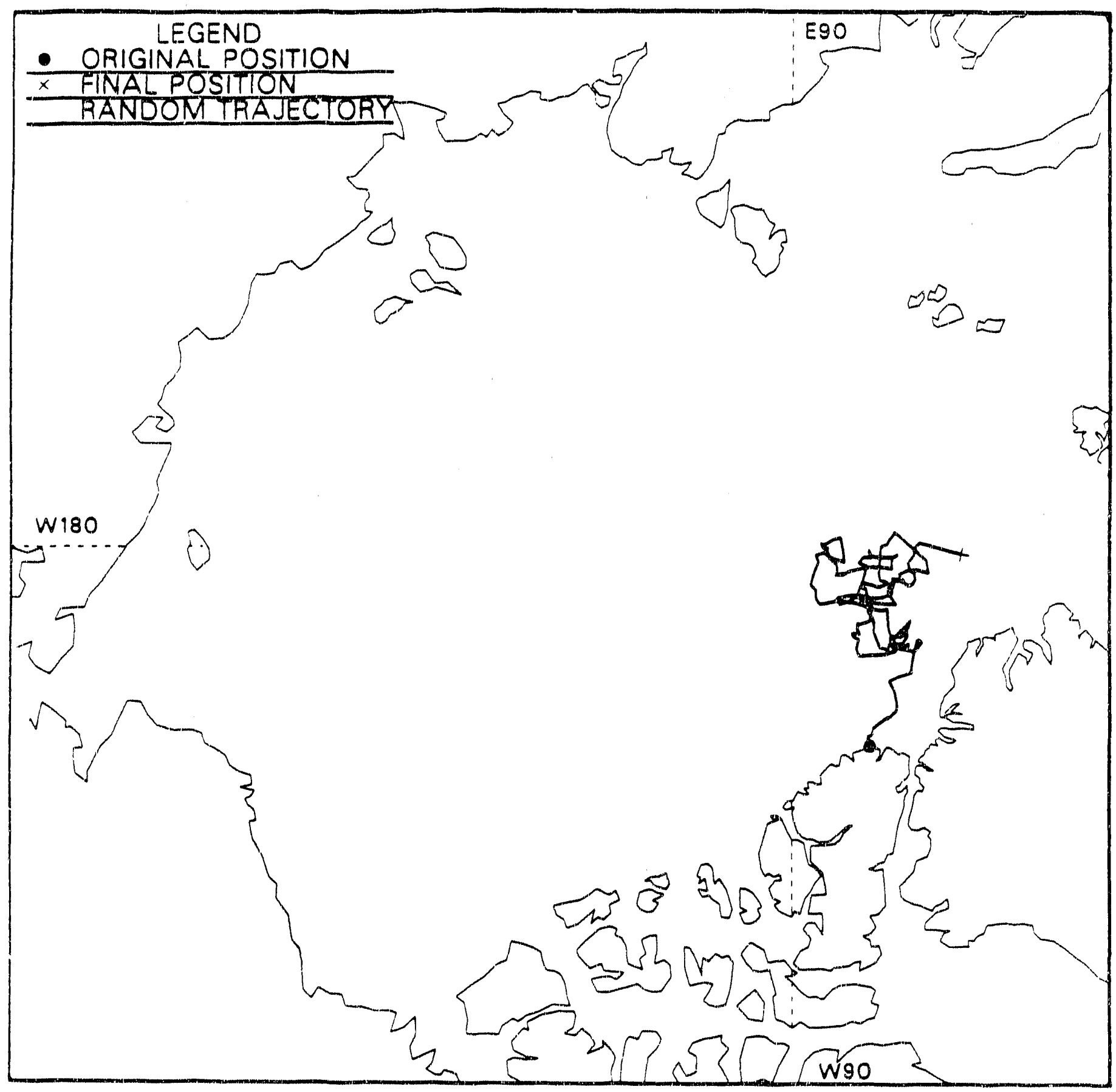

Fig. 135. Random ice island trajectory 16. 
RANDOM ICE ISLAND TRAJECTORY 17

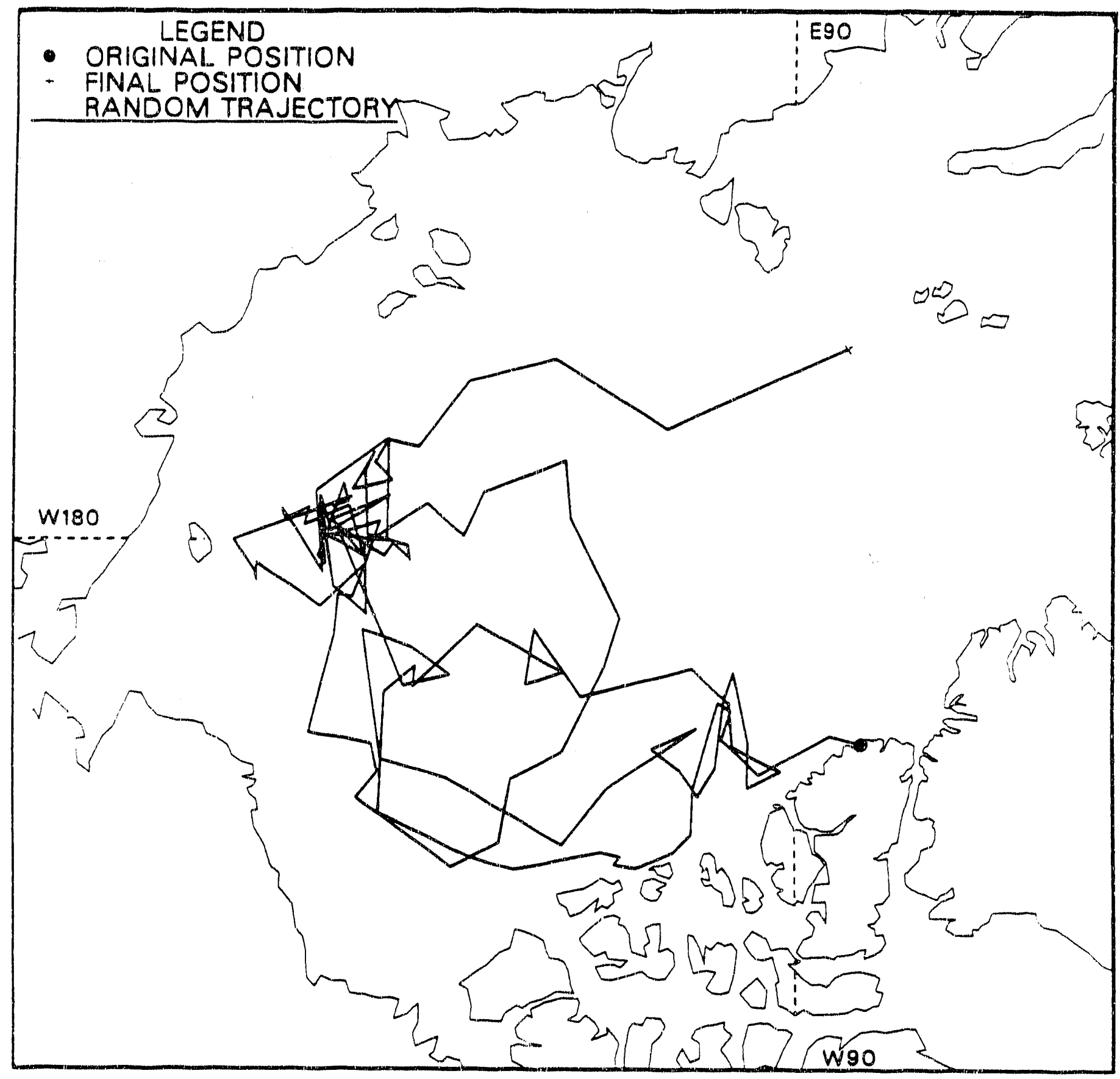

Fig. 136. Random ice island trajectory 17. 
RANDOM ICE ISLAND TRAJECTORY 18

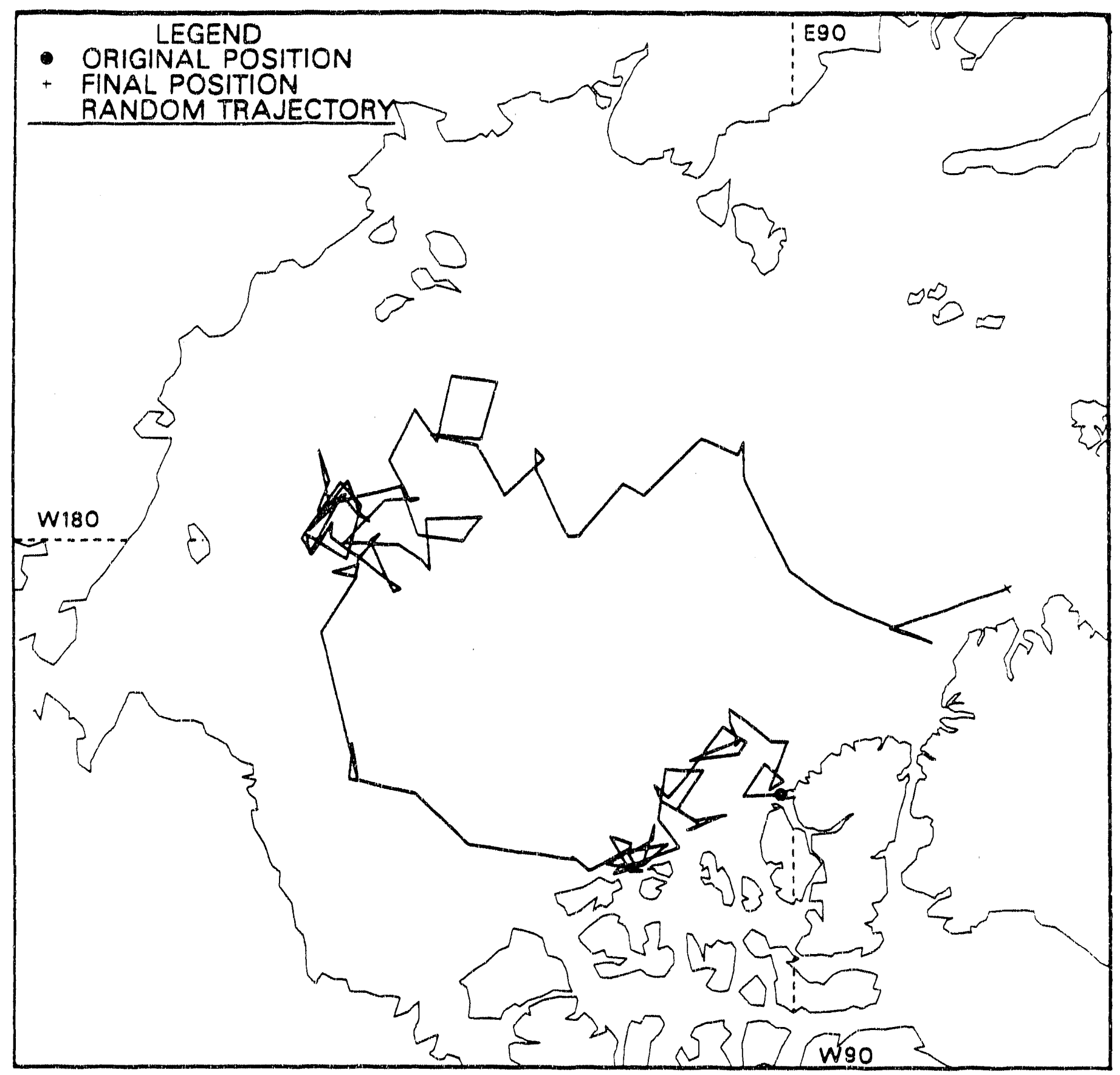

Fig. 137. Random ice island trajectory 18. 


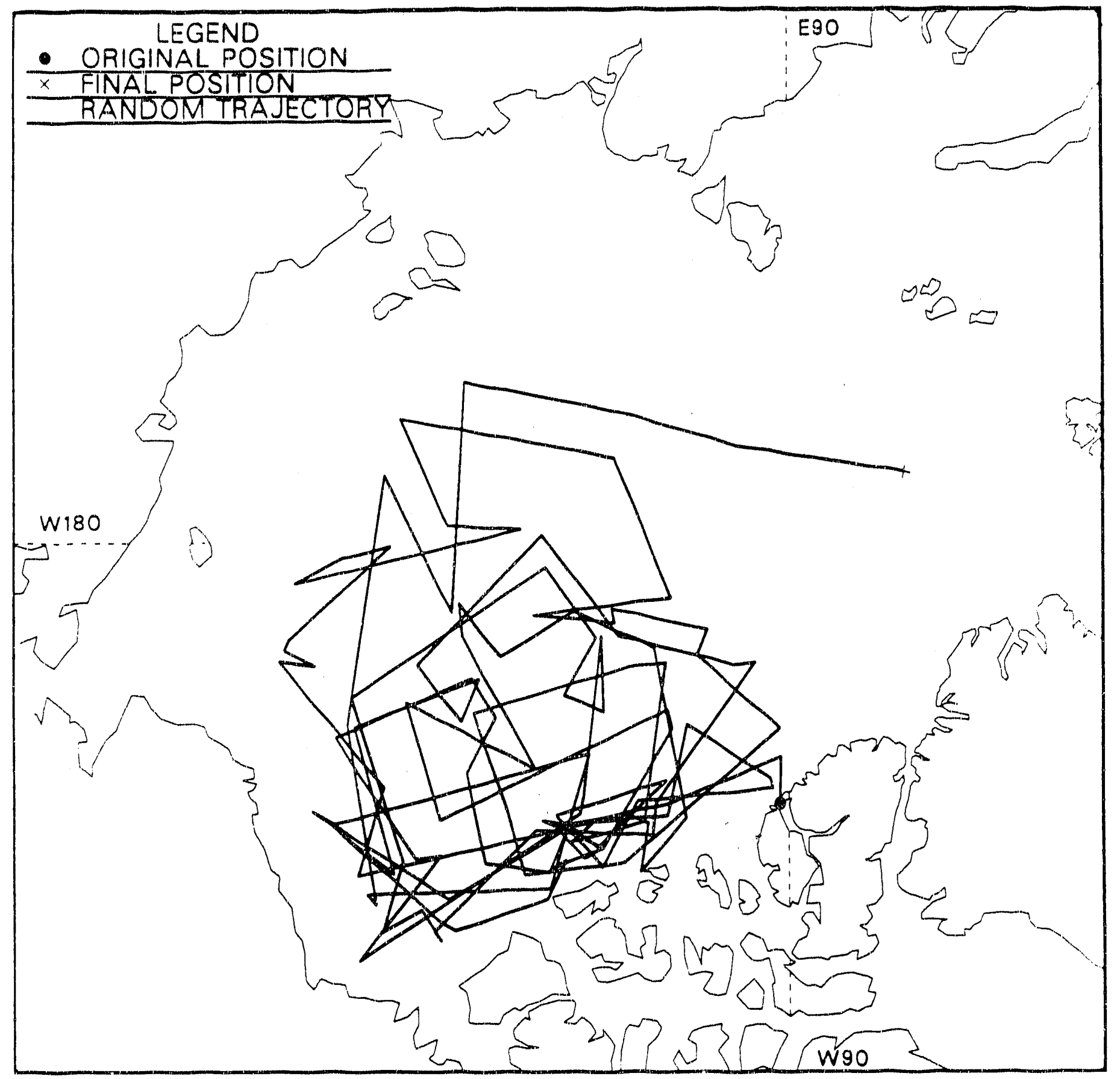

Fig. 138. Random ice island trajectory 19. 


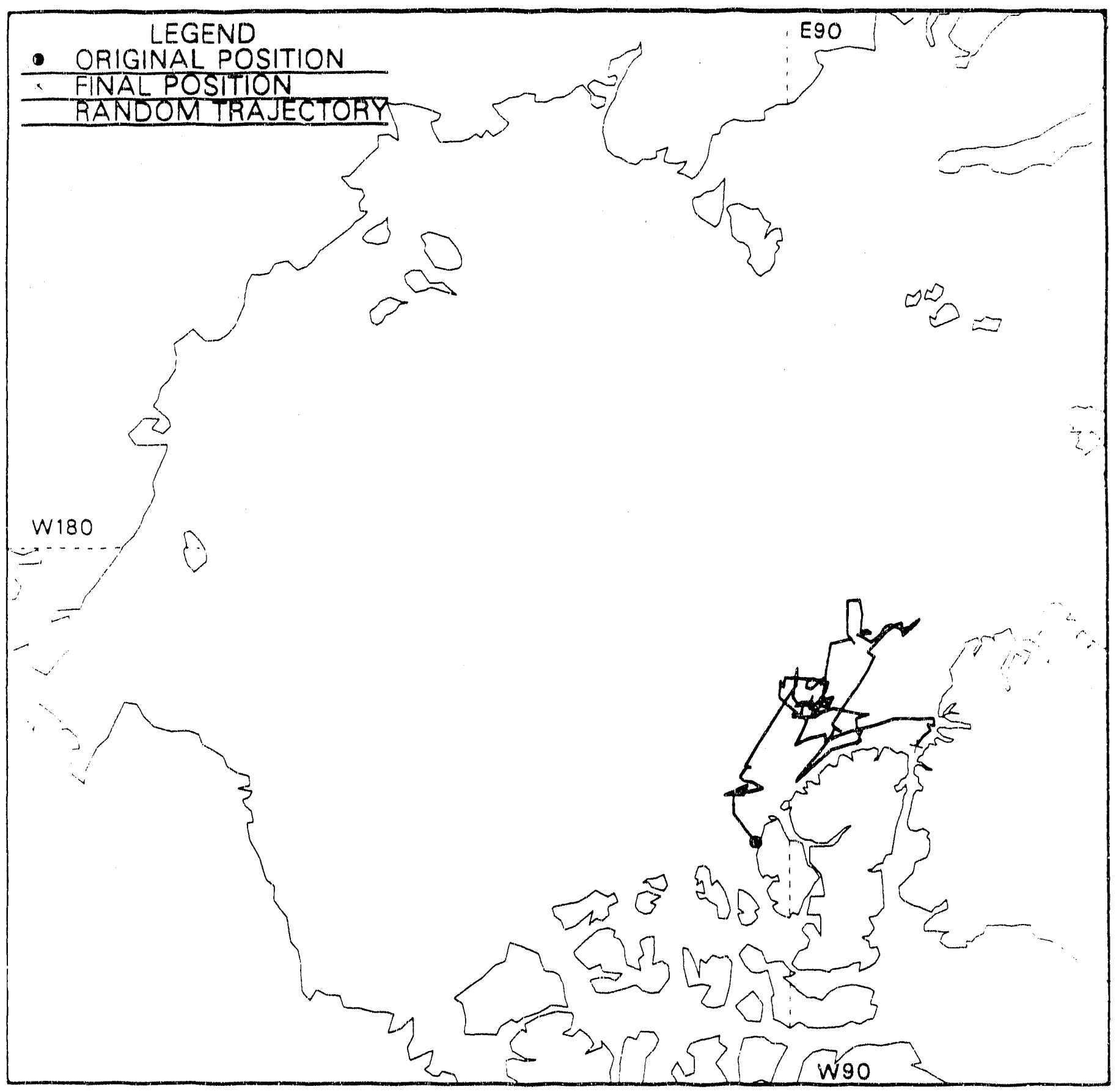

Fig. 139. Random ice island trajectory 20. 


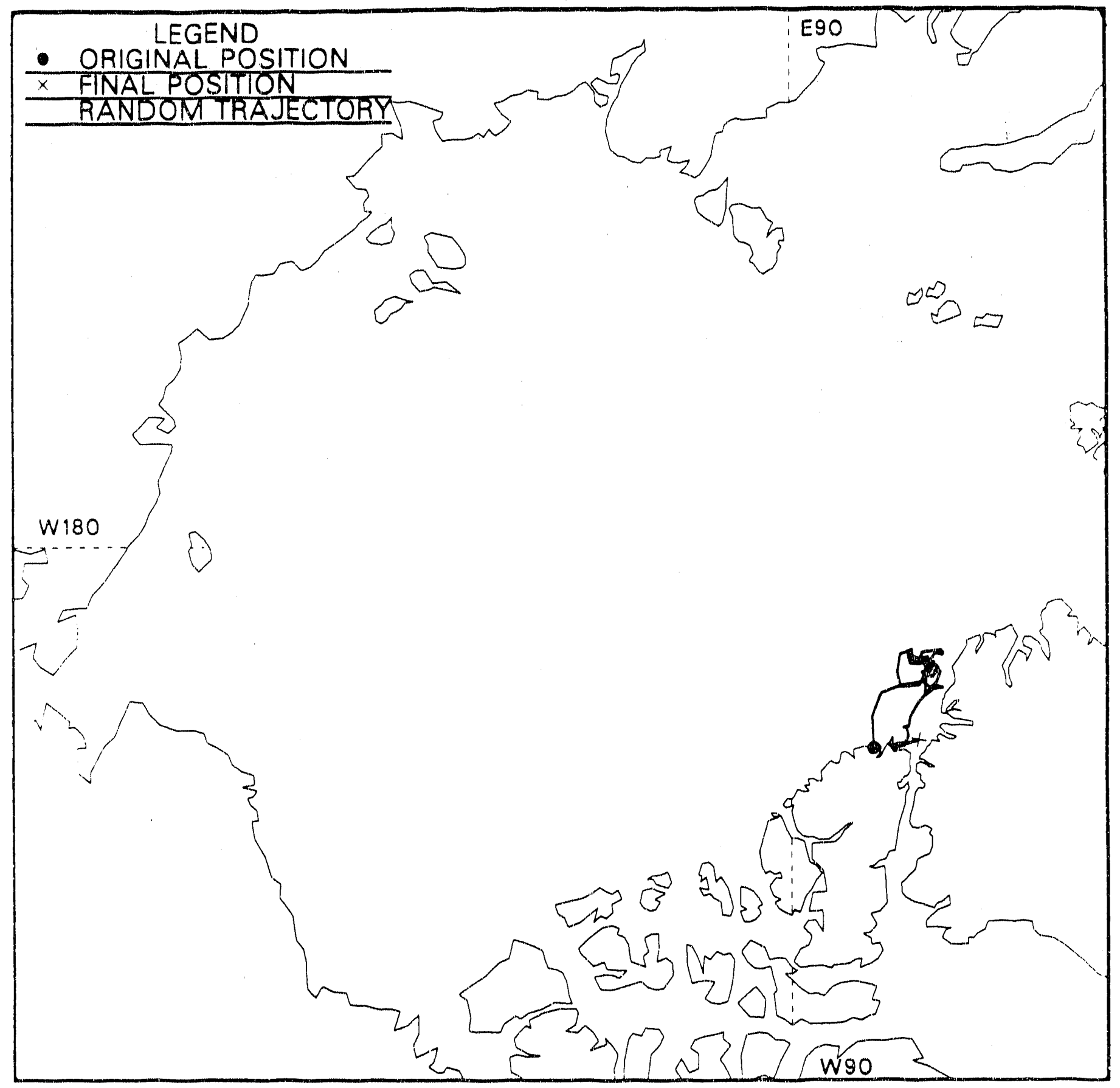

Fig. 14ก. Random ice island trajectory 21. 
their path, they move clockwise in the large scale gyre. Some ice islands simply complete one circulation before being ejected out of the Arctic Ocean, while others may complete two,three or even four circulations in the Arctic ocean with frequencies of $47 \%, 6 \%, 29 \%$ and $18 \%$ respectively. The most frequent behavior is $47 \%$ for one circuit. To examine this second pattern, the ice island T-3 drift track in the Arctic Ocean is shown in Figure 141. The ice island T-3 completed 3-4 circuits of the Beaufort Gyre from 1950 to 1984 before it drifted out of the Arctic Ocean (Sackinger, 1985). There is a common character in both trajectory patterns, in that the large scale trajectory consists of many small loops, either clockwise or anti-clockwise as shown in Figure 142 which represents the random trajectory 8 in Figure 127, but which is plotted with more detailed data points. This behavior can be compared with the tracking of Hobson's Choice Ice Island; as shown in Figure 143.

In the real case of ice island drift, the probability of ice island trajectories is related to the ice island life-time and number of live ice islands in the Arctic Ocean. These two factors were automatically produced from this simulation. By recording these two values in the simulation, the distributions of lifetime and number of live ice islands were obtained as shown in Figures 144 and 145.

In Figure 144 a distribution of ice island lifetimes in the Arctic Ocean is given, with cumulative frequencies of approximately $40 \%$ between 5 to 15 years and $85 \%$ less than 35 years. The approximate $10 \%$ frequency for less than 5 years is consistent with the frequency of the short trajectory pattern. This means the ice islands moving in the second trajectory pattern - circulation covering the Beaufort Gyre, will drift at least 5 years to complete one circuit in the Arctic Ocean. This is consistent with the estimation of one Beaufort Gyre circuit time of 5 to 10 years for ice island T-3.

In Figure 145, the distribution of the number of live ice islands in the Arctic Ocean is shown. This is approximately a Gaussian distribution with mean value of 


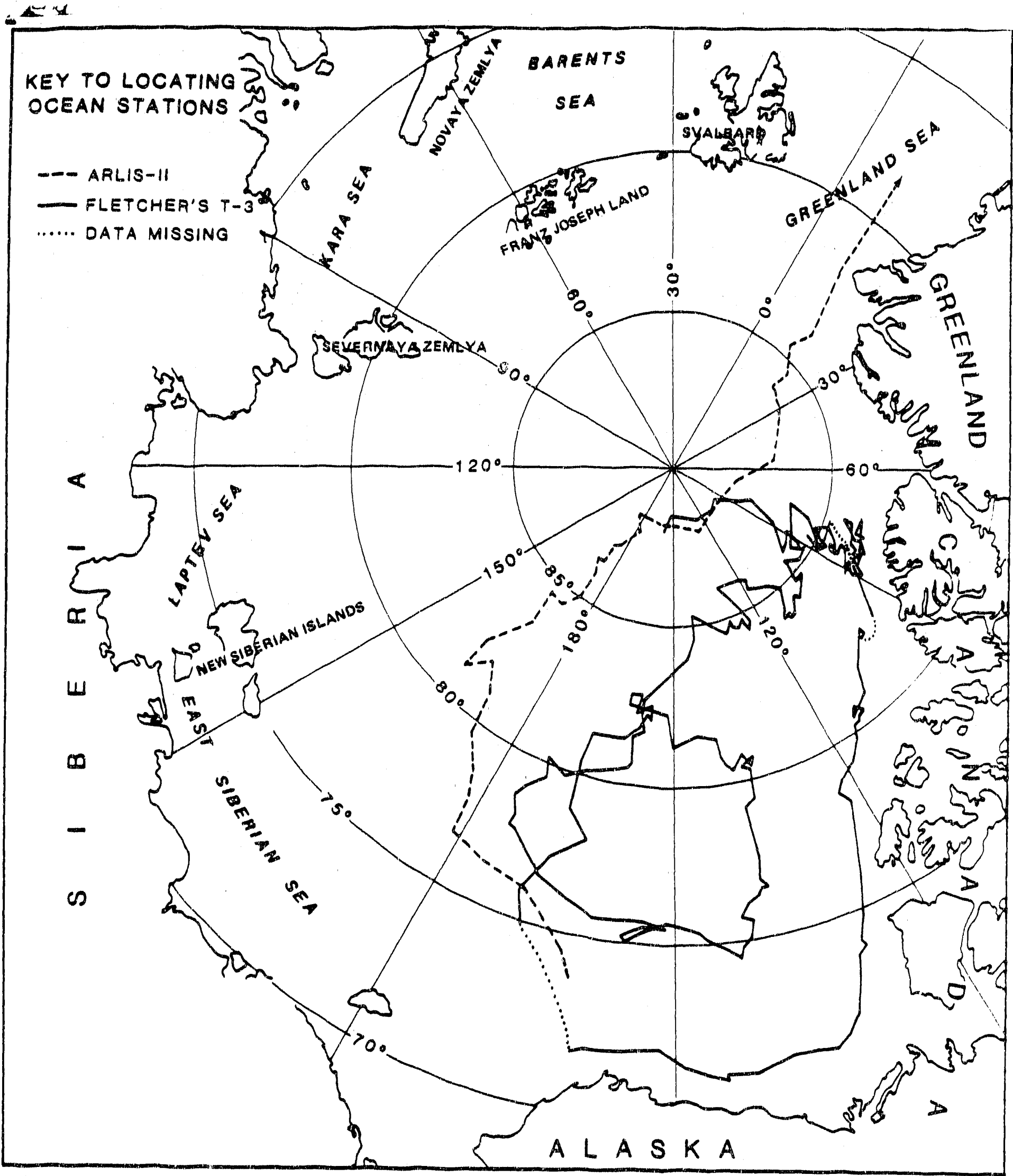
Fig. 141. Drift tracks of ice islands T-3 and Arlis- $\Pi$ in the Arctic Ocean (based on
Sackinger and Yan, 1986). 


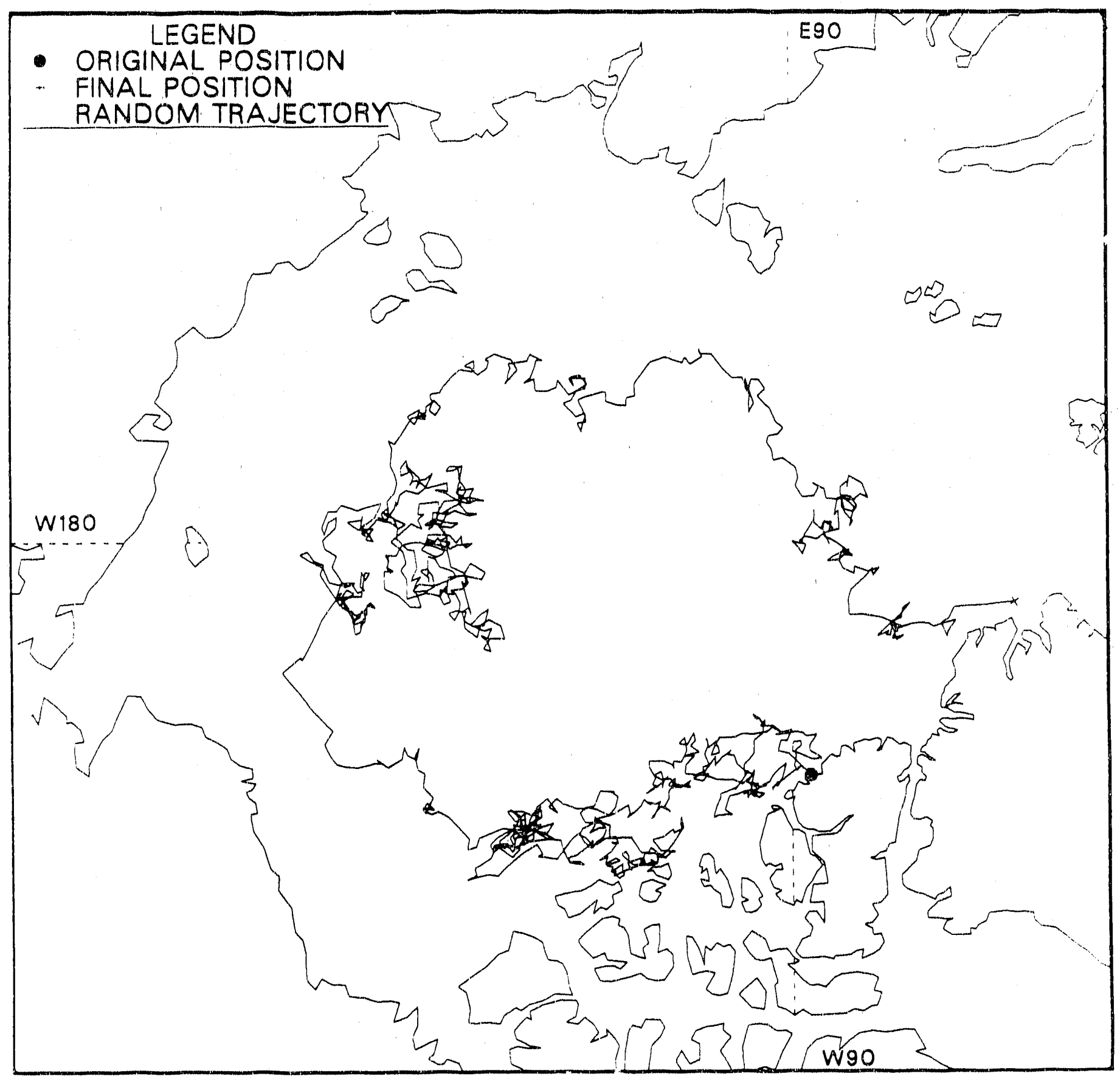

Fig. 142. Random ice island trajectory in fine detailed scale showing many small loops. 


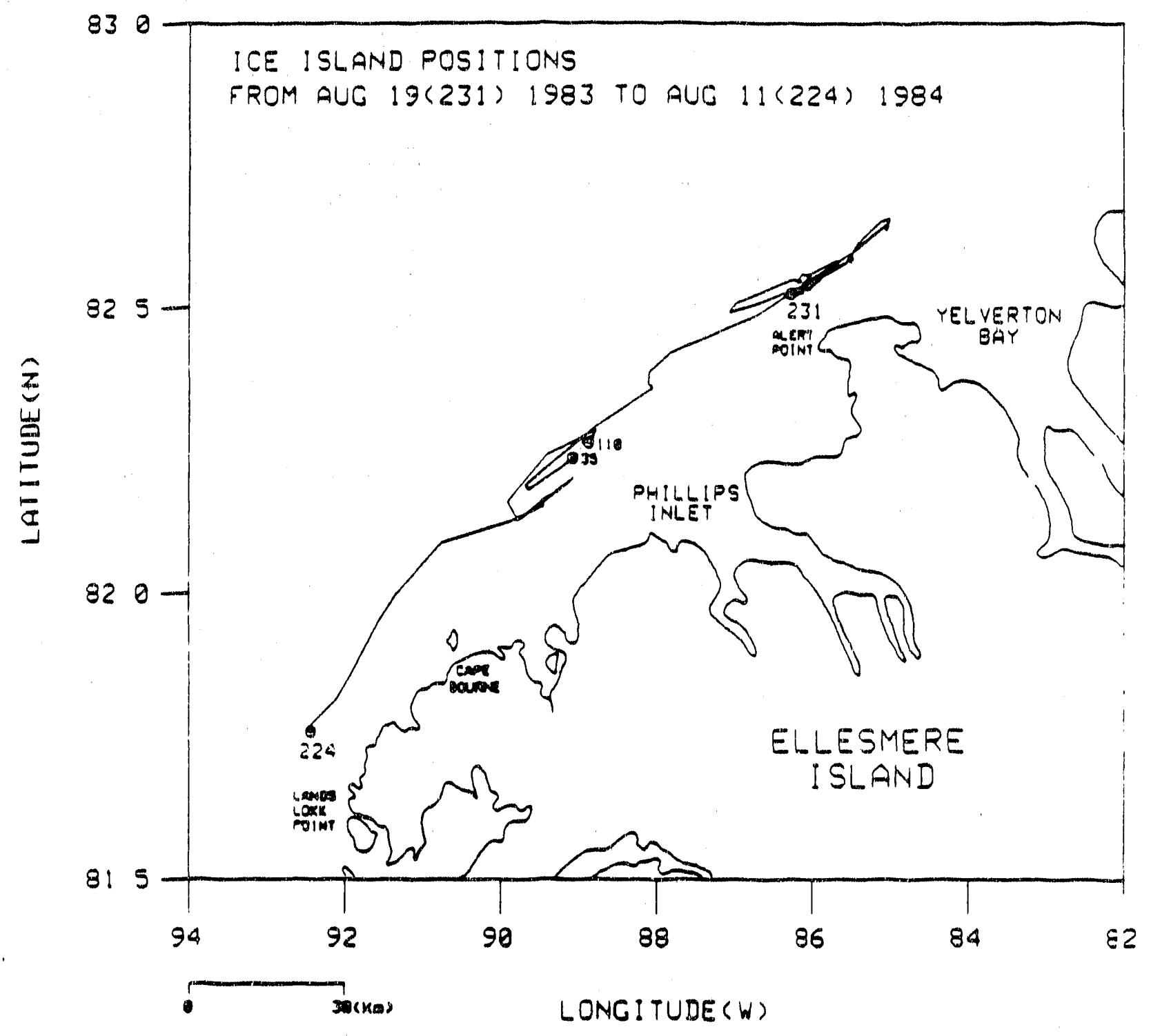

Fig. 143. Hobson's Choice Ice Island track showing many small loops (source: Yan, 1986). 


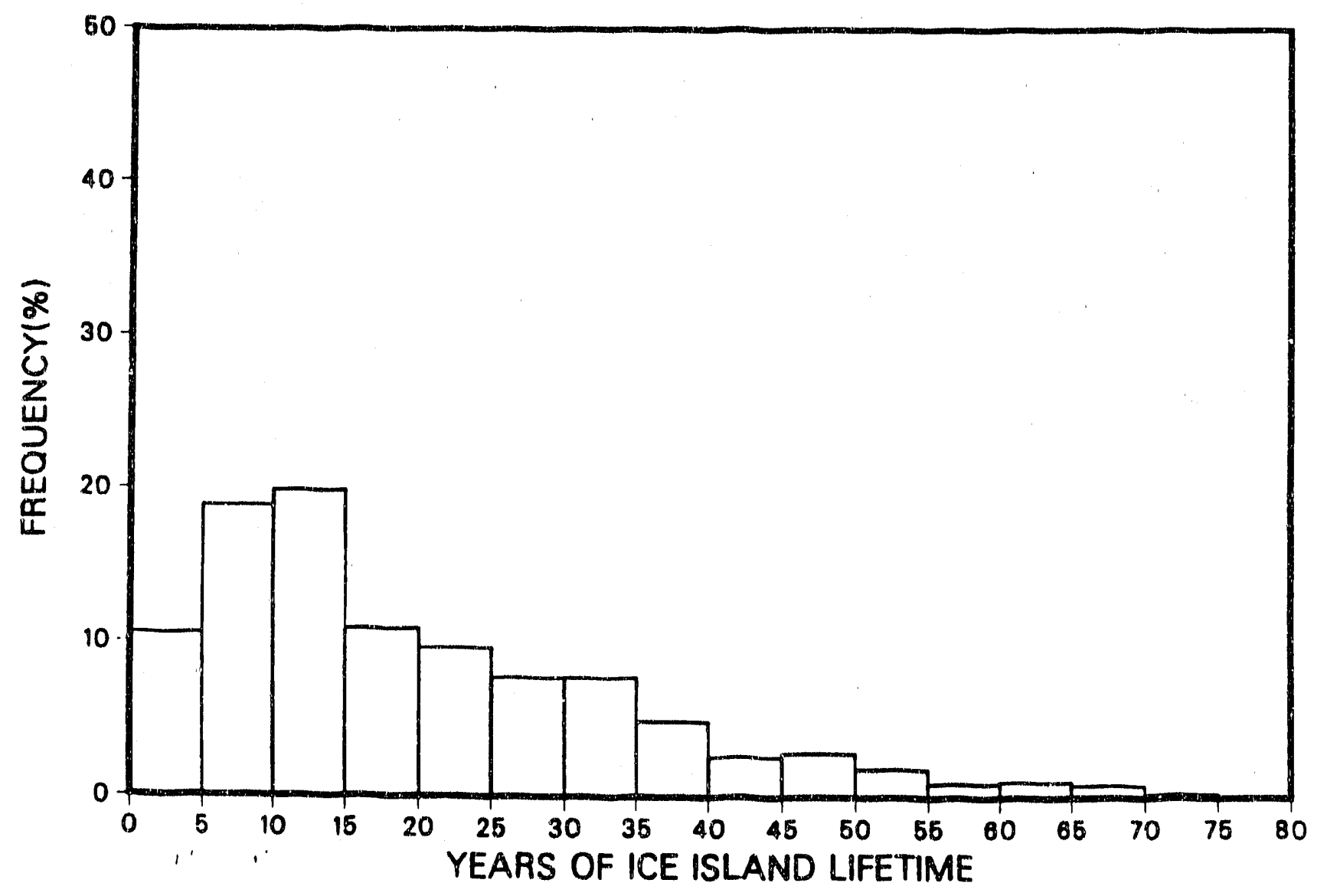

Fig. 144. Frequency of ice island lifetime in the Arctic Ocean (4-year interval of generation). 


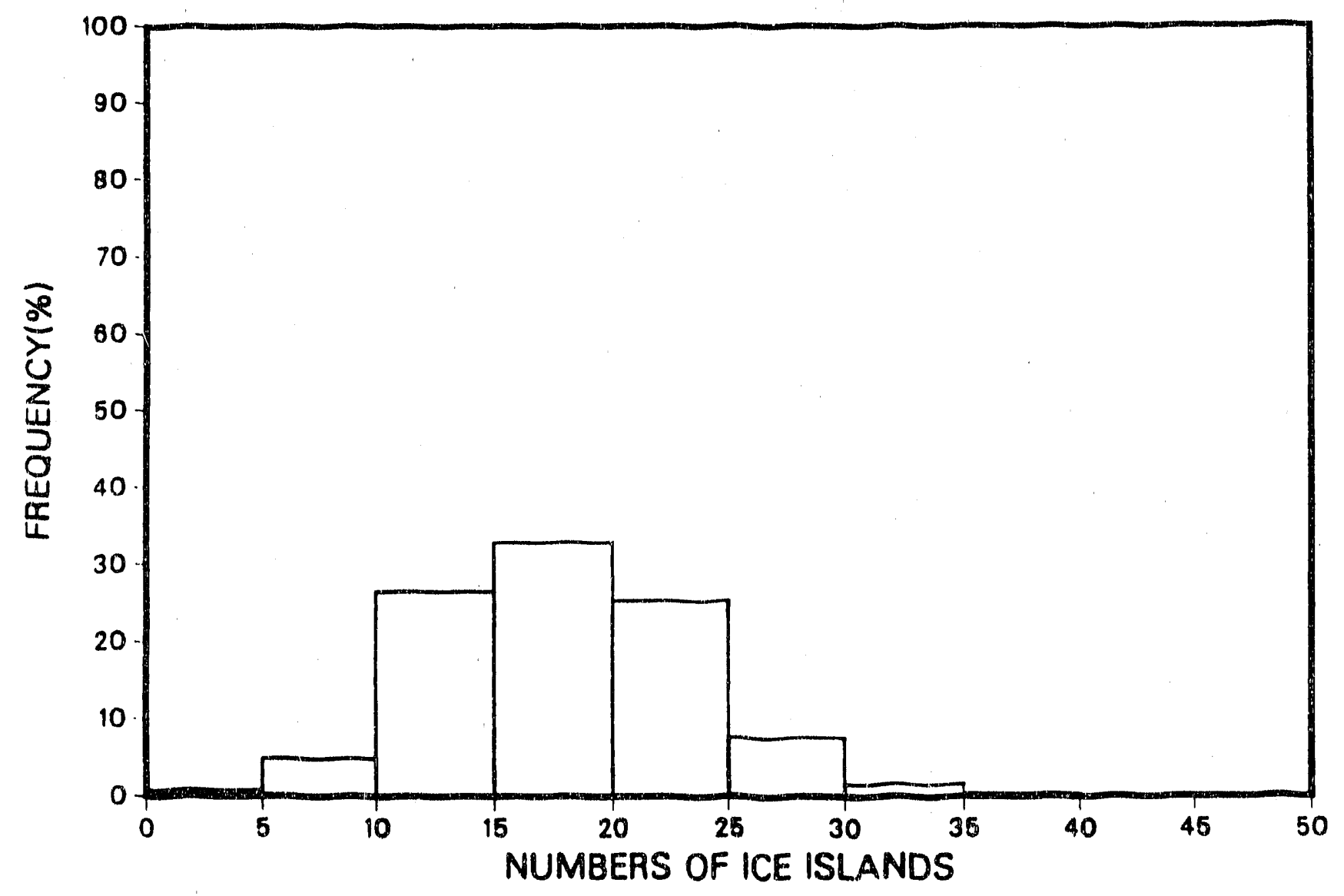

Fig. 145. Frequency of ice island numbers in the Arctic Ocean (4-year interval of generation). 
18 , and with an approximate $90 \%$ probability of less than 30 ice islands existing in the Arctic Ocean at time. This is only for ice islands without fragments; the real number of ice islands, including fragments, may well be greater than this. More detailed examination has shown that these distributions are not affected appreciably by the time intervals of ice island generation, which have been tried at 3,4 and 5 year intervals.

The results of probabilities of simulated ice island trajectories are plotted in the form of differential return period (years) contours over the Arctic Ocean (Figure 146). The contours represent the recurrence interval (years) of ice islands in each square area of $50 \times 50 \mathrm{~km}$. The results show that there are two zones of highest recurrence. One is near the Canadian Beaufort Sea, which is likely due to ice islands originating at Ellesmere Island and which are then driven southwestward by northeasterly winds along the Canadian coast. Another high recurrence zone is near the Chukchi Sea, which is likely due to ice islands being driven through the Alaskan Beaufort Sea by easterly winds to the boundaries of the Chukchi Sea, where they are temporarily confined to some extent by boundaries and currents from the Bering Strait, and then are pushed back to the Arctic Ocean under the influence of ocean currents and winter geostrophic winds. There is a broad area of 1 to 10 year recurrence interval in the central ocean, and the gradient of probability is high along the Alaskan Beaufort Sea coast and in the Chukchi Sea. The contours are deflected toward the Arctic Ocean at the Chukchi Sea due to the influence of Bering Strait water inflow. There is a high probability zone near the north end of Greenland, which implies that most of the ice islands escape out of the Arctic Ocean through Fram Strait between Greenland and Svalbard.

To quantify the frequencies of ice islands ejected out of the ocean at each open water boundary, a record was made of the numbers of ice islands ejected through each boundary and the number of ice islands melted down in the ocean. 


\section{CONTOURS OF RETURN PERIOD (YEARS)}

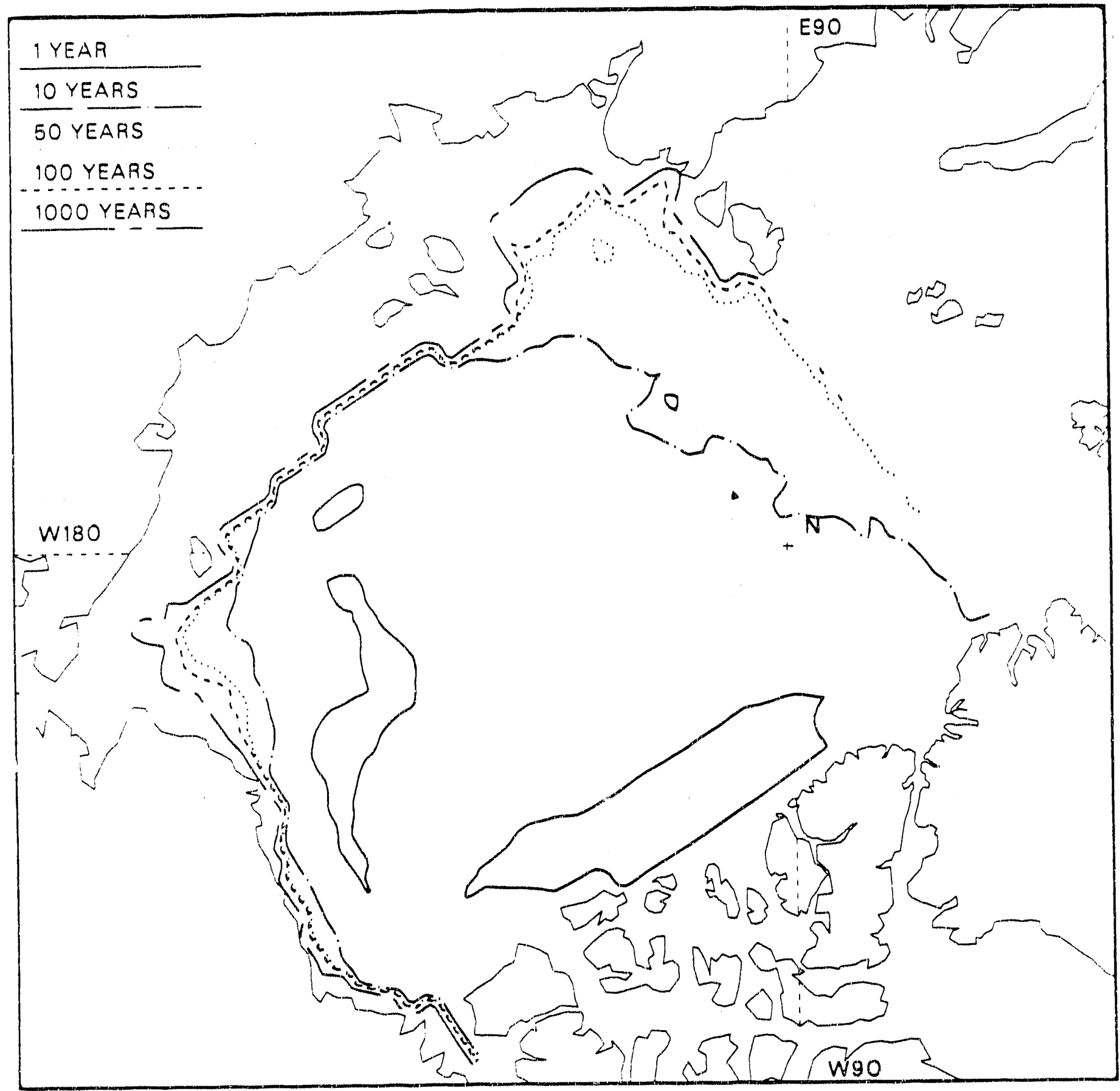

Fig. 146. Return period contoliss (years) of simulated ice islands in the Arctic Ôcean. 
From Table 17 the most frequent situation is ejection at the boundary between Table 17. Frequencies of ejection of ice islands.

\begin{tabular}{|l|c|c|}
\hline \multicolumn{1}{|c|}{ Ejection Route } & Number of Ice Island Ejected & Frequency \\
\hline $\begin{array}{c}\text { Between Greenland } \\
\text { and Svalbard }\end{array}$ & 582 & $75.0 \%$ \\
\hline Nares Strait & 151 & $19.5 \%$ \\
\hline Amundsen Gulf & 42 & $5.4 \%$ \\
\hline Bering Strait & 0 & $0.0 \%$ \\
\hline Melted down in ocean & 1 & $0.1 \%$ \\
\hline
\end{tabular}

Greenland and Svalbard, which is consistent with observations. Less frequent ejection at the Nares Strait and Amundsen Gulf are noted with zero chance for ice islands to escape out of the ocean by the Bering Strait. The number of ice islands melted down in the ocean is not significant, and has a frequency of $(0.1) \%$.

Because wind force is the only random driving force on the ice islands considered in this simulation, pressure maps averaged over a short time period (monthly) were used to calculate the wind field. The maps in Figures 147-158 show a extremely variable surface geostrophic wind field, from an anticyclonic pattern in winter to a cyclonic pattern in summer. The annually-averaged surface geostrophic wind field over the Arctic Ocean is an anticyclonic system as shown in Figure 159. To compare the effects of these two types of different time-averaged wind fields, the simulation program was run with the annually averaged wind field as input wind for each month. The probability of :e island trajectories obtinined is shown in Figure 160 in the form of contours representing different recurrence intervals (years) of ice islands in a square area of $50 \times 50 \mathrm{~km}$. Comparing this result with that shown in Figure 146, we can see that the regions of 1 -year return interval are along the Canadian and Alaskan Beaufort Sea coastline, rather than covering the entire Beaufort Gyre. The influence of the Chukchi Sea current in reducing the frequency of 


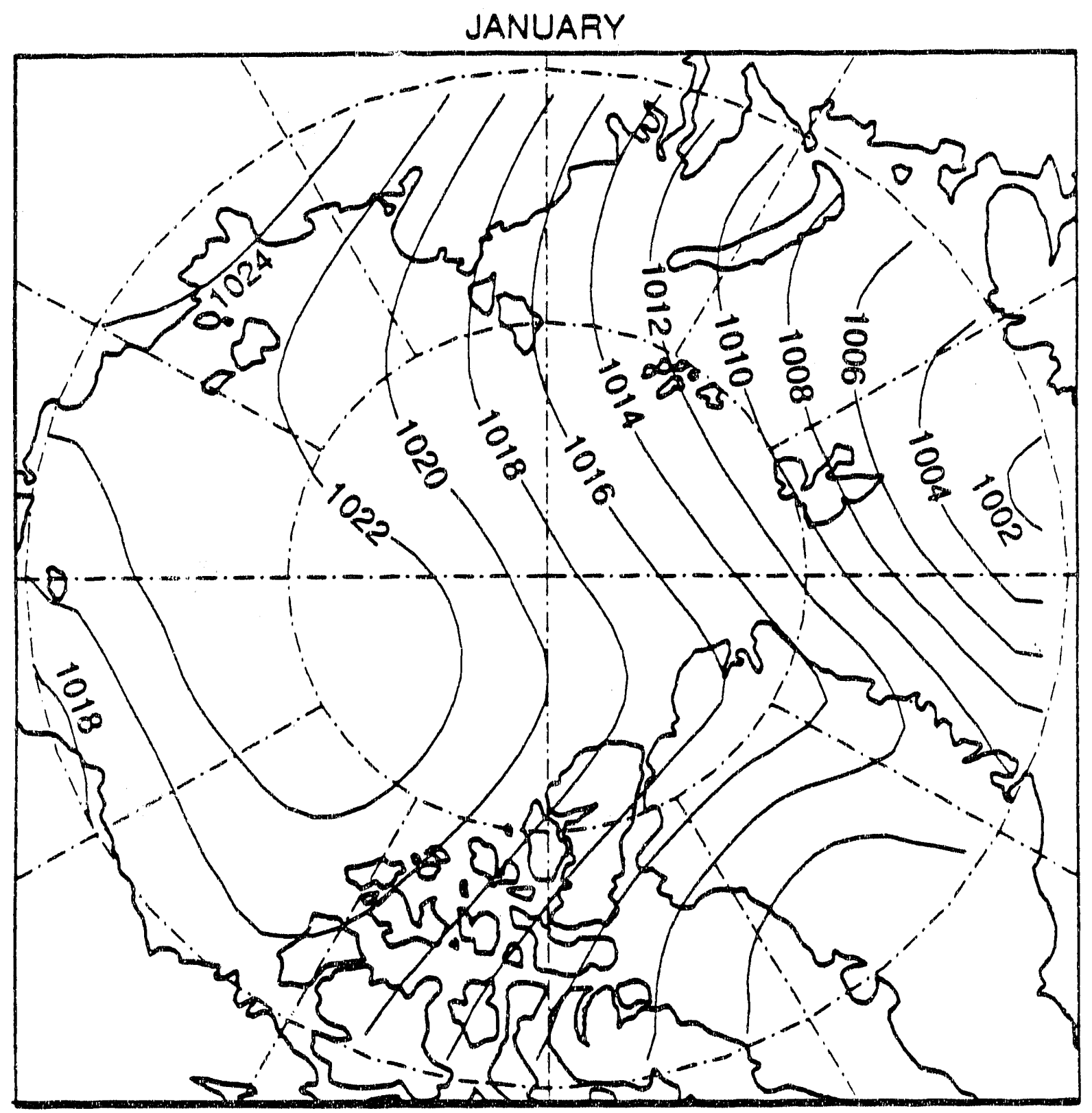

Fig. 147. Monthly averaged pressure map over the Arctic Ocean for January (after Colony, 1987). 


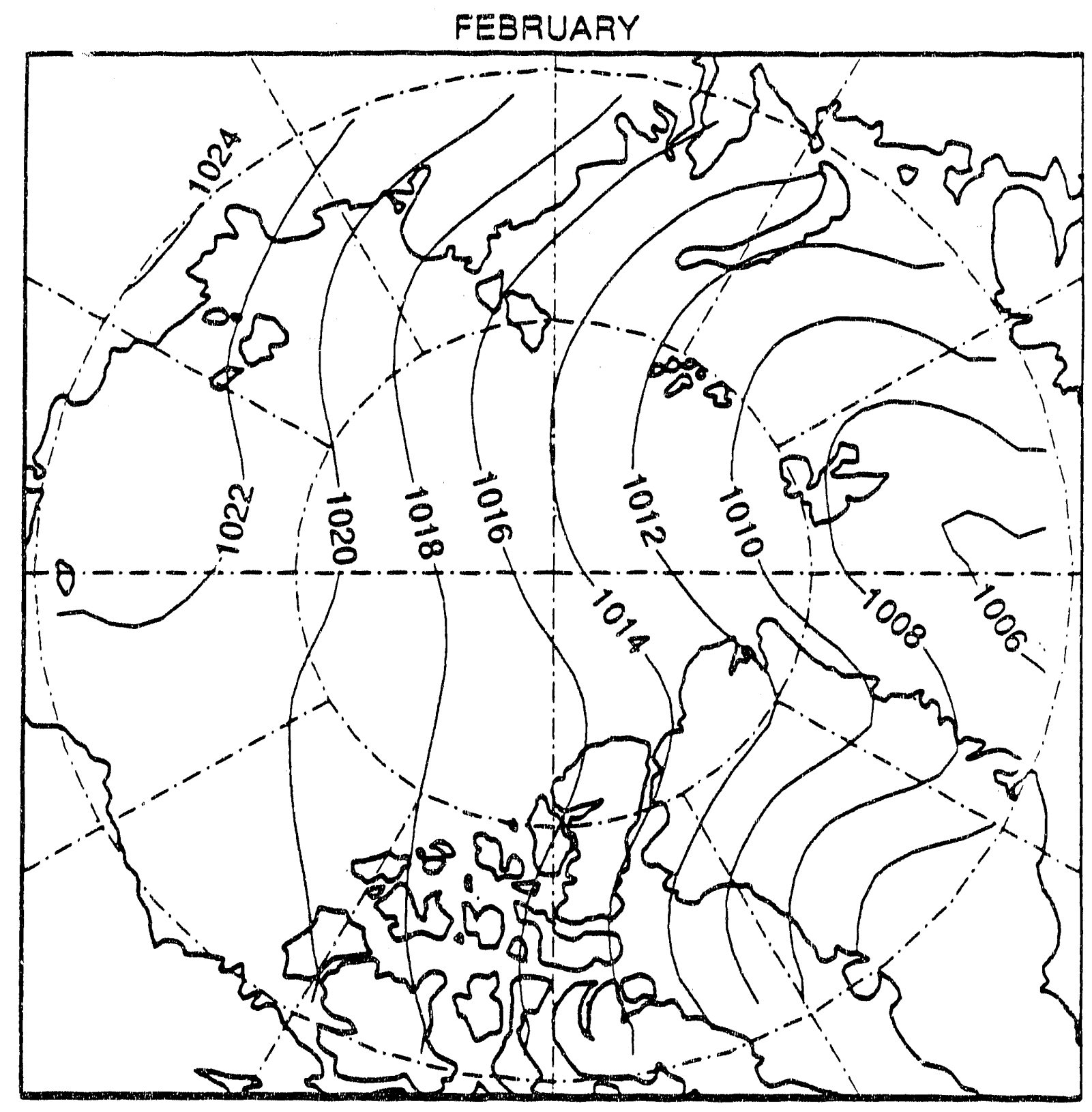

Fig. 148. Monthly averaged pressure map over the Arctic Ocean for February (after Colony, 1987). 


\section{MARCH}

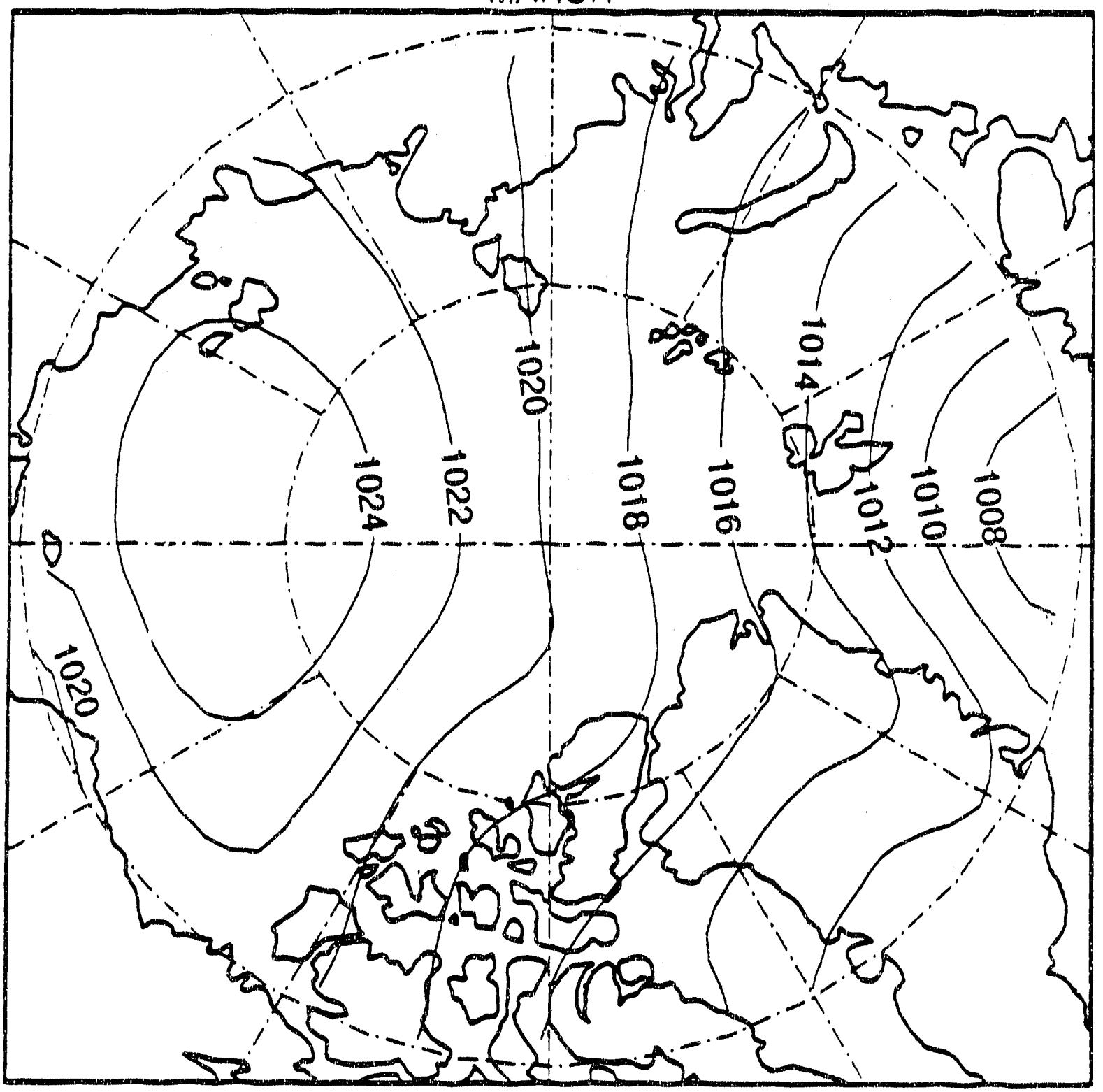

Fig. 149. Monthly averaged pressure map over the Arctic Ocean for March (after Colony, 1987). 


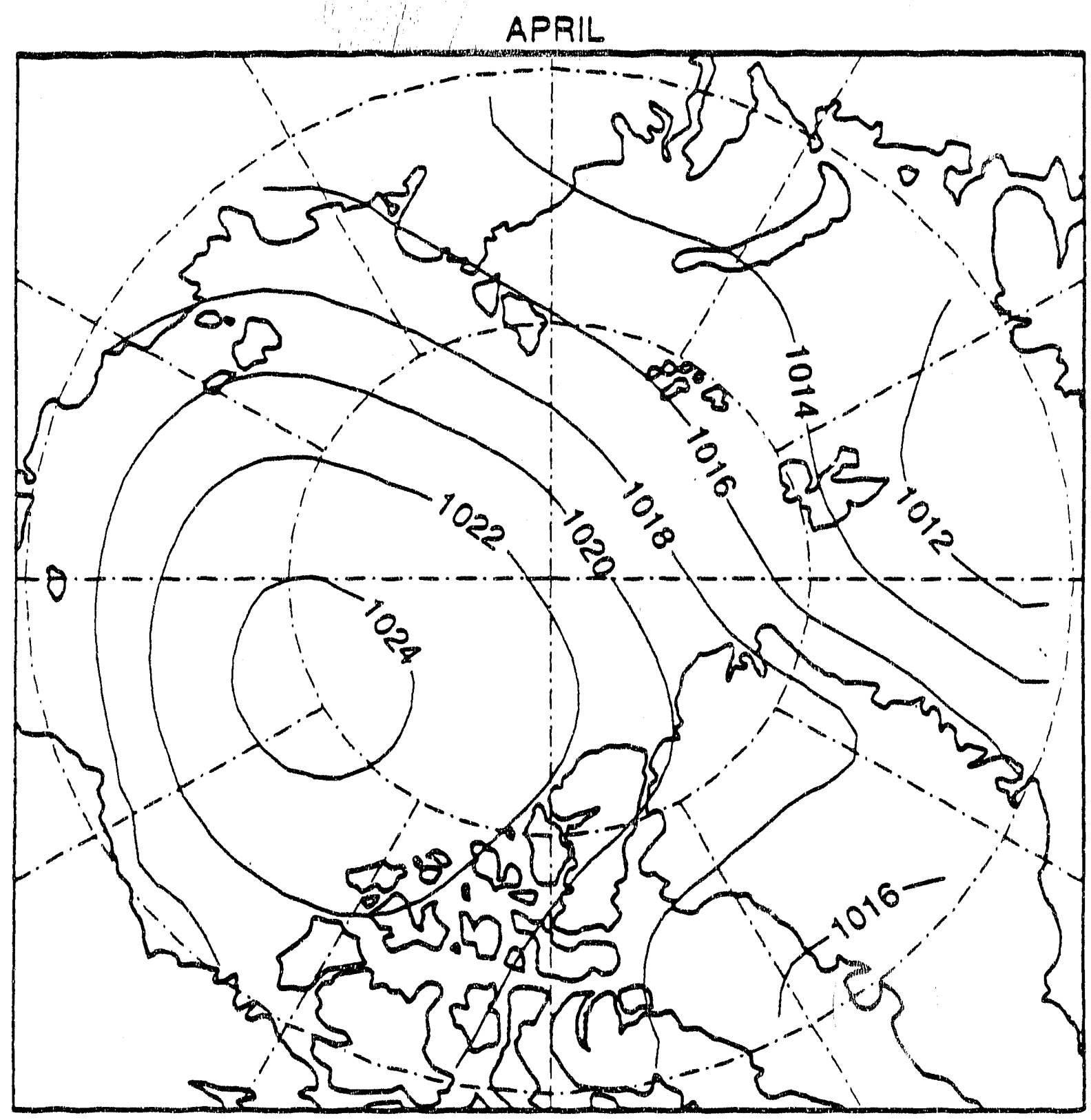

Fig. 150. Monthly averaged pressure map over the Arctic Ocean for April (after 


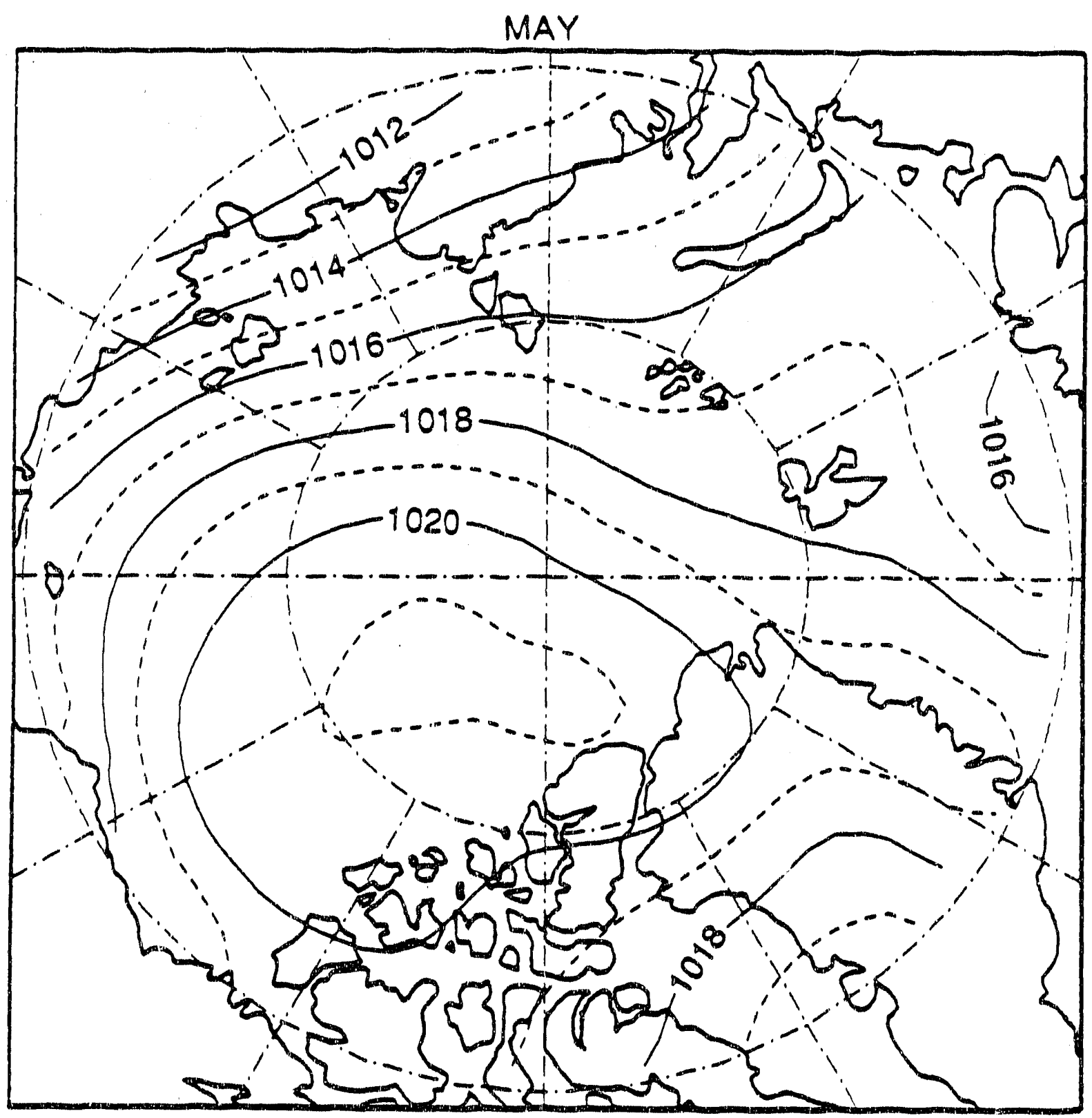

Fig. 151. Monthly averaged pressure map over the Arctic Ocean for May (after Colony, 1987). 


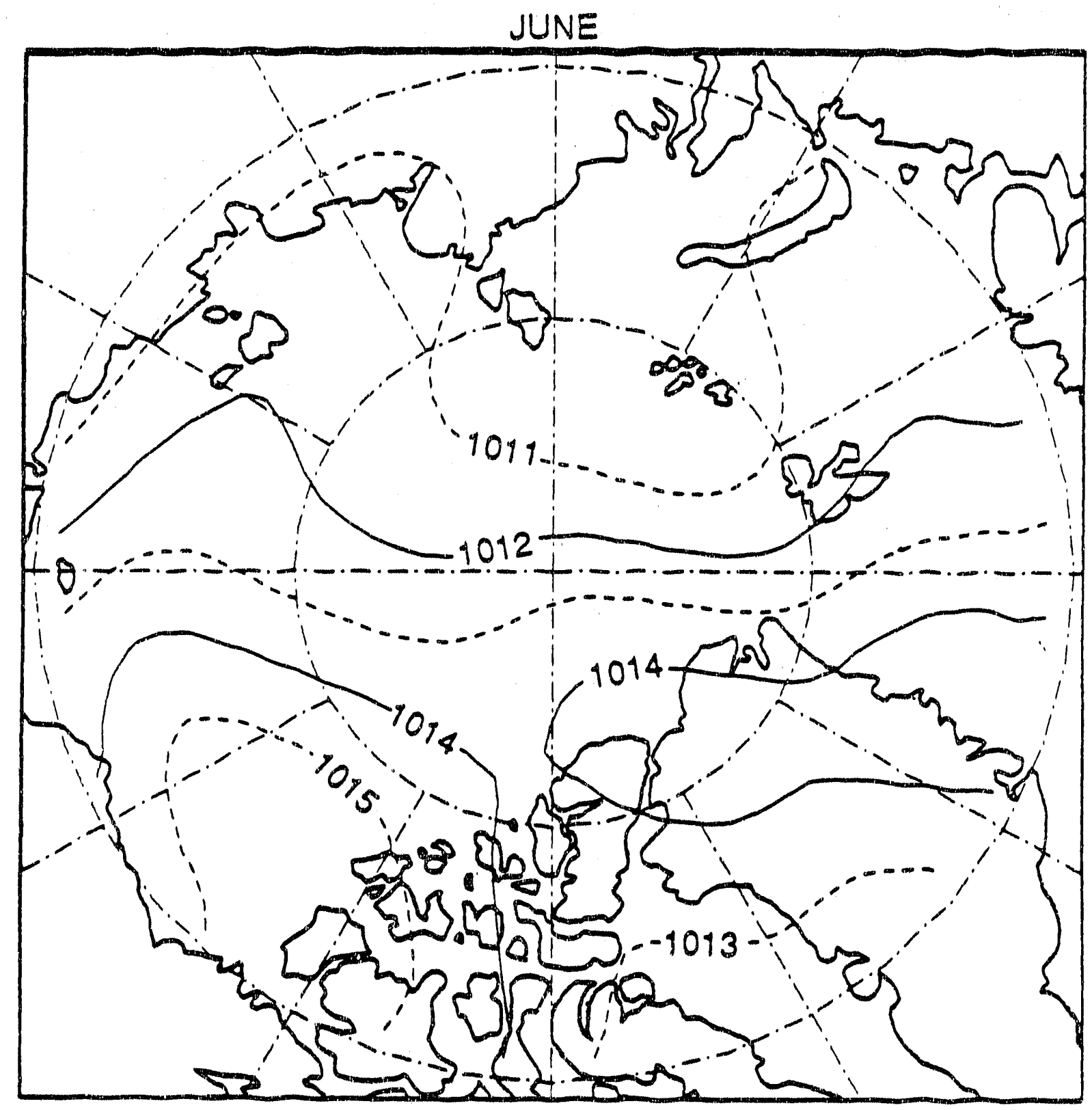
Fig. 152. Monthly averaged pressure map over the Arctic Ocean for June (after
Colony, 1987). 


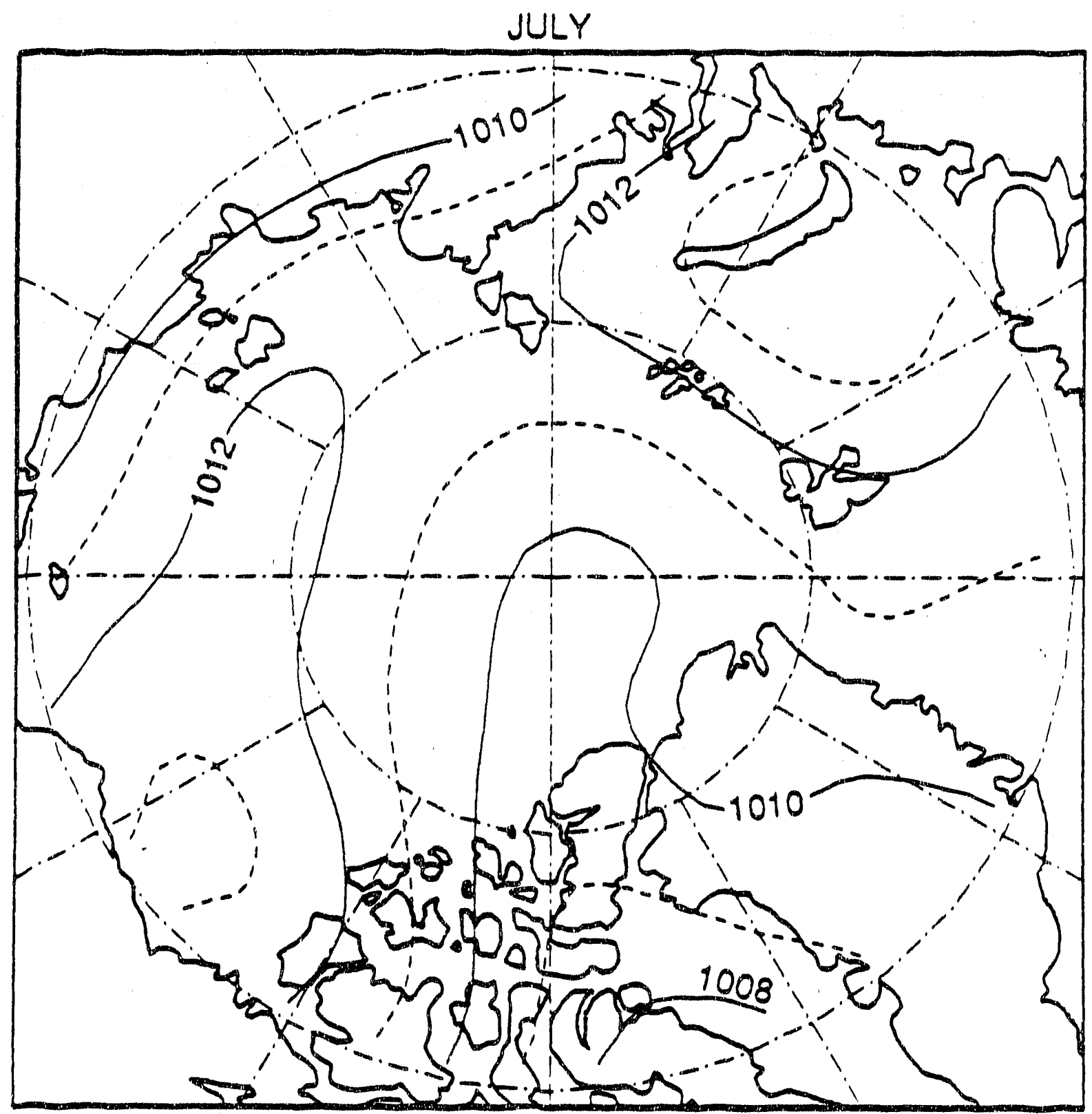

Fig. 153. Morthly averaged pressure map over the Arctic Ocean for July (after Colony, 1987). 


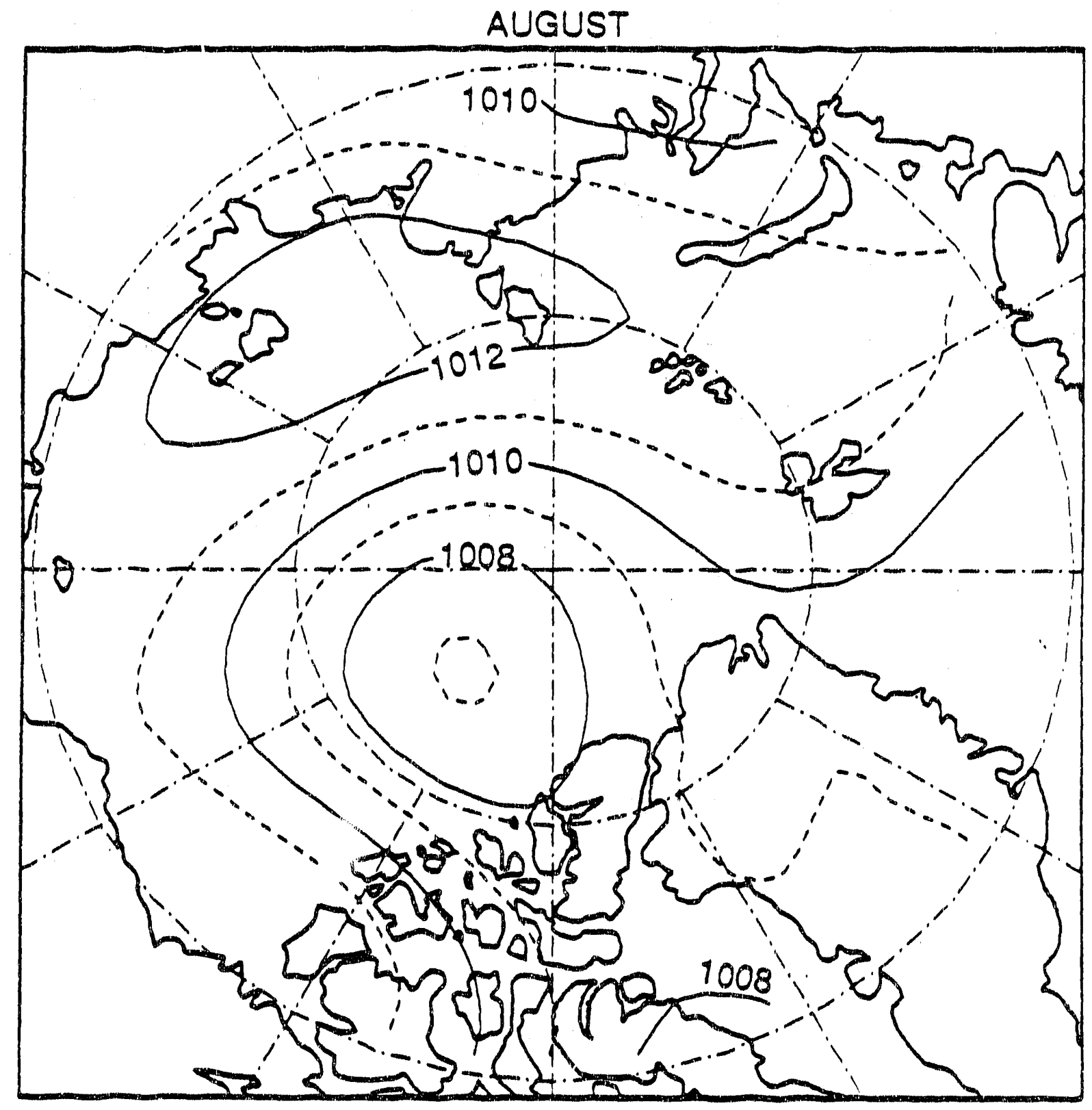

Fig. 154. Monthly averaged pressure map over the Arctic Ocean for August
(after Colony, 1987). 


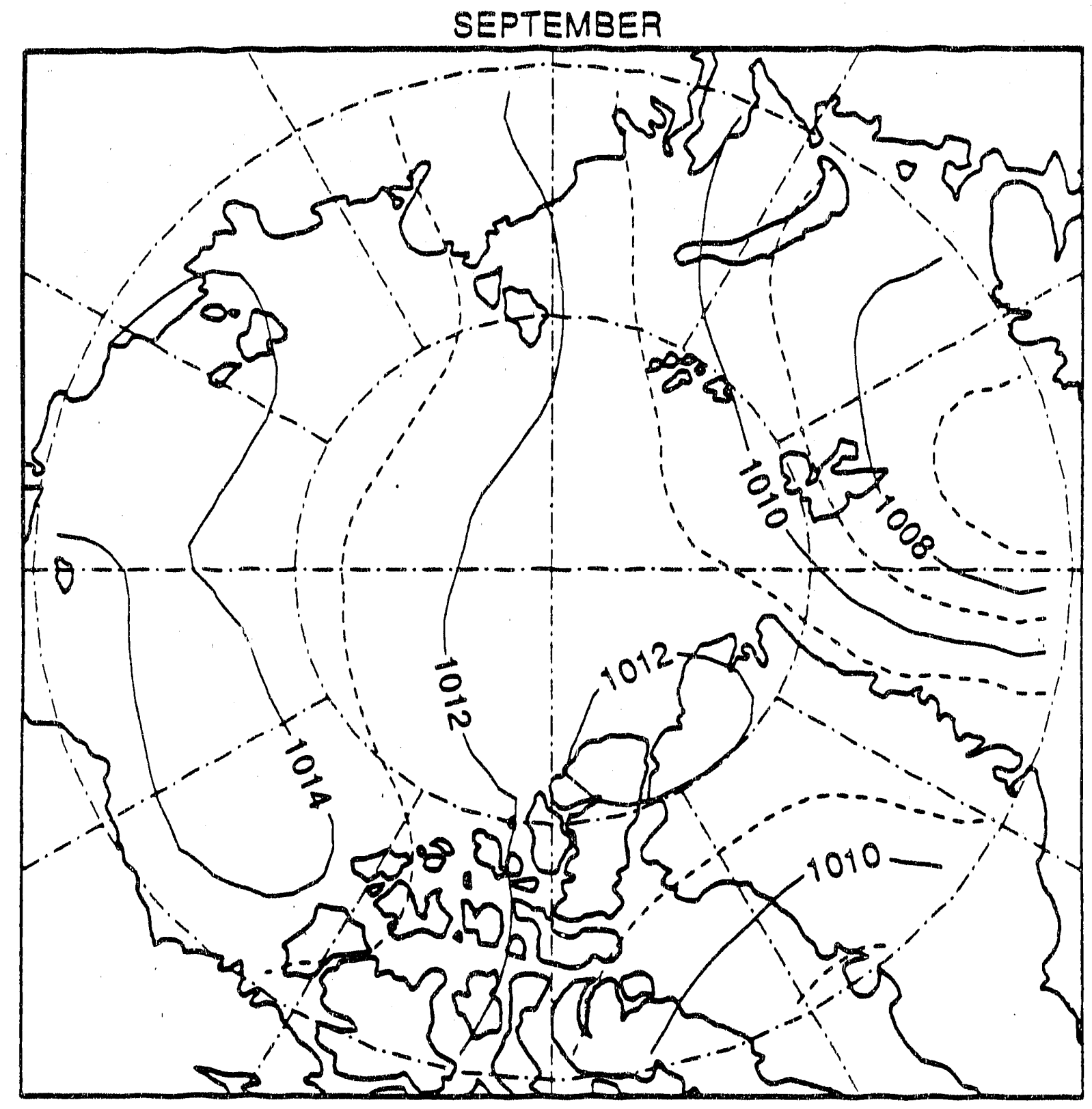
Fig. 155. Monthly averaged pressure map over the Arctic Ocean for September
(after Colony, 1987). 


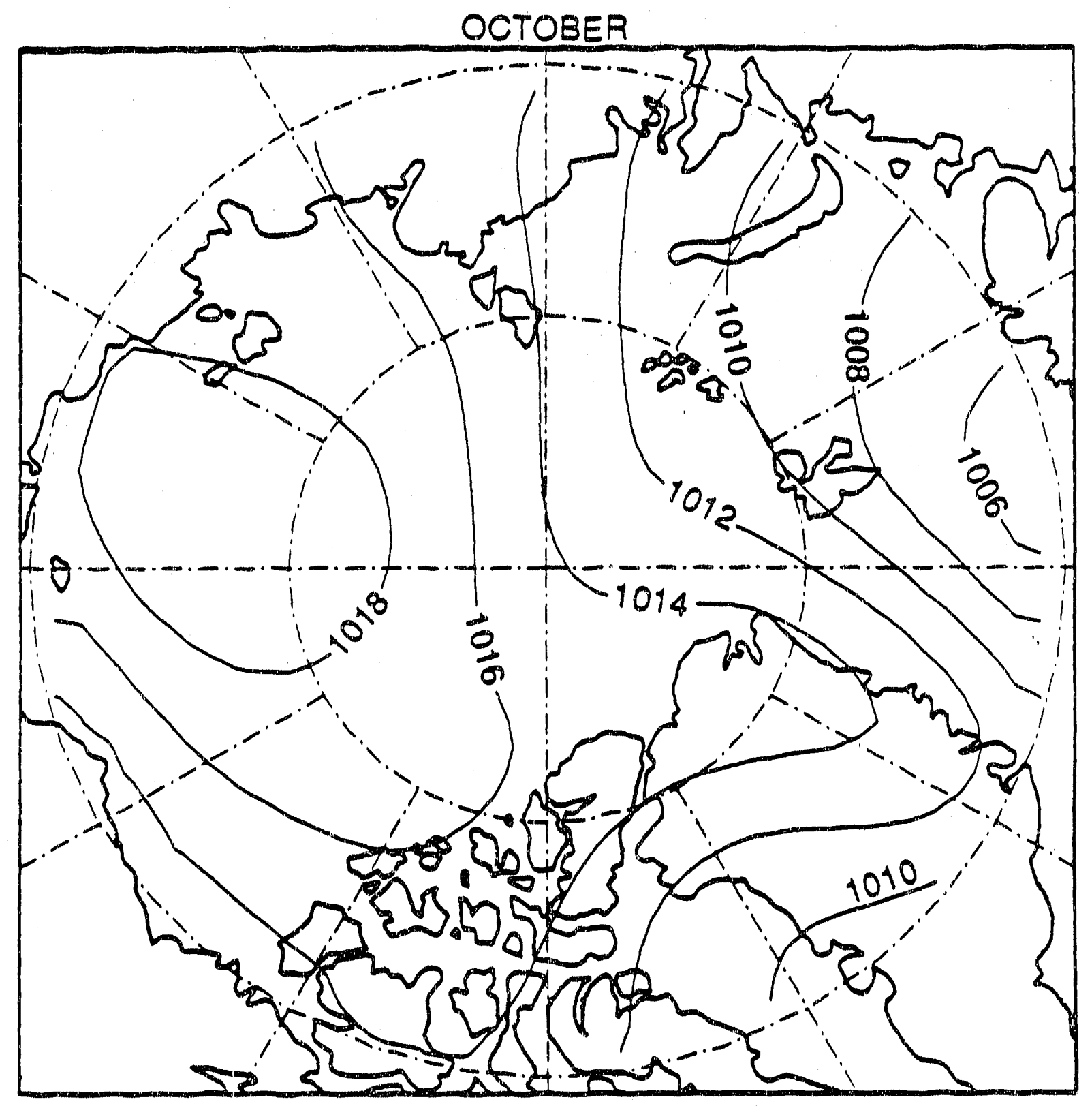

Fig. 156. Monthly averaged pressure map over the Arctic Ocean for October (after Colony, 1987). 


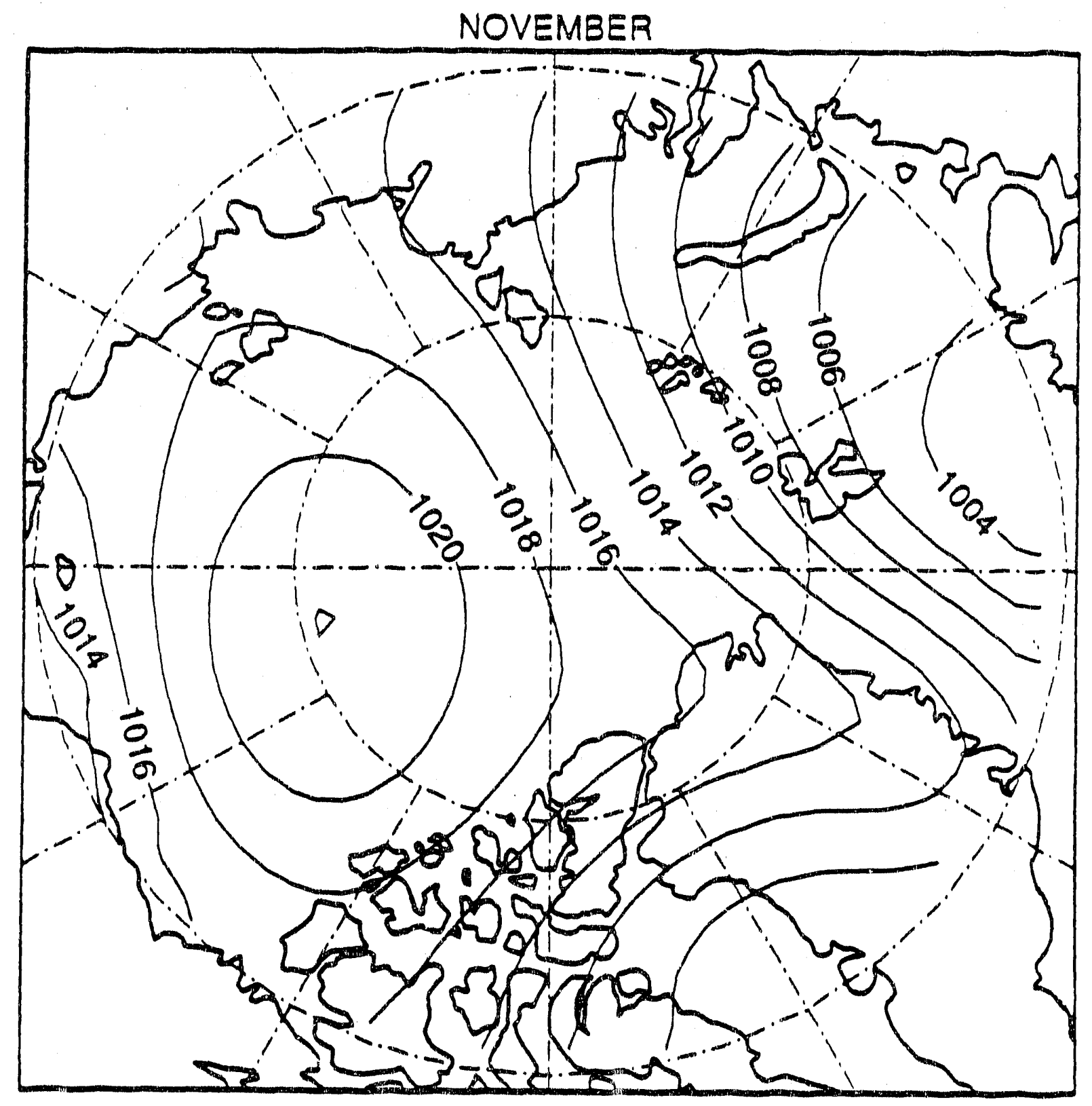

Fig. 157. Monthly averaged pressure map over the Arctic Ocean for November (after Colony, 1987). 


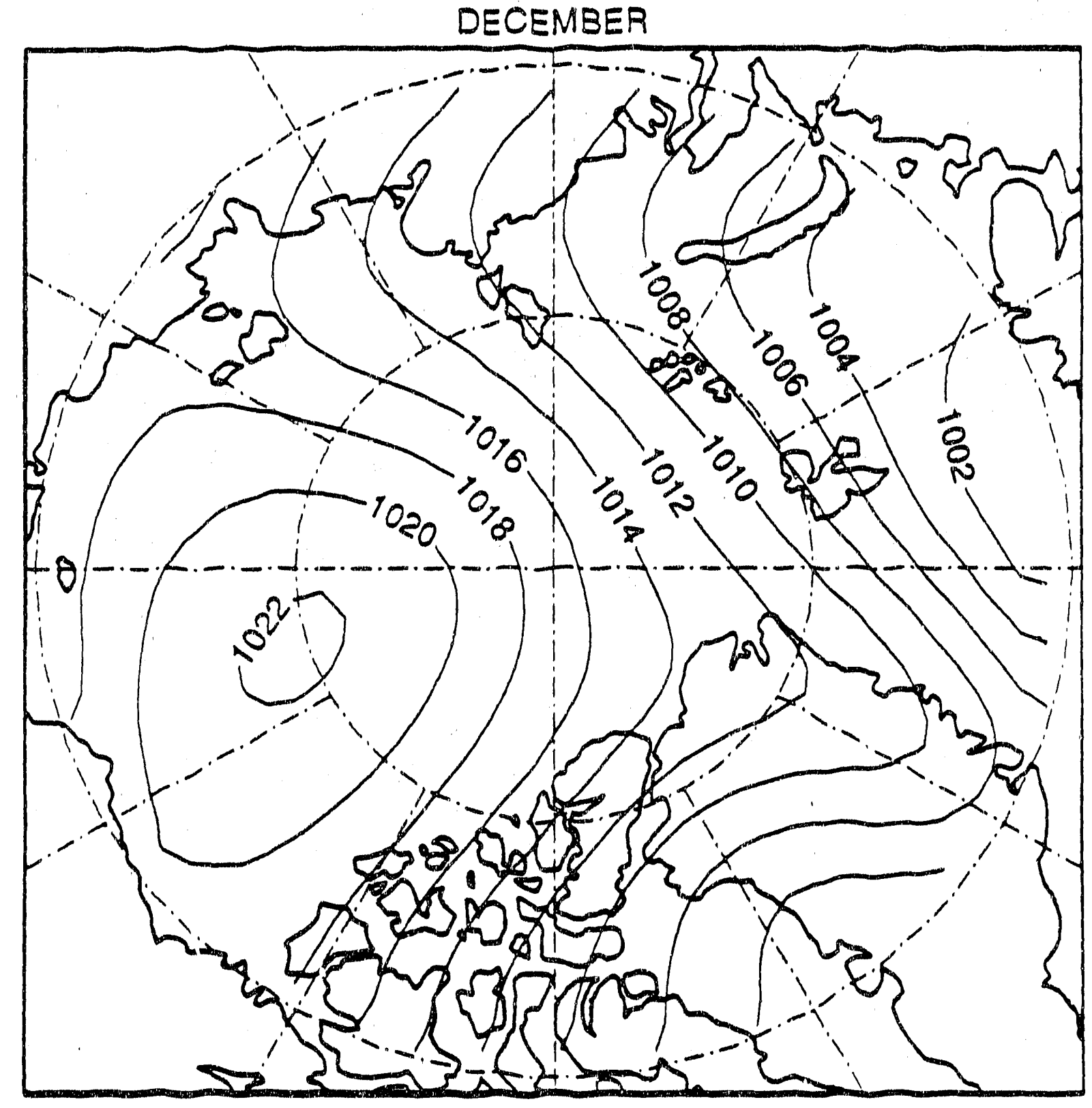

Fig. 158. Monthly averaged pressure map over the Arctic Ocean for December
(after Colony, 1987). 


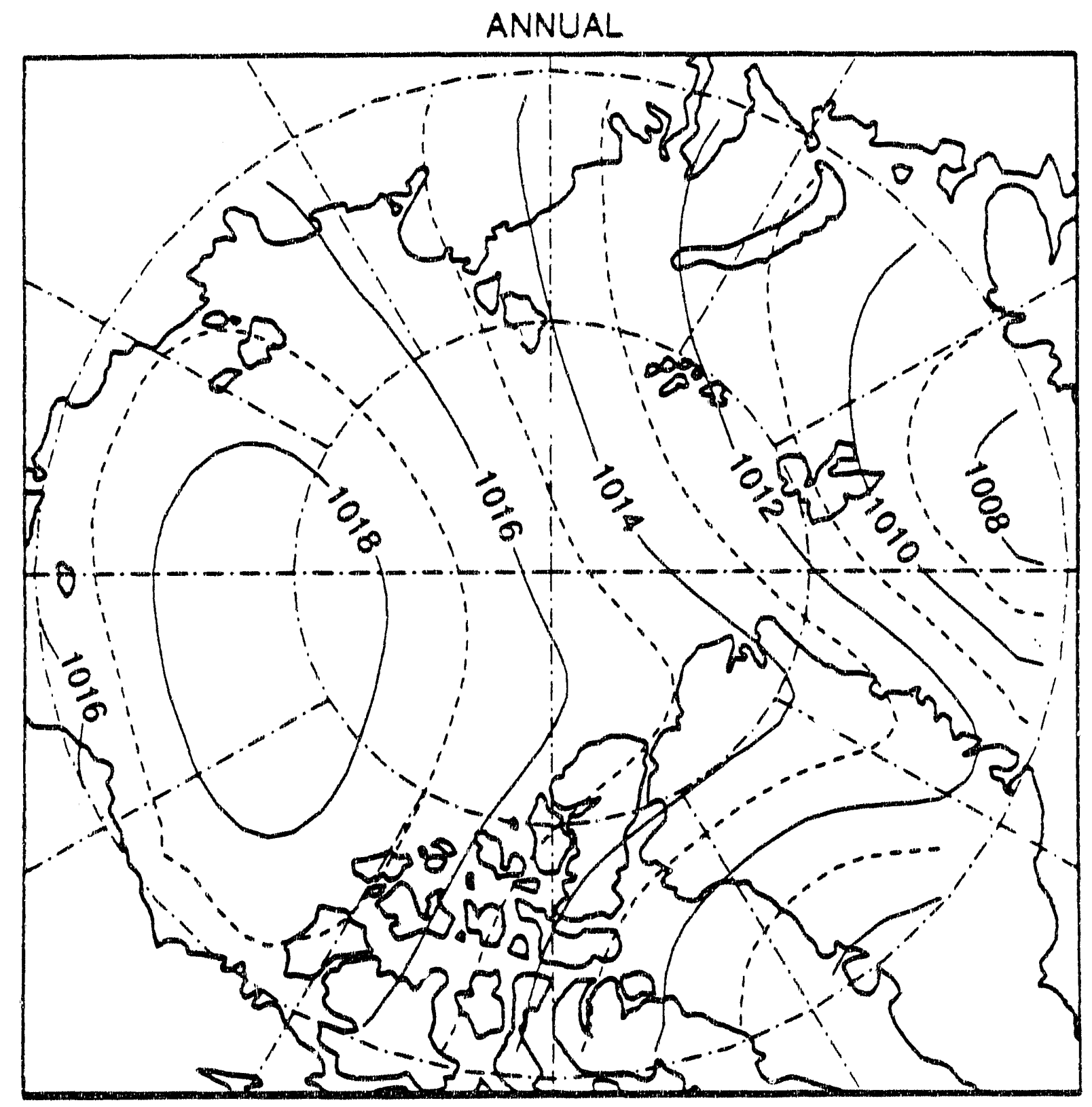

Fig. 159. Annually averaged pressure map over the Arctic Ocean (after Colony,
1987). 
CONTOURS OF RETURN PERIOD (YEARS)

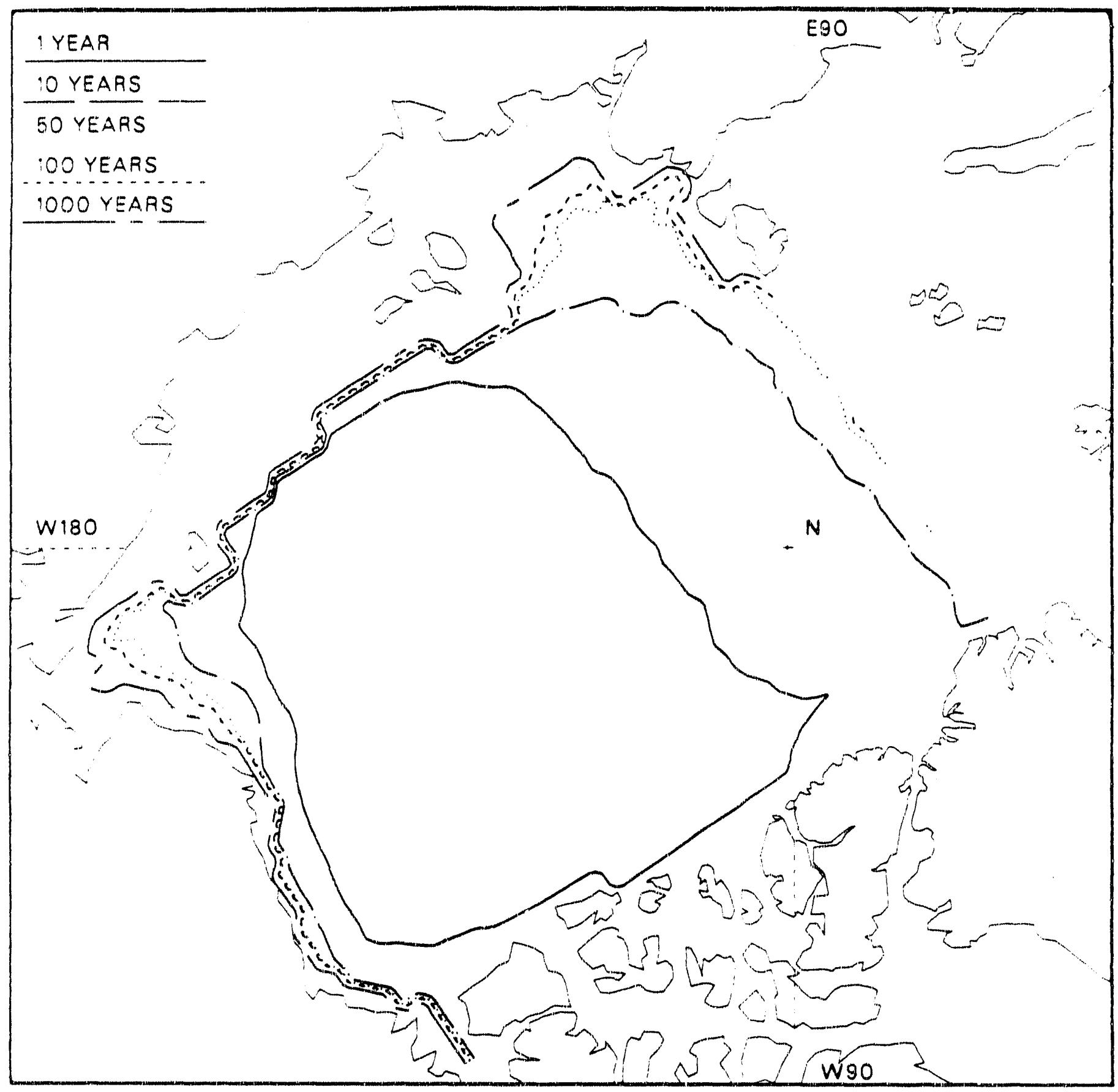

Fig. 160. Return period contours (years) of simulated ice islands in the Arctic Ocean for the case where the annually-averaged pressure field was used throughout the year for wind generation. 'This is less exact than 
ice islands on the Chukchi Shelf was offset by the wind patterns assumed in the calculation which produced Figure 160. The results in Figure 146 are believed to be closest to reality.

To examine the sensitivity to the water current effect near the Chukchi Sea and the Alaska Beaufort Sea, the simulation program was also run, neglecting the water current in these areas, and the simulation results are shown in Figure 161.

By comparison of this result with that shown in Figure 146, we can see that the dominant effect of the Chukchi Sea currents is to increase the return period from 1-10 years to $10-100$ years in the northern Chukchi Sea.

\section{IV.7. Conclusions of the Simulation}

A random ice island motion model has been established which is capable of simulating random ice island movement and the probability of ice island trajectories over the Arctic Ocean. The model is unique in that it uses a dynamic equation and the Monte Carlo method to overcome the difficulty of lack of extensive field data on ice island trajectories, and makes use of statistical data of wind fields, ice island generation, and movement laws as inputs, which are available at the present time.

The results of probabilities of simulated ice island trajectories show that there are two zones of highest recurrence of ice islands, one near the Canadian Beaufort Sea, another near the Chukchi Sea. There is a broad area of 1- to 10-year recurrence interval in the central ocean, and a high probability zone near the north end of Greenland, which implies that most of the ice islands are ejected out of the Arctic Ocean through Fram Strait between Greenland and Svalbard. The frequency of ejection by this route is the highest at (75)\%. The lifetime of ice islands has a cumulative frequency of $40 \%$ for between 5 to 15 years and of $85 \%$ for less than 35 years. The distribution of the number of live ice islands in the Arctic Ocean is approximately a Gaussian distribution, with a mean value of 18 years and a $90 \%$ 
CONTOURS OF RETURN PERIOD (YEARS)

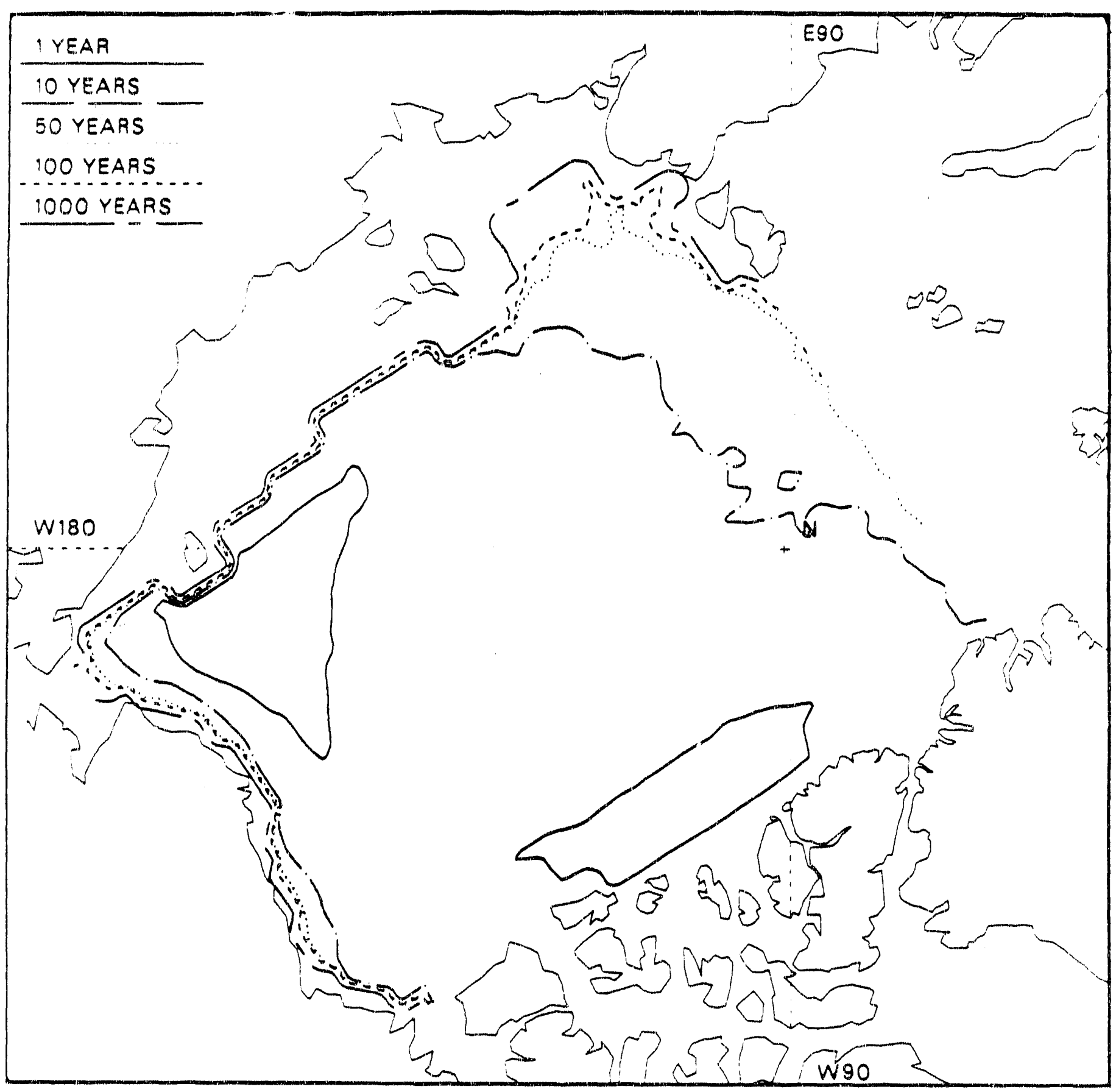

Fig. 161. Return period contours (years) of simulated ice islands in the Arctic Ocean for the case where the Chukchi and Beaufort Sea water currents were set to zero. This is less exact than Fig. 146. 
probability of numbers less than 30 , excluding ice island fragments. The ice island motions mainly display two basic patterns. For the first pattern, approximate $10 \%$ of ice islands move directly out of the ocean by northeast Greenland in less than 5 years after generation. About $90 \%$ of the ice islands fall in to the second motion pattern, in which the ice islands circulate clockwise covering the Beaufort Sea in one to four circuits. Among them, $47 \%$ of the ice islands complete only one circuit in at least 5 years. 


\section{CHAPTER V \\ CONCLUSIONS \\ (W. M. Sackinger, M. O. Jeffries, M. C. Lu, F. C. Li)}

Most ice islands originate by calving from the floating, partially-grounded ice shelves located along the northern coast of Ellesmere Island in Arctic Canada. The calving records of the past century have been assembled from historical records, to the extent possible. Regeneration mechanisms of the ice shelves have been established from ice core analysis. Surface snow accumulation, and ice accretion from below, tend to build additional thickness into sea ice ridges which are held against the coast throughout most of the year by prevailing Arctic wind systems, with the mountain barrier effect and the general trend direction of the coastline playing a complementary role. Calving of ice islands seems to occur at seemingly random intervals, generally with a spacing of 3 to 5 years. Two thickness categories, 42 meters and 10 meters, are most likely. Movernent of ice islands along the coast in the direction of the Beaufort Sea is most common, under the dominant forces of wind, current, Coriolis effect, and pack ice forces. Analysis of movement episodes has determined that the ice islands have short-term trajectories different from sea ice, due to the large values of water drag and Coriolis effect. Open water on one side of the ice island, and sea ice ridge building on the opposite side, is the result. Field observations of ridge heights exceeding the 5-meter ice island freeboard have been made, and the accumulation of attached additional multi-year sea ice around ice islands is evident from radar imagery. A threshold windspeed of about 5 meters/second is needed to initiate a major movement episode in regions of $100 \%$ pack ice cover.

A computer-based Monte Carlo simulation study of ice island generations and movernents in the Arctic Ocean has resulted in contour plots of the return intervals for ice islands in the Arctic Ocean regions. Coastal regions of the Beaufort and 
Chukchi Sea, which have been suggested for offshore oil development, show return intervals of 10 years to 100 years, depending upon water depth. This implies that the ice island hazard must be considered thoroughly, and appropriate safety measures must be adopted, when offshore oil production plans are formulated for the Alaskan Arctic offshore. 


\section{CHAPTER VI \\ REFERENCES}

Underlined authors' names indicates a publication arising from work undertaken under the DOE Contract No. AC21-83-MC20037.

Ahlnaes, K. and W.M. Sackinger, 1988. "Offshore Winds and. Pack Ice Movement Episodes North of Ellesmere Island." In Port and Ocean Engineering Under Arctic Conditions, W. M. Sackinger and M. (. Jeffries (Eds.). The Geophysical Institute, University of Alaska, Fairbanks, Vol. III. pp. 271-286.

Albright, M., 1980, Geostrophic Wind Calculations For AIDJEX, Sea Ice Processes and Models, R. S. Pritchard ed., University of Washington Press, 402-409.

Banke, E. G., S. D. Smith and R. J. Anderson, 1980, Drag Coefficients at AIDJEX from Sonic Anemometer Measurements, Sea Ice Processes and Models, edited by R. S. Pritchard, University of Washington Press.

Bialek, E. L., 1966, Handbook of Oceanographic Tables, U. S. Naval Oceanographic Office.

Brower, W.A. et al., 1977. Climatic Atlas of the Outer Continental Shelf Waters and Coastal Regions of Alaska, Volume 3: Chukchi-Beaufort Sea, U.S. Department of the Interior, Bureau of Land Management and Alaska Outer Continential Shelf Environmental Assessment Program, 10.

Brown, R.A., 1980, Planetary Boundary Layer Modeling for AIDJEX, in Sea Ice Processes and Models, R.S. Pritchard, ed., University of Washington Press, Seattle, 387.401.

Brown, R.A., 1981, Modeling of the Geostrophic Drag Coefficient for AIDJEX, $J$. Geophys. Res., Vol. 86, No. C3, 1989-1994. 
Browne, I.M. and A.P. Crary, 1958. The movement of ice in the Arctic Ocean, In Arctic Sea Ice, Proceedings of the conference held at Easton, Maryland, February 1958, National Academy of Sciences National Research Council Publication 598, 191-209.

Campluell, W.J., 1965, The Wind-Driven Circulation of Ice and Water in A Polar Ocean, J. Geophys. Res., Vol. 70, No. 14, 3279-3301.

Coachman, L.K. and K. Aagaard, 1988, Transports through Bering Strait: Annual and Interannual Variability, J. Geophys. Res., Vol. 93, 15535-15539.

Colony R. and E. A. Munoz, 1983, Arctic Ocean Buoy Program Data Report From January 1 to December 31,1983 , Polar Science Center, University of Washington, $115 \mathrm{pp}$.

Colony, R., 1987. Pressure Maps Over the Arctic Ocean, Personal Communication. Crary, A.P. and R.D. Cotell, 1952. Ice islands in Arctic research, Scientific Monthly 75:298-302.

Crary, A.P., 1958. Arctic Ice Island and Ice Shelf Studies, Part I, Arctic, 11:3-42.

De Paoli, S., T. B. Morrison and R. W. Marcellus, 1982, Analysis of Interaction Probabilities between Large Ice Features and Offshore Structures in the Canadian Beaufort Sea, Beaufort E.I.S. Reference Works, 101 pp.

Dunbar, M. and W. Wittmann, 1963. Some features of ice movement in the Arctic Basin, Proceedings of The Arctic Basin Symposium, October 1962, Arctic Institute of North America and the Office of Naval Resmrch, Tidewater Publishing Corp., Maryland, 90-108.

Frederking, R. M. W., G.W. Timco, M. O. Jeffries and W. M. Sackinger, 1988.

"Initial Measurements of Physical and Mechanical Properties of Ice from Hobson's Ice Island," Proc. Int'l Assn. Hydraulic Research Ice Symposium, Vol. 1, Sapporo, Japan, pp. 188-198. 
Greeley, A. W., 1886, Three Years of Arctic Service, An Account of the Lady Franklin Bay Expedition of 1881-84, New York 1886, Vol. 1, 428pp, Vol. 2, $444 \mathrm{pp}$.

Greenaway, K. R., 1952, Additional Information from Flights and Air Photographs in the Canadian Arctic, Arctic, Vol. 5, No. 2, 75-82.

Hattersley-Smith, G., 1955. Northern Ellesmere Island 1953 and 1954, Arctic 8:136.

Hattersley-Smith, G., 1957. The Ellesmere ice shelf and the ice islands, Canadian Geographer 9:65-70.

Hattersley-Smith, G., 1963, The Ward Hunt Ice Shelf: Recent Changes of the Ice Front, J. of Glaciology, Vol. 4, 415-524.

Hattersley-Smith, G., 1963a. Climatic inferences from firn studies in Northern Ellesmere Island, Geografiska Annaler 45:139-151.

Hattersley-Smith, G., 1963b. The Ward Hunt Ice Shelf: Recent changes of the ice front, Journal of Glaciology 4:415-424.

Hattersley-Smith, G., 1967. Note on ice shelves off the north coast of Ellesmere Island, The Arciic Circular 17(1):13-14.

Hattersley-Smith, G. and H. Serson, 1970. Mass balance of Ward Hunt Ice Rise and Ice Shelf: A 10 year record, Journal of Glaciology 9:247-252.

Hibler, W. D. III, 1984, Ice Dynamics, Cold Regions Research and Engineering Laboratory, Monography 84-3, 52 pp.

Hobson, G. D. and the Canadian Ice Island Scientific Party, incl. M. O. Jeffries and W. M. Sackinger, 1989. Ice Island field station: new features of the Canadian Polar margin. $E \oplus S 70$; p. 833.

Hoerner, S., 1965. Fluid-Dynamic Drag, Practical Information on Aerodynamic Drag and Hydrodynamic Resistance, Hoerner, Midland Park, N.J >, 11-16. 
Holdsworth, G., 1971, Calving from Ward Hunt Ice Shelf, 1961-1962, Canadian Journal of Earth Science, Vol. 8, 299-305.

Holdswnrth, G. and A. Traetteberg, 1973. The Deformation of an Arctic Ice Island, Proceedings $c_{1}^{f}$ the Second International Conference on Port and Ocean Engineering Under Arctic Condtions, University of Iceland, 419-440.

Hunkins, K., 1967. Inertial oscillations in Fletcher's Ice Island (T-3), Journal of Geophysical Research 72:1665-1174.

Hunkins, K., 1975, The Oceanic Boundary Layer and Stress beneath a Drifting Ice Floe. Journal of Geophysical Research 80(24): 3425-3433.

Jeffries, M. O. and H. Serson, 1983, Recent Changes at the Front of Ward Hunt Ice Shelf, Ellesmere Island, N.W.T. Arctic 36: 289-290.

Jeffries, M.O., 1985a. Ice islands of the Arctic Ocean, Gulf Canada Resources Inc., Frontier Development Division, Report, 78 pp.

Jeffries, M.O., 1985b. Physical, chemical and isotopic investigations of Ward Hunt Ice Shelf and Milne Ice Shelf, Ellesmere Island, N.W.T., Ph.D. Thesis, University of Calgary, Alberta, Canada, $310 \mathrm{pp}$.

Jeffries, M. O., W. M. Sachinger, H. R. Krouse and R. Fiennes, 1986. "Ice Core Analysis, Ward Hunt Ice Shelf." Report to the P.U.N.S. 1985-1986 Expedition to Ward Hunt Ice Shelf, 19pp.

Jeffries, M. O., 1986, Ice Island Calvings and Ice Shelf Changes, Milne Ice Shelf and Ayles Ice Shelf, Ellesmere Island, N.W.T. A rctic 39: $15-19$.

Jeffries, M. O., W. M. Sackinger and H. V.Serson, 1987. "Remote Sensing of Sea Ice Growth and Melt-Pool Evolution, Milne Ice Shelf, Ellesmere Island, Canada." Ann. of Giaciol. 9, pp. 145-150.

Jeffries, M. O., 1987. Structure and growth of arctic ice shelves and ice islands. Workshop on extreme ice features, Banff, Alberta, 3-5 November 1986, National Research Council of Canada. Technical Memorandum 141:39-51. 
Jeffries, M. O., 1987. Oxygen isotope evidence of freshwater pools and ice accretion below multiyear landfast sea ice, northern Ellesmere Island. Workshop on extreme ice features, Banff, Alberta, 3-5 November 1986, National Research Council of Canada, Technical Memorandum 141:405-412.

Jeffries, M. O. and H. R. Krouse, 1988. Salinity and isotope analysis of some multiyear landfast sea ice cores, northern Ellesmere Island, Canada, Annals of Glaciology 10: 63-67.

Jeffries, M. O., W. M. Sackinger and H. Shoemaker, 1988, Geometry and Physical Properties of Ice Islands, Port and Ocean Engineering under Arctic Conditions, edited by W. M. Sackinger and M. O. Jeffries, The Geophysical Ins., University of Alaska, Vol. 1, 69-83.

Jeffries, M. O., W. M. Sackinger and H. D. Shoemaker, 1988. "Some Physical Properties of Multiyear Landfast Sea Ice, Northern Ellesmere Island, Canada." In Port and Ocean Engineering Under Arctic Conditions, W. M. Sackinger and M. O. Jeffries (Eds.). The Geophysical Institute, University of Alaska, Fairbanks, Vol. I, pp. 57-68

Jeffries, M. O., W. M. Sackinger, H. R. Krouse and H. V, Serson, 1988. "Water Circulation and Ice Accretion Beneath Ward Hunt Ice Shelf (Northern Ellesmere Island, Canada) Deduced from Salinity and Isotope Analysis of Ice Cores." Ann. of Glaciol., 10, pp. 68-72.

Jeffries, M. O., W. M. Sackinger, R. M. IV. Frederking and G. W. Timco, 1988. "Initial Mechanical and Physical-Structural Property Measurements of Old Sea and Brackish Ice From Ward Hunt Ice Shelf, Canada," Proc. Irt'l Assn. Hydraulic Research Ice Symposium, Vol. 1, Sapporo, Japan, pp. 177-187.

Jeffries, M. O., H. R. Krouse, W. M. Sackinger and H. Serson, 1989. Stable isotope (180/160) tracing of fresh, brackish and sea ice in multiyear landfast sea ice, Ellesmere Island, Canada. J. of Glaciol., 35, pp. 9-16. 
Jeffries, M. O. and W. M. Sackinger, 1989. "Some measurements and observations of very old sea ice and brackish ice, Ward Hunt Ice Shelf, N.W.T." AtmosphereOcean, 27; pp. 553-564.

Jeffries, M. O. and W. M. Sackinger, 1989. "Analysis and interpretation of an airborne synthetic aperture radar image of Hobson's Choice Ice Island," Proc. Tenth International Conf., Port and Ocean Engineering under Arctic Conditions (POAC 89), Vol. 2, K. B. E. Axelsson and L. A. Fransson (editors), Luleå, Siveden, pp. 1063-1072.

Jeffries, M. O. and W.M. Sackinger, 1989, "Airborne SAR châracteristics of arctic ice shelves and multiyear landfast sea ice, and the detection of massive ice calvings and ice islands." Proc. International Geoscience and Remote Sensing Symposium (IGARSS '89), 12th Canadian Symposium on Remote Sensing. University of British Columbia, Vancouver, B.C., Vol. 4, pp. 2715-2718.

Jeftries, M. O., W. M. Sackinger, H. R. Krouse and H. V. Serson 990. "Surface Topography, Thickness and Ice Core Studies of Multiyear Landfast Sea Ice and Ward Hunt Ice Shelf, Northern Ellesmere Island, N. W. 'T." In Canada's Missing Dimension: Science and History in the Canadian Arctic Islands, C. R. Harrington, ed., Canadian Museum of Nature, Ottawa Ontario, Canada, 229254.

Jeffries, M. O., N. K. Sinha and W. M. Sackinger, 1990. "Failure stress and failure modulus of natural ice island ice under uniaxial compression at constant strain rates." 9th International Conf., Offshore Mechanics and Arctic Engineering, Houston, Texas, 223-229.

Johnson, W.R., 1987. Physical Oceanography, The Environment and Resources of the Southeastern Chikchi Sea, U.S. Departments of Commerce and the Interior, 34 . 
Khandekar, M. L., 1979, Inertial Oscillations in Floe Motion over the Beaufort Sea Observations and Analysis, Atmosphere-Ocean 18 (1) 1980, 1-14.

Koenig, L. S., K. R. Greenaway, Moira Dunbar and G. Hattersley-Smith, 1952, Arctic Ice Islands, Arctic, Vol. 5, 67-103.

Koerner, R.M., 1977. Devon Island ice cap; core stratigraphy and paieoclimate, Science 196:15-18.

Kowalik, Z. and N. Untersteiner, 1978, A Numerical Study of the $M_{2}$ Tide in the Arctic Ocean, Deut. Hydrogr. Zeit., 31: 216-229.

Kozo, T. L., 1980, Mountain Barrier Baroclinity Effects on Surface Winds along the Alaska Arctic Coast, Geophys. Res. Letters, Vol. 7, No. 5, 377-380.

Kozo, T. L., 1988, Mountain Barrier Effects on Sea Ice Drift in the Beaufort Sea Coastal Zone, in Port and Ocean Engineering under Arctic Conditions, Vol. III, W. M. Sackinger and M. O. Jeffries, eds., The Geophysical Institute, University of Alaska.

Langleben, M. P., 1982, Water Drag Coefficient of First-Year Sea Ice, J. Geophys. Res., Vol. 87, No. C1, 573-578.

Leavitt, E., M. Albright and F. Carsey, 1978, Report on the AIDJEX Meteorological Experiment, AIDJEX Bulletin, No. 39, 121-128.

LeSchack, L. A., 1961, Arlis II: new Arctic drift station. Naval Research Reviews, September, 12-18.

Li Fu-cheng, W. M. Sackinger, Lu Ming-chi and M. O. Jeffries, 1988. "A Probabilistic Study of Ice Island Trajectories," Pros. Int'l Assn. Hydraulic Research Ice Symposium, Sapporo, Japan, pp. 405-414. 
Li, Fu-cheng, W. M. Sackinger, M. O. Jeffries and Lu Ming-chi, 1989. "Computer simulations of the probability of ice island movements in the ARctic Ocean." Proc. Tenth International Conf., Port and Ocean Engineering under Arctic Conditions, Vol. 2, K. B. E. Axelsson and L. A. Fransson (editors), Luleå, Sweden, pp. 1063-1072.

Lindsay, D., W. Seifert and N Anderson, 1968. Ice islands, 1967, Arctic 21:103105.

Lu, M-C., 1988. Analysis of Ice Island Movement, Masters Thesis, University of Alaska, Frirbanks, Alaska.

Lu, M. and W. M. Sackinger, 1989. "The Mountain Barrier Effect and Modification of Tabular Iceberg Motion in a Coastal Ice Zone", J. Coastal Res., 5, pp. 701-710.

Macklin, S. A., 1983, Wind Drag Coefficient over First-Year Sea Ice in the Bering Sea, J. of Geophysical Research, Vol. 88, No. C5, 2845-2852.

Martin, F. and A Thorndike, 1974, Ice Island Report, AIDJEX Bulletin, No. 27, 108-116.

Maykut, G.A. and N. Untersteiner, 1971. Some results from a time-dependent thermodynamic model of sea ice, Journal of Geophysical Research 76:15501575.

McBean, G., 1986, The Atrnospheric Boundary Layer, The Geophysics of Sea Ice, edited by Norbert Untersteiner, University of Washington, NATO ASI Series, Series B, Physics: Vol. 146, 283-338.

McPhee, M.G., 1979. The Effect of the Oceanic Boundary Layer on the Mean Drift of Pack Ice: Application of a Simple Model, J. Phys. Oceanogr., 9:388-400.

McPhee, M. G., 1980, An Analysis of Pack Ice Drift in Summer, Sea Ice Processes and Models, edited by R. S. Pritchard, University of Washington Press, 62-75. 
McPhee, M. G., 1982, Sea Ice Drag Laws and Simple Boundary Layer Concepts, Including Application to Rapid Melting, USA Cold Regions Research and Engineering Laboratory, CRREL Report 82-4, 52pp.

McPhec, M. G., 1986, The Upper Ocean, The Geophysics of Sea Ice, edited by Norbert Untersteiner, University of Washington, NATO ASI Series, Series B, Physics: Vol. 146, 339-394.

Muguruma, J. and K. Higuchi, 1963. Glaciological studies on ice island T-3, Journal of Glacioiogy 4:709-730.

Nansen, F., 1902, The Oceanography of the North Polar Rasin, the Norwegian North Polar Expedition 1893-1896, Scientific Results, Vol. 3,357-386.

Nordlund, O. P., W. M. Sackinger and M. Yan, 1985. "Ice Features and Movement North of Ellesmere Island, Canada". Proc. of the Eighth Int'l Conference on Port and Ocean Engineering Under Arctic Conditions, Narssarssuaq, Greenland, pp. 293-304.

Nutt, D.C., 1966. The drift of ice island WH-5, Arctic 19:244-262.

Parish, T. R., 1983, The Influence of the Antarctic Peninsula on the Wind Field over the Western Weddell Sea, Journal of Geophysical Research, Vol. 88, No. C4, 2684-2692.

Parliamentary Paper, $v$ LVI, 1877. Journals and proceedings of the arctic expedition of 1875-6 under the command of Captain Sir George S. Nares, R.N., K.C.B., London, 484 pp.

Peary, R., 1907, Nearest the pole, A Narrative of the Polar Expedition of the Peary Arctic Club in the S. S. Roosevelt, 1905-1906, Hutchinson, London.

Pease, C. H. and J. E. Overland, 1984, An Atmospherically Driven Sea-Ice Drift Model for the Bering Sea, Annals of Glaciology, Vol. 5, 111-114.

Pease, C. H., S. A. Salo and J. E. Overland, 1983, Drag Measurements for FirstYear Sea Ice over a Shallow Sea, J. Geophys. Res., Vol. 88, No, C5, 2853-2862. 
Polunin, N., 1955. Attempted dendrochronological dating of ice island T-3, Science 122:1184-1186.

Prager, B.T., 1983. Digital signal processing of UHF radio-echo sounding data from northern Ellesmere Island, MSc. Thesis, University of British Columbia, Vancouver, Canada, $88 \mathrm{pp}$.

Sackinger, W. M. and W. J. Stringer, 1983, Arctic Ice Island and Sea Ice Movements and Mechanical Properties, First Quarterly Report, Univ. of Alaska-Fairbanks, $122 \mathrm{pp}$.

Sackinger, W. M., 1984. "Ice Island Generation and Trajectories". Proc. of the Arctic Energy Technologies Workshop, Morgantown, West Virginia.

Sackinger, W. M., W. J. Stringer and H. Serson, 1984. "Arctic Ice Island and Sea Ice Movements and Mechanical Properties." Second Quarterly Report to U. S. ircpartment of Energy, Geophysical Institute, University of Alaska, Fairbanks, $266 \mathrm{pp}$.

Sackinger, W. M. and W. J. Stringer, 1984. "Arctic Ice Island and Sea Ice Movements and Mechanical Properties." Third Quarterly Report to U. S. Department of Energy, Geophysical Institute, University of Alaska, Fairbanks, $47 \mathrm{pp}$.

Sackinger, W. M. and W. J. Stringer, 1984. "Arctic Ice Island and Sea Ice Movements and Mechanical Properties." Fourth Quarterly Report to U. S. Department of Energy, Geophysical Institute, University of Alaska, Fairbanks, $108 \mathrm{pp}$.

Sackinger, W. M. and M. O. Jeffries, 1984. "Arctic Ice Island and Sea Ice Movements and Mechanical Properties." Fifth Quarterly Report to U. S. Department of Energy, Geophysical Institute, University of Alaska, Fairbanks, 47 pp. + Appendix. 
Sackinger, W. M., H. Serson, M. O. Jeffries, H. D. Shoemaker and M. Yan, 1985. "Ice Island Generation and Trajectories North of Ellesmere Island, Canada". Proc. of the Eighth Int'l Conference on Port and Ocean Engineering Under Arctic Conditions, Narssarssuaq, Greenland, pp. 1009-1040.

Sackinger, W. M., M. O. Jeffries, H. Serson, M. Yan and H. D. Shoemaker, 1985. "Ice Islands as Hazards to Arctic Offshore Production Structures". Proc. of the Offshore Technology Conference, Voi. 2 (OTC 4943), Houston, Texas, pp. 399408.

Sackinger, W. M. and M. Yan, 1985. "Generation and Movement of Ice Islands Near the Canadian Arctic Archipelago." Proc. of the Arctic Oceanography Conference, Bay St. Louis, Missouri, pp. 44-49.

Sackinger, W. M., 1985. "Ice Islands as Locations for Arctic Data Collection." Arctic/Cold Weather Surface Ship Operations Symposium, Rockville, Maryland.

Sackinger, W. M. and M. O. Jeffries, 1985. "Arctic Ice Island and Sea Ice Movements and Mechanical Properties." Sixth Quarterly Report to U. S. Department of Energy, Geophysical Institute, University of Alaska, Fairbanks, $62 \mathrm{pp}$.

Sackinger, W. M. and M. O. Jeffries, 1986, Arctic Ice Island and Sea Ice Movements and Mechanical Properties, 12th Quarterly Report (1 July - 30 September, 1986), U. S. Department of Energy, Morgantown Energy Technology Centre, Western Virginia.

Sackinger, W. M., M. O. Jeffries, K. Ahlnaes, M. Yan and H. Tippens, 1986. "Development of Quantitative Information on Arctic Sea Ice and Ice Island Movement, Thickness and Mechanical Properties: Ice Island Production and Movement." In, Proc. of the Gas Hydrates, Arctic/Offshore Research and Deep Source Gas Contractors Review Meeting, C. A. Komar (Ed.). U. S. Department 
of Energy, METC, Morgantown, West Virginia., DOE/METC-86/6037, pp. 6380 .

Sackinger, W.M., 1986. "Generation and Trajectories of Ice Islands and Multi-Year Ice Floes". Ice Technology, T. K. S. Murthy, J. J. Connor and C. A. Brebbia (Eds.). Springer-Verlag, Berlin, pp. 579-594.

Sackinger, W. M. and M. Yan, 1986. "Loss, Decay and Recent Drift of Ice Islands."

National Research Council of Canada, Technical Memorandum. Proc. of the Workshop on Extreme Ice Features, Banff, Alberta, pp. 53-66.

Sackinger, W. M. and M. O. Jeffries, 1986. "Arctic Ice Island and Sea Ice Movements and Mechanical Properties." Thirteenth Quarterly Report to U. S. Department of Energy, Geophysical Institute, University of Alaska, Fairbanks. Sackinger, W. M. and M. O. Jeffries, 1987. "Ice Island Characterization." Proc. Unconv. Gas Recovery Meeting. C. A. Kornar (Ed.), U. S. Department of Energy, Morgantown Energy Technology Center, DOE/METC 87/6080, pp. 426-442.

Sackinger, W. M. and M. O. Jeffries, 1987. "Arctic Ice Island and Sea Ice Movements and Mechanical Properties." Fourteenth Quarterly Report to U. S. Department of Energy, Geophysical Institute, University of Alaska, Fairbanks. Sackinger, W. M., 1988. "Total Ice Force Measurements on an Instrumented Structure, an Overview of Ice Islands, and Spray Ice Bonding to Offshore Structure Coatings", Proc. Conf. on Sea Ice Forces and Mechanics, Minerals Management Service, Anchorage, pp. 61.64.

Sackinger, W. M. and H. R. Tippens, 1988. "Analysis of Ice Island Movement." In Port and Ocean Engineering Under Arctic Conditions, W. M. Sackinger and M. O. Jeffries (Eds.). The Geophysical Institute, University of Alaska, Fairbanks Vol. I, pp. 269-278. 
Sackinger, W. M., 1988, "Ice Mechanical Properties in Relation to Arctic Engineering Activities, "Invited Paper in Proc. Int'l Assn. Hydraulic Research Ice Symposium, Vol. 3, Sapporo, Japan, pp. 9-25.

Sackinger, W. M., 1988, "Coastal Ice Dynamics,"in Arctic Coastal Processes and Slope Protection Design, A. T. Chen and C. B. Leidersdorf (Eds.), American Society of Civil Engineers, New York, pp. 63-84.

Sackinger, W. M., M. O. Jeffries, H. Tippens, F. Li and M. Lu, 1989. Dynamics of ice island motion near the coast of Axel Heiberg Island, Canadian High Arctic. Ann. Glaciol., 12, pp. 152-156.

Sackinger, W. M. and F. Li, 1989. "Permanent Artificial Islands and Structures in Ice-Infested Coastal Locations", J. Ocean Engineering (China), No. 4, (in Chinese).

Sackinger, W. M. and M. O. Jeffries, 1989. "Recent Ice Island Creation Events, Drift Laws and Recurrence Intervals, Mechanical Properties and Interactions with Offshore Oil Production Structures", Proc. Natural Gas $R \& D$ Contractors Review Meeting, C. A. Komar, R. D. Malone, C. W. Byrer (eds.) U.S. Dept. of Energy, Morgantown, WV, pp. 419-431.

Schmidt, M., J. Popelar and J. Kouba, 1987, Ice Island 1985-86 Navigation and Geodetic Positioning, Geological Survey of Canada, Open File, Polar Continental Shelf Project, Ice Island Contribution No. 6.

Schwerd tfeger, W., 1975, Mountain Barrier Effect on the Flow of Stable Air North of the Brooks Range, in Climate of the Arctic, G. Weller and S. A. Bowling, eds., Geophysical Institute, University of Alaska, 204-208.

Serson, H. V., 1984. Ice conditions off the north coast of Ellesmere Island, Nansen Sound, Sverdrup and Pear Channels, 1963-1980, Appendix A in, Arctic ice island and sea ice movements and mechanical properties, Second quarterly report submitted to U.S. Department of Energy, Morgantown, W.V., fromt he 
Geophysical Institute, University of A laska, Fairbanks (W.M. Sackinger, W.J. Stringer and H. Serson).

Service Argos Technical Brochure, 1934, The Argus Satellite Based Data Collection and Platform Location System, Centre National d'Etudes Spatiales, France, 12pp.

Service Argos Technical Brochure, 1987, The Argos Satellite Based Data Collection and Platform Location System, Centre National d'Etudes Spatiales, France.

Shirasawa, K., N. P. Riggs and D. B. Muggeridge, 1984, The Drift of a Number of Idealized Model Icebergs, Cold Regions Science and Technology, 10: 19-30.

Shreider, Y-A., 1962. The Monte Carlo Method, Pergamon Press.

Skiles, F.L., 1968, Empirical Wind Lrift of Sea Ice, Proc. of the Arctic Drifting Sy,nposium, Warrenton, Virginia.

Smith, D. D., 1964, Ice Lithologies and Structure of Ice Island Arlis II. J. of Glaciology, Vol. 5, No. 37, 17-38.

Spedding, L.G., 1977, Ice Island Count Southern Beaufort Sea 1976, APOA 99, IPRT-13ME-77, Imperial Oil Limited, 50pp.

Stefansson, V., 1922, The Friendly Arctic, MacMillan, New York.

Stoiber, R.E., J.B. Lyons, W.T. Elberty and R.H. McCrehan, 1960. Petrographic evidence on the source area and age of T'-3, Scientific studies of Fletcher's ice island T-3, 1952-1955, V.C. Bushnell (ed.), Geophysical Research Directorate, U.S. Air Force Cambridge Research Centre, Bedford, Mass G.R.D. Research Papers, No. 63, 58-72.

Sverdrup, H.U., 1928, The Wind-Drift of the Ice on the North Siberian Shelf, the Norwegian North Polar Expedition with the Maud 1918-1925, Scientific Results, Vol. 4, 1-16. 
'Thorndike, A. S. and R. Colony, 1982, Sea Ice Motion in Response to Geostrophic Winds, J. Geophys. Res., Vol. 87, No. C8, 5845-5852.

Thorndike, A.S., 1982. Statistical Properties of the Atmospheric Pressure Field Over the Arctic Ocean, Journal of the Atmospheric Sciences, Vol 39, 2229-2338.

Thorndike, A. S., 1986, Kinematics of Sea Ice, The Geophysics of Sea Ice, edited by Norbert Untersteiner, University of Washington, NATO ASI Series, Series B, Physics: Vol. 146, 489-550.

U.S. Navy, 1967. Birds Eye 2-67, 15 March - 19 April, 1967, U.S.N. Oceanographic Office, Informal Report, No. 67-81, 173 pp.

Weast, R. C., M. J. Astle and W. H. Beyer, 1985, Handbook of Chemistry and Physics, CRC Press, Boca Raton, Florida.

"'oeks, W. F. and W. M. Sackinger, 1981. "The Physical Environment of Arctic Alaska". In, U. S. Arctic Oil and Gas, Working Paper No. 21, 137 pp., National Petroleum Council, Washington, D. C.

Yan, M., 1986, The Relationship between Ice Island Movement and Weather Condition, M.S. Thesis, University of Alaska-Fairbanks.

Zubov, N. N., 1945, Arctic Ice, Izdatel'stvo Glavsevmorputi, Moscow, Translated for Air Force Cambridge Research Center by U.S. Nával Oceanographic Office and American Meteorological Society, 360pp. 


\section{APPENDIX}

Computer Program Listing for Simulations of Ice Island Trajectories 

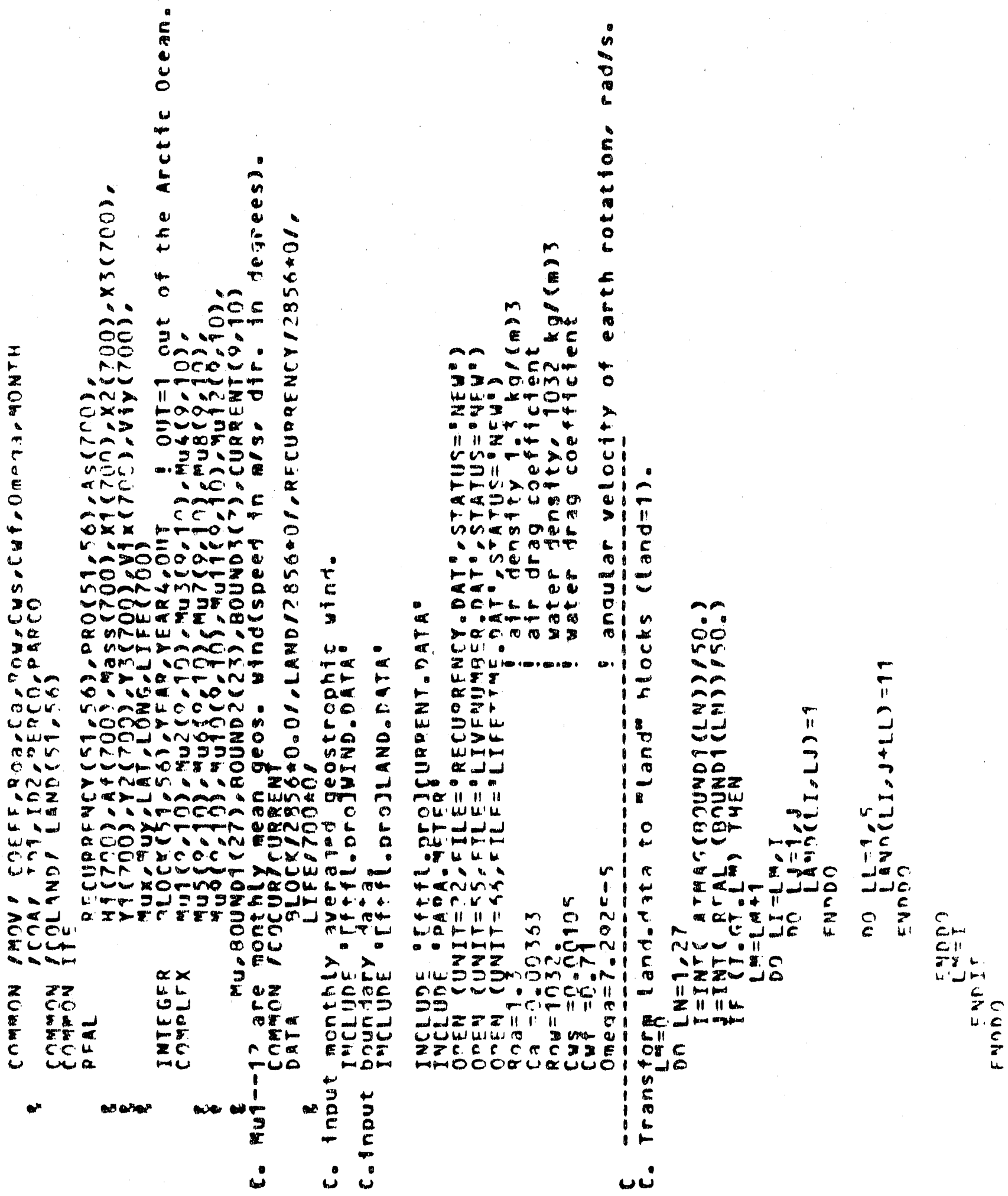


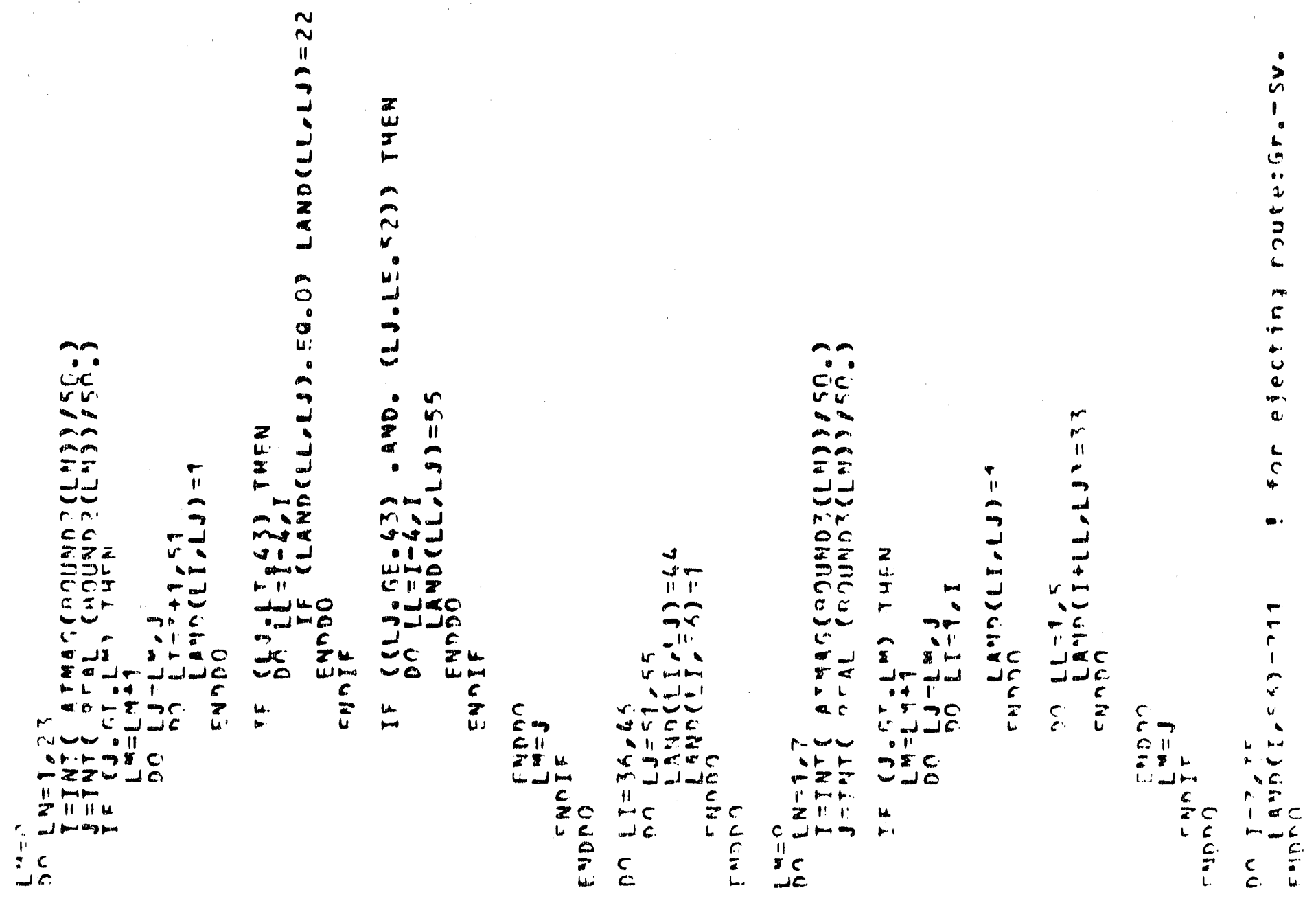




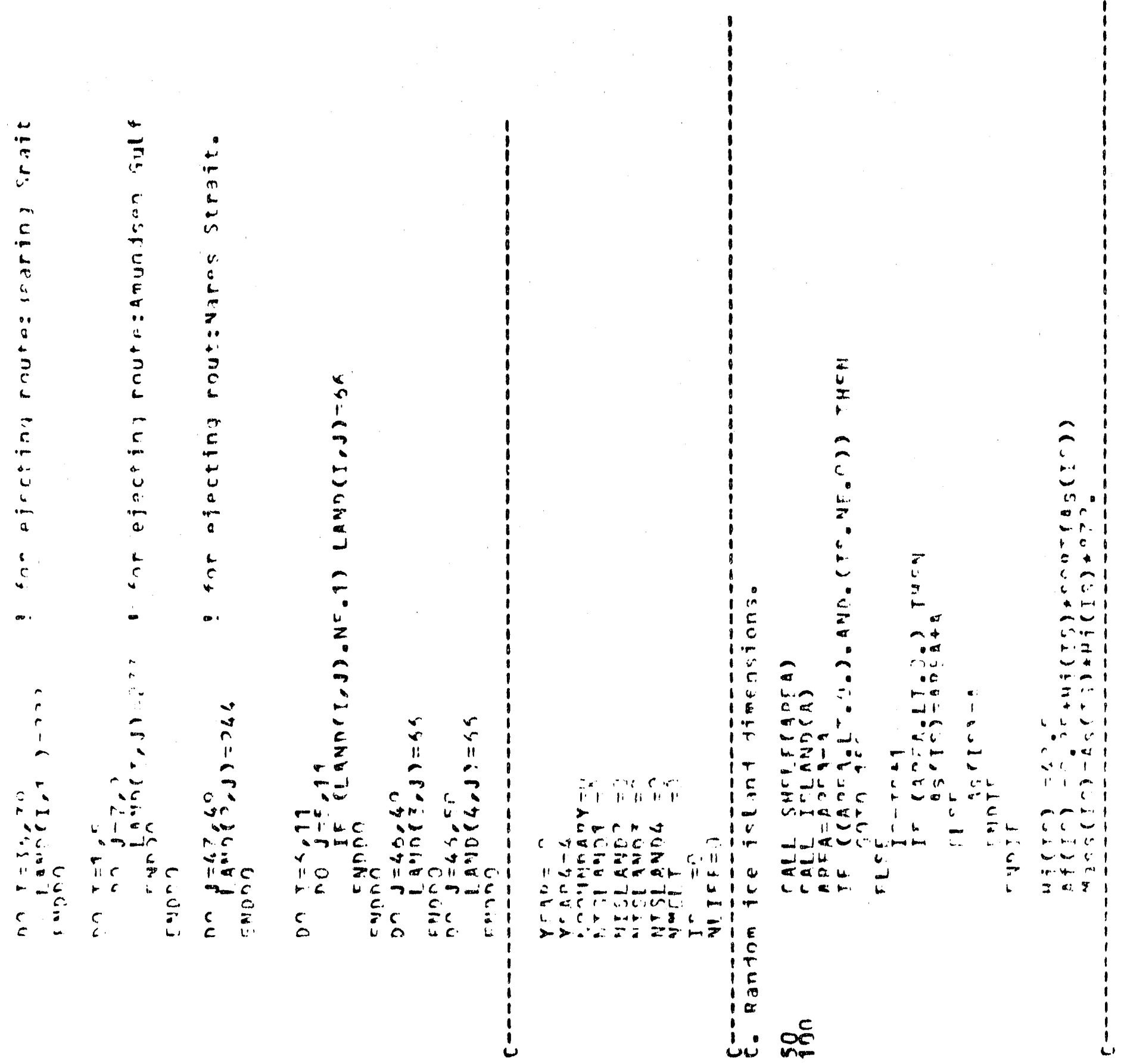




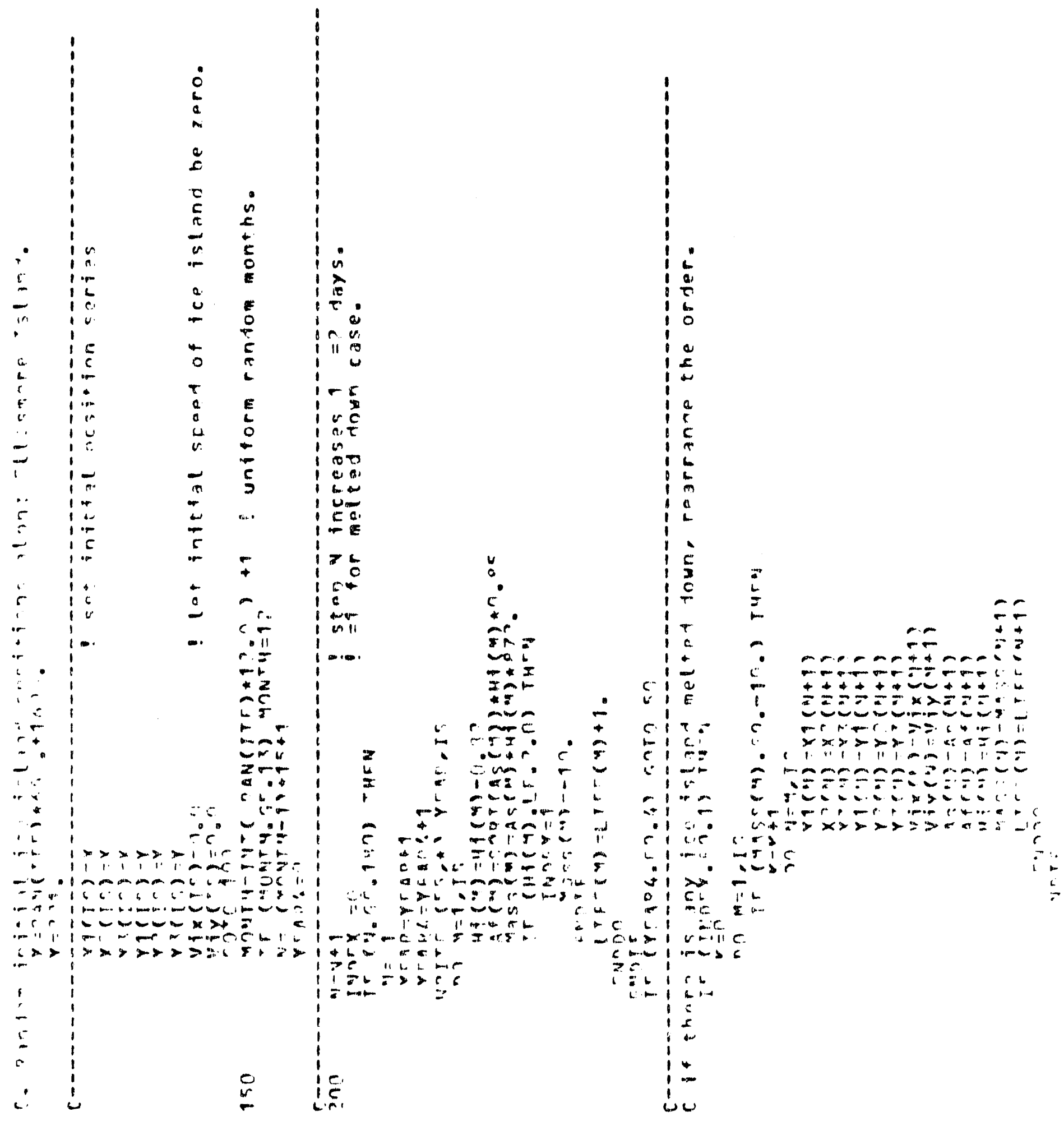




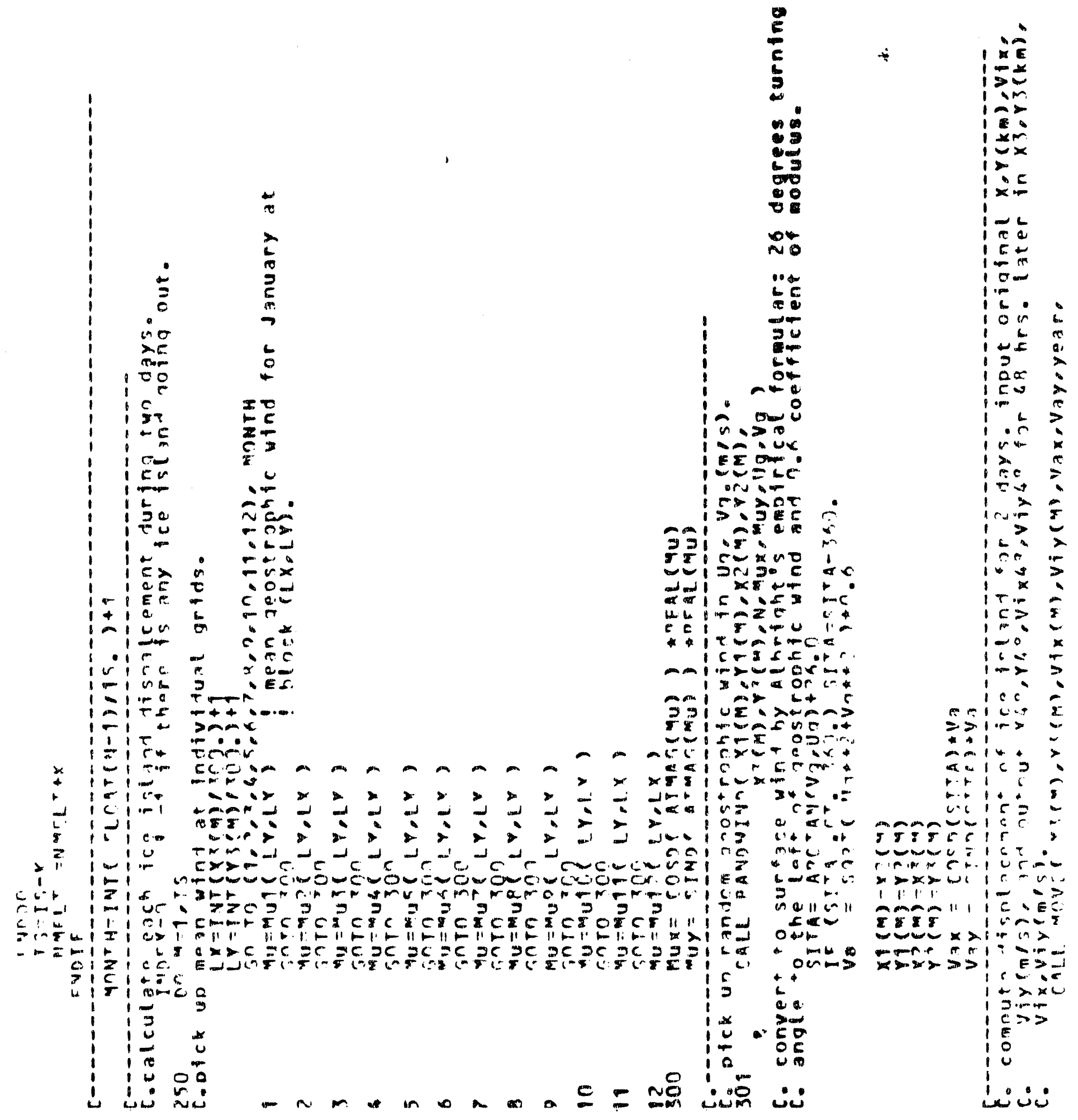



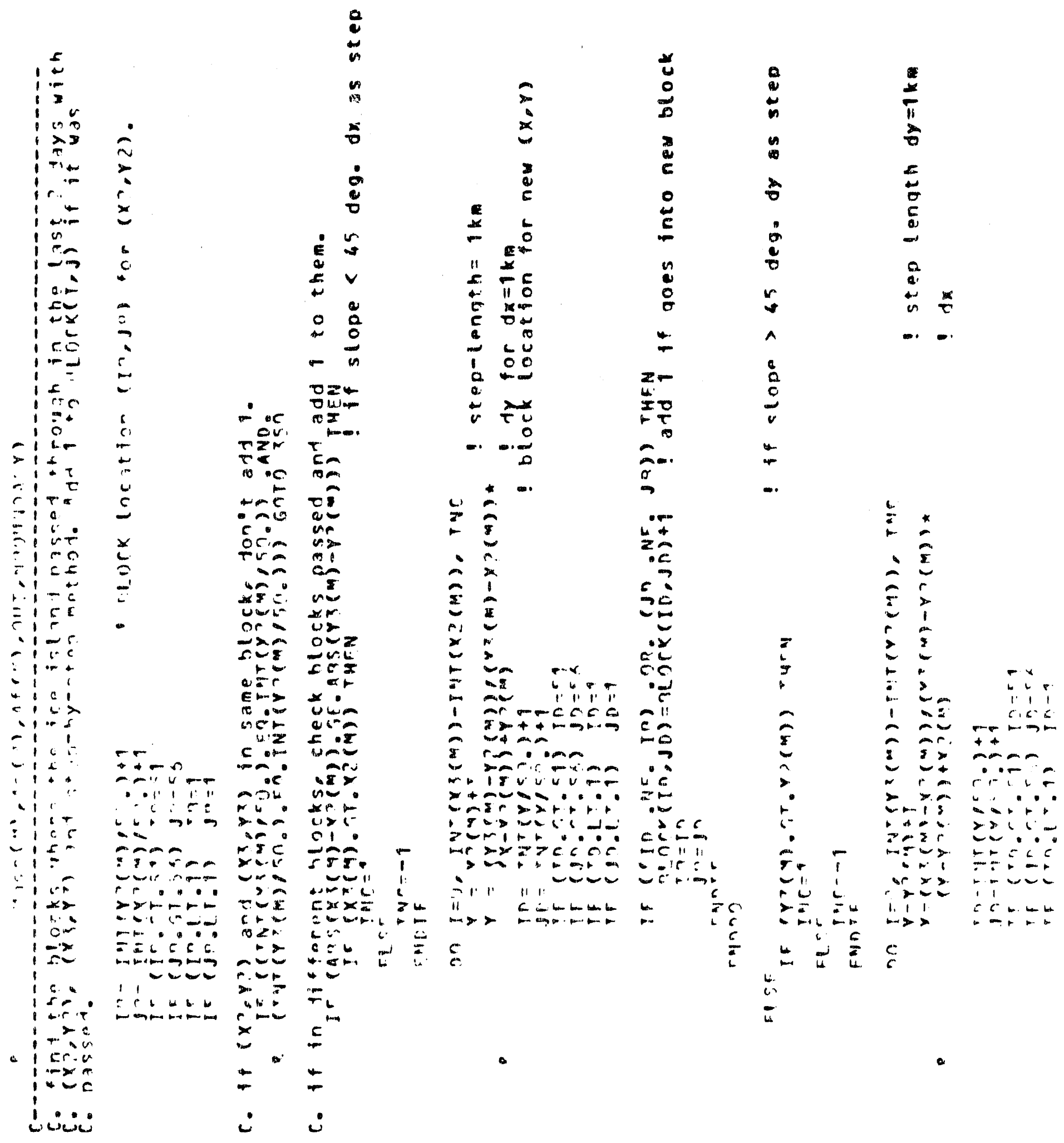


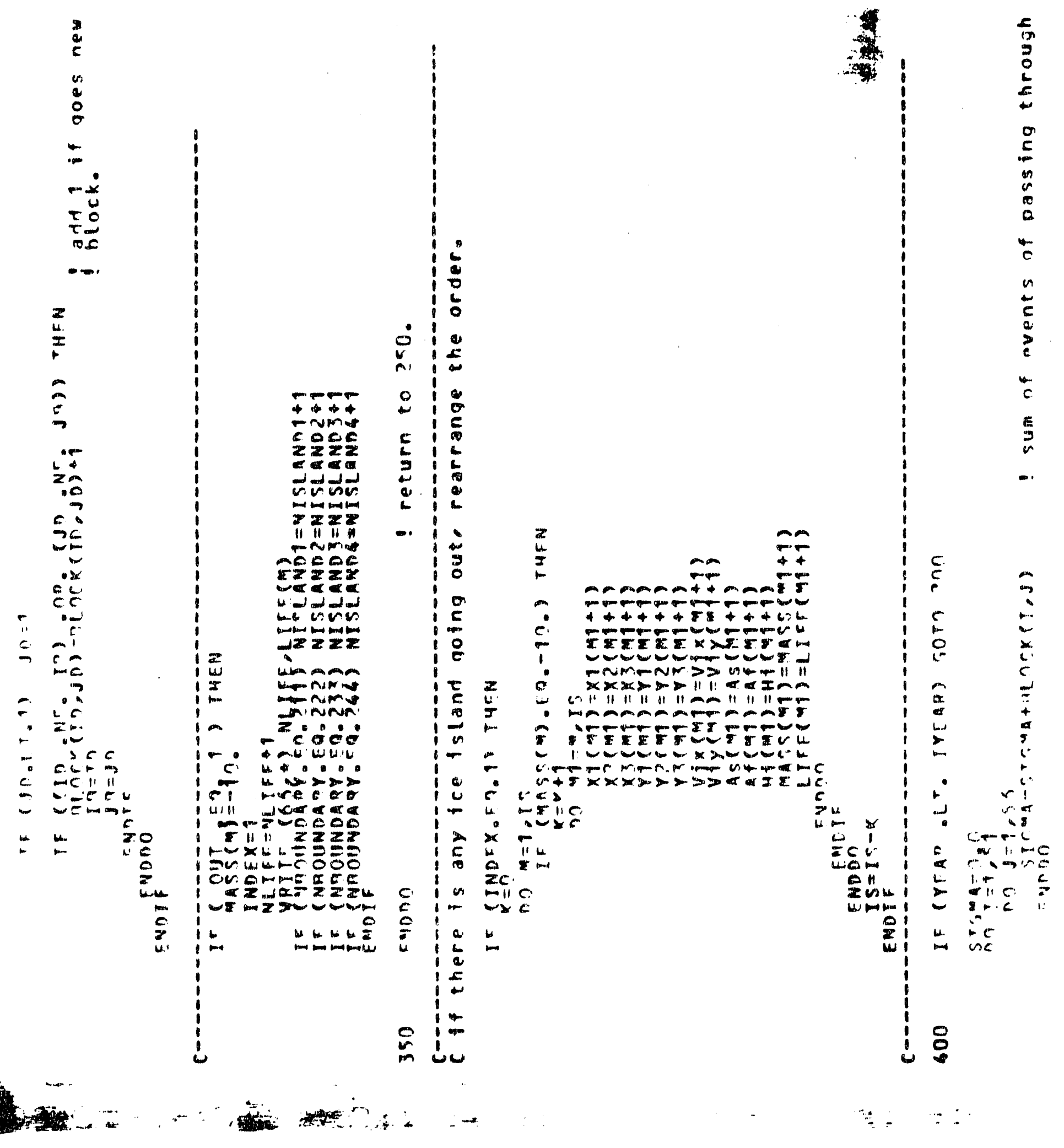




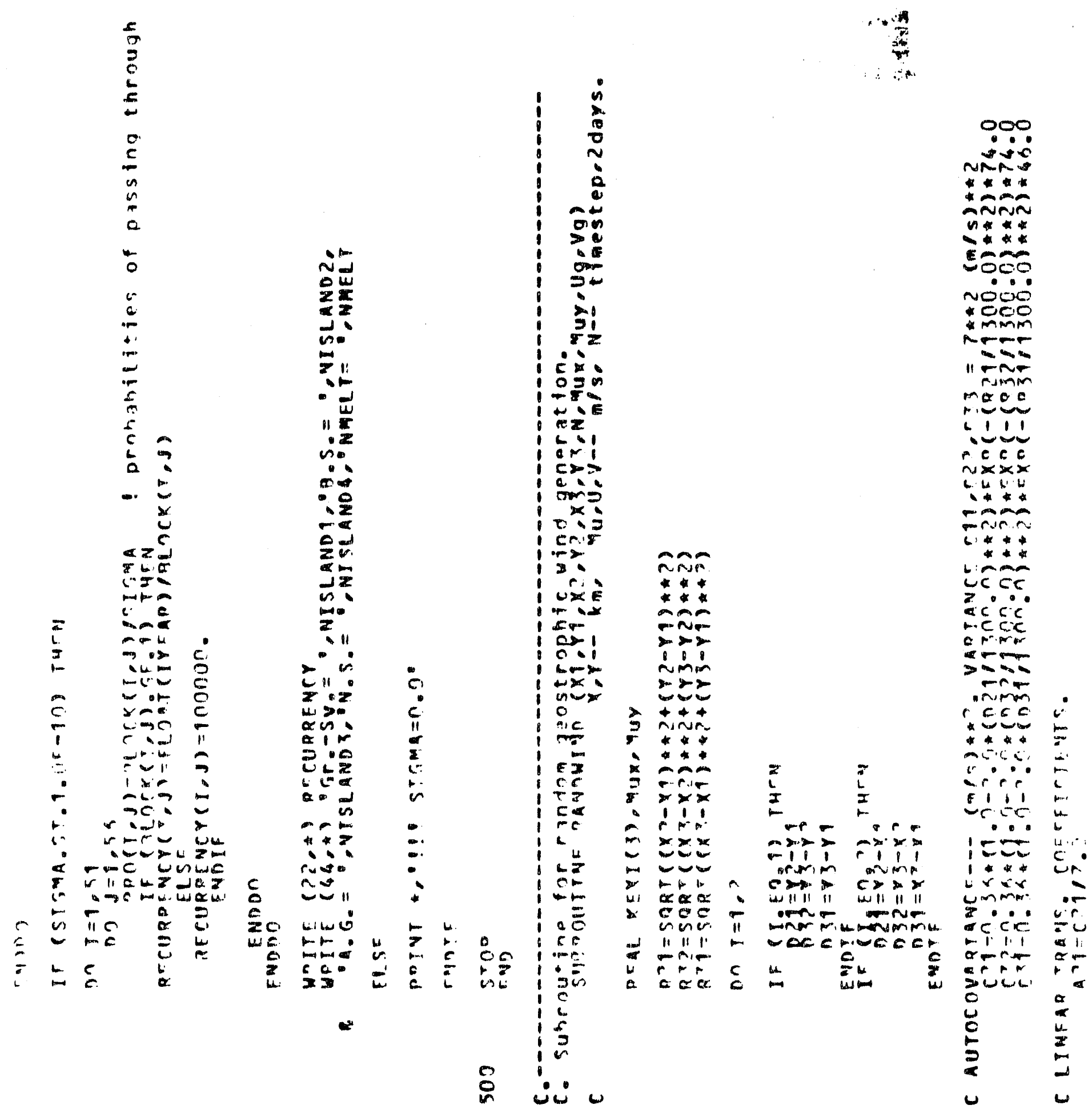




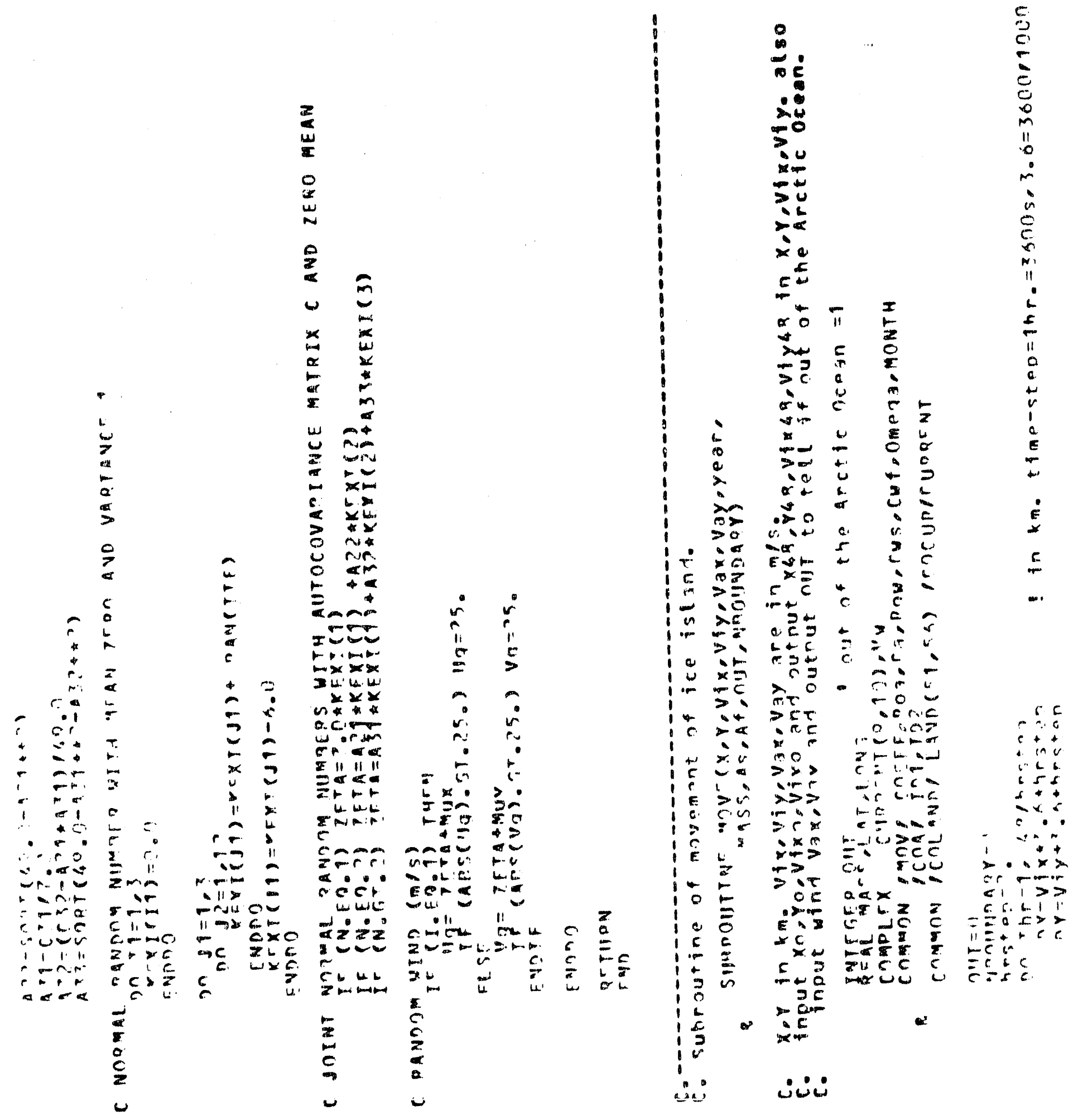



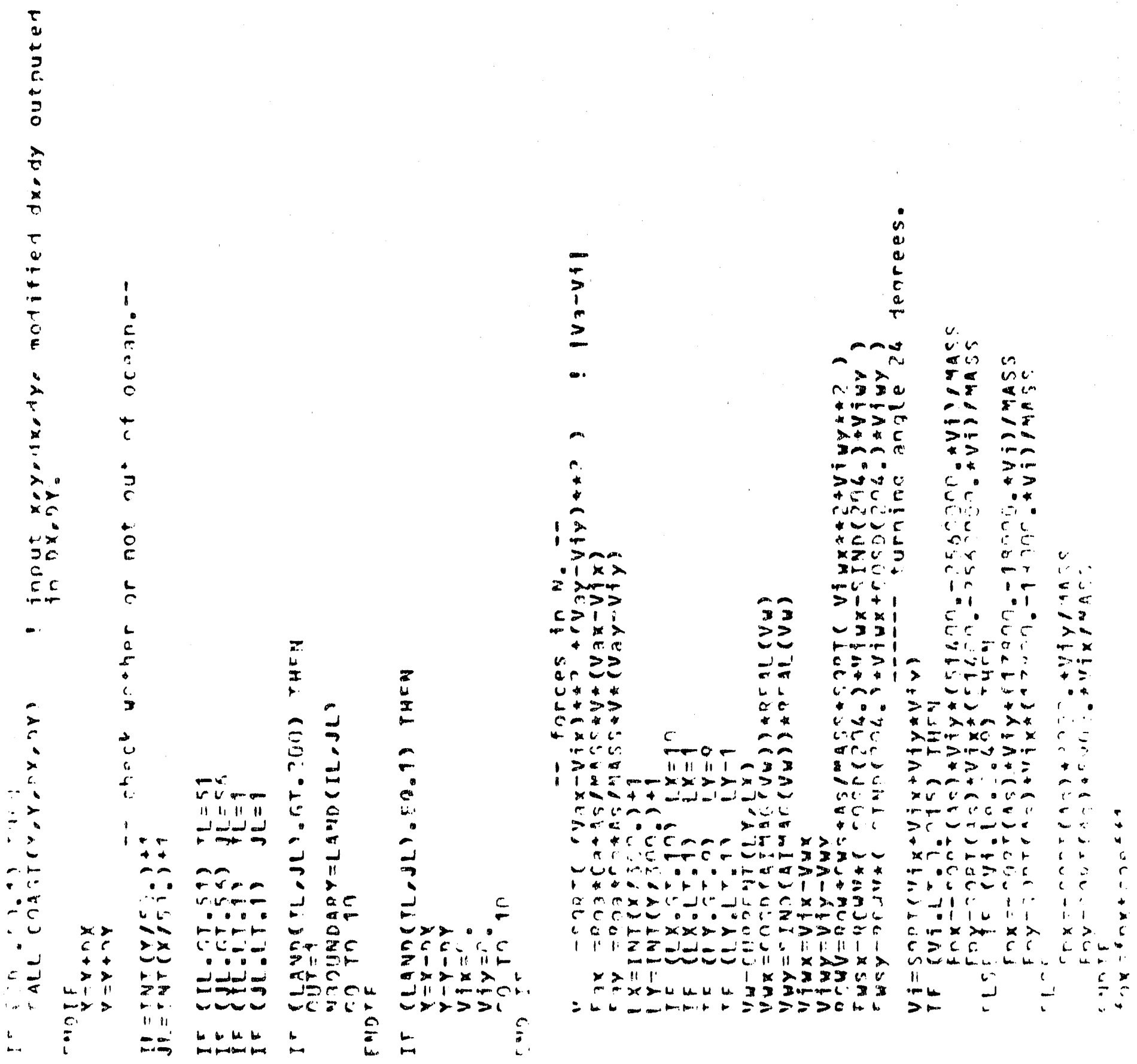

$$
\text { ن }
$$




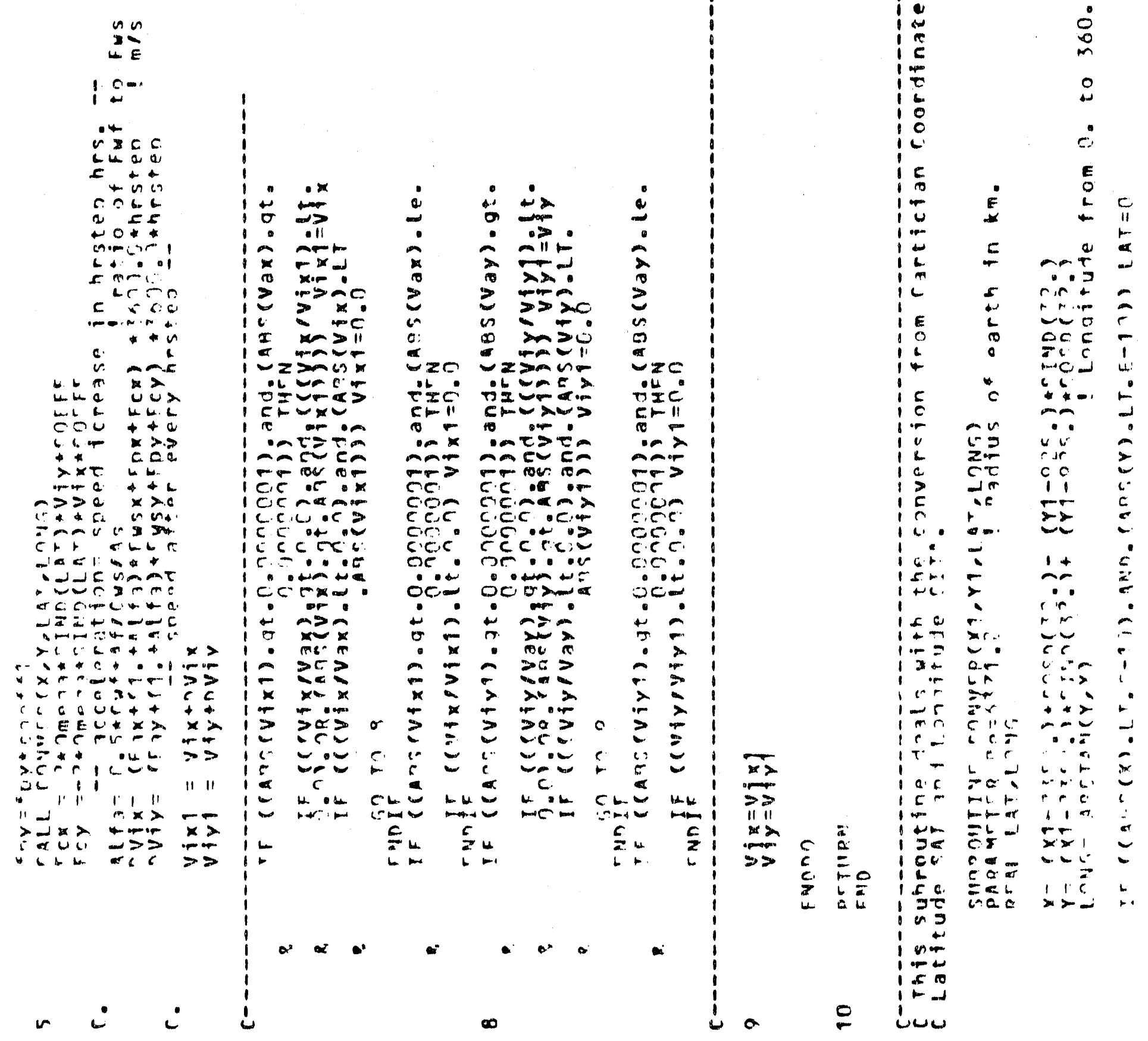




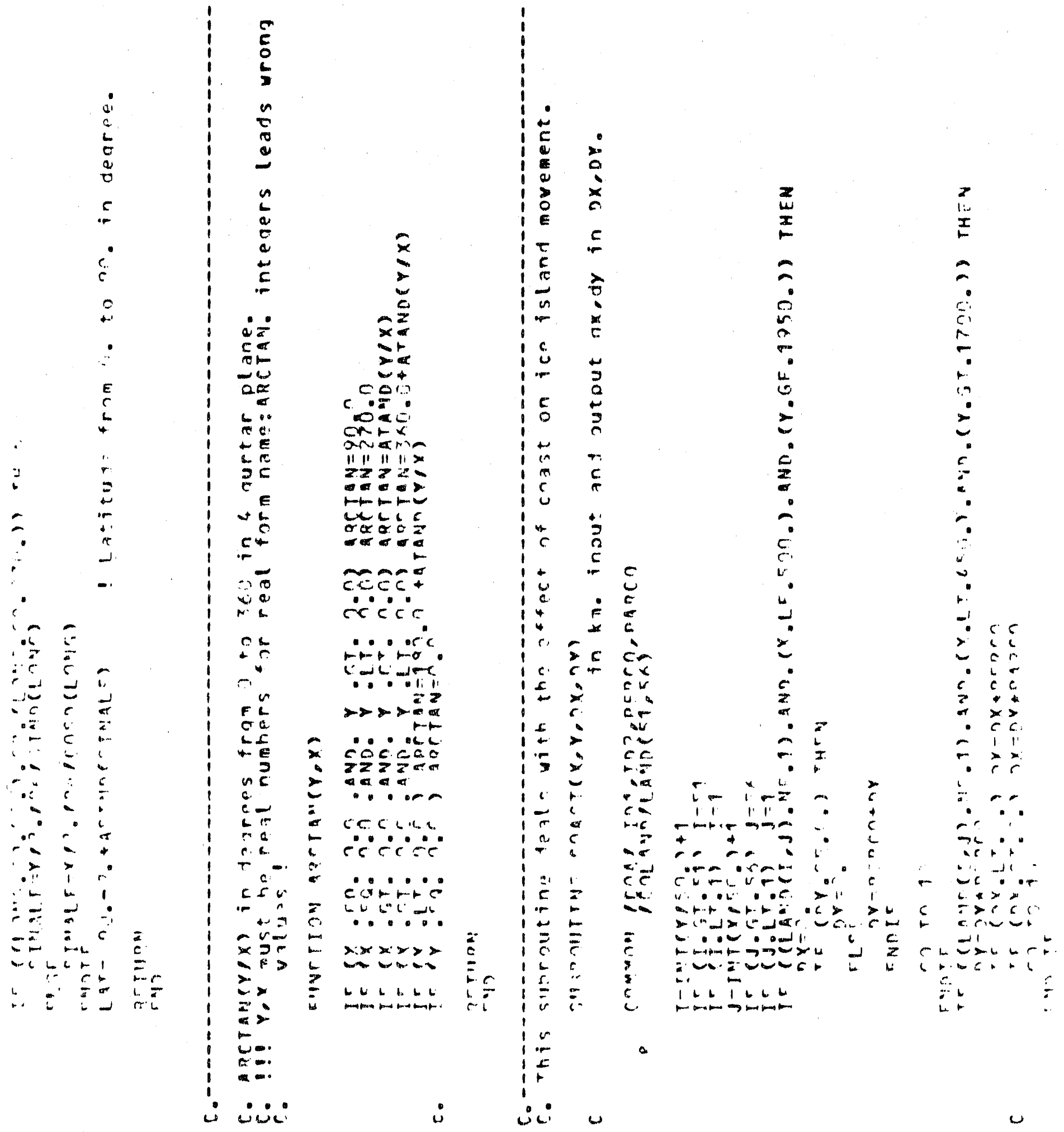




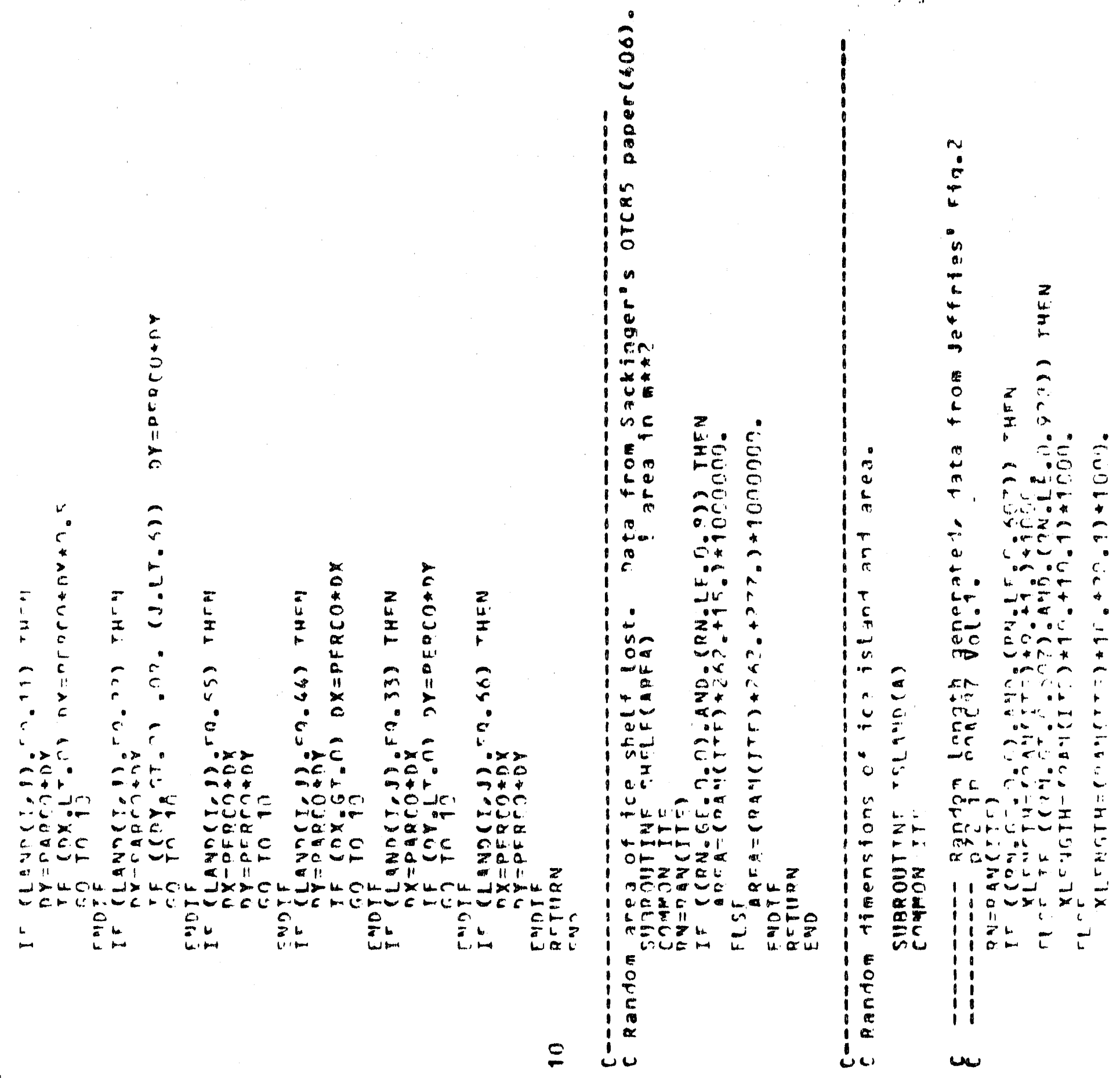




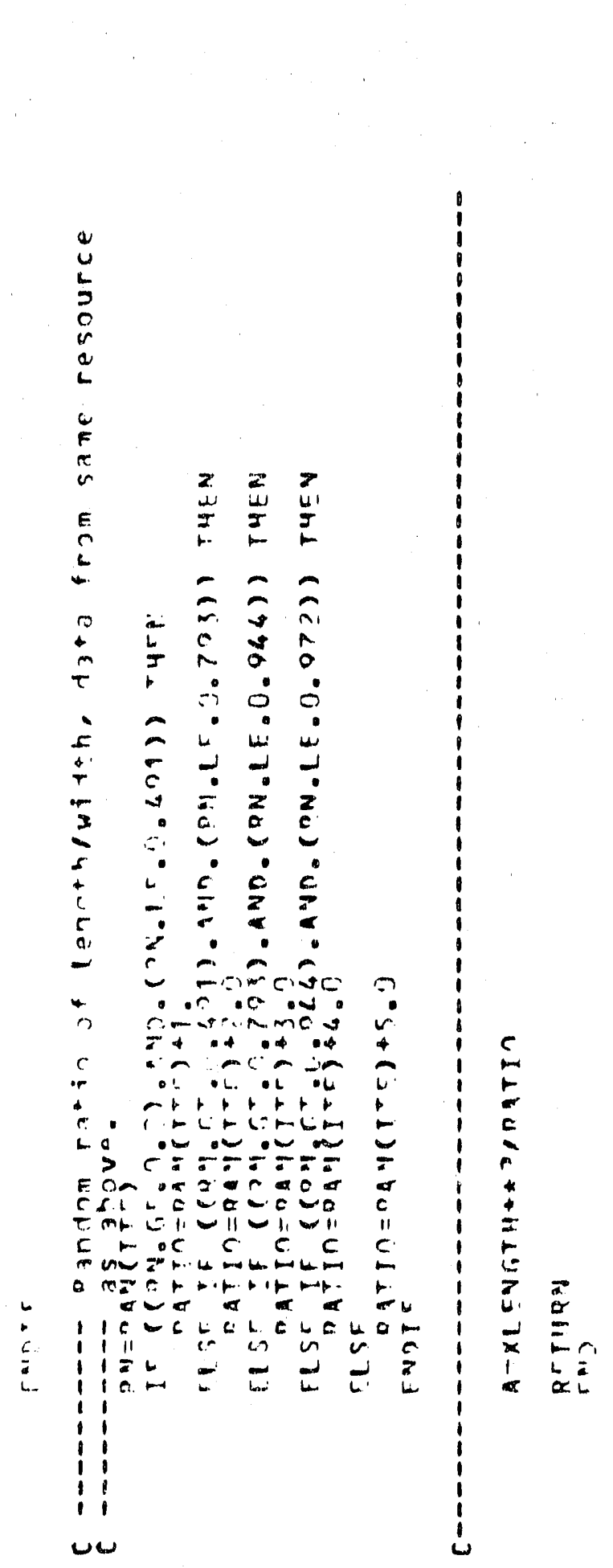



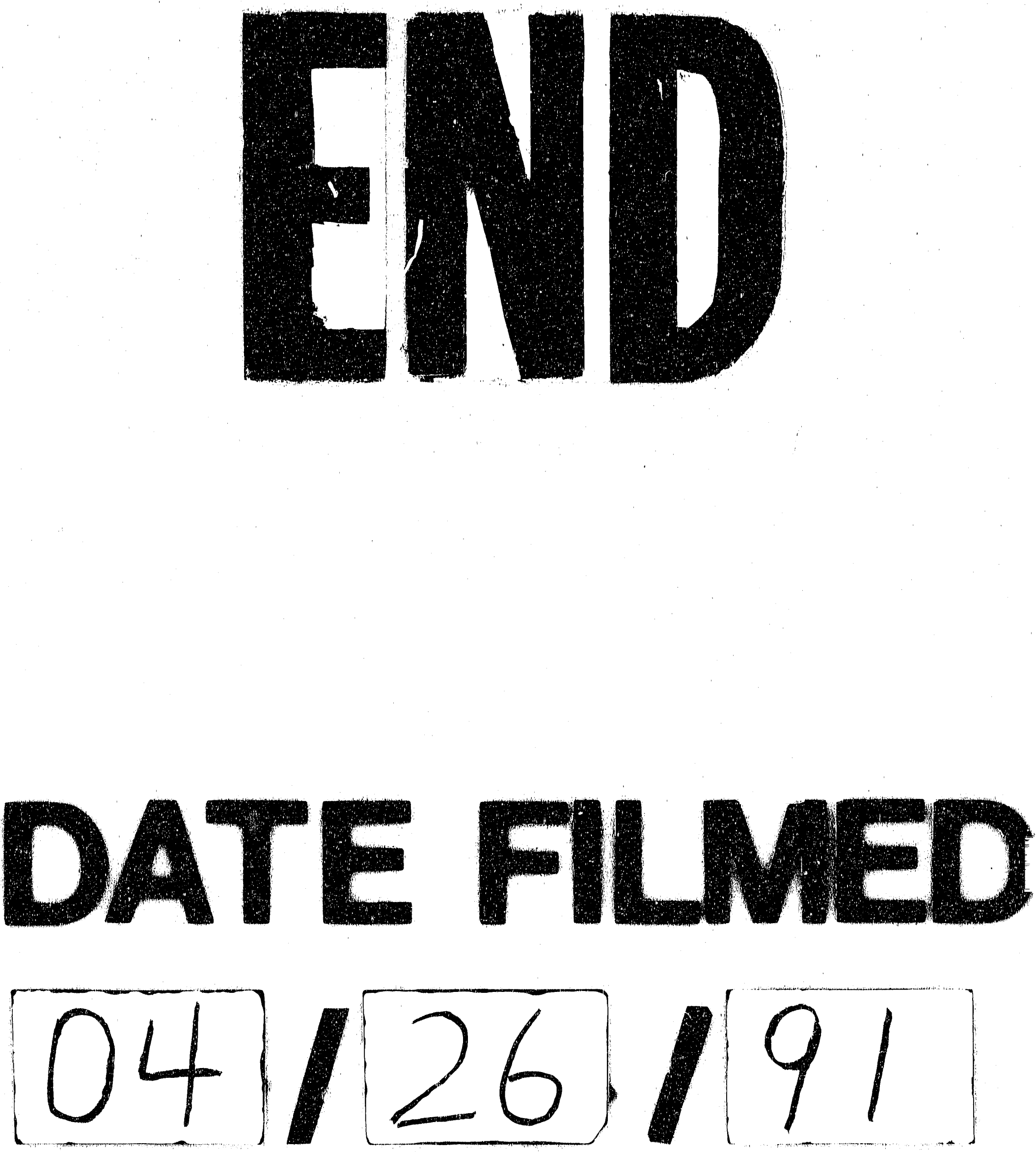
